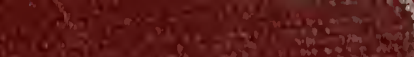
$\therefore$ 잔

(1. -1.40

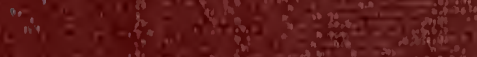

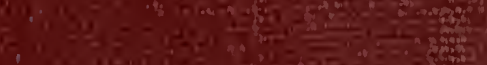

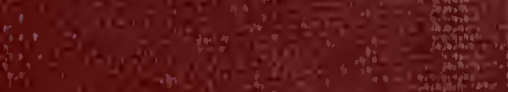

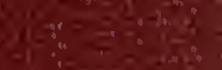

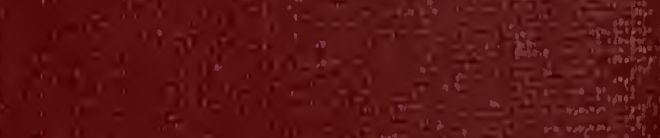
$\rightarrow 205 \cdot 3 x^{2}$ हnt? $\therefore=30$ $x_{n-2}=2$ 20

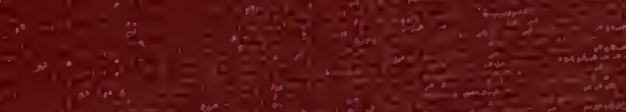

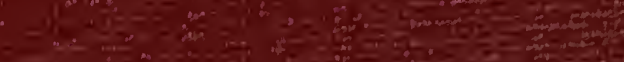

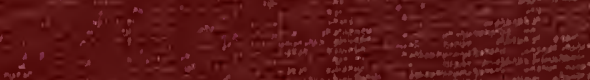

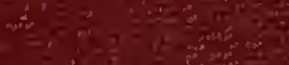

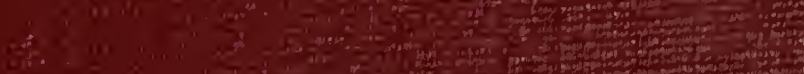

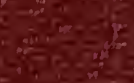

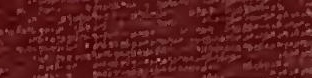

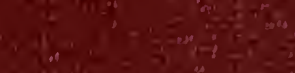

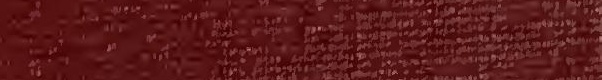
$6=\frac{1}{6}$,

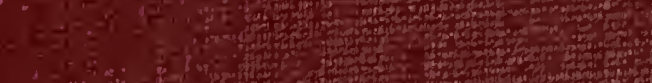
$\therefore$ int

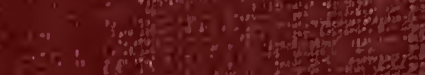

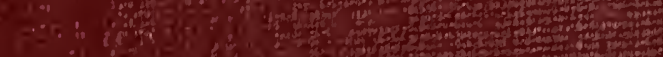
16.54 



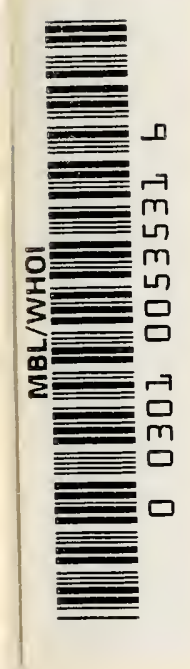







\title{
REPORT
}

or mu

\section{SECOND NORWEGIAN ARCTIC EXPEDITION IN THE "FRAM" 1898-1902}

\author{
VOI. IV \\ AT THE EXPENSE OF THE FRIDTJOF NANSEN FUND \\ FOR THE ADVANCFMENT OF SCIENCE
}

PUBLISHED BY

VIDENSKABS-SELSKABET I KRISTIANIA

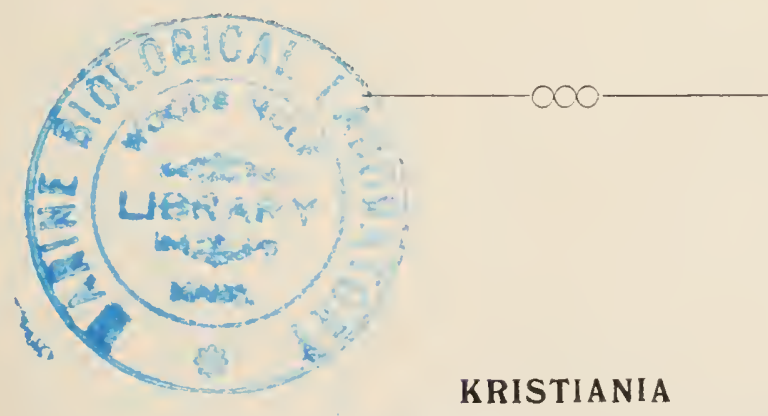

IN COMMISSION BY 'T. O. BRØGGER

PRINTED BY A. W. BRפGGER

1919 

T

he collections of saltwater- and freshwater algæ brought home by the $2^{\text {nd }}$ Fram Expedition, are not included in the treatises contained in Vol. 4.

The Volume must go to press without waiting for the treatment of this group of plants, as the scientist who had originally engaged to undertake the task, has now declared that he is not in a position to do so. Besides, he states that he cannot say where many of the saltwater algæ are at present to be found.

If these collections of algæ should be dealt will later on, the results will appear as separate treatises in the publications of "VidenskabsSelskabet, Christiania".

Kristiania, April 1919.

N. Wille.

Editor. 



\section{CONTENTS OF VOL. IV,}

No. 28. Olaf Holtedahl: The cambro-ordovician beds of Bache Peninsula and the neighbouring regions of Ellesmereland. With 1 map and 4 plates. (Printed 18. January 1913)

29. Oskak-Erich Meyer: Die devonischen Brachiopoden von Ellesmereland. Mit 8 Tafeln. (Gedruckt 28. Mai 1913)

- 30. Stephan Loewe: Die devonischen Korallen von Ellesmereland. Mit 7 Tafeln. (Gednckt 31. Oktober 1913) . . . 1-2:3

31. Oscar Carlgrex: Actiniaria. (Gedruckt 13. Dezember 1913) 1-8

- 32. Olaf Holtedahl: On the fossil faunas from Per Schei's series B in South Western Ellesmereland. With 2 maps and 8 plates. (Priuted November 1913) ......... 1-48

- 33. Johan Kifer: Upper devonian fish remains from Ellesmereland with remarks on Drepanaspis. With 8 plates and 8 figures in the text. (Printed 2. March 1915) .... 1-56

- 34. Тh. Tschernyschew und P. Stepanow: Obercarbonfauna von König Oscars und Heibergsland. Mit 12 Tafeln. (Gedruckt 14. Marz 1916) . . . . . . . . . . . . .

- 35. A. G. Nathorst: Terliäre Pflanzenreste aus EllesmereLand. Mit 2 Tafelı und 2 Figuren im Texte. (Gedruckt 24. August 1915) . . . . . . . . . . . . . 1-16

- 36. Olaf Holtedahl: Summary of geological results. With geological map, 6 plates and 4 figures in the text. (Printed 6. November 1917) . . . . . . . . . . . . 1-27

\section{5}

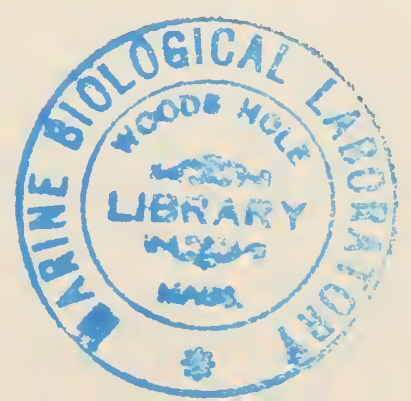


wallonith

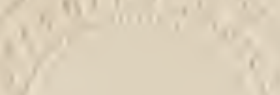

r

ntwis $x=1$

$1+1$

in ,

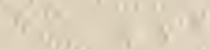

tronilumat 
REPORT OF THE SECOND NORWEGIAN ARCTIC EXPEDITION IN THE „FRAM” 1898 - 1902. No. 28.

O LA F H O L T E DA H L:

\section{THE CAMBRO-ORDOVICIAN BEDS OF BACHE PENINSULA}

AND THE NEIGHBOURING REGIONS OF ELLESMERE LAND

WITH I MAP ANI 4. PLATES

AT THE EXPENSE OF TIE ERIITHIOF NATSEX FUNI) FOR THE ADVANCEMENT OF SCIENCE

PUBLISHEI BY

VI DENSKA B S-SELSKA B ET I KR ISTIA N IA (THE SOCIETY OF ARTS ANI SCILXCES OF KRISTMNIA)

K R IS T I A N I A

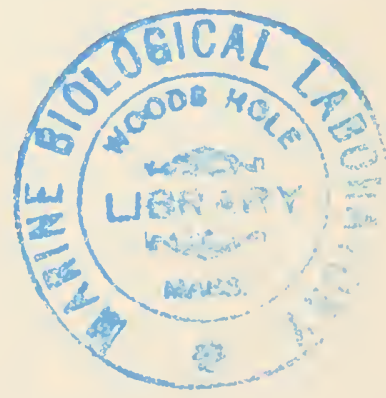

PRINTED BY A. IV. BROGGER 



\section{D}

uring the winter period 1898-99 the "Fram" lay in winter quarters at Rice Strait, between Ellesmere Lind and Pin Isle, at about latitude $7 S^{\circ} 46^{\prime}$ N. In September and October 1S9S, the geologist P. Schei, whose early death is much regretted, undertook excursions from the winter quarter's westward and nortlwestward, and made observations and geological collections. 'Thus from this period observations occur' in his diary from Hayes Sound and its two north-western arms Flagler Bay and Beitstad Bay. In March 1899 a sledge excursion was taken northwards to Bache Peninsula, but the cold compeller the polar explorer's to return to the "Fram" after a short stay at the south-east corner of the Peninsula. At the end of April, Screr set out on another excursion, and in the first half of May genlogical investigations were made on Bache Peninsula, Norman lockyer lsland in Princess Marie Bay, and also along the coast at various places north of the latter. Finally in July an excursion was made from Rice Strait westwarl to Twin Glacier Valley and Alexandra Fjord.

Scher himself, in his preliminary report, gave the chief results of his investigations. As regards the geological conditions, especially the sedimentary beds, on Bache Peninsula and the surrounding districts, there is in reality not much more of note that can be found in the diaries. The essential feature of this present report is the account of the fossil material which was brought back. Unfortunately this is not a very grateful task. The collections of fossils which occur from the lower horizons in the beds studied by ScHei are extremely fragmentary, with only a few fossils, and these moreover quite incomplete. This in even more regrettable, as a closer knowledge of these older fauna, which are otherwise unknown in these regions, would be of extremely great interest. From one occurence only - the Ordovician beds of Norman Loccyer Island - we have a somewhat considerable amount of fossil material in a better state of preservation. 
the Iracts risiterl hy somer were the object of geological investigalion during the British expedition commanded hy Captain Sir Gaorga Nare in 1STe T6. I mumber of fossils were collected from about the same localities as those from which Scum brought his collections le. g. Fron Victoria Head on Bathe Peninsula and Norman Lockver Island). Only one ol lwo forms. howerer, arr mentioned from these places: the majority of the Ordovicic-silurian fossils from these regions were collected farther to the north-east hy the said expedition.

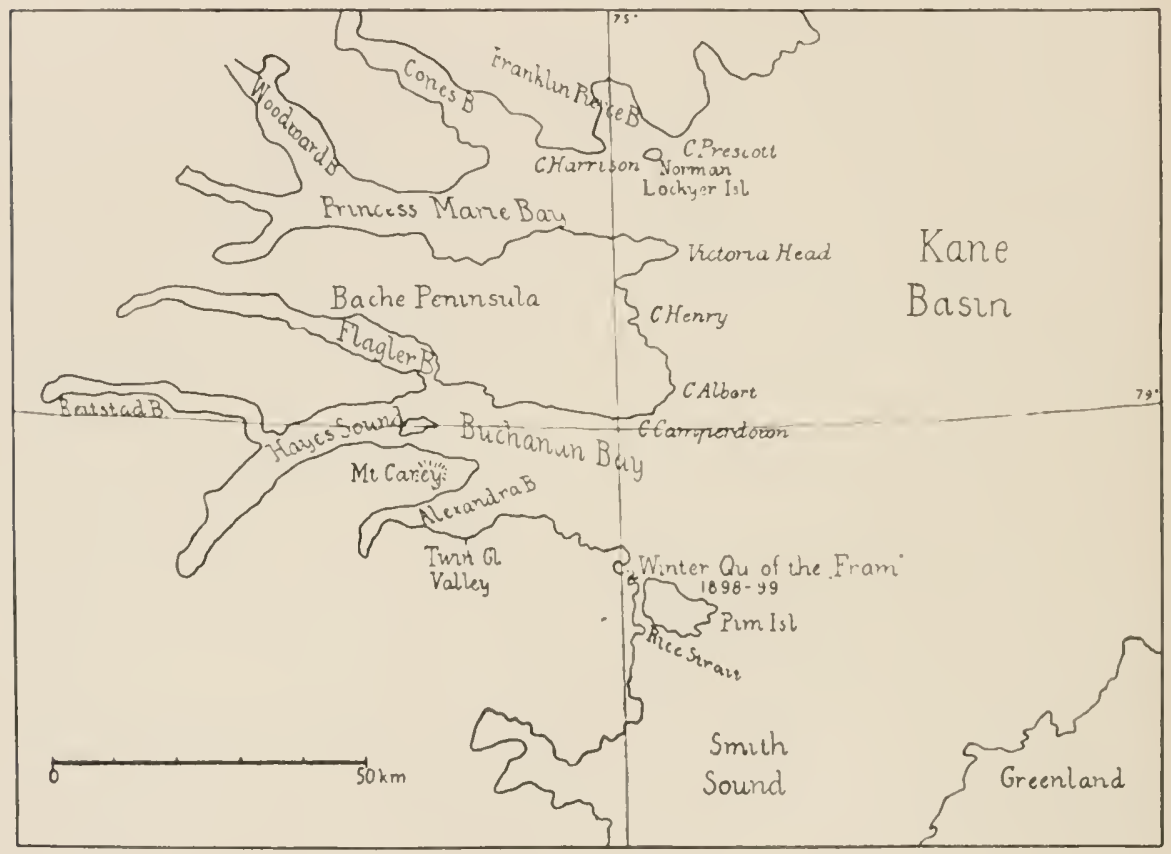

The results of the expedilıon were collecterl in ".The Geology of the Coast of the Arclic Lands visited hy the late British Expedition under Captain Sir George Namse, hy Feilden and De Rance, and "Palamntology of the Coasts ete". by Euls eridge, both in the (Guaterly Juminal of the Geol. Soc. of London Vol. 34, 1878.

Suhsequently. Ike PEaky expedition. which was almosl contemporary will Scuer's, collected fossils at Princess Marie Bay in 1S!S. These were described by R. P. Wurtertan in "Observations and Descriptions of Arelic Fossils", Bull: of the American Musemm of Natural History, Vol XIII, 1900.

The pre-cambrian rockis to the south of the Cambrosilurian beds in the region of Bache Peninsula and the neighbourhood were described by C. Bugge, from the collections hrought back ly Scret, the lists 
contained in the diaries, and the analyses carried ont after the return, in "Petrographische Resultate der 2ten Fram-Expedition"1. These rocks, which comprice both acirl and more basic deep-eruptives, (all characterised hy containing rhombic pyroxen) presumalily belonging to a newer division of the archean rocks. constitute the principal features of the mountain mass south "f Buchanau Bay, Hayes Sound and Beitstad Bay.

Upon these rocks then follow northwards the younger sedimentary heds from underneath.

The locality at which ScHer studied more particularly the oldest portion of the beds, is situated at the south-eastern corner of Bache Peninsula, at Cape Camperdown. Here at the bottom. the older eruptives can still be seerr, consisting according to BugGe of a hypersthene-quartzpolash syenite. Above this syenite we have the oldest sedimentary beds with a slight N.N.W dip.

Scher thus describes the series at Cape Camperdown in his "Preliminary Report on the Geological Observations made during the Second Norwegian Polar Expedition of the "Fram". (Journal of the Royal Geographical Society 1903).

"Granite crops ont at Cape Camperdown on Bache Peninsula, and is overtain by an "arcose", in part conglomerated variety of sanclstone, disposed in flat strata that dip towards the north-north-west. Its thickness scarcely exceeds 500 feet, although the contour rises considerably higher in consequence of the intrusion of diabase 2 . which attains attogether a thickness of probably :350 feet. The upper strata of this sandstone, which have been gradually metamorphosed, pass over by alternate stratification into a series of grey arenacrous ant marly shates and limestone conglomerates. These conglomerates and schists arranged in alternate layers that vary from a few inches to $S$ or 10 feet each in thickness are built up into a series that attain a total thickness of 650 to 1000 feet, but are interrupted by two compact beds of yellowish-grey limestone some 160 feet in thickness.

These again are overlain by a similar series to that beneath, except that the limestone conglomerates predominate over the shales. In a detached "boulder" which in all probability had fallen from one of the beds of yellowish-grey limestone just mentioned. we discovered traces of fossils. _ - "

1 Report of the Second Norwegian Arctic Expedition in the Fram 1898-1902, No. 22. Published by Videnskapsselskapet i Kristiania, 1910.

2 Described by Bugge. 
We have not in fro pieces from the beds mentioned ahove at Cape Campertown. Various simdstones are in evidence, red and grey, fine grained and coarse sramol. Somm plainly exhibil ripple markis un the upper smrfare. A mirrosiopric suction of a fine grained sambtone shows somewhal rombled grimins ol less than 0.5 m. m. in si\%e. almost entirely consisting of yuart\% with hut a few grains of felspar. A rock of coarser gram. shmwing grains as large as several m. m.s, contains much more rolspar, esprecially microclime. (see pl. 4. fig. 9). We also find a beautiful piece of lime-conglomerate from the lower portion of the sedimentary series. (see pl. 4, fig. 10). This shows pieces up to 1 dm in size, of a grey limestone, extremely compact in some parts, lying in a lighter and companatively coarse rystalline matrix of calcite frequently also with fuart\% grains. The pebbles in the main are rather flat or lenticular As regards the flat pebbles the distribution shows an indication of parallelism.

The limestone in which the fossil remains were found in loose pieces. is a very fine crystalline yellowish-grey rock.

As regards the fossil remains themselves, they are deplorably frag. mentary. We have some incomplete pieces of a quite small tribobite form: some free cheeks, a rery imperfect specimen of the central part of the head shield and one incomplete pygidium.

The specimens. of which some are represented in pl. 4 fig. 1-3, belong indoubtedly to a Ptychoparia sp. Lut no exact identification can he made with the above material. The specimens show a very close comlormity with certain of the Plychoparia forms describerl by Has. and Wutrated as Crepricephalus from the Postram Group in Nevada, in "Geol. Exploration of the Fortietlı Parallel". In the form of both the cheek and of the pygidium the above form lies very near $P$. anylus (t. e. P. 219, H. II, fig. 19-21), and also the two forms $P$. nitidus (p. 212, pl. II, figs. S, 10) and $P$. simulator (p. 21S, pl. II, figs. 16-18), which W.alcotre in ..The Paleontology of the Eureka district" $\mid$ r. 57 , comblnes into one form, I'. nitidns

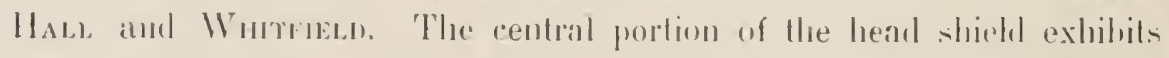
some diviation from that of the forms alowe mentioned. It las a marrower frombl limb, and also He facial sutures diverge less makedly. As regards the central portion of the rephalon. this agrees hetter with that of P. unisulcalus, shown in ".fieol. Fixpl. of the Forth. Pau." pl. II, fig. 22. 
As concerns the stratigraphic evidence of this trilobite, we see with considerable certainly that we are in the middle or upper part of the Cambrian, altlough no more exact determination is possible.

This single find of a cambrian fossil is of extremely greal interest, as it is the only one hitherto known from the Arctic Nortlı American Archipelago. In the coarse clastic sediments that occur commonly all over the Arctic regions, above the archæan rocks, no fossils older than from the Trenton period have so far been discovered.

Once more reverting to Sches. "The next member in the stratigraphical order, overlying the second of the above series of conglomerates, is a bed of light greyish-white limestone, about $350 \mathrm{ft}$. thick which cropped out midway up the vertical face of Cape Victoria Head".

The limestone here mentioned exhibits, in the pieces brought back, a somewhat irregular appearance, some being rather dark and extremely compact, others lighter and more coarsely crystalline. Especially typical are the extremely frequent stylolite fornations, varying from quite small to $1 \mathrm{dm}$ in height. As regards fossils we can commonly see sections of fossil fragments, especially of orthocerites, from which fact the limestone is named orthoceras-limestone by ScHer. In addition we can see some badly preserved bryozoa stems without structure. We only see the central canal indicated by more coarsely crystalline calcite, whilst the matrix around is very finely grained. Any systematic determination is out of the question.

The only remains of organism which could supply us witlı any clue to the geological age of this limestone, are those of certain small trilobites. In spite of a very fragmentary character they are of considerable interest. Although a study of these remains does not give us a determination of the species, we may presume that we are dealing with the transition zones between Cambrian and Ordovician. As far as can he understood we have a stratigraphical equivalent to the zone which is now considered as the very lowest Ordovician, and which round the earth's surface in characterised by a Cambro-ordovician mixed fauna. It corresponds to the Pogonip Group in Nevada, the Tremadoc in England, the Ceratopyge division in Scandinavia, etc.

In the limestone from Victoria Head we find two imperfect central portions of head shields, which show an evident Cambrian character. Presumably they represent Ptychoparia species. One head (pl. 4, lig. 5) 
is very finely gramulated all wer. the other not so on the glabella. 'Together with these specimens we find the remains of a trilobite of prite another type. We have two fragnentary central portions of the cephalon, which undoubtedly helong to an Illomurns sp. (see pl. 4. fig. 4) lut it is nol possible to make any exact detemination. 'Tlie Illonurns forms is typical of the lowent ordovician in N. America. Only one form. I. quadratus 11 aL.. is given from the Potsdam Gromp.

OHber forms belonging to this younger type of fauma include one small fragment of a heal uf a Lichas sp.

Sintel further describes the beds thus: -

"On the lop "If this lightecolonred limestone with its fossil orthocerites lie less slrongly developed strata of quartz sandstone, allernated will limestones, and on the top of that again a bed of chose-gramed brown limestone. about 100 feet thick, some of the layers of which are fossiliferous. - _.."

The fossils in this case are just as fragnentaly as in the underlying limestone. Most rommonly wr find gastropodes. preserved as cast.s.

In some pieces we ser rery freguently a little slender form with numeroms coils (see pl. 4. fig. (i) which camnot easily be separated from varieties of the common Hormotoma gracilis H.w... which has a very wide vertical extension within the Ordovician. Another form, which the sperimens before us greatly resemble, is that described ly HaL and

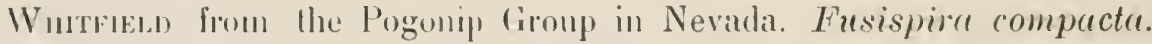
As regards other gistropodes we find one incomplete sperimen of a Machurea sp. (see pl. 4, fig. S). Some fragments of tribohites also occul. Great interest will he altached to a yuite small. hadly preserved pygidium with hollowed outer rim (pl. 4, lig. 7). It has a Cambrian character and presumably belongs to a Bathyuriscus or Ptychoparia form. Although these few fossil remains do not give any particularly good diata for the age of this horizon, yet it suggests that the limestone in reality is only slightly younger than the underlying limestone rich in mbthorerites. Bollo zones are presmmaly to be elassified in the lowest Ordovician lransilion horizon.

A section of a limestone conglomerate laken from a piece collected above the limestone with orthocerites at Victoria Head is shown in ll. IV, lig. 11. 
From Victoria Head in his work previonsly mentioned, "Palaentology of the Coasts of the Arclic Lands etc". Etheridge, reports the dis. covery of Maclurea magna Lesteuk, which is an ordinary (hazy form in the sontlierly North American regions.

'The locality from which the lutk of Scines's collections of fossits in these regions helong, is Norman Lockyer Island in Princess Marie Bay, outside the mouth of the little northerly branch, Franklin Pierce Bay. The island is formed of limestone with the same N-N-W dip as the lieds farther south. The fossils, which lie in a grey-brown limestone which is mostly very compact, but in places more crystalline were according to Scuei's diaries gathered on the east or south-east of the island, although no quite precise locality can be given.

The following forms have been identified:

Anthozoa.

Halysites catenulatus var. gracilis HaLL.

In one single specimen we find portions of this coral, not particularly well preserved. We can however see the comparatively rectangular section of the coral tubes, which are characteristic of this variety of H. catemulatus L.

Calapoecia canadensis Billings.

One colony of a regular rounded form. Greatest diameter $9 \mathrm{~cm}$. Streptelasma corniculum HALL.

Various small specimens occur, mostly less than 2 cm. long.

\section{Bryozoa.}

Bryozoans inust have been extremely common in the limestone. We find numerous somewhat large pieces - unfortunately not in a very good state of preservation - of a Mesotrypa, which seems much to agree with $M$. discoidea UlRich var. orientalis BASSL. ${ }^{1}$

In addition there is a small piece of a small ramified form, with a thickness of $3-5 \mathrm{~mm}$. the structure of which can be studied well, and which agrees entirely with Callopora angularis ULRICH.

1 I am inclined to believe that the form described by Lambe (Geol. Surv. Canada 1907) as a coral under the name Jabyrinthites chidlensis is very closely related to this species. 


\section{Brachiopoda.}

Rafinesquia deltoidea Connad.

One or two fragmentary specimens.

Plectambonites sericea Sow.

Orthis tricenaria Conrad.

Triplesia sp.

One small fragment.

Rhynchonotrema incquivalvis CASTELA.

One whole specimen and several fragments.

\section{Gastropoda.}

I'rochonema cf. umbilicatum HALL.

One piece only, too fragmentary in rharacter for any exact determination to be made.

\section{Cephalopoda.}

\section{Gonioceras occidentale HALL.}

Several fragments which show beantifully the lypical form of the septa. The greatest diameter observed in one complete sertion was $11-12$ '․․

\section{Trilobita.}

I haleops ovata Coxnan.

Several typical headshields.

Vileus (Bumastus?) sp.

Onr. frogmentary pygirlim.

Ostralcodil.

Leperditia fabulites Cons.

Srvoril right and left shells, well preserved. 
In addition to the forms mentioned here we have some others, brachiopodes, gastropodes, trilobites etc, where the material before us has been too incomplete for determination.

The vertical extent of these forms as known from other regions of North America is as follows: -

\begin{tabular}{|c|c|c|c|c|}
\hline & $\begin{array}{l}\text { Cha- } \\
\text { zyan }\end{array}$ & $\begin{array}{l}\text { Black } \\
\text { River }\end{array}$ & Trenton & $\begin{array}{l}\text { Cincin- } \\
\text { natian }\end{array}$ \\
\hline Halyites catemulatus var. gracilis $\mathrm{H}_{\mathrm{ALL}}$. . & & & + & \\
\hline Calapcecia canadensis Bullngs. . . . . & + & + & & + \\
\hline Streptelasma corniculum HALL. . . . . & & & + & \\
\hline Mesotrypa cf. discoidea var, orientalis Bassu. & & & $c f$ & \\
\hline Callopora angularis Ulrich . . . . . . & & & + & \\
\hline Rafinesquia deltoidea Conr. . . . . . . & & & + & + \\
\hline Plectambonites sericea Sow. . . . . . . & & & + & + \\
\hline Orthis tricenaria Conr. . . . . . . . . & & & + & \\
\hline Triplesia sp. . . . . . . . . . . . . & & & & \\
\hline Rhynchonotrema incequivalvis CASTELN. . & & & + & \\
\hline Trochonema cf. umbilicatum $\mathrm{H}_{\mathrm{ALL}}$. . . & & & $c f$ & \\
\hline Gonioceras occidentale $\mathrm{H}_{\mathrm{ALL}} . . . .$. & & & + & \\
\hline Thaleops ovata Covr. . . . . . . . . & & + & + & \\
\hline Nileus (Bumastus?) sp. . . . . . . . . & & & & \\
\hline Leperditia fabulites Conr. . . . . . . . & + & + & & \\
\hline
\end{tabular}

We have here a typical Trenton fauna with a series of the rharacleristic forms of this division, besides some which are found in considerable vertical extent. The fauna exhibits an extremely close agreement with that described by ScHuchert from Silleman's Fossil Mount in Baffin Land, ${ }^{1}$ which again with its 72 species lies very close to the Galena fauna in Minnesota, Iowa, and Wisconsin.

Norman Lockyer Island was visited by Sil George Nares's expe. dition, and in the account given by Feilden and De Rance (p.55S), Favistella (Columnaria) reticulata Salter is mentioned from there.

According to Scher the limestone from Norman Lockyer Island recur's on the north side of the Princess Marie Bay:

"The same linestone, with the same fossils, occurs again at the foot of Cape llarrison, where however it is overlain ly thick berls of limestone, calcareous sandstone, quartz sandstone, and on top of all a

1 On the lower Silurian (Trenton) Famna of Balfin Land. I'roc. U. S. Mus. XXII 1900 . 
massive limestom anglomerate. 'This last rops ont also on the roast at lape Prescott, and ly its presente there along the strike of the limestome lords of Norman Lockyer Istand. Hown- light mmon the tectonic disturbances to which the district has been subjected. The line of these disturhancen is imlicated again on the west side of Franklim Pierer Bay. where the lieds of the limestome ronglomerate, dipping vertically to the strike lrom the altitude of Cape Harrison, are roul off ly a dark grey limestone broken down to the consistency of a hreccia."

Feilden and De Rance also mention a disturbance preceeding east. westwards from Norman Lockver Istand. As regards the stratigraphical position of the heds on the north side of Princess Marie Bay, the views of these discoverers differ from Hose of Scma, in that they con. tend that the conglomerate from lape Prescott is "the hasement eonglo. merate", whilst Scuei's studies appear to prove that it is a younger conglomerate-horizon, the stratigraphic position of which is above the limeslone of Norman Lockver Island.

R. P. Wmafeno in his previously mentioned work, "Oliservations and Descriptions of Arelic Fossils", describes from the limestone from Cape Harrison Receptaculites. Halysites. Heliolites. Calapocia, and Stromatopora which according to him gives as revent an age as the Niagara or Clinton period.' 'These fossils must then presumably have been taken from a comparatively high horizon.

Unforlunately we lave no fossil collections from Scuen's exurrsions. either from the northern districts or from other localities in these regions heyoud those already mentioned.

Nor are we able to report anything more of notr: from his diaries as to geological observations of the sedimentary beds in these regions.

One river profil which was made on the north side of the imer part of Flagler Bay, shows extremely frequent fauls ly which the strata here comsisting of limestone, calcareous sandstone, and limestone conglomerate, are divided into numerous pieces.

Wills regard to the sedimentary rocks and their dostribution it is mentioned that Flagler Bay is entiroly suroumded ly them, whilst aromol Beitstarl Bay they are only fomol on the summits. The lunge diabase intrusions which occur easterly on Bache penimsula appear to le: lacking in these westerly regions.

On the south side of Hayes Somnd the stratified rockis cannot be discovired except in Mount Carey. 
In addition, at one or two places on the west side of Alexandra Bay and at Twin Glacier Valley, smaller portions of limestone have been found which appear to lie near faults, sunken between the older eruptives, and the stratigraphical position of which is mnknown. If they correspond to the ollest strata lying on the arrhean beds, we here obtain another petrographic development, since the coarse clastic rocks which form the basal beds at Cape Camperdown are wanting. 


\title{
Explanation of plates.
}

\author{
Planche I.
}

View of the eastern part of Bache Peninsula from the south coant of Burhanan Bay. Precambrian rocks in the foreground

\section{Planche II.}

Fig. 1. Part of the sontl coast of Hayes Somnd, consisting of pretanbrian rocks, to the west of Mlt. Carrey, and seen from the nortl.

Fig. 2. View towarts Care Allent from Cape Henry, rast roast of Bache Peninsula.

Fig. 3. Cape Virloria Hearl, spen from Cape Henry.

\section{Planche III.}

Fig. 1. View of Cape Camperdown. The precambrian eruptives al the base Fig. ‥ Norman Lockyer Island, seen from the sontlt.

\section{I'lanche $1 \mathrm{~V}$.}

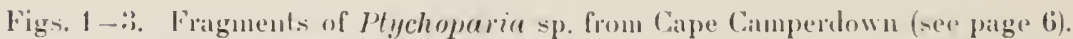
Fig. 4. Fragment of lwal of Illenurus sp. from Cape Victoria Heat (page 8).

l"ig. D. Fragment of hearl of Ptygchoparia sp. (?) trom Cilpe Virtoria Head (page 7).

Fig. 6. Hormotoma yracilis Hall (?) from the upper limestone herls at Calpe Victoria Head (page 8).

Fig. 7. Fragment of pygidinm of an modeternined triblife (Brethyurisors or Ptychoprevire sp.) from the sane berk.

Fig. 8. Maclurea sp. from the same beds.

Fig. 9. Mierosenpieal section of a felspatic coarse sandstone from Cape Camperdown.

Fig. 10. Section of a limestone conglomerate from the fower portion of the sedimentary series at Cape Camperdown.

Fig. 11. Section of a limestone conglomerate from Cape Vicloria Head. 


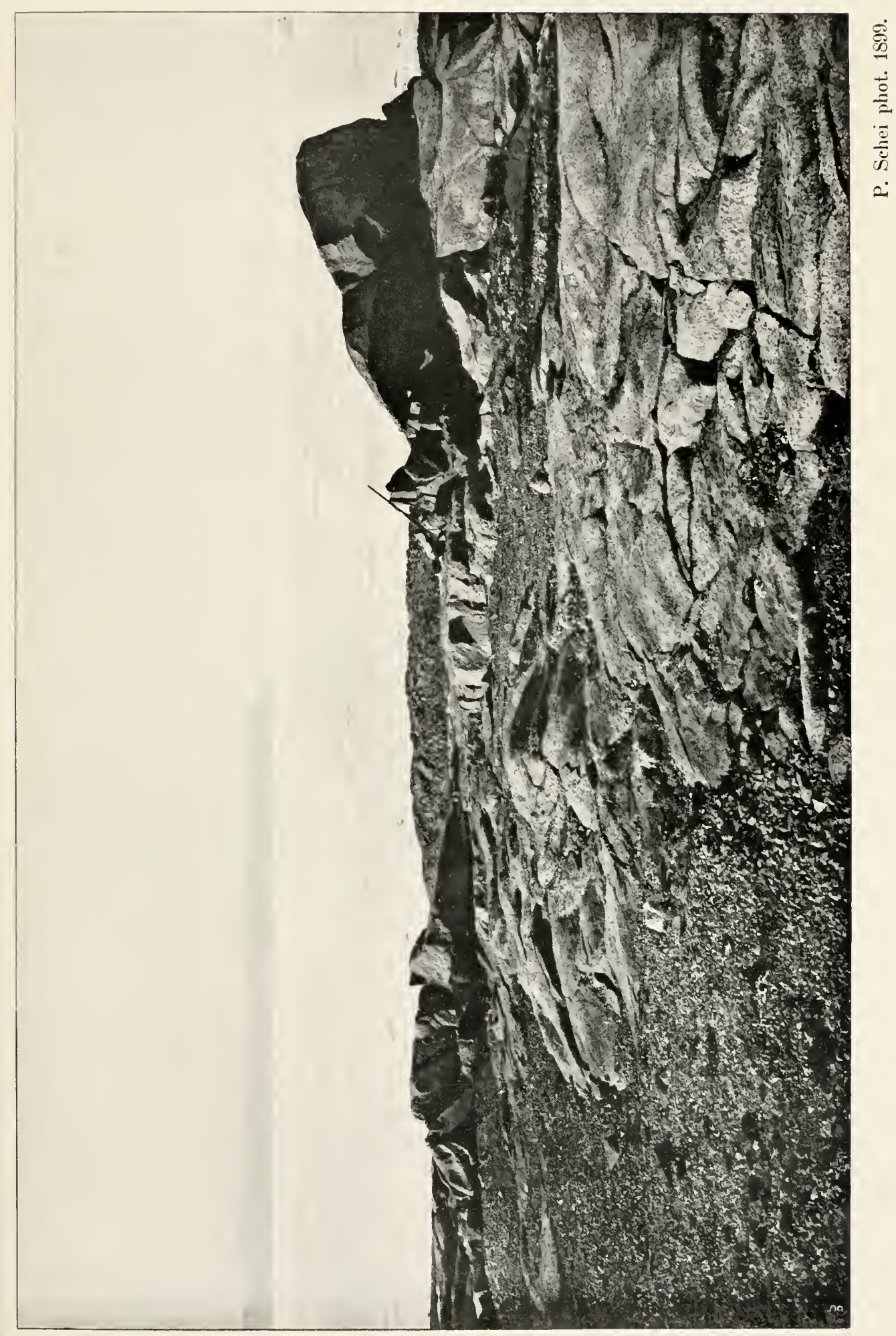





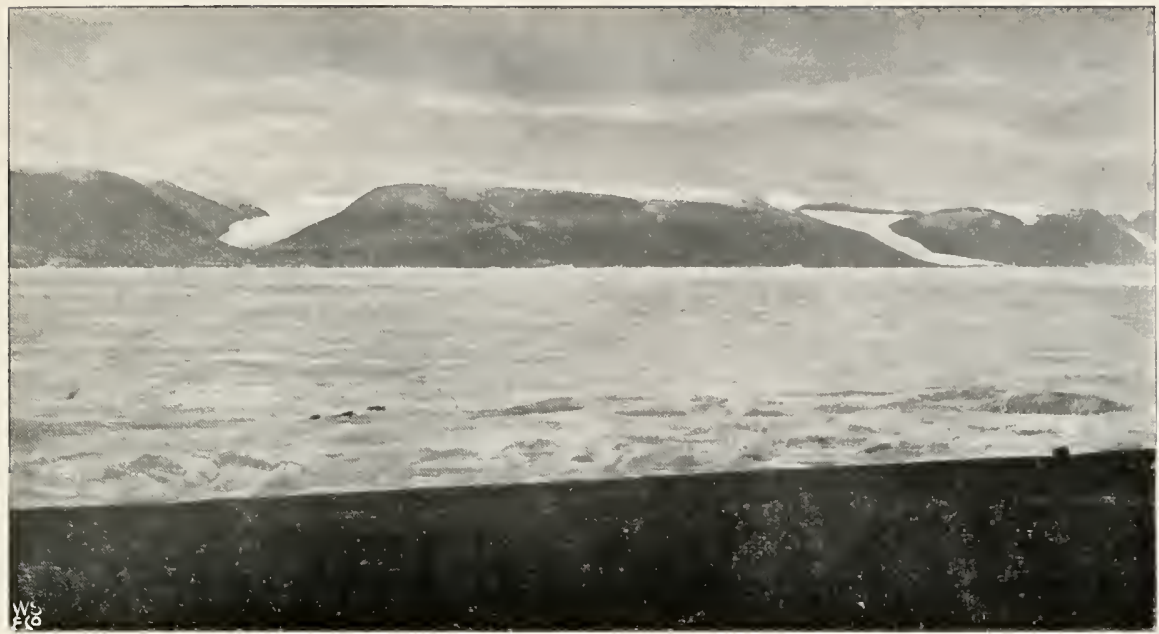

Fig. 1.

G. Isachisen phot. 159!.

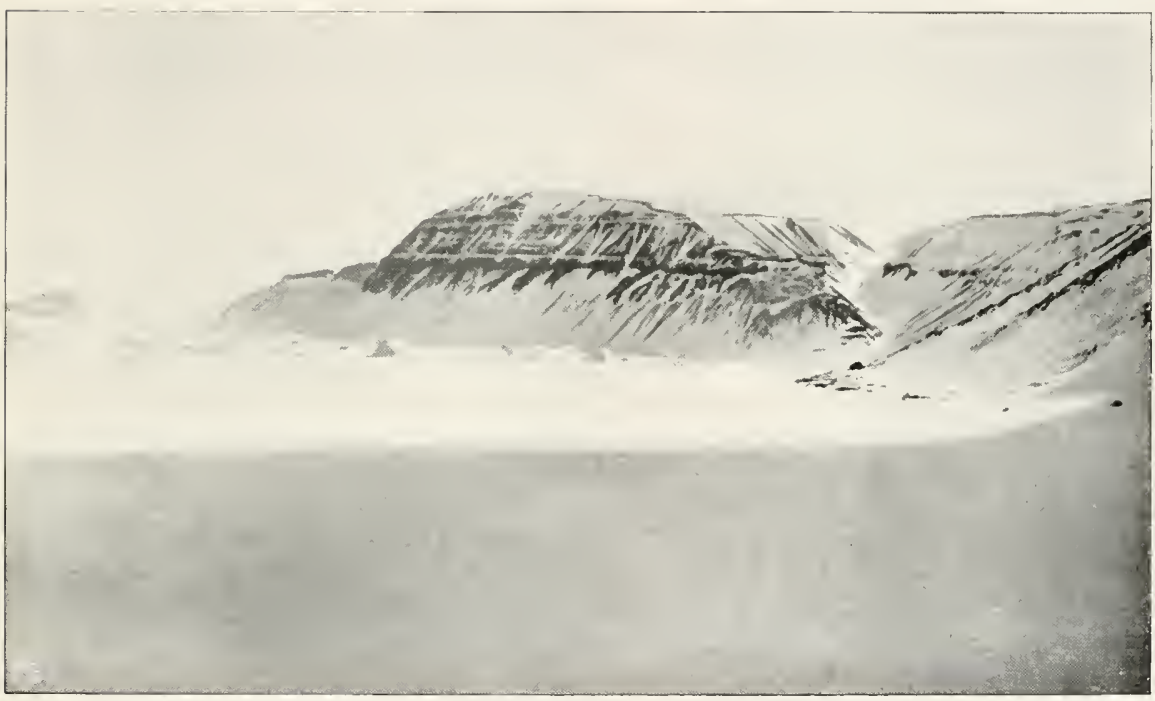

Fig. 2.

P. Schei phot. 1899.

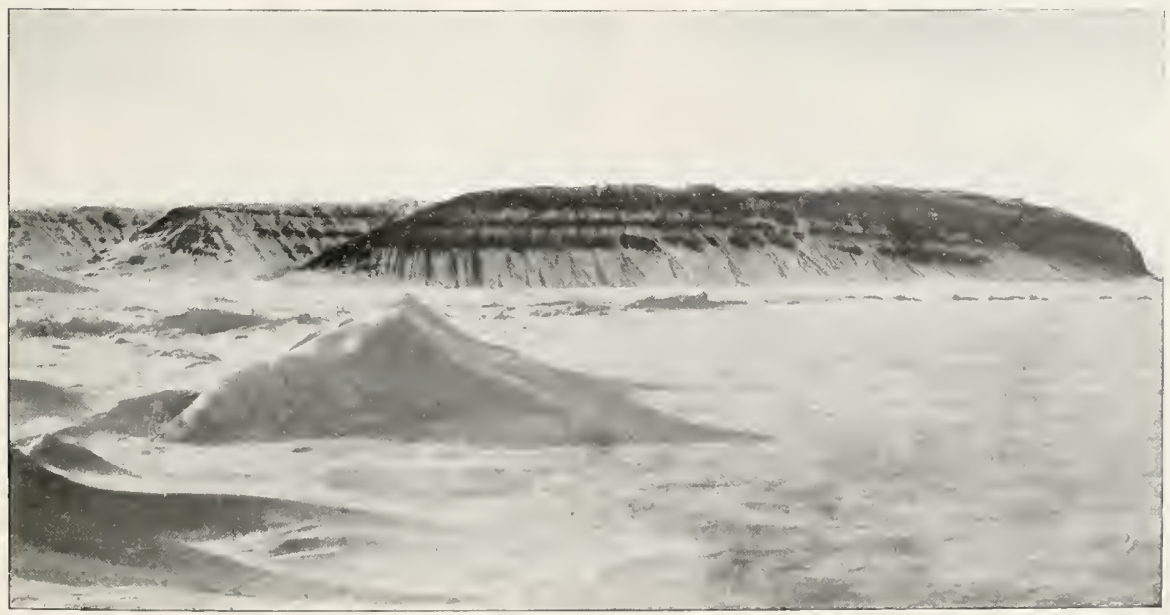

Fig. :?. 


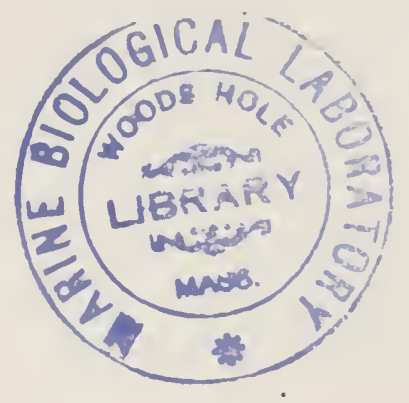



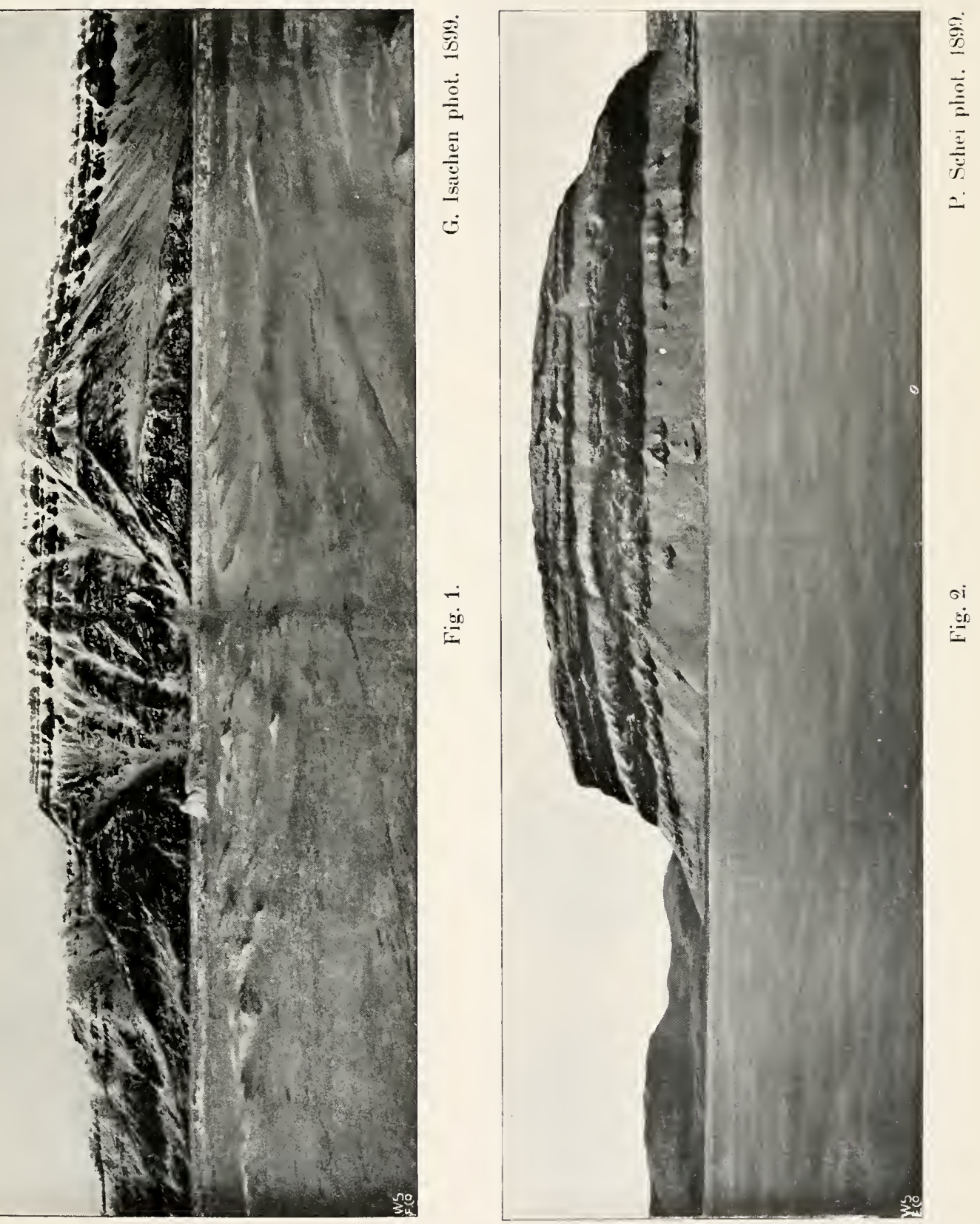


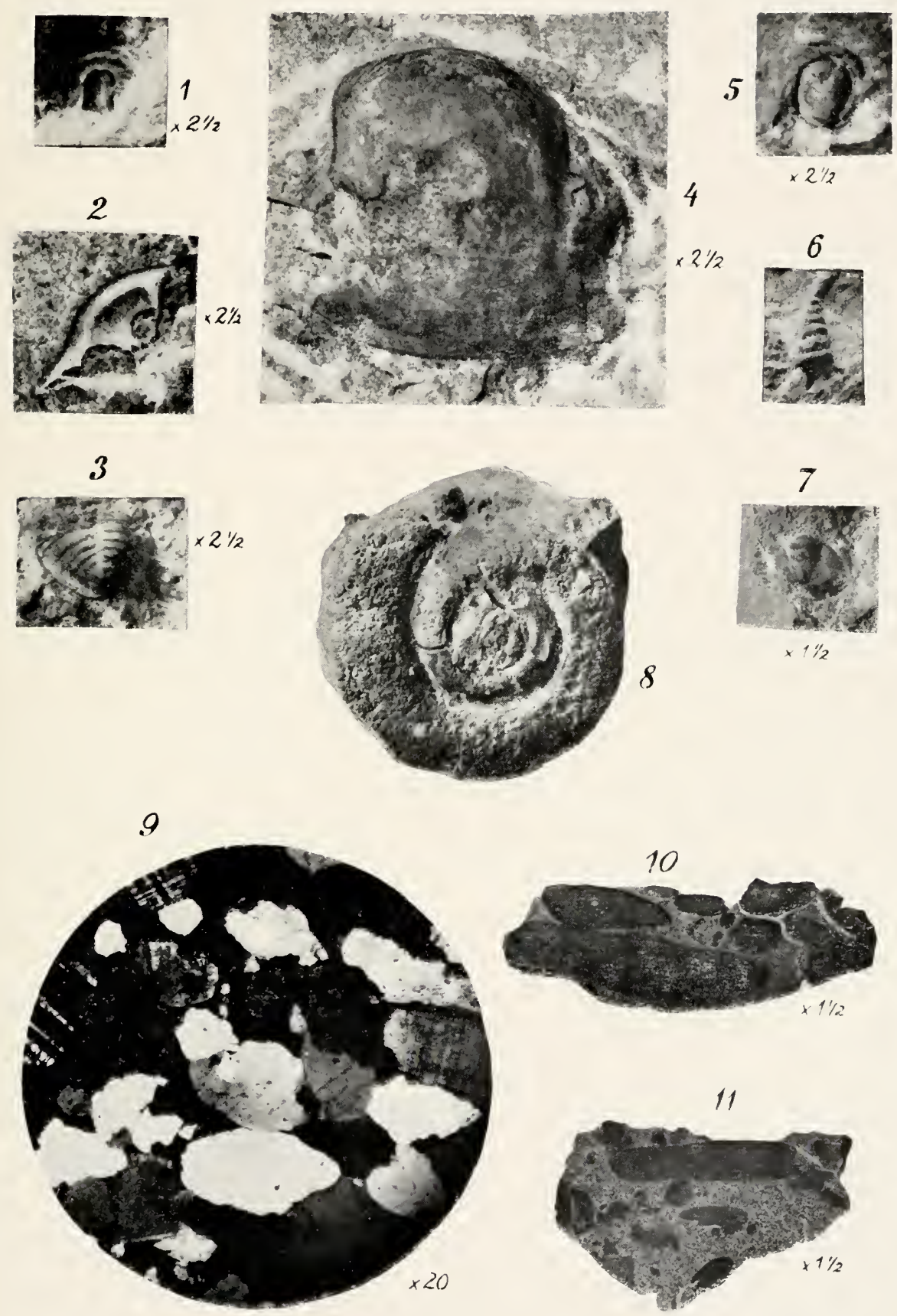

Fig.s 1-11.

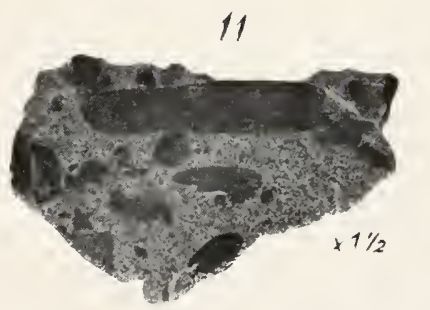



REPORT OF THE SECOND NORWEGIAN ARCTIC EXPEDITION

IN THE „FRAM” 1898-1902. No. 29.

OSKAR-E R I C H MEYER:

\title{
DIE DEVONISCHEN BRACHIO- PODEN VON ELLESMERELAND
}

\author{
MIT 8 TAFELN
}

AT THE EXPENSE OF THE FRIDTJOF NANSEN FUND FOR THE ADVAXCEMENT OF SCIENCE

PUBLISHED BY

VIDENSKA BS-SELSKA B ET I KR ISTIA N IA

(THE SOCIETY OF ARTS AND sCIENCES OF KRISTIANIA)

K R I S T I A N I A

PRINTED BY A. W. BRØGGER 



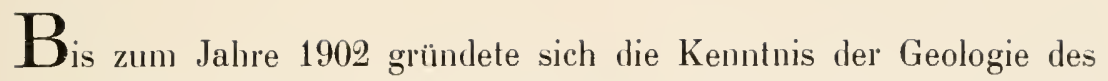
nordcanadischen Archipels auf die beiläufigen Beobachtungen von Teilnehmern der Expeditionen, die unternommen wurden, um Franklin's Schicksal aufzukläıeı.

Die sportliche Energie Peary's, des jüngsten erfolgreiclıen Nordpolfahrers, richtete sich mehr auf das Ziel als auf die wissenschaftlichen Probleme, die an dem Weg zum Pole lagen. Überdies führte ihn seine Bahn im Anfang durch die von A. P. Low (1903 bis 1904) erforschten Gebiete um die Hudson Bai.

Ältere, wissenschaftlicher Forschung dienende Fahrten waren wenig vom Glück begünstigt. Reiche Sammlungen von Fossilien und Gesteinsproben mussten unterwegs liegen gelassen werden, um die durch Krankheit gebrochenen Mannschaften nicht über Gebühr zu belasten. Immer* hin komnte aus der Bearbeitung des geringen Materiales auf Vorhandensein von Urgebirge, Cambrium, Silur, Devon, Carbon, Jura und Tertiär geschlossen werden. Diese Ergebnisse, die nur sehr allgemeiner Natur waren und z. T. den Charakter von Vermutungen trugen, wurden durch die zweite norwegische Expedition (189S-1902) nach den arktischen Inseln bestätigt und erweitert. Von dem umfassenden Material, welches Kapitän Sverdrup nach vierjähriger Abwesenheit an Bord der „Fram" nach Norwegen brachte, wurden mir die Fossilien devonischer Ablagerungen zur Bearbeitung übergeben.

Die Reichhaltigkeit dieser Funde macht zum erstenmal eine genauere Bestimmung der einzelnen Schichten möglich. Dennoch kann infolge ungüıstiger Erhaltung mancher Arten, besonders aber infolge des Fehlens untrüglicher Leitformen das vorliegende Material nicht als unumstössliche Grundlage der Einzelheiten des folgenden Gliederungsversuches angesehen werden.

Schon P. Schei ${ }^{1}$, der Geologe der „Fram“, dem ein früher Tod die Früchte seiner Forschungen entriss, hatte auf das Vorhandensein von

1 Report of the second norwegian arctic expedition in the Fram 1898-1902. 1. 4. u. 8 . 
hohem Mittel- und Oberdevon geschlossen. Ich konnte diese Annahme hestätigen und durch den Nachweis von Unterdevon und eines vereinzelten Vorkommens von Untercarbon erweitern. Die folgende Tabelle ${ }^{1}$ möge einen Überblick ïber das Alter des arktischen Devon und seiner Brachiopodenfauna geben 2 . Mit $D_{a}$ wurde von P. Scuen die ïlteste fossilleere, mit $D_{2}$ die höchste Schichtenserie bezeichnet.

\section{$D_{i}$}

Spirifer bisulcatus Sow.. . . . . . . Aelteres U'ntercarbon

Spirifer (Martinia) URı? . . . . . Oberdevon (bis Untercarbon)

Spirifer (Martinia) inflatus Scnxur. . . Oberes Mitteldevon bis Oberdevon

$D_{h}$

Dalmanella multistriata HALL. (= Dalma-

nella striatula Schloth.). . . . . . Unter- bis Oberdevon

Stropheodonta varistriata CONRAD $(=$ Stroph.

interstrialis Phil, ?). . . . . . . . . Unter- bis Oberdevon

Productella ex aff. lacrimosa Conrad. . . Chemung group

Productella arctirostrata HaLL . . . . . Chemung group

Productella subaculeata Murch. var. latior.

Gürıcıl . . . . . . . . . . Corniferous heds bis

Chemung

Atrypa reticularis Linsé. . . . . . . Unter- bis Oberdevon

Spirifer Scheii nov. spec. . . . . . . vereinzelt Unter-, meist

Oberdevon

Spirifer elegans Steis. var. . . . . . Mitteldevon

Spirifer gregarius CLapr. . . . . . . Corniferous beds

Spirifer inflatus Schnur. . . . . . . Oheres Mitteldevon bis Oberdevon

Rhynchonella princeps BARr. . . . . . . Koniepruser Kalke, Mar. cellus shales, Hamilton beds

1 Eine Übrrsicht, die nach palaeontologischen Gesichıspmnkten geordnet ist, gebe ich am Sclilusse dieser Arheit.

2 Die palaeogengraphischen Frgelnisse hahe ich in meiner Arleit ïher "Die Ent. wicklung der arktischen Meere in palatozoischer Zeit" zusammengestellt. Jahrb. f. Mineralogie ett. Beilageband 31. S. 184-219. 
Dalmanella multistriata HALL. $(=$ Dalm. striatula Schlotr.) . . . . . . . Unter- bis Oberdevon

Stropheodonta varistriata CoNRAD (= Stroph. interstrialis Phul. ?) . . . . . . . . Unter- bis Oberdevon

Stropheodonta inaequiradiata HALL. . . Upper Helderberg group Stropheodonta callosa HaLL. var. nov. latior Upper Helderberg group Chonetes lineatus Conrad . . . . . . Comiferous beds Productella ex aff. lacrimosa Connad . . Chemung group Productella arctirostrata HALL . . . . . Chemung group Atrypa reticularis Linné. . . . . . . Untel- bis Oberdevon Spirifer elegans Stein. var. . . . . . . Mitteldevon Spirifer gregarius CLAPP . . . . . . Corniferous beds Rhynchonella Horsfordi HaLL . . . . . Hamilton beds, Marcellus shales

Rhynchonella princeps BARr. . . . . . . Koniepruser Kalke, Marcellus shales, Hamil. ton beds

$D_{f}$

Orthothetes umbraculum SchLotн. . . . Calceolaschichten

Stropheodonta arctica nov. spec.

Atrypa reticularis Linsé. . . . . . . Unter- bis Oberdevon

Spirifer concinnus HaLL . . . . . . . Port Ewen-, Upper Pentamerus-, Lower Pentamerus limestone

Spirifer Scheii nov. spec. . . . . . vereinzelt Unter-, meist Oberdevon

Spirifer curvatus Schцотн. . . . . . Coblenzquarzit, ob. Coblenzschichten

Spirifer Maureri . . . . . . . . . Stringocephalenkalk

Pentamerus pseudogaleatus HALL mut. nov. recurrens

Rhynchonella Sverdrupi nov. spec.

$D_{b}$

Dalmanella multistriata HALL (= Dalmanella striatula Schцотн.). . . . . . . Unter- bis Oberdevon 
Dalmanella assimilis HaLL

Lower Helderberg group

Stropheodonta varistriata Coxnan (= Strophl.

interstrialis Pıı.. ?) . . . . . . . . Unter- bis Oberdevou

Stropheodonta demissa Coxran mut. nov. praecursor

Stropheodonta Leavenworthana HALL: . . Lower Helderberg group

Stropheorlonta spec.

Stropheodonta arctica nov. spec.

Leptaena spec.

Orthothetes woolworthamus HaLL. . . . . Lower Helderberg group Orthothetes Kiaeri nov. spec.

Atryna reticularis IINNÉ . . . . . . Unter- bis Oberdevon

Atrypa aspera Schloth. . . . . . . . Oberstes Silur bis Oberdevon

Spirifer concimms HaLl . . . . . . Port Ewen, Upper Pentamerus-, Lower Pentamerus limestone

Spivifer Scheii nov. spec. . . . . . . vereinzelt Unter-, meist Oberdevon

Pentamerns psendogaleatus HaLL . . . Upper Pentamerus limestone

Rhynchonella formosa HaL. . . . . . . Lower Helderher'g group Rhynchonella transversa HaL. . . . . . Lower Helderherg group Errtonia medialis Vanuxem var. . . . . Lower Helderberg group

Da diese Fauna eine dentliche Verwandtschaft mit den devonischen Vorkommen des Stautes New York reigt, vergleiche ich die arktischen Schichten \%um \%wecke der Bestimmung ilıres Alter's naturgemüss in erster linie mil amerikanischen Horizonten. Diese wurden in letzter \%eit melufach umbenannt oder anders alggegrenzt, so dass man häufig жwei, ja drei verschiedenen Bezcichnungen für diesellıe Schichtenfolge loggegruet. lch füge deshall, zur hesseren Ühersicht des amerikanischen Mittel- mol Unterdevon rine Tabelle an, in welcher ich die Namen für Sidhichten gleichen Alters gleichsel\%e und die, welche ich allein hemulzen werle, sperre:

\section{Mittelateristh.}

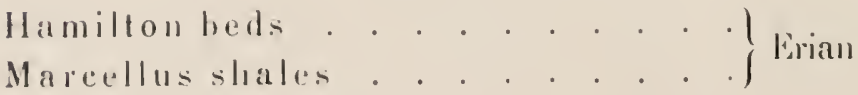


Corniferous beds = Onondaga limestone. Upper Helderberg

Schoharie grit . . . . . . . group

Esopus shales .......... . J = Ulsterian

Unterdevonisch.

Oriskany formation

Port Ewen = Kingston beds = Upper shaly limestone

Upper Pentamerus limestone $=$ Becraft limestone

New Scotland beds $=$ (Delthyris) shaly limestone

Lower Helderberg gro u p

$=$ Helderbergian

Lower Pentamerus limestone $=$ Coey. mans limestone . . . . . . . . . .

\section{$D_{a}$}

Die Serie $D$, welche eine Mächtigkeit von mindestens $500 \mathrm{~m}$ besitzt, überlagert die Schichtenfolge $C$, welche in ihren unteren Lagen als sandige Mergelschiefer, in ihren oberen als Quarzsandsteinbänke und Tonsandsteine ausgebildet ist. Aus dem tiefsten Horizont $D_{a}$ ist keine Versteinerung vorhanden, welche dieser Schicht mit Sicherheit angehört. Einige wenige nit $D a-b$ bezeichneten Stücke entstammen nach einer Vitteilung von Prof. KIER wahrscheinlich der Schicht $D_{b}$.

\section{$D_{b}$}

Diese weist einen grossen Reichtum an Fossilien auf und steht an den folgenden Punkten an:

1. Ostre Borgen

2. Vestre Borgen $f$ zwei gegenüberliegende Felsen des Gaasefjords,

3. Kap Dönninghausen (Westkap der Simmonshalbinsel).

Das Alter dieser Schicht entspricht dem der unteren Helderberggruppe und zwar besonders ihrer mittleren Ablagerungen. Für diese ist Pentamerus pseudogaleatus HaLL bezeichnend, der vor allem im Upper Pentamerus limestone häufig vorkommt. Die übrigen Fossilien sind in der ganzen Unteren Helderberggruppe und darüber hinaus im Devon verbreitet, olne einer bestimmlen Zone ein besonders Gepräge zu leihen. 


\section{$D_{c}$}

Diese Schicht, aus der nur spärliche Fossilfunde vorliegen, scheint einen Horront zu repräisentieren, ler merklich jünger ist als $D_{b}$. Neben ler für keinen Horizont clarakleristischen Atrypa reticularis findet sich von den ans $D_{b}$ bekannten Arten nur Spirifer concimms, der in der ganzen Unteren Helderberggruppe verbreitet ist. Daneben treten neue Formen auf, die eine merkliche Zeitspanne zu ihrer Entwickelnng be. durft haben müssen. An Stelle des Pentamerus psendogaleatus ist die jïngere mut. recumens getreten. Daneben fluden sich zu der Gruppe des spivifer curvatus gehörige Arten, die auf höheres Unterdevon deuten. Das Auftreten der neuen Art Rhynchonella Sverdrupi fügt sich in den Rahmen dieser Betrachtung.

$$
J_{d}, J_{\epsilon}, D_{j}
$$

sind fossilarme Schiefer und Kalksandsteinablagernngen, die an der Ostseite des Gaasefjords anstehen (Kadaverdalen und Hareuren). Nur von diesem zweiten Fundort liegen Stücke vor, die dem Horizont $D_{f}$ angehören und in grossen Mengen Orthothetes umbraculum ScnLoth. entlıalten. Diese Schichten würden, da $D_{g}$ bereits reines Mitteldevon reepräisentiert, dem obersten Unterdevon und unteren Mitteldevon zuzuweisen sein und etwa dem New Yorker Port Ewen limestone (Upper slaty limestone), der Oriskany formation und den Esopus shales entsprechen.

$$
D_{g}
$$

Schicht $D_{g}$ zeigt den Charakter von ausgesprochenem Mitteldevon. Auf unteres his mittleres Mitteldevon deuten die folgenden Arten:

\section{Stropheorlonta incequiradiata HaLL.}

Stropheodonta callosa HALL var. nov. latior.

Chonetes lineatus Connan.

Spivifer eleyans Steıs. var.

Spivifer gregarius Cisspr.

Daneben finden sich Andentungen hölıeren Mitteldevons:

Rhymchonellı Horsfordi HALL, auch

Rhynchonelle (Wilsonia) minceps Barr.

reicht, wie ich nachweisen komnte, lis in lïhlere devonsche Schichten hinein. Das Auftreten zweier Prodnctellen in vereinzelten Exemplaren. dic erst in der nïchsthöheren Schicht zu weiterer Entfaltung gelangen. liefert den Übergang zu den oberdevonischen Schichıten: 


\section{$D_{h} \quad D_{i}$}

Die beiden im Felde mit $D_{h}$ und $D_{i}$ bezeichneten Schichten weisen eine bemerkenswerte Übereinstimmung mit der amerikanischen Chemung. gruppe auf. Diese äussert sich nicht nur in grosser Ähnlichkeit der Faunen, sondern auch in überraschender Gleichartigkeit des Gesteins. Die unreinen Kalke der Serie $D_{h}$ werden von einer kalkigen. Sandsteinlage $D_{i}$ überdeckt. In ähnlicher WVeise sind auch in den vorherrschenden Sandsteinablagerungen der Chemungformation Bänke unreinen (sandigen) Kalkes eingelagert.

\section{$D_{h}$}

Ebenso wie sich in $D_{g}$ schon einige oberdevonische Anklänge finden, enthalten die Ablagerungen der Schicht $D_{h}$ noch vereinzelte Reste der mitteldevonischen Fauna:

Spirifer elegans STEIN. var.

Spirifer gregarius CLAPP.

Rhynchonella (Tilsonia) princeps BARR.

Daneben finden sich typische Vertreter des New Yorker Oberderon (Chemung):

Productella ex aff. lacrimosa ConRAD.

Productella arctirostrata Hall.

Auch Productella subaculeata, die durch ihre breitere Varietät in den arktischen Schichten vertreten ist, tritt in der Chemunggruppe auf. Frech sammelte sie im Jahre 1891 in derselben Schicht, in die el Productella hirsuta gebettet fand.

Die übrigen Brachiopoden aus $D_{h}$ geben keine Anhaltspunkte für die genauere Horizontierung der Schicht.

Dalmanella multistriata HALL.

(= Dalmanella striatula Schloтн.).

Stropheodonta varistriata CoNRAD.

(= Stropheodonta interstrialis PHILL.).

sind durch das ganze Devon verbreitet.

Zu voller Entfaltung gelangt.

Spirifer Scheii nov. spec.,

der bereits in $D_{b}$ und $D_{c}$ in einzelnen Exemplaren auftritt. Diese zeigen noch eine etwas gröbere Berippung als die zahlreichen Stücke aus $D_{h}$, 
deren Habitns sich deutlich den der geriptten carbonischen Spiriferen nähert. So lügt sich auch das Auftreten dieser neuen Art gut in die Anuahme, dass die mit $D_{h}$ u. "bezeichneten Ablagerungen in ilırer Entstelıung der carhonischen Schichtenfolge zeitlich vorausgegangen sind.

\section{$D_{i}$}

Die kalkigen Sandsteinlagen $I$, führen wohl zahlheiche aber schlecht erhaltene Fossilien, die zudem nur wenige Arten reprüsentieren. Ausser einigen Exemplaren einer Modiomorpha spec. findet sich in grossen Mengen

\section{Spirifer inflatus Scunur.}

Neben diesem Funde erlauben hesonders die erwähnten stratigraphischen Verhitltnisse das Alter dieser Schicht als oberdevonisch zu hezeichnen.

Ein dunkles Kalksteinfragment von demselben Fundpunkte Sandstens. odden wird durch die Aufschrift gleichfalls der Serie $I_{i}$ zugewiesen, olwohl es besonder's carlonische Arten enthïlt. Wohl findet sich

\section{Spirifer Urii}

auch noch in Oherdevon, doch deutet (abgesehen von Myalina amaena. L. G. DE KonINCK (?))

\section{Spirifer bisulcatus Sow.}

auf das Untercarbon.

Ich trenne deshalb dieses Fragment von der Serie $D_{i}$ und vergleiche es mit den dunklen fossillosen Kalken am Bärenkap. Diese werden von weissen feuersteinführenden Kalken und reinen fossilführenden Feuersteinen üherlagert, die einem obercarbonischen Horizonte, wahrscheinlich der Moskaustıfe, angehören '. Noclı weiter nördlich, vom Troldfjord, liegen weisse und rötliche Sandsteine in einzehnen Bruchstücken vor, die Fragmente von Spiriferen mit deutlichen Bündelrippen enthalten. Nan kömnte sie an besten mit Spirifer cameratus Mostront (Lethaea, Atlas, 'T'is. 47 c, Fig. 9) vergleichen. Vielleicht deutet ilı Vorkommen auch sclion auf marine Dyas hin, die ja in Spitzhergen gut entwickelt ist. Jedenfalls koummt noch weiter ü̈rdlich die von KitTu, heschriehene 'T'rias ror, so dass von Sirdosten nach Nordwesten immer jüngere marine Formationen erscheinen, An Gaasefjord lagert üler dem von Krar

1 Siehe O. 1\% MlYen, Dic Entwicklung der arktischen Meere in palaeozoischer 7.eit. a. a. 11. S. $210 \mathrm{fr}$. 
bestimmten Silur (Serie B und C) das ganze marine, mit der Helderberggruppe beginnende und Chemunggruppe schliessende Devon. ${ }^{1}$

Die Schichtenfolge wird abgeschlossen durch die oberdevonischen Old Red-Sandsteine, mit den von NaTnorst beschriebenen Pflanzen.

Der vereinzelte Fund des carbonischen Spirifer bisculcatus deutet auf eine Wiederkehr des untercarbonischen Meeres hin, das weiter nördlich an Bärenkapland vollständigere Schichtenfolgen hinterlassen hat.2 Das oberste Carbon (untere Dyas) wird durch Spirifer $c f$. cameratus vom Troldfjord angedeutet, während die Meeresablagerungen der Trias vom Ost.Grant-Land und den Inseln der Sverdrup-See versteinerungsreicher entwickelt sind. Mit dem Rürckzuge des triadischen Meeres schliesst im hohen Norden die geologische Überlieferung der äleren Vorzeit ab.

Strophomenidae King.

Gattung Dalmanella Hall en. Wrsogínski.

1887 Fisher, Manuel de Conchyliologie, S. 1286-1298.

1900 Zeitschrift der Deutsch. Geol. Gesellsch. Bd. 52 S. 226 ff.

Dalmanella (Schizophora) multistriata HaLL. (= Dalmanella striatula Schlotr).

Taf. I. Fig. 1 u, 2.

1859 Orthis multistriata, Halt. Pal. of New York, Bd. III S. 176. Taf. 15, Fig. 2.

1892 Schizophoria multistriata, Hall and Clarke, Pal. of New York Bd. VIII, Teil I, S. 212, 226. Taf. 6 A, Fig. 25.

Schuchert hat bereits auf die Zugehörigkeit melırer Dalmanellen (.:Schizophorien", "Orthiden"), die von amerikanischen Autoren mit besonderen Namen belegt wurden, zu der weit verbreiteten Dalmanella striatula Sснцотн. hingewiesen. Es kann kaum einem Zweifel unterliegen, dass auch Schizophoria multistriata HaLL mit der in Europa verbreiteten Dalmanella striatula Schlotн. identisch ist. Elwa 15 Stücke unterdevonischen u. 7 oberdevonischen Alters der arktischen Sammlung gehöreı zu dieser Art.

Schuchert fasst unter dem Namen Schizophoria striatula Schloth. nur die mittel- und oberdevonischen Vorkommen zusammen und behält für die unterdevonischen Vertreter den Namen Schizophoria multistriata HaLl bei. Aus dem europäischen Devon lüsst sich jedoch leicht nach-

1 a. a. O. S. $199 \mathrm{ff}$.

$\therefore$ a. a. O. S. 209-219. 
weisen, dass Dalmanella (Schizophoria) striatula nicht auf Mittel- แnd Oberdevon beschränlit ist, sondern schon in Unterdevon anftritt.

Aus den Ober-Coblenzschichten und den 'T'entaculitenschiefern von Wetzlar ist D. striatula wohlbekannt. Das Vorkommen verwandter Formen in dem Unterdevon von Podolien und Galizien emwänt Wexus. korf (Lethaea 2, 117 c). Ein Exemplar des Breslauer Museums endlich enstammt dem Unterdevon von St. Jean sur Mayenne.

Serie: $D_{\iota} D_{g}, D_{h}$.

Findort: Ostre Borgen, Brönden, Terrassen u. Spakkassen.

Dalmanella (Rhipidomella) assimilis HaLL.

Taf. I, Fig. 3.

1859 Orthis assimilis Hall, Pal. of New York III S. 175, 'Taf. 15. Fig. 1.

1592 Rhipidomella assimilis, Hall and Cilarke, Pal. of New Jork. VIH, 'T'eil I, S. 2294.

Etwa 20 schlecht erhaltene Steinkerne orler Bruchstücke von Sclıalenexemplaren gehören wahrscheinlich zu dieser Art. In Durchschnitt sind die arktischen Exemplare etwas breiter als die von HaL a. a. O. abge. bildeten.

Serie: $D_{b}$

Fundort: "wahrscheinlich" Ostre Borgen.

Stropheodonta varistriata Coxisn.

T'af. I, Fig. 4.

1859 Stropheodontı varistriata HaLl, Pal. of New Jork, Bł. III, 'Taf. 16, lig. $1-S$.

1892 Stropheodonta (Brachym)ion) varistriatu, HALL ant CLARlie, Pal. of New York, VII, 'Teil I, 'Tiaf. 13, Fig. 6-16, 21, 22.

Diese mit geringen Abweichungen weitverlureitete Art liegt auch aus dem arktischen Norden in einigen Stücken vor. Nach den Abbildungen HALs's besitzt Stropheodonta varistriatı eine grosse Variationshreite sowohl in dem Lmass als besonders in aler Wölbung der Schale. Die arktischen Stücke ïhnehn in dieser Hinsicht den kteineren flachen Exemplaren, wie sie im 3. Bande auf Taf. 16 in Fig. 1 a, b, dargestellt sind. Die charakteristische Berippung, ein regehuässiger Wechsel von einzehnen stïlkeren und 4 oder 5 schwachen Rippen, entspricht genan den Bilderı 
$3 \mathrm{c}, 3 \mathrm{~d}, 5 \mathrm{c}$ anf derselben Tafel. Auch die feine Querstreifung lïsst ein besser erhaltenes Stück gut erkennen. Die Area ist niedrig und langgestreckt, der Schlossrand mit Zähnchen besetzt. Der doppelte Schlossfortsatz ist gleichfalls gut ausgeprägt (vergl, Abb).).

Die vorliegenden $S$ Stücke lassen sich insofern in 2 Gruppen gliedern, als die starken Rippen bei der einen Gruppe scheinbar etwas grösseren Abstand haben. Bei diesem Exemplar lassen sich Rippen dreifach verschiedener Stärke unterscheiden: 2 starke Rippen umrahmen ein Feld von $2 \times 4$ (oder 5 ) feinen Rippen, die durch eine mittelstarke Rippe wieder in zwei kleine Felder von je 4 oder 5 Rippen geteilt werden, sodass im Grunde wieder dasselbe Bild entsteht. Wahrscheinlich ist dies nichts als ein Wachstumstadium, in' dem eine der feinen Rippen, die sich durch Einschaltung vermehrt haben, allmählich die Rolle einer Hauptrippe übernimmt.

Ein Exemplar von Str. interstrialis PhILl, aus dem Ob. Devon des Polnischen Mittelgebirges unterscheidet sich, ausser durch leicht welligen Verlauf der feinen Rippen, nur dadurch von der arktischen Str. varistriata, dass ein Paar der starken Rippen ein Feld von 6-S feinen umrahmen, das nicht durch eine mittelstarke Rippe geteilt wird.

Die Tatsache, dass sich je ein vereinzeltes Exemplar von Str. varistriata auch in der mitteldevonischen Schicht $D_{g}$ u, der oberdevonischen $D_{h}$ fand, macht die Annahme der nahen Verwandtschaft oder Identität der europäischen und amerikanischen Art noch wahrscheinlicher.

Fundort: Ostre Borgen (1 Stück: Brönden). (1 Stück: Spakkassen). Serie: $\quad D_{b}\left(D_{l, h}\right)$.

\section{Stropheodonta demissa ConRad m. n. praecursor.}

Taf. II, Fig. 1.

Diese unterdevonische Stropheodonta des arktischen Meeres zeigt die nächsten Beziehungen zu der aus dem Mittel- und Oberdevon bekannten Str. demissa Conrad. Mit dieser hat sie Umriss und Wölbung der Schale gemein, wie besonders Hall's Abbildung in Band VIII, Teil I, Taf. 14, Fig. 8, 9 deutlich zeigt. Hingegen lässt sich aus Fig. 7 derselben Tafel die abweichende Skulptur der Schale deutlich erkennen. Während die jüngere amerikanische Form eine gleichmässige in der Wirbelgegend gebündelte Streifung zeigt, wird die ältere arktische Mutation durch einen sehr regelmässigen Wechsel gerundeter Radialstreifen mit sehr feinen engstehenden Zwischenstreifen gekennzeichnet. Dazu kommt noch ein Querstreifung, die die meisten Steinkerne deutlich veran- 
schaulichen. Sie entspricht dem Bilde, das HaLl im IV. Bande auf Taf. 13, Fig. 2 von Str. Patersoni gibt. Doch hält sich die Querstreifung von Str. demissa m. n. praecursor in grösserer Nähe des Wirhels.

Endlich bietet die Form der Area ein Unterscheidungsmerkmat von der jüngeren Mutation. Wäłrend Str. demissa Coxr. eine spitz zulaufende Area besitzt, ist die Area von Str. demissa mut. praecursor an den Flügelenden gerundet, entspricht also in dieser Hinsicht nicht dem Bilde das Hall a. a. O. Bd. VIII, Teil I, Taf. 14, Fig. 10 (auch Bd. IV, Taf. 17, Fig. 2 p) gibt, sondern vielmelı dem der nahe verwandten Str. concava Hall, die auf derselben Tafel in Fig. 16 (auch in Bd. IV, Taf. 16 Fig. 16) dargestellt ist. Eine senkrechte Streifung der Area wie bei Str. demissa konnte ich nicht beobachten.

Ein Deltidiun (es ist nach HaLL verkümmert) fehlt der Urform und Mutation in gleicher Weiss. Die Untersuchung des inneren Baues, die der Erhaltungszustand des vorliegenden Materials verwehrte, wird erst gestatten, die palaeontologische Stellung der arktischen Form mit Sicherheit zu bestimmen. Es liegt ausser zahlreichen Steinkernen nur ein Schalenexemplar vor.

Anzalle: 10.

Fundort: Ostre Borgen.

Serie: $D_{b}$.

\section{Stropheodonta Leavenworthana HALL?}

Eine schlecht erhaltene zerbrochene Stielklappe von Stropheodonta gehört vielteicht z.ı dieser Art. Eine sichere Bestimmung ist unmöglich.

Fundort: (wahrscheinlich) Ostre Borgen.

Serie: $D_{b}$.

\section{Stropheodonta spec.}

Taf. II, Fig. 2.

Fünf schlecht erhaltene Steinkern. und Schalen-Bruchstücke ron dem Funtont Vestre Bergen (eins trïgt die Bezeichnung „wahırscheinlich Ostre Bergen") gehören anscheinend derselben Art der Gallung Stropheodonta an.

Zwei Stücke zeigen die Querrunzelı wie sie Stropheodonta Patersoni Hatr eigentümlich sind. Andererseits weist ein mülsam gewonnenes Steinkernpräparal, das ich abbilde, auf die Verwandtschaft von Str. concava Hald hin. 
Die schlecht oder garnicht erhaltene Skulptur der Schale besteht anscheinend in engen Radialstreifen, die sich am Schalenrande häufig gabeln, am Wirbel in Bündel zusammenzulaufen scheinen.

Serie: $D_{b}$.

Stropheodonta arctica nov. spec.

Taf. II, Fig. 3 u. Taf, III, Fig. 1.

Diese neue Art gehört zur Gruppe der Str. interstrialis (Str.varistriata der amerikanischen Palaeontologen). Übereinstimmend ist die Skulptur der Schale, abweichend die Verhältnisse der Wölbung. Wenn HALL unter dem Namen Str. varistriata neben flachen Stücken auch solche von starker Wölbung zusammenfasst ${ }^{1}$, so entsprechen die Wölbungsverhältnisse von Str. arctica doch keiner der Übergangsformen.

Die Stielklappe von Str. varistriata ist entweder nahezu gleichmässig gewölbt (HaLL, Bd. 3, Taf. 16, Fig. 5 b) oder aber die Stelle stärkster Wölbung liegt, im Zusammenhang mit dem wenig ausgeprägten Wirbel, näher am Stirnrande als am Schlossrande.

Die Flügel sind klein oder fehlen ganz, sodass der Schlossrand nicht immer die grösste Breite der Schale bezeichnet (a. a. O. Taf. 16, Fig. 3 a).

Im Gegensatz dazu ist Str. arctica in der Umgebung des gut ausgeprägten Wirbels am stärksten gewölbt. Ausgewachsene Exemplare nähern sich deshalb in ihren Umrissformen dem Genus Productella. Stets folgt die Linie der grössten Breite dem Schlossrande. Die gut entwickelten Flügel liefern ein weiteres Unterscheidungsmerkmal.

Taf. III Fig. 1 zeigt die Ausbildung des Schlosses und der Area. Zwei verhältnismässig kräftige Zähne unfassen den doppelten Schlossfortsatz. Die Stielöfnung ist durch ein Pseudodeltidium anscheinend völlig geschlossen, die Area durch schmale Querfurchen skulpturiert.

Fundort: Ostre Borgen $D_{b}(6)$.

Vestre Borgen $D_{c} \cdot(3)$.

Stropheodonta inaequiradiata Hall.

Taf. III, Fig. 2.

1867 Stropheodonta inaequiradiata Halt. Pal. of New York, Bd. IV Taf. 11, Fig. 24-31, Taf. 12, Fig. 12, Taf. 13, Fig. 6-11.

1892 Stropheodonta inaequiradiata, Hall and Clarke. Pal. of New York VIII, Teil I, Taf. 14, Fig. 13-14.

1 Vergl. auch die Bilder von Str. varistriata var. arata $\mathrm{H}_{\mathrm{ALL}}, \mathrm{III}, \mathrm{S} .183$, Taf. 18, Fig. 1, u. VIII, Teil I, Taf. 13 Fig. 17, 18. 
Diese aus der Upper Helderberg group des Staats New York bekannte Art ist in einem Exemplar in der canadischen Sammlung vertreten. Es zeigt mit den Stücken aus dem Schoharie grit völlige Übereinslimmung, die Hall a. a. O. Bd. IV, 'Taf. 11, Fig. 24-31 abhildet. Diese Uebereinstimnung itussert sich sowohl in Umriss und Skulptur der Schale wie in der Form und Anordnung der Muskelabdrïcke.

Fundort: Brönden.

Serie: $D_{\eta}$.

Stropheodonta callosa HaL var. nov. latior. Taf. III, Fig. 3.

$1 S 67$ Stropheodonta callosa Hal,, Pal. of New York, IV, Taf. 11, Fig. 4-10 u. Taf. 20, Fig. S, 9.

$1 S 92$ Stropheodonta callosa, Hald and Cuarke. Pal. of New York, VIII, Teil I. Taf. 16, Fig. 37.

Die zwei leidlich erhaltenen Armklappen der arktischen Varietüt dieser amerikanischen Art stimnen mit dem Bilde äberein, das HaLL a. a. O. Bd. IV, Taf. 20, Fig. 9 b und Teil VIII, Bd. I, Taf. 16, Fig. 37 gibt. Der gleiche Umriss der Muskeleindrücke und die Zühnchen am Schlossrande weisen auf die nahe Verwandtschaft der canadischen Varietat mit der New Yorker Stammform hin.

Die nicht unbeträichtliche Abweichung, die sich aus den anderen von Hatr gegebenen Abbildungen erkennen lisst. liegt in dem Schalenmmriss. Wïlrend die grösste Breite der arktischen Varietiit der Linie des Schlossrandes folgt, liegt sie bei der New Yorker Form etwa in der Mitte der Schale. Diese Tatsache äussert sich darin, dass die Flügel von Str. callosa var. latior im Gegensatz zu Str. callosa s. str. leicht ausgezogen erscheinen.

Die Skulptur der Schaten bestelıt in einer feinen Lïngsstreifung.

Anzahl: 6 .

Fundort: Bröndeı.

Serie: $D_{g}$.

\section{Leptaena spec.}

'Taf. III, Fig. 4.

Diese Art, die keiner der mir bekannten völlig gleicht, dürfte Leptaena lepis $\mathrm{Br}$. am nächsten stehen. Das vorliegende Material kann nicht als sichere Grundlage für die Aufstellung einer neuen Art gelten. 
Neben einer leidlich erhaltenen Armklappe sind nur Bruchstücke einer Stielklappe vorhanden. Die Umgebung des Wirbels dieser Klappe ist stärker gewölbt als bei Leptaena lepis, sodass der arktische Vertreter äusserlich einer Productella nicht unähnlich ist. Abweichend ist der Umriss der besser erhattenen Armklappe. Die Linie des Stirnrandes kommt einem Halbkreis nahe, während sich die von Leptaena lepis der einem Rechteck nähert. Dieser Formunterschied ist zum Teil dadurch bedingt, dass in den Stirnrand der europäischen Art ein flacher Sinus eingesenkt ist, welcher der nordischen fehlt. Uebereinstimmend ist hingegen die feine radiale Skulptur und die deutliche Punktierung der Schale. (Vgl. Quenstedt: Brachiopoden 1871 Taf. 57, Fig. 56, 57 S. 595-97. Schnur: Brachiopoden der Eifel 18.;. Paleontographica Bd. III S. 223, Taf. 39, Fig. 5.

Fundort: "wahrscheinlich" Ostre Borgen.

Orthothetes woolworthanus HaLL. Taf. IV, Fig. 1.

1859 Strophomena woolworthana, HALL, Pal. of New York. Bd. III, S. 192, Taf. 17, Fig. 1, 3.

1883 Streptorhynchus woolworthana, HaLL, Sei. Ann. Rep. New York State Geolog. Taf. 39, Fig. 25-31.

1892 Orthothetes woolworthana, Hall and Cranke. Pal. of New Tork. Bd. VIII, Teil, S. 255, Taf. 9, Fig. 25-31.

Die Skulptur der flach konkaven Stielklappe besteht in einer radialen Streifung mit Ansätzen zur Gabelung in der Nähe des Stirnrandes. Der gerade Schlossrand bezeiclmet die Linie der grössten Breite. Das Medianseptum ist kräftig und kurz. Die Stielöffnung ist durch ein Pseudodeltidium abgeschlossen. Darunter befindet sich ein gerundeter Höcker, der rechts und links von je einem Schlosszahn flankiert wird (Vgl. a. a. O. VIII, I. Taf. 9, Fig. 3 c).

Eine Armklappe liegt nicht vor. Die Innenseite der einzigen Stielklappe ist durch eine Slielklappe fast gleicher Grösse der Gattung

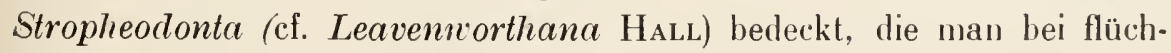
tigem Anblick für die zugehörige Armklappe halten könnte.

Fundort: (wahrscheinlich) Ostre Borgen.

Serie; $D_{b}$. 


\section{Orthothetes Kiaeri n. sp. \\ Taf. III, Fig. 5 .}

Diese neue Art hat auf den ersten Blick eine gewisse Aehnlichkeit mit Orthothetes umbraculum Scmotr., ist aber im allgemeinen grüsser als die arktischen Vertreter dieser jüngeren Art. Ein wichtigeres Unterscheidungsmerkmal ist die Berippung. Die Rippen der neuen Art sind in der Niihe des Schnabels gebündeft und neigen äherdies zur Gabelung am Stimande, wihrenul sich die von Orth. umbraculum duch Einschaltung vermehren (siehe unten). Auch die Körnung der Rippen fehlt der neuen arklischen Art.

Die Höhe der Area beträgt ein Viertel ihrer ganzen Breite. Ein grosses Pseudodeltidium verschliesst lie Stiebuffnung zum grössten Teil. Medianseptum und Zahnstützen sind nicht sehr lang, aber kriftig entwickelt. Die Form der Muskeleindrücke zeigt Fig. う.

Anzahl: 6 .

Fundort: (wahrscheinlich) Ostre Borgen.

Serie: $D_{\iota}$.

\section{Orthothetes umbraculum ScuLotinew.}

Taf. IV, Fig. 2.

1566 Orthis cf. Pecten Richten Zeitschı. d. Deutsch. Geol. Ges. Bd. XVIII, S. 417 Taf, VI Fig. 14-17.

1971 Orthis umbraculum. Quesstedr, Die Brachiopoden, Taf. 56, Fig. 23-25 S. 574, wo die ïlteste Literatur angefülırt ist.

1992 Orthis umbraculum, HaLl. Pal. of New York Bd. VIII Teil I S. 256 Anm. 1.

1596 Orthothetes umbraculum Orment, Fossiles Devoniens. Bull. Soc. Geol. de France 3. Serie Bd. XXIV Tal. 27 Fig. 9-11.

1907 Orthothetes umbraculum WV ALTEs; Jahrb. f. Mineralogie etc. Beilagebd. 24 S. 281 S2 ('Tuf. VIll, Fig. 12?)

Diese Art, die schon im Unterdevon auftrilt, ist besonders aus den Unteren Calceolaschichten von Gerolstein hekannt. Doch wurle sie auch in Amerika aufgefunden, wenn auch Hal., die Ilentitiit der amerikinischen und europaisischen Vertreter in Frage stellt.

Einzelne mit I) bezeichnete Kalkphatten, die wahrscheinlich dem unteren Mitteldevon angehören, sind fast gan\% aus Schalen dieser Art zusanmengesetzt. Besonders charakteristisch fïr alle mir vorliegenden Vertreter dieser Art ist die 'Tatsache, dass die Rippen sich niemals 
durch Gabelung vermehren, sondernn schwächere Rippen zweiten, bei grossen Individuen auch dritten Grades zwischen sich nehmen. Die arktischen Stücke zeigen diese Art des Wachstums ebenso wie die von Gerolstein. Diese unterscheiden sich nur dadurch von den nordischen Vertretern, dass die europäischen Stücke die Körnung der Rippen, die Rıchter auf das nahe Zusammenrücken der Anwachsstreifen zurückführt, deutlicher erkennen lassen. Dies kann durch den Erhaltungszustand bedingt sein; wahrscheinlicher noch ist die Annahme, dass dies Merkmal nicht konstant ist, zumal mir ein Stück vorliegt, das zwischen Lissingen und Gerolstein gefunden wurde und den arktischen Exemplaren in dieser Hinsicht völlig gleicht.

Area und Muskeleindrücke sind leider bei allen Stïcken zerstört.

Fundort: Hareuren.

Serie: $D_{f}$.

\section{Productidae GraY.}

Chonetes lineatus ConraD.

Taf. IV, Fig. 3.

1867 Chonetes lineata, HALL, Pal. of. New York, Band IV Taf. 20 Fig. 3.

1902 Chonetes lineata, Hall and Crarke, Pal. of New York Bd. VIII Teil I Taf. 16 Fig. 34.

Einzelne Kalkfragmente enthalten zahlreiclıe Schalen dieser Art oder ihrer Bruchstïcke. Der gerade Schlossrand bezeichnet die grösste Breitenausdehnung der Klappe. Die niedrige Area trägt an ihrem oberen Rande je 4 Stachelansätze rechs und links des flachen Wirbels. Die Höhe des Deltidiums ist grösser als seine Basis. Einzelne Steinkerne zeigen das nicht sehr lange aber verhältnismässig kıäftige Medianseptum. Die Skulptur der Schale besteht in einer feinen Längsstreifung.

Fundort: Brönden.

Serie : $D_{g}$.

Genus Productella Hall.

Taf. IV.

Neben der Gleichartigkeit des Gesteins sind es vor allem Productellen, welche die Schicht $D_{h}$ der Chemunggruppe gleichzustellen erlauben. Zwei Arten dieser Gattung, Productella subaculeata Murch., 
besonders aber Productella arctirostrata HaLL aus dem arktischen Gebiete sind denselben amerikanischen Arten zun Verwechseln ihnlich, ol wohl fast 30 Breitengrade zwisehen den Fundorten liegen. Die Gleichartigkeit des Gesteins, das die fossilen Reste in New York wie am Gaasefjord umschliesst, machen die Uebereinstimmung noclı angenfailliger.

Die ledulende Entfernung erklitrt ohne weiteres, dass das arktische Becken nehen diesen bekannten Formen anch eine nene Productella herrorzubringen vermochte, die sich mit keiner Art der anerkanischen Fauna völlig decki, sich aber gut in den Formenkreis der in Amerika lıeinischen Productella lacrimosa CoNRAD einfügt. Sie grehört der milteldevonischen Schicht $D_{\text {g }}$ an, die jedoch auch oberderonische Anklänge aufweist.

\section{Productella ex. aff. lacrimosa Connad. Taf. IV, Fig. 7.}

In einem einzigen Exemplar liegt die Stielklappe einer Productella vor, deren Umriss und Wölbung der bei HaLL Brachiopoda I. Taf. 23, Fig. 22 algebildeten Productella lacrimosa var. lima Coxrad sehr ähnlich ist. Die flache mediane Einbuchtung ron Wirbel zum Schalen. rand ist fast ebenso deutlich ausgebildet. Die Flügel sind etwas länger ausgezogen, wodurch die rechteckige Form der HaLs'schen Abbildung trapezartig verzert ist. Die Flügel tragen wie bei Productella lacrimosa var. lima die Stellen stärkster Ausliddung der Stachehn (Areal. stachelı). Doch bildel die Form mul Anordnung der Stachelansitze ein Merkmal der Unterscheidung. Das arktische Exemplar hat stecknadelknopfförmige Stachelansïtze, die dicht gestellt aber unregehmissig verteilt sind. Demgegenüber fällt sofort die altemierende konzentrische Anordnung anf, wie sie die linglichen, wie kleine Leisten gefornten Stachelansitze von P'roductella lacrimosa lima zeigen.

Da mir nur ein einziges Exemplar vorliegt, dessen Erhaltungsoustand weitere Merkinale zu heobachten verwehrt, sehe ich von der Aufstellung einer nenen Art oler Varietiit ab.

Fundort. Brönden, Gitasefjorden.

Serie: $I)_{y}$.

Einige (3) andere unvollstïndige und verquetschte Schalenreste von Sprekkassen ans Serie $D_{\text {h }}$ gehı̈ren wahrscheinlich zu dieser Art. 


\section{Productella arctirostrata HALL.}

Taf. IV, Fig. 6.

1857 Productus arctirostratus Hald. 'Tenth Report New York State Cab. Nat. Hist. S. 177.

1867 Productella arctirostrata HaLl. Palaeontology of New-York, IV Taf. 26 Fig. 16-23, Taf. 25, Fig. 22.

1892 Productella arctirostrata Hall and Clarke, Palaeontology of New-York VIII Teil I Taf. 17, Fig. 36.

Es gelang, von dem einzigen vollständigen Exemplar die Stielklappe loszulösen und dadurch auch die Brachialklappe freizulegen. Erst hierdurch wurde es möglich, fünf weitere Armklappen gleichfalls dieser Art sicher zuzuweisen, da zwar die gut erhaltene Stielklappe durchaus mit der von HaLl abgebildeten übereinstimmt, die Brachialklappen jedoch bedeutende Abweichungen zeigen. Auf Grund dieser Tatsachen muss angenommen werden, dass besonders die Band IV Taf. 26 Fig. 18, Taf. 25 Fig. 22 u. Bd. VIII, I. Taf. 17 Fig. 36 abgebildeten Klappen einer anderen Art angehören. Die vorliegenden kleinen Klappen zeigen zwar dieselbe Skulptur wie die Stücke, welche Hall unter Fig. 16 u. 17 a. a. O. abbildet, doch dehnen sich die Stachelansätze ${ }^{1}$ gleichmässig über die ganze Schale bis zum Schnabel aus. Dieser ist auch stärker herausgewölbt, als es das Profil in Fig. 17 zeigt, sodass die Brachialklappen des arktischen Gebietes auf den ersten Blick den Eindruck von Stielklappen erwecken. Das erwähnte zerlegte Präparat schliesst jedoch jeden Zweifel aus, wenn auch der der kleinen Klappe eigentümliche Schlossfortsatz nicht zu beobachten ist.

Fundort: Terrassen, Brönden.

Serie: $D_{h}, D_{g}$.

\section{Productella subaculeata Murch var. latior GÜRICH.}

Taf. IV, Fig. 4-5.

1896 Productella subaculeata var. latior GüRICH. Palaeozoikum im polnischen Mittelgebirge Seite 218. Vergl. auch

1903 Gürich, Das Devon von Debnik bei Krakau. Pal. und Geol. Oester.Ungarn Band 15 Seite 135.

1897 Schuchert: American fossil Brachiopoda Seite 318.

1 Dass die Oberseite der Armklappe, auf welcher der Leib des Tieres ruhte, nicht eigentliclıe Stacheln getragen haben kann, ist selbstverständlich. Wenn die grosse Klappe auf ihrer Aussenseite produziert, kann die kleine das gleiche Bestreben zeigen, ohne jedoch echte Stacheln hervorzubringen. 
Productus subaculeatus Murcn. bildet die grundlegende Form für das Genus Productella Has.. Von den zahbeichen, nicht selu scharf begrenzten Productellaarten seien hier erwïhnt: Die hesonders im Mittelaber anch in Oberdevon ${ }^{1}$ weit verbreitete Productella subaculeata HaLl. und dic ihr mahe verwandte l'roductella spimulicosta HaLL. Dieser schliesst sich eng an die durch stärkere Wölung der Schale ausgezeichnete Productella Herminae Frecn, wïhrend dersellue Autor die von ihm anfgesteltte Productella forojuliensis als eine vicarierende Lokalart von Productella subaculeata HALL. ansieht. Sie unterscheidet sich auf de:: ersten Blick durch eine wesentlich flaclsere und breitere Siliale.

Die von Hal abgebildeten Exemplare von Productella subaculeata. entstammen mitteldevonischen Schichten nnd zwar den Corniferous beds. Doch fand ich in der Sammlung von Professor Finecu Productellen der oherdevonischen Chemunggruppe, die ohne Zweifel zu Productella sub. aculeata gerechnet werden müssen. Sie wurden in den gleichen Schichten gesammelt wie die an die Chemunggrupe gebundene, mit starken Arealstacheln ausgestattete Productella hirsuta Hals. Die zur Gruppe Productella subaculeata (Murcir.) Hals gehörenden kleineren Formen kommen also auclı noch neben den grösseren Formen vor, die in Amerika das Oberdevon kennzeichnen.

Die arktischen Formen unterscheiden sich von den New Yorker Stücken mit Ausnahme eines, das ihmen völlig gleicht nur durch etwas flachere und breitere Schalenform. Ich stelle sie deshalb zu der von Gürıcı beschriebenen var. latior. Auch mit Productella shmmardiana HALL, einer flacheren Lokalvarietat (Burlington) von Productella spimulicosta HALl, zeigen sich bemerkenswerte Uebereinstimmungen (vergl. HaLl Band IV Taf. 23 Fig. 36 und Brachiopoda Band II Taf. 17 Fig. 6).

Productella subaculeata Murch. var. latior Gürici unterscheidet sich von der Urform und besonders von der $\mathrm{Pr}$. subaculeata var. angustior durch geringere Wölbung und stärkere Breitenausdehnung am Stirmiand.

Das nur kurze aber deutliche Medianseptum ist beiderseitig von zwei Leisten, die vom Wirhel ausgehen, eingefasst.

Die lïnglichen, gnt ausgeprägten Stachelansätze sind gleichnüssig angeordnet und zienlich dicht über die grosse Klappe verteilt.

1 Mir liegen obredevonische Stücke vor aus Rusland, (Ranowsk, Werchi, Rjüsan), dem polnischen Mittelgebirge (Karczowska) mnd Belgien (Rhisne). 
Die Stücke aus der Chemunggruppe des Staates New-York, die mir zum Vergleich vorliegen, gehören, mil Ausnahme eines, der schmäleren Varietät an.

Eine Stielklappe der Breslauer Sammlung, die ich in den devonischen Geschieben von Preussisch Stargard (Suzemin) fand, rechne ich zu der breiten Form. Die Schalen endlich, die Gürich im Polnischen Mittelgebirge sammelte, liegen mir gleichfalls im Original vor. Sie lieferten die Grundlage für die Scheidung der beiden Varietäten. Ich stelle die Pr. subaculeata var. latior der var. angustior im Bilde einander gegenüber.

Einzelne der bei HaLL in Band IV und VIII abgebildeten Schalen von Pr. subaculeata (Murch.) Hall und Pr. spinulicosta Hall zeigen einen stärker überhängenden Wirbel als die mir in Original zugäng. lichen Stücke. Iın übrigen stehen die beillen von HALL aufgestellten Arten der Pr. subaculeata Murch. var. angustior Gürich am nächsten.

Fundort: Terrassen, Gaasefjorden.

Anzahl: 12 Stielklappen oder deren Steinkerne.

Serie: $D_{h}$.

Atrypidae DALL.

Gruppe der Atrypa relicularis Linné.

Atrypa reticularis LinNé.

Taf. V. Fig. 1-5.

Die häufige Atrypa reticularis zeigt im hohen Norden eine bedeutende Variationsbreite. Das eine Ende der Reihe deckt sich fast völlig mit dem von Hall Taf. 55, Fig. 5 abgebildeten Exemplar aus den New Yorker Fundorten. Meist ist jedoch die Brachialklappe etwas stärker gewölbt als es Fig. 6 zeigt. Ihr Profil nähert sich mehr dem des in Fig. 4 dargestellten Stückes.

Bei weitem grössere Abweichungen zeigt das andere Ende der Entwickelungsreihe. Ein tiefer Sinus schneidet in die Brachialklappe ein und wölbt diese stark heraus im Gegensatz zu der flachen Stielklappe. Der Schlossrand verläuft gradlinig. Breite stets grösser als Hölı. Mit den typischen New Yorker Exemplaren, wie in Fig. 3, Taf. 55 dargestellt, deckt sich keines der vorliegenden arktischen Stücke. Sie zeigen sämtlich grössere Breite. Doch ist diese Schalenform nicht auf die arktische Region beschränkt. In der Eifel (Gerolstein) finden sich Stücke, welche dieselbe extreme Ausbildung des Sinus zeigen. Die jungen Exemplare zeigen oft eine Rille vom Schnabel zum gegenüberliegenden Schalenrand auf rer Brachialklappe, was auf das Vorhandensein eines Mediansep- 
tums schliessen lassen könnte. Die Stücke erwecken deshalb auf den ersten Blick den Eindruck ron Orthiden. Doch zeigt unter melırfachen Schliffen einer deutlich die Ausbildung eines Spiralkegels, der auch diese Stücke der Gruppe der Atrypa reticularis zoweist. Der Sinus ist ganz schwach ausgebildet. Die Schalen sind elıenso wie die ler ausgewachsenen Exemplare breiter als die der bei HaLL abgebildeten jungen Tiere.

Fundorte: Ostre u. Vestre Borgen, Kap Dünninghausen, Brönden. Vestsiden af Gaasefjorden, Terrassen, Spakkassen, Rypeelven.

Atrypa aspera Schloti.

Taf. V. Fig. 6.

1865 Atrypa aspera Davidsox, British Fossil Brachiopoda Band III Taf. 10 Fig. $5-8$ und ebenda 1884 Bd. V S. 40.

1867 Atrypa spinosa Hal., Pal. of New York, Bd. IV, p. 322, T'Taf. 53 A, Fig. 1-14, 18, 24, 25.

1885 Atrypa spinosa Hall and Clakke, Pal. of New York, Bd. VIII, Teil II, Taf. 55, Fig. 21, 22.

Neben der in der ganzen Schichtenfolge des arktischen Devon verbreiteten Atrypa reticularis findet sich in der ältesten Serie $D_{b}$ in vielen Exemplaren die ihr nahe verwandte Atrypa aspera Schlotн. Nur eins der Exemplare erreicht die Grösse von dem, welches Davidson a. a. O. in Fig. 6 abbildet. Dieses stammt von Kap Dönninghausen. Der Durchmesser der äbrigen, die an Ostre Borgen gesammelt wurden, be. trägt nur $6-8 \mathrm{~mm}$.

\section{Spiriferidae KıNG.}

Spirifer concimmus Hal,L.

Taf. V. Fig. 8.

1861 Hall, Naturel history of New York. Part VI Palaenntology Vol 3. Seite 200. Taf. 25, Fig. 2 a-i.

1894 Ebenda. Vol S. Brachiopola II. 'Tar. 30, Fig. 1-2.

1895 Hall and Cuarke, Handhook of the Brachiopoda II Tar. 27, Fig. 4-5.

Zu der von Hat. Spirifer concimmus genannten Species rechue ich 33 Exemplare ans den Schichten $I)(a$ ?) $b$ u. $c$. In Gesamthabitus stimmen sie durchaus mit den Stincken ans den Helderherg mountains 
überein. Die Breite übertrifft stets die Höhe, die Flügel sind meist gerundet, oft leicht vorspringend. Die Seitenflïchen tragen etwa je 14 gerundete nicht sehr hohe Rippen, die bei einzelnen Exemplaren Ansätze zur Spaltung zeigen. Diese geringe Abweichung von den von Hall abgebildeten Stücken kann ich nicht als ein wesentliches Unter'scheidungsmerkmal anselıen, da Schalen ohne Spaltrippen neben solchen mit Spaltrippen in derselben Schicht vorkonmen. Die flacheren breiteren Rippen von Sinus und Wulst laufen fast stets in der Richtung anf den Sinus zusammen, wie dies auch die Abbildung bei HALL erkennen lässt. Die kleinen Schlosszähnchen sind genau so ausgebildet, wie dies die Abbildung auf Taf. XXX Fig. 2, des 8. Bandes der Palaeontology of New York erkennen lässt.

Fundorte: Ostre und Vestre Borgen, Gaasefjorden.

Spirifer Scheii nov. spec.

Taf. V. Fig. 7 u. Taf. VI. Fig. 1.

In $D_{b}, D_{c}$, besonders aber in $D_{h}$ finden sich Speriferen, die von den bekannten Arten genügend abweichen, um die Aufstellung einer neuen Spezies zu begrïnden. Besonders gekennzeichnet sind sie durch eine starke Tendenz zur Spaltung der Rippen, wie sie in solchem Maasse den bekannten devonischen Spiriferen nicht eigentümlich ist. Die vier Seitenteile der Schalen tragen je 18-21 Rippen. Die letzte Zahl scheint bei ausgewachsenen Exemplaren die Regel zu bilden. Die dem Sinus zunächst liegenden Rippen sind zu zweien oder zu dreien gebündelt und laufen erst dicht am Schnabel zusammen. Die Bündel sind besonders auf der Brachialklappe deutlich sichtbar und oft durch verhältnismässig tiefe Furchen getrennt. Die Sattelrippen sind rechts und links neben einer schmalen Medianfurche gruppiert, und gleichfalls als Spaltrippen entwickelt.

Der grade Schlossrand übertrifft an Länge stets mehr oder weniger die Gesamthöhe der Schale. Der gekrümmte Schnabel umschliesst eine konkave Area von normaler Ausdehnung. Der Sinus, welcher bei den flacheren jungen Exemplaren geringer ausgebildet ist, schneidet bei ausgewachsenen Formen tief in die Brachialklappe ein und reicht anderseits bis zur Schnabelspitze. Die Skulptur der meist garnicht, in einzelnen Fällen schlecht und unvollständig erhaltenen Schale scheint in einer feinen conzentrischen Streifung zu bestehen.

Die Art der Berippung schliesst eine Verwandtschaft mit Spirifer Verneuili, dessen typische Formen niemals Spaltrippen zeigen, aus. Auch zu Spirifer aperturatus, dessen Mittelrippen geteilt zu sein pflegen, 
ergeben sich keine natürlichen Beziehungen, olwolıl diese Gruppen in ihrem Gesamthabitus den arktischen Stücken nicht unähnlich sind. Besonders ein Exemplar aus den Unt. Calceolaschichten von Schmidtheim, das Scupin 1 abbiklet und der Verwandtschaft des $S_{p}$. aperturatus zuWeisl, zeigt eine bemerkenswerte Ähnlichlkeit. Doch ist Sp. Scheii stets viel gröber berippt als das erwälnte Stück, welches mir im Original zum Vergleich vorliegl.

Hieraus ergeben sich die nächsten Beziehungen zu Spirifer daleidensis Steın., der nach Sctrox zuerst in der Siegener Grauwacke auftritt und bis in die Oberen Coblenzschichten reicht. Doch übertreffen die arklischen Stïcke diese Art stets an Feinheit und deshalb an Zahl der Rippen. Auch scheint die seltene Spezies des Sy. daleidensis stets einen etwas gekrümmten Schalenrand zu hesitzen.

Sp. Scheii dürfte als ein Vorläufer der gerippten carbonischen Spiriferen anzusehen sein, ron denen besonder's Spirifer duplicicosta PhuL., der mir in schömen Exemplaren aus Neurlorf bei Silberberg in Schl. vorliegt, eine bemerkenswerte Änlichkeit in der Berippung aufweist.

Erwähnt sei noch die auffallende Convergenz mit Spirifer fasciger Kaysers., die sich in nahezu gleicher Ausbildung der dreifach gebündelten Rippen ïussert.

Eine Entwickelung zu immer feinerer Ausbildung der Rippen ist insofern wahnehmbar, als die wenigen aus $D_{b}$ und $D_{c}$ vorliegenden Stïcke gröhere Berippung zeigen als die, welche der Schicht $D_{h}$ angehören. Infolgedessen tragen die Seitenflächen der älteren Vertreter auch mu je 14-16 Rippen.

Fundorte: vereinzelt Ostre u. Vestre Borgen, häufig Terrassen u. Spakkassen.

\section{Gruple des Spirifer curvatus Schuotu.}

'Taf. VI, Fig. 2-4.

1900 Scurix. Die Spririferen Deutschlands S. 3S, Taf. 3. Fig. S-11, wo weilere Jiteratur.

Es liegen mir einige schlecht erhaltene Spiriferen mit ungefalteten Schalen vor, die ich zu der Gruppe des Spivifer curvatus stelle. Während die kleineren Stücke der Jugendform dieser weit verlneiteten Art gleichen, seheinen mir die grö̈sseren (ausgewachsenen?) sich dem Habilus

1 Die Spiriferen Deutschlands. Palaeont. Ahlamdl. VIII Heft 3. Taf. VII, Fig. 13. 
des mit Spirifer curvatus eng verwandten, nur wenig jüngeren Spiri. fer Manreri Holzapfel zu uäherı.

Die ersten.zeigen denselben seitlich nicht allzu scharf abgegremzten mehr oder weniger hoheı Sinus, der Spirifer curvatus kennzeichnet. Die Flügel sind etwas mehr gerundet und weniger ausgezogen als bei den durchschnittlichen Individuen der Eifel. Die niedrige Area, deutliche Zahnplatten und der bis in die Schnabelspitze reichende Simus lassen es als gesichert erscheinen, dass dieser Teil der arktischen Stücke in diese Gruppe zu stellen ist. Das Fehlen des Medianseptums in der Stielklappe schliesst eine Verwandtschaft mit Spirifer robustus Barr. aus.

Andererseits zeigen andere Stücke eine völlige Übereinstimmung mit dem Bilde, welches Scupin 1. c. Taf. 4, Fig. 3 a von Spirifer Manreri giebt. Durch feinere Ausbildung der Zahnplatten, ein charakteristisches Merkmal von Spirifer Maureri, wird diese Annahme gestützt.

Die Ausbildung der Skulptur zur Bestimmung heranzuziehen, verwehrte der Erhaltungszustand, da die meisten Exemplare nur als Steinkerne erhalten sind. Wo sich Bruchstücke der Schale finden, ist ihre Oberfläche zerstört.

Fundort: $D_{c}$ Vestre Borgen.

Spirifer curvatus sieben Exemplare.

- Maureri fünf Exemplare.

Gruppe des Spirifer elegans Stein.

Spirifer elegans Stein. (var.).

Taf. VI, Fig. 5.

1853 Spirifer elegans Stein. Geognost. Beschr. der Eifel S. 72 Taf. 7 , Fig. 2.

1871 - $\quad$ - Kayser (Ex parte). Die Brachiopoden des Mittelund Oberdevon der Eifel. Zeitschr d. Deutschen Geologischen Gesellschaft Bd. 23, S. 569, Taf. 11, Fig. 2 d, e.

1882 - - Barrors. Asturie et Gallice, S. 248.

1884 - - Tschernischew. Mater. z. Kenntnis der devonischen Ablagerungen Russlands S. 31, Taf. 2, Fig. 9.

1887 - $\quad$ - Tschernischew. Fauna des mittleren und oberen Devon etc. S. 65, Taf. 9, Fig. 3-4, 7.

1896 - - Gürıcu. Polnisches Mittelgebirge S. 247. 
1903 Spirifer elegans Güırn. Das Devon von Debnik bei Krakau. Beitrïge zur Palaeont. u. Geol. Oesterreich Ungarns und des Orients S. 139, 140. 'Taf. 14, Fig. 16-17.

Unter Spirifer elegans s. str. verstehe ich nur die schmaleren For. nten im Sinne Scurns (l. c.t. S. 94), von der die nahe verwandten breiteren Formen mit zahlreicheren Rippen, wie Spivifer mucronatus Habl. oder Spirifer diluvianus Streıx. zu trennen sind. Ob diese beirlen Arten identificiert (Frecu, Jahrb. f. Mineralogie etc. 1895 Bd. 2, S. 65) werden müssen oder ob die rheinischen Vertreter als var. diluviana (Scupis l. c. t. p. 95) von dem amerikanischen Spirifer mucronatus ${ }^{1}$ zu scheiden sind, kommt hier nicht in Frage, la vom Gaasefjord nur Stücke vorliegen, die der Spezies des Sp. elegans s. str. angehören.

Nur in der Ausbildung der Rippen lässt sich eine geringe Abweichung erkennen. Während Scurrs die Zahl 6 als durchschnittliches Minimum für jede der Seitenflächen angiebt, bildet diese Angabe für die vorliegenden Muscheln die Regel. Einzelne Exemplare tragen sogar nur je vier Rippen rechts und links neben Sinus und Wulst. Die Abbildung Taf. VI, Fig. 5 zeigt eine solche extreme Form. Naturgemäss geht mit dieser Verringerung der Anzahl eine Verbreiterung der Rippen Hand in Hand. Doch kann ich diese Abweichung bei dem recht variablen $S p$. elegans nur als ein untergeordnetes Merkmal ansehen.

Von entscheidener Bedeutung ist die Übereinstimmung im Gesamthabitus und dem inneren Bau. Die kurzen aber kräftigen Zahnstülzen, die diese Species kennzeichnen, lassen sich deutlich wahrnehmen. Eine Skulptur der Oberflïche ist wegen des ungünstigen Erhaltungszustandes nicht zu erkennen.

Der nur wenig gekrümmte Schnabel unschliesst eine verhälnismïssig hohe Area. Der Schlossrand ist gerade, der Umriss der Schale halbelliptisch. Die Brachialklappe scheint durch ein Medianseptum geteilt zu sein.

15 Exemplare.

$$
\begin{aligned}
& D_{h} \text { Spakkassen, Swinesund. } \\
& D_{h} \text { 'Terrassen, Gaasefjorden. } \\
& D_{g} \text { Brönden, Gaasefjorden. }
\end{aligned}
$$

1 Die Forn, welche Baron ron Tou, I. c. 1. als Sp. elegans var. novosibirica ab. bildet, dirfte besser der Gruppe des Sp. mucronatus zuzuweisen sein. 
Spirifer gregarius. CLAPP'.

Taf. VII, Fig. 1.

1857 Spirifer gregarins (Clapp M. S.) Halt, Tenth Rep. N. I. State Cab. Nat. Hist. S. 127.

1861 - gregaria Brlungs, Canadian Journ. n. ser. VI S. 260, Fig. $74-76$.

1863 - $\quad$ - Geol. Canada S. 372, Fig. 391.

1867 - $\quad$ Hall. Pal. New York IV. S. 195, Taf. 28 Fig. 1-11.

1880 - $\quad$ - White, Second Ann. Rep. Indiania Bureau of Statistics and Geol. Taf. 4. Fig. 10-11, S. 504.

1881 - $\quad$-- Halt. Tenth Rep. State Geol. Indiana S. 136, Taf. 4, Fig. 10-11.

1889 - $\quad$ - Nettelroth, Kentucky fossil shells, Mem. Kentucky Geol. Survey S. 119, Taf. S, Fig. 9-13, Taf. 10, Fig. 6-10.

1893 - gregarius Hall and Clarke, Pal. New York VIII Teil II S. 17, 36, Taf. 29, Fig. 7, Taf. 37, Fig. $11-12$.

Die nahe Verwandtschaft von Spirifer gregarius mit der vorstehenden Art ist auch in den Funden von Ellesmereland durch Stücke grösserer Breite und geringerer Höhe veranschaulicht, die sich z. T. nur schwer von dem typischen Spirifer elegans unterscheiden lassen. Im Durchschnitt scheinen überhaupt die arktischen Exemplare einen etwas niedrigeren Schnabel zu haben als die aus New York. In allen anderen Einzelheiten stimmen sie mit der von HALL beschriebenen Form überein.

Einzelne Steinkerne lassen ein Medianseptum der Brachialklappe erkennen. Die Abbildung zeigt ein nicht ganz ausgewachsenes Exemplar,

Fundorte. Brönden $\left(D_{g}\right)$.

Terassen $\left(D_{h}\right)$.

Vereinzelt: Spakkassen, Swinesund $\left(D_{h}\right)$.

Über 50 Exemplare.

Gruppe des Spirifer (Martinia) inflatus Schnor. Taf. VII, Fig. 2.

Dasselbe mit $D_{i}$ bezeichnete Kalksteinfragment, das ich bei der BeBeschreibung des Spirifer bisulcatus erwähnte, enthält auch die Stielklappe einer Martinia. Eine zweite Stielklappe derselben Art findet sich zusammen mit Productella subaculeata var. latior in der Schicht $D_{h}$ von 
Spakkassen. Da die Ausbildung der Zahnstützen, die für die sichere Bestimmung einiger glaltschaliger Martinien wie inflata, Urii, glabra Bedeulung haben, der Untersuchung nicht zugänglich ist, und die Armklappe gänzdich fehlt. kann das Vorkommen des dem Sp. inflatus nahe verwandten jüngeren Spirifer Lrii in den arklischen Grensschichten von Devon und Casbon nur vermutel, nichst aher siches begrinndet werten.

Die besser erhattene Klappe aus /), von Sandstensodden zeigt eine schmale aber deutliche Medianfurche, die vom Schnahel bis zum Stirnrand vertünft. Im Gegensal\% zu der Ansicht Scupms ist nach einzelnen Antoren (Karsen, Davidson) diese Furche für Sp. Urii charakteristisch. Andererseits lässt das Fehten scharfer Arealkanten auf Spivifer inflatus Schyun schliessen.

Die Wölbung der Schale deckt sich ebenso wie die Biegung und Form des Schnabels völlig mit der von HaLl, Bd. IV, Taf. 33. Fig. 23 abgebildeten Martinia subumbona, die Scuprs mit Martinia inflata identifiziert. In der 'Tat zeigen auch die grösseren von Hall a. a. O. Fig. 25-29 abgebildeten Exemplare gute Uebereinstimmung mit dieser weit verbreitelen Art.

So sind die beiden vorliegenden Stücke wohl am besteri als Übergangsformen von $S p$. inflatus und $S p$. Uriizu betrachten. Damit steht in gutem Einklang, dass ein Stück in die oberdevonische Schicht $I_{h}$. das zweile in das dunkle, wahrscheinlich unlercarbonische Kalksteinfragment $D_{\imath}$ gebeltet ist.

Diese Annahme findet eine weitere Stülze darin, dass der echte $S p$. (Martinia) inflatus Scmvur nur schlecht erhalten, aher massenhaft in den oberdevonischen sandigen Kalkstemlagen $D_{i}$ auftritı. Neben typischen Schalen dieser Art finden sich zahlreiche Ühergangsformen, die zwischen tem echten Sp. inflatus und der oben geschilderten Forn vermiltehn, die sich dem 'Typus des Sp. Urii nïhert.

Fundorte: Spakkassen (1) Sandstensodien.

\section{Spirifer bisulcatus Sow (?) \\ Taf. VII, Fig. 3.}

1900 Spirifer bisulcatus, Scupss, Pal. Abhandlungen Nene Folge, Bd. IV, Heft 3, S. 111, Taf. 10 Fig. 6.

l90S Spirifer bisulcalus, Gröвеr, Jahth. f. Mineralogie usw. Beilagebd. 26, S. 222 1. 239, 'Taf. 26, Fig. 3 11. S-10.

1909 Spivifer bisulcutus, Sommen, ebenda, Beilagebd. 29, S. 632. Taf. ¿s, Fig. 2. 
Neben den kalkigen Sandsteinlagen des obersten Mittel- und Oberdevons, welche die Bezeichnung $D_{i}$ tragen, ist auch ein dunkles Kalksteinfragment durch die Aufschrift derselben Serie zugewiesen, obwohl es carbonische Arten enthält. Neben 2 Exemplaren von Myalina amaena de Kon. und einer Stielklappe von Spirifer (Martinia) glaber MART. fand ich in diesem Stück eine Stielklappe, die wahrscheinlich der Art des Spirifer bisulcatus Sowv. zuzuweisen ist.

Unter den oben angeführten Abbildungen stimmt sie am meisten mit der überein, die Scupin gibt. Ich konnte das Original zum Vergleiche heranziehen. Die übrigen Stücke scheinen etwas breitere Rippen nit geringerer Tendenz zur Spaltung zu besitzen. Besonders abweichend sind in dieser Hinsicht einige der Abbildungen Davidsons (British fossil Bradriopoda II, Taf. VI und Scottish Carboniferous Brachiopoda Taf. I, Fig. 19-25) während die Uebergangsform von Sp. bisulcatus u. Sp. mosquensis, die GröвER a. а. O. S. 224 abbildet, bemerkenswerte Aehnlichkeit mit dem arktischen Exemplar besitzt.

Fundort: Sandstensodden.

\section{Pentameridae M'Coy.}

Gruppe des Pentamerus Sieberi v. Buch $=$ Gattung Sieberella Oehlert 1887, Hall et Clarke 1894.

1887 Sieberella Fischer, Manuel de Conchyliogie S. 1311.

1894 Sieberella Hald, Palaeontology of New York, Vol. VIII. Brachiopoda II, S. 242.

1897 Gypidyla Schuchert, American fossil Brachiopoda S. 225-227. 1906 - Grabau, Geology and Paleontology of the Schoharie Valley, S. 138, Fig. 39.

Die Abtrennung der Gruppe Sieberella von der Gattung Pentamerus beruht auf einer schwächeren Ausbildung der Zahnstützen und des Medianseptums und einer damit ursächlich zusammenhängenden Verdickung des Schnabelteiles beider Klappen. Ferner heben sich die Muskeleindrücke durch die Granulierung der Innen-Seite der Schale im Gegensatz zu Pentamerus conchidium deutlich ab. Pentamerus conchidium $^{1}$ zeigt das hohe, durchgehende Medianseptum und starke Zahnstützen in extremer Weise ausgebildet, wodurch ebenso wie durch die Verstärkung des Schnabels bei Sieberella eine grössere Verfestigung der Schale erzielt wirl. In Anbetracht dieser nicht allzu wesentlichen Merk-

1 Siehe Abb. in Dalmann 1827 Terebratuliter Taf. IV. fig. $1 \mathrm{f}$. 
male scheint es mir richliger, nicht eine Gattung oder Untergattung somlern wie bisher eine Gruple (des Pentrmerns Sieberi) anzunehmen. Scmucuert hat 1597 hereits insofern eine Vereinfachung in der Namengebung vorgenommen, als er Sieberella mul Gypidula unter dem Gat. tungsnamen Gypidula zusammenfasste.

Sicberella zeigt stets eine mehr oder minder gerippte Schale, mit Ausmahme der S. pseudogaleata, während die typische Form der Gypidula einen ghalten Wirbel mit gefaltetem Schalenrand besitzt. Ein weiterer Interschied heruht auf der Aushildnng einer Area bei Gypidula, die jedoch im Alter wieder verschwindet. In der 'T'at lïsst sich eine Trennung in Gattungen auf so geringwerligen Unterscheidungsmerkmalen nicht aufbauen, die aher 7.0 einer Trennung in Gruppen durchaus berechtigen.

Aus den oben kur\% angeführten Ursachen, die zur 'Tilgung des Gattungs-Namens Sieberella fühıten, ist es vielmehr nur folgerichtig, auch den Gatlungsnamen Gypidula zu beseitigen. Unter dem Gattungs. namen Pentamerus möchte ich demnach die folgenden Gruppen zusammengefasst wissen:

1. Die Gruppe des Pentamerus oblongus Sow. (Pentamerus Halı, et Clarke s. str.)

2.

Sieberi v. Buch (hierzu Pent galeatus)

= Sieberella OenLert.

3. Die Gruppe des Pentamerus comis Meck = Gypidula Schuchert $=$ Gypidula HaLs.

Der Gattung würden sich die folgenden Untergattıngen anschliessen:

1. Conchidium Liñé.

¿. Pentamerella HaLL.

3. Anastrophia HALL.

In Zatress Grundzügen der Paleontologie (1903) sind als weitere Untergattungen Amphigenia und Striklandinia angefühıt, von denen die erste sicher, die zweite wahrscheinlich zu den Terebratuliden zu rechnen ist.

\section{Pentamerus pseudogaleatus HaL. 'Taf. VII, Fig. 4.}

1 stil Pentamerus pseudogaleatus HALL, Pateontology of New York. Vol. III, Taf. 46, Fig. $2 a-l$ 'Texthand, Seite 259.

1894 Siebrella pseudogaleata Hatr et Cuakke, ibidem Vol. VIII, Brachiopoda II. Taf. 72, Fig. 14.

$1 S 9$ - Gypidula psendogaleata Has.. Bulletin of the United States. Geological Survey N. S7: Cunarees Scuucunrt, A Synopsis of 
American fossil Brachiopoda including Bibliography and Synonymy. Seite 227.

1906 Sicberella pseudogaleata, New York State Museun Bulletin 92, Paleontology 13, Guide of the Geology and Paleontology of the Schoharie Valley in eastern New York by Amadeus W. Grabau. S. 156, Fig. 74.

Starke Verdickung des Schnabelteiles kennzeichnet demnach den als Sieberella pseudogaleata Hall beschriebenen Pentamerus pseudogaleatus Hall des dem Unter-Devon angehörenden Upper Pentamerus. limestone. Für die Bestimmung der arktischen Formen war das Vorlıandensein zweier Suiten besonders wichtig, die Prof. Frech im Jahre 1891 im Staate New York gesammelt hat. Die eine enstammt dem typischen Profil von Schoharie, die andere dem gleichfalls bekannten Fundort der Beecraft-Mountains.

Im Allgemeinen zeigen die arktischen Exemplare einen etwas tieferen Sinus, als die amerikanischen und deshalb eine elwas stärkere Abflachung der kleinen Klappe, wie dies auch der Vergleich mit der Abbildung bei Hall erkemnen lässt; doch finden sich im Slaate New York auch Stücke, die den arktischen völlig gleichen. Abgesehen hiervon ist die stärkere oder schwächere Ausbildung des Sinus als ein variables und wenig wesentliches Merkmal anzusehen.

Auch Hall fasst unter dem Namen pseudogaleatus schmalere und breitere Formen mit flacherem und tieferem Sinus zusammen.

Die palaeontologische Aehnlichkeit wird noch durch die Gleichartigkeit des Gesteins in beiden Gebieten erhöht. Ein dunkler, harter, ziem. lich reiner Kalk umschliesst hier wie dort die in weissem Kalkspat erhaltenen organischen Reste.

Nach dem Vergleichsmaterial und der Abbildung bei HALL kann über die Übereinstimmung der arktischen Formen mit Pentamerus pseudogaleatus HaLl kein Zweifel bestehen. Die Erwähnung der wesentlichen Abweichungen von Pentamerus globus Brons Schnur möge die Stellung des $P$. pseudogaletus zu dieser Species kurz charakterisieren. Holzapfel bildet (Atlas zu den Abhandlungen der kgl. pr. Landesanstalt, Taf. 18, Fig. 19, 20) zwei extreme Formen des Pentamerus globus ${ }^{1}$ ab: die eine, Fig. $20 b c$ mit fast gleich grossen Klappen, die andere, Fig. $19 b c$ mit wesentlich grösserer Stielklappe. Dennoch übertrifft jedes der vorliegenden Stücke des arktischen pseudogaleatus auch die Grenzform

1 Sie auch: Tschervischew, Devon des Ural, Bd. I, Taf. 3.

Ferner: Palaeontographica, Bd. III, Taf, 31, Fig. 4. 
Fig. 19 bc durch die grössere Ungleichkeit der Ǩlappen; d. h. die Stielklappe ist bedeutend stärker gewölbt und daher grösser als die Brachialklappe. Der tief in die grosse Klappe eingreifende Sinus hilft den Unterschieal in der Wölbung noch verschärfen.

Die palaeontologische Entwickelung des Pentamerus galeatus würde sein:

Pentamerus galeatus: ${ }^{1}$ Schale meist vollkommen berippt. Auf dem Sinus 3-4, aut dem Wulst 4-5 stark ausgeprägte, auf den Seitenteilen schwïchere Rippen.

Pentamerus pseudogaleatus: Schale fast immer glatt. Nur gelegentlich schwach angedeutete radiale Streifen zum Sinus und Wulst. Sinus meist rund, Wirbel etwas niedriger als bei galeatus.

Pentamerus pseudogaleatus mut. nov. recurrens. Auf dem Sinus 3, auf dem Wulst 2 stark ausgeprägte Rippen, die sich als schwache, kaum sichthare Streifung in den Seitenteilen fortsetzen. Diese Form nähert sich in ihrem ganzen Habitus wieder dem P. galeatus. (S. unten).

Pentamerus galeatus wurde nur der Übersicht wegen mit angeführt, obwohl er in den Ablagerungen des arktischen Devon nicht vertreten ist. $P$. pseudogaleatus findet sich in Schichtserie $D_{b}$ als loäufiges und bezeichnendes Leitfossil. Von dieser Form liegen 102 Exemplare vor. Hingegen wurde $P$. pseudogaleatus mut. recurrens nur in 4 Exemplaren als Seltenheit in Serie $D_{c}$ aufgefunden.

Fundorte: An den gegenüberliegenden Felsen Vestre Borgen und Ostre Borgen zu beiden Seiten des mittleren Gaasefjorden.

Pentamerus pseudogaleatus, Hall, mut. nov. recurrens. Taf. VII, Fig. 5.

Nur in $D_{c}$ findet sich (in 4 Exemplaren) eine Pentameride, die sich ihrem ganzen Habitus nach mehr dem Pentamerns (Sieberella) galeatus als ihrem unmittelbaren Vorliufer, dem P. pseudogaleatus, nähert. Deshalb erschien für diese neue Art der Name pseudogaleatus mut. recurrens angebracht. In der Tat zeigt der loreite gekrümmte Wirbel ganz den Typus aus dem galeatus aus dem Lower Pentamerus limestone. Nur die stïrkere Berippung des P. galeatus, die sich in der Regel unge-

1 Siche insbesondere Palaeontographica, Bd. Ill, Taf. 29, Fig. 2 im Gegensatz zu: Mauner 1885. Die Fauna der Kalke von Waldgirmes, Taf. IX, Fig. 1-3.

Ferner: Davinsox. Fossil Brachiopoda I, Taf. VII, Fig. 114-115. 1851-55. Hat.t 1861, Palueontology of New York. Vol. 3, Taf, 47. 1906 Gramav, Geology and Palaeontology of Schoharie Valley, S. 138, Fig. 39. 
schwächt auch auf die Seitenteile ausdehnt, unterscheidet diesen von der jüngeren Mutation, welche nur innerhalb des Sinus eine starke Berippung zeigt. Die anscheinend konstante Zahl dieser Rippen (auf den Sinus 3, auf dem Wulst 2) liefert ein weiteres Unterscheidungsmerkmal von dem echten Pentamerus galeatus, dessen Sinus durch 3-4 und dessen Wulst durch 4-5 Rippen ausgezeichnet sind.

Dem sonst nur sekundären Merkmal der Berippung ist in diesem Falle ein besonderer Wert beizulegen, da es sich hier un Arten verschiedenen Alter's handelt, die durch dieses Merkmal deutlich geschieden sind.

Fundort: Vestre Borgen.

\section{Rhynchonellidae Gray.}

Rhynchonella (Rhynchotrema, Stenocisma) formosa HAL. Taf. VII, Fig. 6.

1859 Rhynchonella formosa, Hall, Pal. of New York Ill, S. 236 , Ta1. 35, Fig. 3-6.

1867 Stenocisma formosa, HalL, Pal, of New York, IV, S. 334.

1893 - - Hall and Clarke, Pal. of. New York, 'Teil II, S. 187, Taf. 56. Fig. $41-45$.

Zwei Steinkerne stimmen mit den Billern üherein, die HALL in Band III, Taf. 35, Fig. 4 a.c gibt.

Serie: $D_{b}$.

Fundort: „wahrscheinlich" Ostre Borgen.

\section{Rhynchonella transversa HaLL. Taf. VII, Fig. 7.}

Rhynchonella transversa, HaLL, Pal. of New York, Bd. III, S. 234, 'Taf. 34, Fig. 9-16.

Fünf Steinkerne gehören wahrscheinlich zu Rhynchonellen die:er Art. Der ungünstige Erhaltungszustand erschwert in Verein mit der grossen Variabilität der Art, die aus HaLL's Abbildungen unschwer zu erkennen ist, eine sichere Bestimnung,

Fundort: „wahrscheinlich" Ostre Borgen.

Serie $D_{b}$. 
Gruppe der Rhynchonella pugnax.

Rhynchonella (Pugnax) Sverdrupi nov. spec.

Taf. VIII, Fig. 6.

Diese Form ist als ein Vorliufer des auch aus der unteren ChemungGruppe bekannten Pugnax Pugnus anzusehen, In die stark gewölbte Brachialklappe greift ein tiefer trapez-förmiger Sinus ein, welcher zwei oder vier starke Falten trägt, denen ebenso viete Furchen der Stiel. klappe entsprechen. Beide verlieren sich in der Nähe des Schnabels. Der Sinus ist an seinen unteren Ecken gleichfalls durch zwei ausgeprägte Falten hegrenzt, die als bogenförmiger Wulst über die Seitenflächen der Brachialklappe und den Schnabel verlaufen. Ähnliche Form nnd Faltung des Sinus zeigt Rhynchonella praecox Barr. (Syst. Sil. de la Boh. V. Taf. 29, doch ist der Gesamtumriss wesentlich verschieden).

Beide Klappen lassen ein dünnes Medianseptum erkennen. Die in der Schnabelgegend stark verdickte Schale ist nur in Bruchstücken erhalten und liisst keine Skulptur erkennen. 4 Exemplare $D_{c}$. Vestre Borgen.

\section{Rhynchonella (Camarotoechia) Horsfordi HalL.}

Taf. VIII, Fig. 3.

1860 Rihynchonella horsfordi, Hat., Thirteenth Rep. New. York, State Cab. Nat. Hist., P. 87.

1884 lihynchonella horsfordi, WaLch. Mon. U. S. Geol. Survey VIII. S. 1:22 Taf 14, Fig. 3, Taf. 15, Fig. 6.

1867 lihynchonella (Stenocisma) horsfordi, HaLL, Pal. New York IV, S. 339, 'Taf. 54, Fig. 24-32.

1893 Camaroloechia horsfordi, Hald and Clakike, Pal. New York VIII, Teil II, S. 192, 'Taf. 57, Fig. 7-9.

3) Kleine aber gut erhaltene Exemplare dieser Art wurden bei Brönden, Gaasefjorden in Serie $D_{g}$ aufgefunden. Sie stimmen durchaus mit der von Has, als typisch bezeichneten Form (l. c. Bd. 4, T. 54, Fig. 2S-32) ïberein.

Rliynchonella (Wilsonia) princeps Barr.

Taf. VIII, Fig. 1 ‥ 2.

$1 S 6 \bar{i}$ Ryglnchonella (Stenocisma) Horsfordi, HALL, Pal. New. York, Bd. IV, 'Taf. 54, Fig. $26,27$. 
1906 Rhynchonella (Uncinulus) princeps Barr. Scupin, Zeitschrift d. Deutsch. Geol. Ges. Band 58, Seite 245, Taf. 14, Fig. 3, wo weitere Litteratur.

Ein reiches Vergleichsmaterial vou Wilsonia, das Prof. Frech in den unterdevonischen Riffkalken von Konieprus gesammelt hat, gestattet mir, einige feinrippige Rhynchonellen aus den Schichten $D_{g}$ und $D_{h}$ dieser Gruppe zuzuweisen. Die typisclıe Wilsonia princeps BARR. unterscheidet sich von den arktischen Stücken durch einen etwas spitzeren Schnabel, der übrigens variabel ist, während das von Barrande, Syst. Sil. V, Taf. 25, Fig. 6 dargestellte Exemplar diesen in jeder Hinsicht gleicht. Die Übereinstimmung der Zahl der Rippen im Sinus (10-14) und dessen hohe rechteckige Form stellen die Zugehörigkeit der arktischen Stücke zu der böhmischen Art ausser 'Zweifel.

Zwar weist Wilsonia princeps auf einen etwas tieferen Horizont (F 2) als die übrige Fauna der Schichten $D_{g}$ und $D_{h}$, welche das untere und obere Mitteldevon repräsentieren, doch muss in Anbetracht der arktischen Funde angenommen werden, dass Wilsonia princeps auch in das Mitteldevon hineinreicht. Diese Vermulung wird bekräftigt durch die Abbildung im 4. Bande der Pal. of New York. Taf. 54, auf welcher die Fig. 24-32 unter dem Namen Rhynchonella Horsfordi zusammengefasst sind. Sümtliche Stücke, die den Abbildungen zugrunde liegen, enstammen den Marcellus shales und den Hamilton beds also dem oberen Mitteldevon. In Fig. 26-27 ist eine schmale feinrippige Form neben (Fig. 24 und 2S-32) grobrippigen Exemplaren mit flügelartig verbreiterten Schalen dargestellt. Nun stimnt aber das in Figur 2627 abgebildete Stück völlig mit Exemplaren der Wilsonia princeps BARr. überein, welche Frech in den Riffkalken von Konieprus gesammelt hat. Auch die Zahl der Rippen innerhall, des Sinus zeigt keine Abreichung. Hieraus ergiebt sich, dass Fig. 26--27 der Rhynchonella Horsfordi HaLL der echten Wilsonia princeps zuzuweisen ist, während die typische Rhynchonella Horsfordi HaLl die sich auch in Serie $D_{g}$ des arktischen Devon findet, in den Figuren 28-32 zum Aus. druck gebracht wäre.

In $D_{g}$ finden sich einige Stücke mit auffallend hohem und sclımalen Sinus, die ich gleichfalls zu Rhynch. princeps Barr. stelle. Die Zahl der Rippen im Sinus beträgt 7. Doch zeigen sie sïmtlich bei genauerer Betrachtung Ansätze zur Teilung. Es ist deshalb anzunehmen, dass die typischen Formen mit breitem Sinus aus der jüngeren Schicht $D_{h}$ aus diesen Stücken hervorgehen.

Fundort: Brönden. Terrassen. 
Ealonia medialis Vaxtenen. var.

Taf. VIII, Fig. 4-5.

$1 S 42$ Alrypa medialis, Vaxuxen, (jeol. New Tork; Rep. Third. Hist. s. 120. Fig. 4.

1857 Ealonia merlialis, Hatr, Thent Rep. New York State (ab). Nat. Hist. p. 90, lig. 1-7.

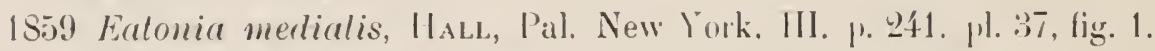
1863 Ealonia medialis, Ballasgs, Prov. Portland Soc. Nat. Hist. III, Taf. 3. Figg. 7.

1893 Hall and Clarke, Pal. New York VIII. PI. H, S. 206, 'Taf. 61. Fig. $29-35$.

1894 Hall and Clanke, Handbook of Brachiopoda II. 'Tar. 44, Fig. 3S-40.

1906 Ealonia medialis, Grabau. New Jork Slate mus. S. 147. S. 146, Fig. 54.

Die vorliegenden 6 zur Gallung Eatonia gehöremlen Schalen unterscheiden sich von der von HALs, als Ealonia medialis beschrie. benen Forn durch den hreiteren lrapezförnigen Sinus, der l'egehnässig 5 kure prägnante Rippen trägt, denen chenso viele Furchen in Wulst entsprechen. Die Schale ist nur an den Riundern gefaltel und verdickl sich nach dem Schmabel zu auf das 3-4 fache. Eine Untersuchung des inneren Baues war des schlechten Erhaltungzuslandes wegen nicht möglich.

$D_{\iota}$ Ostre Borgen (?)

\section{Palacontologische Übersicht}

Articulata Hexus.

Unterordnung: Aphaneropegmala WAaGEN.

Familie: Strophomenirlae Kinti.

Dalmanella mullistriata HaLs . . . . Ostre Borgen. Brönden 'T'errassen, Spakkasseı

Jalmanella assimilis Hos... . . . . . Wahrscheinlich Ostre Borgeı

Stropheorlonla intristriala Connas). . . Ostre Borgen, Brönden. Spakkasseı

Stropheodonla demissa (ionkan mut. nov. merecuser). . . . . . . . . Ostre Burgen

$1 \mathrm{~V} g \mathrm{l}$. die nuolı straligruphischen Gesichtspunkten geordnete Übersicht auf S. 4 ff, 
Stropheodonta Leavemurthana HALL? . . wahrscheinlich Ostre Borgen

Stropheodonta spec. . . . . . . . . . Vestre Borgen

Stropheodonta arctica nov. spec.. . . . Ostre Borgen, Vestre Borgen

Stropheodonta increquiradiata HALL . . . Bröuden

Stropheodonta callosa HALL var. nov. latior Brönden

Leptaena spec. . . . . . . . . . . Wahrscheinlich Ostre Borgen

Orthothetes woolworthanus HALL. . . . wahrscheinlich Ostre Borgen

Orthothetes Kiaeri nov. spec. . . . . . . wahrscheinlich Ostre Borgen

Oithothetes umbraculum Schlotr. . . . Hareureu

Familie: Productidae Grar.

Chonetes lineatus Conrad . . . . . . . Bיönden

Productella ex aff. lacrimosa Conran). . . Brönden, Spakkassen Productella arctirostrata HaLL . . . . . Brönden, Terrassen Productella subaculeata Murch. var. latior.

Gürich. . . . . . . . . . . . . Terrassen, Spakkassen

\section{Unterordnung: Helicopegmata WaAgen.}

Familie: Atrypidae DaLL.

Atrypa reticularis LinNÉ.

Ostre u. Vestre Borgen, Kap Dönninghausen, Brönden, Vestsiden af Gaasefjorden, Terrassen, Snakkassen, Rypeelven

Atrypa aspera S̈снотн.. . . . . . . . Kap Dönninghausen, Ostre Borgen

Familie: Spiriferidae KING.

Spirifer concimms Hall . . . . . Ostre u. Vestre Borgen Spirifer Scheii nov. spec. . . . . . . . vereinzelt Ostre u. Vestre Borgen, häufig 'Terrassen und Spakkassen 
Spirifer curvatus Schloti.. . . . . . Vestre Borgen

Spirifer Maureri . . . . . . . . Vestre Borgen

Spirifer elegans Stex (car.) . . . . . Brönden, Terrassen, Spakkassen

Splirifer gregarius Clapr. . . . . . Brönden, Terrassen, Spakkissen

Spirifer inflatus Scunur . . . . . . Spakkassen? Sandstens. odden

Spirifer bisulcatus Sow. . . . . . . Sindstensodden

Unterordnung: Ancistropegmata Zi'Tr.

Familie: Pentameridae M'CoY.

Pentamerns psendogaleatus HALL . . . Ostre (u. Vestre) Borgen Pentamerus pseudogaleatus Hall mut. nov. recurrens . . . . . . . . Vestre Borgen

Familie: Rhynchonellidae Gray.

Riliynchonella formosa HALL . . . . wahrscheinlich Ostre Borgen

Rhynchonella transversa HALL . . . . Wahrscheinlich Ostre Borgen

Rhynchonella Sverdrupi nov. spec. . . . Vestre Borgen Rhynchonella Horsfordi HaLL . . . . . Brönden

Rhynchonella princeps BARR. . . . . . Brönden, 'T'errassen

Eatonia medialis Vanuxen var.. . . . . Ostre Borgen 


\section{Tafel I.}

Fig. 1 a-c. Dalmanella multistriata HaLL.

.2 a-e. Dalmanella multistriata HALt.

" 3 a-c. Dalmanella assimilis Hall. Unterdevon. $D_{b}$, wahrscheinlich Ostre Borgen.

" 4 a-d. Stropheodonta varistriata Conrad. Db, wahrscheinlich Ostre Borgen. a) vollständiges Exemplar. b) Armklappe. c) Stielklappe. Sämtlich 2: 1. d) Skulptur, stark vergrössert.

\section{Tafel II.}

Fig. 1 a-c. Stropheodonta demissa Conrad mut. nov. praecursor. Unterdevon. $D_{b}$, Ostre Borgen. a) Stielklappe. b) Area. c) Skulptur vergr. d) Steinkern der Armklappe, zu a) gehörig. e) Wölbung der Stielklappe.

"2 a,b. Stropheodonta spec. Unterdevon, $D_{b}$, Vestre Borgen. a) Steinkern der Armklappe. b) Wölbung der Stielklappe (Steinkern).

r $3 \mathrm{a}$-d. Stropheodonta arctica nov. spec. Unterdevon $D_{b}$, wahrscheinlich Ostre Borgen. a) 11. b) Stielklappen. c) Vollständiges Exemplar, die Stielklappe ist in der Umgebung des Wirbels losgesprengt. Vergl. auch Tafel III, Fig. 1. d) Wölbung der Stielklappe. Sämtlichı etwa 2: 1.

\section{Tafel III.}

Fig. 1 Stropheodonta aretica nov. spec. Unterdevon $D_{b}$ walırscheinlich Ostre Borgen. Etwa 6: 1. Steinkernpräparat mit Schloss. Dieses Präparat wurde durch Lossprengen beider Schalen des Exemplares gewonnen, das auf Tafel II, Fig. $3 \mathrm{c}$ abgebildet ist. Es zeigt: den Abdruck des Wirbels, die Area der Stielklappe und ihre Streifung, die beiden Schlosszähne, die Muskelzapfen, die Area der Armklappe unit Streifung, ein Pseudodeltidium?, und den Steinkern der Armklappe.

2 a, b. Stropheodonta inaequiradiata HaLL. Mitteldevon, $D_{y}$, Brönden.

3 a-d. Stropheodonta callosa Halu var. nov. latior. Mitteldevon, $D_{g}$, Brönden. a) -c) vollständiges Exemplar in natürlicher Grösse. d) Steinkern mit Muskeleindrücken, $21 / 2: 1$.

4 a-c. Leptaena spec. Mitteldevon $D_{b}$, wahrscheinlich Ostre Borgen. a) u. b) Armklappe. e) Stielklappe.

" 5 a-f. Orthothethes Kiaeri nov. spec. Unterdevon $D_{b}$, wahrscheinlich Ostre Borgen.

\section{'Tafel IV.}

Fig. 1 a-c. Orthothetes woolworthanus Hac.. Unterdevon $D_{b}$, wahrscheinlich Ostre Borgen. a) Stielklappe. b) Profil. c) Area.

$" 2$ Orthothetes umbraculum Sсиьотн. Mitteldevon $D_{f}$, Hareuren. Arm. klappe. 
Fig. 3 a-c. Chonetes lineatus Coxrad. Mitteldevon $D_{g}$, Brönden. a) u. b) Stielklappe. c) P'rofil der Stielklappe.

" 4 a-d. Productella subaculeatu Muncı. var. latior Gërıcn. Oberderon Dh, T'errassen. Stielklappen verschiedener Breite und deren Profile. c) u. d) nahert sich der var. angustion Günucıs.

" 5 a, b. Productella subaculeata Mcrocn. var. angustior Gürıcn. Cliemung, New lork. (Colz. Frecir).

"6 a-f. Procluctella arctirostrata $H_{\text {Al. }}$. a) u. b) vollständiges Exemplar, $D_{h}$. Terrassen. c)-f) zwei Armklappen und deren Profile von $D_{g}$. Brönden.

" $7_{i 1}$ - Productella ex. aff. lacrimosa Cosiad. $D_{g}$, Brönden. Stielklappe.

\section{Tafel V.}

Fig. 1 a-c. Atrypa reticularis Lixí. Unterdevon $D_{c}$, Vestre Borgen. Mit unge. wölnlich hohem Sinns.

"2. Atrypa reticularis Lıxx́. Devon von Gerolstein. Zun Vergleich mit Figur 1.

"3. Atrypa reticularis Lixis. Unterdevon $D_{c}$, Vestre Borgen. Mit bloss. gelegtem Spiralkegel.

" 4 a, b. Atrypa reticularis Lisxí. Mittelderon $D_{y}$, Brönden. Breitere Form.

$" 5$ a-c. Atrypa reticularis Lixxé. Unterderon, $D \iota$, (nach Aufschrift: $D_{a-\ell}$ ). Sclimalere form.

" 6 a, b. Atrypa aspera ScmLom. Underdevon $D_{b}$. Kup Drnninghausen. Etwa $2: 1$.

"7. Spirifer Scuen nov. spec. Dh. Terrassen. Armklappe. Siehe auch Tafel Vl, Fig. 1.

" 8 a-c. Spivifer concinnus Hal... Unterdevon $\mathrm{D} \iota$, Ostre Borgen.

\section{Tafel VI.}

Fig. 1 a-c. Spirifer Scuen nov. spec., Dh, Terrassen.

"2 a-d. Spivifer cf. curvatus Scmiotm. $D_{c}$, Vestre Borgen.

a), b) u. d) ausgewaclisenes Exemplar, c) junges Exemplar.

, 3 a-d. Spirifer Mauniam Holzapfel. 1$)_{c}$, Vestre Borgen.

n 4 a, b. Spirifer Macheri Holzapiel. $D_{c}$, Vestre Borgen.

" 5 a-c. Spirifer elegans Srux, var. $D_{h}$, Spakiassen, Svinesund. Extreme Form mil wenigen, hesonders kriftigen Rippen.

\section{'I'afel VII.}

Fig. 1 a-c. Spirifer gregarius Cusp. $D_{g}$, Brönlen.

n 2 a-b. Spirifer influtus Scnvin. Ol,erdevon $D_{i}$, Sandstensodden. a) Strielklappe. 3:1. b) Seitenansicht in natürlicher Grösse.

"3 a-c. Spirifer bisulcutus Sow. (?) Untercarbon, 1),? Sandstensodden. Stielklappe.

"4 a-c. I'entamerus psemdogaleatus Hai,.. D) , Unterderon, Vestre Borgen. Ausgewaclisenes grosses Ex(mplar.

" 5a-c. Pentamerus pseudogaleatus Has., mut. nov. recurrens. Dc, Unterdevon, Vestre Borgen.

"6a-e. Rhynchonella (Khynchotrema, Stenocisma) formosa Ilat.. Etwa 2:1. $D \imath$, Unterdevon, Ustre Borgen.

"7a-c. Rhynchonella, transversa H.ıL. Unterdevon $D_{\iota}$, walırscheinlich Ostre Borgen. b) nattirliche Grösse. Die abrigen 3:1. 


\section{'Tafel VIII.}

Fig. 1 a-d. Rhynchonella (Wilsonia) princeps Barr. Dg, Brönden. 2:1. Mit schmalem Sinus, dessen Rippen Ansätze zur Teilung zeigen. Vorläufer von Fig. 2.

"2a-d. Rhynchonella (Wilsonia) princeps Barr. $D_{h}$, Terrassen. $2: 1$.

" $3 \mathrm{a}, \mathrm{b}$. Rhınchonella (Camarotochia) Horsfordi Hat.. $\mathrm{D}_{g}$, Brönden. Junges Exemplar 2:1.

" 4 a-d. Eatonia medialis Vanuxem var. $D_{b}$, wahrscheinlich Ostre Borgen.

$" 5$ a, b. Eatonia medialis VAnuxem var. $D_{b}$, wahrscheinlich Ostre Borgen. Breiteres Exemplar.

"6a-c. Khynchonella (Pugnax) Sverdenu'ı nov. spec. D $c$, Vestre Borgen. 
Gedruckt 오. Mai 1!13. 

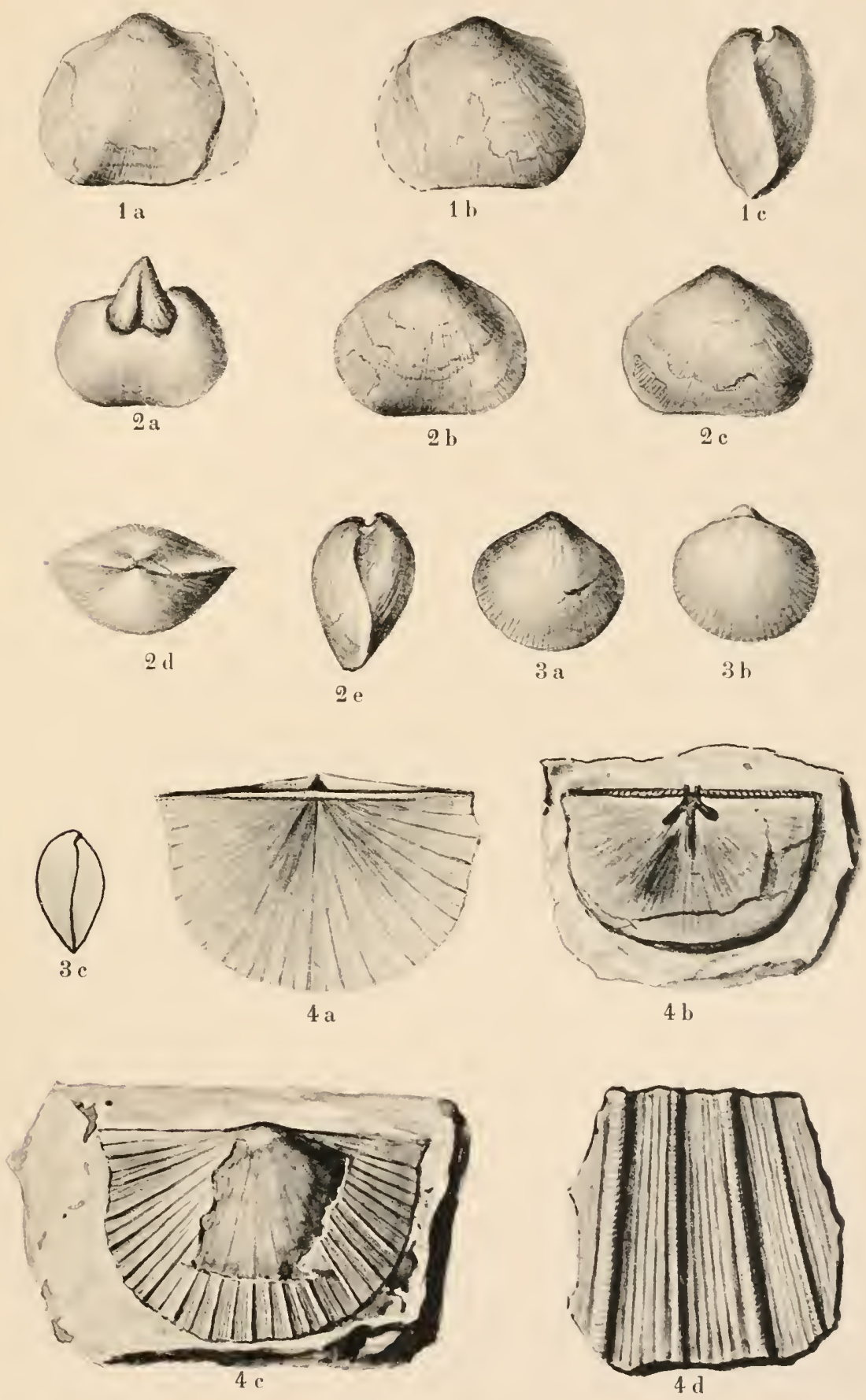


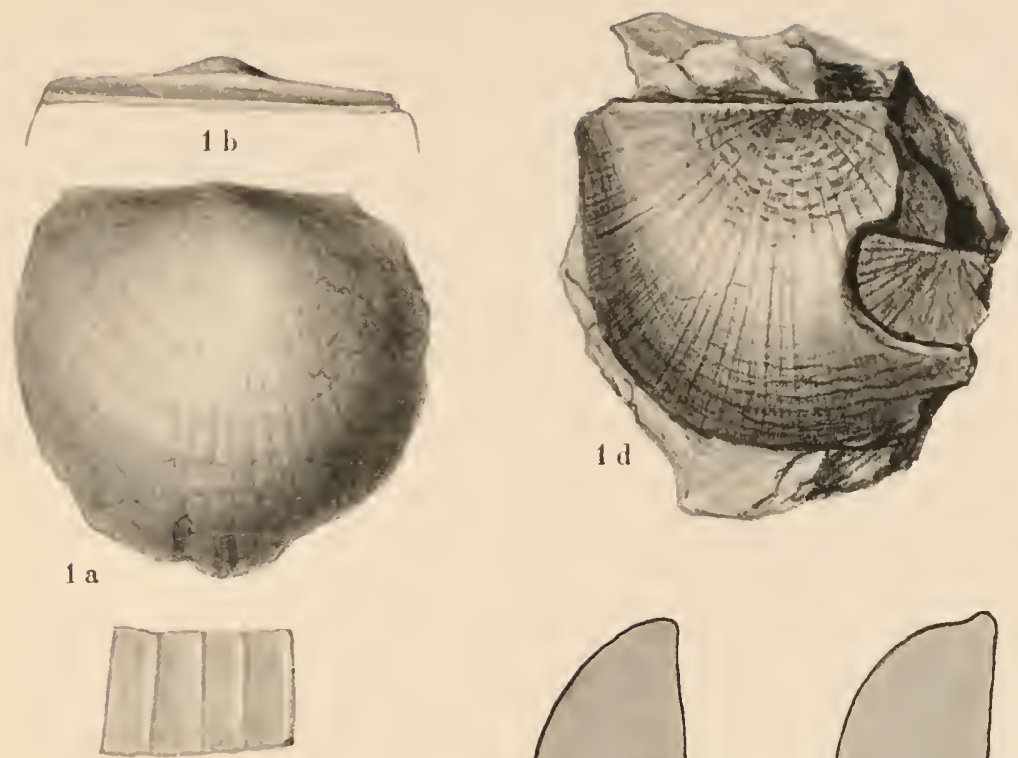

$1 \mathrm{c}$
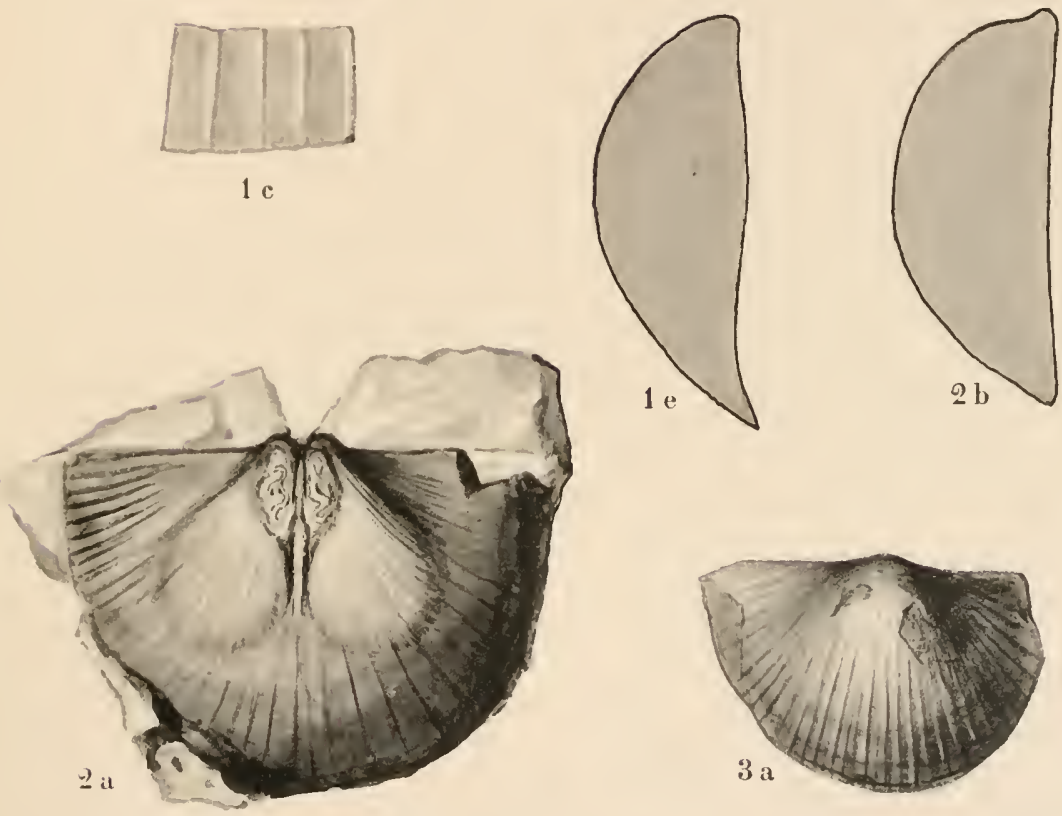

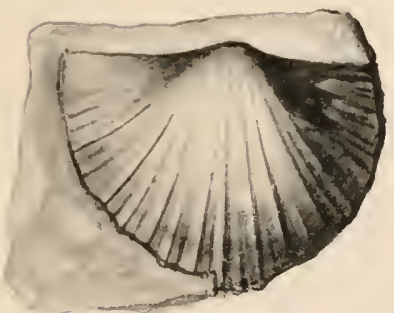

36

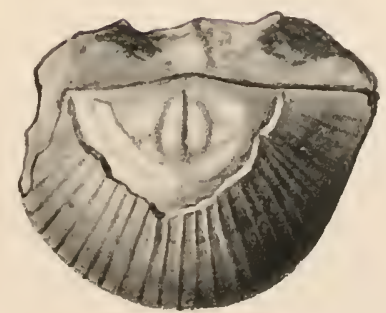

$3 \mathrm{c}$

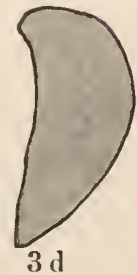




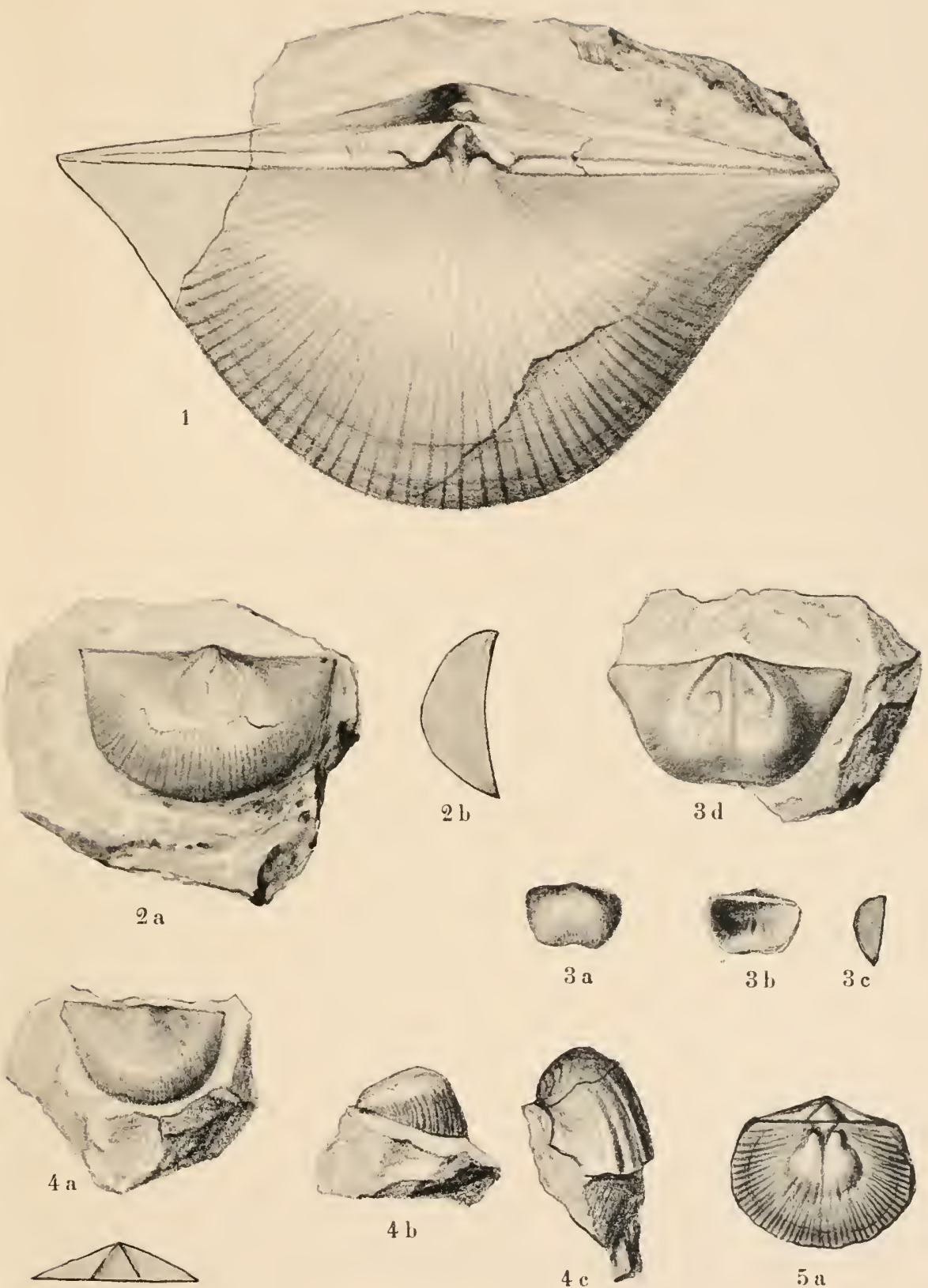

3 a
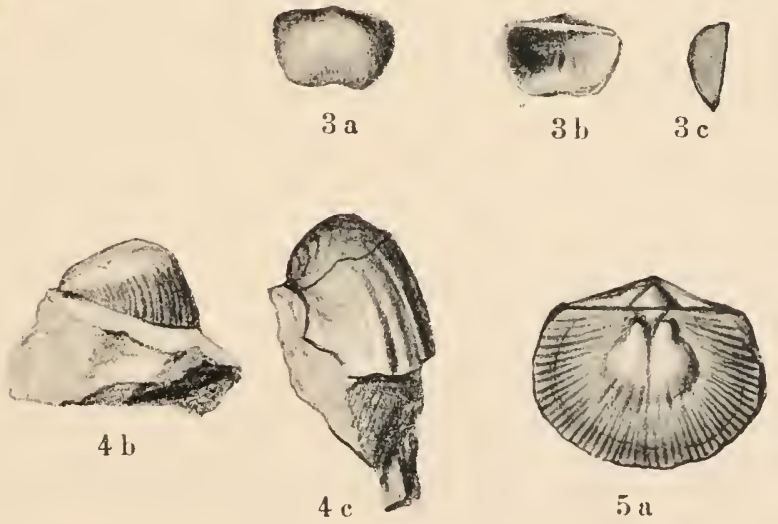

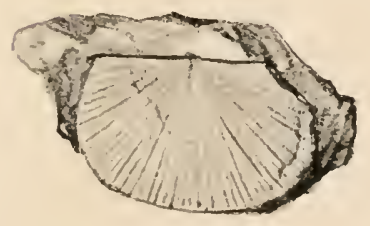

$5 \mathrm{~b}$

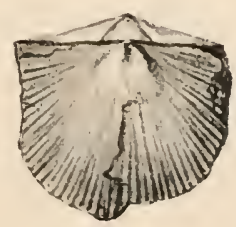

$5 \mathrm{c}$

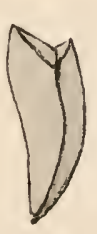

51

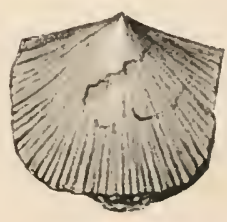

$5 \mathrm{e}$ 


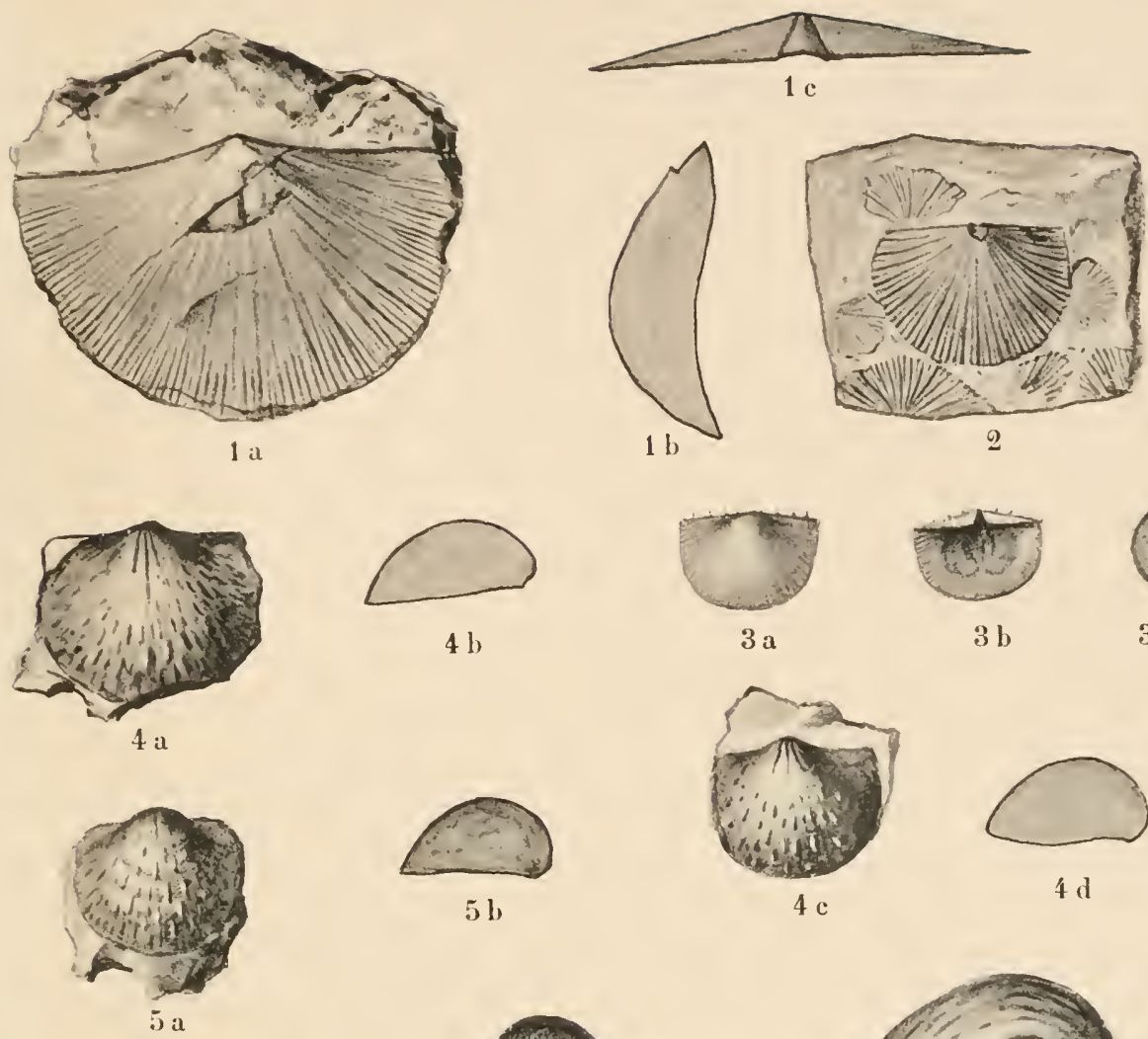

$5 b$
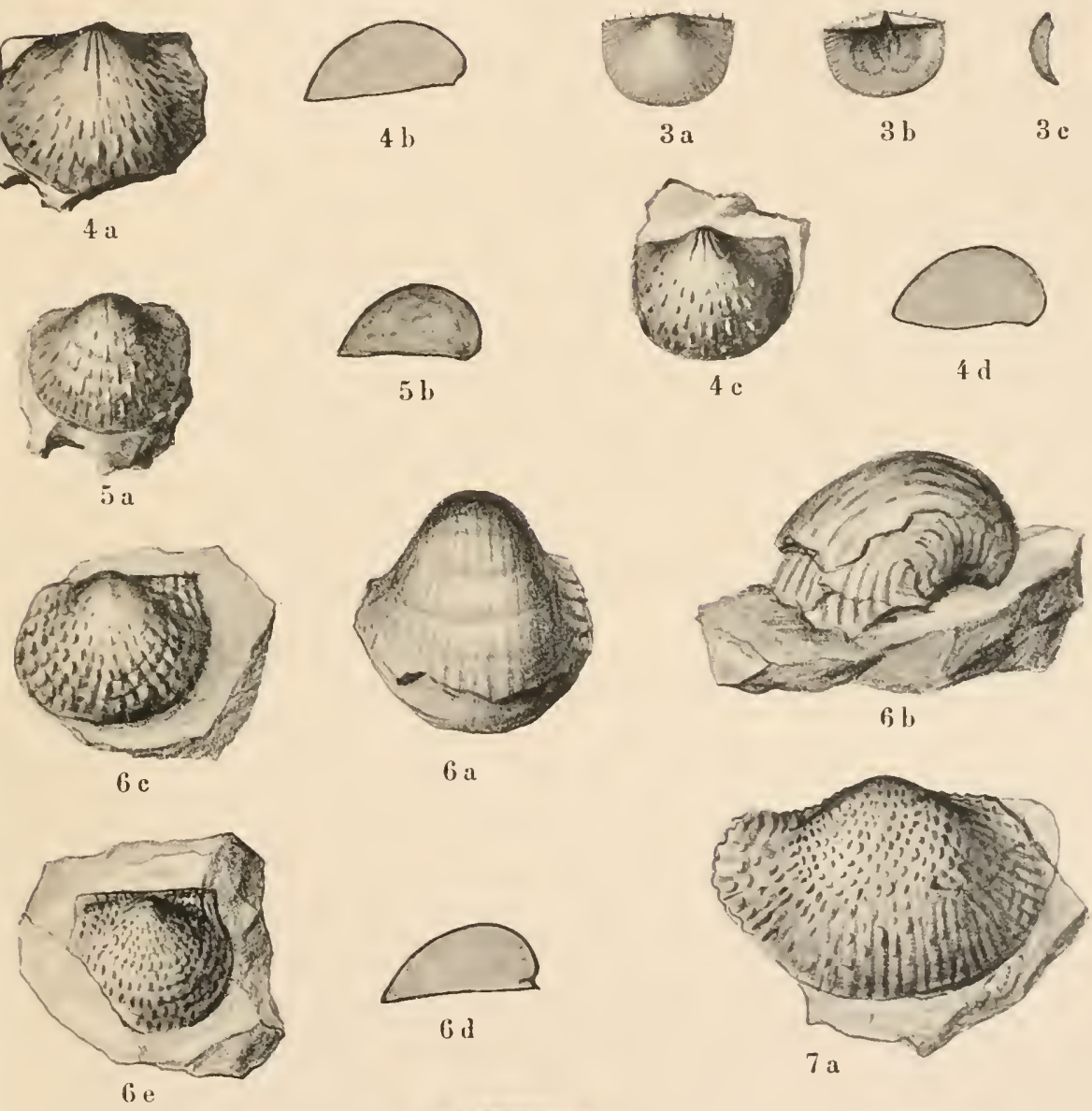

6 b
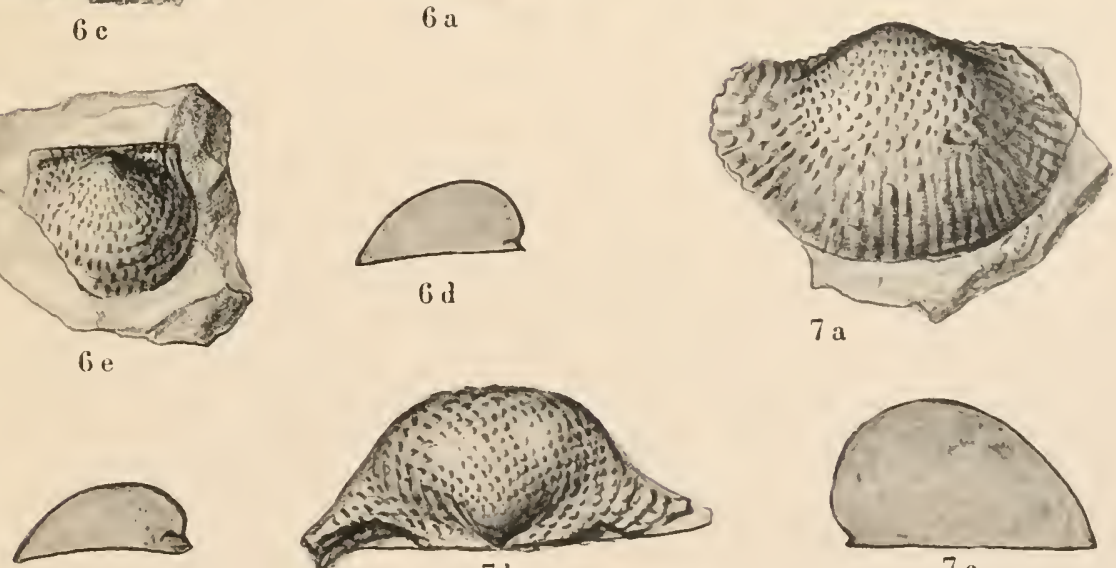

$6 \mathrm{f}$
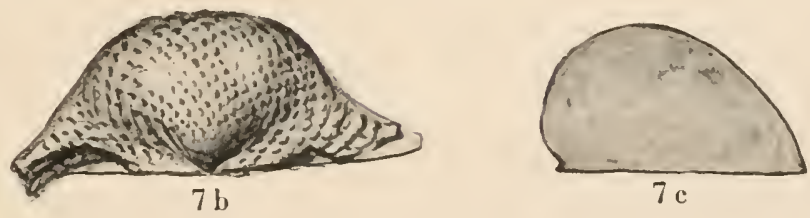



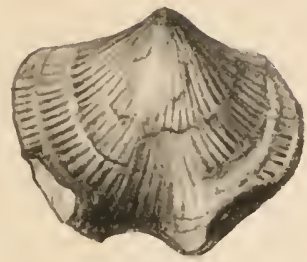

1 a

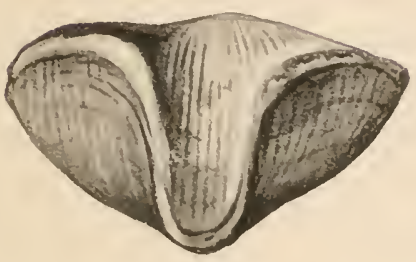

2

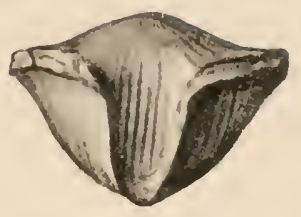

1 b

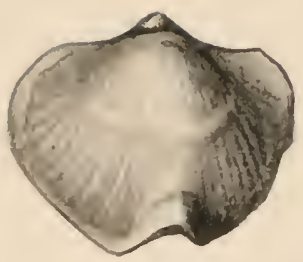

1 c.

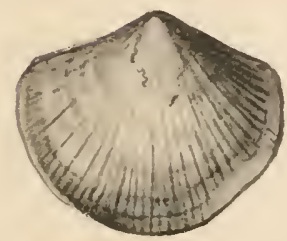

$4 \mathrm{~b}$

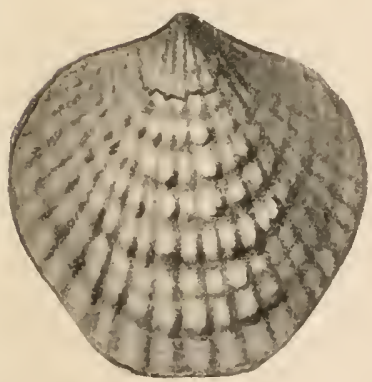

6 a

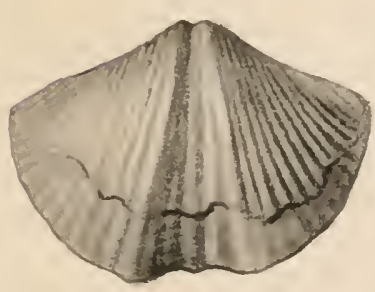

$8 \mathrm{a}$

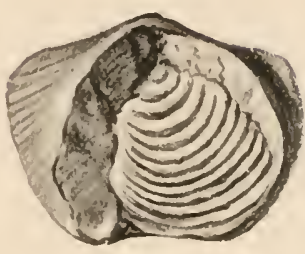

3

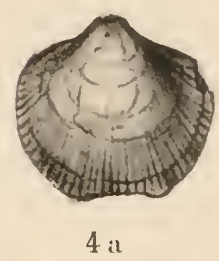

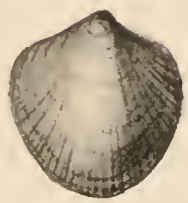

5 a

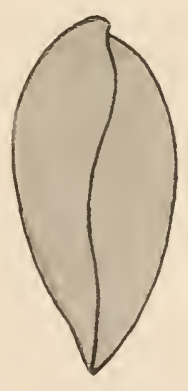

$6 \mathrm{~b}$

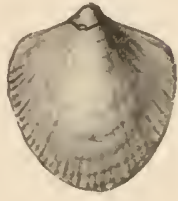

5 b

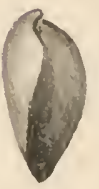

5 c

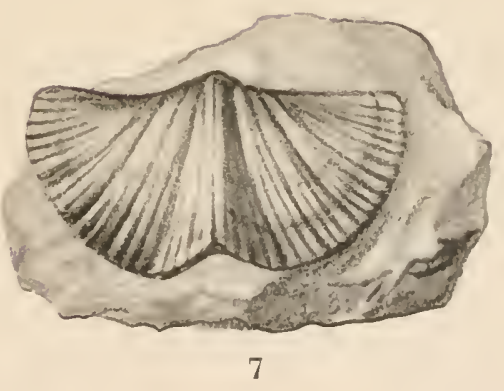

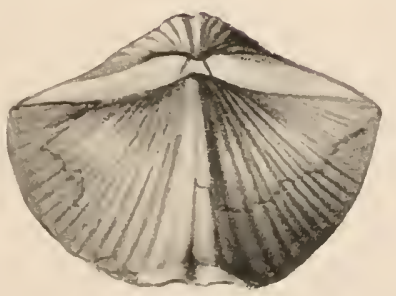

Sb

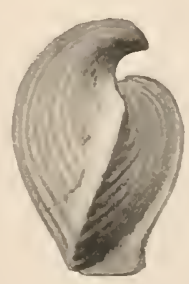

$8 \mathrm{c}$ 



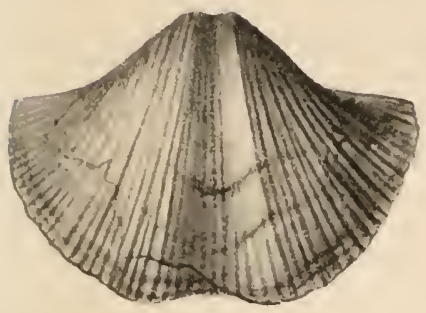

1 a

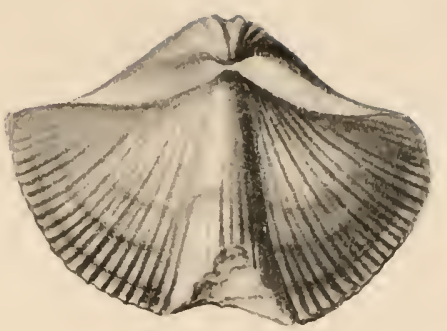

1).

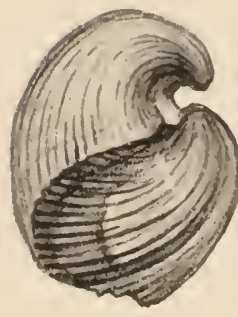

$1 \mathrm{c}$

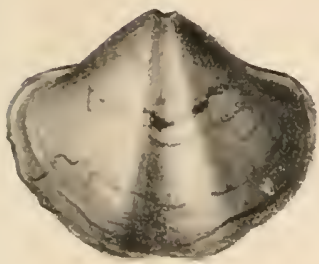

2 a

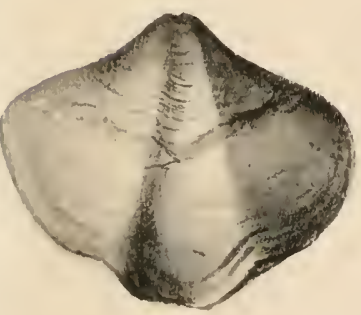

$3 \mathbf{a}$

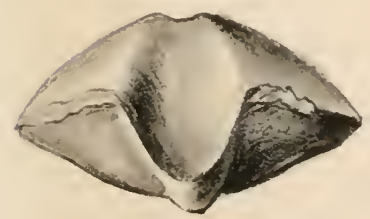

; d

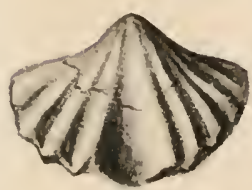

5 a

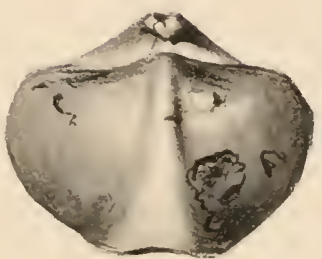

$2 b$

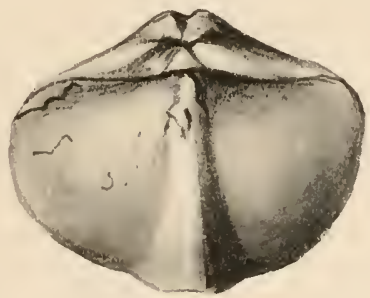

$3 b$

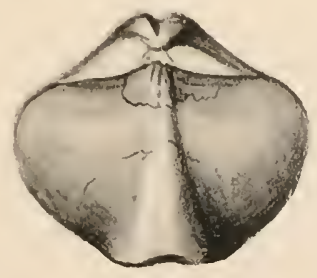

4 a

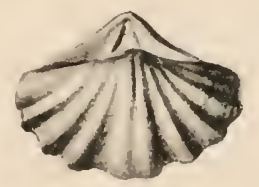

51
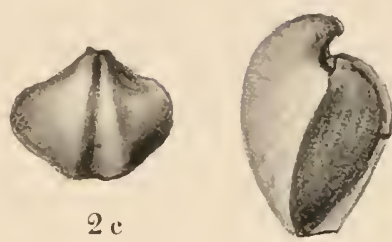

2 d

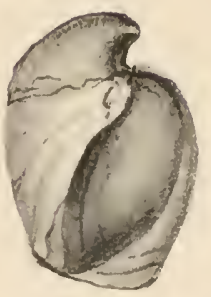

3 c

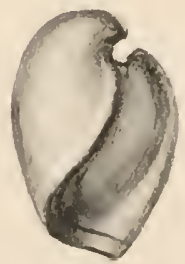

$4 \mathrm{~b}$

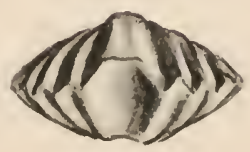

$5 \mathrm{c}$ 



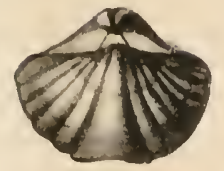

1 is

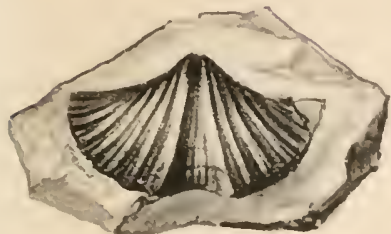

$3 a$

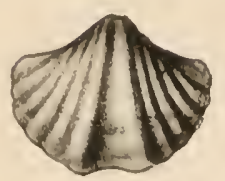

1 b

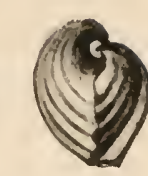

$1 \mathrm{c}$

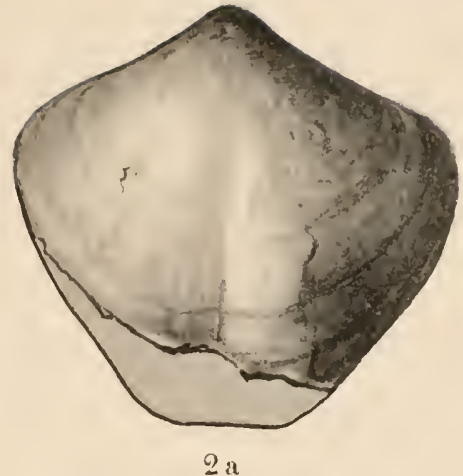

21

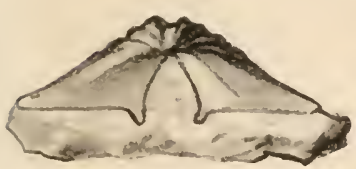

$3 \mathrm{~b}$

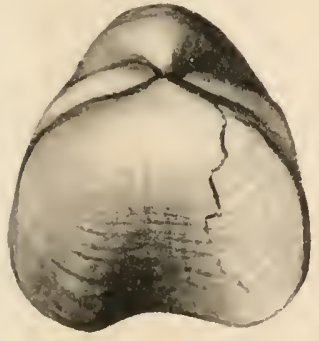

4 a
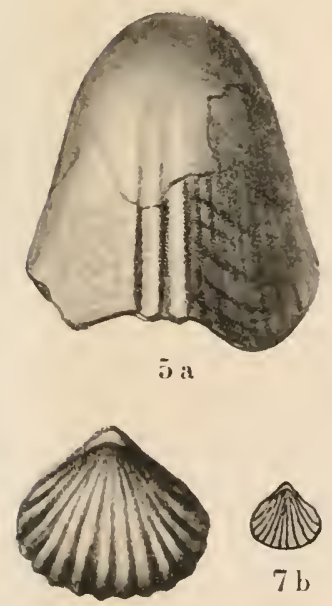

7 a

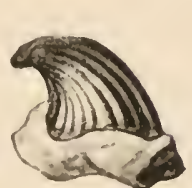

30

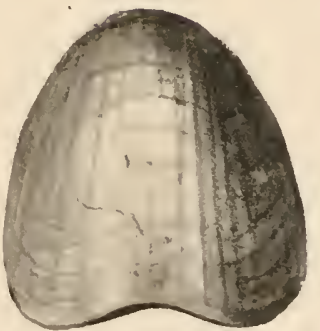

4 b)

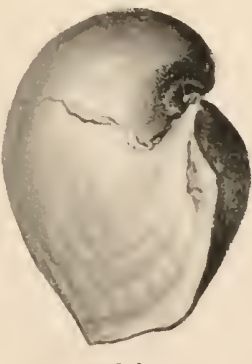

5 b
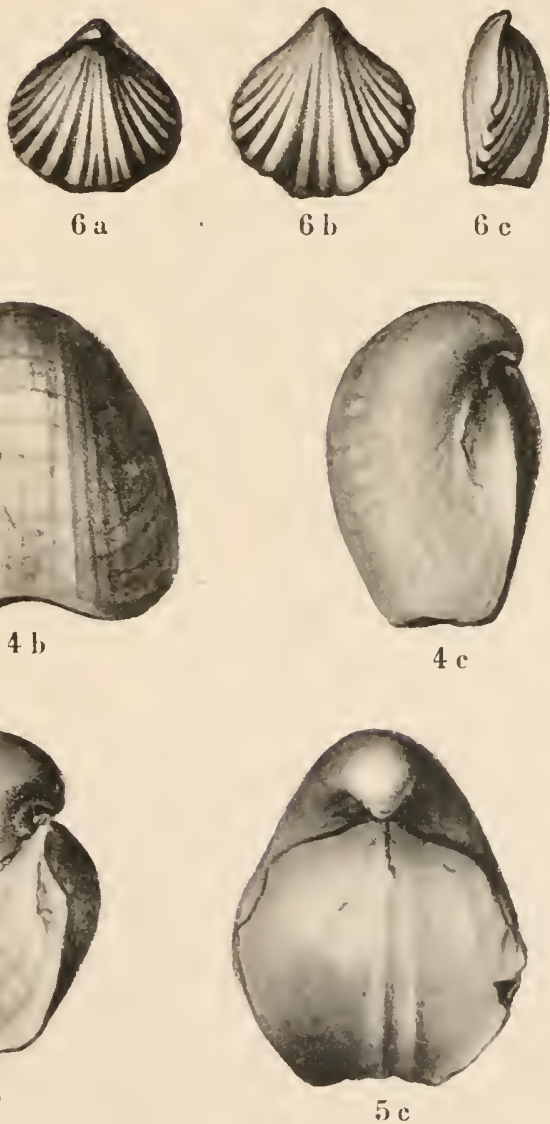

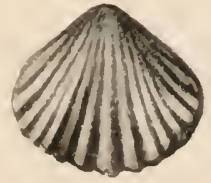

$7 \mathrm{c}$

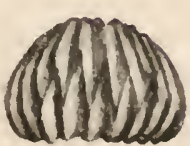

$7 \mathrm{~d}$

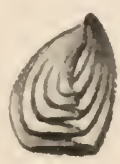

$7 \mathrm{e}$ 


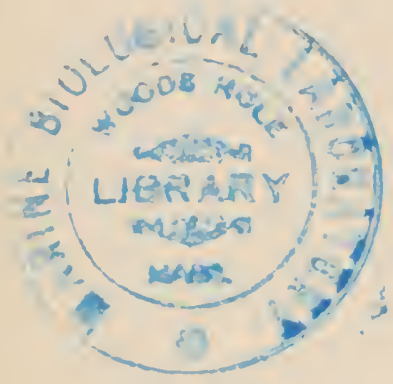




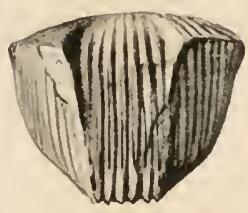

1 a

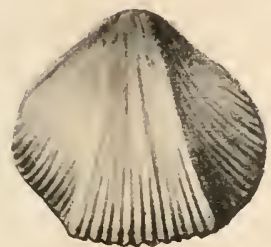

$2 \mathrm{a}$
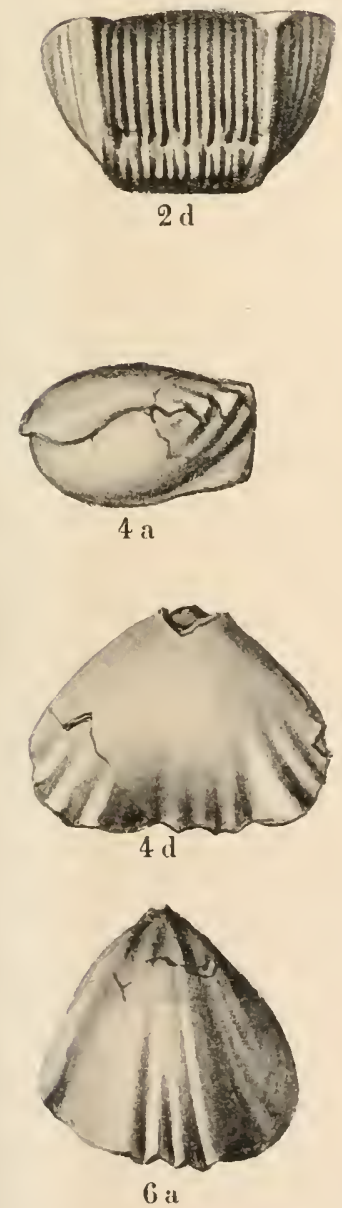
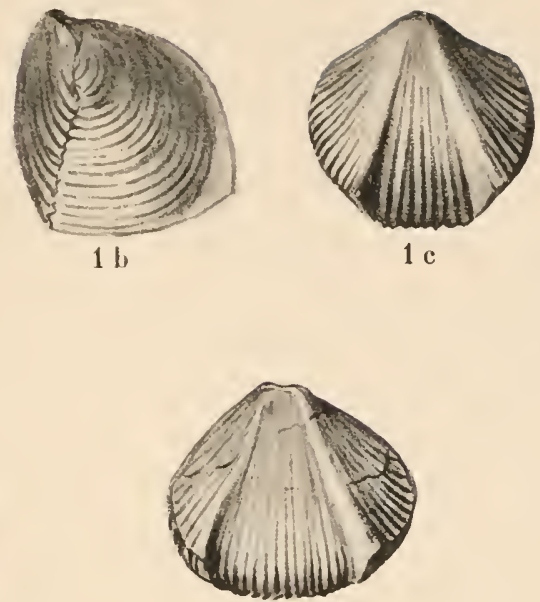

2 b

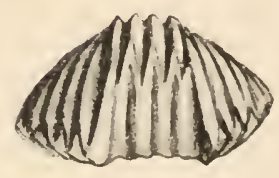

3 a
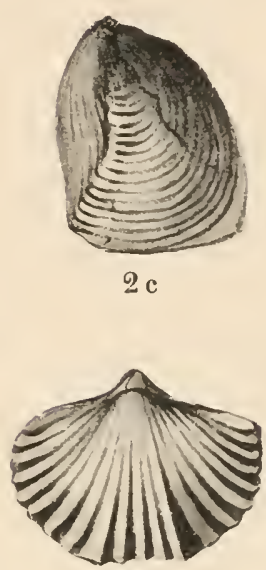

$3 \mathrm{~b}$

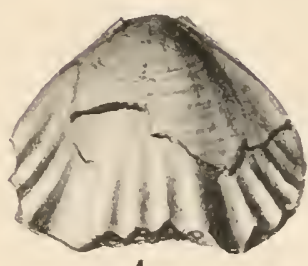

$4 \mathrm{c}$
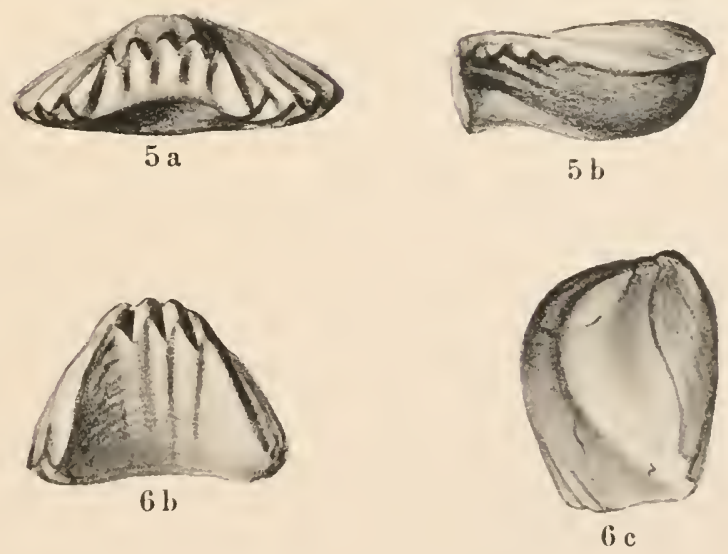



\section{REPORT OF THE SECOND NORWEGIAN ARCTIC EXPEDITION IN THE}

$$
\text { ,,FRAM“ 1898-1902. No. } 29 .
$$

Oskar-Erich Meyer: Die devonischen Brachiopoden von Ellesmereland.

\section{Druckfehler-Verzeichnis.}

Seite 20: Zeile 7 von oben "becleuteude" statt bedutende.

"26: Zeile 6 von oben "feiner" statt gröber.

"29: Zeile 3 von unten „auf S. 31 erwaihne" statt erwähnte.

" 34: Zeile 2 von unten "des" P. galeatus statt aus dem galeatus.

"36: Zeile 8 von oben "nach dem" statt und den.

" 38: Zeile 9 von oben "Fig." statt Figg.

" 41: Taf. III, Fig. 4 a c Leplaena spec. "Unterdevon $D_{b}$ " statt Mitteldevon $\mathrm{D}_{b}$

" 41: Zu Tafel I Figur 1 und 2: $D_{b}$, Ostre Borgen.

" 42: Zeile 12 von unten "Stiel"klappe statt Strielklappe. 

REPORT OF THE SECOND NORWEGIAN ARCTIC EXPEDITION IN THE ,FRAM” 1898-1902. No. 30.

STEPHA N LOE WE:

\section{DIE DEVONISCHEN KORALLEN VON ELLESMERELAND}

MIT 7 TAFELN

AT THE EXPEXSE OF THE FRIDTJOF NANSEN FUND FOR THE ADVANCEMENT OF SGIENCE

PLBLISHED BY

VI DEN SKA BS-SELSKABET I KRISTIA IA

(THE SOCIETY OF ARTS AND SCIENCES OF IRISTIANIA)

K R I S T I A N I A

PRINTED BY A. W. BRøGGER 

$\mathrm{U}$ nter den reichen paläozoischen Funden, die PER Schei, der Geologe der Fram, auf der zweiten norwegischen arktischen Expedition in den Jahren 1898-1902 gemacht hat, befindet sich eine grösser'e Sammlung von Korallen devonischen Alters, die sich zum 'Teil durch recht guten Erhaltungszustand, jedoch nicht durch grosse Mannigfaltigkeit der Arten auszeichnen. Die Bestimmung dieser Korallen bestätigt in gleicher Weise wie die Bearbeitung der aus denselben Schichten stammenden Brachiopoden (vergl. Report No. 29) den geographischen Zusammenhang des New Yorker Helderbergmeeres mit der nahezu 30 Breitengrade nördlicher nachgewiesenen Flachsee. Wie sich nämlich die typischen Vertreter der Brachiopoden des Helderbergmeeres auf der Insel Ellesmereland finden, zeigt auch die Korallenfauna eine deutliche Verwandtschaft mit den aus dem Staate New York bekannten Arten. Während die an Arten und Stückzahl weitaus reicheren Brachiopodenfunde eine genauere Horizontierung der Schichten gestatten, enthält die artenärmere Korallensammlung nur in den höheren devonischen Schichten einige wenige Spezies, die für die Lösung stratigraphischer Fragen von Bedeutung sind. Immerhin bleibt die Tatsache von grossem Interesse, dass die an eine warme Flachsee gebundenen Anthozoen sich über eine einheitliche Klimazone von solchem Ausmass verbreitet haben. Damit ist eine neue wertvolle Stütze für die Hypothese gegeben, welche einheitliche Klimazonen von ausserordentlich grosser räumlicher und zeitlicher Ausdehnung während des Altertums der Erdgeschichte annimmt.

In der folgenden Tabelle ist eine nach stratigraphischen Gesichtspunkten geordnete Übersicht über die von der Fram mitgebrachte Korallenfauna des arktischen Devons gegeben. Von P. Scher wurde mit $D_{a}$ die älteste, fossilleere, mit $D_{i}$ die höchste, jedoch nicht korallenführende Schicht bezeichnet. Korallen wurden nur in den Schichten $D_{b}$, $D_{g}$ und $D_{h}$ aufgefunden. 


\section{$D_{b}$.}

1. Cyathophyllum Sverdrupi nov. spec.

?. Phillipsastraea gigas Bullixgs . . . Lower Helderberg group.

3. Facosiles Heldergerine HaLL . . . Lower Helderberg group.

f. Favosiles framensis mul. nov. praecursor.

5. Cyalhophylhum quadrigemimum mul. nov. aretica.

6. Syringopora nobilis Buduxgs . . Upper Helderberg group, Hamilton berls.

$$
D_{g}
$$

7. Cyathophyllum cf. bathycalyx Frecn . Grinoidenschicht, Grenzhorizont von Calceola- und Grinoidenschicht, mittlere Stringoceph.-Schichten.

$$
D_{h} .
$$

8. Cyalhophyllum nepos HALL . . . Hamilton beds.

9. Mesophyllum (Aclinocystis) robushum Hall

Niagara, upper Helderberg group, Hamilton beds.

10. Cyalhophyllum caespilosum Gordfuss Oberes Mitteldevon bis unteres Oberdevon.

11. Phillipsastra a Scheii nov. nom.

12. Phillipsastraea Verneuili, Minse EDw. und Hame . . . . . . . . . Hamilton beds.

13. Favosiles framensis nov. spec.

14. Alceoliles suborbicularis Lan. . . Mitteldevon bis unteres Oberdevon.

15. Syringopora nobilis Bumixas . . Upper Helderberg group, Hamilton beds.

16. Syringopora Meyeri nov. spec.

Da siclı unter den aufgeführten Arten neben einigen weltweit verbreiteten sechs ausschliesslich aus Amerika bekannte Arten befinden, empfiehlt es sich, zun stratigraphischen Vergleich amerikanische Horizonte heranzuziehen, deren Benemungen, um Verwechshungen vorzubengen, der Zusammenstellung von O. E. Meyer (Report 29) entıommen sind. 


$$
D_{u} \text {. }
$$

Günzlich fossilleer (vergl. O. E. MeYer a. a. O.).

$$
D_{b} \text {. }
$$

Dieser Schicht gehören sechs verschiedene Arten an, die sämtlich am Vestre Borgen, einen Felsen am Ufer des Gaasefjords, gefunden wurden. Die neue Art, Cyathophylhum Sverdrupi, liefert keinen Anhaltspunkt für die Horizontierung der Schicht. Ebensowenig kann Syringopora nobilis Billings hierfür von Bedeutung sein, da, wie unten nachgewiesen werden wird, diese Art durch das ganze Devon verbreitet ist.

Favosites Helderbergiae und Phillipsastraea gigas weisen auf die untere Helderberggruppe hin. Damit steht in gutem Einklang, dass Cyathophyllum quadrigeminum mut. nov. arctica als ein älterer Vorläufer des aus den unteren Stringocephalenschichten bekannten Cyathophyllum quadrigeminum s. str. angesehen werden kann.

Eine genauere Horizontierung der Schicht ist auf Grund der vorliegenden Arten nicht möglich, doch ist die Tatsache von Interesse, dass die Korallen, ebenso wie die Brachiopoden, welche fast durchweg auf die untere Helderberggruppe hinweisen, ohne für einzelne enger begrenzte Horizonte charakteristische Leitfossilien zu enthalten, erst in höheren devonischen Ablagerungen eine schärfere Abgrenzung ermöglichen.

enthalten keine Korallen.

$$
D_{c}-D_{f}
$$

$$
D_{g} .
$$

Aus $D_{g}$ liegt nur ein Cyathophyllum vor, das als nahe verwandt mit Cyathophyllum bathycalyx Frech aufzufassen ist und dem Fundorte Brönden am Gaasefjord entstammt. Diese Art deutet auf höheres Mitteldevon, was durch die Brachiopoden aus der Schicht $D_{g}$ bestätigt wird. Das dunkle Kalksteinfragment, welches das eine der beiden aufgefundenen Exemplare enthält, umschliesst auch eine Stielklappe von Chonetes lineatus und von Spirifer Scheii MEyer, von denen Chonetes lineatus auf die corniferous beds deutet, während Spirifer Scheii Meyer im ganzen Devon verbreitet ist.

$$
D_{h} \text {. }
$$

Die Schicht $D_{h}$ ist mit Sicherheit dem obersten Mitteldevon bis Oberdevon gleichzusetzen. Aus den Hamilton beds sind die folgenden Arten bekannt: 
Cyathophyllum nepos HaLL,

Phillipsastraea Verneuili,

Syringopora nobilis BuLungs,

Mesophyllum robustum HaLL,

von denen die letzten zwei Arten allerdings auch gelegentlich in älteren Schichten vorkommen.

Bis in das Oberdevon reichen:

Alveolites suborbicularis Lan.

Cyathophyllum cciespitosum GoLdFuss.

Diese Funde lehren in völliger Übereinstimmung mit den a. a. O. be. schriebenen Brachiopoden, dass die Schicht $D_{h}$ neben oberdevonischen Vertretern noch Reste der mitteldevonischen Fauna enthält.

\section{$D_{i}$.}

In den kalkigen Sandsteinlagen dieser Schicht, die nur vereinzelte Brachiopoden und Zweischaler enthalten, finden sich keine Korallen. Darüber lagern bekanntermassen die von Nathonst beschriebenen Pflan. zen. Der damit bewiesene langsame Rückzug des oberdevonischen Meeres lüsst sich - entsprechend dem Gesteinscharakter - bis in die Schicht $D_{h}$ hinein verfolgen. Eine Gesteinsplatte, welche Syringopcra Meyeri enthält, nähert sich im Gegensatz zu Fragmenten aus $D_{g}$, die aus dunklem. ziemlich reinem Kalk bestehen, in ihrer Zusammensetzung den sandigen Kalksteinlagen der darüberliegenden jüngeren Schichten.

\section{Cyathophyllum nepos HaLL. \\ Tafel I, Fig. $1 a-d$.}

1881 ('yathophyllum corniculum Quexstedt, Röhren- und Sternkorallen, S. 397 ff., 'Taf. 156, Fig. 58, 59.

1876 Hat., Devonian Fossils, Taf. 22, Fig. 10, 11.

1876 Cyathophyllum comicula Romxger, Michigan, Bd. III, 'Teil @, Taf. 36 I. u.

Aus der Hamilton-Gruppe bildet HaLL ein Cyathophyllum al, das drei Stizcken aus den kanadischen Insehn zu entsprechen scheint. Die Exemplare sind nicht sonderlich gut erhalten, doch zeigen zwei unbeschidligle Kelche cine völlige Übereinstimmung mit der in Figr. 11 a. a. 0. ahgebildeten Koralle. Die kräftig ausgebildeten Septen verlaufen in gleiclunitssigen Abständen von der Peripherie zum Kelchzentrum, doch sind, meist alternierend, auch deutliche Septen zu erkennen, die nicht his zur Kelchnitte reichen, sondern in etwa $2 / 3$ der Lünge des Kelchradius 
enden. Ein Längsschnitt ist bei HaLL nicht abgebildet, so dass sich die Bestimmung auf die Zeichnung des Kelches und das Gesamtbild einer Einzelkoralle (Fig. 10) gründen muss. Der Kelchdurchmesser beträgt bei alten drei Stücken $1-2 \mathrm{~cm}$. Rominger bildet unter dem Namen Cyatho. phyllum cornicula auf Tafel 36 l. u. sechs Exemplare einer Koralle aus dem corniferous limestone ab, die Cyathophyllum nepos HALL überaus ähnlich, wenn nicht mit diesen identisch sind. Besonders die kleimeren der abgebildeten Exemplare sind den vorliegenden Stücken in jeder Hinsicht sehr ähnlich. $\mathrm{Ob}$ es sich um eine nur nahe verwandte Art handelt oder eine Identität besteht, könnte mit Sicherheit nur durch Vergleich des Originalmaterials entschieden werden. Die Identität der von Hall und von Rominger beschriebenen Stücke ist um so wahrscheinlicher, als ihre beiden Werke im gleichen Jahre erschienen sind.

Die Art kommt zusammen mit Mesophyllum robustum in der Serie $D_{h}$ vor', die dem obersten Mitteldevon bis Oberdevon gleichzustellen ist, wie von O. E. Meyer a. a. O. nachgewiesen wurde.

\section{Cyathophyllum caespitosum Goldfuss.}

Tafel I, Fig. $2 \iota-d$.

1826 Cyathophyllum caespitosum Goldfuss, Petref. German., S. 60, Taf. 19, Fig. 2.

1850 Diphyphyllum caespitosum D’Orbigny, Prodr. de paléont., S. 106, Taf. 1.

1851 Cyathophyllum caespitosum Milne Edwards et Haime, Polyp. foss. des terr. palaeoz., S. 384.

1850-54 Cyathophyllum caespitosum Milne Edwards et Haime, British foss. corals, S. 229, Taf. 51.

1881 Cyathophyllum caespitosum Quenstedt, Petrefactenkunde III, Röhren- und Sternkorallen, S. 509, 'Taf. 161, Fig. 7-15.

1897 Cyathophyllum caespitosum Frech, Lethaea palaeoz., Bd. I, S. 337 , Taf. XXVI, Fig. $S$ a, b.

Diese Art kommt nicht nur in den bekanmten Fundorten des oberen Mittel- und Oberdevon von Europa vor, sondern findet sich ebenso in Asien, ja sogar in den Schichten von Manitoba, deren Fauna nach Frech (Lethaea II, S. 249-250) eine erstaunliche Ähnlichkeit mit den Stringocephalenschichten der Eifel aufweist. Begrenzter ist die vertikate Verbreitung, da die Art im allgemeinen auf das obere Mitteldevon beschränkt ist, jedoch gelegentlich auch in kaum wesentlicher Veränderung in das untere Oberdevon hineinreicht. 
Die folgende Tabelle veranschaulicht die horizontale und vertikale Verbreitung von Cyathophyllum caespitosum:

1. Mitteldevon der Loire (Frankreich).

2. Oberes Mitteldevon (Plattenkalk des Mont Bataille).

3. Rheinisches Mitteldevon (obere Calceolaschichten).

4. Mittel- bis Oberdevon ('Tuffe von Planschwitz in Thüringen).

5. Karnische Alpen (oberes Mitteldevon).

6. Oberstes Mitteldevon von Graz.

7. Ober-Kunzendorf hei Schweidnitz, Schlesien (unteres Oberderon).

S. Oberes Mitteldevon im polnischen Mittelgehirge.

9. Bosporus.

10. Ural (oberstes Mitteldevon).

11. Zentral-Rnssland.

12. Altai (unteres Oberderon).

13. 'Tian-Schan (oberes Mitteldevon, Tschon Terek).

14. Stringocephalen-Dolomit von Manitoba (oberstes Mitteldevon).

Es ist deshalh auch nicht verwunderlich, lass diese Art unverändert auch in der Schicht $D_{h}$ der kanadischen Inseln auftritt, die dem oberen Miltel- bis Oberlevon gleichzusetzen ist. Ein reiches Vergleichsmaterial, besonders aus der Eifel (Sammlung Frech), zeigt im Dümnschliff die völlige Übereinstimmung des inneren Baues. Die äussere Form der Stücke entspricht mehr del Ablildung von Midxe Enwards und Haime (a. a. O.) als den Bildern, die Quenstemt (a. a. O.) gibt, d. h. die verhältnismässig reiche Verïstelung verhindert die Entstehung gleichmiissig dicker, nebeneinanderstehender Röhren. Vielmehr erfolgt ein rasches Anwachsen der einzelnen, häufig knospenden Kelche.

Die Aussenwand des Kelches weist eine deutliche Längsstreifung auf. Diese ist auf die Stirnlamellen zurückzuführen, welche nach Zerstörung der dümnen Epithek sichthar werten.

Der Lüngsschliff zeigt beiderseits die charakterische Randzone aus blasigem Gewehe, welche eine zentrale Innenzone ungiht, die durch die Querböden eingenommen wirl.

Es liegen zwei Bruchstücke eines Stuckes vor, die der Schichtengruppe $D_{h}$ entstammen und in Rypeetven (Gaasefjorl) aufgesammelt sind.

\section{Cyathophyllum cf. bathycalyx Frech.}

Tafel I, Fig. f mol II, Fig. 1.

1857 Cyathophyllum bathycalyx Frecn, Paliontologische Mhandlungen. Bd. IIl, S. 181, 'Taf. XVII, Fig. 17-2't, Taf. XIX, Fig. S-11. 
Nur in der Schicht $D_{g}$ fanden sich zwei nur mässig erhattene Cyathophyllen, welche die nïchsten Beziehungen zu dem von Frecu beschriebenen Cyathophyllum bathycalyx zeigen. Verschiedene der für diese Art charakteristischen Merkmate lassen sich auch an dem geringen vor* liegenden Material beobachten, das aber für eine absolut sichere Bestimmung nicht als ausreichend angesehen werden kann. Das Fchlen der Anwachswülste ist ebenso gut erkennbar wie das Vorhandensein von Anwachsstreifen und Septalfurchen. Die Zahl ter Septen beträgt in Übereinstimmung mit Frech, der 60-70 angibt, 64, einschliesslich der Septen zweiter Ordnung. Diese treten an Grösse weit hinter den Hauptsepten zurück, die aher ihrerseits auch nicht die Kelchmitte erreichen. Die peripherische Blasenzone zeigt etwa vier unregelmässige Reihen kleiner Bläschen. Während diese in einem Querschnitt gut zu erkennen sind, zeigt der Längsschliff des zweiten der vorhandenen Exemplare nur schwache Andeutingen der Querböden. Die äussere Gestalt des Kelches ist nach Frech entweder hornförmig oder zylindrisch, während die beiden arktischen Exemplare einen ziemlich regelnıässig kegelförmigen ocler nur schwach hornförmig gekrümmten Kelch zeigen.

Fundort: $D_{g}$ Brönden. Anzahl: 2 Stück.

Cyathophyllum quadrigeminum mut. nov. arctica.

Cyathophyllum quadrigeminum s. str.

Tafel II, Fig. $3 a--c$.

1S26 Cyathophyllum quadrigeminum Goldfuss, Petretacta Germ. I, S. 59, Taf. XVIII, Fig. 6 b, c; Taf. XIX, Fig. 1 a.

1551 Cyathophyllum quadrigeminum M. Edwards et Harme, Polyp. palaeoz., S. 383.

$1 S 81$ Cyathophyllum quadrigeminum Quenstent, S. 549, Taf. 163 , Fig. 13, 14.

1SS1 Cyathophyllum quadrigeminum SchuÜter, Zeitschrift d. D. Geol. Ges., S. 99, Taf. 12, Fig. 3.

1SS6 Frech, Die Cyathophylliden und Zaphrentiden des deutschen Mitteldevons. Paläontologische Abhandlungen, Bd. III, Heft 3, S. 72, Taf. III, Fig. 1, 1 a.

Die vorliegenden Reste eines massigen Cyathophyllum können wegen des schlechten Erhaltungszustandes leicht mit Michelinia verwechselt werden. Grosse, hier und da blasig entwickelte Böden durchzichen das Innere, während die Reste der Septen auf die peripheren 
Teile der zylindrischen Koralliten beschränkt sind. Besonder's können die Individuen, in welchen grober Kalkspat die Zwischenräume der Büden erfüllt, bei oberflächlicher Betrachtung kaum von ungünstig erhaltenen Michelinien unterschieden werden. Jedoch ergibt ein sorg. fältiger Vergleich, besonders bei Berücksichtigung einiger vollständiger erhaltener Stücke, dass erstens die Mauer bei dem vorliegenden Cyatho. phyllum stets zackigen Verlauf zeigt, wobei die Zacken durch das Ausstrahlen der Septa bedingt sind, zweitens, dass niemals auch nur eine Spur von Poren beobachtet wurde. Dagegen sind bei Michelinia die Wünde niemals gezackt, sondern geradlinig und kräftig. Ausserdem sind sie stets von deutlichen Poren durchbohrt. Diese Beobachtungen erlauben es, die erwähnte Koralle der Gruppe des Cyalhophyllum quadrigeminum zuzuweisen. Ehenso wie bei dieser, aus den unteren Stringocephalus-Schichten bekannten Art sind die massigen Stöcke aus vier-bis sechsseitigen Prismen zusammengesetzt. Der Durchmesser beträgt S-12 nm. In Gegensatz zu diesen übereinstimmenden Merkmalen unterscheidet sich die neue Mutation von der bekannten Art durch eine geringere Septenzahl. Nach Frech schwankt bei Cyallo. phyllum quadrigeminum die Septenzahl zwischen $20+20$ und $25+25$, während Cyathophyllum quadrigeminum mut. arctica nicht einmal die untere Grenze von $20+20$ erreicht. Bei den der Untersuchung zugäıg. lichen Individuen beträgt die Zahl der Septen $18+1 S$. Ob die Primärsepta wie bei Cyalhophyllum quadrigeminum den Kelchmittelpunkt erreichen, liess sich infolge des schlechten Erhaltungszustandes des Kelchinneren nicht feststellen. Die Septalleisten sind schwach ausgebildet. In bezug auf die Ausbildung der Blasenzone weicht die neue Mutation gleichfalls wesentlich von der bekannten Art ab. Während sich bei dieser l,is z.n vier Blasenreihen beobachten lassen, konnte bei der arktischen Spezies nur eine, üherdies sehr schmale Blasenzone festgestellt werden. Auch diese war nur bei den besterhaltenen Kelchen zu erkennen. Neben diesen palïontologischen Unterschieden schliessen die stratigraphischen Verhältnisse eine Identitit der beiden nahe verwandten Formen an-. Cyathophyllum quadrigeminum s. str. ist an die unteren Stringocephalus-Schichten (mittlerer Korallenkalk) von Gerolstein und andere Fundorte gebunden, willıend Cyalhophyllum quadrigeminum mut. nov. arclica in die gleiche Schicht gebettet ist, in der sich Pentamerus pseudogaleatus fand, der aus den mittleren Ablagerungen der unteren Helderlerg-Gruppe bekannt ist (vergl. Report 29).

Fundort: $I_{\iota}$ Vestre Borgen. Anzalıl: S Stück. 
Cyathophyllum Sverdrupi nov. spec.

Tafel 1, Fig. 3 und II, Fig. $4 a$ und $b$.

Die vorliegende Art, die in mehreren Gesteinsstücken von Vestre Borgen aus der Schicht $D_{b}$ vorliegt, zeigt die nïchsten Beziehungen zu Cyathophyllum vermiculare GoLDfuss oder vielmehr zu dessen älterer mut. praecursor FRECH. ${ }^{1}$ Die meist zylindrischen, ziemlich geraden Kelche sind einfach und vermehren sich nur selten durch Knospung. Der Durchmesser beträgt etwa $1 \frac{1}{2}-2 \mathrm{~cm}$. Ein sicheres Längenmass lässt sich nicht angeben, da keiner der zahlreichen Kelche in der ganzen Länge erhalten ist. Septalfurchen sind gut sichtbar. Die Zahl der Septen beträgt im Gegensatz zu denen von Cyath. vermiculare, die Frecn auf $30+30$ bis $38+38$ angibt, nur etwa $24+24$. Ein weiterer Unterschied, der wichtiger ist als der der Grösse, besteht darin, dass die Septa zweiter Ordnung nicht nur zackenartig vorspringen, sondern die halbe Länge der Hauptachse erreichen. Ausserdem ist das Blasengewebe etwas schmaler als bei der von GoldFuss zuerst beschriebenen Art, doch gleichfalls deutlich von der zentralen Bödenzone geschieden. Demnach zeigt Cyathophyllum Sverdrupi besondere Ähnlichkeit mit Cyathophyllum vermiculare mut. praecursor FRECH, da diese Mutation sich gleichfalls durch geringere Dicke der Theka und bedeutendere Länge der Septa zweiter Ordnung auszeichnet, ohne jedoch in bezug auf diese Merkmale der Art aus dem arktischen Gebiete gleichzukommen. Da die neue Art bereits in der unterdevonischen Schicht $D_{b}$ auftritt, ergibt sich folgende Entwicklungsreihe:

1) Cyathophyllum Sverdrupi. Septa 24+24, Septa zweiter Ordnung halb so lang wie die erster Ordnung. Blasengewebe $1 / 3$ des Gesamtdurchmessers.

Im arktischen Unterdevon.

2) Cyathophyllum vermiculare Goldfuss mut. praecursor Frech. Blasengewebe etwas dicker. Zahl der Septen $30+30$. Septen zweiter Ordnung etwas kürzer als bei der vorstehenden Art.

Unterer und mittlerer Stringocephalenkalk usw.

3) Cyathophyllum vermiculare GoLdfuss s. str.

Blasengewebe nimmt $2 / 3$ und mehr des gesamten Durchmessers ein. Septa zweiter Ordnung nur zackenartig vorspringend. Zahl der Septen wie bei vorstehender Mutation.

Oberer Stringocephalenkalk.

Die neue Art findet sich am Vestre Borgen. $D_{b}$, Gaasefjorden.

11587 F. Frecr: Die Cyathophylliden und Zaphrentiden des deutschen Mitteldevons. Paläontologische Abhandlungen Bd. III, S. 176, 177, wo weitere Literatur. 
Mesophyllum (Actinocystis) robustum HalL.

Tafel II, Fig. $2 a$ und $b$.

ISte Cyathophylhum robustum Has... Devonian Fossils. Tafel XII, Fig. 1-9 und 14.

Diese Art, die Halt aus der Hamilton-Gruppe heschreibt und die nach Miller in der Niagara und Upper Helderberg group wie im Corniferous limestone auftritt, muss zur Gruppe des Mesophyllum gerechnet werden, demn sowohl die Abbildung bei HALL als auch die zahlreichen Längs. schliffe, the das reiche Material derselhen Art aus dem arktischen Norden herzustellen erlaubte, lassen die für Mesophyllum oder Actinocystis charakterische dïtenförmige Anordnung der Septen erkennen, wïhrend für das typische Cyathophyllum eine deutliche Trennung der horizontal angeordneten Tabulae von dem blasigen Gewebe der Dissepimenta charakleristisch ist. Die Grösse der einzelnen Korallen ist sehr variabel. Ihr Durchmesser schwankt zwischen $1 \frac{1 / 2}{2}$ und $5 \mathrm{~cm}$. Der Kelchrand ist ziemlich scharf abgesetzt. Die längeren der radial angeordnelen Septen reichen bis zur Mitte des Kelches, während die kürzeren nur um wenig mehr als die Hälfte den Kelchradius an Linge übertreffen. Infolgedessen erscheint das Zentrum des Kelches gegen die randlichen Teile leicht abgesetz. Einige wenige gut erhaltene Stücke zeigen in der Nïhe des Kelchrandes die interseptalen Blïschen, wie sie Halt in Fig. 14 zur Darstellung bringt.

Fundort: $D_{h}$ 'Terrassen, Gaasefjorden. Anzahl: etwa 25 Stück.

\section{Phillipsastraea Vernenili, Phillipsastraea Scheii nov. nom.}

Tafel III, Fig. $1 a, b$ und IV, Fig. $1 a, b$ und $3 a-c$.

Phillipsastraea Verneuili Mane Enwands und Hame und Phillipsastraea alpenensis Romwger sind zwei konfluente Phillipsastraeen, die im oberen Mitleldevon von Michigan ehenso miteinander vorkommen, wie fast :30 Breitengrade weiter nördlich in dem gleichen Horizont von Ellesmeredand. Nach den guten, von Romxgen gegebenen Abbitdungen der verkieselten Exemplare und den ausgezeichneten Präparaten, die von den dunkeln Korallenkalken von Spakkassen und Gaasefjord (Svinesund) angefertigt werten konnten, ist eine vollstindige Ühereinstimmung festzustellen, die sich sogar auf die Zahıl der Septen (40) erstreckt. Die imere Struklur, die infolge der Verkieselung der Stöcke weder ron Milase Edwaris und Haime, noch von Romingen beobachtet werden 
konnte, zeigt bei Ph. Vernenili im peripheren 'Teile der konfluenten Kelche ein wohlentwickeltes Blasengewebe, während das enge Kelchzentrum durch konkave, unregelmässige Böden ausgelïllt ist. Auch die Struktur der Septen aus vertikal angeordneten Prinä̈rlornen ist im Prïparat gut sichtbar. Die Bezeichnung der im hohen Norden vorkommenden Arten wäre ungemein einfach, d. h. man würde den Milne Edwardsschen Namen Phillipsastraea Verneuili und die Bezeichnung Phillipsastraea alpenensis Rominger spec. (Strombodes Ronnnger) einfaclı auf die arktischen Arten anwenden können. wenn nicht eine Namensverwechslung in der Beschreibung von Romnger untergelaufen wïre. Es kann nach Vergleich der Abbildungen Roungers, Taf. 3S, Fig. 1, mit der Figur von M. Edwards und Hane, Taf. 10, Fig. 5, keinem Zweifel unterliegen, dass Strombodes alpenensis in Wirklichkeit Phillipsastraea Verneuili von Milne Ebwards und Hane gleich ist, die auch aus dem Mitteldevon von Wisconsin, Michigan stammt; denu beide, Phillipsastraea Verneuili wie Strombodes alpenensis, besitzen vollkommen konfluente Kelche mit ebenen Kelchgrenzen, während nur das von Böden eingenommene Kelchzentrum von einer niedrigen Aufwölbung umgeben ist. Strombodes alpenensis Rominger ist also ein Synonym und demnach einzuziehen. Dagegen ist die von Rominger als Phillipsastraea Verneuili bezeichnete, Taf. 3S, Fig. 2 abgebildete Art durch erhöhte Kelchzentren auf der Oberfläche und relativ deutliche Abgrenzung der Individuen im Dünnschliffe ausgezeichnet. Das Zentrum der Kelche ist gleichmässig vertieft, ohne dass eine Aufwölbung die Zentralregion abgrenzt. Es handelt sich also um eime nicht konfluente Form, die den Übergang zu den stockförmigen Cyathophyllen aus der Gruppe des Cyathophyllum hexagomm oder basaltiforme darstellt. Diese, Phillipsastraea Verneuili, Rouinger, non Milne Edwards und Hame, ist demnach unrichtig bestimmt und neu zu benennen. Ich schlage hierfür den Namen des verdienstvollen unglücklichen Geologen PER Scher vor und nenne sie:

\section{Phillipsastraea Scheii nov. nom.}

Es ergibt sich also folgende Synonymik:

a) Gruppe der Phillipsastraea Hennahi (mit vollkommen zusammenfliessenden Kelchen)

Hierher gehört von amerikanischen Formen des Mitteldevons: Phillipsastraea Verneuili Milne Edwards und Hame

(Phillipsastraea Verneuili Mine Edwards und Haime, Archiv du Mus. Histoire Naturelle, Teil V, Taf. 10, Fig. 5)

= Strombodes alpenensis Romnger, Michigan, Taf. 3S, Fig. 1. 
Vorkommen:

Oberes Mitteldevon (Hamilton-Gruppe),

Michigan (Thunder Bay),

Spakkassen, Svimesund (Ellesmereland),

Wisconsin (Coll. de Verneuil).

b) Gruppe der Phillipsastraea Ananas (mit ziemlich deutlich abgegrenzten Kelchen).

Hierher gehört:

Phillipsastraea Scheii nor. nom. = Phillipsastraca Vernenili

Rominger, non M. Edwards und Hame, I. c. Taf. 3S, Fig. 2. Vorkonmen :

Mitleldevon (Erraticum der mitteldevonischen Hornsteinkalke in Michigan),

Oberstes Mitteldevon ( $D_{h}$ Rypeelven, Gaasefjord).

Von beiden Arten, besonders von Phillipsastraea Verneuili, liegen zahlreiche Bruchstücke vor.

\section{Phillipsastraea gigas Billings. \\ Tafel IV, Fig. 2.}

1S76 Rominger, Geological Survey of Michigan, Teil II, Palaeontology, Corals, S. 129, 'T'af. 37, Fig. 3 1. u.

Der im Vorstehenden beschriebenen Phillipsastraea Verneuili nahe verwandt ist die iiltere Phillipsastraea gigas, die nach Rommgen in der unteren Helderberg-Gruppe verbreitet ist. Sie unterscheidet sich von der jüngreren Mutation nur durch etwas umfangreichere Kelche, ileren Rändler gleichfalls in charakteristischer Weise aufgewölbt sind. Die Ïhnlichkeit der von Romngen gegebenen Abbildungen beider Arten ist ein weiterer Beleg dafür, dass das auf Tafel 3S, Fig. 1 dargestellte Stück in der 'Tat irrtünlich als Stromborles alyenensis bezeichnet ist, wie bereits oben dargelegt wurle. Zwar liess sich an den einzigen vorliegenden Brnchstïck von V'estre Borgen die Aufwölbung des Kelchrandes nicht beohachten, doch zeigte ein Querschliff durchaus deuthich die Zugehörig. keit dieser Art zur Gruppe der Phillipsastraea Verneuili, resp. zu ihrem älteren Vordïufer Phillipsastraen gigas. Die beiden Arten kommen auch im arktischen Norden nicht nebeneinander vor, was mit den Beobachtungen Romxgers auf Mackinac Island übereinstimnt. Während Phillipsastraea Verneuili anf die mittel- bis overdevonische Schicht $D_{h}$ beschrankt ist, findel sich das einzige Exemplar von Phillipsastraea gigas in der unterdevonischen Schicht $D_{t}$. 
Favosites Helderbergiae HaLL.

Tafel IV, Fig. $4 a-e$.

1883 Favosites Helderbergiae HalL, Report of the St. Geolog. from the year 1SS2. Taf. 4-6 und Taf. 13, Fig. 15 a.

1887 Favosites Helderbergiae Hall, Palaeontology, Bd. 6, Taf. 4-6 und Taf. 13, Fig. 15 a.

Diese aus der unteren Helderberg.Gruppe bekannte Art liegt in zahlreichen verhältnismüssig gut erhaltenen Stücken vor. Der Querschnitt der meist 5-6 seitigen Prismenzellen zeigt völlige Übereinstimmung mit dem Bilde, das Hall (a. a. O. auf Taf. 5) gibt. Die reihenförmig angeordneten Poren sind an den Aussenwänden einzelner Zellen der Untersuchung zugänglich. Diese lassen den aufgeworfenen Rand gelegentlich erkennen. Auch einer der Längsschnitte, der zufällig eine Porenreihe durchschneidet, zeigt deutlich ihre Anordnung. Sämtliche Längsschnitte lassen die zahlreichen Querböden klar hervortreten, die den dünnen Zellwänden an Dicke etwa gleichkommen. Die Zahl der Querböden innerhalb eines Zentimeters beträgt durchschnittlich 14. Doch sind auch Zellen zu beobachten, deren Bödenzahl die von HaLL angegebene Höchstzahl (15) um ein Geringes übersteigt. Da die Art nur in Bruchstücken aus dem Innern der Stöcke vorliegt, ist die von HaLL abgebildete runzelige Epithek nicht vorhanden.

Fundort: Vestre Borgen, Gaasefjorden. Anzahl: 10 Stück.

\section{Favosites framensis nov. spec.}

Tafel V, Fig. $1 a$ und $b$.

Unter den Favositiden des arktischen Devons findet sich in der Schicht $D_{h}$ eine Art, die mit den bekannten amerikanischen Vertretern nicht identifiziert werden kann. Der von Milne Edwards und Haime irrtümlich zu Favosites Emmonsii bezogene und als Emmonsia hemisphaerica neu benannte Favosites hemisphaericus, der in der Helderberg-Gruppe und auch den Hamilton beds weit verbreitet ist, zeigt keine Beziehungen zu Favosites framensis. Ein Längsschliff, der von einem Exemplar angefertigt werden konnte, das Professor Frech im Staate New York am Cajuga-See aufgesammelt hat, zeigt auf den ersten Blick, dass der arktische Vertreter nicht zu der Gruppe des Farosites hemisphaericus gestellt werden kann (vergl. Taf. V, Fig. 2). Die ungewöhnlich enggestellten Querböden, wie sie ein gut gelungener Längsschliff von 
einen Stürk der neuen Art deuthich zeight, weisen vielmelır auf verwandt. schaftliche Bezielıungen zu Farosiles Goldfussi. Obwohl sich diesel auch schon durch enge Stellumg der Querbüden auszeichnet (vergl. Quexstent, Rïhren- und Sternkorallen, S. 20), so bleilst er doch hinter $F a$. rosites framensis in dieser Hinsicht noch zurück. Ein weiterer Unterschied lient in dem geringeren Zelldurchmesser. In bezug anf dieses Mrrkmal entspricht die arlitische Röhrenkoralle einer Varietit von Farosites Cooldfussi, die FrECu in ten Cultrijugatus-Sehichten von Lissingen hri Gernl-tein gefunden mul als larietas microcalyæ bezeichmet hat. Docls zeigt der Längsschliff dieser Varietail in bezug auf die Häufung der. (Onerbülen die gleiche Abweichung wie Farosites Goldfussi s. str. Die \%ellwïnde sind. wie die beigegebene Abbildung des Längsschniltes an einigen Stellen erkennen lässt, von anscheinend nicht sehr regelmässig angeordneten Poren durchbrochen. Deutlicher sind die kurzen, aher krïf. ligen Septaldornen auf dem Querschliff zu erkennen, die in regelmässiger Anordnung die Kelclıänder besetzen.

Fundort: Sclicht $D_{i}$. Anzalıl: 4 Stïck, Spakkassen 1, Rypeelven 3.

\section{Favosites framensis mut. nov. praecursor.}

Tafel V, Fig. $3 a, b$ und VI, Fig. $1 a, b$.

Dieselben Alweiclungen von den amerikanischen Favositiden der Helderberg-Gruppe, wie der vorstehend beschriebene Favosites framensis, zeigl eine Anzahl gut erhaltener Stücke aus der Schicht $D_{b}$, deren Alter walıs sheinlich als unterdevonisclı (upper Peutamerous limestone) anzumelımen ist. Die eben gegebene Ciarakteristik des nenen Farosites framensis, inshesondere die üherius enge Stellung des Querscheidewïnde, findel sich auch hei ten von Ostre umbl V'estre Borgen slammenden Anthozoen. Fin wesentlicher Unterschied lässt sich nur in bezug auf den Yelhdurchmesser feststellen, der nur reichlich die Häfte des hei Favosites framensis genessenen Durchmessers heträgt. Da irgendwelche /wischenformen nicht vorliegen, ist die Vermutung berechtigt, die erwïhnten Stücke wohl in die Gruppe des Farosites framensis zu stellen, sie aber ats Mulation von der Stanmform abzulrennen. Wir haben es demnach mit einen Vorliufer von Farosites framensis zu tun, da dieser an die millel- his olierdevonische Schichn $D_{n}$ gebunden ist, während Favosites fromensis mul. nov. maecursor allein in $D_{b}$ vorkommt.

Aı\%alıl: S Stück. 
Alveolites suborbicularis Lamarck.

Tafel VI, Fig. ; $a$ und $b$.

1816 Alveolites suborlicularis Lam., Histoire des anmanx sans vert. Bd. 2, S. 186.

1529 Calamopora spongites Goldruss. Petref. German., S. S0. Tafel XXVIII, Fig. 1 a.

$1 S 51$ Alveolites suborbicularis Mune Edwards und Hame, Pol. Pal., S. 255.

155.3 Alveolites suborbicularis Milne Edwards und Haime, British Foss. corals, S. 219, 'Taf. 4!), Fig. 1.

1S63 Alveolites suborbicularis MiLne Enwards, Histoire naturelle des Corall., Bd. III, S. 264.

1879 Alveolites suborbicularis Nicholson, Tabulate Corals, S. 126. Taf. VI, Fig. 2.

$18 S 1$ Alveolites suborbicularis F. Roemer, Leth. palaeozoic, S. 442, Taf. XXVI, Fig. 4.

1855 Alreolites suborbicularis Frech, Die Korallenfauna des Oberderons in Deutschland. Zeitschrift der D. Geol. Ges., S. 10S ff., Taf. VII. Fig. 2.

Einige gut erhaltene Stücke gestatteten die Anfertigung von Schliffen, die eine durchaus einwandfreie Grundlage für die Bestimmung dieser, aus dem hohen Norden bisher unbekannten Art abgaben. Sïmuliche Schliffe veranschaulichen die charakteristische Zellform, die in eitrem verzerten Dreieck mit einer längeren konvexen und zwei kürzeren konkaven Seitenwänden besteht. Aus dieser Form der Zellen ergilıt sich, dass der grösste Durchmesser zum kleinsten sich in derselben Zelle wie 2:1 verhält. Die Böden stehen in regelmässigen, relativ geringen Abständen voneinander. Ein vollständiger Stock liegt nicht vor, doch sind die konzentrischen Lagen, die das IV achstum der Koralle charakterisieren, deutlich erkennbar. Einzelne Fremdkörper, die durch einen der Schliffe getroffen sind. werden von den jungen Individuen, die sich deren Oberfläche genau anschmiegen, überwuchert. So zeigt der in Frage konmende Schliff eine völlig umschlossene Stromatopora und ein kleines fast gauz überwachsenes Cyathophyllım.

Bisher war Aleolites suborbicularis hekannt aus:

1. dem rheinischen Mitteldevon (Zone des Spirifer cultrijugatus),

2. dem unteren Oberdevon von Oberkunzendorf,

3. dem Mitteldevon von Graz (Kalkschiefer der Hubenhalt; Leth., Bd. II, S. 242). 
4. den oberen Mittelderon der Kamischen Alpen,

¿. den miltelderonischen Kalken zu beilen Seiten des Bosporus (Leth, Bi. II, S. 244).

fi. dem jüngeren Devon von Hocharmenien, zusammen mit Calceola sandalina (ehenda S. 297 ),

7. dem unteren Oberderon des Altai (Frech-Ricutuorex, China V, S. 27 und 29.

Weitere Fundorte siehe Frecu, Korallenfanna des Oberdevons in Deutschland, S. 110.

Zur Veranschaulichung der völligen Ilentibat der arktischen, unter $74^{0}$ 1. Br. gesammelten Tiere mit den übrigen, vertikal und horizontal weitverbreiteten Vorkommen (Mittel- bis Oberdevon) diene neben der Angahe der zahlreichen Fundorte die Abbildung eines Schliffes der Sammlung Frecus (einem Stücke aus Reffrath bei Köln entstammend).

Fundorte: $I_{h}$ Rypeelven (Gaasefjord) und Spakkassen (Svinesund). Anzalıl: S Stück.

\section{Syringopora nobilis Bumas.}

'Tafel ViI, Fig. 2ِa und $b$.

IStti Syringopora nobilis Romsgen, Michigan. Bd. III, 'Teil 2. S. Si. Taf. XNXI.

$1 S S 1$ Syringopora nobilis ()uensteot, Petrefaktenkmude Dentschlands. Bul. VI, S. 118, 'Taf. 147, Fig. 40.

ln den Schichten $D_{b}$ und $D_{h}$ worle eine Anzahl von Gesteinsfragmenten anfgesammelt, welche Bruchstücke von Syringoporen-Stücken enllalten, die dersellon Art angehören.

Eime Anzahl von Dïmmschliffen zeight ebenso deutlich wie der Durchnosser und der ïussere Halilus die vällige Überemstimmung mil Syringopora nobilis. Einen \%weifel über die Zngehörigkeit des arklischen fundes zu dieser Art kïmulen mu die stratigraphischuen Ver-

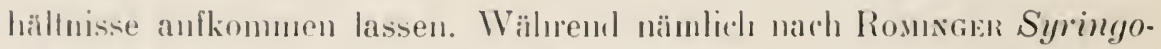

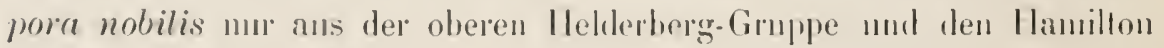
berls, also ans dem Mitteldevon bekann ist, sind die Schichten, in welehe die arktisclien Vertreter gebettet sind, einerseits den mittleren Ablage. rungen der 11 uleren Heklerberg-Gmppe, andererseits den Grensschichten von Millel- und Oberdevon gleichzusetzen. Wenn auch die Schicht $D_{h}$ nelien oherdevonischem auch milteldevonischen Charakter anfweist, also ıen llanilton berk mahesteht, kann doch ïher die Zngehörigkeit der 
Schicht $D_{b}$ zum Unterdevon kein Zweifel bestehen. Auf Grund des palïontologischen Befundes muss deshalb angenommen werden, dass Syringopora nobilis nicht erst in Mitteldevon auftritt, sondern bereits im Unterdevon vorhanden war. Doch darf nicht unerwähnt bleiben, dass eines der Stücke im Gelïnde versehentlich der Schicht $D_{b}$ zugewiesen worden ist, obwohl es zweifellos in den Horizont $D_{h}$ gestellt werden muss, denn es findet sich neben Syringopora nobilis in demselben Gesteinsfragment der sonst an die Schicht $D_{h}$ gebundene Alveolites suborbicularis.

Das gleiche Versehen kann bei den übrigen mit $D_{b}$ etikettierten Stücken nicht angenommen werden, da der Gesteinscharakter, ein dunkler Kalk, dessen organische Einschüsse durch Kalkspat ausgefüllt sind, auf den Fundort Vestre Borgen $\left(D_{b}\right)$ hinweist.

Die Übereinstimmung sämtlicher Stücke mit Syringopora nobilis gründet sich nicht nur auf die guten Abbildungen, die Romingen (a.a. O.) gegeben hat, sondern auch auf ein von dem gleichen Autor eigenhändig bestimmtes und an Ferd. Roemer gesandtes Stück von dem Fundort Louisville, das sich im Besitz des Breslauer Museums befindet Der Röhrendurchmesser erreicht fast stets das von Rominger angegehene Höchstmass von 8 mm. Die Anwachsstreifen der ziemlich glatten Röhren treten an mehreren Exemplaren deutlich zu Tage, ebensowie die charakteristischen dümnwandigen Zellmündıngen. Die trichterförmige Struktur ist zwar aus Romngers Abbildungen, der wegen der Verkieselung seines Materials keine Dünnschliffe anfertigen konnte, nicht zu entnehmen, doch lässt das erwähnte Originalstück des Breslaner Museums die Übereinstimmung des Baues in voller Deutlichkeit erkennen. Das Vorkommen dieser dickzelligen Syringopora ist ein weiterer Beleg für die Verwandtschaft der arktischen Fauna mit der des Helderberg-Meeres, da die aus Europa bekannten Syringoporen an Umiang der Kelche weit hinter dem amerikanischen Vertreter zurückbleiben.

Fundort: $D_{b}$ Vestre Borgen und $D_{h}$ Rypeelven.

\section{Syringopora Meyeri nov. spec.}

'Tafel VII, Fig. $l a$ und $b$.

Über der vorstehend beschriebenen extrem dickzelligen Syringopora nobilis findet sich in arktischen Devon eine zweite, nahe verwandte, aber doch deutlich unterschiedene Art der gleichen Gattung, deren Zelldurchmesser etwa dem der bekannten Syringopora Eifeliensis gleichkommt. Von der aus der oberen Helderberg-Gruppe beschriebenen Art dürtte Syringopora Meyeri am meisten der von BıLlings aufgestellten 
Syringoporn Muchmei ïhneln. Doch sind die Kelche dieser Art. wie die Abhildangen Romagras zeigen, merklich dïmmer. sind aher in ähn-

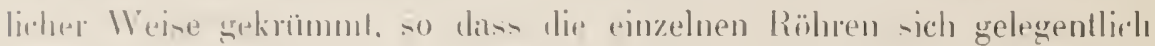

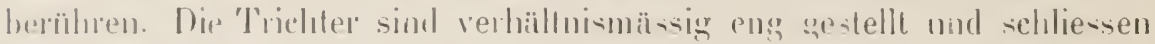

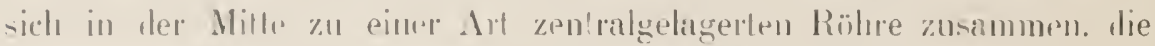

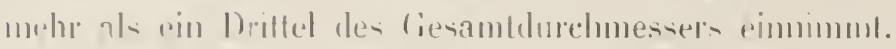

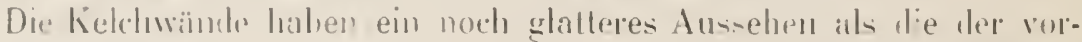
stehend besthrishenen grösseren Art. lassen aher doeh die Anwachs-

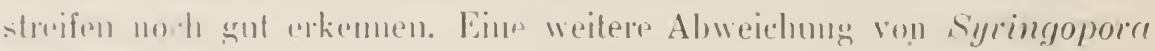

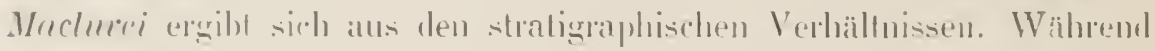
dieste an die Conniferons beals gebunden ist. findel sich Syringopora Mryeri in der jüngeren Schichl $D_{h}$. ohne, wie Syringopora nobilis (sithe oben). bereits in älteren Schichten des arktischen Devons anf\%nlretril.

Fimblorl: Ih ligpeelven. Spakkassen. Anzahl: 2 Stürk.

\section{Palïontologische Übersicht.}

lolelklasse: Yountharia M. Emwanss mol Hane.

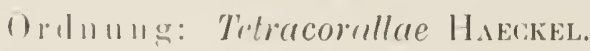

Fil milie: Cyathophillidate li. H.

C'ynhlhophlyllum nepos Has. . . . . . . Terassen.

ryalhophyllum coespitosum Gomerss . . Rypeetven.

('yulhophyllum of. balh!/calyx: Frecil . . Brönden.

C'yalhophyllum quadrigrminum mul. nor.

arclica . . . . . . . . . Vestre Borgen.

ryathophyllum Srerdimpi nor. spec. . . Trotre Borgen.

Mesophyllum (Aclinocystis) robustum Hal.L. Terlassent.

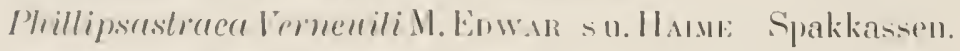

Phillipsastrarer Scheii nor. mom. . . . Ryprestrent.

Philligsastrara gigas Basasas . . . . Vestre Borgen.

Familie: Fiarositiclale li. II.

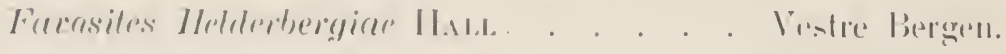

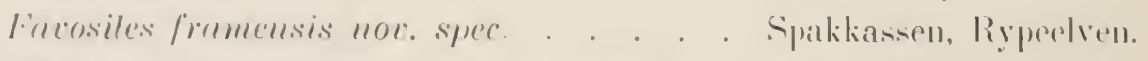

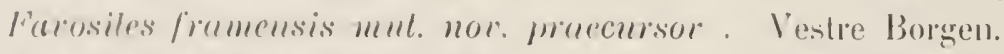

Aleooliles suborbicularis Lan. . . . . Spakkasisen.

Familie: Syringoporidace li. 11.

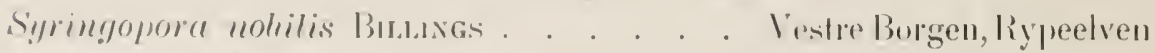

Syyringoporn Meyeri nov. spec. . . . . Riypeelven, Spakliassen. 
Yon diesen Arten at die weitaus grösste Kahl bisher mur aus dem llehlerberomeer des shates New York hekinnt. Aul die Notwendigkeit. einen Zusammenhang dieses Meeres mit dem des kandischen Archipels anzunehmen, wurde hereits in ter stratigraphischen Einleitung hingewiesen. Es bleibt nur zu untersuchen, inwieweit die übrigen Arten geeignet sein köunten, ïber den Zusammenhang dieser grossen Flachsee mit anderen Meeren Aufschlüsse zu geben.

Einige dieser Arten, wie Alvooliles suborbicularis, sind weltweit verbreitef und deshalb nur wenig geeignet, zur Lösmm paläogeographischer Fragen zu dienen (vergleiche die Aufzählung der Fundorte auf S. 17, 1S). Andere, wie Cyalhophyllum caespilosum und Cyathophylhm cf. balhycalyx, Cyalhophyllum quadrigeminum mul. nov. arctica, vielleicht auch Favosiles framensis, weisen ani europïische Verwandtschaft hin. Auch die neue Art Cyalhophylhum Sverdrupi fügt sich unschwer in den Formenkreis des europäischen Cyalhophyllum vermiculare Gounfuss. Die Syringoporen mit starkem Zelldurchmesser, wie Syringopora nobilis, sind durchweg auf Amerika heschrankt. Dagegen scheint Syringopora Meyeri zwischen den dünneren Eifelformen. wie Cuyringopora Eifeliensis, und den ihr ähnlichen amerikanischen Vertretern zu vermittehn. Doch sind solche Annahmen durch das vorliegende Material nicht genügend begründet, um Schlüsse auf die Konfiguration der devonischen Meere zuzulassen. Als sicheres Eigehnis bleiht die Tatsache bestehen, dass das bereits mehrfach erwähnte Helderbergmeer sich über den 76. Breitengrad nordwärts unter einlıeitlichen klimatischen Bedingungen erstreckt haben muss.

Abgesehen von diesem Zusammenhang des arktischen Beckens mit der Flachsee, die zur Zeit des Devons den Staat New York und die nördlicher gelegenen Gebiete bedeckte, ist allein die Feststellung von Interesse, dass an warme Meere gebundene Lebewesen weit über das Helderbergmeer hinaus gleiche Existenzbedingungen vom Bereiche des Mittelländischen Meeres bis nordwärts über den Polarkreis gefunden haben. Somit bilken die von der Fran aus arktischen Gebieten heim. gebrachten Bewohner warmer Meere einen neuen Beleg für die eigentümliche Erscheinung, dass man im Palïozoikum noch nicht in dem Simne von Klimazonen reden kann wie in späteren Perioden der Erdgeschichte. 


\title{
Ta fe I- E r k I ä r un ne n.
}

\author{
Tafel I.
}

Fig. 1 a-d. Cyalhophyllum nepos Haı.. Dh, Terrassen.

" ¿̈u-d. Cyuthophyllum caespitosum Goumuss. Din, Rypeelven.
a) Liingsschliff (nat. Grösse).
b) Desgleichen $(3 ; 1)$.
c) (Uersehliff (nat. Grösse).
d) Desgleiclien $(3:$ : 1).

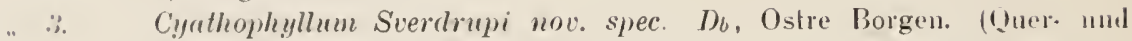
Längsscluliff aus demsellen Gesteinsliagment.) 1:1. (Vergleiclue 'Taf. II, lig. $\dot{f}($ e, b.)

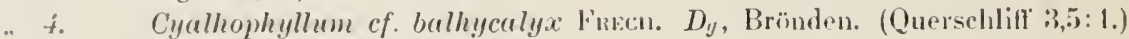
Vergleiche auch Taf. Il, Fig. 1.

\section{'Tafel II.}

Fig. 1. Cyalhophyllum $c f$. bathycalyx Finecu. Dg, Brïmden. (Nat. Grïsse.)

„ ¿a. h. Mesophyllum (Aclinocystis) robustum Haı.. Dh, Terrassen.

a) Aussenansicht einer lielehïflumug.

b) Huerschlitt (nal. Cirösse).

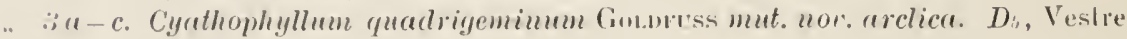
Borgen.

a) Aussemansicht.

l) (buersolilitl:

r) Angeschlifines Giestriusfragment.

. i $a, 6$. Cyathoph!llum Siesdrupi uov. spec. 1). Vestre Burgen.

i) (Bureselilitt (nat. Grösss).

1) 1) resgleichuril (3: 1).

\section{'liafel III.}

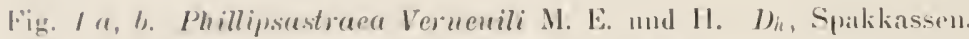

a) buterseile mit Epilleck (nat. Grïsse).

b) (Hbersute dessiollen Slorelies (nat. Gö̈sse).

Vergleiclar ancl, Tiaf. IV, Fig. I a, b.

\section{'Talel IV.}

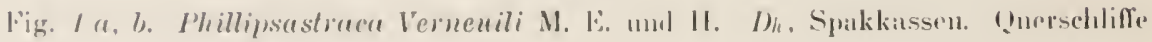
(nat. Girisses).

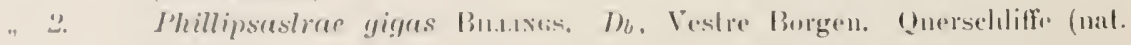
(irions(r). 
Fig. :3a-c. Phillipsastraea Scheii nov. nom. Dh, Rypeetven.

a) Quersihliff (nat. Grösse).

b) und c) Lüngsschıliffe (nat. Grösse).

" $\quad \& a-e$. Favosites Helderbergiae Hatr. $D_{b}$, Vestre Porgen.

a) Läingsschliff (etwal $21 / 2: 1$ ).

b) Querschliff (etwa 3:1).

c) Quersehliff (nat. Grösse).

d) Angeschliffenes Fragment (nat. Grösse).

e) Aussenansicht (nat. Grösse).

\section{Tafel V.}

Fig. 1 a, b. Fuvosites framensis nov. spec. $D_{h}$, Spakkassen.

a) Laingsschliff $\left(3^{1 / 2}: 1\right)$.

b) Querschliff $\left(3^{1 / 2}: 1\right)$.

Vergleiche auch Taf. VI, Fig. 2.

". Favosites hemisphaericus Yandel, et Snumaro. Oriskany sandstone Cayuga, New York.

Lïngssehliff (nat. Grösse). Kollektion Frecrr.

" $3 a, b$. Favosites framensis mut. nov. praecursor. D, Ostre (Vestre) Borgen. a) Längs- und Querschnitt (nat. Grösse).

b) Lüngs- und Querschliff (nat. Grösse). Vestre Borgen.

\section{Tafel VI.}

Fig. $1 a, b$. Favosites framensis mut. nov. praecursor. Db, Vestre Borgen.

a) Längs- und Querschliff $(21 / 2: 1)$

h) Lü̈ngsschliff (nal. Grösse).

"2. Favosites framensis nov. spec. Dh, Rypeetren.

Längsschnitt (nat. Grösse).

\# $a, b$. Alveolites suborbicularis Lan. Dh, Spakkassen.

a) Dünnschliff (nat. Grösse). Der Pfeil deutet auf ein fast gänzlichı̈ überwuchertes Cyathophyllum spec. ind. Ausserdem umschliesst der Alveolites eine nicht näher zu bestimmende Stromatopora.

b) Dassetbe Stück $(21 / 2: 1)$.

4. Alveolites suborbicularis Lam Aus Reffrath bei Köhn. (Koltektion Frear zur· Vergleichung.)

\section{Tafel VII.}

Fig. $1 a, b$. Syringopora Meyeri nov. spec. Dh, Rypeetven.

a) Lïngsschnitt (etwa $3: 1$ ).

i) Querschnitt (etwa $3: 1$ ).

"2a,b. Syringopora nobilis Bumngs. Dh, Rypeelven.

a) Läingsschnitt (nat. Grösse).

b) Querschnitt (nat. Grösse). 


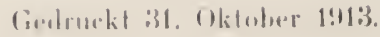


SEC. ARCT. EXP. FRAM 1898-1902. No. 30.

TAF. I.
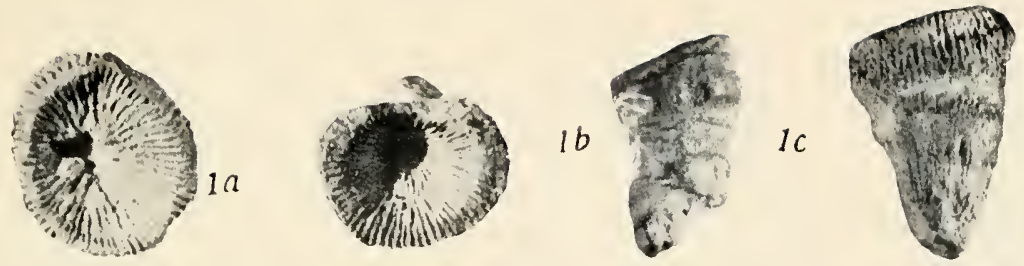

$1 d$
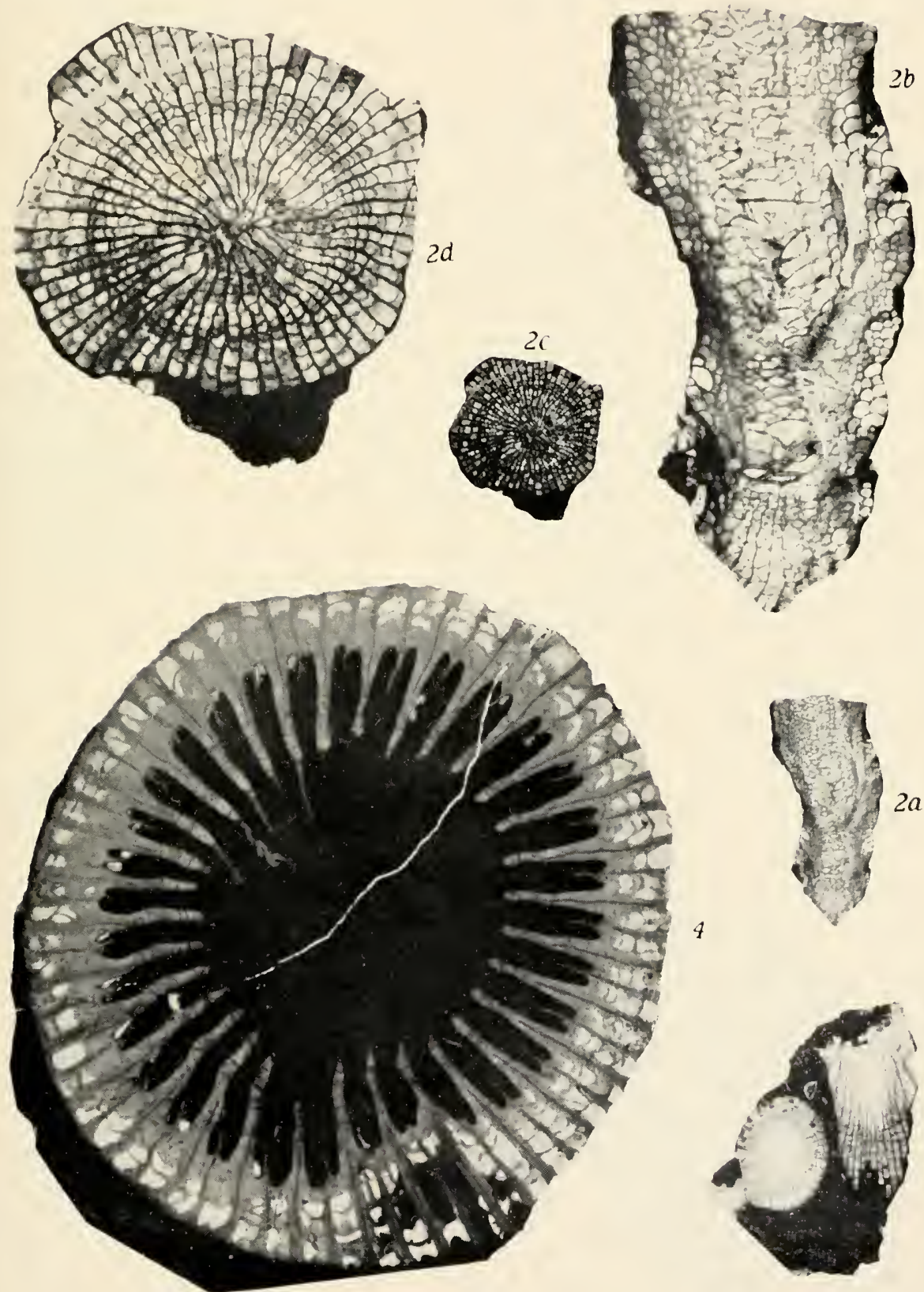

4
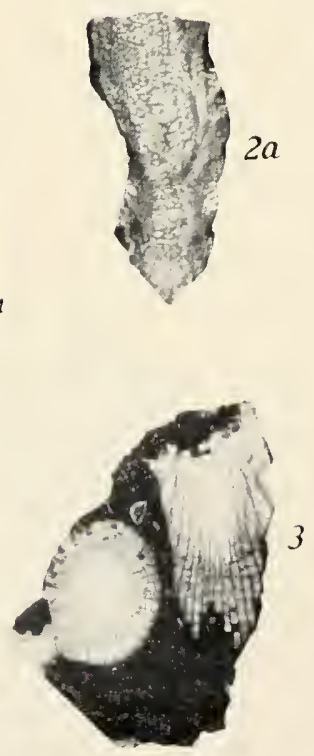


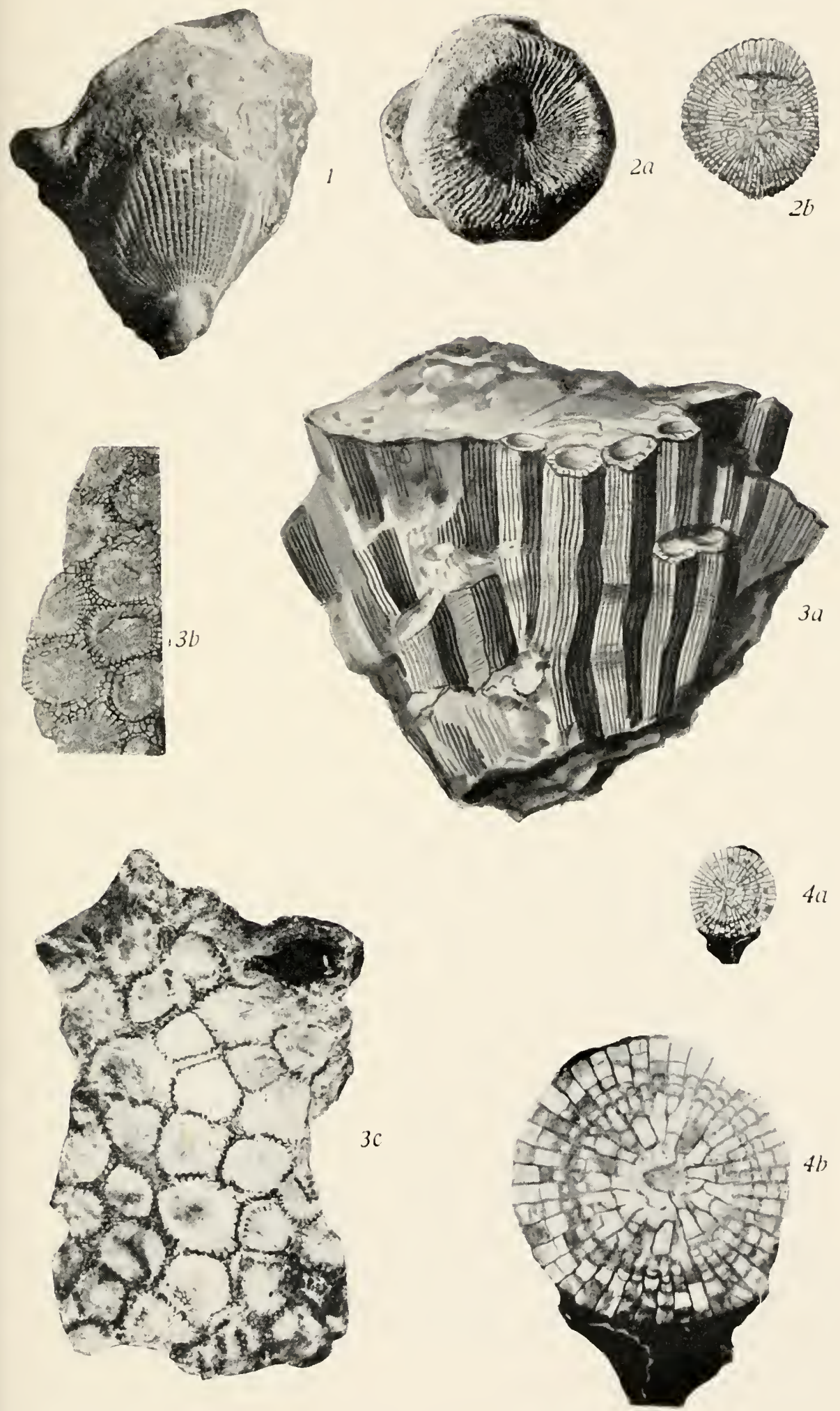


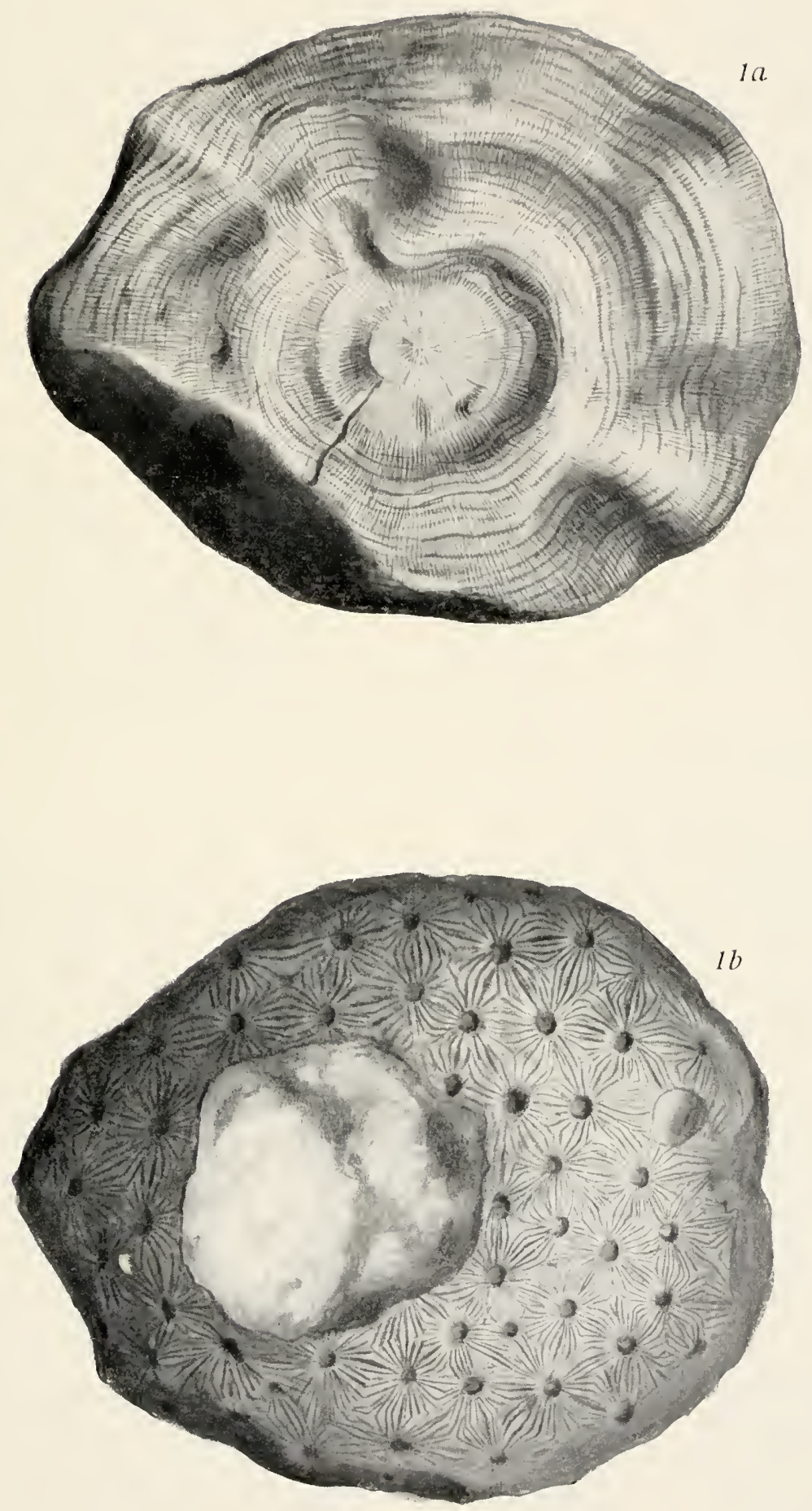


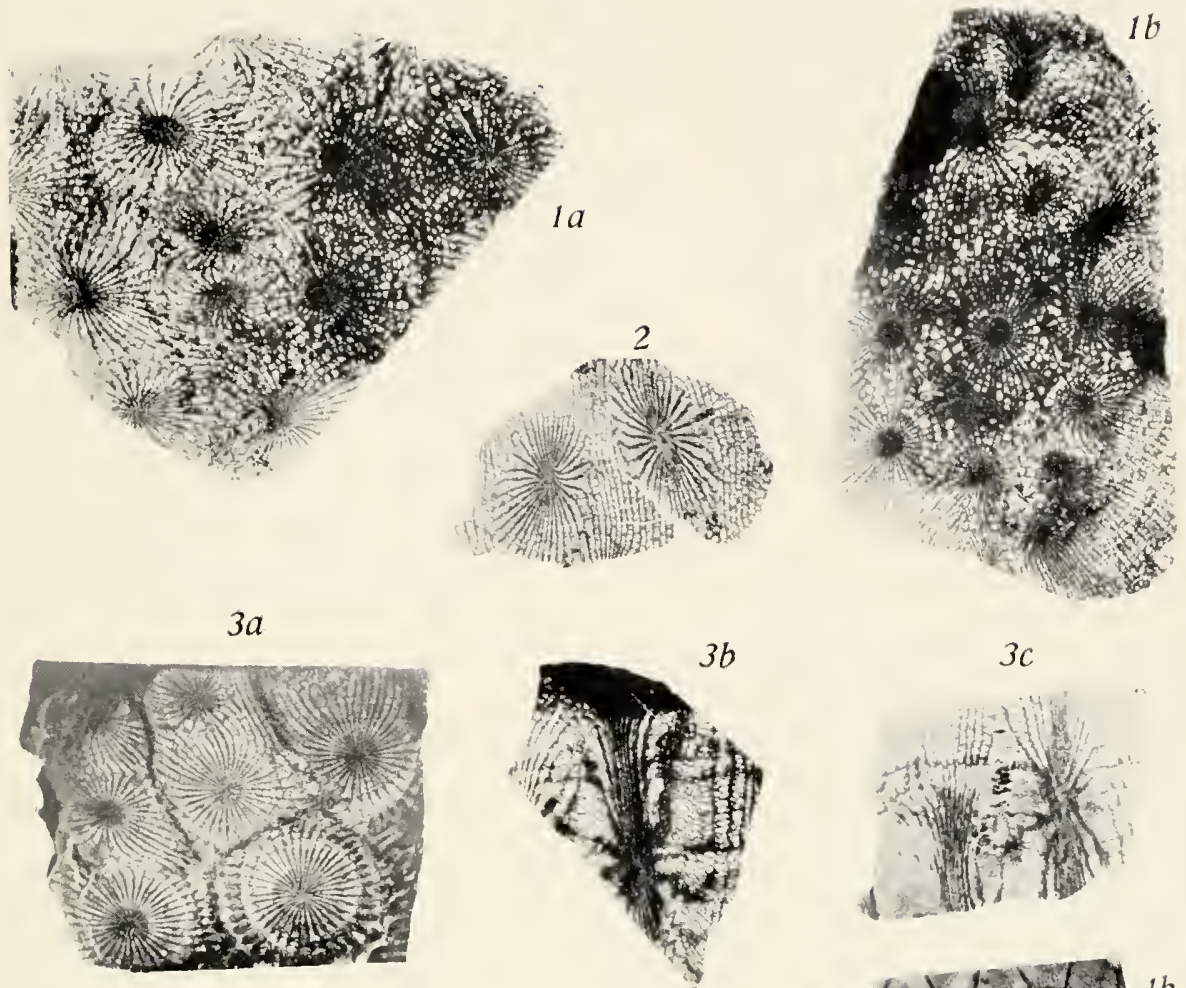

$3 c$
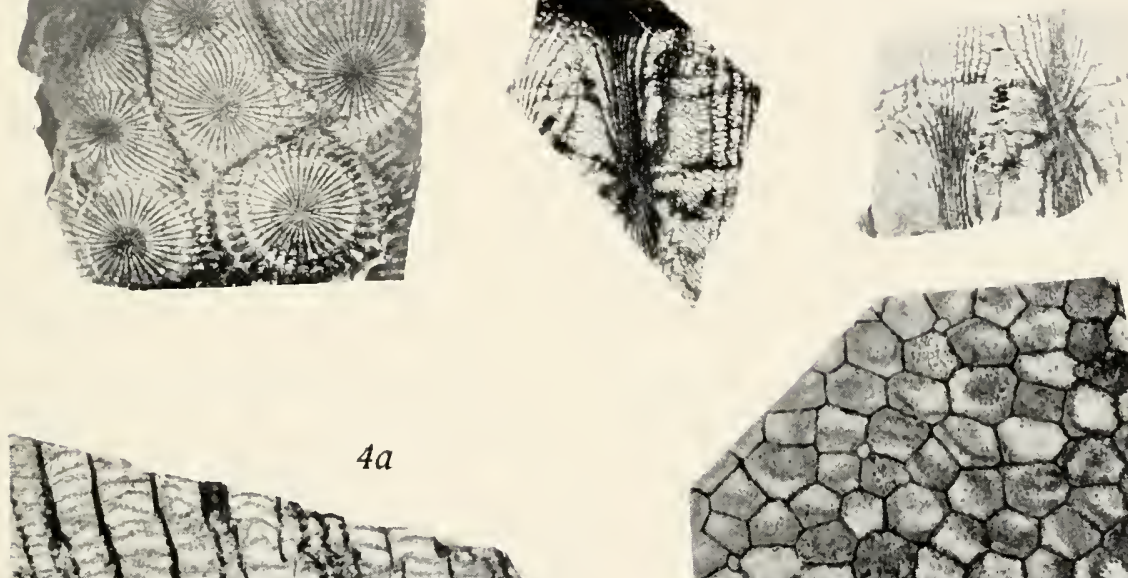

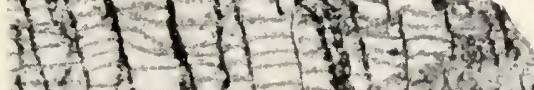

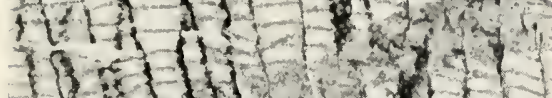

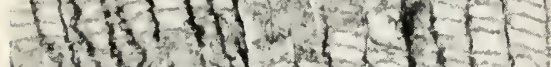

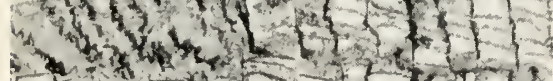

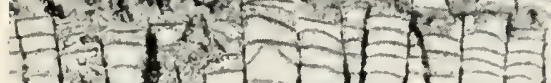
$-10+1010$
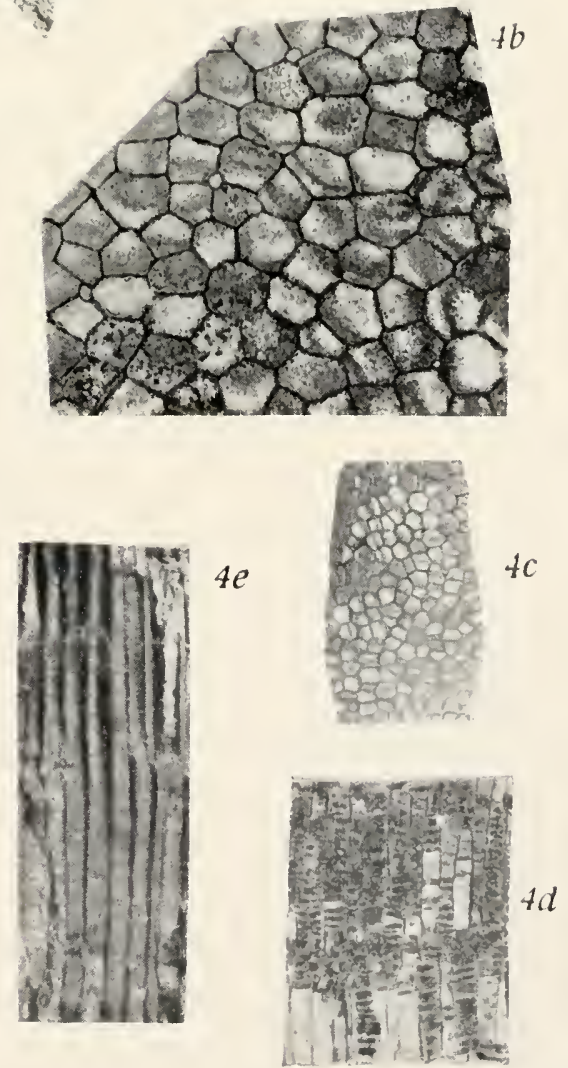

-is 1

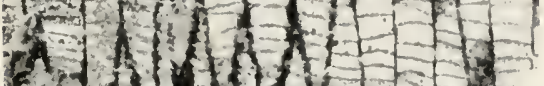
(5.t) $x+y=1, y=$

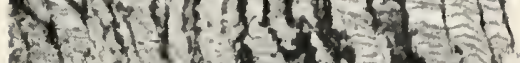

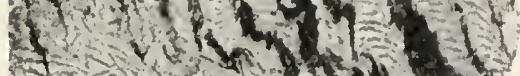
$-1=-1-1-1-1$ 


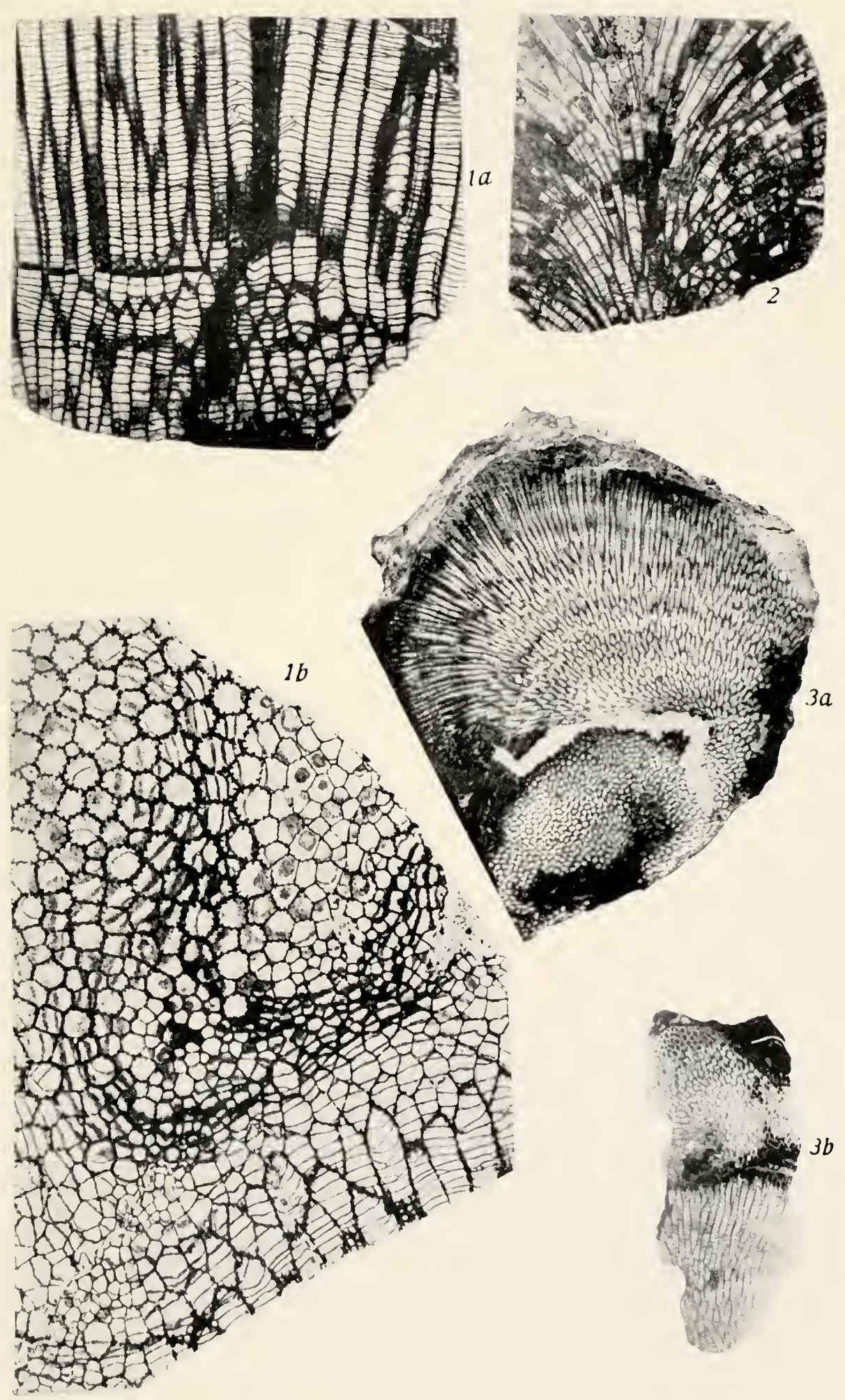


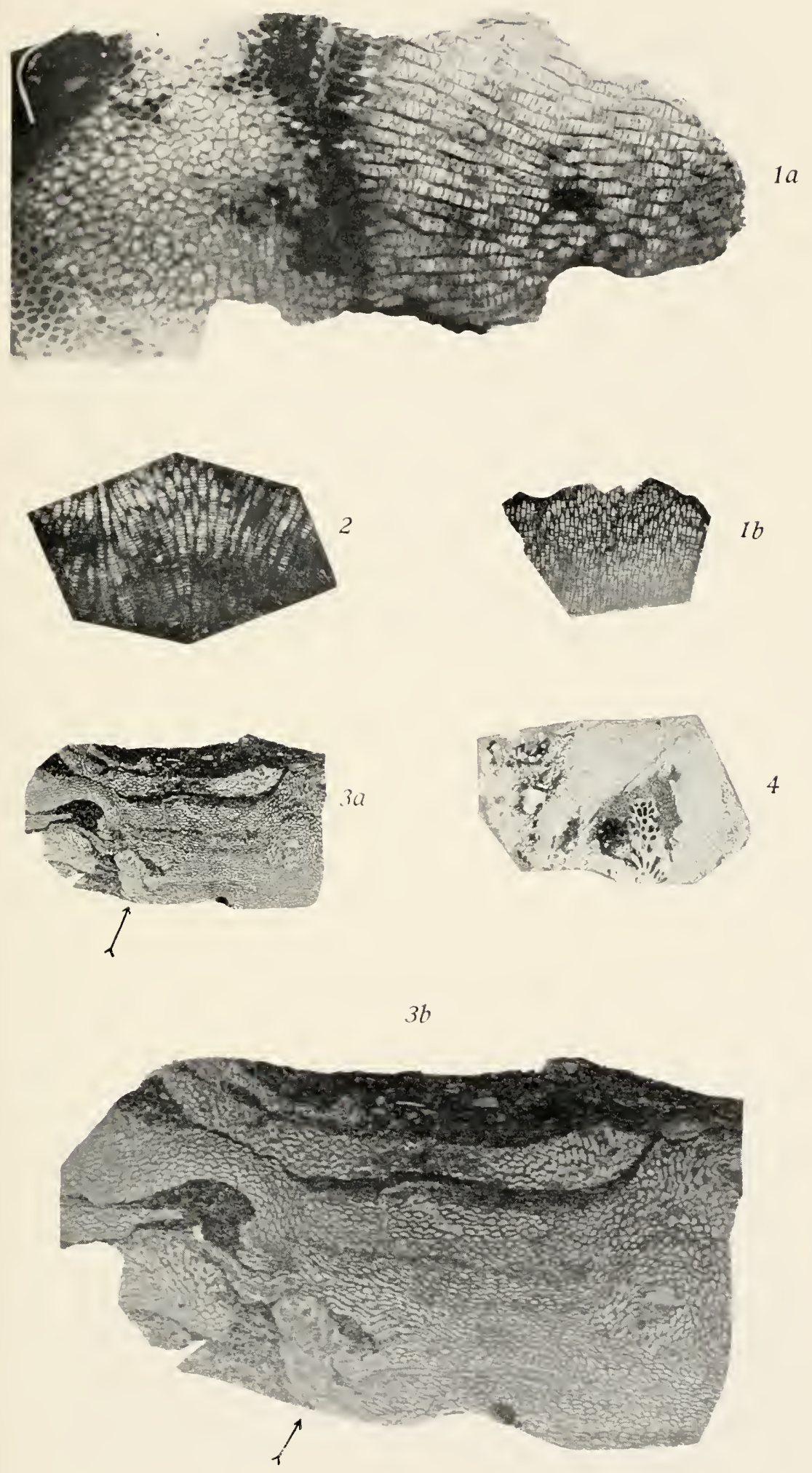


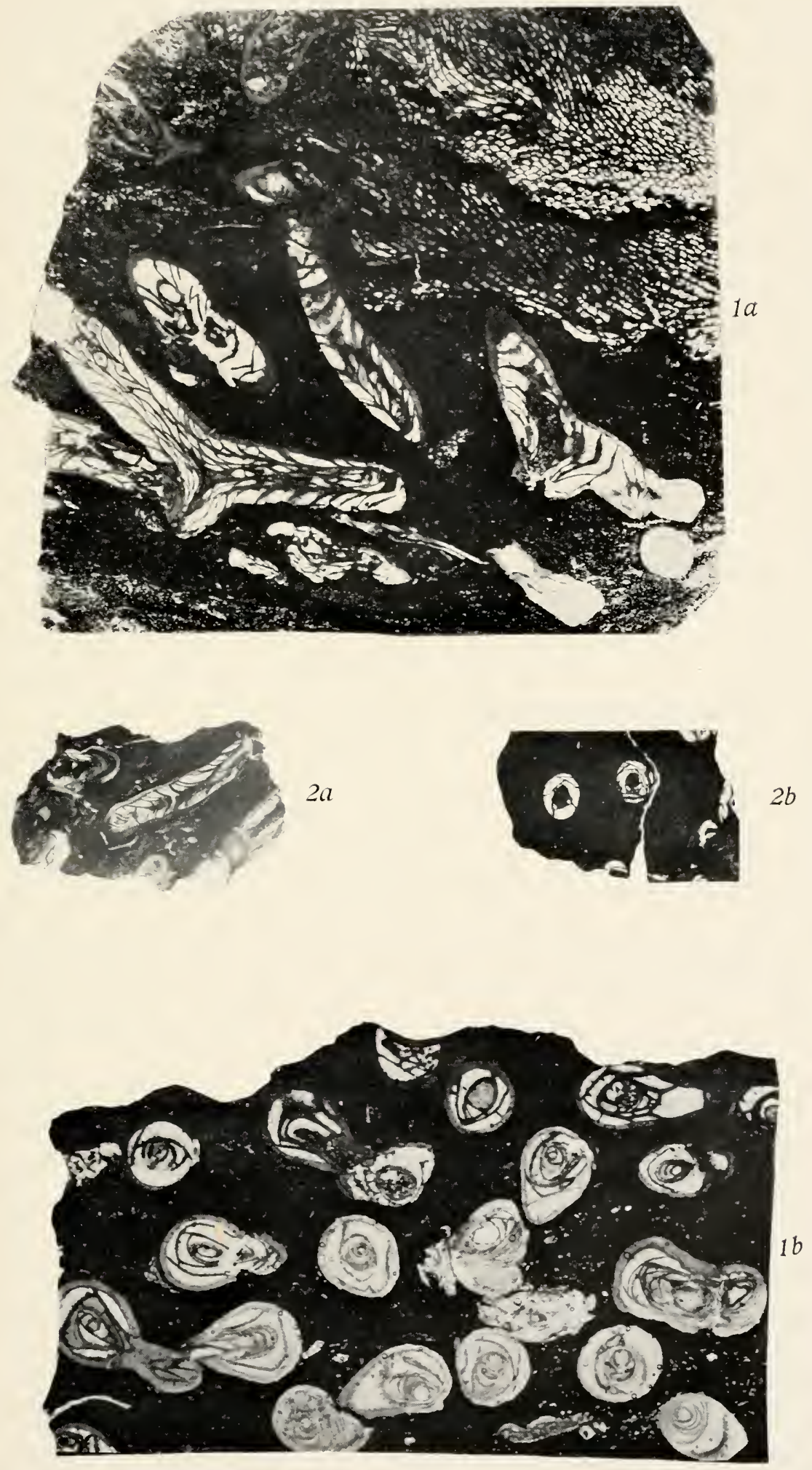

REPORT OF THE SECOND NORWEGIAN ARCTIC EXPEDITION IN THE „FRAM” 1898-1902. No. 31.

\section{OSKAR CARLGREN: \\ ACT I N IAR IA}

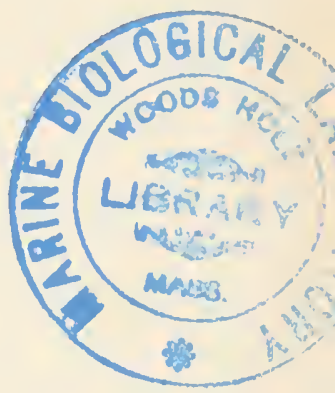

AT THE EXPEXSE UF THE FHITJOF NAXSEX FUXU FOR THE AHVANCEMENT OF SCIENCE:

IUHAISHEI BY

VIDENSKA BS-SELSKABET I KRISTIA IA (THE SOCIETY OF ARTS AND SCIEXCES OF KRISTIINIA)

K R IS T I A N I A

PRINTED BY A. IV. BROGGER

1913 

Die von der Expedition mit zurückgebrachte Sammlung von Actinarien ist nicht gross. Nur 4 Arten, Vertreter der Familien Actinostolidae und Sagartidae, sind aufgefischt worden. Von diesen ist Actinostola spetsbergensis in ler Sammlung am zahlreichsten vertreten.

In Betreff der Dredge-Stationen sind die Angaben nicht vollständig. Nach einer Mitteilung von Dozent Dr. Simmoss, einem der Teilnehmer an der Expedition, stammen die zwischen dem 7. März 1900 und 8. August 1900 eingesammelten Tiere aus dem Havnefjord zwischen $76^{\circ} 25^{\prime}-76^{\circ} 40^{\prime} \mathrm{N}$. Br. und $84^{\circ} 20^{\prime}-84^{\circ} 45^{\prime}$ W. L. Die Stationen 20. Sept. 1900 und 30. Aug. 1901 liegen in Gaasefjord, die rrstere etwa aul $76^{\circ} 48^{\prime} \mathrm{N}$. Br. und $88^{\circ} 40^{\prime}$ W. L., die zweitgenannte wahr'scheinlich auf $76^{\circ} 44^{\prime} \mathrm{N}$. Br. und $88^{\circ} 45^{\prime} \mathrm{W}$. L.

Eine nähere Beschreibung der nachstehend aufgefülıten Arten bahe ich bereits in den Jahren 1893 und 1902 gegeben.

\section{Fan. Actinostolidae.}

Genus Actinostola Verr.

$\mathrm{Sp}$. Actinostola spetsbergensis CarLgr.

Actinostola spetsbergensis 11. sp. Carlgren 1893, S. 76, Taf. 1, Fig. 15; Taf. 8, Fig. 9, 10; Tat. 9, Fig. 1. Textlig. 20, 21.

$\begin{array}{lll}- & - & \text { Carlgr. Kivietniewsit 1898. S. } 130 . \\ - & - & \text { Carlgren 1901, S. 469. } \\ - & - & \text { Carlgr. Garlgren 1902. S. } 46 .\end{array}$


linudorte:

21. Juli 1899. Winlerhafen. Rice Strait $78^{\circ} 45^{\prime} .7$ N. Br. $74^{\circ} 56^{\circ} .5$ W. L. \& Faden. ¿ Exemplare.

7. Mäı\% 1900. Süd von (Sparlnäs?). 10-20 Faden. Steine und Lann. naria. 1 lixemplar.

2.). Juli 1900. 2 Exemplare.

g9. Juli 1900. Ausserhall, Öderlalarne. 20 Farlen. 'Ton mon slrine. 11 Exemplare.

31. Juli 1900. In del Nälı des westlichen Sundes. I0-30 Faden. ¿) Excmplare.

1. Aug. 1900. 80 Faden. 2 Exemplare.

3. Ang. 1900. Fosheims Peak nehen dem 'Tale an der Westseite des Fjords. 2-20 Faden. 3 Exemplare.

4. Aug. 1900. 4 Exemplare.

:3). Jug. 1901. Gaasefjorl. 1 Lixemplar.

Von ten anfgefischten Exemplaren waren verschiedene gross. Hähe 9,5-3 ('ul. Durchmessel $6-7 \mathrm{~cm}$.

In den Gastrovasculärräumen melnerer Exemplare waren grosse limbronen vorlanden (vergl. Carbirex 1902, S. 47). In einem Exemplar fanden sich verschiedene parasitische Copeporlen, wahrscheinlich zu Genus Antheacheres gehörent. Ähnliche Parasiten habe ich früher in Exemplaren aus Spitzhergen gesehen (vergl. Carmarex 1902, S. 47).

\section{licmus Stomplita Liosis.}

Sp. Stomphia coccineal (0. F. MüL..) Ciskrak.

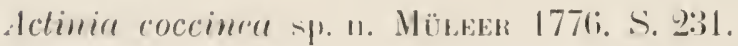

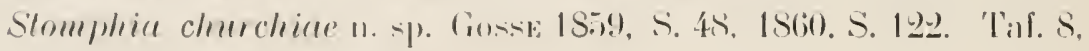
Fig. $\div$.

- Gosse, Cinkgkex 1s!\%, S. so. Til. 1. Fig. 11, 19; 'Tif. S, Fig. 4-6; 'Taf. 9, Fig. 2, :2; Tal. 10, lig. 4. Textfig. $22-95$.

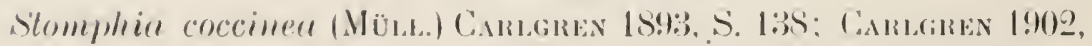
S. 47. Hier ein ansfülndicheres libraturverzeichuis).

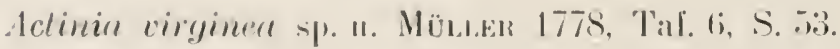

Sngurtin repens 11. sp. Dantessex 1890, S. 27. 'Taf. 1, Fig. 6. 'Taf. 10, Fig. 2, :

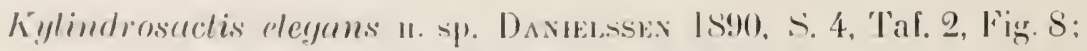

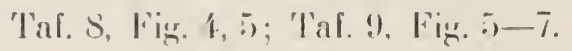


Actinia carneola n. sp. Stimi'son 1852, S. 7.

Rhodactinia Davisii var. 4 Verrill 1864, S. 19, 20.

In meiner Arbeit vom Jahre 1902 habe ich auch Tealiopsis potaris Danielssen für identisch mit Stomphia coccinea gehalten. Zwar ist die Art eine Stomphia, aber sie muss als eine eigene Art angesehen werden. Eine nähere Untersuchung der Nesselkapsehn an dem Originalexemplar zeigte nämlich Unterschiede zwischen potaris und coccinea. Übrigens gibt es auch andere Merkmale, die die beiden Arten voneinander unterscheiden, die ich zwar nicht bei dem schlecht erhaltenen Originalexemplar gefunden habe, aber doch an dem von Römen und Schaudinu an den Küsten von Spitzbergen eingesammelten Actinia, die identische Nesselkapseln mit St. polaris hat und gewiss auch diese Ait ist (vergl. Carbgren 1902, S. 49).

\section{Fanl. Sagartidae.}

Genus Allantactis Dan.

Sp. Allantactis parasitica DaN.

Allantactis parasitica 11. genl. et sp. Danielssen 1890, S. 20, Taf. 2. Fig. 3; Taf. 9, Fig. 1-4.

Calticactis Kröyeri 11. sp. DANielssen 1890, Taf. 2, Fig. 2; 'Taf. 8. Fig. 6, 13, 14.

Atlantactis parasitica Dan. Kwietniewsin 1898, Taf. 14, Fig. 1 -2. S. 122.

\section{- $\quad$ - Dan. Carlghen 1902, S. 50.}

Fundort: 20 September 1900. 3-20 Faden. 3 Exemplare.

Die Exemplare waren gross, das grösste mass in Durchmesser $7 \mathrm{~cm}$. und hatte eine Höhe von $4 \mathrm{~cm}$.

\section{Genus Chondractinia Lütren.}

Sp. Chondractinia nodosa (FABR). LÜtken.

Activice nodosa \&p. n. Fabricius 1780, S. 350.

Chondractivia nodosa FABr. LÜTKEN 1861, S. 190.

$-\quad$ Fabr. Carlgren 1893, S. 115, Taf. 6, Fig. 9.
Textfig. 38.
$-\quad$ Fabr. Carlgren 1902, S. 50. (Hier ein voll-
ständigeres Literatur- und Synonym-Ver-
zeichnis).


Fundorte:

25. Juli 1900. Winterhafen. 1 Exemplar.

3. Ang. 1900 Fosheims Peak nehen dem Tate an der Westseite des Fjorks. 2-20 Faden. 2 Exemplare.

s. Aug. 1900. Winterhafen. 1 Exemplar.

Die Exrmplare waren mittelgross, das grössle slark zusimmen. gezogene Exemplar war 3,5 cm. hoch und mass 2,5 (m. in Durchmesser. Die Körperwand war quer und liungsgerunzelt, übrigens kamen keine grosse Taherkeln vor, mur hie und da Andeutungen von solchen.

\section{Literatur.}

1593. Canutimx, O. Studlen über nordische Actinien. 1. K. Svenska Vet.Akad Handl. 25. No. 10.

1901. - Üher dir Brutptlege der Actiniarien. Biol. Centralbl. 21.

1!)2. - Zoolngische Ergebnisse einer Untersurhmugfahrt auf Olga. Wiss. Meeresuntersuchungen. Untersuch. deutscher Meere. hinl und Helgoland. N. F. Bd. 5. Abt. Helgoland. Heft 1.

18!10. Daxnasix, D. C. Actinida. Den Norske Nordhavsexpedition, 19 Zool. Christiania.

1780. Fatsmens: C. Famna groenlandica (Hafniar: Lipsiac).

1859. Gosse, P. II. Characters and Deseriptions of Seaanemones. Ann. Mag. Nat. Hist. 3. 3, S. 46.

1860. - Actinologia brittamica. A history of the british Seannemones. London.

189S. Kwetsuwsh, C. R. Actinaria von Ost.Spitzhergen. \%ool. Jahrl. Aht. Systematik. Bd. 11.

1861. Lërkix, C. Nogle bemerkninger on de ved de danske kyster iagtlagne arter av Actiniernes grappe. Naturh. For. Vidensk. Meddeletser 12. 1881).

1776. Mïr.t:n, O. F. Zoologiae Danicue prodromus. Hafniat 1776.

1775. - Zoologia danica. Vol. 1. 2.

18:33. Stumess, W. Synopsis of marine Invertebrata of Graml Mlenan. Smiths. Inst. 6, 1853.

1861. Vrimun., A. E. Revision of the Polypsete. Men. Soc. Nat. Hist. Boslon 1. P. 1. 

REPORT OF THE SECOND NORWEGIAN ARCTIC EXPEDITION IN THE "FRAM" $1898-1902 . \quad$ No. 32.

O LA F HOLTEDAHL:

\section{ON THE FOSSIL FAUNAS \\ FROM PER SCHEI'S SERIES B}

IN SOUTH WESTERN ELLESMERELAND

IVITH \& MAPS AND 8 PLATES

AT THE EXPENSE OF THE FHUTJOF NANSEX FLND

FOR THE AWVANCEMENT OF SCIENCE

PUBL,SHEIS BY

V I D E N S K A B S-SELSKA B E T I KR IST I A N I A

(THE SOCHETY OF ARTS AND SCIENCES OF KRISTIANIA)

K R IS T I A N I A

PRINTED BYA. IV. BRøGGER

1914 



\section{Preface.}

The present contribution to Arctic Palæontology is the result of studies made principally during a stay at Yale (Pealody) Museum, New Haven, Conn., U.S. A. Besides having at hand there one of the largest scientific libraries in America, I was also greatly assisted by the exislence in this museum of precisely the material that I needed, viz, fossils from corresponding horisons in typical localities on the American Continent. Of even greater importance to me however, was the fact that 1 had opportunities of daily intercourse with the learned palæontologist Professor Charles Schuchert, Curator of the palæontological collections at Yale University, one of the greatest living authorities on American Ordovician, Silurian, and Devonian faunas and their Arctic development.

Furthermore Schuchert gave me an opportunity of studying in the field under his guidance, the eastern N. American Silurian and Devonian, in most beautiful sections in Maryland, Vurginia and W. Virginia, on a delightful 8 days' excursion during the spring of 1913.

It is not only a duty, but a great pleasure for me to take this opportunity of expressing my heartiest thanks to Professor Schucuent for all that he did for me during my stay in America.

Christiania November, 1913.

Olaf Holtedahl. 


\section{Contents.}

Lutrofuctury licmatis on sories $A$ and $B$. Patarontologival Descriptions of the Fossils from Suries B . . . . . . . . . 9 Conclusions . . . . . . . . . . . . . . . . . . . 40 40 


\section{Introductory Remarks on Series A and B.}

$A_{s}$ is well known from the preliminary report by PER Schei on the geological observations made during the Second Norwegian Polar Expedition of the "Fram" (Appendix to Otтo Sverdrup: "New Land"), published in 1903, the sections of palæozoic rocks yielding the greatest stratigraphical and palæontological results, were found in the southwestern corner of Ellesmere Land, between Harbour Fjord (Norw.: Havnefjord) in Jones' Sound and Baumann Fjord (which lies between Björnekapland and Raanes Peninsula, cp. the map, p. 3).

Within this region the more detailed observations were made in the environs of Goose Fjord (Norw.: Gaasefjord) where the "Fram" had her winter quarters during the two seasons 1900-1901 and 1901-1902. The stratigraphical systems of the Goose Fjord were divided by ScHeI into the series $\mathrm{A}, \mathrm{B}, \mathrm{C}, \mathrm{D}$ and $\mathrm{E}$ of which the last two were regarded as Devonian. The preliminary identifications of fossils and their stratigraphical bearing were made by Dr. Johan KIER, now professor of palæontology of the University of Christiania.

Since the publication of Schel's report, several papers by specialists on different collections from these series have appeared. In 1904 Professor Nathorst of Stockholm published "Die oberdevonische Flora des Ellesmere-Landes" ${ }^{1}$, describing the fossil plants from Series E. In 1900 "Neues Jahrbuch für Mineralogie etc.", Beilagehand. 31, contained an article by Oscar Erich MeYer: "Die Entwicklung der arktischen Meere in paläozoischer Zeit", in which he gives, inter alia, a short summary of his studies on the fossils collected by Scher from Series D and sent to Professor Frech in Breslau for detailed examination. In the spring of this year, 1913, the final result of Dr. Meyers palæontological investigations was printed as No. 29 of the said report under the title:

1 Report of the Second Norwegian Arctic Expedition in the "Fram" 1898-1902. No. 1. Christiania 1904. 
"Die devonischen Brachiopoden von Ellesmereland". Finally a paper by another German palæontologist Stephan Loewe: "Die devonischen Ko. rallen von Ellesmereland" (same report, No. 30) appeared, printed as recently as Oelober 1913.

Concerning the lower series of south-western Ellesmereland, nothing has been published since ScHei's report. A contribution on the Cambrian and Ordovician beds and fossils of Bache Peninsula to the N.E of Ellesmere Land was issued by the present writer a year ago, and published in the early part of 1913 as No. $2 S$ of the "Report", but this makes no mention of the older palæozoic beds of the south-western corner.

In the spring of 1913 I was asked by the curator of the palæontological collections of the University of Christiania, Professor Kien, who has been 100 much pressed by other work to be able to find time for a further study of the Ellesmereland material, to set to work on the fossils from the lower series of the Goose Fjord region.

The chief purpose of the present small contribution is a palæontological study of the fauna collected by Scher in series B, which is the only one of A, B, and C, found by Scuei to contain any considerable amount of fossils, though even this series is poor compared with the series D. Nearty all of the species of B are found in only one or very few specimens - oflen fragmentary - a fact that has made the detailed idenfications difficult and often impossible.

In addition to this work I shall also briefly summarise what we know about the older series of this south-western region. I have studied the few and fragmentary fossils, that unfortunately do not provide us with any great enlightenment.

\section{Series A.}

The lowest part of the sedimentary series of souther'n Ellesmereland, resting on the archean granite, is beautifully exposed in the Harbonr Fjord, as can be seen on plate I.

Scher writes that at Harbour Fjord, corresponding to the older (Cambrian and Ordovician) beds of Bache Peninsula: "We have a strongly developed series of limestone conglomerates wilh marty shales and pure limestones, the whole having a thickness of 1300 to 1600 feet. These congfomerates rest upon their lanmine of quart\% sandslone, and this again is immediately underlain by the gneissic granite. On the other hand, the limestone conglomerate in question is overlain hy a succession of thick heds, not less than 2000 feet in depth, of close-grained, hard, impure limestones, of a 


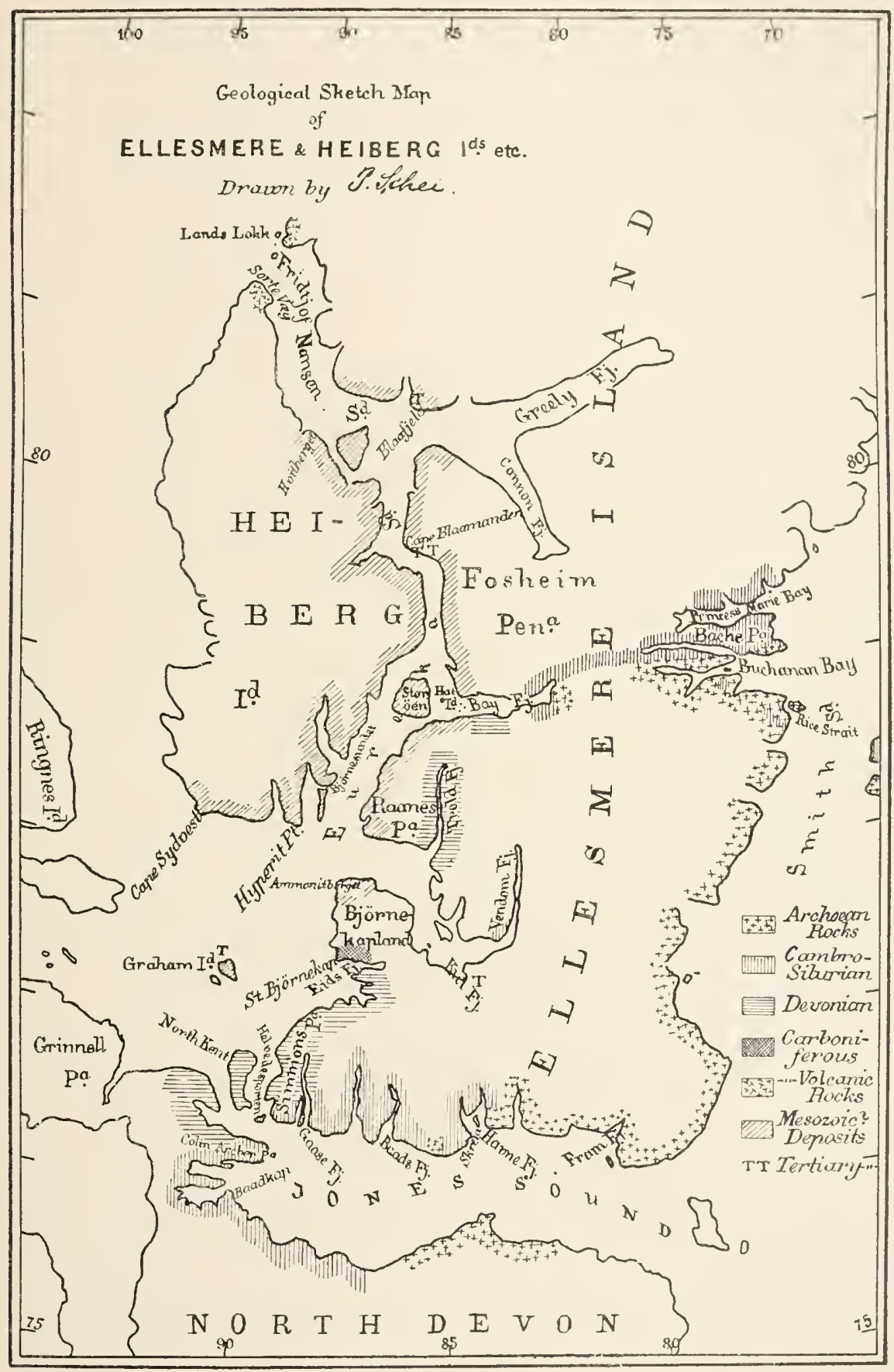


brown or greyish-yellow colour, and rery often surpisingly heary. South Cape $^{1}$ is huilt up entirely of this brown limestone (se pl. II, fig. 2). In its lower layers were found species of Machrea, and Halysites, pointing to midllle Silurian."2

I have studied the material from South Cape, but I cannot add very much to what has been written already. The fossils are found to be:

\section{Halysites catenularia Lis.}

The form agrees very much with the variety gracilis HaLb. in having corallites of subrectangular form without intervening lubules.

\section{Strophomena sp.}

Two very imperfect outer mouhls of ventral valves and a fragment of a dorsal valve are found. Outline sub-hemicircular, the valves are nearly flat in the posterior part, the ventral with slightly elevated beak, strongly curved at the rounded margin with an extension in the middle. 'The surface with fine radiating striae, every second, and in some instances, every third one of which is stronger than the rest. They are crossed hy very faint concentric lines and by very delicate oblique wrinkles. The form seems to come fairly close to forms both from the Trenton and the Richmond of North America, but any closer determination is, however, made impossible by the fragmentary character of the material.

\section{Maclurea sp.}

Only the under side of two specimens known. We have a large form before us, the diameter of an incomplete piece with about three volutions being $11 \mathrm{~cm}$. As the upper part of the shell is not known at all, no determination can be made.

Though the material is too insufficient for any quite exact conclusion as to the age of those fossils, I an inclined to believe that it is another locality of the old Trenton-fanna, which is so well known from a great many accurrences in the Arctic Archipelago. Specimens of Halysites are quite common in this horizon and the same may he said of the Machureas.

In the higher portion of this limestone series, "the brown-limestone uf the capes" we find Silurian fossils. The best collection of fossils from this uppre part was made on the east coast of North Devon at "Baal.

1 On the west side of the month of Hartonur (Havne) Fjord.

2 Silurian in the semse Orelovioian-Siluriat. 
kap", at about $76^{\circ} \mathrm{N}$. L. The scanty fossil remaius are contained partly in a brownish limeslone, partly in yellowish-grey coarse and massive dolomites in which only the interior moulds of the fossils can be seen. They are the following:

\section{Strophonella cf. euglypha His.}

An incomplete specimen of Strophonella, embedded in a piece of brown limestone agrees, especially as to the character of the surface (5-S faint lines between very conspicuous, strong ones), completely with Strophonella euglypha His. while the form seems to differ a little in that the valves show a relatively larger flat (for the dorsal) or faintly convex (for the ventral) posterior portion, a relatively narrower marginal curved and here very strongly curved one while in S. euplypha the curved portion, which bends at a more obtuse angle, is very large, leaving a relatively smaller flat portion near the hinge-line.

As, however, the entire form cannot be seen from the specimen in question I will refrain from any further consideration.

\section{Conchidium arcticum nov. sp.}

\section{Pl. VI, fig. 5-7.}

In a massive coarse dolomitic rock a great number of internal casts of a pentameroid brachiopod occur. They are all, however, very fragmentary, not a single one showing more than a small part of the entire form. Yet judging from all the various pieces we are able to obtain an idea of the different characters of the fossil.

The shell is of medium size, greatest length observed or judged from the fragmentary pieces, $5-5.5 \mathrm{~cm}$., greatest width about the same. The ventral valve is moderately curved, greatest in the region of the beak. The septım is comparatively short, only about one third of the length of shell. The dorsal valve is very slightly convex, one specimen with preserved beak showing two short septa. Some of the moulds have a well marked radiating striation of the surface.

The form here mentioned shorvs several characteristics that disting. uishes it from others and gives it a specific value even if all the character's are not known. It differs from all other Conchidium species known to me by being relatively very slightly convex, and by the shortness of the septum in the ventral valve. In these respects it seems also to differ decidedly from the Conchidium-form described by SALTER from Cornvallis Island in the Arctic Archipelago (see Sutherlands Journal, Appendix, p. 225, pl. 5, figs. 9-10), a form that a priori night be con. sidered identical. 


\section{Ceraurus sp.}

A fragment of the head of a trilobite, showing the anterior two thirds of the glabella, belongs to a Ceraurus sp., yet without seeming to agree completely with any known species as far as can be seen.

These fossils are probably of Niagaran age, but no more detailed correlation is possible.

The different sedimentary series just mentioned all belong to Scues's serie $A$, the distribution of which he has shown on his preliminary map. He states also that "The brown limestone of the capes stretches from South Cape westwards to Sealbay in Hellgate, but is interrupted at the Little Sandbank, where the tectonic disturbances have brought to the surface the underlying conglomerate-series and even the Archæan rock."

\section{Series B.}

Respecting the rocks of the Goose Fjord Scher writes: "On the south side of Reindeer Valley the limestone of the capes (series A) crops out with a gentle dip towards the north-north-west; but on the north side of the valley there was a section of dark schists (series B), lying conformably upon the berls of brown limestone. This section contained, especially in its lighest and its lowest strata, thick layers of pure dark-coloured limestone, which was often fossiliferous. In both Reindeer valley and Seal bay, where this section was also ohserved, we collected a tolerably large number of specimens, a cursory examination of which lias resulted in the identification of some fifteen species, including Facosites, Strophomena cf. cuglypha, large numbers of Meristella, Rhynchomella cf. borealis, Pentamerus cf. galeatus, Spirifer cf. elevatus. The age of this section of series $B$ is consequently Wenlock.

The uppermost strata of series B, crops out at the cape which lies north of Tunnel Valley in Walrus Fjord. First, there is a hlack sliale witlı fossils of a species of Monograptus and Leperditia cf. phaseolus. Upon that lies a bed of fragmenlary limestone, with Favosites, Stropho. mena cf. pecten, Atrypa reticularis, Pterinea cf. Soverbyi. Iı one locality in Goose Fjord at the same level in the stratigraphical order, we found Favosites cf. Hisingeri, Fav. gollandicns. Thecia Swinderenana, Spirifer elevatus, Spirifer cf. crispms, Strophomena cormgatella DAvins. and species of Pterinea. 'T'hus the uppermost division of series B would appear to lielong to the Ludlow group. The total thickness of the series is about 1000 feet." 


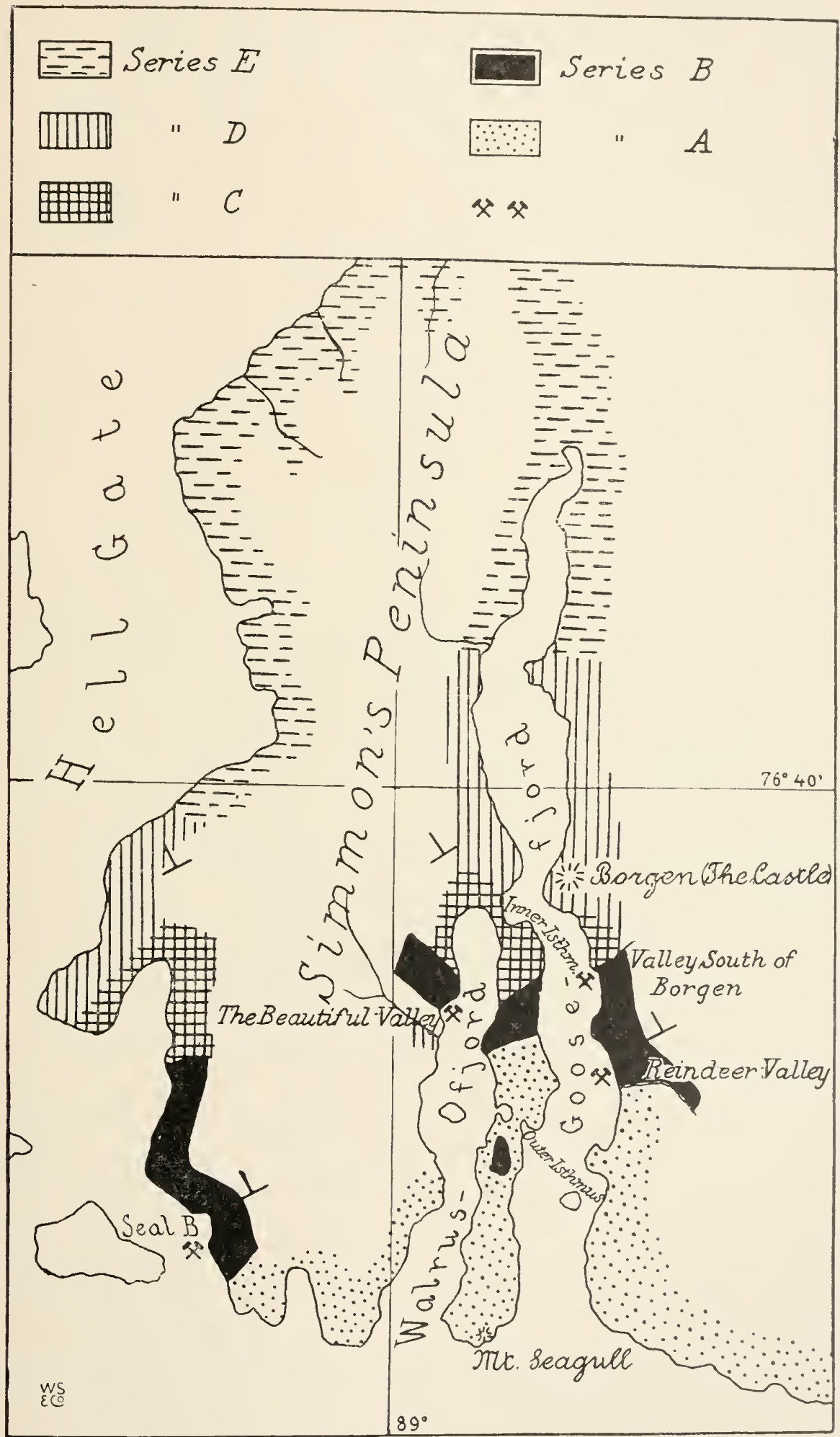

Map showing the distribution of Series A-E in soutlı.western Ellesmereland accord. ing to ScuEı. The places where fossils were found in Series B are specially marked. 
I will now give helow the revised identifications of the fossils found in the series $B$, the result of my own studies on the material.

In series B Screr collected from the following localities:Representing the lower part of B:-

I. Reindeer Valley, Goose Fjord.

II. Seal Bay, Hell Gate.

Representing the mildle part:-

Between Reindeer Valley and Valley south of Borgen (the Castle). Representing the upper part:-

I. Valley south of Borgen.

A. In the "fragment-limestone".

B. Over the "fragment-limestone".

C. Near the "fragment-limestone".

Il. Point nortl of "The Beautiful Valiey", Walrus Fjord.

IIl. South of this locality.

For convenience, and also because I do not think the two parts of the series very different in age, in the paleontological part of this paper that follows below, I have not arranged the fossils in groups according to the locality where they were found, but placed them all together in systematic order. At the end of this paper they will be classified according to localities and horizons. 


\section{Palæontological descriptions.}

\section{Plantae. Algae. Corallinaceae.}

Solenopora Dyв. Solenopora sp.

Pl. IV, fig. 1-2.

An irregular, flat sub-hemispherical piece of limestone, with a greatest diameter of 8.5 and a greatest thickness of about $2 \mathrm{~cm}$., that even to the naked eye showed a faint surface structure, revealed by studying microscopic sections the characters of a true Solenopora. As, however, the preservation of the structure is far from perfect I will refrain from any specific determination. In fact the structural characters in which the differences between the species of Solenopora may be studied are so few and generally so little marked that very good material is necessary in order to obtain definite conclusions.

The radiating cells are generally perfectly or nearly straight, any marked curvature being very seldom seem. The width varies from $1 / 11$ to $1 / 13$ of a mm. Crossing these cell are seen the ordinary concentric dark lines or shades although often very indistinctly marked. In tangential sections the cells generally appear as polygonal. usually pentagonal or hexagonal. In some places, however, they are more rounded. (PI. IV, fig. 1, shows a part of a section with relatively rounded cells.) The cell walls are usually thin; places with very thicks walls that also occur would be naturally explained as due to a secondary thickening of the walls, though no line corresponding to the original wall is seen in the middle of the thick portions.

The specimen probably represents a new species as yet not described. The Silurian form that is described by RoTHPLETz from Gotland as 
Solenopora gotlandica ${ }^{1}$ differs distinctly by its much thinner cells, according to RotнrLetz only $0.025-0.030 \mathrm{~mm}$. thick. The specimen appro. aches nearer to Solenopora compacta Bitz. from the Ordovician (Trenton) of North America and Europe but this form also shows usually narrower cells. A. Browr in his article "On the Structure and Aftinities of Solenopora, together with Descriptions of New Species" 2 says the diameter of the cells of this form is about $1 / 1 ; \mathrm{mm}$. while Rothpletz l. c. p. 12 writes $0.070-0.130 \mathrm{~mm}$. If the latter dimensions of the cells are correct it will be difficult to distinguish the Ellesmere Land specimen from Solenopora compacta ${ }^{3}$. It would require very good material in which all minute details could be studied.

I have seen some sections of an hitherto un-described Solenopora from the Silurian of the Islant of Oesel in the Baltic Sea, made from material collected by Professor KLER, and they show a very marked resemblance to those made of the Arctic specimen. It is possible that the cells of the first mentioned form are slightly narrower, generally about ${ }^{1} 1+\mathrm{mm}$. in dianeter.

Occurrence: B, lower part, Seal Bay.

\section{Coelenterata. Anthozoa. \\ Tetracoralla.}

In a light coloured massive dolomitic rock, differing from all others seen in the material from series $B$, some pieces of very badly preserved aggregate corals that cannot be identified even as to genus occur. The corallites which are subparallel, or in some cases more irregularly divergent, show a circular or subcircular section with a diameter of from 2 to $4 \mathrm{~mm}$. In some of the pieces we see numerous septa reaching the center, in others they cannot be seen at all, but we find instead horizontal or curved tabulie. I presume, however, that the different specimens belong to one species, having both septa and diaphragms. The genus that comes nearest into consideration is probably Diplophyllum $\mathrm{H}_{\text {ALL }}$, although nothing can be seen of the peripherial wrinkled epitheca characteristic of this and other related genera.

Occurrence: B, lower part, Reindeer Valley.

1 Üher Algen und Hydrozoen im Silur von Gotland und Oesel. Kgl. Sr. Vet.Ak. Handl. Vol. 43, No. 5. Stockholm 19:08.

2 Geological Magazine. Dec. IV. Vol. I, IS91.

is After this was written a paper hy lintur,t:Tz "Üler die Kalkalgen, Spongiostro. men und einige andere Fossilien ans dem Ohersihur Gotllands" (Sver. Geol. Unders, Sur. Ca. No. 10, 191:3) has appeared where this form is cited also from the Silurian. 


\section{Tabulata. \\ Favositidae. \\ Favosites LaM. \\ Pl. VI, fig. 3.}

Favosites cf. helderbergiae HALL.

Amongst the specimens of corals is a flat fragment of a Favosites, which in all visible characters seems to agree closely with Favosites helderbergiae HaLL, but as the outer form and the size are not exactly known it cannot with certainty be given any specific name. The piece which has a longest diameter of $5-6 \mathrm{~cm}$. and an average thickness of $S-9 \mathrm{~mm}$. is built up by a number of parallel or only very slightly radiating corallites, arranged vertically to the upper surface of the piece, which may represent the original one. The tubes show on the whole a very uniform size, the diameter being about $1,5 \mathrm{~mm}$. The tabulae are throughout extremely closely arranged, $3-4$ in one $\mathrm{mm}$. that is, still more closely than is usually found in Favosites helderbergiae. Whether this character is a constant one or not in the form in question, can of course not be decided before more inaterial is available.

Oc currence: B, lower part, Reindeer Valley.

Favosites forbesi E. and H., var. eifelensis Nich.

Pl. IV, fig. 5-6.

1879. Favosites forbesi E. and H. var. eifelensis Nicholson. On the Structure and Affinities of the Tabulate Corals of the Palæozic Period. p. 61, pl. II, fig. 3, pl. III, fig. 1-1 b.

Several specimen of a Favosites which must be referred to this form are found. The outer form varies from pyriform to more flat subhemispherical. Greatest diameter measured $7 \mathrm{~cm}$. The tubes are of very unequal size, the greatest about $2 \mathrm{~mm}$. in width. Between the larger hexagonal or pentagonal cells, there commonly occur very small, triangular or quadrilateral ones. Tabulae close, on an average 2 per $\mathrm{mm}$. On the inner walls of the tubes are developed numerous rows of quite prominent spines. The pores seem to be arranged in two or three rows. With the unequal size of its lubes and also relatively small dimensions of the colonies, this form without doubt is closely related to Favosites forbesi $\mathrm{E}$. and $\mathrm{H}$. With its well-developed septal spines it seems furthermore to agree with the type, which Nicholson (from Devonian specimens from Gerolstein) has named var, eifelensis. I have howevei, by preparing microscopic sections of a Fav forbesi from the Silurian of Got- 
lamb, observed quite prominent spines in this older specimen too. 'This Gotland-specimen differed from the Arctic specimen chiefly in having less numerous tabulae, the distance helween two of them generally equalling the width of the cell. The closentess of the tabulae is very conspicuous in the Ellesmereland form as seen in pl. IV, fig. 6; the type specimen of Nicnolsox may also have as many as 7 tabulae in the space of two lines.

'Two forms which probably may be regarded as identical with the one here descrihed are the Fuvosites pyriforme HaLL as described and depicted by Stuart Weller ${ }^{1}$ from the Decker Ferry Group of New Jersey and by Swantz² from the Keyser member of the Lower Helderlierg of Maryland.

The original Astrocerium pyriforme Hall (Pal. New York. Vol. 2, 1552. p. 123, pl. 34 a, figs. 1 a -1 e) as early as in 1899 is placed by l.a.mBE ${ }^{3}$ under Farosites hisingeri E. and $H$.

HaLL's form with its very long spines seems also to he lecidedly different from the two forms just mentioned, and from the Arctic species.

Occurrence: B, upper part, point north of the Beauliful Valley, IValrus Fjord.

\section{Favosites sp.}

A fragment of the uppermost highly convex portion of a very regularly huilt frovosites, that differs from the two preceding species, is visible in a small piece of rock in the material. The nicely radiating corallites have mostly a hexagonal section with an average diameter of alhout $2 \mathrm{~mm}$. Rarely, we observe smaller ones between. The tabulae are not so closely armanged as in the previously mentioned species. Only one or less ncurs per mm. The pores in this specimen are discernable. They are comparatively large, show an elevated outer rim, and are disposed in two rows.

On account of the fragmentary condition no specific determination (an he made with certainty. With the tendency to variation of the specific characteristics of these Favosites-forms it is evident that it is valueless lo make delailed illentifications on very scanly material.

Oc curence: B, upper part, over the fragment-limestone, valley south of Burgen.

\footnotetext{
1 Cient. Survey of New Jersey, vol. 13, 19)3, p. 220, pl. 17, figs. 3-5.

2 Geol. Survey of Maryland. Lower Devonian. 1913, p. 211, pl. 23, figs. 1-4.

3 Contributions to Canalian Palaeontology. Vol. IV, Part I, 1899, p. 6.
} 
Parallelopora favositiformis nov. geus. et sp.

Pl. IV, fig. 3-4, pl. V, fig, 1-5.

About one half of a colony of this interesting form is found in Scher's material. The general form is irregularly flat sub-hemispherical with a greatest diameter of about $11 \mathrm{~cm}$. and a greatest thickness of about 4 .

By macroscopic examination the specimen will at once be taken for an ordinary Favosites. On the surface we readily discern the sections of the fairly regular, mostly pentagonal or hexagonal corallites and in longitudinal fractures numerous tabulae. The diameter of the cells is on an average $1 \mathrm{~mm}$, and the number of tabulae in one nm. generally $1-2$.

In microscopic sections however, we at once find that the form shows a character that is not found in any true Favosites. In a tangential section we commonly see at the junctions of the thick walls of different corallites the section of a circular cell or tube, developed in the wall itself, which at these places curves regularly around the tube. It has the appearance of a section of a thick walled cylinder, the walls of which run out into the straight ordinary walls of the large polygonal corallites.

The diameter of the circular cells is about $0,2 \mathrm{~mm}$. and varies very little. I have succeeded in obtaining longitudinal sections of these tubes and they are found to run as narrow, generally slightly curved, cells parallel or sub. parallel to the ordinary large ones. On account of their small diameter we never find them rumning through the whole section, one or both ends are closed by the slightly converging walls, but I have no doubt that they run through as well as the large cells. The fact that seen in tangential section they always show nearly the same size indicates their true cylindrical form. What distinguishes these small tubes from the large ones, in addition to their form and small, regular size, is the fact that they never show any tabulae. The tabulae of the neighbouring cells never enter these small ones. From this fact we may conclude that the cylindrical tubes represent something quite different from the large cells and cannot for instance be regarded as embryonal stages of the latter. They undoubtedly had a function of this own.

In the Ordovician North American form Columnopora cribriformis Nicholson observed small circular or oval cells situated-chiefly at the junctions of the cell-walls - imbelded in the wall. These "intramural canals" may probably be anatomically and biologically related to the cylindrical 
tubes in the Aretic form. Similar cells are also known from the genera Pleurodictyum and Lyopora. In all the three genera mentioned these tubes are relatively much smaller than in ours, and the wall shows no curvature round them. The tubes remind one also to some extent of the "spiniform corallites" of many Monticuliporidae.

As to the other characters of our form septal spines are found in most of the polygonal cells. The greatest number seen in one cell in tangential section is $4-5$ while their length does not generally amount to more than $1 / 5-1 / 6$ of the diameter of the cell. Very often spines in neighbouring cells are seen to be directly opposed to each other, having their base at the same spot.

The pores of the new form are much the same as in Favosites. Compared with that genus they are relatively large, the diameter varying from $0,15-0.25 \mathrm{~mm}$. or from more than $1 / 3$ to $1 / 5$ of the width of the walls that they perforate. In one place only (see pl. V, fig. 3) I have seen sereral of them together and they appear somewhat irregularly arranged.

With its prominent, cylindrical or subcylindrical longitudinal tubes, without tabulae, the form here described differs essentially from any one known to me and I propose for this and similar, in other respects Favosites-like forms the generic name Parallelopora.

Occur rence: B, upper part, over the fragment-limestone, Valley south of Borgen.

\section{Cladopora HaLl.}

\section{Cladopora rectilineata Simpsos.}

Pl. IV, fig. 7.

1559. Cladopora rectilineata Sinpson. 'Trans. Amer. Philos. Society. New Ser. vol. 16, p. 459, lig. 30.

1903. Cladopora rectilineata IVelurr. Paleontology of New Jersey. Vol. 3, p. 221, pl. 17, ligs. 14-17.

1913. Cladopora rectilineata Swantz. Geol. Survey of Maryland. Lower Devonian, p. 216, pl. 25 , figs. 47.

Several pieces of a dark limestone showing a great number of the thin stems of this species, in places very nicely weathered out. They have a diameter of from 2 to $1.5 \mathrm{~mm}$., with the apertures of the cells arranged in abont ten rows. Some of the stems shown on pl. IV, fig. 7 are too much worn, and the arrangement of the interior lubes appears here less linear than is the ease when the real apertures are seen on the original surface. 
Cladopora rectilineata is known fron the Decker Ferry of New Jersey and from the Keyser of Maryland. On an excursion in Maryland in May 1913 in the company of Professor Schuchert I liad an opportunity of collecting fine specimens of this form, and these have now been of great value for comparison with the Arctic ones.

Occurrence: B, upper part, point north of the beautiful valley.

\section{Theciidae.}

Thecia M. EDw. a. Haime.

Thecia swinderenana GoLDF.

Pl. VI, fig. 4.

1826. Agaricia Swindernana GoldF. Petref. Germ. Vol. I, p. 109, pl. 38, figs. $3 \mathrm{a}-\mathrm{b}$.

1851. Thecia Swindernana M. Edw. a. Hatme. Polyp. foss. terr. palaeoz. p. 307, pl. 2, figs. 4-4 b.

1860. Thecia Swindernana F. Roemer. Sil. Fauna Westl. Tennessee, p. 26, pl. II, figs. 4-4 b.

1876. Thecia minor Rominger. Corals Lower Peninsula, Geol. Surv. Michigan. Vol. III, p. 68, pl. 25, fig. 3.

Only a very small portion of a thin expansion, with the characters of the surface beautifully preserved is seen of this characteristic species. The tubes with their 12 septa show a diameter of $1 \mathrm{~mm}$. and the septa not seldom unite with those of the adjoining tubes across the interstitial space.

There can be no doubt as to this identification. In Europe the form generally occurs in rocks of Wenlock age, in Norway however, it has been found by Professor Kise extending high in Ludlow. In America Thecia swinderenana is cited from the Niagaran.

Occurrence: B, middle part, between Reindeer Valley and valley south of Borgen.

\section{Syringoporidae.} Syringopora GoLDF.

Syringopora sp.

Pl. VI, fig. 1-2.

A specimen of dark grey, somewhat crystalline limestone contains some imbedded fragments of colonies of a Syringopora, too small for any certain identification. At one place on the face of the rock the basal portion of a colony can be seen, corallites here growing in a flat expansion from which they then bend upwards and become erect and subparallel, 
always with a slightly irregular curvature. The diameter of the corallites is 1,5-2,5 $\mathrm{mm}$.. the distance between the cells about the same. In longitudinal sections, numerous closely arranged funnel-shaped diaphragms are visible in the interior. The detailed characters of the surface as to annulations etc. not known.

Occurrence: B, lower part. Seal Bay.

\section{Hydrozoa.}

Stromatoporoidea.

Stromatopora GoLdF.

Stromatopora sp.

A portion of a colony, not large, of a Stromatopora was found, but unfortunately the preservation is so poor that scarcely any structure can be seen in microscopic section, and we will therefore refrain from any closer consideration. Macroscopically the numerous undulating laminae can well he seen.

Occurrence: B, lower part, Seal Bay.

\section{Graptoloidea.}

Axonophora.

Monograptus GeiN.

Monograptus sp.

In pieces of dark argillaceous limestone from two localities representing - according to Schei's preliminary report - the upper part of series B, occur several hadly preserved specimens of a Monograptus. No specific determination can be made. The rhabdosomes are straight with a wilth from the smooth margin to the end of the theca amounting to $1^{1 / 2}-1^{2 / 3} \mathrm{~mm}$. The theca generally seem to be nearly straight, but some of the hetter preserved ones indicate a very slight curvature near the aperture. In some polyparies an axis can be olserved along the smooth margin.

As firr as can be seen, the form seems to approach a species like the European Monograptus (Pristiograptus) colonus Bann. and allied forms. With its fairly straight theca it is distinctly different from the M. priodon group which is the only one of large Monograpti known from North America, represented hy the Lwo species, M.clintonensis $\mathrm{H}_{\Delta \mathrm{LL}}$ and the very closely related M. chapmanensis Ruedemans from the Clinton. 
In the Devonian, besiles Dictyonema and related forms, some minnte Monograptus species only are known.

The occurrence of graptolites in this Arctic locality is in several respects of much interest. First, because the age of the beds (if they really belong to the other fossiliferous beds of Series B) probably is very young to hear such graptolites - as will he more fully discussed later on. Secondly it is very interesting to meet graptolites here in this relatively very little known Arctic region, showing a type that is not known in the exceedingly well investigated American Continent to the south. We have here no doubt a European faunal element occurring in the Arctic.

It seems as if graptolites are not so very scarce in the Arctic Silurian. A Monograptus form, M. convolutus var. Coppingeri Етн. was previously described by ETHERIdge in his paper on the fossils collecterl on the expedition of Sir George Nares (Quart. Journal Geol. Soc., vol. 34, p. 577 , pl. 25, fig. 1).

Occurrence: B, upper part, south of Point north of the Beautiful Valley. B, loose in debris in "Sundene" (?).

\section{Echinodermata.}

Crinoidea.

Fragments of stems of crinoids are found in all localities, especially lowever from the upper part of $B$ from the Point north of the Beautiful Valley in Walrus Fjord. Some pieces of the rock brought from these localities might be termed crinoid-limestone.

\section{Molluscoidea.}

Bryozoa.

Cyclostomata.

Fistuliporidae.

Fistulipora M'Coy.

Fistulipora sp.

A small piece of dark limestone shows the strongly concentrically wrinkled hasal epitheca of a Fistulipora, in places covered by parts of the upper celluliferous layer, exhibiting the oval sections of the zooecial tubes. These tubes are strikingly narrow, only about $0,15-0,20 \mathrm{~mm}$. in diameter and the distance between them is generally equal to the width. 
Unfortunately the upper surface of the colony is not well preserved so that the characters of the apertures, which are very important for a specific determination. are not known. 'The thickness of the upper layer' is abont 2 mm. in the thinner parts. A thickening at one place may possibly inclicate the former presence of a monticule.

Oecurrence: B. upper part, in the fragment limestone, Valley south of Borgen.

\section{Criptostomatia. Fenestelliclac.}

Fenestella Loxsd.

Fenestella sp.

'Two very small fragments of an impression of what probably has been a Fenestella-form are found in pieces of black limestone. me also with the Fistulipora sp.

Oceurence: B, upper part, in the fragment-limestone. Valley soutlı of Borgen.

\section{Brachiopoda.}

Atremata.

\section{Lingulidae.}

Limgula Brug.

Lingula sp.

Pl. VII, fig. 1.

The immer side of one vilve and an incomplete internal cast of another are known. The form is oblong, nicely rombled, with the greatest wilth to the front of the rentre. Length 10 imm., wilth $7 \mathrm{~mm}$. The anterior marain is relatively very hoally rombled, the posterior margins meeting at the beak at an obluse angle. The cast slows a moderate comvexily, will, a narow, hal, or slighly concave marginal rim. hroadest in front. A fine concentric striation is visible on the surface, and in the rentre of the cast a very faint lomgilmbinal depression is visible, rorresponding to a very low median ridge. On the inner side of the valve, to the front of the eentre and in the median line, a fant elevated point, corresponding (1) a lepression on the surface of the valve is visible.

This specimen shows some resemblance. inter alia. to several of the forms from the Lower Helderberg of New York and the Gaspe district. r. ה. I. spathata and I. rectilaterata $H_{A L L}$, yel it seems to exhibit distimet differences in outline, hesides being smalter. On arrount of the frogmentary malerial I will refrain from maming it.

(lectronce: B, middle part, belween Reindeer Valley and Valley sonth of Burgent. 
Neotremata.

Discinidae.

Orbiculoidea d'OrB.

Orbiculoidea sp.

An exterior mould of a very small depressed conical ventral valve with diameter $2 \mathrm{~mm}$. is seen on a piece of black argillaceous limestone hearing Monograptus sp. The pedicle groove is indistinctly indicated while the concentric striation is well marked.

Occurrence: B, upper part. south of Point to the north of the Beautiful Valley.

\section{Protremata.}

\section{Strophomenidae.}

Stropheodonta HaLl.

Stropheodonta patersoni HALL var. antiqua nov, var.

PI. VII, fig. 2-3.

On some pieces of dark limestone we observe several isolated ventral and one dorsal valve, which agree with Stropheodonta patersoni from the Schoharie Grit and the Onondaga Limestone of New York in all respects except the size, which is decidedly smaller. The outline is sub-semicircular with acute angles. The ventral valve is moderately and regularly convex, varying somewhat in different specimens, flattening out in the well defined cardinal extremities. The dorsal valve is nearly flat except near the anterior margin, where it is strongly curved. The surface shows the typical system of strong striae, between two of which come from six to eleven finer ones, and the well marked small arched wrinkles. As mentioned above, the size is considerably smaller than in the New York species. The largest specimen seen measures only $15 \mathrm{~mm}$. in length and 25 in width. The Arctic form differs in this respect also from the two varieties of $S$. patersoni which Dr. J. M. Clarke described from the Gaspé district of Eastern Quebec $^{1}$, S. bonamica (from the Bon Ami Beds) and precedens (from the Grand Grève limestone). From Stroph. corrugatella DAv. the form differs by its greater convexity.

Occurrence: B, upper part, over the fragment limestone, Valley south of Borgen, Gaasefjorden.

I See New York State Mnseum. Memoir 9, Early Devonic History of New York and Eastern North America, Part. 1, p. 186, Part. 2, p. 44. 


\section{Strophonella Hate.}

Strophonella ef. englypha H心.

I'I. VII, fig. 4.

The fragmentary exterior side of one ventral valve and the hadly preserved interior side of another are all that can be seen. The specimens are comparatively small, measming in wilth only $2 \mathrm{~cm}$. 'The outline is subtriangular, the posterior half of the valve slightly comvex, the valve at alont the middle of the length curving concavely, with an angle of about $130^{\circ}$. On the surface a system of relatively very faint radiating striae of first order, between any two of which are from two to five finer ones. The distance between any two of the stronger ribs - and also the number of finer ones between them - is greater in the posterior lhan in the anterior part, as a rapid interpolation of new strong ribs takes place towards the anterior margin.

The specimen showing the interior is too much worn to show the exact form of the muscular scars, only the strongly curved outer ridges are indicated.

This species looks very much like the common Emropean Silurian Strophonella euglyphe His., hut is smaller and has a less marked striation llan typical specimens of this form. In general form the specimens also approach small types of Strophonella leciveniorthana Hall from the Lower Helderberg of New York but differ in the surface ormamentation.

Occurrence: B, lower part, Reindeer Valley.

\section{Orthothetinae.}

Schuchertella GinTr.

Schuchertella interstriata Holls, var. simata nov. var.

PI. VII, fig. 6.

Only one good, nearly romplete specimen to hand. The outline is subrectangular as the lateral margins only very slighlly diverge anteriorly: The length of the hinge-line is accordingly very slightly shorter than the greatest width of the shell. The rentral valve is nearly flat, wills a very slight elevation of the heak region, especially the portion just in frout of the leak itself and an up-curvalure of the margins on hoth sides of the contre of the front, in oller work, we have a sinual depression at and near the anterior margin. 'The dorsal valve regularly convex but not markedly so. The low smooth triangular area of the ventrat valve with its convex deltidium is easily discerned, no dorsal area can he noticed. Apart from the slight sinus, the outer form of the 
specimen comes extraordinarily near to Schucherlella interstriala HaLl, a very common species in the Manlius of New York. The characters of the surface agree completely with those described and depicted from this species. We find a series of well marked. rounded radialing strie, with new ones appearing as we pass nearer to the front. The distance between the ribs equals their width. These strix are crossed by very numerous fine concentric lines, visible to the naked eye in a good light.

The characters by which this form differ's from $S$. interstriata are chiefly the occurrence of a sinus, secondly also by a less elevated beak.

Occurrence: B, lower part, Reindeer V'alley.

\section{Pentameridae.}

Gypidula HaLL.

Gypidula coeymanensis var. prognostica SCHUCHERT.

PI. VII, fig. 5.

1913. Gypidula coeymanensis Schuchert var. prognoslica Schuchert Geol. Survey of Maryland, Low. Devonian, p. 344, pl. 62, figs. 9-11.

A sing!e and not quite complete ventral valve of a rather small Gypidula agrees with the more slender types of this variety, characteristic of the Keyser member of the Maryland Lower Helderbergian. In Professor Schuchert's collections in New Haven I have been able to examine Maryland-specimens for purposes of comparison.

The length of the specimen from the beak to the anterior margin is $2 \mathrm{~cm}$. ; greatest width, - not quite complete, - amounts to $1,5 \mathrm{~cm}$. On the middle part of the valve run a series of longitudinal plications of different strength. They are most conspicuous in the anterior part, disappearing towards the beak.

Occurrence: B, lower part, Reindeer Valley.

\section{Telotremata.}

Rhynchonellidae.

\section{Stenochisma Conrad.}

Slenochisma deckerensis WeLLER var. arctica nov. var.

$$
\text { PI. VII, fig. 7-S. }
$$

This is one of the few forms that are really well represented in the material, occurring as it does in a very great number of fine, free specimens. The size varies greally, the largest specimens having a length of $16 \mathrm{~mm}$., a width of 19 , and a thickness of $10-12 \mathrm{~mm}$., the thickness varying greatly in different specimens. The number of plications in the 
larger shells is about 20, usually with 3, - sometimes more - in the sinus, and 4 - sometimes more - in the fold.

I thought at first that this form was identical with S. deckerensis Wliblen ${ }^{1}$ from the Decker Ferry of New Jersey and the Keyser of Maryland but as I have had an opportunity of comparing it with specimens from Maryland in Prof. Schuccient's collection in the Peabody Museum in New Haven, I have observed that there is some difference. although very minute. The Arctic form is distinguished by a little more acute, less globose beak, and by a distinctly deeper sinus and higher fold. Furthermore the number of plications in the sinus is nearly always 3 , sometimes nore; while in Stenochisma deckerensis the usual mmber is 2, very seldom 3. White we generally find these distinctions, I have seen specimens from both localities so alike that it would have been impossible to distinguish between them if they were found alone. 'The Ellesmereland form may well be regarded as a northem representative of the other one.

Occurrence: B, lower part, Reindeer Valley (a few, small specimens). B, upper part, over the fragment limestone, Valley south of Borgen.

Camarotoechio Hath and Clarke.

Camurotoechic litchfieldensis Schuchent var. angustata nov. var. PI. VIII, fig. 1.

A single but complete specimen, showing a close relation to the narrower specimens of Camarotoechia litchfieldensis Schucher't from the Keyser of Maryland, as for instance depicted in the "Lower Devonian" of the Geological Survey of Maryland (pl. 63, figs. 11-14) yet it exhibits a still narower outline and furthermore a larger size than the small form mentioned. The number of plications is about 15 in each valve, 3 in the sinus of the ventral, 4 in the fold of the dorsal valve. Greatest length of the shell $12 \mathrm{~mm}$., width 10 and thickiness $S \mathrm{~cm}$.

Occurrence: B, npper part, in the fragment-limestone, Valley south of Borgent.

\section{Uncinulus BaYte.}

Uncinuluss septentrionalis nov. sp.

PI. VIII, fig. 3.

There are two well-preserved specimens of this form hoth showing nearly the same size: length 10 mun., wilth $S$, thickness in one 5 , in the

1 Sim S. Whatrin, Geol. Survey of New Jersey. Report on Paleontology. Vol. 3, p. 231, pl. 21, figs. 1-1, 190\%3. T. P. Mayxan1, Geol. Survey of Maryland. Lower Devonian, p. 319, pl, 6i3, figs. 1-4, 1913. 
other $6 \mathrm{~mm}$. The outline is oblong subpentagonal, moderately globose. The depression of the sinus is only marked in the anterior third of the shell; it is characterized by having, with three broadly rounded plications, a flat or slightly convex base. The fold, that is also conspicuous only near the front, shows when seen from the front a corresponding, sub-rectangular section with in one specimen four, in the other only two rounded plications. One of the plications of the latter specimen shows, however, a division into two quite near the margin. The furrow in the middle of the fold is visible across the whole valve, from the front to the beak. On the lateral portions $3-4$ distinctly marked plications, in a very good light we find an indication of still other's near the beak. In one of the specimens particularly the plications show a tendency to divide into two. The surface of the shell is marked by very fine concentric lines of growth.

The chief characteristics of this form are the small size, the rectangular section of sinus and fold as seen from the front side and the very broadly rounded plications with their tendency to divide.

The form is related to Uncinulus nucleolatus HaLl, var. angulatus Maynard from the Keyser of Maryland (see Low. Devonian p. 366 , pl. 64, figs. 1S-20) but differs by it small size and the characters of sinus and fold.

Occurrence: B, lower part, Seal Bay.

\author{
Atrypidae. \\ Atrypa DALM. \\ Atrypa reticularis Lins. \\ PI. VIII, fig. 5.
}

Very abundant from one locality, and showing as usual a good deal of variation in form. The specimens are mostly relatively small, ranging in width from $17 \mathrm{~mm}$. down to $5 \mathrm{~mm}$. The dorsal valve is usually not very globose, the ventral varying from nearly flat to moderately convex. The surface-ornamentation well marked without being extremely strong. 'The younger specimens show a more evenly lenticular form and fewer plications.

Occurrence: B, upper part, over the fragment-limestone, Valley south of Borgen. 


\section{Lissatrypa 'T'Wenhofel'. \\ Iissatrypa scheii nov. sp. \\ Pl. VII, figs. 9-12.}

This highly interesting fossil is no dound the one most abundintly occurring in the material. A great number of free specimens are present, and some pieces of a brownish grey, very fine-gramed limestone filled with it, give us a good illea of the abundance of the specimen in the rock.

I posses specimens of very different size and the outer form changes with the size. The adult specimen usually reaches a length of ahout 2 cm., a widll of 1,S. The thickness varies much, in globose types it amolints to $15-16$ mm., in flatter ones to 12-13. The outline of the shell seen from above also varies considerably; sometimes it is evenly rounded, oval, hut with the umbonal region more sharply lined and prominent. Most specimens have a more polygonal outline, the margins on hoth siles of the beak straight, meeting at the beak at very obtuse angles. From these lines the lateral margins turn almuptly forwards, then gently curve towarls the medium-line and meet at the anterior end in a nicely rounded curve. 'The greatest width of the shell is generally at a point just hehind the centre. The convexity of the specimen varies, as mentioned above greally, the strongest convexily in the posterior part. Specimens with relatively that ventral and convex dorsal valve remind us as to the general form, apart from the character of the surface, very much of small Atrypa relicularis. As to the presence of a sinus and fold, there is considerable variation to he seen. In fact the specimens from the two localities, where the specimens were fomnd show a slight difference in this respect. The specimens from Seal Bay show in the anterior third, a more or less well marked sinus and fold. In some cases the vertral valve in the front runs out into a tongue-shaped process. In the more mumerous specinems from the Remdeer Valley we very rarely sec a real depressed simus at all. What often conveys the motion that a simms is indicated, is the fact that the margin in the froml makes a slightcurve upwards and forwarls in every mature shell.

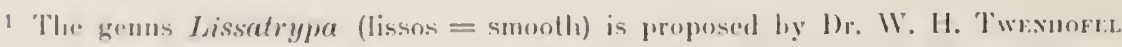
in Hore mamereript of a still nu-printed work on the Ordovician and silurian

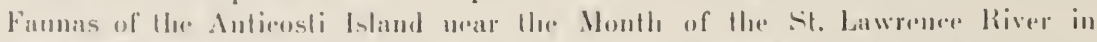

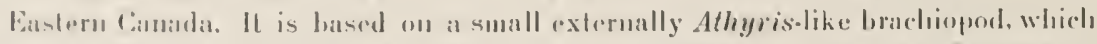
in its internal chanacters agrees with a true Atrypa. (Genotypo Lissatrypa

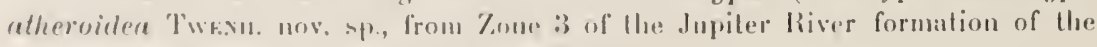
Autionati soction. the equnivalent of the Clinton). 
The surface shows numerous lines of growth which are strong in the larger specimens, particularly near the front. 'The shell sulsstance is fibrous.

The small specimens usually show on the whole a much broader, more circular outline than mature ones and are always thinner and flatter. A distinct, often ridge like, elevation is to be seen from the beak and half way forwards.

This form and the few related ones, that are known, are rendered especially interesting by the fact that the smooth shells show in the interior the characters of an Atrypa and not of an athyroid brachiopod, which they strongly resemble externally. Haughton and Etheridge (see farther down) removed the exceedingly closely related Rhynchonella phoca SAlter fiom Rhynchonella, and placed it with Atrypa simply because they could find no aperture in or under the beak. I have now obtained positive evidence of the near relationship of the Ellesmereland form (as well as of L. phoca from Beechey Island) to Atrypa by getting at the characters of the interior and finding spiral cones with their top directed towards the middle of the dorsal valve. The number of the spiral rings, in one specimen where they are most clearly visible, is eight. In horizontal section the cones show an oblong form, with the greater diameter in the direction of the length of the shell. 'The inner' side is flatter than the outer, just as in Atrypa reticularis. The two cones also seem to be very close to each other at the base. As to the loop, it is exactly of the same type as in Atrypa, as far as can be seen from the specimen mentioned above.

We have liere before us what we might call a smooth Atrypa, and as one of the generic characters of a true Atrypa is a rather prominent striation or fine plication, we are obliged to put these shells into a new genus. I had myself intended to establish a new genus but learnt at an early date that Dr. W. H. Twenhofel of the University of Kansas, in the manuscript of a monograph on the Ordovician and Silurian rocks and fossils of the Anticosti Island, had preceded me by proposing a new generic name Lissatrypa, for the same type of shells, founded on a small Athyris-like brachiopod. He will accordingly stand as the author.

On first looking over the material and examining the form in question I though that I had the true Lissatrypa phoca ${ }^{1}$ Salter before me.

1 1852. Rhynchonella phoca Satrer. Appendix to Sutherlands Journal of a Voyage in Baffins Bay and Barrow Strait, p. 226, pl. 5, figs. 1-3.

1858. Atrypa phoca HaUghrox. Journal of Royal Dublin Society, vol. 1, p. 240, pl. 5, figs. 3, 4, 7. - - Continued on next page. 
Subsequent stulies, however, made it apparent that species from Ellesmereland must be distinguished as a distinct species, because of its cons. tantly smatler size and somewhat different form. I harl an opportunity of studying the $I$. phoca not only in the descriptions and old figures hut fortunately in specimens from a collection from one of the lype localities. Beechey Island. The collection was brought to the University of Kristiania by the "Gjüa"-Experlition of 1903-1905, Caplain RoALD Amcroses. As a result of this comparison I found that there undoubt. edly exists a difference in size and some also in form between these specimens, and those from Ellesmereland. Out of more than one hundred specimens I possess of the latter, only the very largest attain nearly the size of small adult specimens of the former. It is evident also from the illustrations of Salter and Haughton that $L$. phoca is a relatively large form. In outline $L$. scheii is much more rectangular than the other form, that has a rather acute triangular outline in the posterior part.

As to the phyllogenetic relation of the new genus, I believe that Dl. Twexhofer will consider this question, especially as he has found the oldest representative of the genus. So much may be sail however, that as the genus as far as we know appears at about the same time as the true Atrypas, it camot be derivel from this genus. We have to seek its origin down in the Ordovician and probably anong the same forms that have given rise to Atrypa, viz. Zygospira-like forms.

Occurrence : B. lower part, Reindeer Valley, B, lower part, Seal Bay.

\section{Spiriferidae.}

Spirifer Sowerby.

Spirifer modestus Hall var. striatissimus nov. var.

Pl. VIII, fig. 2.

We have one complete and several fragmentary specimens. The size aud the onter form are exactly like in Spirifer modestus HaL which is one of the most common hrachiopods of the Keyser of Mary-

157s. Atrypu phoca Enemunes, Palieontology of Aretir Coast etr. Quart. Jour-

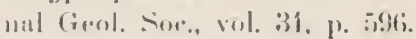

1906. Hendelle phose Am. Cited in the list of fossils firmu Beechey Island, Apperdix lo the "Couse of the Neptune" (by A. P. Low - Othawa 19016),

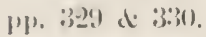

1910. Atrype phoce Lasuss: Appendix to "Rieport on an Expedition to the Aretic Ist. ele on Buard the Arelie" (hy J. F. Bersuar. Ottawa 19/0), p. 481.

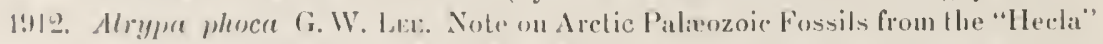

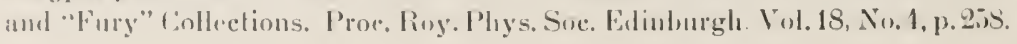


land. The specimens differ, however, by having a relatively distinct concentric striation, while the other form has a very faint surface-ornamentation, viz. only a few, very slightly marked lines of growth. The concentric lines in the Arctic form are very closely arranged, and in their anterior part exhibit distinct fimbriate spines.

On grinding a ventral valve, I observed two strong, diverging dental plates but no median septum. These character's distinguish the form from the younger Reticularias and Squamularias, which embrace species externally very much like ours. According to Dr. G. Girtr, who in his extensive paper on the Carboniferous of Colorado (Professsional Paper U.S. G.S., vol. 16, ps. 387-392) discusses the gencra in question with considerable fullness, Reticularia has a medium septum and dental plates, whilst Squamularia has neither.

Occurrence: B, lower part, Reindeer Valley.

Spirifer vamuxemi HaLl, var. prognostica SCHuchert.

Pl. VIlI,, fig. 4.

1913. Spirifer varuxemi Hall, var. prognostica Schuchert. Geol. Survey of Maryland, Low. Devonian, p. 403, pl. 68, figs. 34-35, pl. 69, figs. 1-3.

This little form, that is very characteristic of the Keyser member of the Lower Helderberg in Maryland, is represented in the material by a fair number of specimens, some of which are fairly well preserved. The identification has been made with certainly, as I have had the opportunity of seeing typical Maryland-specimens in Professor Schuchert's collection in New Haven. The size varies somewhat, the largest specimen measured having a length of $7 \mathrm{~mm}$., and width of $9 \mathrm{~mm}$. Where the surface is well preserved a concentric striation, - the lines marked by minute fimbriae - can be seen.

The American variety is exeedingly near to Spirifer vamuxemi HaLL from the Manlius of New York and New Jersey, the only distinguishing eharacter being somewhat more numerous plications in the variety.

Several small specimens fron the lower part of Series B, from the Valley south of Borgen, measuring only about $7 \mathrm{~mm}$. in width, $6 \frac{1}{2}$ in length, as far as can be seen from the not very well preserved exterior has only about 3 plications on each side of fold and sinus, and might therefore perhaps be determined as $S$. vamuxemi.

Occurrence: B, lower part, Reindeer Valley. B, upper part, in the fragment-limestone, Valley south of Borgen. 


\section{Mollusca.}

\section{Pelecypoda.}

\section{Prionodesmacea.}

Grammysiidae.

Grammysia Verseum.

Grammysia (?) triangulata nov. sp).

Pl. Y'III, fig. S.

Only one well preserved right valve of a very small lamellibranch of a peculiar type. Placed preliminarly under Grammysia although it differs strongly from the large shells with strong concentric undulations that are most common in this gemus. Vet it certainly approaches that genus - or to related members of the family Grammysiidae - nearer Han Lo any other known groups of lamellibranchs.

The outline is obliquely and roundly triangular, with the anterior and posterior margin as seen in lateral view meeting nearly at right angles. Except for an abrupt curvature near the margins the shell is nearly flat in longitudinal section, while vertically it is strongly curved, especially in the apical portion. The posterior margin is not wholly preserved, hut we see indicated here a sort of mimule wing with its plan nearly vertical to that of the shell in general and thms not visible in the lateral view.

The surface shows a not strong, hut distinct concentric striation and in a good light an indication of radiating strix.

Dimensions of the valve: length $9 \mathrm{~nm}$, height $7 \mathrm{~mm}$.

I do not know of any limelliluanch approaching very near to this form, which may represent only an immature stage. A species which in its younger stages slow a considerable likeness, is Hax.'s Grammysia (Sphenomya) cuneala from the Hamilton of New York?.

Oceurreuce: B, upper part, near the fragment-limestone, Valley soutls of Burgen.

Aviculidiate.

Pterinea Gint.

Plerineacf.aciculoidea Hata.

Pl. l'III, lig. 6.

A left valse of a medium-sized lamellihanch which might possibly le referred to Megambonia ariculoided Has, from the Manlius of New lonk and Now dersey", lut as llue shell is not completely preserved I 
will refrain from making any identification. From the oblique, highly convex umbonal ridge, which terminates in a prominent, moderately incurved beak expands anteriorly a very small wing and posteriorly a rather large one. In the outline of this posterior wing there is possibly a slight difference between my species and the original, the latter showing a broadly sinuate margin just below the hinge-line, while the Ellesmereland-form seems to have a straight margin. As however, the dorso-posterior corner of the valve is not completely preserved, it is possible that originally a slight curvature was present.

The surface of the cast is markerl by broad, not very strong concentric undulations, especially prominent on the umbonal ridge. An indication of a radiating striation may also be seen in this part of the shell and better defined, at the margin of the posterior wing.

Occurrence: B, upper part, over the fragment-limestone, Valley souti of Borgen.

\section{Nuculidae.}

Nucula(?) sp.

PI. VIII, fig. 7.

Two casts of a relatively small and flat oblong lamellibranch, probably belonging to a Nucula, were found. From the quite prominent beak the dorsal margins slope gradually, at the anterior and posterior extremities curving strongly and meeting in very slightly rounded basal margin. Greatest depth of the valve about one third of the height. On the surface, a rather faint concentric striation or undulation is visible.

The material to hand of this form is too scanty for any exact determination. Forms that in some varieties come very near to it are Nucula randalli $H_{\text {ALL }}$ and $N$. lirata ConRAD, both known from the Hamilton of New York (see Pal. New York, vol. 5, part 1, Lamellibranchi. ata, II, p. 315-316).

Occurrence: B, upper part, near the fragment-limestone, Valley south of Borgen.

\section{Gastropoda.}

\section{Aspidobranchina.}

\section{Murchisoniidae.}

\section{Hormotoma sp.}

In some large pieces of a fine-grained brownish-grey limestone occur a number of casts of a small and slender gasteroporl, too fragmentary for any specific identification. They seem to be much like a form 
as the Ioxonema liossi described by Haugutox in the Jommal of the Royal Dublin Society, vol. 1 (p. 240, pl.5, figs. 6, S-11) from Beechey Island sprecimens. In the list of fossils which H. M. Am has published in Low's report on the Aretic royage of the "Neptune" (Ottawa 1906) Loxonema rossi is quoted, 1. 320, from a hlush grey limestone of the same locality. In a collection in Peabody Musemm in New Haven I have had an opportunity of examining specimens of this form. (labelled hy Dr. Ams), and I have found them to be extremely similar to the specimens collected by Scnes. A certain conchusion as to the identity of the forms. however, cannot he made with no hetler preserved material that which is now in my possession.

The specimens in the collection attain a maximum length of $13-$ $14 \mathrm{~mm}$. but are usually much smaller. The most complete ones show ahout 9 volulions, yet originally there were still more. The height of the rolutions is about two thirds of the greatest widh. In one specimen with partially preserverl surface an indication of a longitudinal band on the lower volutions can be seen. showing that the form is no Loxonema, lut probably belongs to Hommotoma.

Occurrence: B, lower part, Reindeer Valley.

\section{Hormotoma (?) sp.}

Pl. VIII, lig. 12.

An imperfect cast, laterally somewhat compressed, of a lorm that eannot be more closely determined. We find in literature several forms, known as casts, that show much likeness and probably are also of about the same age. Amongst others come into consideration the Loxomema (?) sp., tescribed hy Websen from the Manlius in the New Jersey report, pl. 22, ligs. 9-11 especially (fig. 11 is very like) and then Loxonema sp. figured by Ornix in the Maryland Devonian, pl. 79. fig. S. In the description Ontrax, p. 468 , also mentions the resemblance to the New Jersey form. A thirl form that is possibly related, is the Muchisonia -p., mentioned by SALTt: in the Appendix to Sutherlands report in pl. 5. fig. 1S. In Hausaroxs articte on the Aretic fossils brought home by M'Clintock (Joumal Royal Dublin Society, vol. 3. 1S60, p. 5j) this form is named Loxonema Salteri. It is reported to occur together with Atrypa phoca on Cormwallis Island, in Assistance Bay, and on the West coast of Boothia Felix. It is necessaly, however, to see the specimen or a better illustration than Salteris old one before chassifying this species with rertainty.

Oceurrence: B, lower part, Reindeer Valley. 


\section{Hormotoma (?) sp.}

PI. VIII, fig. 9.

We have an incomplete cast of a medium-sized conical gasteropod (apical angle about $20^{\circ}$ ) with 7 volutions, but several nissing. No more exact determination is possible.

Occurrence: B, upper part, over the fragment-limestone, Valley south of Borgen.

\section{Ctenobranchina.}

Pyramidellidae.

\section{Loxonema PHILI.IPS.}

\section{Loxonema fitchi HaLL.}

Pl. VIII, fig. 10.

1859. Loxonema fitchi HAL.. Pal. New York, vol.3, p. 296, pl.54, figs.9. 11. 1913. Loxonema fitchi OHers. Geol. Survey of Maryland. Low. Devo. nian p. 467 , pl. 79 , fig. 7.

A medium-sized, slender, subcylindrical gasteropod, represented by a few imperfect casts which seem to agree completely with the descriptions and figures of this species which is reported also from casts only from the Helderbergian of New York and Maryland. However, an identification of gasteropods hased on casts will generally be a little mncertain, so that no very great value for purposes of correlation can be ascribed to these specimens. It is also with hesilation that I place the specimens under Loxonema, they too may possibly belong to Hormotoma, or another related genera of the Murchisoniidae.

In the most perfect specimen I have counted five volutions, very characteristic in their straight margins and great height. At least three whorls at the top, however are missing.

Occurrence: B, lower part, Reindeer Valley. B, upper part, over the fragment-limestone, Valley south of Borgen.

\section{Litorinidae.}

\section{Holopea HALL.}

\section{Holopea sp.}

Pl. VIII, fig. 11.

Only a single and incomplete cast of a small form occurs, allowing no specific determination. Outline broadly conical, about four volutions, lower end incomplete. The volutions slow a subcircular section and a smooth surface.

Occurrence: B, lower part, Reindeer Valley. 
Capulidae.

Platyceras Coskad.

Platyceras ellesmerelandi nov. sp.

PI. V'llI, fig. 20.

Shell spiratly and obliquely conical, consisting of one whorl that rapidty increases in thickness from the apex towarls the aperture, the detailed characters of which can not be directly seen. On the surface can be observed one hroad and relatively strong longitudinal ridge, on the onter side of the whorl, and faint indications of other's on both sides of the above.

This form shows some likeness to several American as well as European Devonian Platyceras-species, yet differs sufficiently to be regarded as an independent form.

Occurrence: B. uper part, point north of the Beautiful Valley.

\section{Cephalopoda.}

Nautiloidea.

Orthoceratidae.

Orthocerces BREYN.

Orthoceras sp.

A smalt fragment, about $2 \mathrm{~cm}$. long with a circular section and the dianeter increasing in the said distance from $S$ to $12 \mathrm{~mm}$. Surface and interior unknown.

Occurrence: B, lower part. Reindeer Valley.

\section{Oithoceras sp.}

Another fragment of aboul the same size, but less conical in form. showing the small siphuncle lying a little eccentric. The section of the shell is circular ats far as can be seen from the incomplete specimen. $A$ septum of moderate convexity closes the lower end of the shell. A faint line, a smath distance above this septum possibly indicates another, in which cose the distance between two septa wonld he $4 \mathrm{~mm}$. white the dianeter of the shell here is $14 \mathrm{~mm}$. Surface smooth.

Occurrence: B, upper part, in the fragment limestone, Valley sonth of Borgen. 


\section{Arthropoda.}

\section{Crustacea.}

Trilobita.

Proetidae.

\section{Proetus Steininger.}

Proetus leptorhachis nov. sp.

PI. VIII, fig. 14.

Only two pygidia are known of this species, both well preserved and of exactly the same size. Their outline is semi-elliptical with greatest length $9 \mathrm{~mm}$., greatest width $14-15 \mathrm{~mm}$. The flat or faintly convex marginal rim is separated from the strongly convex middle portion by a well defined line of depression.

The axis is prominent, slightly convex longitudinally and relatively very narrow, the width being only about one-fourth of that of the entire pygidium in the anterior region, the margins not very markedly tapering towards the rounded, well defined end, which is situated a little more than two min. from the posterior border. The number of the annulations $11-12$.

In the lateral parts of the pygidia on each side, we see 7 distinct pleural lobes, with relatively broad interspaces, and indications of others nearer the posterior end. Where the shell-substance is still preserved the pleural lobes - which do not cross the marginal rim - show the longitudinal furrow very distinetly.

The entire surface is covered by very small pustules, in a good light visible to the naked eye. No regular arrangement can be noticed in these pustules.

As is indicated by the name proposed for this species one of the chief characteristics is the relatively narrow axis. A form-also known only through a pygidium - that is somewhat alike, is Proetus hesione Hall (see Pal. New York, vol. 7, p. 93, pl. 20, figs. 15-16) from the Schoharie grit of New York. The axis of this species, though narrow, is still relatively broader than in the new form in question, and furthermore the surface ornamentation is different. Another related form is Protens planimarginatus МЕек from the upper Helderberg of Ohio (see Geol. Survey of Ohio, Paleontology, vol. I, p. 233, pl. 23, figs. 3 a-b). 
The pygidium upon which this species is based differs distinctly by its narrower marginal rim.

Occurrence: B, upper part, over the frament-limestone. Valley south of Borgen.

\section{Encrinuridae.}

Encrinurus Eмменси.

Encrinurus sp.

Pl. VIII, fig. 13.

A badiy preserved fragment of a trilobite-pygidium indicates this genus. The form of the pygidium is a very elongated triangle, the surface in transverse section moderately convex. The axis is prominent, with a strong tubercle on each segment. As the lower part is strongly weathered the number of the segments cannot be discerned. On the left lateral portion about $S$ pleural lobes can be counted, corresponding to the same number of segments on the axis, all with one or more tulsercles. In outline and number of segments and pleura the pygidium comes near to Encrimurus (Cromus) transiens BarR ${ }^{1}$ from Etage E. This form differ's, however, hy having many tubercles of equal strength on eacli segment of the axis.

On another piece of limestone from the same locality and of exactly the same lithological character as the one in which the pygidium was found, occurs a very small fragment of what I think is the head of the same Enccinurus sp. It shows only the marginal part of the left half of the head, from the middle of the glabella and half down the free cheek, strongly ormamented with big round tubercles.

Occurrence: B, lower part, Reindeer Valley.

\section{Encrinurus (?) sp.}

Another weathered pygidium of broader triangular ontline may probably also be referred to Encrinums. The number of the axial segments is about 13, that of the plenral lobes 10-11. The marginal part of the pleura is greatly curved downwards throughout. There appear to have been lubercles present on the surface, but they are now worn away.

Ocrurrence: B, lower part, Reindeer Valtey. 


\section{Calymmenidae? \\ Frammia dissimilis nov. gen, et sp.}

Pl. VIII, figs. 17-18, fig. 19?

In a piece of the common greyish, finegrained limestone from the Reindeer Valley I found by first examination of the material, a part of a thorax with connected pygidium, that reminded nue of a Calymmene sp. I also observed close by a hidden fragment of a trilobite head and succeerled in preparing it out. I was highly astonished to find that it looked quite different from anything I have ever seen of trilobite heads. It is highly regrettable that no more material of this interesting form occurs. In the following I will give a description of what can be seen.

Head. Nothing of the original outline is known with certainty. The glabella reminds one much of an Encrinurus, it is moderately convex with nicely rounded front line. The lateral margins, which are of a quite peculiar character as will be explained presently, diverge strongly forwards. Instead of the regular straight dorsal furrows, dividing between the glabella (with more or less marked transverse lobes) on one side and the fixed cheeks on the other, we find two deep depressions about two $\mathrm{mm}$. in depth and projecting at the surface like four highly crenuated lines, with the crenulae or lobes on both sides of each depression arranged in such a way that the lower side of the apex of the outer lobes is extremely near to the upper of those on the immer side. The furrows which was filled with stone-material and detailed character's of which I was only able to study by breaking the head along the furrows has accordingly a very different trausverse section in various places as may be seen from fig. 18. They might be compared with incomplete cylinders with relatively regular sides except for the lobes running out at the top, and in addition some funnel-shaped depressions on the lower inner side. These depressions seem to be situated one below each of the interspaces between the lobes of the surface. The number of lobes that can be seen on the outer side of the furrows where they are best preserved is five. A longitudinal section of a furrow shows that it is curved parallel to the surface, thus having the same depth in front and behind.

That which is visible of the head outside these furrows - in other words of the fixed cheeks, - shows a relatively flat surface in the posterior and inner part, curving markedly downwards towards the anterior margin of the head. On both sides we find a trace of the eye preserved, too small however, to give any exact idea as to the form. On the strip of the surface that we find roughly preserved on the right side 
behind and to the right of the eye, curving markedly dowmards. no trace of a sulure-line is risible, but owing to the rough state of preservation it is difficult to draw any conclusion as to the real structure.

Very little surface ormamentation is to be seen, only some faint pustule-like irrregularities may be observed in the glabella.

As regards the palaeontological explanation of the strange furrows described, it seems reasonable to assume that they represent a rery peculiar type of dorsal furrow, deepened and widened and combined with a lobation of the margins.

Very deep dorsal furrows are not seldom met with, and one of the genera that possesses them most conspicuously is the one with which the fragments found with this head show the strongest relation, Calymmene. In fact somewhat similar furrows are described by Lridströs from a Calymmene from the Silurian of Gotland (Calymmene excavata Lixiströn. Öfrersigt, Kgl. Vet.-Ak. Förhandlingar, Vol. 42, Stockholn 1S55, p. 72, pl. XVI. figs. 1-4).

In this form atso, lobes are developed at the inner margin of the fixed cheeks. In general appearance, however, the Gotland form is quite Calymmene-like, while the head of the Arctic form has no resemblance whatever to a Calymmene. It is more like Encrimurns. As it cannot he incorpated into any known genus of trilobites I propose to place it under a new genus Frammia, characterized by very deep and broad dorsal furrows in the head, diverging towards the front, and with distint lobes at the surface on both sides. The genus is named after the vessel "Fran" that thrice carried Norwegian explores on great polar expeditions.

Thorax and pygidium. The fragmentary thoras with the pygirlium. Hot is found in the same small piece of limestone as the head just described, in my opinion certainly belongs to the same tribohite spucimen, of which the head is a part. The head has been moved from its original position, and is now to be seen close to the posterior part of the thorax with its longitudinal axis nearly at right angles to that of the thorax. As no other trace of trilobites is found in the rock sperimen, and the two parts seem to agree to as to size. state of preservation, etr. I thunk it very probable that the different fragments betong to one sperimen. 'The fact that dorsal furrows, somewhat simular to those that found in the heal, are known hefore just from a Calymmene points towards the same comblusion.

'The posterior, hetter prestrved part of the thorax that has 13 segments show a strongly convex trinsverse section, the lateral part of 
the pleura standing nearly vertical. This form corresponds with that of the head, the lateral part of which also was strongly curved downwards. The axis is moderately convex, widt a width from 9 11 m. in the middle part, $6-7$ on the last thoracic segment The pleura show a rather flat and hroad surface.

The pygidium is relatively broad with the two margins, when viewed from above, meeting as nearly straight lines at slightly obluse angles The axis strongly tapers, has 9 distinctly visible segments, the anterior ones of which curve slightly, the posterior stronger, and more angularly forwards. The transverse furrows are deepest near the margius of the axis. On the sides can be seen about 9 pleural lobes, the posterior ones directed strongly backwards and downwards, and are sub-parallel. The first 6-7 lobes are very well marked, wilh broad flat surfaces and hroad furrows between. It is impossible to decide whether there has been a fine punctation on the surface or whether the same has been quite smooth, as the specimen is somewhat weathered. The broad form of this pygidium. the laterally strongly down-curved and posteriorly suhparallel pleural lobes remind one strongly of a Calymmene, and without the head I should probably have determined the fossil as belonging to this genus.

Occurrence: B, lower part, Reindeer Valley.

\section{Ostracoda.}

\section{Leperditiidae.}

\section{Leperditia Roualt.}

Leperditia symmetrica nov. sp.

Pl. VIII, fig. 15.

I have before me a great number of right valves of a Leperditic, in a good slate of preservation. The size varies considerably, the largest specimen found having a length of $S \mathrm{~mm}$., and a height of $5 \mathrm{~mm}$. The valve is elongate in form, with a relatively long, straight or slightly downward curved hinge-line. The anterior and posterior margin are very finely and regularly curved, rumning strikingly symmetrically and converging ventrally in a gentle curve. Where they meet the hinge-line, they run into a small well-rounded process. The convexity of the valve is not very great, greatest point of elevation in the middle, where the valve often rises somewhat abruptly. A faint and narrow marginal flattening can be observed in the larger specimens in the upper half of the anterior and posterior margin. The eye-tuberble is distinct, situated 
at about the middle of the antero-dorsal quarter or slightly higher. Muscular spot easily observed when the shell-substance is removed; it is situated a little downwards and backwards from the eye, shows an oval outline (in a large specimen the greatest diameter is about $1 \mathrm{~mm}$.) and an ornamentation of fine punctie. Finely anastomosing lines run from Uhis muscular spot towards the ventral and posterior margins.

'The form liere described is especially characterized hy its oblong form in combination with a symmetrical outline, the anterior and posterior margins corving equally strongly.

A form that I first thought was very like this one is the Leper. ditia baltica Hisinger, var. aretica SAlter, lescribed from Arctic materials in the Appendix to Sutuentand's report, p. 221, pl. 5, fig. 13, judging from the illustration given there. Professor R. Jones, however. later on in "Ammals and Magazine of Natural History" for February 1556 gave a new description and new illustrations of this form (see p. S7. pl. 7, figs. 1-5) and from these it is evident that the two forms are quite different, the right valve of Leperditia arctica strongly projecting downwards, giving a more triangular outline.

Occurrence: B, lower part, Reindeer Valley. B, upper part. neir the fragment-limestone, Valley south of Borgen.

\section{Leperdilia sp.}

A not quite compleie left valve of a medium-sized ostracod may probably be referred to a Leperditia. The outline is decidedly oblong (renumb much of a Bythocymris), the length being $3.5 \mathrm{~mm}$., the height only 1.S. 'The dorsal margin is straight, the ventral - not fully preserved, - a litlle rounded. The valve is highly convex, with the most elevated portion a little in front of the rentre. A slighlly matred marginal rim can be seen at the anterior and posterior margins. The surface is completely smooth, withoul any visible ocular or muscular spot.

The shell is well characterised by its extremely oblong form and great convexity. I know of no ostracod of the same size approaching it. The nearest are some carhoniferous forms from Great Bribin, Leperdilia oblonga Jones a. KnKBY and L. parallela J. a. K. (see Annals and Mag. Nat. Hist., Ser. 3. vol. 15, 1865. p. 407) but they do not entirely agree.

Occurrence: B, uppert part, point north of the Beautiful Valley. 


\section{Primitia arctica nov. sp.}

PI. VIII, fig. 16.

Some small pieces of black fine-grained limestone are rich in minute ostracods, most of which cannot be nearer determined as they are too incomplete.

Also of the species named above I have only a single right valve, The greatest length is $0.9 \mathrm{~mm}$., greatest height $0,6 \mathrm{~mm}$. The posterior part is very globose, the sulcus not strongly defined, as the anterior portion of the valve is only slightly elevated. Quite near the upper margin and in front of the sulcus a strong nodule is situated. A broad rim runs round the valve.

Occur r e n ce: B, upper part, near the fragment-limestone, Valley south of Borgen. 


\section{Conclusions.}

The forms identified from Series $B$ are the following:

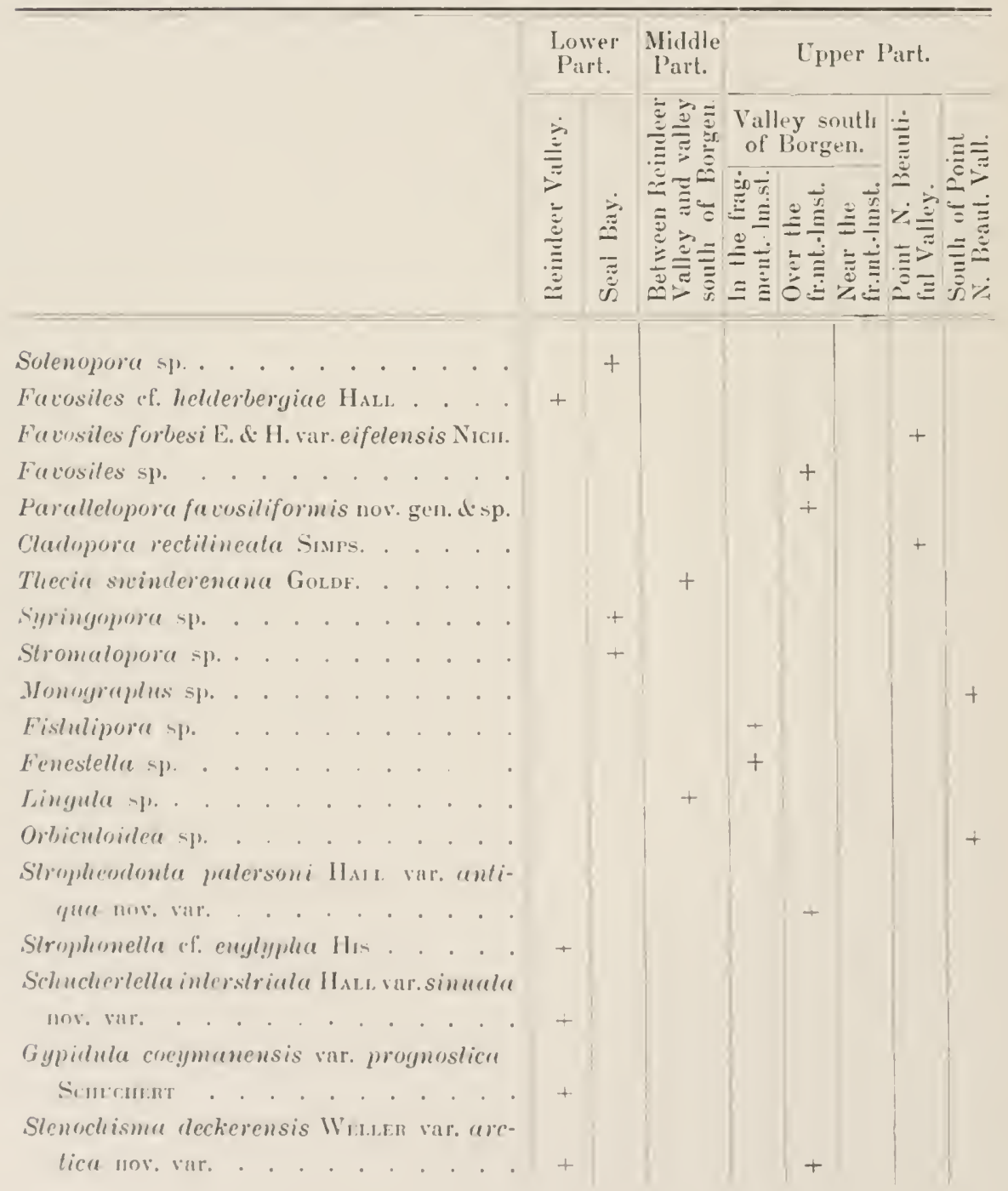




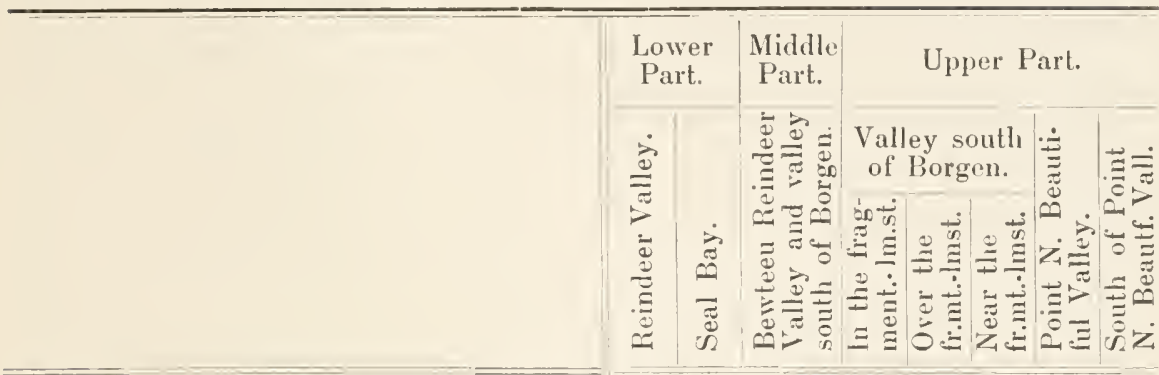

Camarotoechia litchfieldensis Scuuchert

var. angustata nov. var.

Uncinulus septentrionalis nov. sp.

Atrypa reticularis LiNs. . . . . .

Lissatrypa scheii nov. sp. . . . . . .

Sp iriter modestus HALL, var. striatissimus

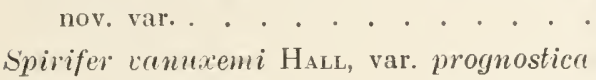

Schuchert . . . . . . . . . . t

Grammysia (?) triangulata nov. sp

Pterinea cf. aviculoidea HaLL . . . .

Nucula (?) sp

Hormotoma sp.

Hormotoma (?) sp.

Hormotoma (?) sp.

Loxonema fitchi HaL

Holopea. sp.

Platyceras ellesmerelandi nov. sp.

Orthoceras sp.

Orthoceras sp.

Proetus leptorhachis nov. sp.

Encrinurus sp. .

Encrinurus(?) sp.

Frammia dissimilis nov. gen. \& sp. . . + +

Leperditia symmetrica nov. sp.

Leperditia sp.

Primitia arctica nov. sp.

When we inspect this list of 43 species, only 21 of which are well enough preserved to be given a specific name, we find 9 new species, 5 new varieties of species known previously, and 7 species which have been identified with known ones. Of these only a very few can be used for purposes of correlation.

The Favosites forms cannot be relied upon as detailed guide fossils, for with our present knowledge of these forms their specific characters 
are not so strongly expressed or invariable as is demanded of horizon makers, two of the brachiopods. Leptena rhomboidalis and Atrypa reticularis are wihtont any stratigraphic value, and therefore cannot he considered. Accordingly, we have only the following left for purposes of correlation : -

Thecia swinderenana GoLDF.

Cladopora rectilineata Simps.

Gypridula coeymanensis prognostica Schucnert.

Spirifer ramuxemi Hald val. prognostica Schuchert.

Loxonema fitchi HALL.

Of these Thecia swinderenana is a rery widespread form, cited from the IVenlock of Northern Europe and from the Niagaran of North America (Michigan, 'Tennessee). It was found, however, by Professor Kı.fr of Christiania University occurning in the Norwegian Silurian in rocks also of relatively high Ludlow age, in other words, it seems to be stratigraphically no greatly restricted fossil. If we consider the other four forms. we are dealing with species that as far as is vet known, have a very limited vertical distribution, occurring in the horizon that is the large new monograph of the Maryland Geological Survey, "The Lower Devonian of Maryland" is called the Keyser member of the Helderberg group of that state and which corresponds to the Decker Ferry-Rondout-Manlius of New Jersey and the (WilburRosendale?)-Cobleskill-Rondout-Manlius of eastern New York. The three first mentioned of these four forms are very common in and typical of this horizon. As mentioned in the descriptive portion of this paper I have had an opportunity of comparing my Arctic specimens with Maryland-specimens of three of these forms and the identifications have furthermore heen controlled by Professor Scuucuent, who knows the fanna of the Keyser in detail. The occurence of certain other of our forms strongly supports this conclusion that we are dealing with an horizon corresponding to those above mentioned. The Stenochisma of the Eillesmereland-famna approaches so closely to S. deckerensis WELLer, from the Decker Ferry of New Jersey and the Keyser of Maryland, that I simply regard it as a nothern representative of this form. The same may he said of the variety of Spirifer modestus, a form belonging lo the most-Iypical Keyser-species.

We have thus reached an important result, in being able to correlate - at any rate a greater part of - the Series B with a well-known lorizon on the American Continent. It is not astonishing to find that only 
a few specimen are found to be quite identical in view of the circumstance that the two regions are situated more than 35 degrees of latitude (or about 2400 miles) apart.

As to the detailed stratigraphical relation between the beds in the different localities, or even hetween the lower and upper part of the series which are distinguished by Scher, I dare not offer any opinion. Of the four species that are in common with the Keyser-fauna of Maryland, one is restricted to the lower and one to the upper part, whilst the other two are found in both. Of other common species the new Leperditic and Stenochisma deckerensis var. arctica also occurs in botl divisions, the latter form but in few and small specimens in the lower one. A considerable amount of time must naturally have elapsed between the deposition of the lowest and highest layers of a marine series, 1000 feet thick, and we find also that most of the forms are restricted to one of the divisions, but it is not on the other hand evident from the faunal aspect that the two divisions, geologically speaking, belong to very different times.

No near relation to European faunas has been found, and apart from the quite cosmopolitan forms, Lept. rhomboidalis, Atrypa reticularis, Thecia swinderenana and the Favosites forbesi-variety the other species differ from European ones.

This wonld not be the place to discuss, on the basis of a small fauna like the above, the Silurian or Devonian character of the Keyser fauna. The corresponding zones of New York and New Jersey have been generally regarded as Silurian, in the "Lower Devonian" of Maryland the Keyser is considered as the basis of the Devonian. The authors of the stratigraplical portion of this very important monograph, CharLes Schuchert, C. K. Schwartz, T. Poole Maynard, and R. B. Rowe, strongly emphasize the fact that the fauna of the Keyser, whilst containing a number of species of Helderberg affinities has also a marked Silurian aspect.

We may quote from the report p. 118: "These Helderberg species entered the Maryland sea in Keyser time, mingling with the Silurian species which continued to consitute the larger part of the faunas. The Keyser' limestone is, therefore, clearly transitional between the Silurian and Devonian. Accepting the principle that the age of a formation is that of its youngest fauna, the Keyser is here referred to the Lower De. vonian although the majority of the species in it are distinctly Silurian".

That the faunas of the Series B of Ellesmereland, when seen detachedly, must be regarded as showing in general a Silurian and not 
Devontan character is certain. The occurrence of the Monograptusspecimens. of fragments of an Encrimmos and of Thecia swinderenana point in that direction. On the other hand a form like on Stenochisma decherensis arctica, show's an extremely near relation to $S$. modestus Hals which in New Tork and New Jersey has its chief development in the New Scolland and Becraft members of the Lower Helderberg gromp. of oller forms showing more Devonian than Silurian aspects may be mentioned forms like our Proctus and Platyceras, though somewhat similar forms are found also in the Silurian. 'Two other Arctic species that probably can he regarded as Devonian types are the strophearlonta patersoni antiqua and Gypidula coeymanensis prognostica ScHechenT.

The chief stratigraphical result of this study is then that a high Aretic representative of a fauna known from the middle part of eastern North Anterica is found. Thus allowing us also to draw the region of the sea for the preriod of this horizon over South-western Ellesmereland, and in the character of the fauna or the rocks there is no evidence for assuming that shores were present very near, or that it was not fully open and salt sea.

After the deposition of this series these conditions seen to change. We get coarser and more exchsively terrigenous deposits, indicating the presence of land not very far distant. We may quote Scuer for the lesriplion of these highter heds: "Series B is overtain, both in Goosefund and Walrusfjord, by Series C, the hottom strata of which ronsist of allernate layers of light and dark marly shales, partly arenaceous, whils its npere strata reveal hedi of fure quarly sandstone and argillareoms sandistones. The total thickness of these strata amomnts to ahout 1000 leret in Goosefjord, but is possibly thicker at Hell gate. Series C rroppert ont also at the foot of the lofty platean walls at the imner sithmu- (Indre Eitet and at Borgen (The Castle). In both these tocalities it is werlain hy a lark limselume and black slates, in part abumdantly smpplied with fossils. 'This formation - dark limestone and black shales

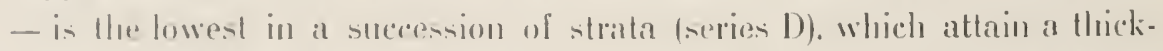
nes of 1600 fect. and conp ont in rertical section on hollo sides of Cionsteford, from Borgen to the foot of Wolf peak (Vargtopp), and from the immer istlmum lo Stomy Valley (Skrabulall ele.".

Areording to the sudies lofore mentioned of Oscan Eracn Meren wr lind within this Sories I) representatives of different Devonian fannar, all rolated to Now Vurker fanmas and ranging from the Lower

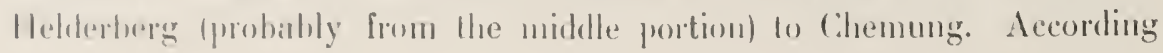


to these views the age of Series C may fall into the Coeymans (possibly also the New Scotland) or thereabouts.

A question that would be of interest to solve would be whether any of the faunas quoted from the earlier investigations on fossils brought home by Expeditions from the Arctic archipelago represent the sane horizon as Series B of Ellesmereland. The difficulty here is that most of the existing lists are so old that they really do not give much information. Besides we very often find that fossils from different horizons are mixerl. A revision of the identifications of the older collections would be of great importance for our knowledge of the stratigraphy and palaeogeography of the Arctic regions. As far as I have seen nowhere else in the Arctic has a fauna been found that shows so much resemblance to the one considered in this paper that I should dare to correlate then. The fauna collected hy Dr. HAYes on the west shore of Kennedy Channel, containing the following forms according to identifications made by MEeK ${ }^{1}$ : Zaphrentis Haysii MeEk, Syringopora, Favosites, Strophomena rhomboidalis, Strophodonta Headteyana HaLL(?). Stroph. Becki Hall (?), Rhynchonetla sp., Coelospira concava Hald, Spirifer perlamellosus Hatl, Loxonema(?) Kanei MeEk, Orthoceras sp., Itlcenus, is - as MeEk emphasizes - of Lower Helderberg age but it is without doubt younger than the faunas of Series B. After the list quoted it must be correlated with New Scotland and Becraft and therefore corresponds probably with the lower part of Schei's Series D.

A fauna very often met with in the list of Arctic fossils, the detailed stratigraphical horizon of which cannot yet be said to be known, is what may be termed the Lissatrypa plooca-fauna. The form which goes under the names Rhynchonetla or Atrypa phoca SALTER has been quoted from a great number of Aretic localities mostly together with certain corals. It was mentioned by Salter ${ }^{2}$, Haughton Etheridge, Am, Lambe and Lee from in all the following places: Cape Riley, Cornwallis Isl., Leopold Isl., Griffith's Isl., Seal Isl., Beechey Isl., Garnier Bay, W. and E side of Boothia Felix, Ferry Point, Dobbin Bay, Bessels Bay, shores of Prince Regent Inlet and possibly others.

The $L$. phoca-fauna is generally mentioned only as Silurian, in the newer reports of the Canadian paleontologists it is placerl at near the Niagaran, yet as alnost all the forms are unknown outside the Arctic ${ }^{3}$

1 American Journal of Science, 1865, sec, series, vol. XL. p. 31.

2 See list of Synonyms on pages $25-26$.

3 See e.g. the lists given by Dr. H. M. Am in "The Cruise of the Neptune". pp. $29-30$. 
or are without matigraphic value, the question is not yet settled. Dr. G. W. LEE in his paper on the fossils from the "Hecla" and "Fury" collections. (I. c. [. 263 ) mentions that a part of the collection may be from the lighest member of the Niagiran, the Guelph.

I have mentioned the phoca-fauna here because in Scuers material from B I found a form, which although not identical, shows a very strong relation to Lissatrypa phoca. There is a possibility that the phoca-fanna may be younger than the Niagaran and come near to the Keyser.

I have myse]f had an oppurtunily of seing collections from one of the $I$. phoca localities, viz. Beechey Island. I have before me a colleclion male in the autumn of 1903 during the Voyage of the "Gjöa". Captain Ronud Asundsen, through the Northwest Passage, and furthermore I have inspected in the Peabody Museum a collection from the same locality made during the cruise of the "Neptune" 1903-1904. The first collection contains, besides numerous and very nice specimens of Lissatrypa phoca the ordinary species: Acervularia austini SALTER and Strephodes picthomi SALTER and a Facosites.

As to the last mentioned collection there is also very little ohtainable from it as very few fossils, that would be available for fixing the age were found. 'The collection mainly contains poorly preserved gastropods, besiles some few brachiopods and ostracods. The only other brachiopods, besides the I. phoca, that occur, is a small Meristella-like form, that is not of great use for stratigraphical purposes. Of great interest is the occurrence of a large, elongate Leperditia, which seems to be entirely like the Leperditia elongata Welten, as far as can be seen from the illustration of this fossil, a form known exclusively from the Keyser of Maryland and form the Rondout of New Jersey.

Another fact which may indicate that the phoca-beds represent relatively young ones is the stratigraphical conditions on Beechey Island as far as they can be judged from the report of "The Cruise of the Neplune". On p. 221 we real: — “- - - Similar conditions prevail ill Bechey Island, where a large collection of fossils was ohtained from the lower limestone bets, while others picked up loose lut evilently fallen from the cliffs ahove, showed that the upper heds passed close to if not into the Devonian - - ". By the lower herts is here ment the rommon rich fossiloluearing limestone with the phoca-famma.

'This renuti is of especial interest for another reason also, nimely hecause annong the material from Bucchey Island hrought by the "Gjöa- 
Expedition I have been able to identify in a black limestone, which is distinctly different from the more light-colored, grey or brown, limestone, with L. phoca, a fauna that is not only Devonian, but leyond all doubt, high Devonian, its age probably corresponding with the Chemung. The fossils are the following:

Schizophoria striatula Schloн, two specimens, one showing clearly the interior characters of the ventral valve.

Atrypa reticularis Lin., numerous large, coarsely plicated and wrinkled specimens.

Spirifer whitneyi HaLl, var. animasensis GIRTY, one complete and several fragmentary specimens. Spirifer whitneyi is a typical Chemuing form and the closely related variety animasensis is described from the lower part of the Ouray limestone of Colorado which is partly high Devonian, partly lower Carboniferous.

Cyrtina gjöai nov. sp. Pl. VI, fig. S. A considerable number of well preserved specimens occur of this form, which though much like several of the American Devonian Cyrtinas, do not fully agree with any of them. The specimens are very small, greatest width observed $9 \mathrm{~mm}$., corresponding to a length of $6.5 \mathrm{~mm}$. Ventral valve is globose hemi-conical with the height varying greatly from less than the width to considerably more. On both sides of a relatively broad but not deep, in section subtriangular, sinus, 4-5 rounded folds, the more central of which are well marked. The subtriangular area have the sides a little curved outwards, the form of the area of the elevated specimen therefore like the half of a transverse section of a thick lens. Width of the prominant pseudodeltidium one third of the total width of the area. Adult specimens, show marked striæ on the area and wrinkles of growth on the broader part of the valve. The dorsal valve is semi-elliptical in outline, slightly convex with a quite prominent round median fold and 4-5 smaller folds on each side. Adult specimens show one or more lines of growth near the rounded margin.

This form comes nearest to Cyrtina dalmani HaLl from the lower Helderberg, but is distinctly more globose, less acute towards the apex.

Loxonema sp.?, very fragmentary.

Straparollus sp., "

Platyceras sp., 
I feel very much inclined to believe that these fossils were collected from a locality very near to the place where the phoca-fauna was obtained, since they have been mixed into one collection. Should this be correct, we have here an indication of relatively small thicknesses for the lower part of the Devonian - with highest Silurian if we regard the phocafauna of Niagaran age - or perhaps for a complete absence of several horizons from a corresponding period. In the Goose Fjord region, 34000 feet of sediment, perhaps more, come between the base of the Series B and the high Devonian. 


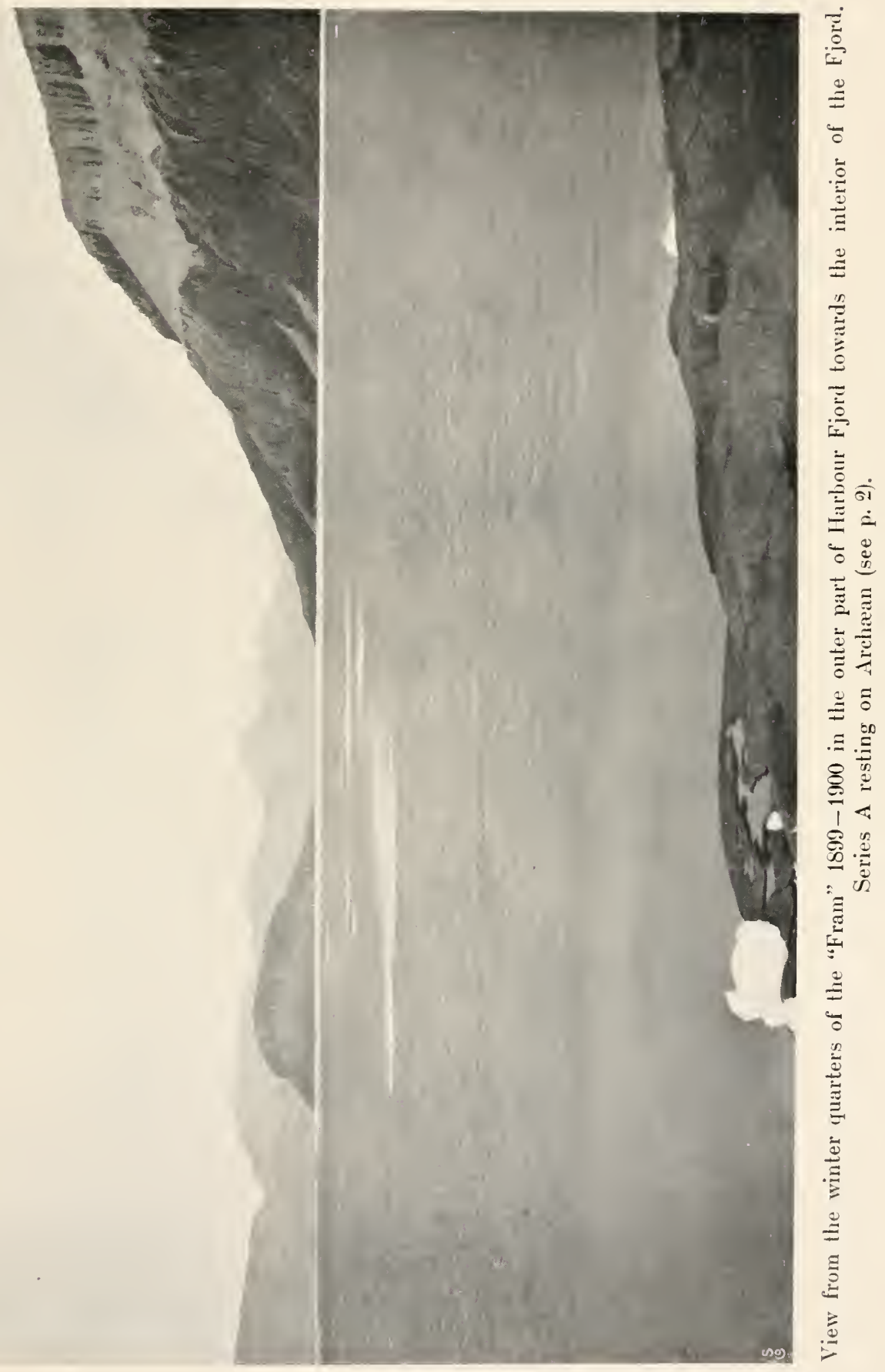





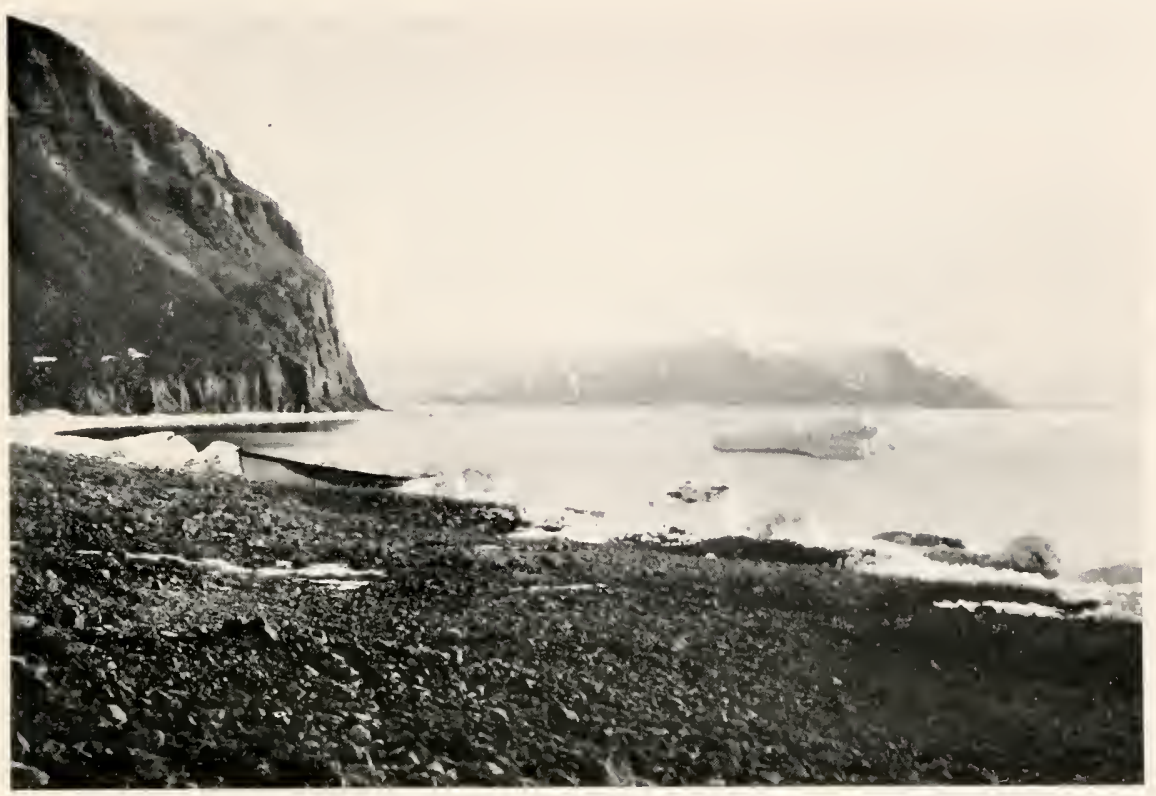

Fig. 1. Series A at MIt. Seagull (see map on p. 7) looking northwards.

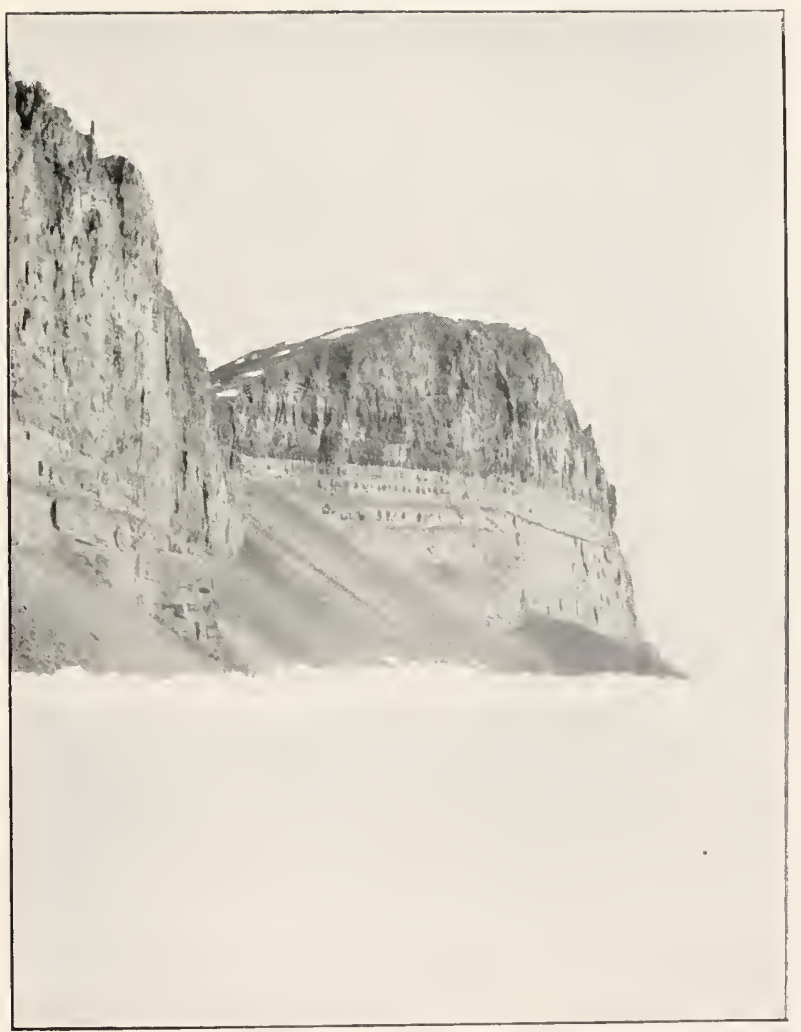

Fig. 2. Brown limestone of Series A at South Cape (see p. 4). 



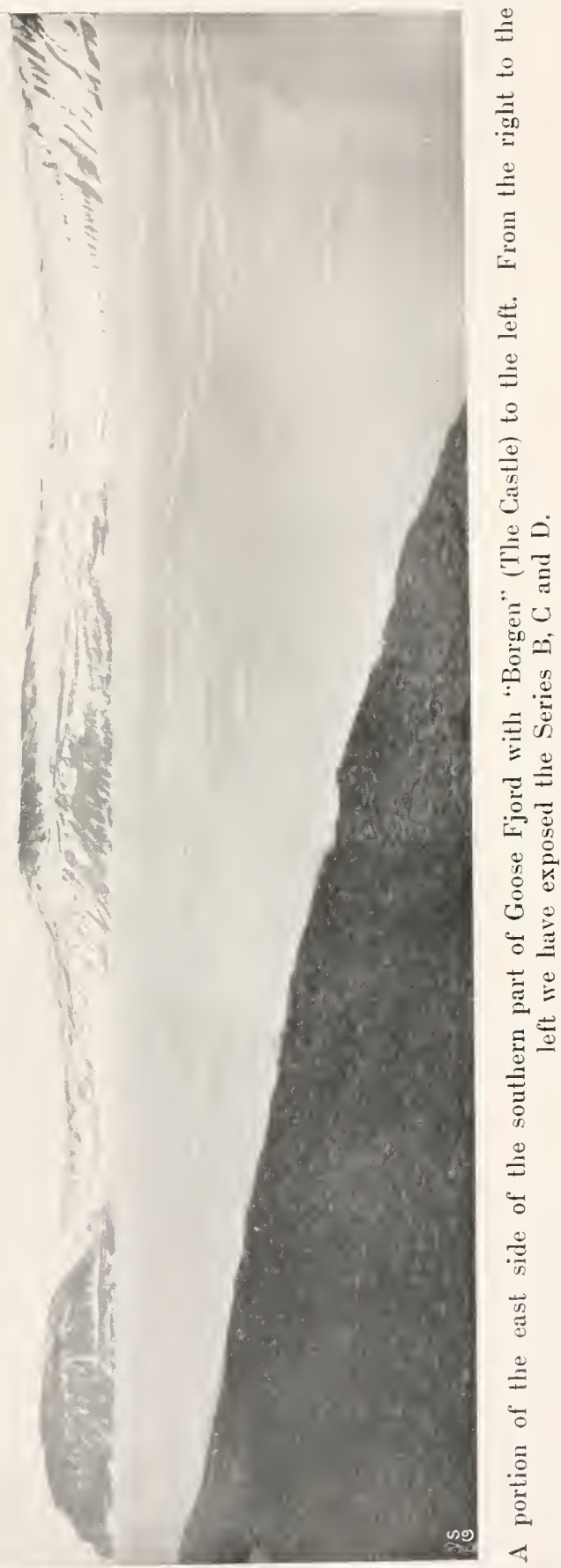




Plate IV.

Page

Fig. 1. Solenopor

Fig. ‥ - $\quad$ - " longitudinal section, $\times 16$. . . . . . . . . 9

Fig. 3-4. Parallelopora favositiformis nor. gen. de sp., tangential and longitudinal sections, $\times 2$. . . . . . . . . . . . . . . . . . 13

Fig. :-6. Fucosites forbesi E. and H. var. eifelensis Nicu., tangential and longitudinal sections, $x$ … . . . . . . . . . . . . . . . . 11

Fig. 7. Cladopora rectilineata Simps, on a slab, nat. size . . . . . . . 14 

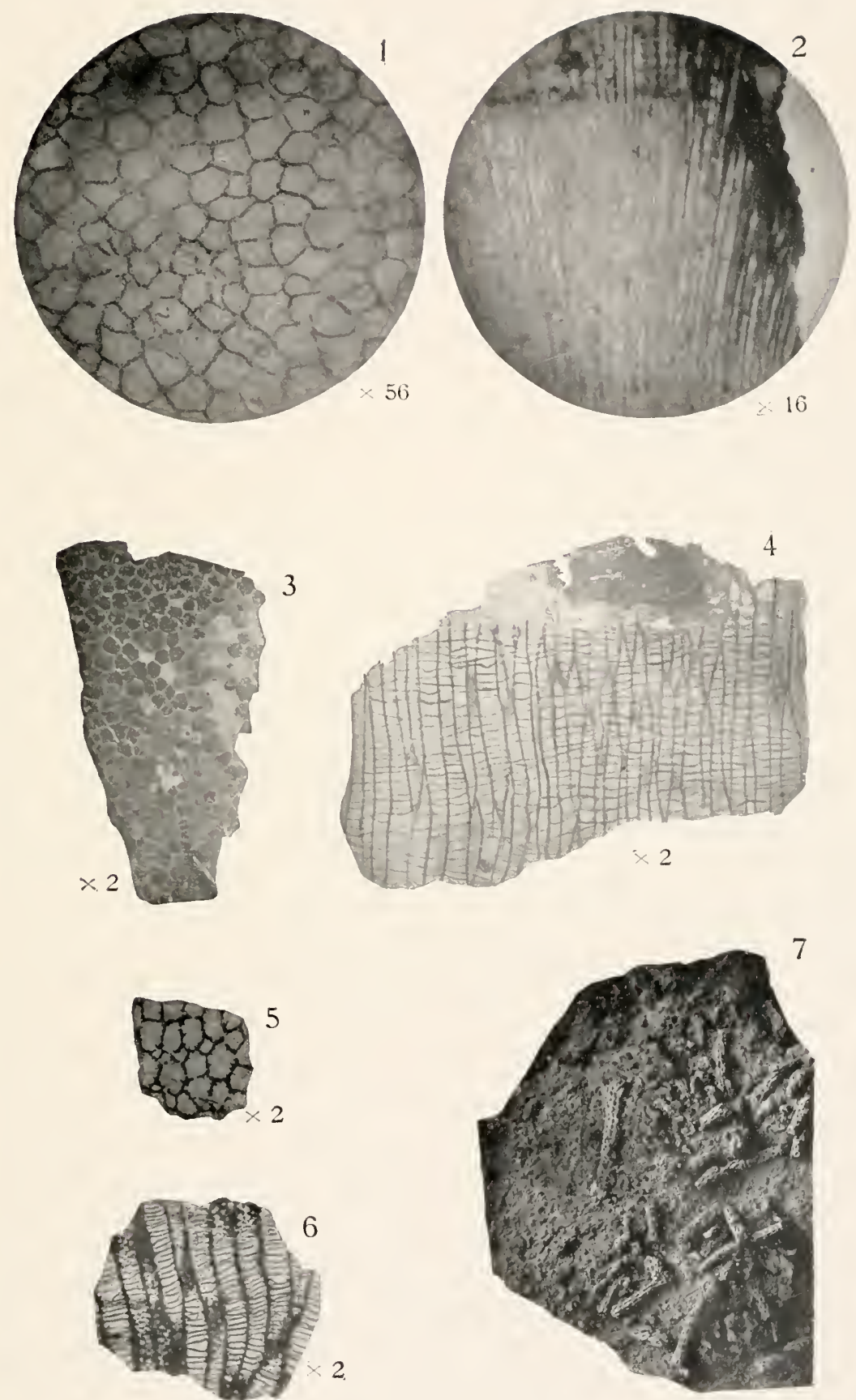

B. Larssen phot. 




\section{Plate V.}

Fig. 1-5. Parallelopora favositiformis nov. gen. \& sp. . . . . . . . 13 Fig. 1, tangential section, $\times 16$.

Fig. 2, - $\quad-\quad \times 24$.

Fig. 3, longitudinal section, showing mural pores, $\times 16$.

Fig. 4, - $\quad-\quad$ with one of the narrow subcylindrical tubes, $\times 16$.

Fig. 5. - $\quad-\quad$ with another, $\times 24$. 

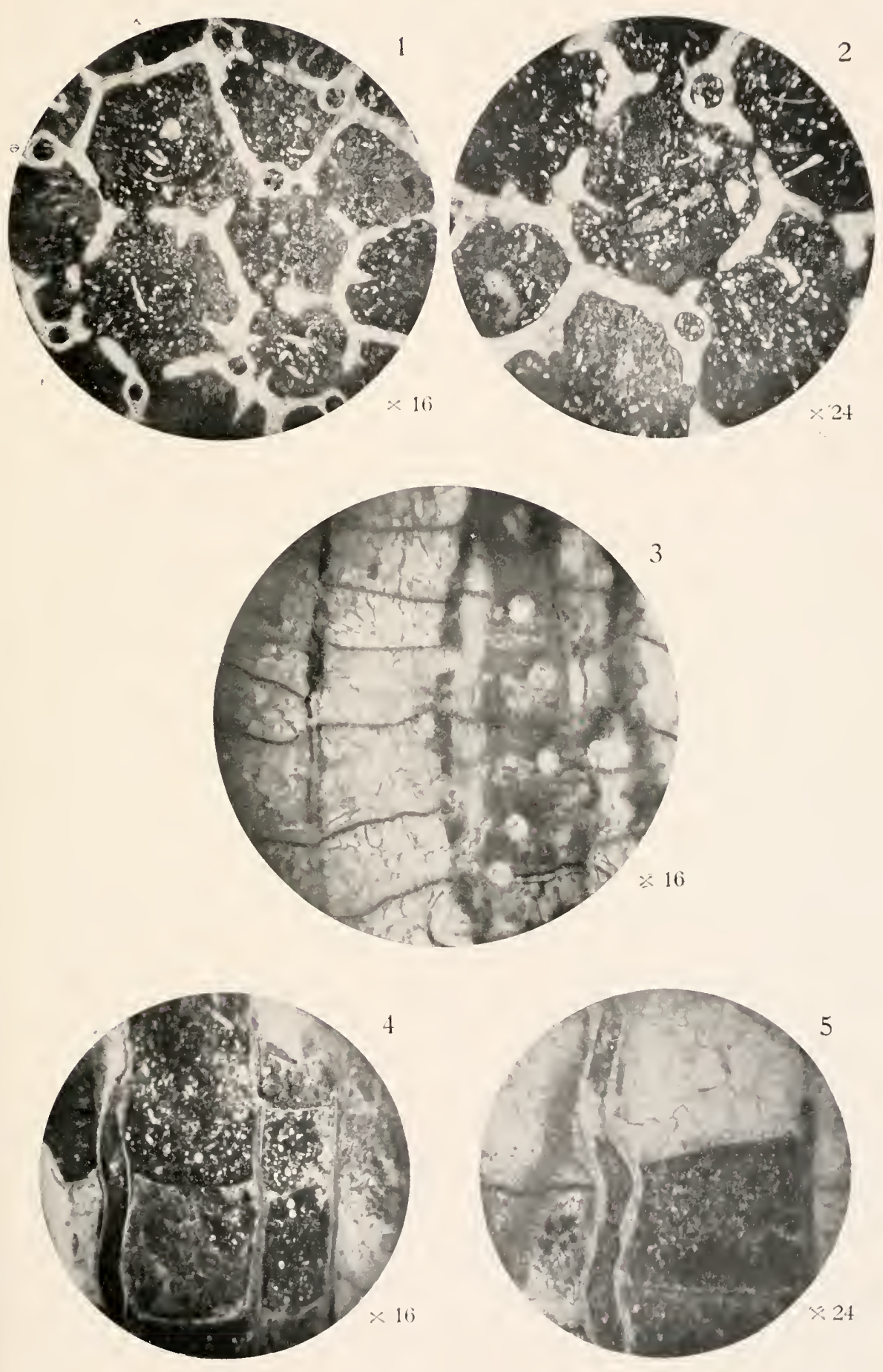




\section{Plate VI.}

Page

Pig. 1-2. Syringopora sp., showing size and outer form of the corallites in

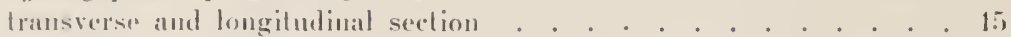

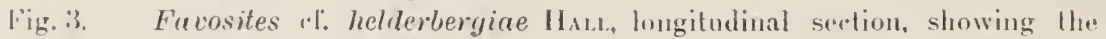
relesely arranged talmbire, $x \cong$. . . . . . . . . . . . 11

lig. 4. Thecia swinderenana Gotof., part of the surface, X 2. . . . . . 15

l.ig. 5-7. Conchidium arcticum nov. sp. lrom Series A, east coast of North Devon 5

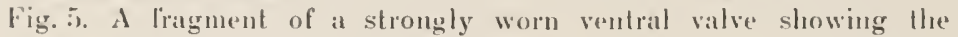
length of the merlian septum.

fig. ti. A liagment ol a dorsal valve with a line showing the convexity in transverse section.

Fig. T. Linf showing the convexity of another dorsal valve in longi. turlinal section.

Fig. S. Cyptima gjöri nov. sp., from upper Dewonian beds of Beceley Is. land, Lancaster Sommel . . . . . . . . . . . . . 47 

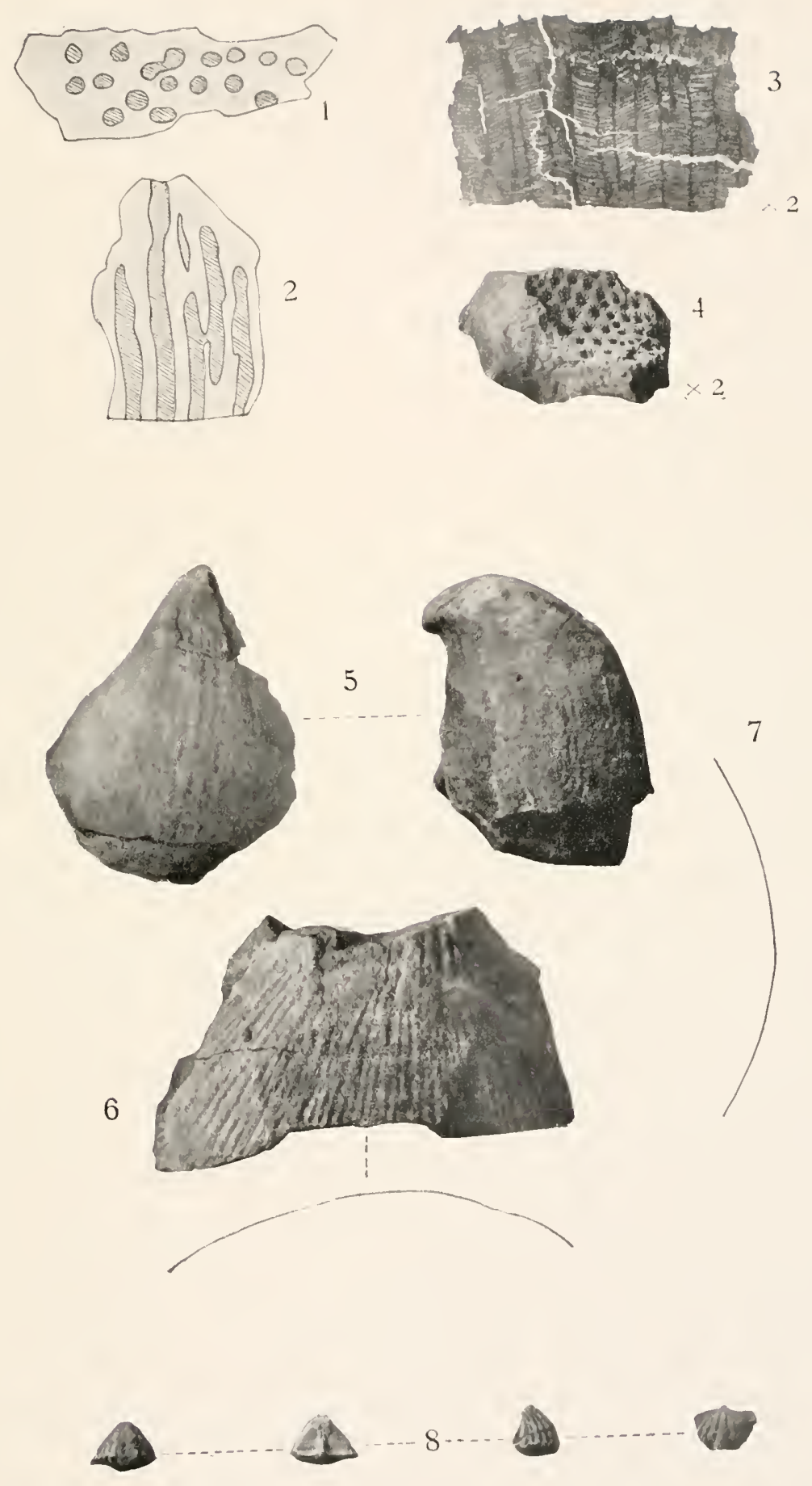

B. Larssen phot. 


Plate VII.

Fig. 1. Linumle sp. . . . . . . . . . . . . 18

Fig. 2-3. Stropheodonta patersoni Has.. var. antiqua nos. var. . . . . . . 19 Fig. 9. A ventral valve, relatively large and flat.

Fig. 3. Onter "ast of a dorsal valve.

Fig 4. Strophonella ef. englypha Hos., a fragnenentary ventral valve. . . . פ0

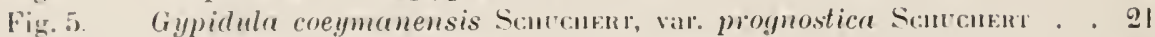

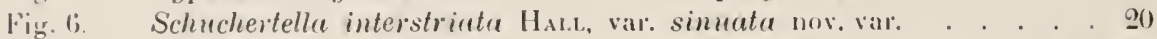

Fig. 7 -8. Stenochisma decherensis Whitr., var. artica nov. var. (from B, npper parl) . . . . . . . . . . . . . gl

Fig. 7. A relatively globose sperimen.

Fig. $\therefore$. A flatter one.

Fig. 9)-12. Lissatryna scheii nov. sp. (from Reindeer Vulley). . . . . . . . It Fig. 9.11. A small specimen.

Fig. 10. A small sperimen with the dorsal ralve removed, showing ther spiral cones.

Fig. 12. A very large sperimen.

Fig. 13. Lissutrypa phoca Salven, a specimen of morlerate size, from Beechey

Isl. (Exp. of the "Gjöa") . . . . . . . . . . . . . . 95 

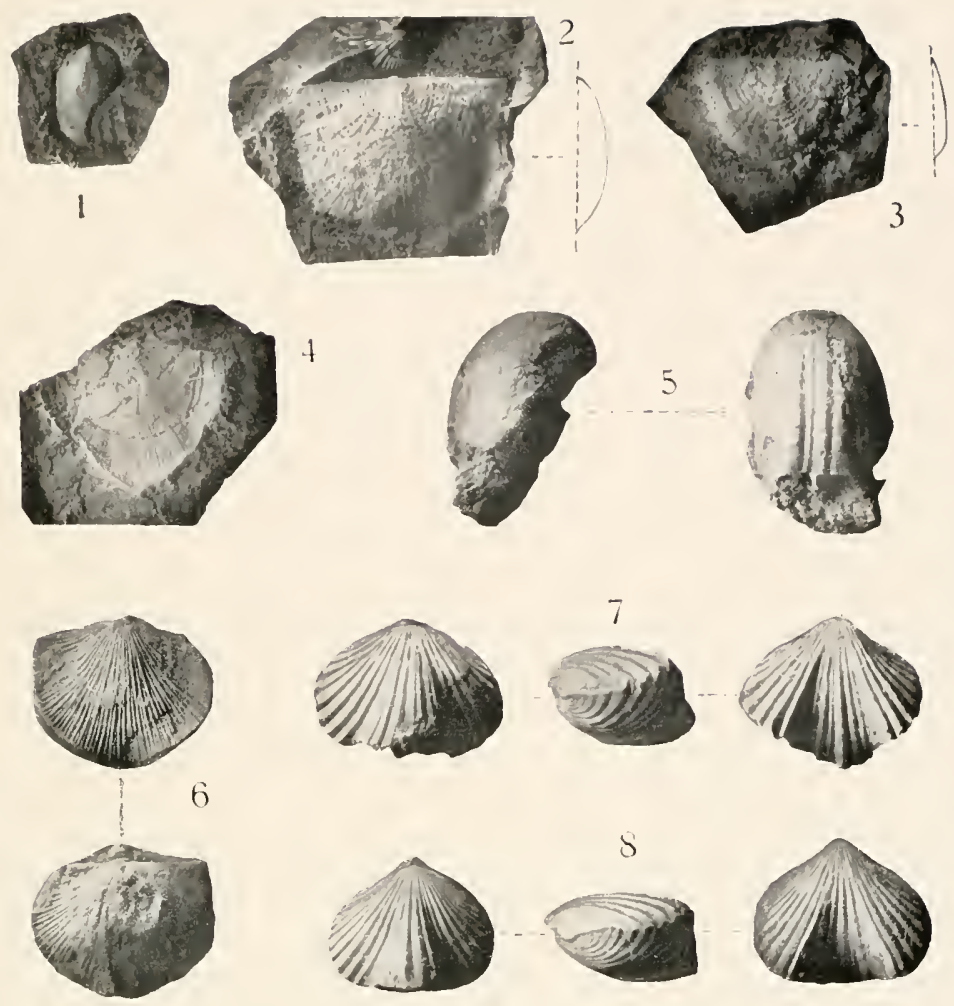

6
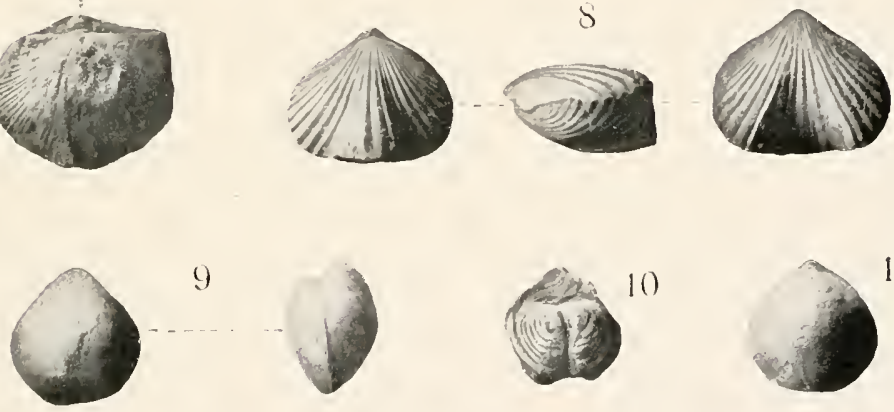

9
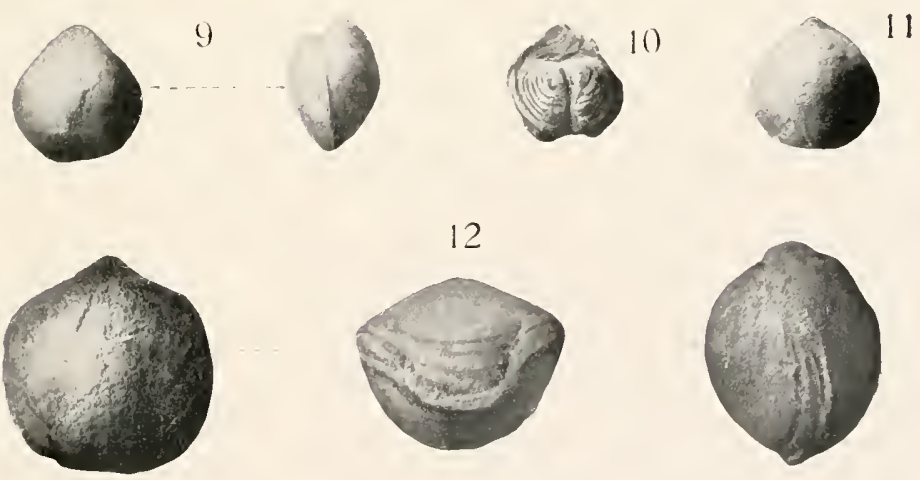

12
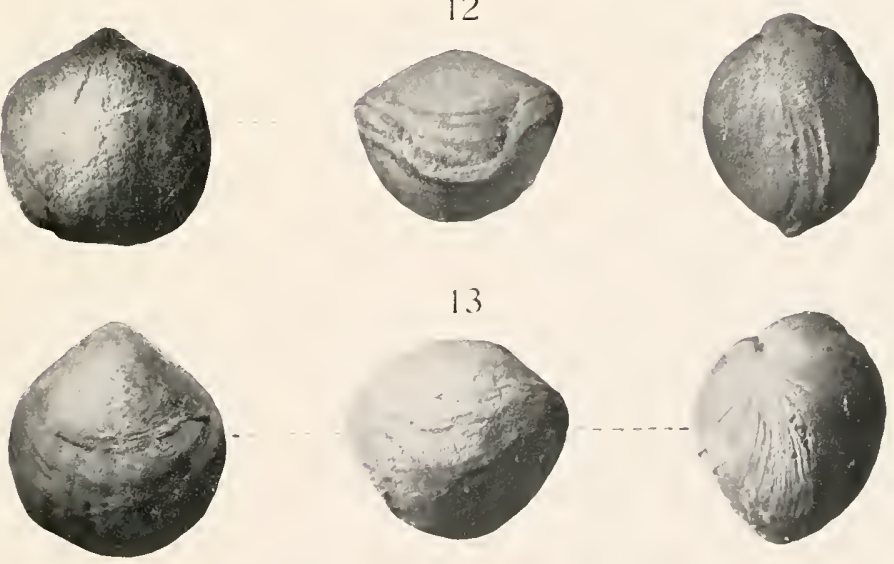

B. Larssen phot. 


Plate V'll.

I'aye

Fig. 1. Camatotoechia litchfieldensis Scirchent, var. angustata nov. var. . . Q2)

Fig. @. Spirifer modestus HAL1, var. striatissimus nov. var. . . . . . . . Qti

Fig. :3. Uncinulus septentrionalis nov. sp. . . . . . . . . . . . . . . 22

Fig. 4. Spirifer vanuxemi Han, var prognostica Schuchem . . . . . . . 27

Fig. 5. Atrypa reticularis Lix. . . . . . . . . . . . . . . . . . . 9:3

Eig. 6. Pterinea ef aviculoidea HaLs. . . . . . . . . . . . . . . 28

Fig. 7. Nucula (?) sp. . . . . . . . . . . . . . . . . . . . . . . 29

Fig. S. Grammysia (?) triangulata nov, sp. . . . . . . . . . . . . . . 28

Fig. 9. Hormotoma (?) sp. . . . . . . . . . . . . . . . . . . . . 31

Fig. 10. Loxmema fitchi HALL . . . . . . . . . . . . . . . . . . 31

Fig. 11. Holopea sp. . . . . . . . . . . . . . . . . . . . . . . 31

Fig. 12. Hormotona $\left({ }^{\circ}\right) \mathrm{sp}$. . . . . . . . . . . . . . . . . . . 30

Fig. 13. Encrinums sp. . . . . . . . . . . . . . . . . . . . . . 34

Fig. 14. Proetus leptorhachis nov. sp. . . . . . . . . . . . . . . . . 33

Fig. 15. Leperditia symmetrica nov. sp. . . . . . . . . . . . . . . . 37

Fig. 16. Primitia arctica nov. sp. . . . . . . . . . . . . . . . . . . 39

Fig. 17. Frammia dissimilis nor. gen. \& sp., the incomplete head. . . . . 3.)

Fig. 18 - $\quad$ - two transverse sections across the head . . .

Fig. 19. ? thorax and pygidinn fonnd in conneclion wilh

the head . . . . . . . . . . 36

Fig. 20. Platyceras ellesmerelandi nov. sp. . . . . . . . . . . . . . . 32 

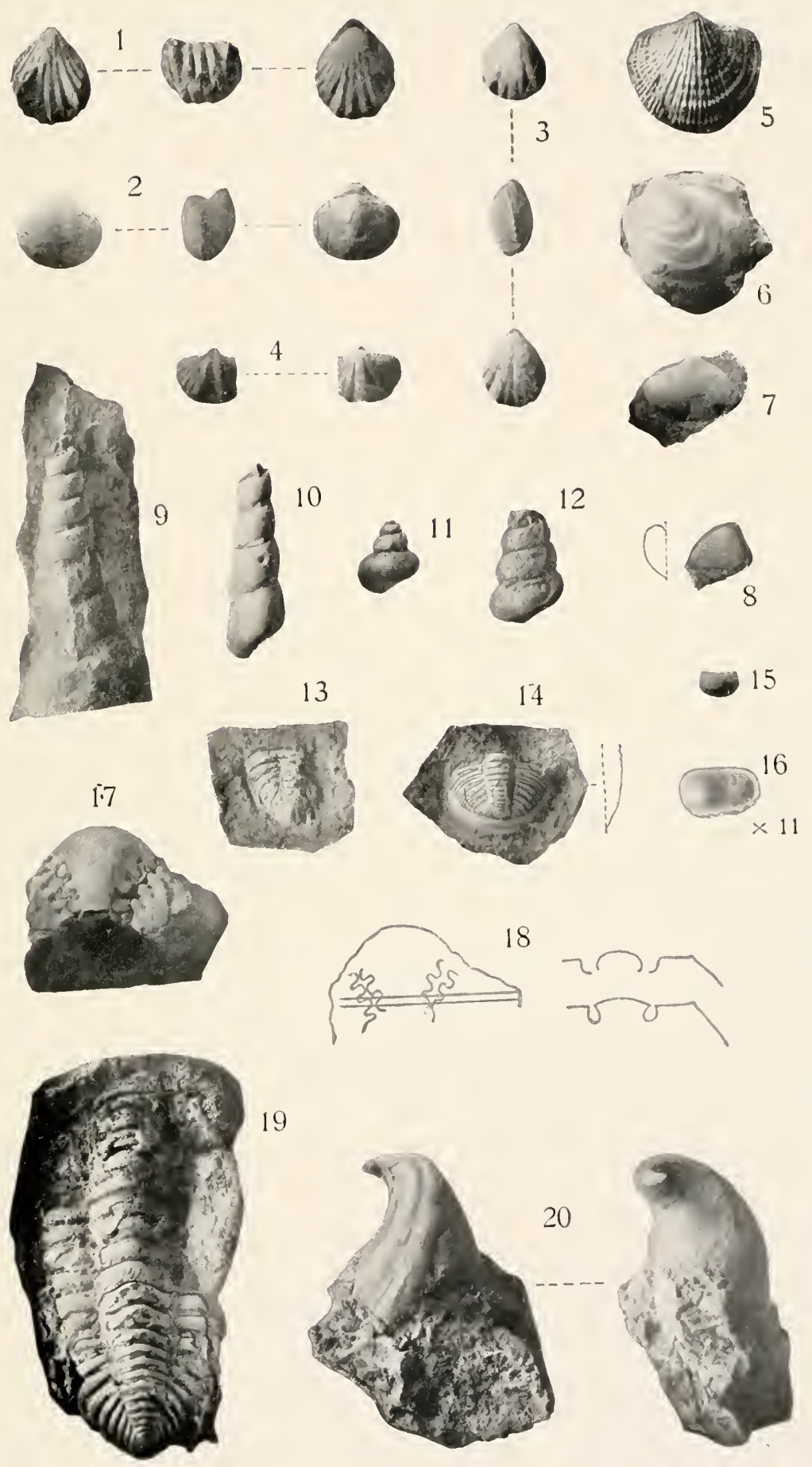

B. Larssen phot. 


IN THE "FRAM" 1898-1902. No. 33.

\author{
J OHAN K I ÆR:
}

\title{
UPPER DEVONIAN FISH REMAINS
}

FROM ELLESMERE LAND

WITH REMARKS ON DREPANASPIS 



\section{Contents.}

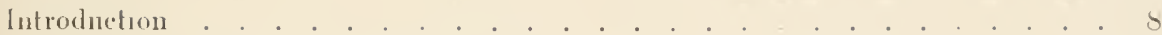

I. Fish Remains from Series D . . . . . . . . . . . . . . . S

Maropetalichthys Seheii, new species . . . . . . . . . . . . . . 9 9

Stratiglaplical results of Series D . . . . . . . . . . . . 15

II. Fish Remains and other Fossils from Series E . . . . . . . . . . 16

Lamellibranchiata . . . . . . . . . . . . . . . . . . . 20

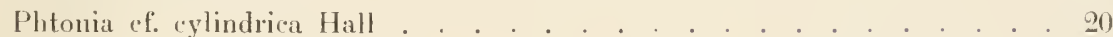

Pisces . . . . . . . . . . . . . . . . . . 21

Psammosteidae . . . . . . . . . . . . . . . . 21

Psammosteus areticus new species . . . . . . . . . . . . . . . 23

complicatus new species . . . . . . . . . . . . . 26

Conrerning Drepanaspis Femündenensis Schlit. . . . . . . . . . . . 29

General remarks on the two new Psammostens species . . . . . . . . 34

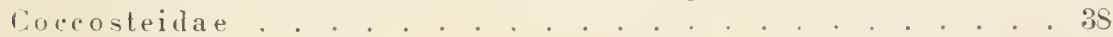

Great Coreosteomorph form . . . . . . . . . . . . . . . . 3S

Asterolepidat. . . . . . . . . . . . . . . . . . . . . . . . . . . . . . . . . . . . . . . . .

Bothriolepis ef. hydrophila Ag. . . . . . . . . . . . . . . . . . 39

Bothriolepis (?) species . . . . . . . . . . . . . . . . . . 43

Holoptychiidale . . . . . . . . . . . . . . . . . . . 44

Holoptychius Schei new species . . . . . . . . . . . . . . . . 44

cf. tuberculatus Newb. . . . . . . . . . . . . . . . 45

Glyptolepis ef. paucidens Ag. . . . . . . . . . . . . . . . 45

Teeth with dendrodont structure . . . . . . . . . . . . . 47

Rlizodontidae. . . . . . . . . . . . . . . . . . 48

looth with rhizodont structure . . . . . . . . . . . . . 4S

Osteolepidae. . . . . . . . . . . . . . . . . . . . . 48

Osteolepis sp. . . . . . . . . . . . . . . . . . . . 4 45

Stratigraphical results of Series E. . . . . . . . . . . 4S

Distribution of the fauna in the fossiliferous horizons. . . . . . . . . 4s

Changes of facies and biological conditions . . . . . . . . . . . . . 50

Conditions of age. . . . . . . . . . . . . . . . . . . . . . . 5.3

Geographical conditions of fauna . . . . . . . . . . . . . . . 5í 


\section{Illustrations.}

P'lats I. Macropetalichtys Scheii new species. . . . . . . . . . is

11. Phtonia ef. eylindricat Hall, great Coceostomorph form, Pximmoatons arrtirn- new species. . . . . . . . . . . . . . . . . (il)

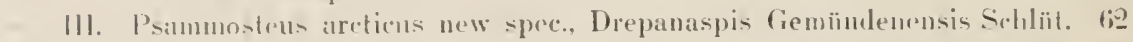

- IV. Psammotells maeandrinns Ag.. Drepanaspis Gemündentensis S.hlüt. 64

- V. l'sammostem amplimalus new speries. Psammostens arelicus new sprecies . . . . . . . . . . . . . . . . . biti

V1. Psammoten complinatus new speries, Psammostens manandrinus $\mathrm{Ag}$. (i)

- ril. Bollıriolepis ef. hydrophila Ag., Bothriolepis (?) sp., Bothriolepis canaldensis Whil. . . . . . . . . . . . . . . . . . . . 71

- VIII. Glypholepio of. pancidens As. Holoptychius Scheii new species, Dendrodont teeth, Rhizodont tooth. . . . . . . . . . . . . T2

Trat Fignre 1. Macropetalinhthys scherii new sepcies . . . . . . . . . 10

2. Marropetalichthys Scheii new speries. . . . . . . . It
3. Genlogical sketch map of the sonth-westem part of Ellesmere latuld . . . . . . . . . . . . . 18

- _ 4. Section of "Bregucklïflon" . . . . . . . . . . . . . . . . . . . 19

6. Drepanaspis (iemiindenensis Schlät. . . . . . . . . . . . 80

- 7. Drepanaspis Gemïhlenensis Sclulït. . . . . . . . . . . 32

- s. P'samuostens maeaulrimus Ag. . . . . . . . . . . . . 35 


\section{Preface.}

During the preparation of the following work I have constantly been reminded of the man to whom the present and other rich geological collections of the Second Fram Expedition are due, the gifted and assiduous geologist of the expedition, Per Scher.

It seems but yesterday since that interesting period after the homecoming of the expedition, - the autumn of 1902 - when Scrier unpacked his rich collections, and we began together the preliminary examination of the specimens.

How his eyes used to gleam when anything of special beauty and interest came to light: How enthusiastic we were over the wonderful Silurian and Devonian collections from Goose Fiord, and the lovely fossils from the carboniferous limestone at Great Bear Cape!

Many of the specimens awakened in him memories of ever memorable days spent in the far north, of journeys and adventures. One story would succeed another, and entranced by his merry humour, or again at times by a more serious note, work was often forgotten.

During the following winter the preparation of the whole material was planned. Scher himself undertook the petrographic and general geological work, whilst the fossils were assigned to various specialists. He threw himself with the greatest energy into the work that he had looked forward to during the whole of that long, arduous expedition in northern latitudes. The views and hypotheses that he had formed in those desolate regions would now at last be tested and examined.

Everything seemed to be bright and hopeful, and we his colleaguen and friends eagerly awaited the work that was about to come from Scher, convinced as we were that he would prove himself to lie not only a fearless and energetic explorer, but also an eminently gifted and original man of science. 
We know now that these hopes were not to be realised. Even as early as the winter of 1904-05 he was attacked by the malady, which after a long illness, at length on the first of November, 1905, caused him death. Scus was then only 31 years of age. The ntmost that he lat lieen able to publish of his geological investigations during the pxpedition was a preliminary accomnt ${ }^{1}$ giving the main features of the geology of the region explored. 'This has been of incalculable value in the subserpent preparation of special works lealing with the material.

The leath of Scus so soon after the return of the expedition was naturatly a great misfortune to the scientific work connected with the large geological collections which were brought home. He was not only the editor of the scientific publications of the expedition. Int with his splendil memory he possessed a store of observalions which were maturatly of the utmost importance to those connected with the work. Only a small amomnt of this material can be gleaned from his diaries, and very much is therefore lost for ever. As will be understood, his death resulted in many difficulties and lelays, and it is not until to-day. i. e. In years after the return of the expedition, that nearly the whole of the work is completed. PER Screi's preliminary account of his geological investigations, and the series of geological works that will appear in the report of the expertition on the hasis of his geologrical collections, will assure him a prominent position amongst geological investigators of the Aretic regions, and like lis collections, will endure as a lasting monmment to a gifted and noble scientific investigator, whose untimely dealh was a great losi to Norwegian science.

Schls lisge and heauliful Silurian and Devonian collections from linose Fiond arr the most complete and valuable that any one expedition in these arrelic regions has secured. Scmol was especially interested in Ihe fossil plants and fishes which le succeeded in discovering in the samd-tone series at the extrente end of lionse Fond. 'The work in connection with the fossil plants Was entrusted lo Professor A. G. Nathorst,

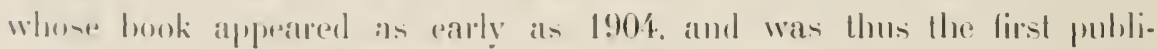
ration of the scientilic report. The lossil lishes were sent lo R. II.

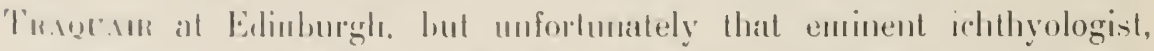
un aceount of ill-frealtl, luring his later years, was mahle ho molertake the work, which was aceordingly entrusted to the present writer.

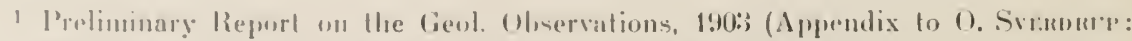
"Now lamul". Mlon publisheed in Renyal Gongraphical Society). 
The prefaration of this material, which was not of groat extent. occasioned great difficulties. Many of the specimens, it is true, were well prescrved with respect to structure and scuphtme, but the great majority were sadly fragmentary. My work has really been, so to speak, a study in fragments, and has demanded a disproportionate amount of time and labour. Moreover the paleontological musenm at Kristiania does not possess much material for comparison when studing these forms. With a well stocked museum at my disposal, I should most probably lave been able in some instances to arrive at more certain results than has actually lieen the case.

In conclusion, I desire to take this opportunity of thanking the editors of the scientific publications of the Second Fram Expedition for the liberal manner in which they have provided for the illustrations to my work. I also wish to thank my old fellow student at München, Professor C. R. Eastman, who has so readily replied to my enquiries concerning a number of doubtful American forms. 


\section{Introduction.}

According to Per Scmeis imvestigations, the heantifully developerl Devonian Series at Goose Fiord in Ellesmere Lambl fall inlo (wo easily recognised livisions. A lower one, at least 500 metres in Mnikness. is mainly composed of dark limestone and schists, with a more or less rich marine fanna. This series, D, appears in the sections on both sides of Goose Fiond, from Borgen to the foot of Mount Varg. and from the inner Eide to Skrap' Valley. 'This is surceeded hy an npler. massive series, mainly consisting of quartz sandslone. Which conslitutes the mountains on both sides of the imner part of Goose lïoril. Scris names this upper portion Series E. It presents an entirely different facies development to the lower series, and contams in certain horizons only, fossils of plants and fishes. The former have heen described h. G. Nathorst.

The ichthyological remains which I shall describe in the following. with fow exceptions belong to the upper series E. Only une specimen is in our possession from the lower marine series D.

\section{Fish Remains From Series D.}

ln his preliminary report. Sims mentions fish remains from two horizons, Dg and Di, of the lower marine series D. Acrording to the motes which I made during my first examination of simsis material Here was also one fish remain from Dl, In the material to lrand we

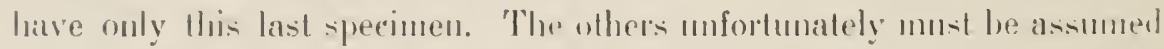
to lee lost. In my first pammination of the material I noted traters of ('occostens (?). The determination, lowwerer. was very mortain. A-

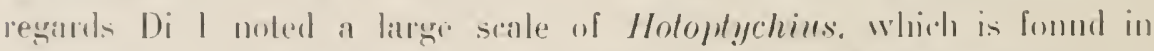

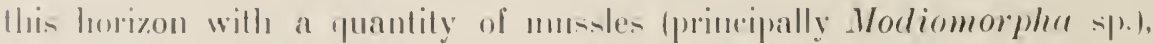

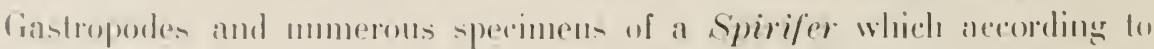

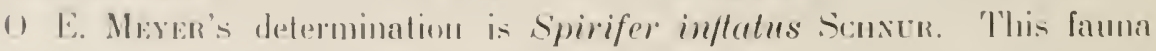

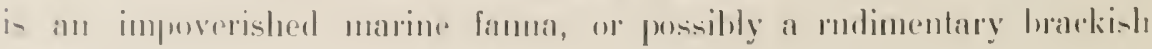
Walce fammat 
Macropetalichthys Scheii new species.

(PI. I, fig. 1-6).

One of the most interesling specimens in my material from Ellesmere Land is a cranial shield belonging to a new, small form of the rare genus Macropetalichthys. Unfortunately only one specimen has been found (S. 1. 107). Even this is not perfectly preserver. It shows comparatively well the hinder portion of the head as far forward as the formost rim of the orbits. but is otherwise defective. The main features of the head, however, can be reconstructed.

General Description. A small form with an extencled oval cranial shield, and very large, extended orbits; the sensory canal system shows at the extreme rear a rudimentary lateral line and opens with only one series of outer pores; supraorbital angle ahout $40^{\circ}$.

\section{Description.}

Dimensions. The following measurements are determinable upon the specimen before us:

1. Length from the posterior edge of the cranium to the supraorbital commissure . . . . . . . . . . . . . $28 \mathrm{~mm}$.

2. Length from the posterior edge of the cranimm to a line between the posterior rim of the orbits . . . . . . 35 -

3. Length from the posterior edge of the cranium to a line between the points in front of the orbits where the supraorbital canals bend forward. . . . . . . . . . 45 -

4. Breadth of the head at the supraorbital commissure . . 36 -

5. Distance between the orbits. . . . . . . . . . 14.5 -

6. Length of the orbits . . . . . . . . . . . 11.5 -

7. Probable brearth of the orbits. . . . . . . . 7.5 -

The length of the head cannot be determined with complete exactitude as the snout portion is missing. However the left supraorbital canal can be traced forwards for a distance of 6 mm. in a slightly convergent direction. It appears, therefore. that we may estimate the total length of the head at abont $55 \mathrm{~mm}$.

For m. The cranial shield appear's to have preserved its form quite well. As mentioned above, it is about $55 \mathrm{~mm}$. in length and $36 \mathrm{~mm}$. in hreadth. The length divided by the breadth is thus about 1.5. As the central and posterior portions are considerably arched, the breartl might increase to about $45 \mathrm{~mm}$. if the specimen were pressed flat. 
The proportion mentioned above wonld in that case decrease to alounl 1.2.

The sreates lireadth appears to be almost exactly at the middle. by the supraorlital commisine. The outline is oval, but in the front (at the smonl) it is narower. The foremost portion of the cranial shield. between the mbits and forwarks, is tlat; farther back the head is rather markedly arched, and as is usmal in this gemms. there is a slightly rounded protuberance behind the eyes. The sides of the hearl hehind the pyes ane somewhat steep.
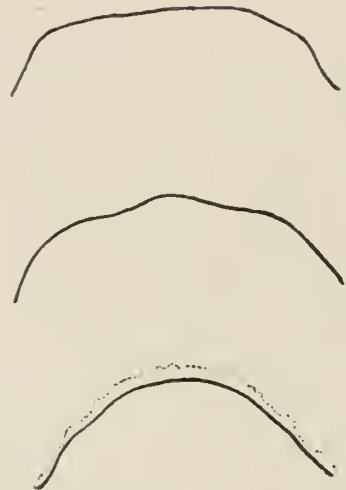

Fig 1. Three rossesections of Macropetalichthys Scheii new species. L Ppermost, near the supra-orhital commissure. The coutre figure at the point where the pust. urlital canal branches off in the medial bone. Below, at the posterior end of the postorbitat canal. Natural size.

$S(\|)$ ture. This is only visille on a small part within the right mbit. At this spot the surface shows fine, slight cremulated tuberches, which behind appear to have a tendency to ron together into longiturlinal ridges.

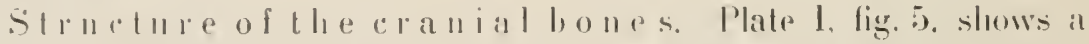
microsepric sedion throngh the right side of the eranial shield, behimd the supranthital and inlraorlital ranals. The portion of the section

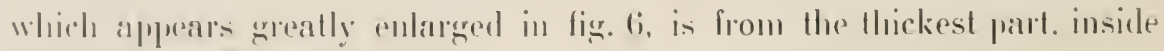
llee protorlital cantial.

The struchure rlearly slums agrement with that of Coccostens drecipiens. 'The vasculal rintal syotem. however, is willer and has thinner walls llant is the atose with the lafler; a comparatively compact basement layer alsu appears- to he latking. 'The lone-cells are small, often lound, in in the anse of Coccosteus.

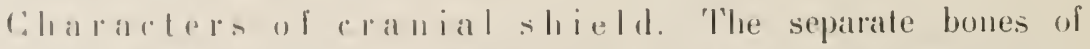
the rantal sheld cannot he distinguished. They must he assmmed to 
have had an arrangement similar to that demonstrated by Cu. R. Esstuan ${ }^{\prime}$ in the rase of a closely related American species.

The sensory cauals, however, are quite plain as usual. In describing them I have chosen a nomenclature differing from Esstuss's, and I prefer to follow that of Brune and Gooprucu. On both sides of the head 3 branches of the sensory canals are distinguishable, and these join behind the eyes. (According to Eastman's description in the hinder central bone.) From this point two branches proceed; one, which first rums outwards and then forwards to the outer side of the eyes, I have named the infra-orbital canal; the other, which at first proceeds invards until it meets the corresponding branch on the other side, and then runs forward in an oblique direction inside the eye, I have named the supra-orbital canal. The two supra-orbital canals thus unite at an angle in a greatly abbreviated supra-orbital commissure. Finally the third branch proceeds backwards from the central bone and may be called the post.o r bital c a u a l.

In the form under consideration the post-orbital canals proceed almost parallel as far as the central bone; the supra-orbital branches then form a slight arc, - with the convex side backwards - in towards the supraorbital commissure; from that point they run forwards as usual between the eyes in a divergent direction, forming an angle of about $40^{\circ}$. In front of the eyes they bend inwards and then converge slightly towards the front edge of the head. This bend is seen on the left side. As the front portion of the head is lacking, the length of these converging branches cannot be determined with certainty. The form of the head, however, goes to show that these branches may be reconstructed as in fig. 2. The infra-orbital branches first run outwards obliquely in a slight are, the convex side of which is turned to the front, but yuickly bend forwards and on the left side may be traced as far as the part ontside the orbits. The course is more like an arc than an angle as in most other species of this genus.

One interesting feature is the hinder end of the post-or b it a I c a nal. Eastmax says that in the case of the carefully studied form Macrop. rapheidolabis NoRw. \& Ow., they disappear beneath the surface of the external occipital plate on either side close to the hinder margin of the head shield, passing obliquely downward and inward helow the cranial roof, and in the living state presumably commmicated with the internal auditory sense organs.

1 Mem. N. Y. State Museum, 10. 1907. Page 10:. 
In the examples of Macrop. Scheii before us we see on the right side that the post-orlital canal at the hinder part hends slightly inwads and tapers. I cannot see, however, that they then proceed downards with funnel shaped openings as in the case of rapheirlolabis. On the other land we can see that from the hinder point of the occipital canal a $n$ e rearwards to the hinder margin of the cranial roof. In my opinjon this appears to he the beginning of the la teral line canal. As is well known a similar condition is seen in the rase of a number of rocrosteomorphous fishes, and is therefore a further proof that the entire head shield of Macropetatichthys contains only the cranial roul.

The sensory canals which have a hreadth of ahout $1 \mathrm{~mm}$. are very clearly discernable in the specimen before 11s, owing to the riremmstance that the hone substance has almost entirely fallen away. As is well known, the canals in this gemus areso deeply emberded in the dermal plates, that in the form liefore ns they appear on the moler side of the cranial shield like ridges. They open upwards by means of a series of pores. which appear to he found only on the outer side of the canals. They are easily discernable along the outer side of the right post-orthital canal and for a short clistance along the right supraortuital canal, inside the orbits. At the former place they are rombl. with a cross section of $0.3-0.4 \mathrm{~mm}$., and at the latter, where the entive hone substance has been preserved, they are oval, about $0.4 \ldots 0.5 \mathrm{~mm}$. in length. and 0.1 mm. in lireadıh.

The specimen also clearly shows the impression of an extensively hranched and fine ranal system on the inner side of the cranial roof (fll. I, fig. 4). As far as I ran understand these fine canals do not appear to haw had anything to do with the semsory camals. but may fossibly le veins that have been embedded in the ranial bones. I have mot been able fo find anything corresponding to them in desoription of the other lorms known of this gemus.

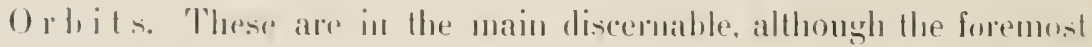
portion of the ranimm is defoctive. On the left side the length maty le detromined at 11.5 mm. it is more diffirult to determine the breattlo. hut presmmably it may he placed at 7.5 mm. The orbits may therefore be pesonstructed as shown un the drawing. lig. 2. They thus afjear to hawe heen umusually large and lengllyy.

$1101 \%$ i\% 11 . Font the zone Dh in marin facies, Goose Fiord. Eillentlester l,and. 


\section{Comparison With Forms Known Previously.}

The following species of this gemus have heen described previonsly:

1. Macropetalichthys rapheirlolabis Norw. \& Owen.

The best known form of which a number of specimens have been found in Onondaga Limestone in New Tork, Colmubus and Delaware Lmst. in Ohio, Corniferous Limestone in Indiana and Canada(?), that is in horizons of Middle Devonian age.

2. Macropetalichthys Agassizi r. Mever.

One specimen, somewhat defective, from the Middle Devonian at Gerolstein, Eifel; the original is at Cambridge, Mass.

3. Macropetatichthys Prïmiensis Kayser.

One specimen, somewhat defective, from the Upper Lower Devonian at Prün, Eifel; the original is at Berlin.

4. Macropetalichthys pelmensis Hexng.

One specimen, of poor quality, from the Upper Middle Devonian at Pelm, Berlingen. Original is at Berlin.

linally, JAEKEL has announced the discovery of a Macropetalichthyid form of a new type from the Lower Middle Devonian at Gerolstein, Eifel. The original, which is at Frankfort on Main, has not yet been fully described.

In the appended figures (fig. 2) I have given a schematic drawing 'of the' new form and of those previously known. which are sufficiently well preserved for the main features to be reconstructed. As will be seen, Macropetalichthys Scheii is here reconstructed in natural size, whilst the other's are diminished; the new form is thus much smaller than those known previously.

It is also distinguishable from them in other ways. One important circumstance is the more or less remarkable divergence of the two supra-orbital canals in front of the commissure. The followiug table gives the size of the supra-orbital angle in the known species:

Macropetalichthys rapheidolabis Norw. \& OW. . . $48^{0}-49^{0}$

$\begin{array}{ll}\text { - Agassizi v. Meyer . . . . . } 39^{0} \\ \text { - } & \text { Prïmiensis Kayser . . . . . } 21^{0} \\ \text { - Pelmensis Hennig. . . . . . ? } \\ \text { - Scheii Kinr . . . . . . } 39^{\circ}\end{array}$

We see that in this respect the new form stands just between the short and broad American form M. rcupheidolabis and the elongated Prümiensis and agrees with Agassizi r. Meyer, and possibly Pelmensis Hennig, both from the European Middle Devonian. On the whole the new form is nearest to M. Agassizi v. Meyer, but differs from the latter at important points. 

In M. Scheii the hearl sheld is more elongated, and therefore llie snout portion was in all probability longer. He orbits much larger and more elongated. and the infra-orbital canal less sharply inclined at an angle.

As we have seen the new form differs markedly from M. rapheirolabis and prïmiensis by its different supra-orbilal angle. 'The form of the hear-shield too is so different, that it is impossible to confuse the two.

As mentioned in my description, there are two other peculiarities deserving of attention, viz. the hindermost branches and the pores of the sensory canals.

As regards the former we should wait until the existence of any corresponding structure in the other forms has been investigated, before we attribute any considerable systematic importance to them. With reference to the pores, double rows of pores are regarded as a mark of the genus Macropetalichthys ${ }^{1}$. Therefore the single row of pores in M. Scheii must he considered to he an important character of this form. Sereral of the other species, however, are so little known that other species, - e. g. M. Agassizi v. Meyer and M. pelmensis Hennig, may also possibly possess the same peculiarity.

We thus obtain as our main result that M. Scheii approaches most closely to M. Agassizi v. Meyer from the Middle Devonian at Eifel, but that the former is quite distinct from the latter.

\section{Stratigraphical Results of Series D.}

Macropetalichthys Scheii new species described here is the only fish fossil that I have been able to describe from series D, e. g. from the zone Dh.

O. E. MEYER, who recently described the brachiopodes from the same series, says concerning the zones $\mathrm{Dh}-\mathrm{i}$ :

"The two strata marked Dh and Di in the field show a remarkable conformity with the American Chemung group. This conformity is seen not only in the great similarily of the faunas, but also in the astonishing likeness of the rocks to each other".

Moreover from other remarks it appears that O. E. MErer places these two zones parallel with Chemung, that is with the upper. part of the Upper. Devonian.

1 Goodrici, Cyclostomes and Fishes, Page 262. 
This determination of age is based upon the 3 Productella forms appearing 111 Dh. (er. aff. lacrimosa Coxr., urctirostrata Habl and subaculeata Mluntil var. latior Gürich), which Mersok considers chararteristic for Clemung.

several conditions of fammistienal and stratigraphical nature do not styplyort this opinion of O. E. Meser.

$1 \mathrm{is}$ of importance here to mote, that Merek las fomml several real Michlle Devonian lirachioporls in [Dh, e. g. Spirifer elegans Stens. var.. Spirifer gregarius Cuspe. and Trilsonia princeps Banr., which lie calls "vereinzelte Reste der milleldevonischen lauma".

'Tlie Middel Devonian forms have now been increased by Macropeta. lichthys Scheii. this characteristic genus mntil the present time having lieen foumd only in the upper part of the Lower Devonian and in the Michlle Devonian.

It seems to me, that the Middle Devonian character of the fauna in Dh in this manner is marked so plainly, that this zone cannol be of any high Uprer Devonian age (Chemung).

In reality, even the 3 Productella forms are not of decisive value. Produclella ex. aff. lacrimose Cons. and Productella arctirostrata HALs, are also found in the characteristic Middle Devonian zone Dg, and Productella subaculeata Murcn was known previously both from the Middle Devonian and from the Upper Devonian.

It therefore appears to me to be evident that the zone Dh, so far from being parallel to Chemung, should preferably be assigned to the lower part of the Upper Devonian, or with even greater reason to the transition strata between the Middle and the Upper Devonian. This view is ronfirmed ly the small extent of the strata ${ }^{1}$ and the stratigraphicul results which may be deduced from the fauna in the succeeding series E.

\section{Fish Remains And Other Fossils From Series E.}

'Thin series. Which superimposes the marinc series D, forms the uppermost member of the Devonian. It is a continental formation, the facies development of which corresponds to the Old Red facies, in the state of New York (Catskill), and East Canala. In his preliminary report Scmis gives a hrief survey of this series. A somewhat fuller

1 1'. Soms, I'relininary Report, 190:3, Page 7. 
account by the same author will he found in A. G. NATnonst's work, "Die oberdevonische Flora des Ellesmere Landes"1. I will give such parts of his account as are of interest in this connection.

The inner part of Goose Fiord is smrounded by slightly oblique mountains, which are mainly composed of sandstone. 'These however' are but seldom seen exposed in precipices and river cuttings. The sandstone, which has a thickuess of at least $600-700$ metres, falls gently towards the NNW.

The lowest 300 - 400 metres of the strata consist of a light quarty sandstone, which here and there contains thin banks of conglomerate, only a few decinetres in thickness. The gravel in this conglomerate is small and consists of quartz and ironstone. In Skrap Valley (1) on the west side of Goose Fiord land above the mildle of the sandstone profile at the inner part of the fiord), there is an occurrence of a conglomerate-like sandstone, red in some places and grey in others, which in Scher's opinion belongs to the middle portion of the series. It contains a quantity of mussels, numerous fish remains, and indeterminable fragments of plants. The fish remains in this the richest fish bearing horizon, are partly scales of Holoptychius forms, partly fragments of Placoderms.

Farther to the north the strata of this series were found exposed in two other river cuttings on the west side of the fiord.

The more southerly one is "Bregnekloften" (2), a little river cutting in which somewhat more than 100 metres of the series can be studied (fig. 4). The main occurrence here is a light quartz sandstone in thick banks. Between these we also find dark, sandy and micaceous schists, thin layers of conglomerate, and anthracite in strips and thin layers. In one lenticular mass of schist, ScHer found numerous remains of plants, some of which were well preserved. They have been described by Nathorst. Just above this plant horizon, indeterminable fish remains were found in a conglomerate strata.

These strata must be assumed to lie higher in the series than the fish horizon at Skrap Valley.

Scher found plant-bearing strata (similar to that at Bregnekloften) in a river cutting in Galge Point (3) somewhat farther to the north. In addition to the remains of plants, some fossil fish of considerable interest were collected here.

1 Report of the Second Norwegian Arctic Expedition in the Fram, No. 1, 1901, pp. 4-9. 


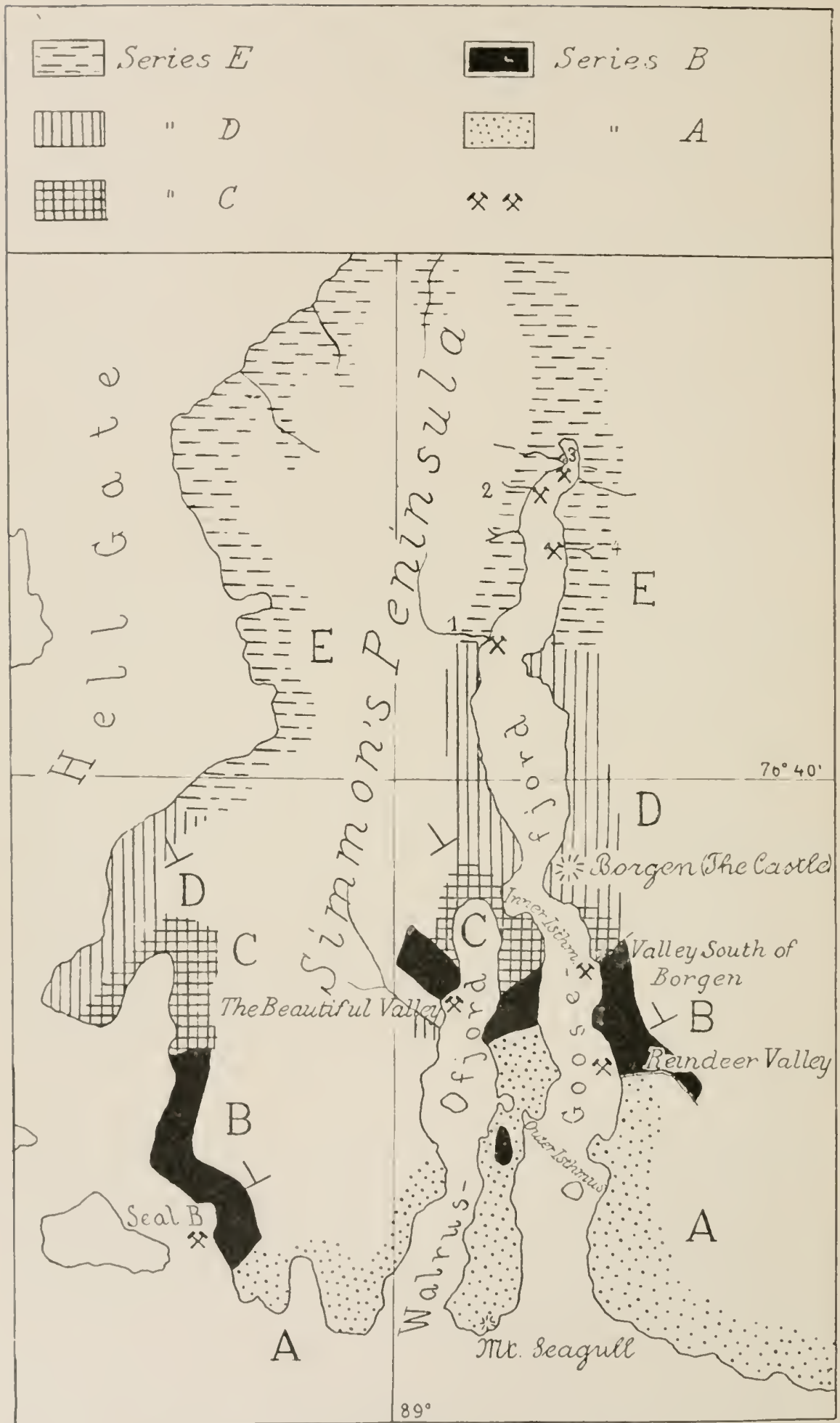

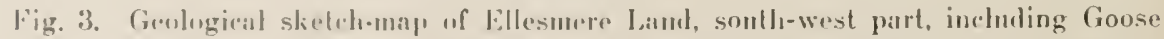
Fiorl, areorling to Suml. Suries A-B are Silurian, $C-D$ Devonian in a mariue facies, l: Theonnian in a Continental facies. The localites where fossils were fonnd in F, ner markml with fwo hammers and the numbers $1-4$. 
Finally one or two fish remains were fomml at a fourtl place which is called S. O. Haken and is situated on the east side of the fiord (4?).

Is regards the upper houndaries of the series, Sruer was unable to make any definite statement. He was, however, able to state that this sandstone series is found from Ren Bay at Hell Gate arross Nordstrand to the east side of the entrance to Eid's Fiord. On the west side of Eil's Fiord limestone appear's, and at Great Bear Cape this rock contains arboniferous limestone fossils. Unfortunately Saner lad no opportunity of determining more exactly the boundary between these formations.

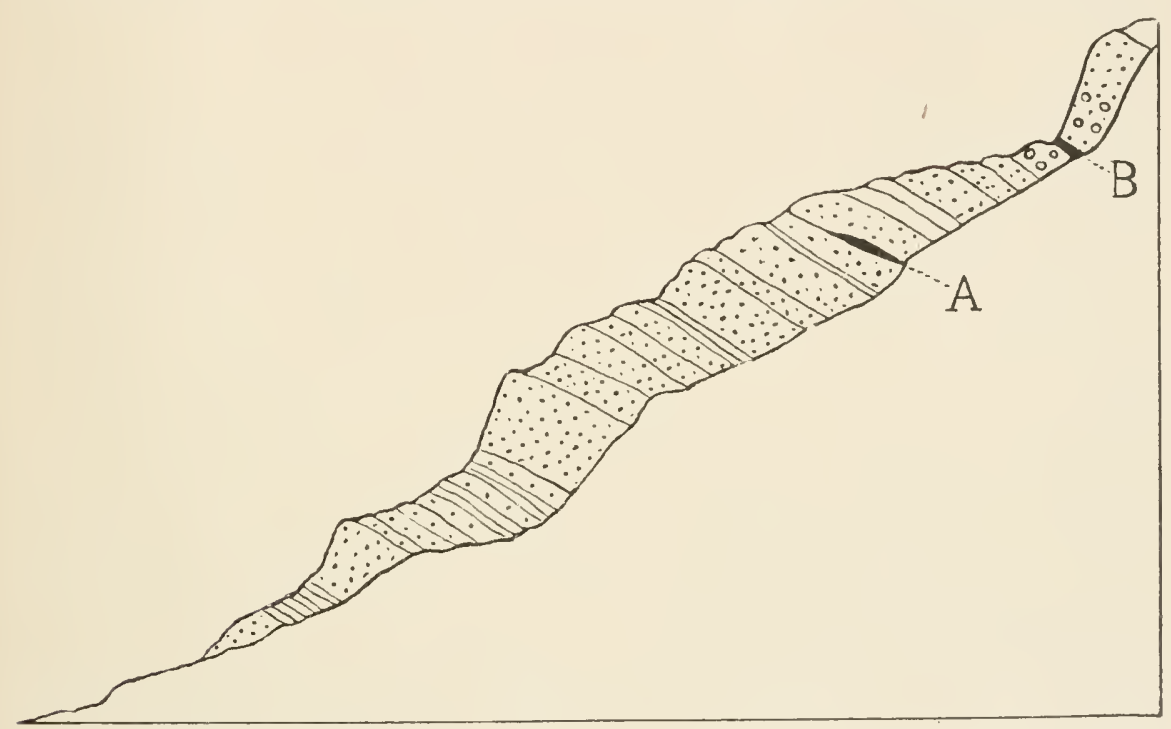

Fig. 4. Section at Bregnekloften after PER Scmeı. The strata mainly consist of quartz sandstone and sandy schisls. At A, plant fossils. At B, anthracitic coal, alont 2-3 cms. in thickness. Conglomerate at the top. The strata are somewhat over $100 \mathrm{~m}$. in thickness.

According to ScHer, the same sandstone series appears on the south side of Bay Fiord, right up in Eureka Sound. "At this place", writes Scher, "I helive I could identify the same indeterminate fossil remains and bituminous layers in the light grey sandstone as at localites 1 and 3 (at Goose Fiord). There were even the same impressions of plants as at the latter in the intervening thin schists. Unfortunately, during my passage I could spare no time for the collection of fossils. I an unable to state how much or how little the sandstone deposits appearing along the whole length of Eureka Sound belong to the age in question. Various mesozoic fossils that were found in this region, however, make it probable that the sandstone mainly belongs to younger formations."

The fish-horizons thus appear to have the following place in the sandstone series: 
1. The fossiliferous congtomerates and sandstones of Skrap Valley in the middle part of the series.

2. S. O. Haken's sandstone probably higher up in the serixs, althongh the precise distance cannot be stated.

i. The dark sehists of Galge point, somewhat higler.

4. The conglomerate strata at Breguekloften. just ahove He precenling.

\section{Lamellibranchiata.}

\section{Plitonia cf. cylindrica HaLt.}

(PI. II, ligs 1 9).

Amongat the specimens collected hy Pen Scuer in the rich fish horizon at Skrap, Valley we find an abundance of a small musise which is of considerable interest.

As regards the determination of the gemus, this is no easy matter, as I have only this species and no material for the purpose of comparison. At first I was inclined to farour the gems Glossites; Iut the absence of a lunula in the new form, the less pointed anterior ent. and the almost straight cardinal line, seem to separate this specimen from the latter. Modiomorpha, which was also posible. has a more oblique form. At the same time it appears to agree very well with HaLd's description of the semms Phtonia

Description. The shell is small, elongate-elliptical the lengll heing a little more than twice the height. The hasal margin is straight or slightly convex. Posterior extremity regularly rounded, hut somewhat ublique on the mper posterin margin. Anterior rond short, narowed. and romoled or somewhat pointed at the extremity. Cambinal line nearly straight, about half the length of the shell. Valves molerately comrex. Beaks sulanterior, low, appressed, with sometimes a faint indicalion of it depresion extemlumg from the heak to the hasal mingin.

Surface marked by fine, even, concentric striate: radiatimgr striate are not to he seen. As a rule a few roarser lines of growth ane visible. Auterior muscolar scar distincl, posterior muscular scar ohicure.

Tharee specimens measure respertively 16 , 17.5 and 17.5 mm. in lenght and $7.5,7.5$ and $\&$ mm. in height.

() loservations. 'This lescription has been liept close to that of I'htonia cylindrica HaL, as griven ly Has., ${ }^{1}$, amd agrees almosl entiraly will, the sime. Cloubl may be orasioned by one or lwo prints. 
According to HALL's description Plitonia cylindrica is larger, from 26-30.5 mm. The anterior end is possibly more rounded; the first of his examples is depicted with a more pointed anterior. 'The extremely fine radiating striate which Hat mentions in the case af $P h$. cylindrica appear to be quite lacking in the form from Skrap Valley. He says, however, that these striae are frequently obsolescent and often obsolete.

Deviations in the dimensions are not of importance. The form from Skrap Valley presumably lived in a brackish lake, and may therefore in consequence be somewhat deformed. The other deviations are not in my opinion of great importance. I shall not, however, venture to assign the specimen to any other place than Phtonia cf. cylindrica HaLL.

Ho r izon. Abundant in the fish horizon at Skrap Valley. Phtonic cylindrica HaLL is previously described from the Hamilton Group. 3 other species are known from the sane horizon, 2 from Chemung.

\section{Pisces.}

\section{Psammosteidae.}

It is very interesting to note that fragments of Psammostens forms belong to the most common fossils in the fish horizon at Skrap Valley. For previously, this genus was known from Liv Land, Scotland, and spitzhergen only, and was quite unknown in the case of American Devonian strata.

Our knowledge of the genus Psammosters is still extremely defective. As is well knowll, Agassiz in his classic work "Reclerches des poissons fossiles", 1844, described several fragments of this genus from the Battic provinces of Russia.

He gives 4 species which are distributed amongst the genera Placosteus and Psammolepis. In a later work, "Poissons fossiles du vieux gress rouge", (1845). lie combined the latter in one genus which was named Psammostens. but at the same time he retained the four species originally mentioned. As regarts the systematic position of these forms he gives no details.

PANDER, who had a large quantity of material at his disposal, in his important work "Die Placodermen d. devon. Systems" (1S57) Ip. 20-24, gives a detailed account of these enigmatical fossils. He believes that the species made are simply fragments of the same form, the sculpture differing greatly in the various body plates. He also gives a 
rery striking description of the inner structure. but strangely enough formed the rondusion. - although not without smme doubt, - that these remains represent fin spines ant fulcra of Asterolepis. the plates of whith. however, have quite another stroture. \%atres, in ha Handhmeh, Vol.?II, 1SS7, p. 1.5. shares the same views.

s. Woomwaro in his excellent work. "Calalogne of fumil fishes", (Vint. I. 1S91. pag. I20(i) places these remains as Ichthyodormlites and says that in their characters they are nearest Orocanthus. These viens are mantained also in his "Outlines of Vertebrate Pakeontology", (1595. 1. 291.

In the same year. R. H. 'Tragram in his "Report of Fossil Fintren in the Silntian Rocks of Scotland", which rontained so much that wan new and fondamental, appeared with puite a fresh interpretalion of Psammostens. By reason of his studien of the mont primitive Ostrucodermi and his investigations of the tower Deronian Drepanaspis Gemimdenensis, he belioved that the fragmentary dermal flates whith had been denoted Psammostens, hetong to an ostracoderm fish insels. related to Drepanaspis. ..It is nom pretty chen that Psammostems in rosely allied to Drepanaspis, so closely that it may he a fue-lion an to whether there is any need for fanty distinction. I think, however. that it is better for the present to kerp them in separate families mntil the microscopir structure of the hard parts of Inrpanaspis can lus imestigated and more atso is known regarding the conliguration of Psammostens and the arrangement of its plates"'

'Trautan's eleseription of Psommostens is so striking and his views apprear to be so well foumded that the majority of subsepnent imsestigators who have ancermed themsetres with the systematic position of Psammostens have subseribud to his hypothesis. In the latent edition of Zitres's Handhuch. E. Lokw has evell aranged Psammostens' under the family Irejumaspidae.

The present anthor has sureeeded in smbing the miromenpic structure of mreponaspis. ho this respeet he is able to smpplemmot

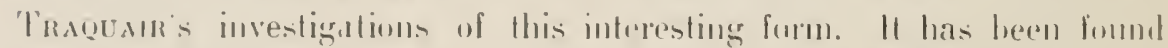
that the strmeture agrees quite chosely with that of Psammostens. and the agreement is surh that the forms must have heen related. This matter will be further discomsed later on.

On the basis of our present knowledge it is easy to decide whether the remains before un are those of a psammosteid form. (On the other hamet it is far mone difficult to determme how far we are justifial in

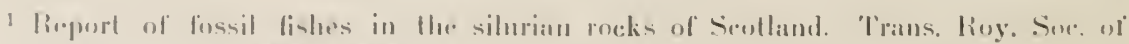
Eslinlough, 31, 18:15. p. 815. 
speaking of new species or not. The variations of the sculpture in Drepanaspis strongly confirm Panner's opinion that the four species given by Agassiz simply represent various dermal plates of one ant the same species.

Should this be the case there appears to be little justification for placing Psammosteus remains from other regions as new species, simply on account of differences in the external ornamentation.

My own microscopic investigations of both the material from Elles. mere Land and some Psammosters remains from other regions from Liv Land, however, have shown that there are certain differences in the microscopic structure which are very much more constant than the exterior scupture that varies greatly even in one and the sane species.

I believe that for the present this provides us with the best method of differentiating species within this family, - which is still very imperfectly known, - and also of controlling the circumstance of certain apparently constant difference in sculpture and their value or otherwise for purposes of classification.

I will therefore first describe the existing material from Ellesmere Land, and later on proceerl to compare the same with forms previously known.

Psammosteus arcticus new species.

(Pl. II, figs 5-7; Pl. III, figs 1-4; Pl. V, figs. 4-5).

Under this name I include a series of fragments the sculpture of which varies considerably with respect to the dimensions and form of the denticles, which however are remarkable for the following outer and inner characteristics.

1. The surface denticles are most often high and markedly ribbed, and have very prominent peripheral points.

2, The putp cavities of the denticles are very wide, and are situated with wide openings in connection with the underlying vascular canals.

These fragments must therefore be assumed to belong to one and the same species.

Description. We may now proceed to a more detailed description of the most important of the specimens.

1. The best of the fragments is a little sketeton plate with extremely well preserved sculpture (s. I. 20). 
Onter ciharateristics. The plate is quite flat; length If mm.. brealth $15 \mathrm{~mm}$. and thickness 1.5 mm. Only the uper surface is visible; it shines hrightly like hlack enamel, and the scolpture is very heantiful and characleristic. (PI. II, fig. 5; PI. III, figs 1-2). By the maked rye it appears to he finely and regularly tuberculated as is the case with many coccosteomorph fishes. hut even a slight enlargement shows that the sculplure is markedly psommosteid.

The latter is comprosed of fairly regular rows wilh markedly ribhed denticles, the points of which slo not lie in the centre, but are quite peripheral to the longitudinal direction of the rows. The highly glistening denticles for this reason when slightly magnified have a mique armw-like form. which however is less striking under higher power. We then observe that the renticles have fine, sharp, and to some extent crenulated ribs, which all run towards the peripherally situated point.

The length of the denticles is $0.7-0.9 \mathrm{~mm}$; the brealth is the same. Now and then we see quite small ones. 'The spaces hetween the formel are seldon wholly extended; here and there, however. we notice that they rmo ahmost directly towards one another.

Interior Structure. Microseopic examination shows that the structure is markedly psammosteid. (PI. III, fig. 3). The denticles are closely situited, but between them open spaces without skeleton sulpstance are rlearly visible. 'The pulp cavilies are very wide and open lownwards with wide urifices, communicating in this mamer with the molerlying ras.ular camals. The latter are narrow and irregular above, will thick walls that as is usually the case show a lamellar structure without bone cells. Deeper down the canals and lacums become wider and more regular, with thimer walls. Underneath there are again trates of namore canals which render prohable the original existence of a hasal layer. The plate, however, is incomplete at this point. Firthent to the right, beyond the part of the microseopical section shown in the ilhotration. (a transwersal soction). thr somewhat close netwoth grows larger aud larger, until at length it ocoupies the whole thickness of the plate, which at this point hecomes thinner. We may therefore prestme that at this moint there has heen a free margin. Between the denticles the canal system opens upwards in pores.

2. Another quile small fragmenl (S. I. S1 a) is shown in P. II lig. 7, 5) times enlarged. The tenticles are here creally extented; as however the strong ribs, the peripheral points and the latge pulp cavilies agree in all resprects with llose of the ahove specimen, there can he no doubt that they helong to one and the same form. 
3. Inother little fragment (S. I. S1 c), in many respects stands between the two above specimens. The denticles in this instance are more compresed, but they agree in other respects. 'To some extent they show a marked alternating arrangement, 11 a manner similar to that described for a piece of Ps. complicatus (fig. in text 5).

4. A particularly interesting fragment (S. 1. 29) will be seen in Pl. V, figs 4-5. It is a piece of a compressed, spine shaped plate with a long oval cross section; all the sides are covered with a very characteristic layer of denticles, which are extremely well preserved on the upper side. The upper and lower edges are fracture surfaces. Greatest length $19 \mathrm{~mm}$; breath below $12 \mathrm{~mm}$; above $9 \mathrm{~mm}$., thickness below $4 \mathrm{~mm}$. above $3 \mathrm{~mm}$. The layer of denticles consists of elongaterl and that denticles. Its breadth is from $0.7 \mathrm{~mm}$. to $0.5 \mathrm{~mm}$., length from $1 \mathrm{~mm}$. to $3.5 \mathrm{~mm}$. On the surface that is visible they are arranged in angular rows, the proint of which turns towards the broader basal end of the spine shaped plate. The separate denticles have a markedly fringed edge against this margin, whitst towards the other they rise gently to a smooth and often undulating edge. On greater enlargement, however. this is found to be faintly crenelated. Towards the sides the denticles become smaller.

I consider these denticles to be of the same type as those of the fragments previously described. They have only been greatly compressed and elongated.

It is worthy of emphasis that the spine shaped element referred to above is not bilaterally symmetrical in construction. One surface, which may be seen in the figure, is indeed stightly concav, whilst the opposite one is slightly convex. The left edge is also slightly concave, the right slightly convex.

The layer of denticles has fallen off on the lower part of the specimen 'The underlying vascular canal system therefore becomes exposed; the longitudinal direction follows the longitudinal axis of this element.

5. Pl. II, fig. 6, shows a small arched plate, (S. I. 69 h) that presumably may also be referred to the above form. A number of strongly crenelated denticles are seen here grouped around a comparatively large rentral denticle. The microscopic structure of this plate is shown in. Pl. III, fig. 4. It agrees well with that described in the case of the specimen first mentioned.

My material contains several similar small plates.

O bservations. The fragments here described as a new species, Psammosteus arcticus, are distinctly differentiated both as regards 


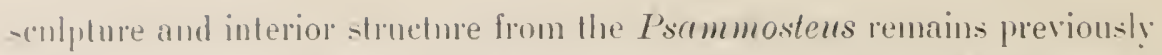
described. In cerlain respeds they are neareg to the well-known Imepanaspis Gemändenensis of 'Travoun's description. but they rannot be combined with that form. I will return to this matter sulserpuently. and simply - late here in whal mammer the specimens described may he orientaled. I make the rery probable assumption that Irrpanaspres is a chonely related form. that provides 11 s wilh a representation of the hahits of the body in the case of Psammosteus.

The specimen described in 1 must therefore he assmmed to be a fragment of one of the large central lody plates, either dorsal wo ventral.

The fragment described in 2 probably belonged to one of the lateral plates, as the denticles on these in the case of Drepanaspis are usually extenderl.

The little plate described in jo shows signs of correspondince to the small, intermediary plates in Jiepanaspis.

The fragnent described in 4 is more dilficult of detemine. It is evidently portion of an elenent with an oblipne, spine-shaped ronstruction, corresponding to those known from the Livland Psammostens form. It might he regarded as either a dorsal spine or a lateral spine, for the pusterior corners of the lateral flaps in these forms possibly emerged in sharp spines or holos, instead of being hountly pointed ats in the are of Drepanaspis.

Ho ri\%, 1 . All the remains in onr possession of this form come from the fisls horizon in Skrap Valley.

Psammostens complicatus new species.

(PI. II, fig. S: PI. I, figi 1-3; PI. I'I. figs 1-3).

A Immber of Psammosters fragments in my material prove to lue s) different brom the alowe and other forms described. both as regaris the interior and the exterior character, that they most be regarded as a new sperose lo which I have given the nime complicatus.

The following peculiarities alpear to he most rharacteristic:

1. The denticles vary greally boht in size and in form. On certain plates-presumably the large leody plates, - they are larger romol, and regnlan, with contral lop and diatinct ribs; in others. - presmmahly portions of the cormer plites formal - Hey are small, flat, oral, of Homblice sometimes strally extended and faintly ribhed. 
2. In the skeleton struclure the laver of denticles is most characteristic. The denticles lave slightly developed pulp ravities which communicate below with the vascular canals by the aid of narow orifices. Between these lenticles we find intermerliary bundles of dentine tubules, which emerge from hranches of the underlying canal system and rise amongst the surface denticles.

Description. Some of the best preserved and mosi characteristic lragments will now be described.

1. A small fragment, (S. I. 21) will be seen in Pl. V, fig. 3. The thickness is considerable, about :3 nm., but it has been even greater, the lower part of the skeleton substance being wanting. 'The denticles are round, the diameter being $1-1.3 \mathrm{~mm}$. They are considerably arched and have a broad. rommlerl, central point and strong ribs.

Another closely related lragment has on the whole smaller denticles. these having a diameter of not more than $1 \mathrm{~mm}$. In other respects it agrees with the preceding.

2. A larger fragment (S. I. 13) is represented in Pl. V. figs L-2. The length of this specimen is $39 \mathrm{~mm}$, breadth $28 \mathrm{~mm}$., and the maximum thickness $7.7 \mathrm{~mm}$. One side, which is depicted here, is somewhat arched. whilst the opqosite one is almost flat. They unite on one side the left in our figure), in a free, rounded margin, which also is covered by denticles. The latter have partly fallen off, but are very well shown on the left side of fig. 1, and are also shown greatly enlarged in fig. . .

The denticles are much smaller than in the precerling specimen. They are closely situated, and oblong rhomboid or oval in form; as a rule they are more or less extenderl, with the longitudinal axis parallel to the free margin. They are slightly arched, without a marked point, and with faintly developed rilss. They often appear arranged in distinctly alternating oblique rows. On the free margin itself they are no longer extended but are farther in. The breadth of the denticles is $0.4-0.511 \mathrm{~m}$., length about $1 \mathrm{~mm}$. the latter increasing now and then in the inner portion to $1.3-1.4 \mathrm{~mm}$,

Several fragments of the same character as that described under 2 are to be found in the material.

In ner Structure. By the ail of series of microscopic sections (PI. VI, figs 1-3) I have been able to investigate most minutely the fragments described in 2. Fig. 5 (in the text) gives the structure more diagramatically.

The denticles, which are slightly arched, will be seen to sland quite closely without intervening spaces; they appear to be almost embedided 
in the skeleton mass. The pulp cavities are generilly namow, canal. like. and are in connection with the molerlying vascular canals ly means of a numow opening of the mature of a canal. The denticles are compored. as msual, of fine dentine lubules: in the spaces between the denticles we also find intermediary lumdles of dentime lubules, that emerge from the underlying eanal system and rise amongst the surface dentirles. 'This permliarity is especially characteristic. In the peripheral

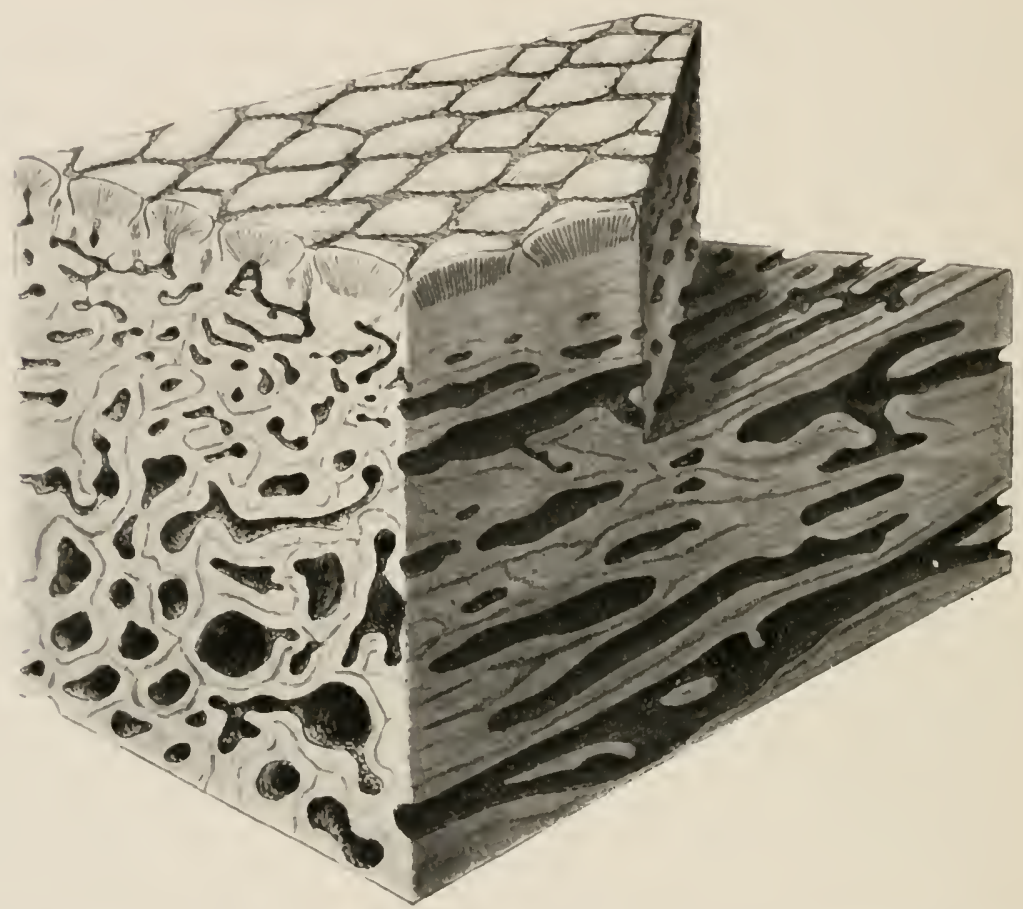

lig. i. Sticteh showing the struchure of the dermal sketeton of Psammostens complicatus new. sp. The dermal skeleton is rot through in sermal directions. At the top we ser. thr dentieles will, their pulp eavities and fine dontine tubntes: between them

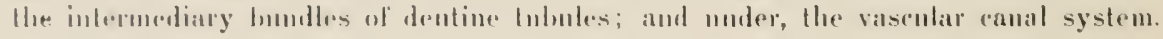

fart of the fragment the vascular canals are narow with thick walls: firther imwarts they beroms wiler. but there too the walls are thick wilh shongly matked alak median layer and lamellar structure. In the longitndinal section we see slraight canals, which are sometimes more irregular, and extend in latomal fashion, often entering into comnection wilh each ollser ly means of large or small orifices and fine camals.

'The fragnent reseribed in 1. shows a similar microscopic structme; the vasmolu canal system, howerer. is willer in this case, and in the lower piat of the plate the latlee has thimer walls. 
3. There are several small plates or plate fragments which show a more or less marker concentric arrangement of the denticles. One of these (S. I. 43.) will he seen in Pl. II, fig. S. 'The denticles are fine, slightly arched, and faintly crenelated. The whole fragment of the plate is slightly archerl. lut at the same time cannot be characterised as spine shaped. It reminds us of the one describerl as No. 5 under Ps. arcticus. The inner structure was not investigated.

Of the fragments here described in greater detail those given in 1 in my opinion belong to the large median body plate. Those in 2, I consider to be parts of cormua, whilst the small plates which I have described in 3 may possibly he regarderl as plates that were intermediate between the large ones.

I shall return more closely to this matter in a later section. (Page 37).

Ho r izo n. All the fragments come from the fish horizon in Skrap) Valley.

\section{Concerning Drepanaspis Gemïndenensis ScHü̈ter.}

(PI. III, figs 5-6, PI. IV', fig. 2).

As mentioned above, this form plays an important part in the classification of Psammosteus. Before proceding to discuss the systematic position of the two new forms of Psammosteus, I will therefore first give an account of one or two new observations regarding this interesting fish, which is describerl hy Traquarr ${ }^{1}$.

The material at my disposal comes from the classic locality at Gemünden in Hönsrück and was acquired through Dr. F. KRaviz at Bonn.

Traquar and several subsequent investigators, as I have before emphasised, strongly maintained the close relationship of the enigmatic Psammosteus fragments and Drepanaspis, (Page 22).

In Traguarr's opinion it will not be possible to determine low close this relationship is until we have succeerled in studying the microscopic structure of Drepanaspis, and the configuration of the body and the form of the body plates in Psammosteus.

As regards the microscopic structure, it was found comparatively easy to study it in my specimens. Even the first microscopic sections that I ohtained from one of the large borly plates gave a good picture

1 The Lower Devonian Fishes of Gemünden. (Transactions Roy. Soc. Edinlurgh. Vol. XL, 1903, p. 733). 
of the struchure. although of course transformation by proites had its umpleasint effects.

PI. III, figs 5-6 are direct photographs of my moroscopic sections and in comprarison with the other illustrations of microscope sections of Psommostens remains, show it mmplete agreenent wilh that genus. Fig. 6, (in the text) gives us a more diagramatical view of the structure wilh cleare details. It passes tromgh both the uper and the lowed hody phate. The fish has been pressed so stongly in lhe schish that

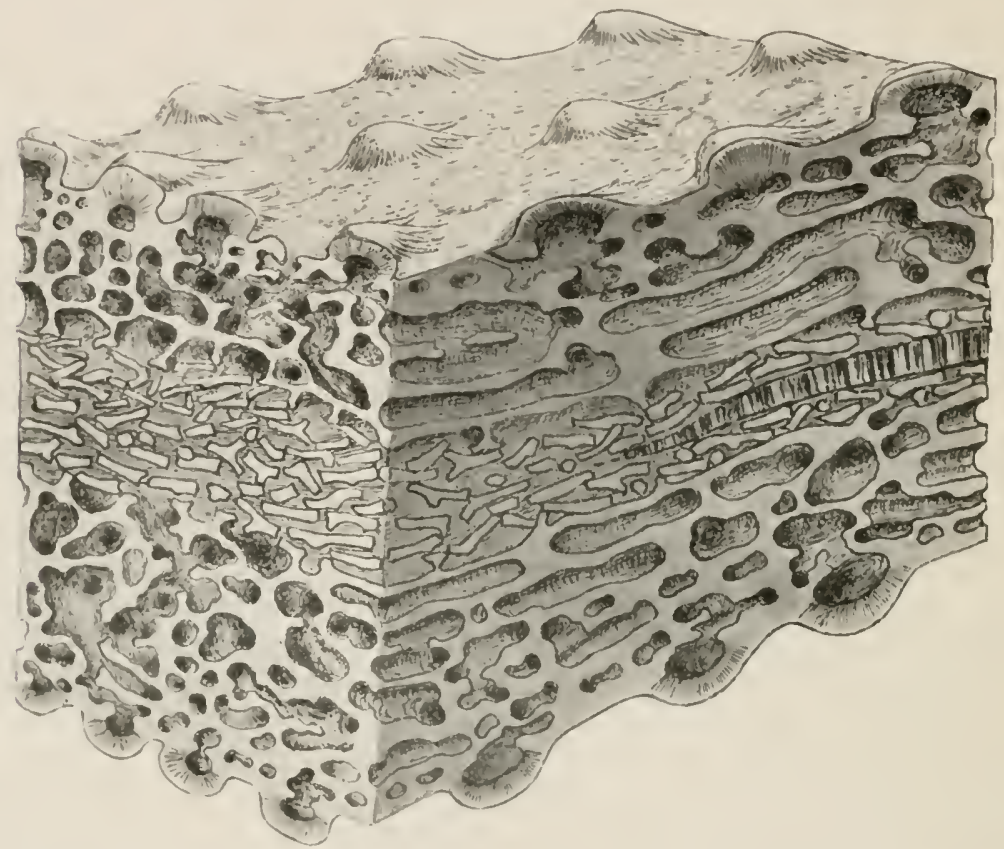

Fig. li. Skethls stowing the structure of the dermal skeleton in Diepanaspis

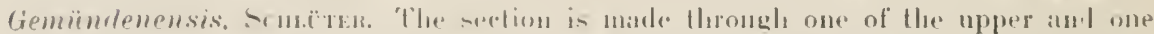

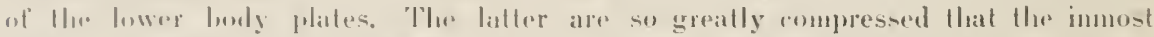

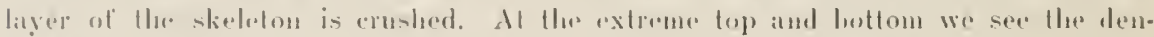

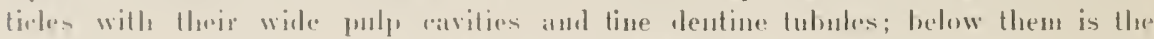
rascular eamal system.

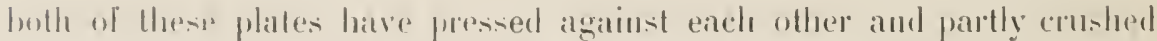
in the inner parts. Otherwise in this and in the said plate we see the

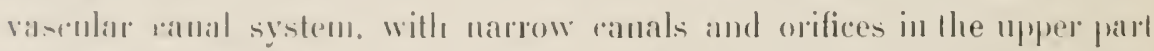
and more opron ones in the lower. 'Thus on the upper surface we have the dentirles wilh fine dentine lubules and rery wide pulp cavilies. which are in comnection hy means of a hoad orifice with the underlying vasenlar camals. By their charaleristic form, these denticles constitute the surface sculphure. This was not very thoroughly described in 'Tragumis works, mor do his illustratims convoy so exact a picture 
that it is possible to use them for comparison. In Pl. IV. fig. 2 I have given a greatly enlargerl photograph of the soulphure of one of the large median borly plates. In this picture we can ctearly see that the points of the denticles are situated peripherally, and that therefore their ribs are longer and more powerful on one side than on the other. Travuan's description of these denticles simply as "stellate tubercles" does not therefore sive the right irlea of their form. We further see that the denticles are rather distant and placed somewhat irregularly. However, I assmme that the denticles are considerably closer to each other than appears from the illustration. Between the typical ribbed denticles we see romol dark spots and these I consider to be denticles that have been torn off by the violent mechanical preparation. As is known, these fossits are brusher out of the schists hy the airl of a metal brush, which on the whole cannot be particularly favourable for the preservation of the finer degrees of sculpture.

I lave given so thorough a description of the scupture on the large median borly plates because it is of importance for the comparisom with Pscmmosteus remains. It would take up too much space to go through ail the variations that the scuplure of Drepanaspis undergoes on the various body plates, scales and fulcra.

Traguan's description of the dermal plates, their arrangement, the caudal part, and the general form of the body, is so exhaustive that 1 cannol add anything of special importance. There is however one point, in which I am quite at variance with him, and that is his views of the dorsal and ventral sides. In this respect I agree with BashFORD DeAN ${ }^{1}$ who in his review of 'Traquar's work on Drepanaspis puts forward the opinion that Traguarr had confused the dorsal and ventral sides. As far as I can understand, Dexs's argument has not been disproved by the new observations put forward by Traqualk in his supplemental work."

I believe this to be apparent from the following.

In his main work on Drepanaspis, Traguan summarises his views of the systematic position of this form in the following way: -

"These character's assign to Drepanaspis a place in the Ostracodermi, and its indubitable resemblance to Pteraspis leads us to class it in the Heterostracous subdivision, although evidente from microscopic

1 Science N. S. Vol. XIX, No. 471, 1904.

2 Supplement to the Lower Devonian Fishes of Geminden. (Transactions Roy. Soe. Edinburgh, Vol. XLI, 1905, y. 469). 
structure is unfortmately mnavilable". In this all subsequent imvestigators who have dealt with this subject. are manimous.

I have now succeeded in ohtaining the proof by reference to the micruscopir structure. The latter has heen found to agree entirely on the one land with the structure of Psammostens, and on the oller to lementhle to a great extent that of Pteraspris. In the cise of the latter the difference only consists in lhe cirmmstance that the vascular canal system is romposed of more regular lacunes, and that the rlentides are welderl together into longitudinal ribs.

This agreement with Pleraspidae, which is thus apparent in the structure of the hody plates, is even more evident when we consider the form and arrangement of the hody plates.

We can hardly he in doubt as to how the large loody plates may he identified in these two types. That side of Drepanaspis Which was identified hy 'Traquan as the ventral, in the median line has I large plates following each other. (T'Ranuan's median ventral and mental platel. It the sides we see the long cormul plates. and in front of these the a pierced ocular plates. These quite correspond to the plates on the dorsal side of Pteraspis, with its median dorsal plate, rostrum. two corma and two ocular plates. ()n the other side, which is identifient by Traguar as the dorsal, the large oval plate which Traguarr described as the median dorsal plate, agrees perfectly with the large ventral plate of Iteraspis. The said plate agrees in the case of the two families. mot anly in its arragement hut also in its form. The sole divergence is fouml in the short form of the rostral plate. which however is quite nalmal in the light of the ray-like body form of Drepamaspis.

In couserucuce, it would be excerdiugly remarkable if the sides of the body, which in the case of these so chosely related species ale chararlerised hy the same deviolopment all al rangement of plates, should not he identiral.

If romse an imestigator like 'Traxudam has not overlooker this commolame, hut nevertheless he amrived at the opposite condusion.

The most important reasons for this are summed 11 , hy him in his -mpplemental work' 1 on Imequnaspis as follows: -

..I sulmuit therefore, Hail I have amply shown -

First: - That the aboral aspect of the carapace of Jrepanaspis is romerilent with the applatent olorial "lolve" or aspect of the candal fin.

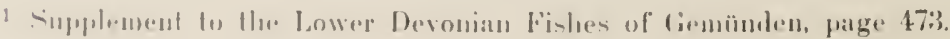



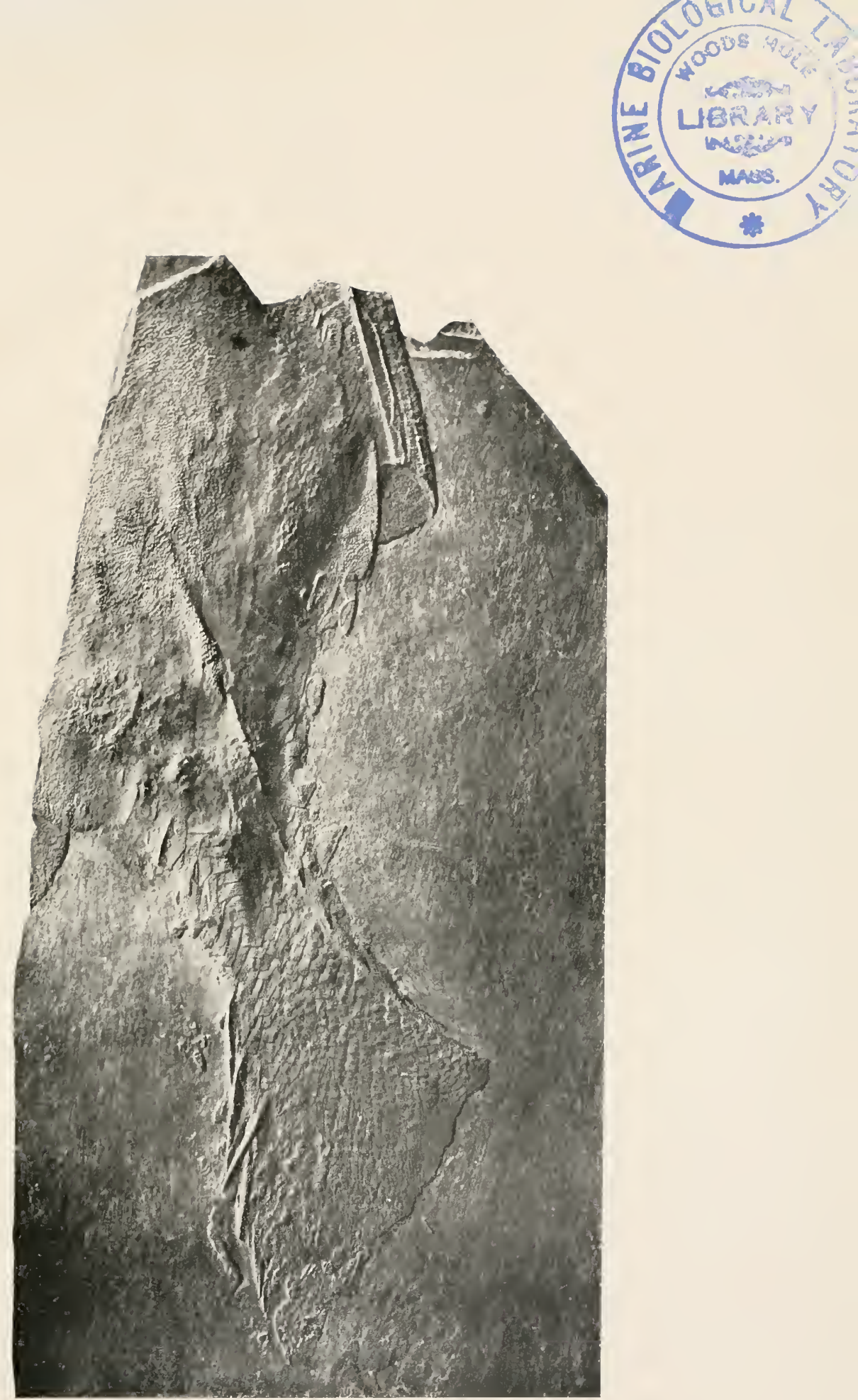

Fig. 7. Drepanaspis Gemündenensis Scrü̈rten from Lower Devonian, Gemünden in IInnsrück. One-half natural size. Spicimen in Palieontological Museum of Kristiania University. 

Second: - That the absence of a cloacal opening on the aboral aspect of the commencement of the tail, amd its apparent presence on the oral one, is equivalent to a proof that the aboral margin of the tail consequently of the entire creature, is the dorsal aspect. Conversely the oral aspect is the rentral; and my previous orientation of the reature is correct, no matter on which side of it the openings supposer to be orbits are placed".

Im my oponion none of these arguments is decisive. As regards the first on, I lo not deny that Drepanaspis has hat a heterocercal caudal fin; but none of the examples depicter by Traquarr show how the dorsal tobe of the tail is situated with relation to the characteristic plates on the more anterior part of the creature. In fact only one of the specimens certainly shows this dorsal lobe, (fig. 1, in plate II of his supplement); but none of the plates is here shown so distinctly that it is possible to arrive at a result. With regard to the second argument. that which Traguar takes to be a probable cloacal opening has probably nothing to do with that part. It is simply an arch behind the dorsal shield, caused by the insertion of the dorsal spine at this point.

In support of this contention I have depicted a specimen of Dre. panaspis belonging to the palaeontological collection of Kristiania University. 'This shows not only the presence of the dorsal spine referred to. but also other things of importance.

The specimen shown in approximately half natural size in fig. 7 (in the text) shows excellently the caudal end - although, unfortunately, not the extreme portion of the caudal fin - and the posterior portion of the body plates. There is no loubt that we here see that side of the creature which Traguar regarded as the ventral. The large median plate shows the characteristic fold the extreme rear of which Traguarr considered to be the cloacal opening. Behind this opening and joined to it, however, we see a pointed skeleton element which is broader than the succeeding fulcra and which can hardly be anything but a short dorsal spine. Behind this we see a continous row of fulcra which by degrees grows larger and larger. 'This in my opinion is the upper margin of the tail. It is clear that the tail has been turned to one side. and farthest down to the left, therefore, we observe the second and opposite row of fulcra. As we see, this is unusually long and spine shaped. If we compare this with Traquarn's illustration in his Supplement. Pl. II, fig. 1. in which the heterocercal nature of the tail is quite apparent, we again find similar long, spine shaped fulcra on the lower 
sille of the tail, whilst those on the upper side, where the dorsal lobe is seen, are of the same form as that of the right row of fulcra in my spremen. I have therefore no doubl that the dorsal lobe of the tail was situater on the right sille. This is also the dorsal side of the hody, as will he observed in lhe specimbn.

Where then was the cloacal opening situated? In accordance with the visws we have stated, it must maturally have been hehind the large merlian plate on the under sile of the animal. The rows of fulcra do not hegin untill some little distance from the rear of this plate, and this is maturally the situation of the opening. It is not surprising that we cannot directly prove this, in the light of the greatly compresiof examples of this form.

\section{General Remarks regarding the two New Species of Psammosteus and Other Allied Forms.}

The two new species of Psammostens which are described in this work, differ distinctly from each other by several easily recognisable characters. The histological construction of the cranial skeleton itself provides the best and surest means of identification; but peculiarities of the outer sculpture also appear to be of service.

We will now see whether these characters can be emploved in differentiating the above from remains of Psammostens and Drepanaspis. - which also evidently are closely allied - aheady described.

As mentioned before, Agassiz marle 4 species of the genus Psammosters, all hased upon small fragments with somewhat different exterior sculpture.

I'sammostens macandrimus, Ar., is thus hased upon a little frag. ment from Ladoga; the three olliers, Ps. paradoxus. Ag.. arenalus, Ari., and undulalus, Ac. are batsed upon small fragments from the Riga district!

Paxneri ${ }^{2}$ who hat a liuge collertion of Psammostens remains, regarded all of these more or less differently ormanented fragments as steleton elemouts of ome aurl the simme form. He rousidered them possibly ichtydorulites and fulcra of an otherwise muknown eartilaginous fish, or as having helonged to the raudal part of Asterolepis, and possibly some other variotins ol Placodermes.

1 Agas-1\%, IInugg. des. puis. fos. du vienx grós ronge, 1814, pag. 103.

2 l'aver Unber dire Placodermen des devon. Systems. 1557, pag. 20 and following piagin. 
These assumptions of PANDER are mainly of historic interest as far as we are concerned. After Traguan's investigations, which have been carried further by my own proots of the structure of the skeleton, it has been considered certain that Psammosteus, Drepanaspis and Pteraspis are nearly related forms. Drepanaspis, the dermal skeleton of which is known in most details, should therefore provide us in the main with a representation of the appearance of Psammosteus as well.

In this connection, however, it is of great interest to note that the Pscmmostens remains in the East Provinces of Russia according to

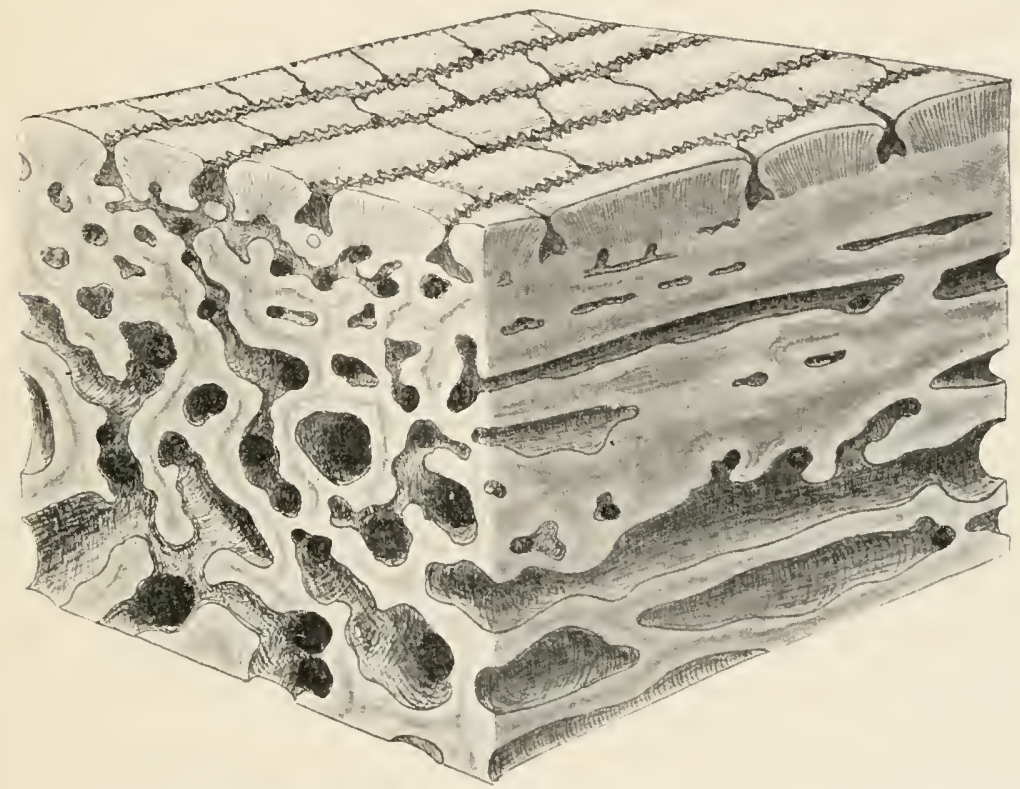

Fig. S. Sketch showing the structure of the dermal skeleton of Psammostens maeanarims Ac. We see the dermal skeleton cut through in two directions. At the top, the flattened denticles with their fine, narrow pulp cavities and fine dentine tubules; below these the vascular canal system.

PANDER's theory belong to one species, which woutd in that case receive the name Ps. mueandrinus Ag.

A. Smith-Woopward in his catalogue ${ }^{1}$ names Agassiz's species without giving his reasons for so doing.

In reality a fresh investigation is required, - particularly of the microscopic structure - in order to decide this question.

Personally I have only had a few Psammosteus remains from the Ballic Provinces for comparison, viz. a spine shaped element from the

1 Catalogue of the Fossil Fishes in the British Museum, II, 1891, page 126. 
river Antoma in the Gomernement of Olone\%, and two plate fragments frum the River Aa at ivenden in Livland.

These fragments show a similar variation of the onter scolpture ats that in the forms I described in this work from Eillemere Land.

'The spinte shaped skeleton element las flattened. rrenclated, often marketly extended denticles (Fig.s in text), whilst the fragments of plate which have denticles on one side only. have rommd, greatly arched dentirles, with makedly prominent rilss (Pl. IV, fig. 1).

'Tlue rorresponding parts in the two now forms described here, show similar conditions. Compare Pl. V, figs 4-5, and P. H. fig. 5. Pl. III. ligs 1-2, for Ps. arcticus, and PI. V, fig. 8 for Ps. complicatus.

The ornamentation clearly shows, however, on comparison will the latter as somewhat different type.

The difference hecomes even more apparent when we investigate the microscopic struchue. As shown by Pl. I'I, figs 4-6 and fig. 8 in the text, the ilenticles have comparatively narow pulp cavoties and in this respect somewhat resemble Ps. complicatus, but however entirely lack the intermetiary lundles of dentine tubules which are so characteristic of the former. In longitudinal microsropical sections we can oftun dearly see that the extended denticles must consist of several fused into one; they show, indeed, several pulp cavities in the direction of their lengtl (Fig. $S$ in text).

This immer struchue when compared with the onter senlphre appears to separate the fragments of Ilie Livlanil form that I have had an opportunity of examming quite readily from my new species. The former are most nearly related to Ps. areticus, which however exhibits a distinct difference ats regards the makedly prominent peripheral points of the renticles and their wille pulp ravities.

In adtition to the Baltic Provinces and the region of Lake Ladoga,

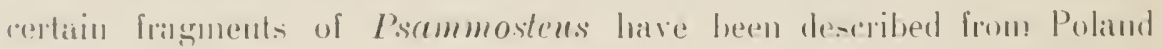

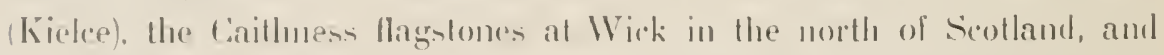

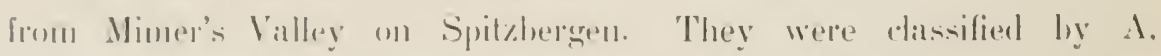

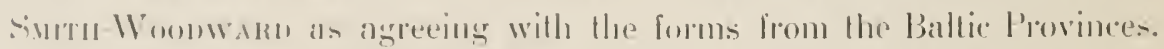

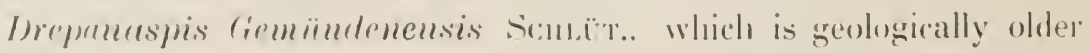
than Psommostens, an wr have shown in the preceding paragraph, is ahos alosely allied. In the structure of its skelelon it greally resembles Psommostrus arclicus. lut differs form the sime ly the sumewhat

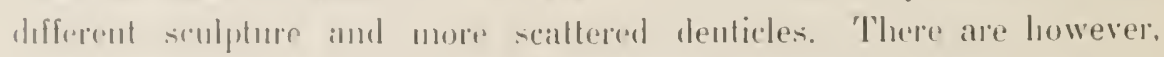
uther ronditions which anse Deepanaspis lo differ form the gemune Pscrmmostens forms. It is fommel that several of the caracteristic 
skeleton elements of Psammosters cannot be determined with certainty. when we attempt to localise them according to the well-known dermal - keleton of Drepancispis.

Fragments of plates with one side covered with denticles, may of comrse he regarded as portions of the large borly plates. In the sane way the small plates with a large mid-denticle which I have described may also with great probability he considered as corresponding to the small intermediate plates of Drepanaspis. The characteristic skeleton that Pander depicts in his PI. 7. fig. 16, may be regarded as a dorsal spine. and other's may be considered to be fulcra, The remarkahle sperimen described and depicted by Agassiz as Ps. paradoxus, may be assumed to be scales from the caurlal region.

On the other hand, it is more difficult to determine compressed and asymetric spine shaped elements of which I have described a fragment under Ps. arcticus (Pl. V, figs 4-5). If compared with Drepanaspis, it is scarcely possible to regard this either as a dorsal spine or as a fulcrum. I believe that it is more probably a portion of a corner spine, cormua in this form having possibly been extended to comparatively short or long spines ${ }^{1}$. The difference that here hecomes apparent between Drepanaspis and Psammostens, was presumably also present in other characters. The family Irepanaspis must therefore be retained.

In consideration of the circumstance that Drepanaspis Gemïndenensis, Schlët. and Psammosteus arcticus Kiær must be regarded as belonging to different genera although the structure of the dermal skeleton in both cases is almost identical, we have good grounds for assuming that Psammosters complicatus KI.ER, with even greater probability forms a separate genus on account of the dermal skeleton. The intermediary bundles of dentine tubules, which are seen in the skeleton plates in the latter form, are not known in any other. It seems to me to be probable that this character has been accompanied by other diverging characters. For the present however, I do not propose to make a new genus: jurlging from other circumslances this must at all events have been closely related to the other's.

From our present knowledge we must therefore assume that alt these forms constitute a natural group, which may best be denominaled the Psammosteidae family. In this we find, of course, several lines of development, which have evolved independently of each other from

1 Vide also Traquan's Report on Fossil Fishes in Silurian Rocks of the South of the South of Scotland. Trans. Roy. Soc. Edin. XXXIG, 1898. 
Thelodus like forms. Palaeaspis, Pteraspis and kindred forms con-litute a relaterl group, which give us a co-ordinate family Pteraspidae will a similar origgin.

Within the family Pstmmosteidae we ran elucidate the development by the series Thelodus - Drepanctspis - Psammosters, which as roncerns the outer form of the body appears to constitute a parallel to the series Thelodus - Ateleaspis - Alieraspis - Cephalaspis.

\section{Coccosteidae.}

\section{Great Coccossteomorph form.}

(Pl. 11. fig. 3-4).

'The fish horizon at Skrap Valley provides us with a somewhat large, heautifully ornamented skeleton plate. (S. I. T). which is probahly a portion of a large, new Coccossteomorph fish.

Description. Figs: -4 on plate II give a better representatioa then any long description can do of this specimen. The upper surface in heautifully ornamented with large, roumd, slightly crenelaterl tubercles. which often have a diameter of $2 \mathrm{~mm}$.

The horters of the plate appear to be the original one on three siles; on the fourth there is an irregular fracture line. On the smonth imel side we see farthest down to the left a strongly developed facet. ly which the plate must he assmmed to have heen superimposed over all adjoining plate.

The maximum length of the plate is $67 \mathrm{~mm}$, At the erlge which in seen turned up to be in the fignre, the lhicknes is $3-4 \mathrm{~mm}$.

Farlhest lo the righl, where the plate however possilly las suffered mosion, this diminishes to $2 \mathrm{~mm}$. and then rises to $7 \mathrm{~mm}$. just insile thre hroarlest part of the fated.

'The plate is thus extremely massive and slrong.

() bservations. The determination of this plate has canned mr. a great doat of labour, atthough I have been mable to arrive al any rntirely saliafactory resull. The somplure may be said to be

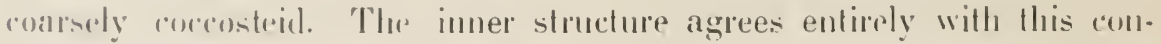
clusion. 'Therefor it wombl apprar to be rertain that we have hefore us it plate of a largr coccosteomorph fish. But which? This question is mot eisy fo solve, especially when we posiess no good material for (omplatison with known forms to aid us in this lask. 
C. R. Eastuan, to whom I sent photographs of the specimen, informs ne that he considers it to be an antero-ventra-lateral plate. In that case the two upper nargins of the figure can scarcely be the original ones. 'They appear, however', to be the original limits of the plate.

In addition we can see no traces of the sensory canals, which are said to be characteristic of this plate. Thus this interpretation is not satisfactory.

It seems to me to be more probable that the plate is a portion of a bilateral symmetric plate. A median dorsal plate is also not improbable. The point which is turned "I) in the figures would in the latter case be the backside and the facet that by which the plate lies over the right anterior dorso-lateral plate. The lack of any median ribs on the inner side argues against this theory, as does also the circunstance that the plate grows thinner on the right side (fig. 3). The latter may be explained by assuming that the plate has been worn down. To judge by the coarse ornamentation, a dorso median plate, however, would presumably be much larger.

The plate may perhaps be best interpreted as a medio occipital plate.

In whatever way the specimen is localised, it must be assumed to belong to a large, new Coccostemorph fish. Several large coarsely ornamented forms have been known previously in certain incomplete fragments. Possibly Aspidichthys ingens v. Koenen, (1) shows the greatest resemblance as to ornamentation, although this form cannot be identified with the preceding with any certainty. Aspidichthys clacatus Newb. lias an even coarser sculpture.

In my material there are also one or two other small fragnents which might possibly be placed here.

Locality. From the abundant fish horizon in Skrap Valley.

\section{Asterolepidae.}

Bothriolepis cf. hydrophila Ag.

(Pl. VII, figs $1-6)$.

From the dark schists of Galge Valley we have 3 remains of a small Bothriolepis, which are of great interest.

Description. The most complete specimen (S. I. 101 and 104) shows the proximal portion of the left arm and the somewhat incompletely preserved anterior ventro lateral plate. (Fig. 1.) The hinder part of this plate is well preserved and shows distinctly the pointed 
Iriangular facel by which it overlapped the posterior ventro lateral plate. IVilhin the hrathial joint of the arm we see the inner cross ril. In front of this the plate is incomplete and cannot be exactly limited. The proximal part of the arm. which is also seen from below, is well preserved in the outer part: we liere see the sculpture. The strong marginal spines and the sulure hetween the external marginal plate and the rentral anroneal plate.

The sculpture consists of a network of fine ribs without nodes.

The anterior ventro lateral plate gives the impression of heing surt and broal. The following dimensions may be determined on this specimen: -

a. Length of anterior ventro lateral plate from the lack point to the cross rib wilhin the hachial joint.

19 เाแा।.

1. Length of the proximal part of the arm. . . . . . . 33 mm.

c. Brealth of the proximale part of the arm. . . . . s mur.

2. Another specimen (S. I. 103), which is shown in Pl. VII, figs $2-3$, gives the interior of a plate; I consider this lo be an anterior dorio-lateral plate. In fromt it is somewhat imperfect. but it, original horders may be seen, especially on the left and posterior sides. Her: we observe fine lines of growth parallel to the margin. Behind we sce a long faced with which this plate werlapperl the posterior dorso lateral plate. 'The plate is short and loroul. and gives the following dimensions: -

a. Lenglli

$17 \mathrm{~mm}$.

b. lirearlth in the centre

19 IIIII.

1. Brearlth farther forwarl

$20 \mathrm{IIIII}$

3. Pl. VII, figs 4-5 shows the onter impression of a third plate 1.5. I. 100) which I regard as a fragment of a posterior dorso lateral 1) lite. It shows a triangular facel before the anterior dorso lateral plate. 'The sculpture is clearly visible and ronsisk of a network of fine rils witlonil nodes.

In addition lo the remains of plalde from Galge Valley described

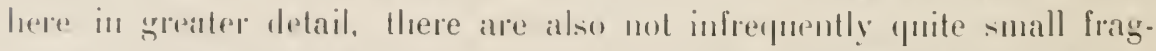
ments of plates with similar sinlphure amongst He material from slirap Valley. It is extremely probible that these remains also belong to the sime form. 'The majorily are fon small aud incomplete for us lo

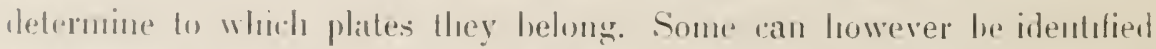

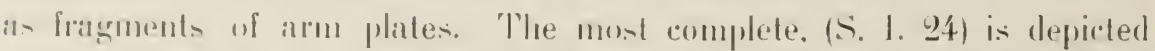
in Pl. V'll, ligg li. I regaril Ihis specimen to be a dorsal artionlar plate. 
Other fragments have a coarser sculpture and show evidences of nodose ribs; they therefore belong most probably to another species.

Observations. The leugth between the proximal portion of the arm and the anterior ventro lateral plate, which can be determinerl in specimen No.. 1, shows that not only are we dealing with a Bothriolepis, but is also of essential importance in determining the species. a task that is naturally difficult with such incomplete remains.

We involunlarily think at first of Bothriolepis canadensis Wnit., which is so common at Scaumenac Bay in East Canada, in strata of something like the same age.

Closer comparison, however shows me that the form from Ellesmere Land cannot be identified with the former. The latter differs from typical specimens of $B$. Canadensis by its sculpture, which consists of a network of fine ribs without nodes, and by the short form of the anterior ventro and dorso lateral plates.

In a small collection made by Dr. O. HoLtedsir, Lecturer at the University of Kristiania, during one of the excursions of the International Geological Congress in Canada 1913, to Scaumenac Bay, and which he subsequently presented to the Palaeontological Museum of Kristiania University, we find, however, small specimens of $B$. Canadensis, shorter and broader in form than the typical examples. The sculpture approaches very closely to that which is characteristic of the remains described here.

At the same time these small and presumably young examples agree in other respects with the typical form, and can scarcely be separated as a special species. The said characters do not seem, therefore, to be as constant as assumed earlier, and thus cannot be employed with certainty in distinguishing it from other forms

There is, however. another character that can lie employed in the determination of these fragmentary remains, viz. the relation between the length of the proximal part of the arm, and that of the anterior ventro lateral plate. This relation must be fairly constant and may therefore be assumed to have great systematic iniportance. Unfortunately it is not possible to determine the whole length of ihe anterior ventro lateral plate in the specimen in question, (No. l). It seems, however, to be sufficient that we can determine the length from the posterior point of the plate to the cross rib that runs inwards from the brachial joint on the inside of the plate.

The following table shows this relation in the forms before us from Galgeolden, B. canadensis, Whiт. and a third form A. hydrophila, Ag. from Scotland. 
In the rase of b. canchensis the measurements are partly determined from examples from Seammenae Bay, partly from 'Traguar's reconstruction, and in the case of B. hydrophila from 'Traudalk's r.reellent illustrations and reconstruction.

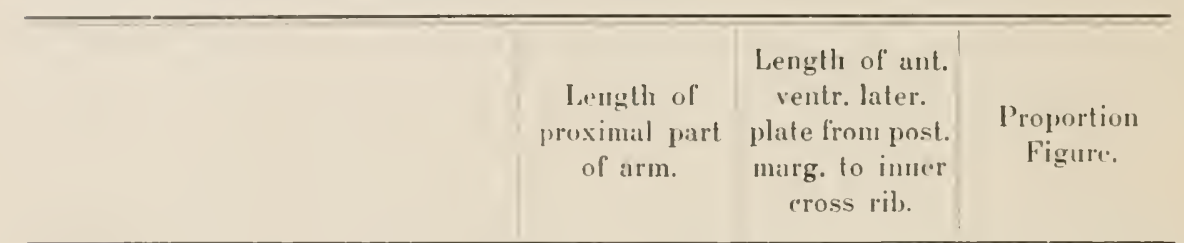

1. Form from Galgeodden, Ellesmere Land

2. B. cunadensis Wurt. Specinen from Sraumenae Bay . . .

3. B. canadensis Whit. 'I'raglatr's reenstrution

4. B. hydrophile Ati. Traguaris reconstruction

\begin{tabular}{|c|c|c|c|c|}
\hline 19 & $\mathrm{~mm}$. & 33 & min. & $1: 1.74$ \\
\hline 12 & $"$ & 58 & $"$ & $1: 1.3 \mathrm{~s}$ \\
\hline 2 &. & 31 & " & $1: 1.27$ \\
\hline $17-18$ & $n$ & $31-32$ & $"$ & $1: 1.5$ \\
\hline
\end{tabular}

As will be seen, the form described differs very considerably from I;. canadensis Whrt, lut agrees ahmost entirely with B. hydrophila Ag. which is known in excellent specimens from Dura Den in Fifeshire, Sintland in the Upper Old Red Sandstone.

Since also according to 'TraugarR's description the sculpture, the shorl and broal form ol the anteriol hody plates, and the size on the whole agree in the lwo forms. I may presune that the remains lrom Ellesmere Land are either identical or nearly related to B. hydrophila Ag. I have not heen able to discover any Anerican form showing closer agreement. 'The most nearly related appears to be B. canadensis Wurt which, however. has consilemal,y shorter arms.

It is difficult to determine exactly whether the fragments with roarsel

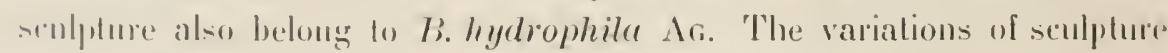
and dimensions in the case of B. cancadensis Whor show that these franments maty possiluly belong to the same form as the others. One frasment, lowever, shows so roarse and so markedly modose ribs. Hat it ran suracely belong to the same species.

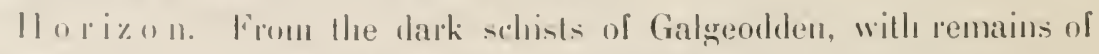
plauls. - and from the fish lorizon of Skrap Valley.

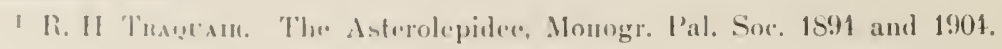




\section{Bothriolepis (?) sp.}

(PI. VIII, lig. 7).

An interesting fragment of a large Asterolepide, (S. I. 5-6), is found from the locality called S.O. Haken on the east side of Goose Fiord, where the rocks appear to consist of a light grey, hard sandstone. Unfortunately the specimen is very defective, and does not lend itself to illustration. I will therefore content myself with a brief rescription.

Description. It is a portion of an angular, bent body-plate, presumably an anterior ventro-lateral plate. The length is about $75 \mathrm{~mm}$. As the specimen before us is merely a fragment, this measurement is only a portion of the real length of the plate, which may be estimated as at least $100 \mathrm{~mm}$. The breath of the ventral portion of the plate in the anterior part is $25 \mathrm{~mm}$. and backwards this increases to $30 \mathrm{~mm}$. The breath of the lateral (rising) part is about $65 \mathrm{~mm}$. at its maxinum. The thickness of the plate is about $2.5 \mathrm{~mm}$.

On the inner side. which is best exposed, we observe a powerful cross rib on the narrower part of the plate, - which latter I have taken to be the ventral. The sculpture cannot be seen distinctly, but it appears to be a coarse, nodose Bothriolepis sculpture. The structure, which is seen on Pl. VII. fig. 7, is coarse, but agrees closely with that which is common in Bothriolepis; it appears distinctly on comparison with Pl. VII. fig. 8, which gives the structure of $B$. canadensis.

Some quite small plate fragments with very coarse Bothriolepis scupture, from the fish horizon in Skrap Valley, possibly belong to the same form. A larger fragment (S. I. 34-36) which lies in a red sandstone. may also be assigned to the same class, although with sone hesitation.

Observations. We are here dealing wilh fragments of a large Asterolepide, the body armour of which, judging from the large piece from S. O. Haken, may be assumed to have been $23-25 \mathrm{~cm}$. in length, or thereabouts. It is thus a form that attained to approximately double the size of Bothriolepis canadensis, Whiteaves, or about thrice the size of the little form (described above) B. cf. hydrophila AG. Judging from the sculpture the former has also been a Bothriolepis form, the more exact classification of which cannot be marle at present.

Hor izon. 'The light grey, hard sandstone at S. O. Haken on the east side of the inner part of Goose Fiord, and presumably also from the fish horizon in Skrap Valley. 


\section{Holoptychiidae. Holoptychius Scheii new specier.}

(I'I. VIII. figs :3-4).

In my material there are several sales of a large Holoptychins form all from the fish Imrizon at Slinap Valley. 'Two only of theso fromit of aletailed sludy.

Description. A lange, hroal, elongated scale (S. I. 26). almost completely preserved. (PI. VIII, lig. 3).

The hreadth is $44 \mathrm{~mm}$, lenght $32 \mathrm{~mm}$. As the seale is somewhat incomplete in the anterior portion and on the right side, the actual lrealth and length may presumably lie estimated at 45 mm. and 35 mm. respectively: 'The ormamentation of the exposed part consist of regular ribs. alout $1 \mathrm{~mm}$. in breadth. The two midtle ones are sub-parallel. lunt the others are bent and tum their convex side inwarls. They thus diverge towards the back margin. In front these regular ribs are supplanterl ly irregular elevations, which are comparalively hoader than He rilss.

2. A little siate (S. I, 2:3), represented in PI. VIII, Ilg. 4. It is almosl cirrular with a diameler of ahout $15 \mathrm{~mm}$. The form and sime of the exposed part are unipue. for the latter extends at least $11 \mathrm{~mm}$. forwards. The rils are powerful, and not quite 1 mon. in lireadth; they branch oul dichotomons forwarls. On this soale, lon, the outer ribs diverge towarks the posterior margin. The original rovered portion of the scale is finely stimed.

Observalions. These lwo best preserved Holoptychins scales. and Ilerefore the most minutely described, must undoubtedly be assumed fo betong to the same forms. It is true, these sables differ considerably as regards size, form and ormamentation, lut as A. Somtu Woomwakn promts ont, Hor scales vary very murls even in rlifferent parts of the same specimen. As they entmely agree in the lackwand diverging ribs, I refor them to one and the same form. It seems to me that the large scale was siluated on the sille of the fish, whilst the stmall onr possibly leetongerl to the dorsal line only.

To junge from thene lwo scales the Eillesmere form is most mearly

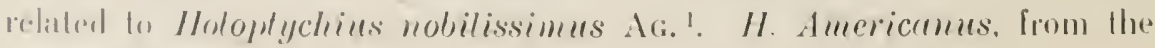

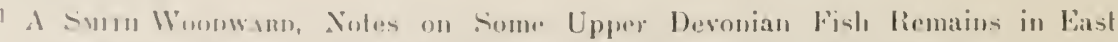

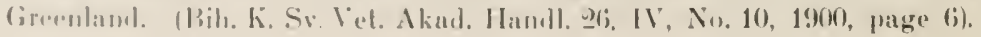


Catskill and Chemung, New York and Pensylvania, tirst described by Leidy, is also nearly related; Sмтти Woodward regards it is almost identical with the preceding 1 .

The form describerl differs fron both of the aloove by the ormamentation of the exposed part of the scale. The ribs are, in fact, divergent towards the posterior part, instead of being sub-parallel or even convergent, as in the case of $H$.nobilissimus (Americanus). In front the regnlar ribs are replaced as a rule by irregular elevations (tubercles).

I must therefore consider it a new form, and I have named it after Per Scher, the geologist of the 2nd Fram Expedition.

Horizon. The fish horizon of Skrap Valley.

\section{Holoptychius cf. tuberculatus NEwB.}

A fragmentary scale (S. 1. 27), which as is clearly shown by some of the exposed part, differ's considerably from the scales described as H. Scheii. The ribs are almost completely replaced by tubercles. The specimen reminds one to some extent of the scales which Newberry depicted and described as Holopt.tuberculatus?. It might however be regarded as a portion of a shell belonging to $H$. giganteus $A_{s}$, in which the ribs may be markedly replaced by tubercles. This form, too, has been found before in America in Upper Devonian strata.

The delermination is thus doubtful.

Horizon. One fragment from the fish horizon in Skrap Valley.

\section{Glyptolepis cf. paucidens AG.}

(Pl. VIII, figs 1-2).

Besides remains of Holoptychius, my material contains scales of a Glyptolepis form. We see partly the back (S. I. 25 b) with fine, concentric lines of growth (fig. 2), and partly the front with claracteristic ornament, as a rule batly preserved. I propose to describe the best preserved specimen somewhat more closely.

1 A. Surti Woodward, Notes on Some Upper Devonian Fish Remains in East Greenland. (Bih. K. Sv. Vet. Akad. Handl. 26, IV, No, 10. 1900, pags 4-5).

2 J. S. Newberry, The Palaeoz. Fishes of N. America, 1889, p. 101, Pl. XIX, fig. 14. 
Description. I. A fragmentary scale (S. I. 25 a), with front side well preservel. (Pl. VIII, fig. 1). In the figure the scale is turned up and down in orter to show the fine ormamentation with greater effert.

'The hameter of the scale must have been about 15 mm. Very fine and sharp ribs, which are smmewhat intermpted, rum in a slightly arched and convergent diection towards the back.

'The inner ones divide forwards. The ribs continue forwards in fine hor-s-shoe shaped tubercles, which appear to form a narow zone shaped like a half moon.

In front of the latter we notice the remains of radial ribs, with very fime tubercles. which most probably have occupied the central part of the portion of the scale that was originally covered. At the sides the latter shows a very fine, grained ornamentation, which can also be seen belween the ribs.

One remarkable fealure of this scale is the circumstance that the rils are slightly arched and converge posteriorly, and that they do not appear to be arrangerl quite symmetrically.

2. On other scales, the surface of which unfortunately is badly preserved, the ribs have a more sub-parallel course and do not appear to be so closely situated as in the case of the previous specimen. The largest scale appears to have had a diameter of about $20 \mathrm{~mm}$.

Observations. As will be seen, these scales vary to some extent with respect to ornament, but not so much that they camnot be referred to the same species. which probably ma be identified wilh rilyptolepis pancidens AG, The two species, Gl. leptopterns Ag. and pancidens Ag. Which have about the same extent in Europe appear, however, to be difficult to differentiate when we have only isolated saales. In A. Surtu Woomans's Calalogue', the scales of hoth forms are described ly the same words. Judging from the scales we are in possession of, i. e. Gl paucidens from the Orkney Islands, and from PAxnen's illustration of Gl. leptoptems, the resemblance is greater in the cirse of the former, which apprears to have finer and more mumerous rilis thinn the latter.

Glyptolepis quebecrnsis IVur." is much smaller than the above and is therefore ont of ronsideration.

1 Vol. 11, 1., 3332 and :336.

3 Fos. Fishus of the Devon. Rorks of Camada. Trans. Roy. Soc. Cant., Vol, VI. 
Horizon. More or less conplete scales appear to he somewhat common in the fish horizon of Skrap Valley. One fragment from the dark schists of Galgeodden, (S. I. 103) also presumably belongs to this category.

\section{Teeth with Dendrodont Structure.}

(Pl. VIII, figs 7-9).

From the Fish horizon in Skrap Valley we have a series of teeth with dendrodont structure, which may be assumed to belong to the forms of which the scales are described above. The dimensions of the specimens vary to some extent. I have depicted some of the hest preserved, and will now give a brief description of them.

Description 1. Fig. S, Pl. VIII, shows a large, powerful tooth, (S. I. 13) the point being broken. The length is $19 \mathrm{~nm}$., the greatest breadth about $S \mathrm{~mm}$. The cross section is round, although there are distinct wedge-shaped edges.

Another example resembles the foregoing, but increases more markedly in breadth below.

2. Quite small teeth, one of which (S. I. 42 b) is shown in fig. 7. The type resembles that first described, but on the average is more flattened.

3. Long, slender teeth of a distinctly bent form (S. I. 42 a). The cross section is almost round at the base, but towards the apex becomes more and more oval. It is very sharply pointed. (Fig. 9). The length varies from $9-11 \mathrm{~mm}$. long, the greatest breadth $2-3 \mathrm{~mm}$.

O bservations. Microscopic preparations have convinced me regarding the dendrodont structure, which moreover is also indicated by the close, fine, longitudinal ribs of the upper surface.

The largest tooth mentioned in 1 reminds one of the type which A. Surth Woodward ${ }^{1}$ classified with Dendrodus biporcatus Owen, and which he considers to belong to Holotychius gigantens AG. I therefore believe that they must be accepted as teeth of Holoptychius Scheii, nov. sp. The quite small ones which are mentioned in 2 , might be regarded as marginal teeth of the same form. Those mentioned in 3, agree on the whole with the type classified by Surth Wondward² as

1 Catalogue, Vol. II, p. 338.

2 Do. p. 399. 
Jendrodus strigutus. Owex. Possibly they are teeth of the Glyptolepis form described here.

My material also contains a fragment of a jaw with remains of tecth. (S. 1. 9), unfortunately badly preserved (Pl. I'III. fig. 5). At the left we see a number of small marginal teeth, and inside remains of the large teeth. The form of the teeth cannot be seen, but the size indicated that they belong to a Holoptychins form, which must be issumed to be Holoptychims Scheii new species.

Horizon. The fish horizon of Skrap Valley.

\section{Rhizodontidae.}

Tooth with rhizodont structure.

(PI. VIII. fig. (i).

My collection contains one tooth showing another structure to that described. The tooth, (S. I. 4) appears to have been about $10 \mathrm{~mm}$. long. and $\overline{5}$ mm. liroad. It is bent slightly concave. The upper part of the tonth is quite smooth, and at the base we see distinct, coarse ribs. The structure must he assumed to be mizodont, hut I cannot renture to state to what species the specimen helongs.

Horizon. From the light, hard sandstone at S. O. Haken, on the rast side of Goose Fiord.

\section{Osteolepidae.}

\section{Osteolopis ip.}

My naterial also contains a few smatl, rhombic scales, which ajpear to belong to an Osteolepis form. The upper surface shows the same extremely fine pores that charaterise Ostrolepis. The microscopic structure atso agrees. I have also other parts of steleton forms that appear to helong to the same species.

Il 6 r i o n. The fish horizon of Slirap Valley.

\section{Stratigraphic Results of Series E.}

\section{Distribution of the Fauna in the Fossiliferous Horizons.}

The remains of the famm which are tescribed in the preceding frages are thus distributed in the Sandstone series D.; - 
I. The grey and red, often conglomerate sandstone in the middle part of the series with

1. Psammosteus arcticus new sp.

2. Psammosteus complicatus new sp.

3. Great Coccosteomorph.

4 Bothriolepis cf. hydrophila AG.

5. Bothriolepis(?) sp. Large form.

6. Holoptychius Scheii new sp.

7. Holoptychius of. tuberculatus NewB.

s. Glyptolepis cf. pancidens AG.

9. Teeth with dendrodont structure, presumably belonging to the preceding Hotoptychiidae.

10. Osteolepis sp.

11. Phtonia ef cylindrica Hatr.

12. Badly preserved remains of plants.

II. S. O. Hakent grey sandstone on the east side of Goose Fiord, probably still higher up in the series, with

1. Bothriolepis(?) sp. large form.

2. Tooth with rhizodont structure.

III. The dark schists of Galgeodden somewhat higher in the series, with remains of plants and

1. Bothriolepis ef. hydrophila AG.

2. Glyptolepis of. pancidens AG.

These strata correspond to the dark schists of Bregnekloften, with their wealth of plants.

IV. 'The conglomerate layers of Bregnekloften, just above the preceding, with remains of plants and one or two doubtfull fragments of fishes.

As we observe, the faunas in the higher horizons show almost no new elements. The difference consists mainly in the circumstance that only one or two of the numerous forms that are found in the lowest and abundant strata are found in the upper. We cannot therefore divide the sandstone series into several faunic zones on the basis of the fauna. This impoverishment of fauna, hovever is of interest, in that it gives us an indication of the biological changes that have taken place in those regions. 


\section{Changes in Facies and Biological Conditions.}

Even in the uppermost part of the underlying marine series 1) we observe the commencement of distinct changes of facies. In his pretiminary report Schei remarks on this point (page 7 ).

"Above these layers (zone Dg) there are banks of pmer limestone Dh, and then again more impure ones, Di. 'The upper layers of Di alteruate with layers of light grey fuartz sandstone, and below with a "lay sandstone, that in places hears a mumber of hadly preserved fossils, amongst which are Lamellibranchiates, Dechenella. sp., remains of Holoptychius etc. At the same time this layer of clay samblone is the last member of series D, which is the firs menber of series E. a huge series of quarty sandstone strata, that form the mombains on hotl sides of the immer part of Goose Fiord". This "samdstone point" famma is an impoverished marine fauna; it is possible that the appearance of an abundance of mussels, presumably a Modiomorpha, and the vccurrence of Holoptychius scales, indicates that even as early as Di we have a brakish water facies.

An mpheaval of this region thus commenced at the end of the perionl in which series D was lepositerl, and continned in the succeeding period. The lumge sandstone serien in series E must in fact be regarded as a continental formation, corresponding as regards its facies to the Catskill of New Yort and Pensylvania, or to the Upper Olal Real in Enrope.

'The fossiliferous borizon in Skrap Valley, with its grey and red, often conglomerate sandstone, now indicates that in the middle of the rontinental perionl there towk place a brief sulsidence with the formation of a new hrackish lake. This is indicated by the appenrance in large fuantities of a small mussel, which mmst he regarted as a deformed form of Phtonia cylindrica Has., which otherwise is foumd in marins facies. With the latter wr find remains of phats, often hadly preserved, and remains of a somewhat abumdant fish fanma. The remains are very fragmentary and consist of various detached soles and fraguents of plates, which have heen divided amd amshed into small pieres. and then emberded promisconoms in the hanks of somblotone, which are often of a conglomerate rharacter; hut the sculpture of the sperimens is as a rule so well preserval that a detromination is possible, and we ure able to form a romepplion of this remarkable aurl long extinct animal life.

'The most fantastic forms in the latter belong lo the Bolleriolepis family. both a small and large form were fouml. The last one 
was a thickly armoured, powerful species, about $0.5 \mathrm{~m}$. in length. The posterior body was probably, — as Pathen believed - bare and without scales, the anterior hody on the other hand being protected by a hard, almost rigid armour. The mouth was without jaw, and presumably a suction mouth. A remarkable feature was the long arms, provided with a kind of elhow, the distal portion of which in this family is almost pointed like an awl. Many attempts have been made at solving the problem of these extraordinary arm-like, jointed processes, that do not appear to be homologous with the real pectoral fins of the fishes. ABeu ${ }^{1}$ attempted recently to explain them as an apparatus for catching prey, which operated in a manner similar to that of the claw of a lobster or the arms of the Mantides. According to Traquan's investigations it appears to be doubtful whether the arms in question really possessed such a large range of movement as the instruments of capture in the case of living types. It seems to me to be more reasonable that the creature employed them to fasten itself to its prey, which then could be sucked at leisme $\%$ The bare posterior body indicates that it was a ground fish. - as has been supposed in the case of Coccosteus, - and that it usually lay half buried in the mud.

The two Psammosteus forms, ray-like, strongly armoured, jawless fishes of considerable size, were presumably still more markedly gromnd fishes. The armour was beantifully ornamented with fine denticles of highly polished enamel, and the tail was armed above and helow with powerful fukra. which must have served for defence. A large coccosteomorph fish, with the anterior hody even more strongly armoured than the preceding, was presumably less common than those already mentioned. The thickness of one of these osseous plates is $0,7 \mathrm{~cm}$.

The hard and massive osseous plates in the dermal sketeton of these fishes, was undoubtedly a very effective protection against an enemy. The most dangerous of the latter was the great Crossopterrygii, of which several forms have been found, fishes of a more mormal appearance which were proterted ly means of thick scales of enamel. The largest belonged to the Holoptychius Genus, was perhaps a metre in length, with beautifully scuptured scales of a greater thickness than that of any existing fish. The long tuft-shaped pectoral fins gave them a remarkable appearance. In these formilable rapacious fishes the jaws were armed with a double set of teeth. The outer row consisted of small flattened teeth, the inner one of more extended, large and wedge-shaped teeth, with

1 O. Abcl, Gründzüge d. Palaeubiologie der Wirbelliere, 1912, p 599.

2 Cr. Kokes, Pisces, Zittel, Grundzüge der Pal. 2 Edition, II, 1911, p. 37. 
which this rapacions creature presmmably could ansh the ranial and osseous plates of the armoured lishes.

Cilyptolepis, which with Holoptychins forms appear to have been ypute rommon in these regions. was closely related to the above. The latter were fishes of a less powerful huild. with more slender leeth and romol. thin seales of enamel.

Finally, certain small Osteolepis forms appear atso to have lived there. They were powerful rapacious creatures, not exceeling about $\because 0-30$ (m. in lenghth.

The fishes which I have lescribed confims the opiniom which I have alrealy put forwarl, that the fossiliferous strata at Skrap Valley were deposited in a large hrackish lake, possibly an estuary in which marine and fresh water fishes mel.

The tiny mussel, Phtonia, entered from the sea, adipled itself to altered conditions of existence, and multiplied in huge puantilies. Some of the fishes, particularly the Holoptychius forms also indieate a free connection with the sea, for their remains are found holls in furely continental formations (lake and river deposits) and in marine sediments: it is therefore matural to assume that like several forms of the present lime, these creatures migrated from the sea to the rivers. 'This is also indicated by their wide exlent over the whote of the northerm hemisphere in resely relaterl forms.

1) ther forms appenring, however, were presmmably gemuine fresh water fishes. which like many of the recent forms were able to adaph themselves to the life in hrackish lakes. This feature concerns prossibly rilyptolepis. but expecially Osteolepis, Psammostens, and Bothriolepris.

'There is however one point that I desire to emphasise. Il is not proved that a fishes has lived in a hackish water lake hecause we find its remains in the sediment. The river or rivers that flowed throngh such a region may have carried the hody with it and deposited it in a different hahitat. los such rasen there will ahways be a revtan ammut of umcertainly.

The wher fossiliferous hurizons that are to be found higher up in the arries present a different aspect to that of the abundant fish horizon of Skiap, Valley. None of them show traces of marime mussels, and the

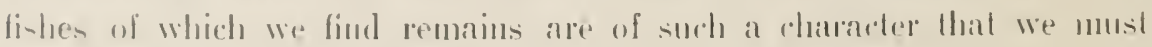

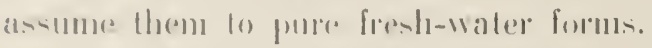

la thr dark schish of Galgeodden with remains of plants. which ilpreale lo lor quite foral in appearance, we find simply the small bothrinlepis and a scalc of Glyntolepis. Al S. (). Haken there are only 
remains of the large Bothriolepis and one looth of a rhimodont fish, which I have been unable to determine more exactly. I therefore assume that we are here concerned with pure lacustrine formations. The sea must therefore be assumed to have retired still farther.

\section{Conditions of Age.}

As previously emphasised, (p. 16) I assume in contrast to O. E. MEYEr, that the uppermost part of the marine series D is not High Upper Devonian (Chemung), but must be accepted as belonging to the lower part of the Upper Devonian, or preferably as a transition stratum from Middle Devonian to Upper Devonian. This view is confirmed by the fauna of Series E.

In the middle of this series we find the abundant fish horizon of Skrap Valley. Amongst the forms found there, special interest must be attached in this connection to the tiny mussle Phtonia, which appears in such large quantities, and which seems to be identical with or at least closely related to Ph. cylindrica HaL from the Hamilton group in New York. Amongst the fishes certain forms such as Holoptychius and Bothriolepis, according to our present knowledge, do not give any more definite information than that we are concerned with L Tper Devonian strata. Others on the contrary, distinctly indicate that this horizon does not belong to the upper part of the Upper Devonian. Thus Psammosteus appears in Russia in the Middle Devonian (Poland) and in the lower part of the Upper Devonian (Baltic Provinces). In Scolland a fragment was discovered in the Middle Devonian (Caithness flagstones of Wick). The third region in which this family is known is Spitzbergen; it was there found in the fish horizon at Mimers Valley of presumably Upper Devonian strata, but of no definitely delermined age. The Glyptolepis scales entirely agree with the European species, (leptopterus AG. and pancidens AG.) which are typical of the Scotch Middle Devonian series of Old Red (Orkadian). In the Baltic Provinces the genus is found sometimes in the lower sandstone of Middle Devonian age, and at other times in the upper sandstone which must be regarded as Low Upper Devonian. In Canada, a kindred form occurs in the fauna of Scaumenac Bay, which must be considered to be Upper Devonian, although no closer determinaton is possible. Frecr ${ }^{1}$ places it with the older Upper Devonian.

1 Lethaea palaeozoica, Vol. II, pg. 232. 
A. is known. Osteolepris also helongs to the Iypical Middle Devonian

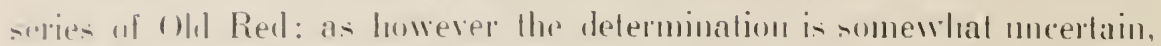
ne grealt strens an he placed mpen it.

In my opinion lhe knowledge convered in llae abore undieafrs that the fish horizon at Sklap lialley cannot he fratlethed with Chemumg hul is of older Upper Devonian

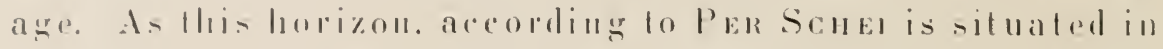
the millle of Scries E. We must assmme that this series with ils continental facies rommenced in the lowest part of Liper levonian.

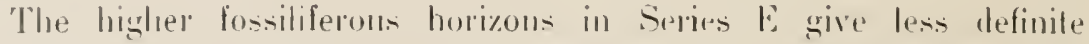
indirations of Leprel' Devonion age. 'The lorizon in Bregnekloften tor, with its abmolance of plant remains, which aceording to PER Scmen is contemporaly will, the diuk schists of Galgeodlen, with Bothriolepris, c.f. hydrophiln As. and filyptolepis, gives us in Natnonst's opinion no rer! definite determinalion of age.

It is therefore not pussible to determine with exatibule low high IIy in the Uprer Devonian Series E goes. It is rery mobable that this contimental period lasted there until the end of the Devonian age, and possihly even motil the Lower Carboniferons.

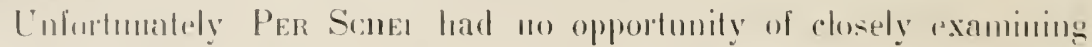

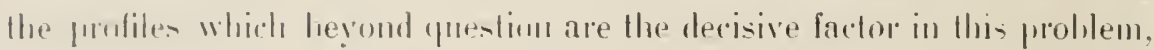
vir. the profiles northwirds to Great Bear Cape, where the abmodant

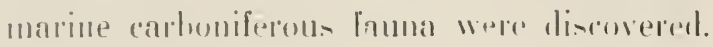

\section{Zoogeographical Conditions.}

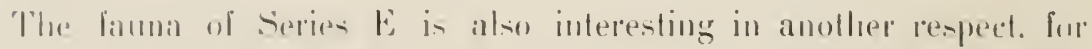

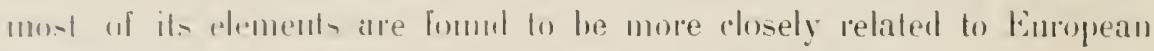

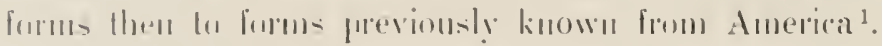

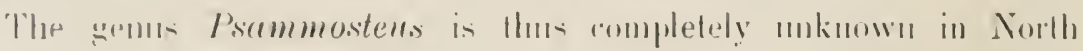

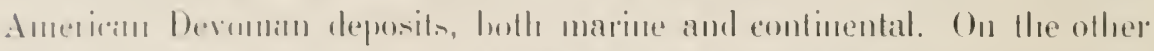

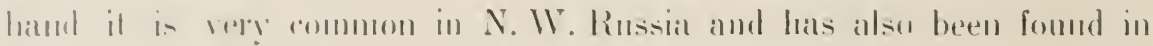
N. Sintlind and on Spityluergen.

The deforminable and-mall Bothriolepis diflers from known Ameritan

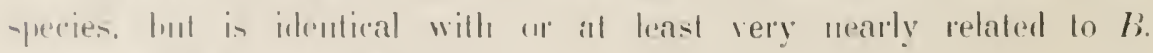

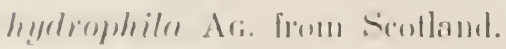

Vifle in purtienlar: A. Sintru Wompwan, Catalogne of Foss. Fislaes in the Britisle .1111-1.1111. II.

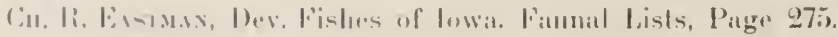


As regards the two proved Holoptychius forms one belongs to at new variety which is most nearly related to $H$. nobilissimus Ag., which appears to be extended in the Ohl Red both in the eastern and the western portions of the northern hemispliere. It thus affords no definite proofs. 'The other appears to be identical with $H$. tuberculatus Newp., which occurs in the Katskill, but may also be considered as H. giganteus Ag. which occurs both in N. America and in Europe. (Belgium, Scotland. N. W. Russia and Bären Island.)

Glyptolepis paucidens AG. and leptopterus AG. are highly characteristic European forms which have only one relative in N. Annerica, viz. Gl. quebecensis Whit. in the Upper Devonian of the Quebec Province (Scaumenac Bay).

Osteolepis is quite unknown in the American deposits, but on account of the uncertain character of the remains cannot be given any special significance.

On the other hand, the tiny mussel belonging to the family Phtonia, shows distinct connection with previously known American faunae, being identical or very nearly related to Ph. cylindrica Hall from the Hamilton Group in New York.

The fishes thus appear to have different conditions to this form emigranting from the marine invertebrat fauna.

In the latter case the conditions are quite remarkable, particularly in view of the marine fauna in the Silurian and Devonian series which according to the investigations of $O$. Holtedanl and $O$. E. Meyer show a markedly Anterican character.

The Devonian fish fauna on Ellesmere Land thus appears - at least as regards the greater part. - to have had a different origin to that known in the case of S. E. Canada and the adjoining parts of the United States. They must have had another connection with the faunal province of N. Europe.

The occurrence of the Psammostens forms gires an indication, for they were formerly only known in N. W. Europe, as stated above.

The earliest occurrence is in the Placodern Sandstone of Poland, belonging to the Older Middle Devonian. There are examples in $\mathrm{N}$. Scotland in somewhat later strata, and in N. IV. Russia very commonly in the Lower Upper Devonian, as also in Spitzhergen and Ellesmere Land. According to our present kmowledge it is naturat to explain this in the following manner.

Psammosteus developed in the European province from the Lower Devonian Drepanaspis Gemiundenensis. Whilst the latter was a marine 
form. I'sammostens migrated in Middle Devonian age to the brackish water latien. - particularly Hose of the soulh-eastern part of the morth Alantic mainland, and thence to the fresh water lakes. During He Midhthe Devonnan one form in this manner penetrated into the morth of Scotland. In the lower part of the Upper Devonian it extended little hy litlle along the morthern part of the north Allanlic mainland right up to the eastern frart of the recent Aretic Archipelago of North America. which presumahly formed the morth-western horder of that vast iontinent.

The line of this Arclic extension appears to have played the most significant part in the formation of the fin fauna lhat are lescribed in the present work. 


\section{PLATES}


The phates are photngraphic, some being prepared by Miss Boncombo Lanssix, flranghtsman and photographer to the University, some ly Mr. S. Wonm-Petensex, plootographer.

Reprodurtions armed ont ly the firm Norsk Lystryk og Reproduktionsanstalt in Kristiania.

\section{Description of Plate $I$.}

Macropetalichthys Scheii Ki.n new species from the zone D) h, Gonsefjord, Ellesmere Land. Page 9.

Fig. 1. The ranial shield, sem from above. Snout portion turning downwards. $\times 1^{1}$ 2. S. 1. 107. Palieonlologiral Musenm of Kristimia Unwersity.

Fig. ‥ The cranial shield seen from alove. Snout portion turning upwards. Nat. sizu. S. 1. 107. Paal. Mus. Krist. Univ.

Fig. 3. The eranial shield, seen from right. $\times 1^{1}$.2. S. I. 107 . Pal. Mus. hrist. Univ.

Fig. 4. Nitural mould of right sille, slonwing system of minufe canals on inner

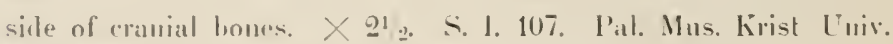

Fig. is. Mleroseope. section of "ranial shieht, right side. Y 3.

Fig. 6. Pint of the latter, more highly magnifiet. $\times 2$. 

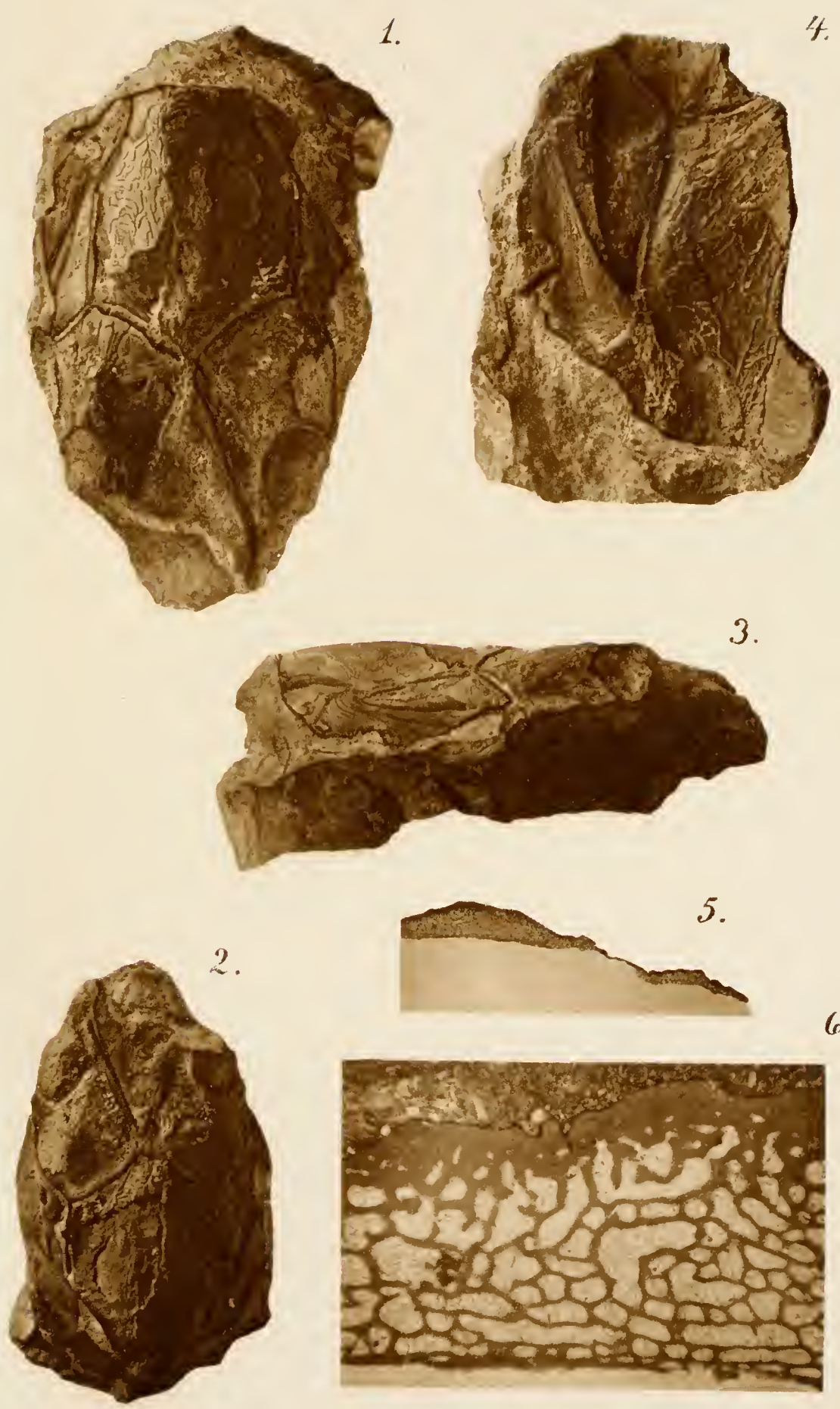

6.

Borghild Larssen phot.

N. L. \& R. 




\section{Description of Plate II.}

Phtonire ef. Ciglindrica Has.. Lpper Devonian (E). Skrap Valley. Ellesmere Lant. Page 20.

Fig. 1. Left valve, withont thell, $\times 1^{1}$ 2, S. I. 43. Pal. Mus. Krist. Univ.

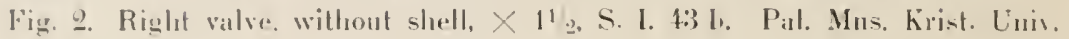

Large Coccosteomorph, Upper Dernnian (E). Skrap Valley, Ellesmere Land. Page :35.

Fig. 3. Somewhat incomplete plate seen from without. Nat. size. S. I. 7. Pal. Mus. hrist. Unis.

Fig. 4. Same seen from wiflin. Nat, size. S. I. 7. Pal. Mus. Krist. Unix.

P'sammosteus areticus hixn new species, Upper Deronian (E). Slirap Vall.y. Ellesmere Land. Pange 2:3.

Fig. 5. Portion of hody plate, $\times$ ‥ S. 1. 90. Pal. Mus. hrist. L'nir.

Fig. 6. Fragment, $x$ 5. S. 1. 69) I. Pal. Mus. Krist. Unis.

Fig. 7. Fragment, $X$ 万. S. I. 81 a. Pat. Mus hrist. Unir.

I'sammostens complicatus hirm new speries, lpper bevmin (E), Skrap Valles. Ellesmere Land. Page 96.

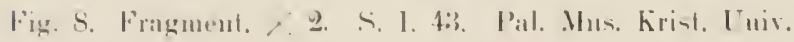

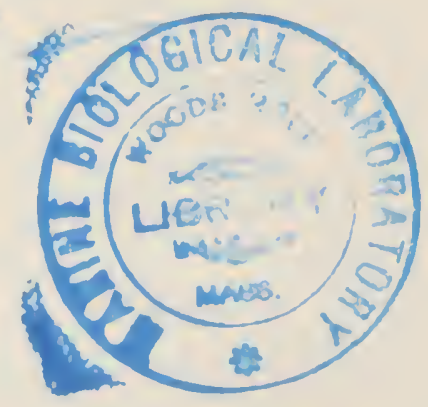


1.
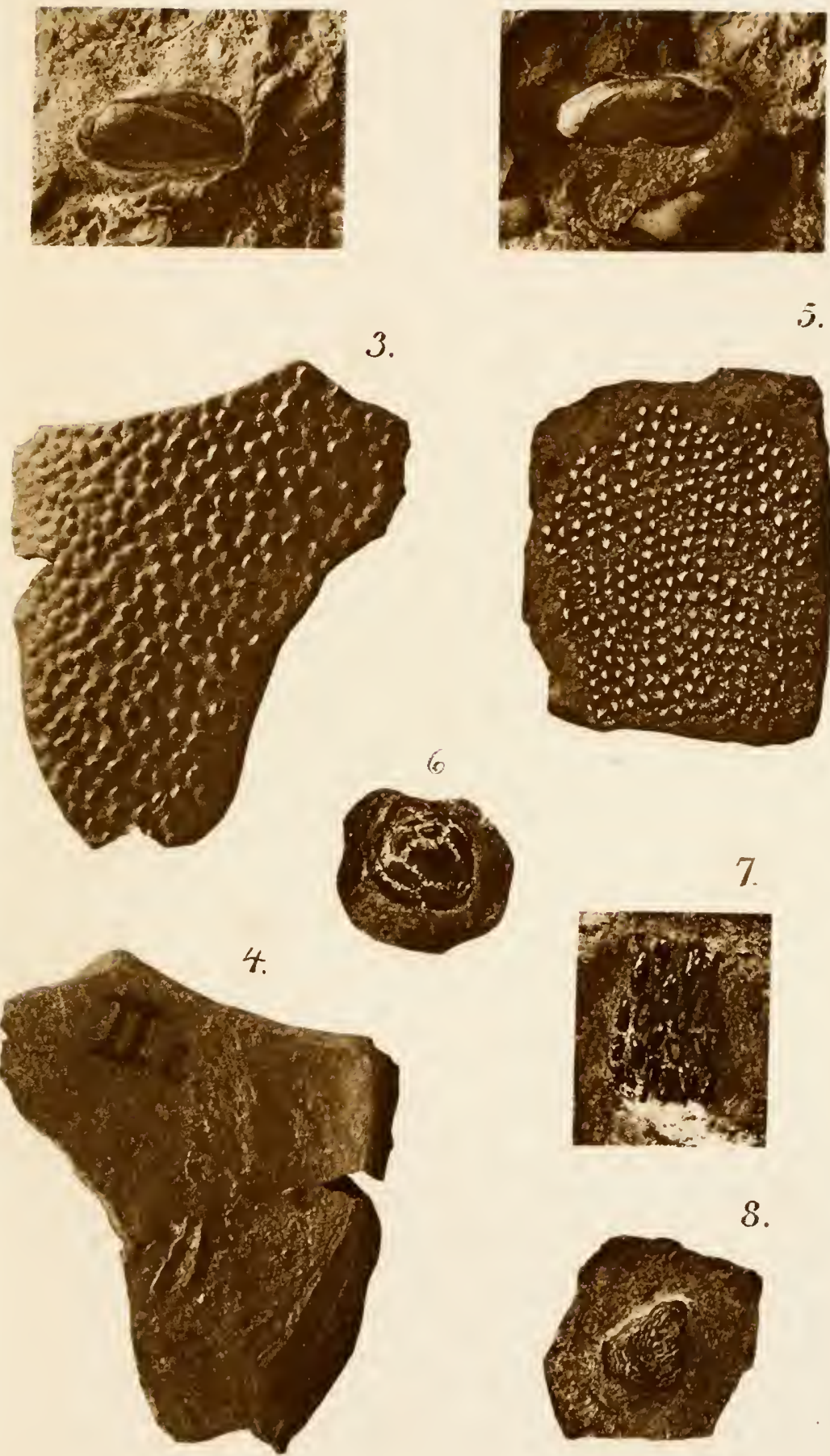

6

5

3. 




\section{Description of Plate III.}

Psrumostens arcticus hi.ro new species, Lpper Deronian (E), Skrap Valley.

Ellesmere Land. Page 23.

Fig. 1. Portion of plate (= I'l. II, fig. 5). $\times 4$. S. 1. 20. Pal. Mus. Krist. Lniv.

Fin. 2. The same. $\times$ 6. Pal, Mus. Krist. Unis.

Fig. 3. Transtersal microscopical section of the latter porlinn, $X \geq 7$.

Fig. 4. Nicroseop. section of a fragment (= PI. II, fig. (6). $\times 40$.

Drepanaspis Gemündenensis SaLïr, Lower Devonian, Gemünden. Formany Pal. Mns. Krist. Luiv. Page 99.

ligg. i. Longitulinal mieroscop. section of horly plate. $X$ 2.5.

Fig. (i. Microsenp. section of denticle. $\times 85$ 

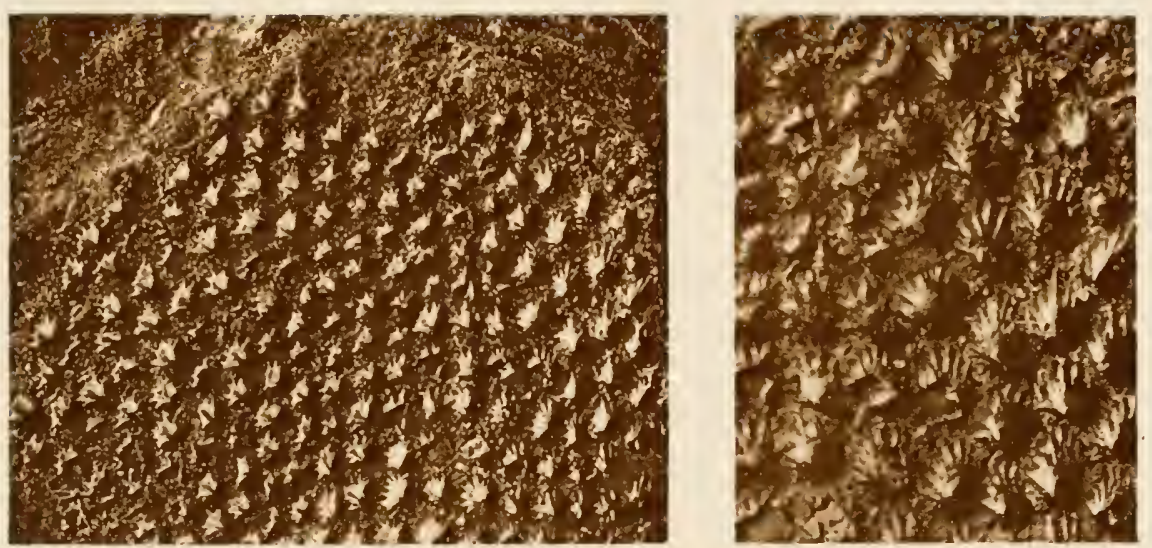

3.

4.
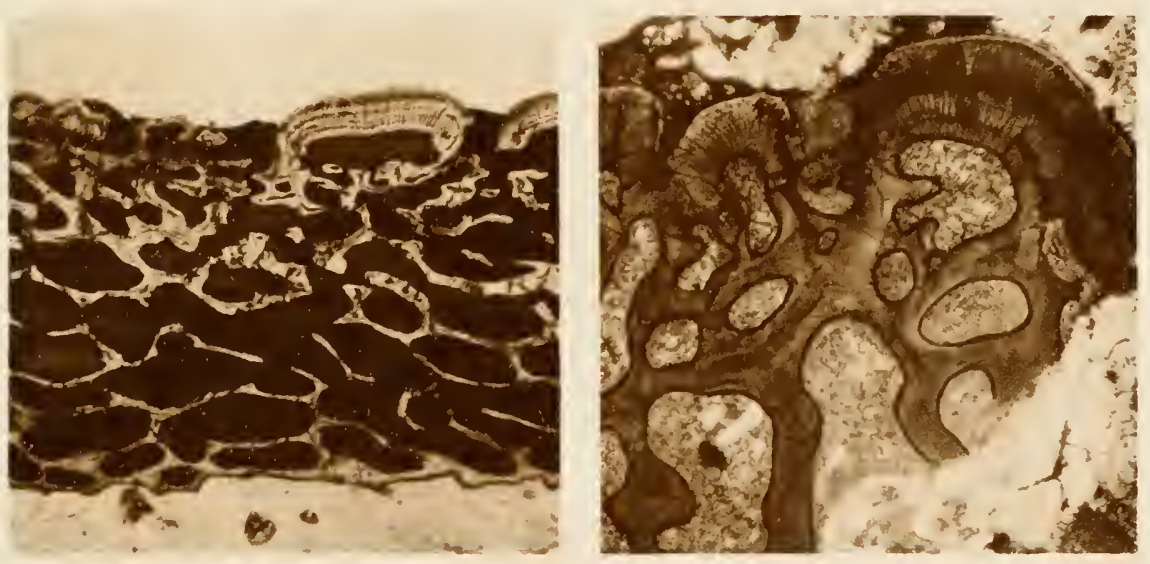

5

6
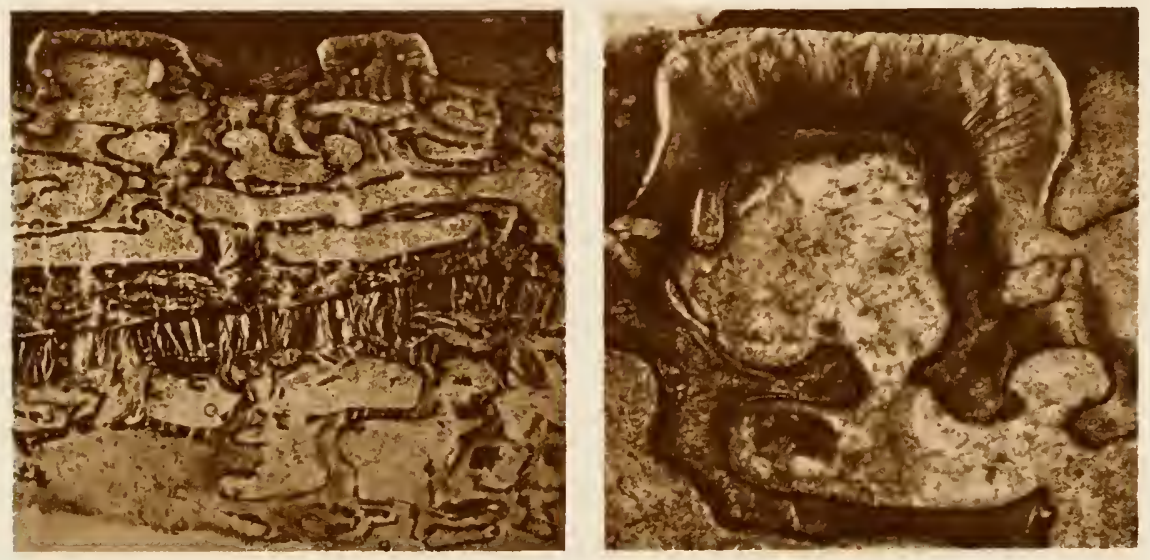




\section{Description of Plate IV.}

Psummostens Maeandrims AG., Upper Deronian. River Aa at Wenden, Livland. Page 36.

Fig. 1. Surfice of a body plate. $X$ is. Pal, Mus, hrist Univ.

Drepanuspis Gemündenensis Scm.̈̈r. Lower Devonian, Gemünden, Germany. l'age 31.

Fig. 2. Surface of lody plate. $\times 6-7$. Pal. Mus. Krist. Univ. 

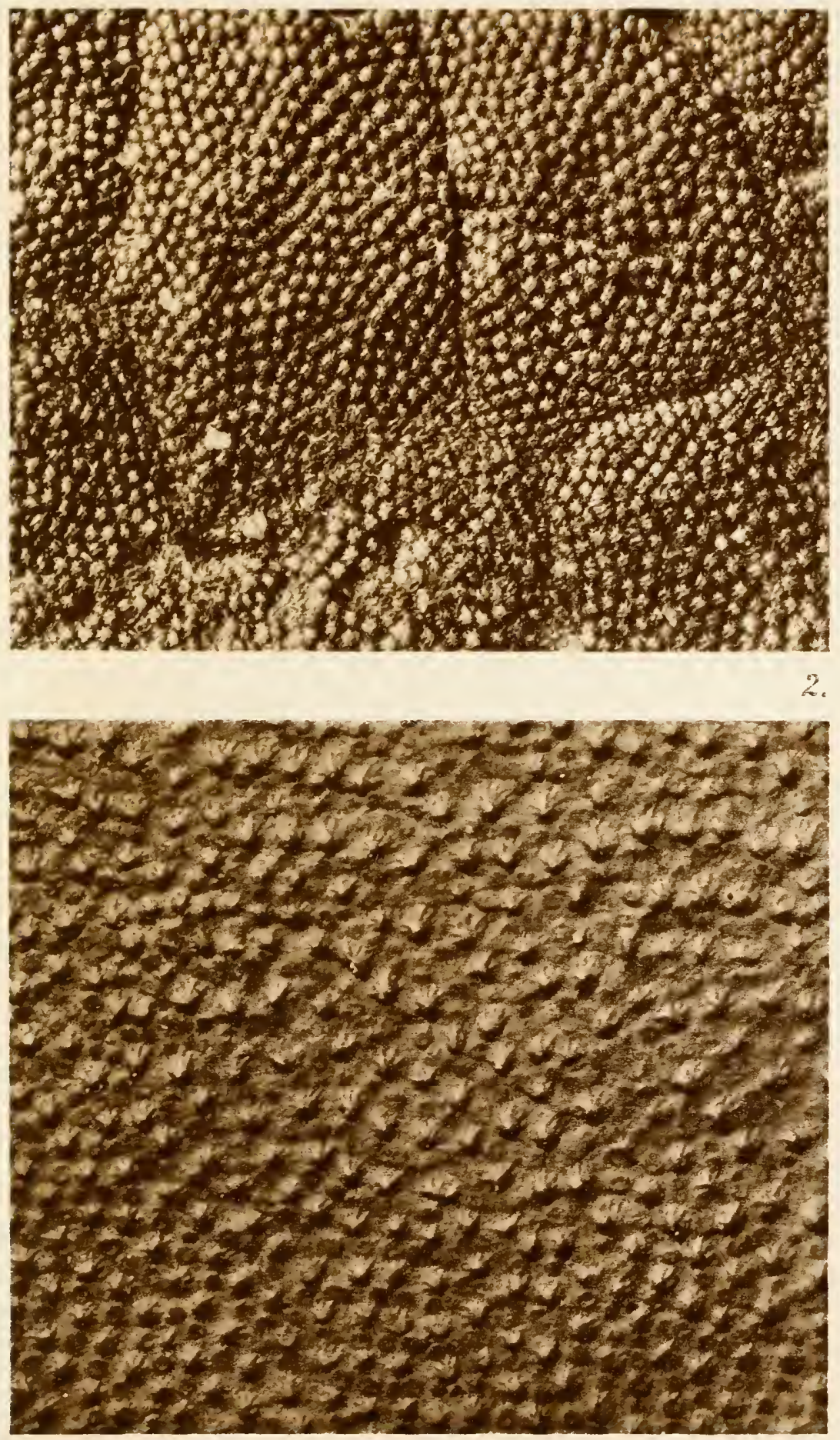

S. Worm-Petersen phot.

N. L. \& R. 
1 



\section{Description of Plate V.}

l'summostens complicatus hian new species, Uprer Deronian (E), Skrap Valley,

Ellesmere Land. Page 96.

Fig. I. Porlim of hody plate with denticles partly preserved. X 1.7. S. I. 13. I'al. Mus. Kirist. Univ.

Fin. 2. Same portion, surface with denticles. $\times 8$. S. 1. 13. l'al. Mus. Krist. Univ.

Fig. 3. Fragment of body plate. $\times 3$. S. 1. 21. Pal. Mns. Krist. Univ.

Psammostens areticus hixn new species, Upper Devonian (E), Skrap Valley, Ellesmere Land. Page 23.

Fig. 4. Fragment of a spine shapred plate. $\times$ 1.2. S. I. Gy. Pal. Mus. Krist. Unis. Fig. 5. Same piece. $\times$ 3. S. 1. 29. Pal. Mus. Krist. Unis. 
1.

3.
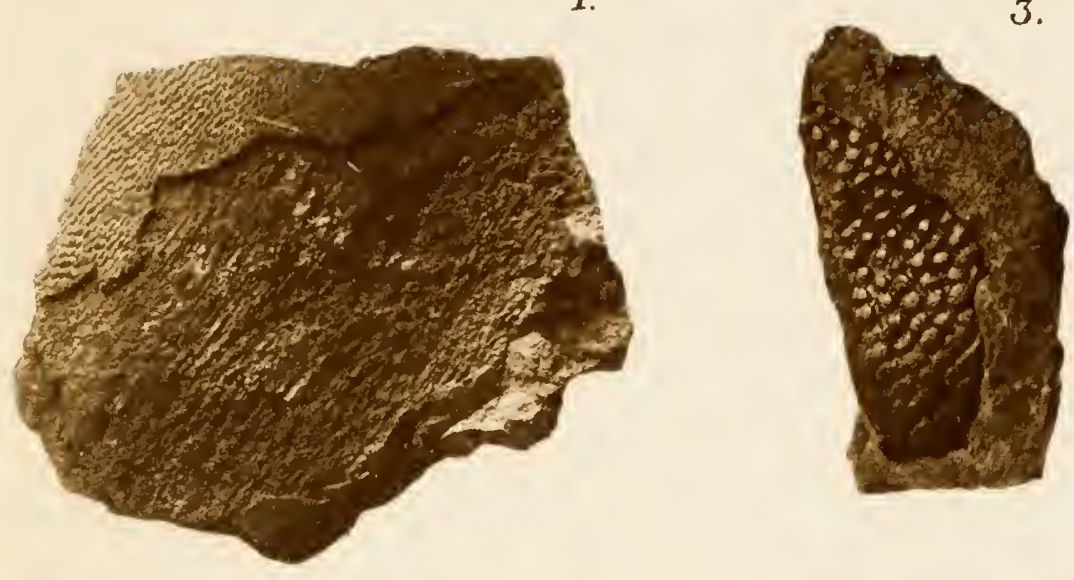

2.

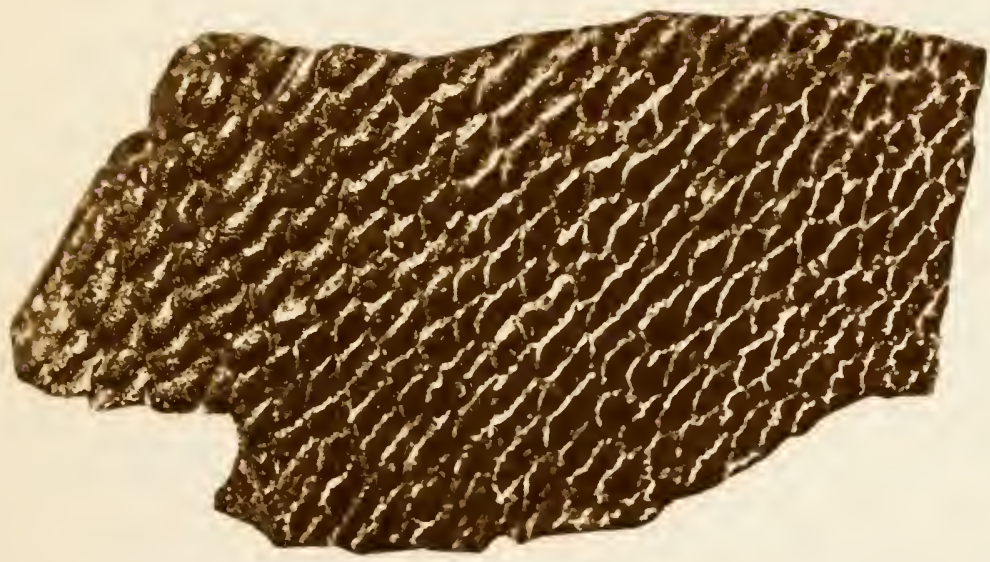

4.

5.
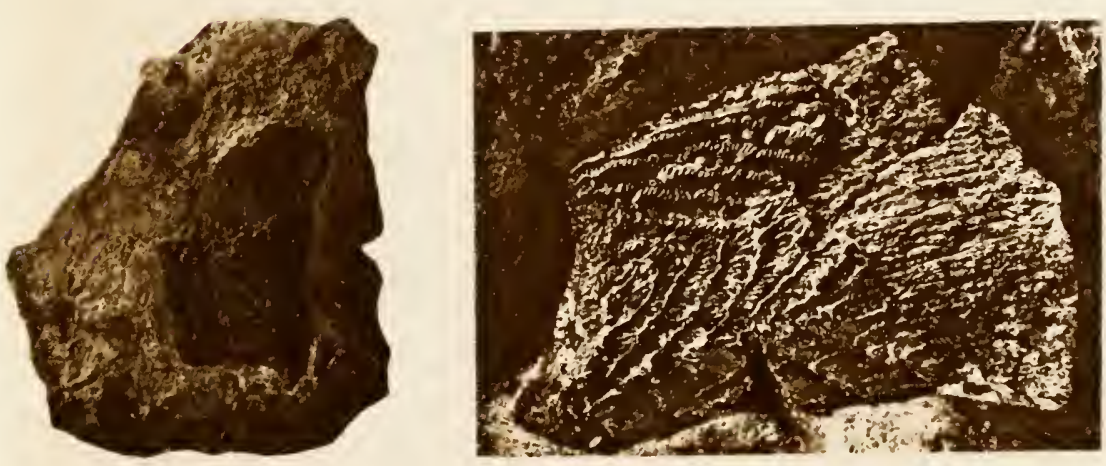

Borghild Larssen and S. Worm. Petersen phot.

N. L. \& R. 




\section{Description of Plate VI.}

l'srommonters compliculus hisa new species, Upper Dernuian (E), Skrap Valley, Ellesmere lanl. Page 26.

Fig. 1. Transtersal microscop. section of upper part of a body plate (PI V. fig. 1). 40. S. I. 13. I'at. Mlus. Krist. Univ.

Fig. Q. Longilulinal microscop. section of same piece. $\times 40$. S. I. 13. Pal. Mus. Krist. Unir.

Fig. 3. Microscop. section of a denticle. $\times$ 80. S. 1. 13. Pal. Mus. hrist. Univ.

Psammostens mandrinus Ak., Upper Devonian, River Andoma, Kurlamb. Page 36.

Fig. 4. Microscop. section of a denticle. $X 80$. Pal. Mus. Krist. Unis.

Fig a. 'Transiersal microscop section of upper part of a body plate. $X 40$. Pal. Mus. Krist. Unis.

liig. (i. Longihndinal microscop. section of se we piere. $\times 40$. Pal. Mus. Krist. Unir. 
1.
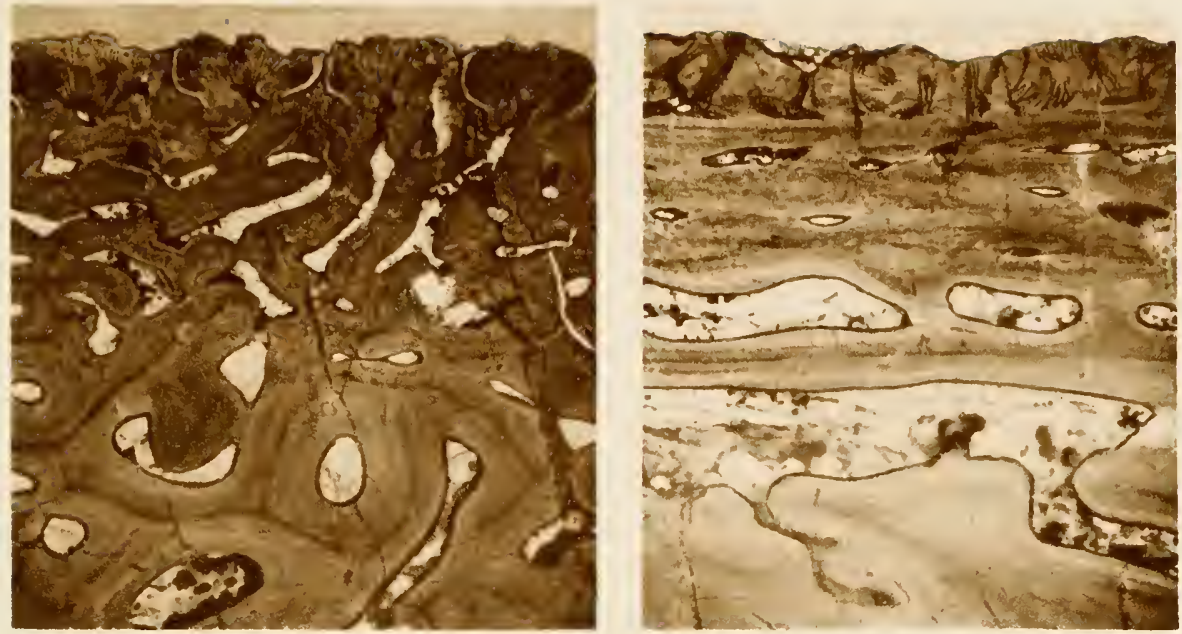

3.

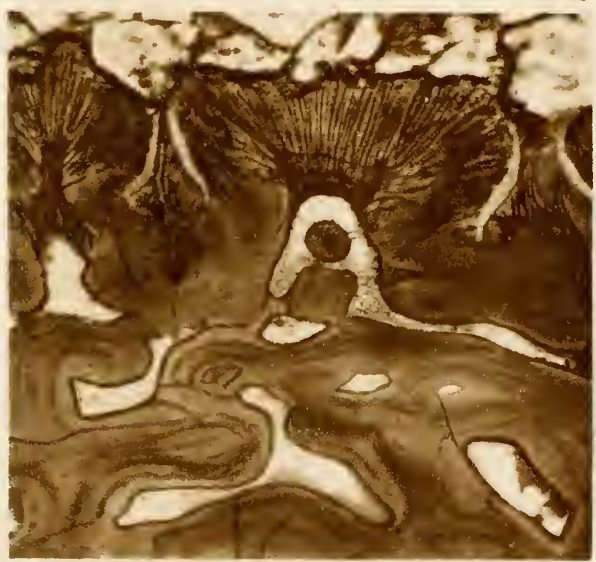

4.

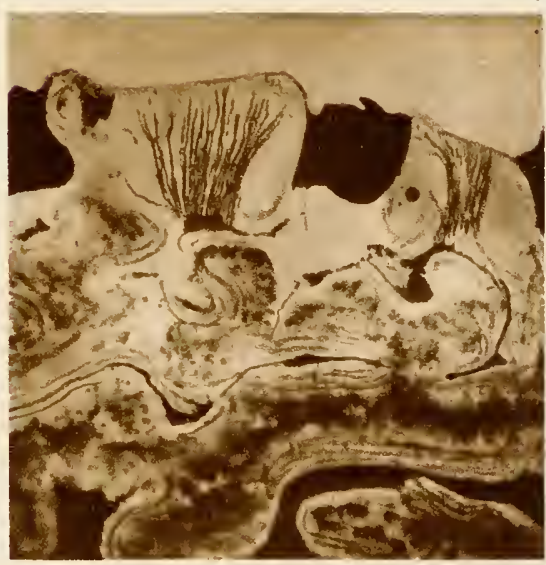

5
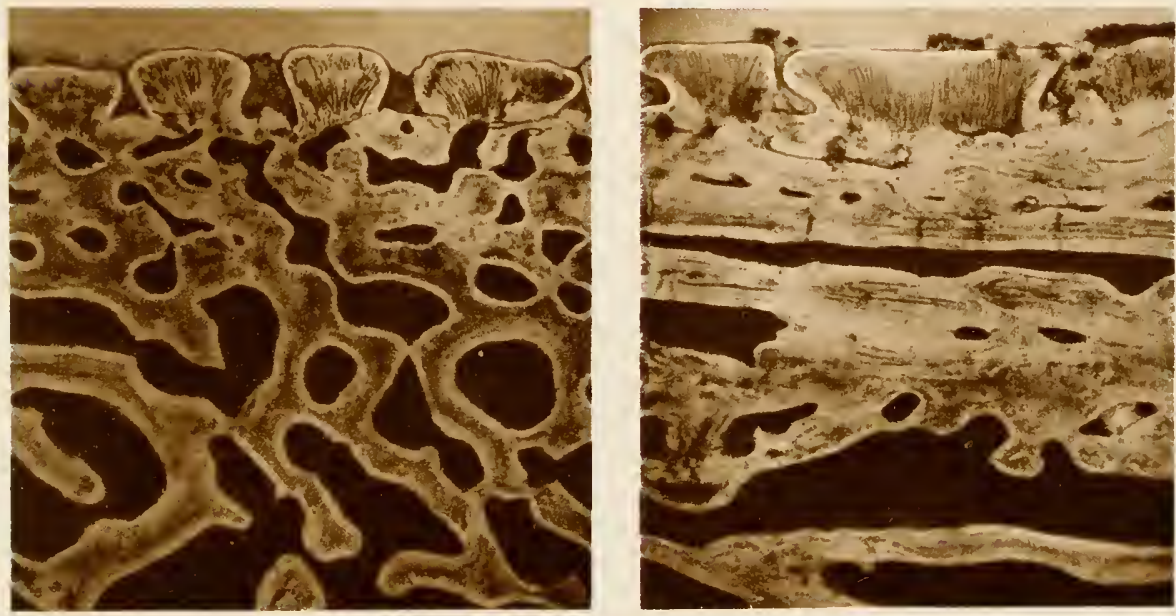




\section{Description of Plate VII.}

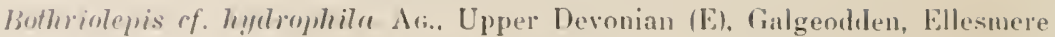
latud. Page :39.

Fig 1. Part of anterior ventro-lateral plate will proximal porlion of left arm, seren from within. $\times$ I.(j. S. I. 101. Pal. Mus. Krisl. Univ.

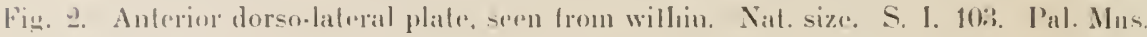
Krist. Univ.

Fig. :․ Sante pirece. $\times 3$. S. 1. 103. Pal. Mus, Krist. Unis.

Fig. 1. Posterion derso-lateral plate, posterior part. Xat. size. S. I. I00. Pal. Mus. hrist. Univ.

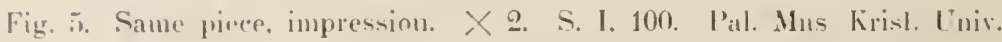

Bothrolepis of. Mydrophila Ar., Upper Devonian (E), Skrap Vulley, Ellesmere Iand, Page 40.

Fig. 6. Dorsal aticular plate. $\times 2$. S. 1, 24. Pat. Mus. Krist. Univ.

Bothiolepis (:) sp., Upper Devonian (E), S. U. Haken, Ellesmere Lanul. l'age 43.

rig. 7. Microscop. section of louly plate $\times 20$. S. I.5-6. Pal. Mus. Krist. Univ.

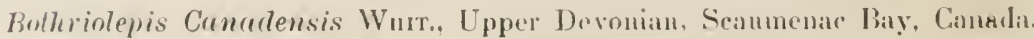
l'ige $\{3$.

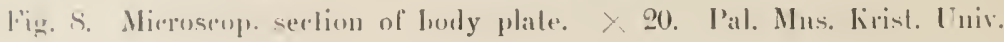



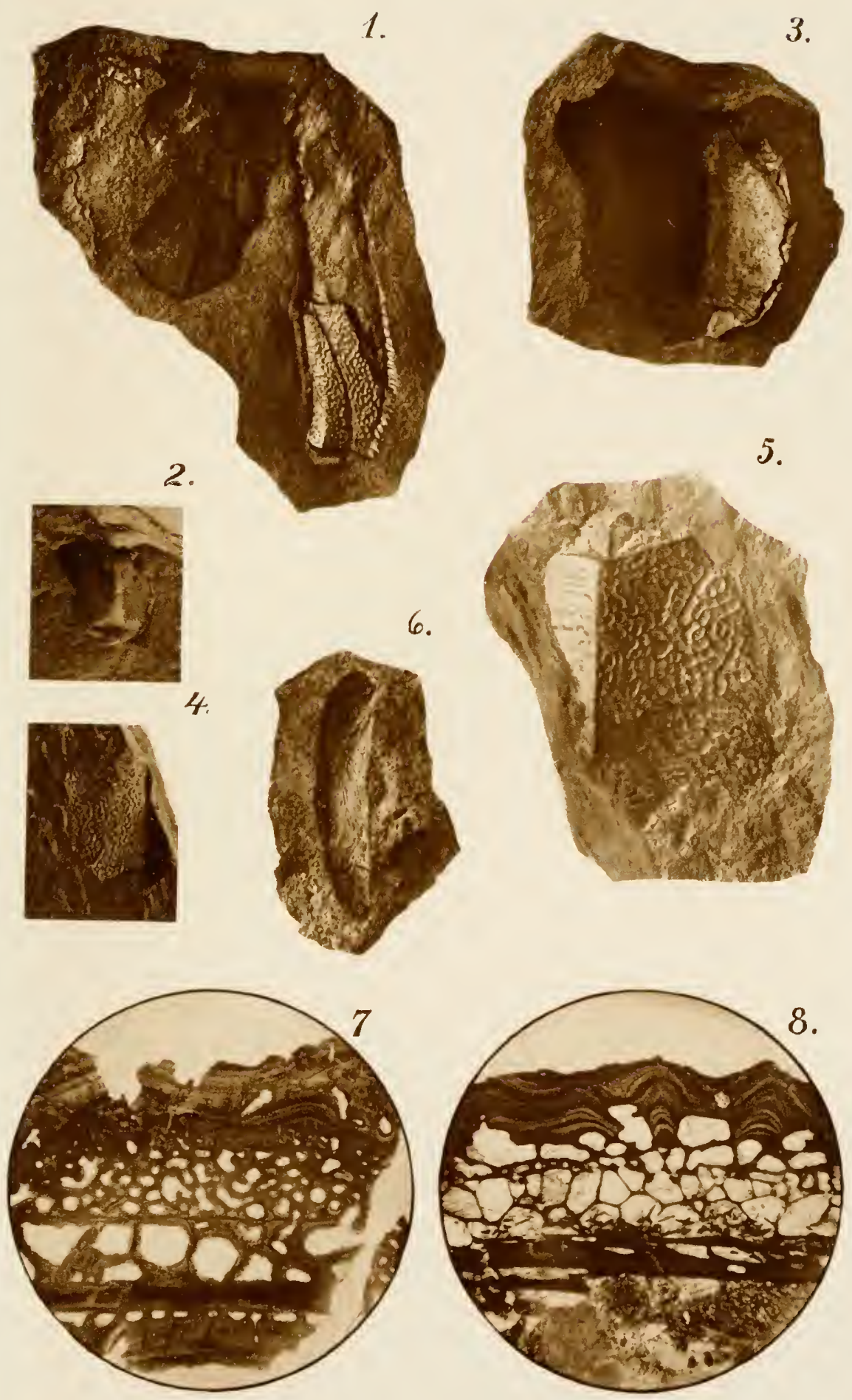




\section{Description of Plate VIII.}

Gluptolepis of. pancidens AG., Lpper Devonian (E). Skrap Valley, Ellesmere Land. Page 45.

Firg. I. I'ortion of seale, outer surface. $\times 4$. S. I 25 a. Pal. Mlus. Krist. Univ. lig. … Seale, inner surfiter, $\times$ 1.S. S. 1.25 l. Pal. Mus. Krist. Lniv.

Holoptychins Scheii hı:1r new species, Upper Devonian (E), Skrap Valley, Ellesmere Land. l'age 44.

Fis. 3. Scale, inner surfate. Nat. size. S. I. 2 (; Pill. Mus. Krist. Univ.

Fig. 4. Scale, onter surface. Nat. size, S. I. 23. Pal. Mus, hrist. Univ.

Fig. 5. Fragment of jaw, prohably leelonging to this species. Nat. size. S. 1. 9. l'al. Mlıs. Krist. Univ.

Tooth with lihizodont Structure, Uprer Devonian (E), S. O. Haken, Ellesmere latul. Paige 48.

Fig. 6. Tooth. 入 2. S. 1. 4. Pal. Mus. Krist. Univ.

Teeth with Dendrodunt Structure, Upper Devonian (E), Skrap Villey, Ellesmere Land. Page 47.

Fig. 7. T'noth. $\times$ 2. S. 1. 42 1. Pal. Mus. Krist. Univ.

Fir. S. Tootl. $\times$ 1. S. 1. 14. Pal. Mus. Kirist. Unir.

Fig. 9. Tootl. $\times 2$. S. 1. 42 a. P'al. Mus. hrist. Univ. 

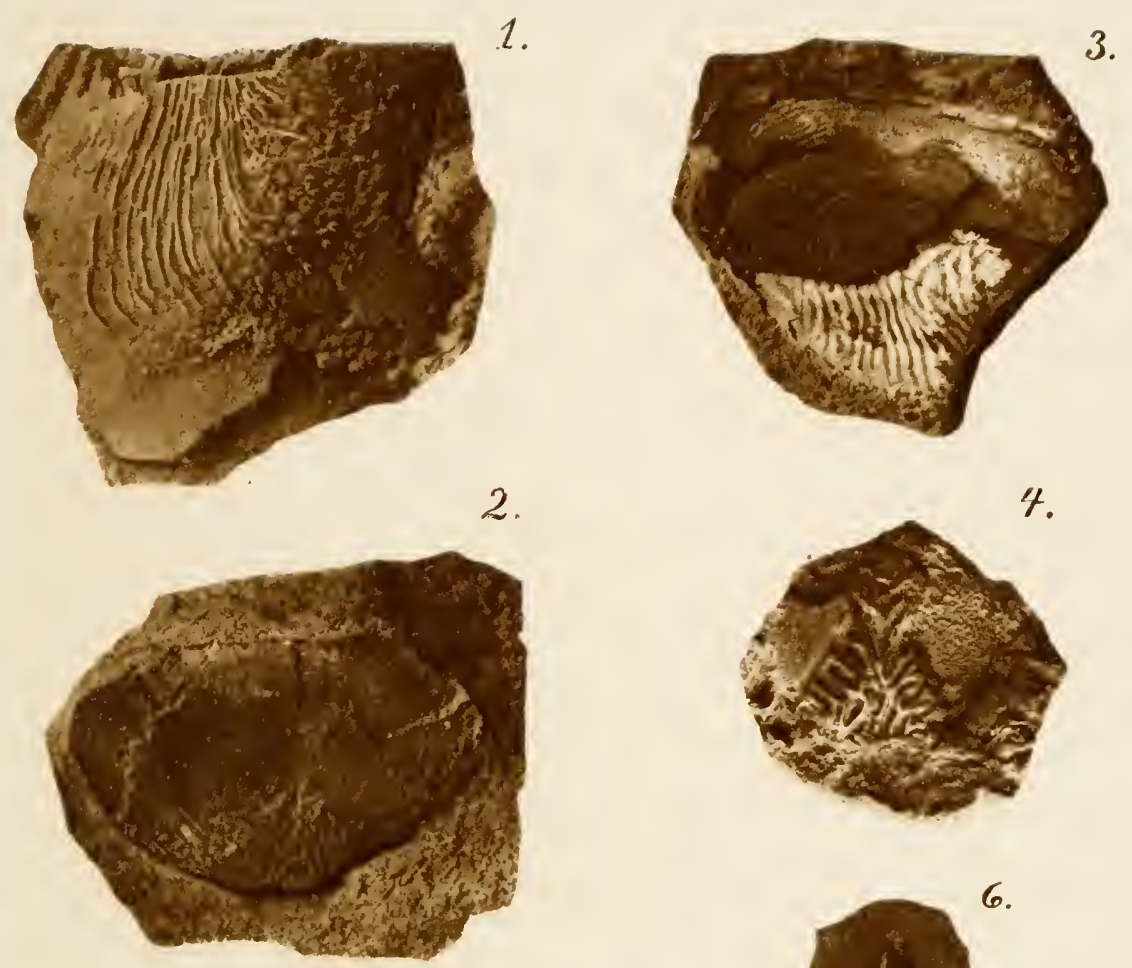

5.
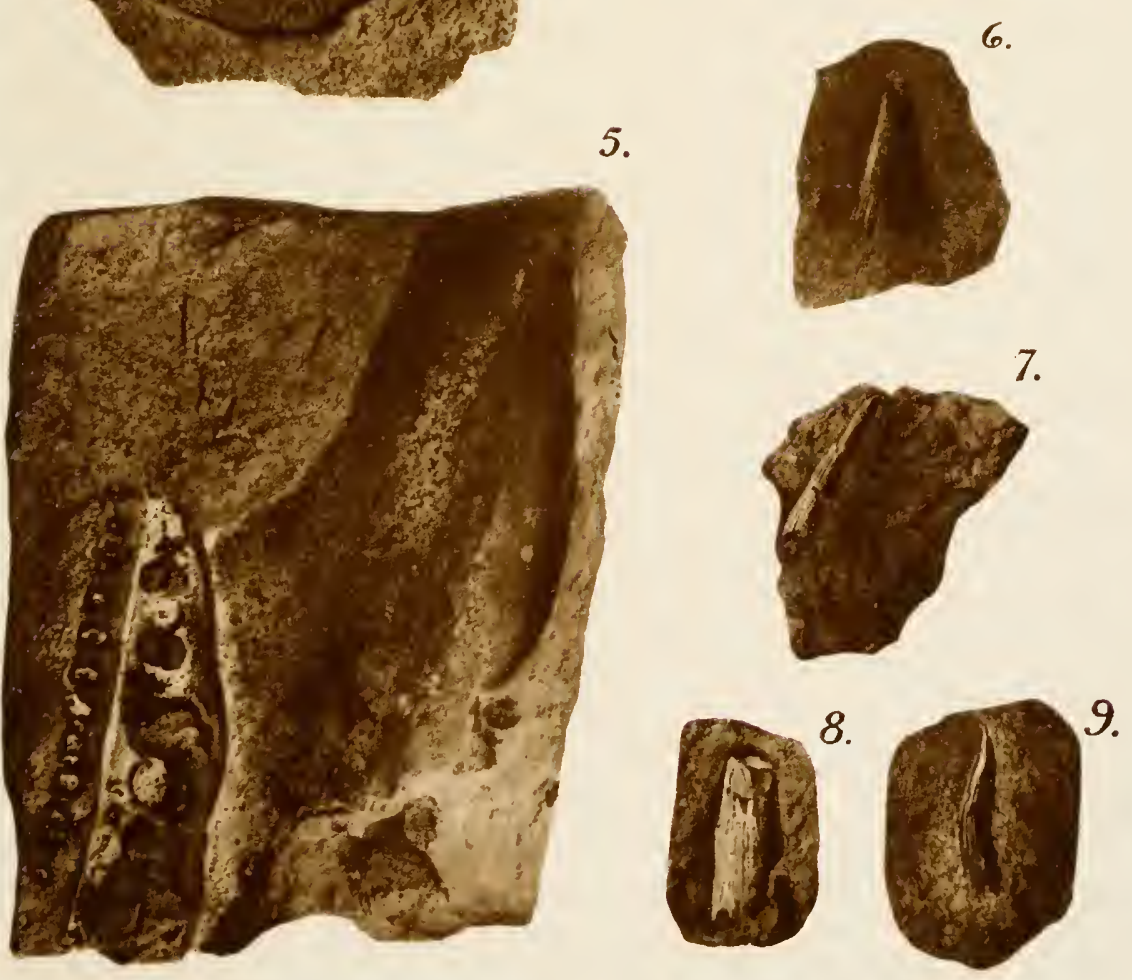

Borghild Larssen phot.

N. I. \& R. 

REPORT OF THE SECOND NORWEGIAN ARCTIC EXPEDITION IN THE "FRAM" 1898-1902. No. 34.

TH. TSCHERNYSCHEW UND P. STEPANOW:

\section{OBERCARBONFAUNA} VON KÖNIG OSC ARS UND HEIBERGS LAND

MIT 12 TAFELN

AT THE EXPENSE OF TIIE FRIDTJOF NANGEN FUND FOR THE ADVANCEMENT OF SCIENCE

PUBLISHED BI

VIDENSKABS-SELSKABET I KRIST IA N IA

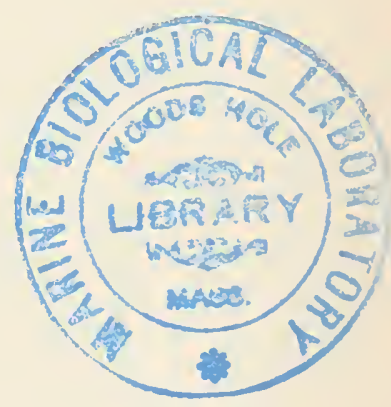

(THE SOCIETY OF ARTS AND SCIENCES OF KRISTIANIA)

K R IS T I A N I A

PRINTEDBYA. W. BROGGER 



\section{Vorwort.}

Der unerwartete Tod des Akademikers Th. Tschernyschew am 2. Januar 1914 hat die Tätigkeit des Verewigten jäh zum Abschluss gebracht.

Zu einer der begonnenen Arbeiten gehört auch die vorliegende $\mathrm{Ab}$. handlung, die das Ergebnis der Beschreibung der auf der Zweiten Norwegischen Expedition der „Fram“ unter Leitung des Kapitän Sverdrup in die arktischen Länder (1898-1902) von Dr. Scheı gesammelten Obercarbonfauna darstellt.

Durch das Ableben des Akademikers Th. Tschernyschew blieb diese Arbeit unvollendet. Fs ist uns die verantwortungsvolle Aufgalee zuteil geworden, die unvollendet gebliebene Arbeit fortzusetzen und druck. fertig zu machen.

Bei der Ausführung dieser Aufgabe hat uns der Herr Akademiker A. P. Kapinsky mit wertvollen Ratschlägen beigestanden, und sind wir ihm für sein freundliches Entgegenkommen zu grossem Dank verpflichtet.

Bei der Durchsicht der Handschriften, die von Tr. Tschernyschew hinterlassen wurden, stellte es sich heraus. dass die Finleitung und die Beschreibung der Fauna vollendet waren bis auf die Tafeln, die die Beschreibung illustrieren. Einige der Tafein waren nicht zusammengestellt, und es lagen keine Zeichenerklärungen vor. Sie trugen auch keine Überschriften, und die beschriebenen Fossilien waren nicht systematisch geordnet. Es war unsere Aufgabe, alles das auszufülıren. Da das Werk die Obercarbonfauna, die auf König Oscars und Heibergs Land gesammelt wurde, enthält, so hielten wir es für angebracht, dieselbe als Obercarbonfauna des König Oscars und Heibergs Landes zu bezeichnen. Was die systematische Anordnung der Brachiopoden anbetrifft, so wurde sie mit den Produktiden begonnen und mit den Terebtatuliden abgeschlossen, so dass die entgegengesełzte Reihenfolge angewandt wurde, wie sie Tschernyschew in seinem Werke „Die obercarbonischen Brachiopoden des Ural und des 'Timan" benutzt hat. Dadurch erklärt sich auch, warum Tschernyschew die Beschreibung der Polarfauna mit den Spongien angefangen hat, und deshalb wurde die Beschreibung so angeordnet, dass sie mit der Familie Productidae heginnt. 
Die wesentlichste Schwierigkeit war das Fehlen des Schlusskapitels. In den Papieren des Verewighten wurden nur einige Notizen über die

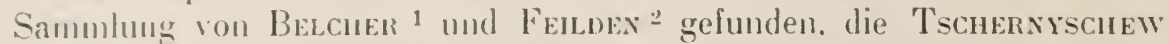
bein Besuch des Kensington Museums machte, wo diese Sammlungen aufhewalnt werden.

In Bezug auf die Sammlung von Bescner wird angefühıt, daso die Durchsicht der Originale noch folgende Formen zn Saltens Liste hinzufügen liisst:

\section{Productus Weyprechti Tousa timanicus Stuck. \\ Marginifera malica \\ Depôt Point.}

Die Bemerkung über die Sammlung Fentoms, die von Ermenoge. bearbeittet wurle. lassen wir hier wörtlich folgen: "Am Exemplar, das von ETIERIDge als Sp. duplicicosta beschrieben wurde, ist die Etikette korrigient nnd in Camarophoria verïndert, diese Korrektur ist richtig, da die letztere zweifellos eine Camarophoria ist und besonders an meine C. Margaritovi erinnert. 'Typisch ist Sp. fasciger an der Etiketle Feilden Isthuns. Ëin Exemplar, das von Etheninge als Streptorhynchus beschrieben und spuiter anf der Etikette in Schuchertella überselzt wurle. stellt eine Dorsalklappe von Prod. Cora von der Innenseite vor. Die Exemplare, die von EThenidge als $P r$ semireticulatus be. -chrieben wurlen, stellen zum 'Teil Pr. irginae und Pr. uralicus (Feilden Isthunus, Gr.-Land) ror. Auf der Etikette. auf der Pr. sp. (der "Pr. punctatus ähnlich ist) von Feihden Isthmus angegeben ist. stellt dasselhe ein lixemplar vor, das zu Aulosteges gehörl und besonder's an Aulost. dalhousi aus dem Schwagerinenhorizont des Ural erinnert. Die area und Skuphtur der Ventralklappe sind ausgezeichnel erhalten. Die von ETHenidie als Productus fimbriatus Sow. beschriebene Form entspricht Pr. irginae und die als Pr. costatus sow. beschriebente dem Pr. influtus Mc. Cusss. nnd ein Teil der Exemplare sehört ohne Zweifel zu Marginifera uralica 'T'scners. Zugleich mil den letzteren konmen anch typische Marg. involuta Tsciners. vor. Als Prod giganteus Mart. ist ein typisches Exemplar von Pr. Cora d'Orn. beschrielen worden. Rihynchonella pleurodon entspricht Rhynch. Nikitini".

Mit den oben angegebenen Bemerkungen werden die Notizen abge. schlossen, die augenscheinlich für das leider nicht vollendete Schluss. knpitel geschrieben wurden. Un es wenigstens zum 'Teil zu ersetzen. wurle

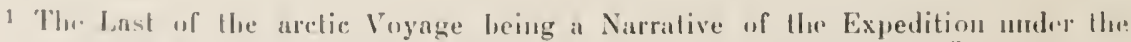
(n)

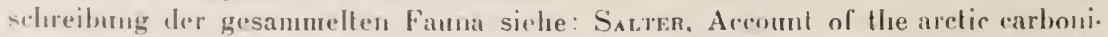

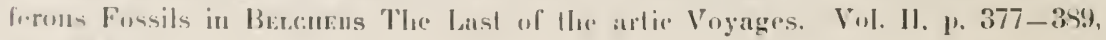
1). XX.T\%।

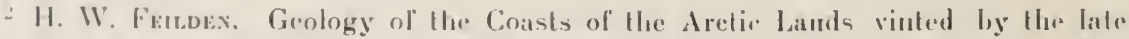

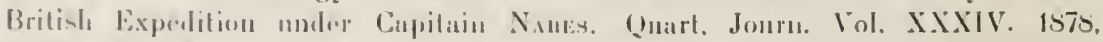

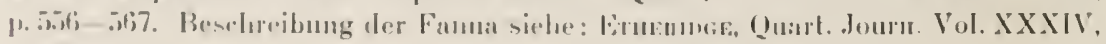
1) . 
von uns eine Tabelle (s. S. 63-65) zusanmengestellt, die die lieschriebene Fauna mit den stratigraphischen Horizonten des Obercarbon Russlands und anderer Lüuder zu vergleichen gestattet. Ein flüchtiger Blick durch diese Tabelle genügt. ın wah'zunehmen, dass die gesammelte Fanna auf König Oscars und Heibergs Land den Schwagerinenkalksteinen des Ural und des Timan am nächsten steht.

Tн. 'Tscherxyschew hat in seiner bekannten Monographie üher' die obercarbonischen Brachiopoden des Ural und des Timan ${ }^{1}$ schon darauf hingewiesen, dass die obercarbonischen Ablagerungen auf den Inseln des anerikanischen Polararchipels eine weite Verlıeitung haben. Diese Schlussfolgermngen beruhen auf der Besichtigung der Sammlungen einerseits der Expedition von Belcher von der Insel Exmus, die von Satrer heschrieben wurden, und anderseits der Sammlungen von Mac Quenntock. die auf der Insel Melville (Cap Gillock) und auf dem Nordostende der Insel Baters (Cap Lady Franklin) angelegt nnd von Goton beschrieben wurden. Mit geringerer Bestinmtleit hat sich Th. Tschernyschew über das Alter der Fanna der Sammlung von Ferboen von der Halbinsel Feilden und Parry, die zu Greenelland gehörten und von ETHERIDGe beschrieben wurden, ausgesprochen.

Die vordiegende Arbeit des verewigten Akademiker's Th. T'schernyschew bestätigt am besten seine Vermutungen und weist auf die Entwicklung der obercarbonischen Ablagerungen vom Typus des Ural und des Timan auf den Inseln des amerikanischen Polararchipels hin.

Die in der Arlseit angeführte Beschreibung der Lamellibranchiaten wurde von Herrn Lıcharew ausgeführt. Alle beschriebenen Fossilien und Dünnschliffe sind mit einer laufenden Nummer versehen, die auf dem Original aufgenterkt und zum Schluss jeder Beschreibung angeführt wird. Alle in der Arbeit beschriebenen Originale befinden sich im Paläontologischen Mnseum der Universität Christiania ausser einem Exemplar der Scheia tuberosa. das von TH. T'schernyschew zum Vergleich benutzt wirde und in der Sammlung des Geologischen Museums der Kaiserlichen Akademie der Wissenschaften zu Petrograd aufbewahrt wirl.

1 Trav. d. Comité Géologique. Vol. XVI, N 2, p. 379-383.

Petrograd, 1915.

P. Stepanow und P. v. Wittenburg. 



\section{In halt.}

Einleitung . . . . . . . . . . . . . . . . . . . . . . 1

Beschreibung der Fauna. . . . . . . . . . . . . . . . . . . 4

Spongiae . . . . . . . . . . . . . . . 4 4

Fam. Hindiadae . . . . . . . . . . . . . . . . . . . . . . 4

Scheiia n. gen. . . . . . . . . . . . . . 4

Anthozoa

Fam. Zaphrentidae . . . . . . . . . . . . . . . . . . . . . . . 9

Zaphrentis . . . . . . . . . . . . . . . . . . 9

Fam. Cyathophyllidae . . . . . . . . . . . . . . . . . . . 9

Clisiophyllum? . . . . . . . . . . . . . . . . . . . . 9

Lithostrotion . . . . . . . . . . . . . . 10

Fam. Monticuliporidae. . . . . . . . . . . . . . . . 12

Geinitzella . . . . . . . . . . . . . 12

Stenopora . . . . . . . . . . . . . . 15

Bryozoa . . . . . . . . . . . . . . 16

Fam. Fenestellidae . . . . . . . . . . 16

Fenestella . . . . . . . . . . . . . . . . . 16

Archimedes . . . . . . . . . . . . . . 22

Polypora . . . . . . . . . . . . . . . . 22

Phyllopora. . . . . . . . . . . . . . . 28

Brachiopoda. . . . . . . . . . . . . . . 30

Fam. Productidae . . . . . . . . . . . . . . . . . 30

Productus . . . . . . . . . . . . . . . . . 30

Marginifera. . . . . . . . . . . . . . . 42

Fam. Strophomenidae . . . . . . . . . . . . . . . . 44

Derbyia . . . . . . . . . . . . . . . . 44

Fam. Spiriferidae . . . . . . . . . . . . . . 44

Reticularia . . . . . . . . . . . . 44

Spirifer . . . . . . . . . . . . . . . . 45

Spiriferella . . . . . . . . . . . . . . . . . . 49

Spiriferina . . . . . . . . . . . . 56 
Fan. Rhynchumollidate. . . . . . . . . . . . . . . . . . 56

Camaroplinria . . . . . . . . . . . . . . . . . 56

Rhy̆ulopmera . . . . . . . . . . . . . . . . . . . 57

Fan. Teroloratulidas . . . . . . . . . . . . . . . . 58

Notolleyris . . . . . . . . . . . . . . . . is

Dielasmat. . . . . . . . . . . . . . . . . . . 59

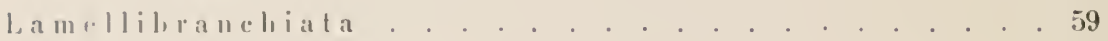

Fam. Avirulopectinidar . . . . . . . . . . . . . . . . . . . . 59

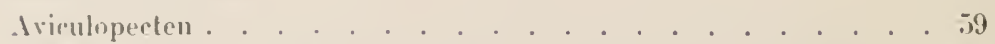

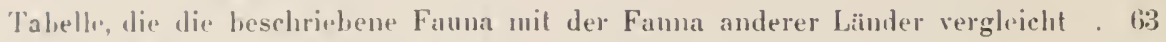
Vrrzeichnis der im paliontologischen Teile hesclurielonen Formen. . . . . . Gi

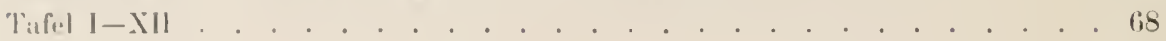




\section{Einleitung.}

Nach der Rückkehr des Herrn Dr. P. Schei, des leider so früh verstorbenen Forschers, von seiner an Ergebnissen so reichen Polarexpedition, wurde mir das Carbonmaterial zur Bearbeitung angeboten. Selı gern habe ich diesem Anerbieten Folge geleistet; zu der Zeit hatte ich eben meine Monographie über die übercarbonischen Brachiopoden des Ural und des Timan abgeschlossen und setzte voraus, dass die Bearbeitung der interessanten Sammlung von Herrn Dr. P. Scheı nicht viel Zeit in Anspruch nehmen würde.

Als ich die Sammlung in St. Petersburg erhielt, nahm ich wahr, dass Brachiopoden den grössten Teil des Materials bildeten, zu denen beim Präparieren eine stattliche Anzahl von Bryozoen und Korallen hinzukam.

Da die letzten Gruppen aus den obercarbonischen Ablagerungen des Timan und des Ural ebenfalls von Herrn Prof. A. Stuckenberg vor kurzem beschrieben worden waren, so schlug ich ihm vor, auch den analogen Teil der Sammlung der Fram-Expedition zur Bearbeitung zu übernehmen. Leider verhinderte der frühzeitige Tod Herrn Prof. A. Stuckenberg die Vollendung der Bearbeitung, und ich übermittelte ihre Fortsetzung Herrn O. I. Stephanow, wohei ich mir die Bearbeitung der Brachiopoden und Schwämme vorbehielt.

Die vorläufige Bestimmung der Carbonfauna wurde von mir schon längst ausgeführt, doch durch viele Umstände gestört, gelang es mir damals nicht, die Beschreibung zu vollenden. Diese Verzügerung blieb jedoch nicht ohne Nutzen, da ich in dieser Zeit Gelegenheit hatte, die Originale von Salter und Etheridge, die im Kensington Museum aufhewahrt werden, und ebenso einige Originale von Fr. Touls aus dem Wiener Hofmuseum kennen zu lernen. Infolgedessen wurde es mir möglich, die Synonymik genau festzustellen und den Hinweis auf die geographische Verbreitung zu ergänzen. 
Au- den Briefen des Herrn Dr. Scurı, die die Sammlung begleiteten. ist zu "rsehen, dass der Hauptteil des Materials am Store Bjornekap auf Känig Osiars Land gesimmett wurde und mit folgenden Marken bezeichnel: P’. s. S. P. S. 39) und P. S. 29; in der mit P. S. 4:; hexeichnelen ki-le hefanden sich hauphätchlich 'Triasfossilien. die späler von Herm Dr. E. Kurt hearbeitel wurlen. und nur (trei Kalksteiustücke $\left(V_{1}, V_{2} . V_{3}\right)$ rom Heiberg: Land, äber die Herr Dr. Scher mitteilt. dass ein Stück, $V_{1}$. das mil Bryozoen ïborfüllt war, aus dem Anstehenden geschlagen wrrde. $V_{2}$ und $V_{3}$, die Brachiopoden führten. \% war nicht in situ gesammelt wurden, aber doch hüchst wahrscheinlich nicht weit davon lierstammten.

Dem Anssehen nach sind lie Kalksteine vom Store Björnekap von denen des Heibergs Land verschieden: die ersteren sind hell, fast weiss, unt enthatten eine Menge Kieselsteine, llie letzteren sind dunkelgrau. fest und ohne Spuren von Verkieselung.

Über die Lagernngsverhältnisse dieser Kalksteine finden wir kurze Anweisungen ausschliesslich in den vortüugen Berichten' des Herrn Dr. Scues: "We also brought lome an important collection of Upper Carhoniferous fossils from Big Bear Cape (Store Björnekap), which have gone into the hands of Prof. 'T'schernyschew, of St. Petershurg. Here are at least forty species. some of them represented by several speci. mens, and all of especial interest, owing to their resemblance to fossils from the Upper Carboniferous rocks found in the north of fiurope".

"The richly fossilferous limestone, will emberderl flints, which exists at Big Bear cape, tells us that at the close of the carboniferous era the sea was again predominant, although of the circumstances which existed inmediately before and immediately after that epoch we know nothing".

Im iuderen Aufsatze des Herrn Dr. Schel * finden wir etwas aus. fiihrlichere Angahen über die Stratigraphie der genannten Kalksteine: .Carboniferons. At the hottom of Big Bear cape there were thick lueds of hard brownish - grey limestone destitute of fossils: but higher up a white pure limestone, a limestone plentifully supplied witl flints, and layers of pure llints, all rich in fossils, amongst them being species

1 The Socond Norwegian Polar Expedition in the "Fram" 1S98-1902. Summary of Geological Results by P. Scuer. (The Geographical Journal for July 1903); Preliminary Rirport on the Geological Observations made during the Second Norwegian Polar Expedition of the "Fram" by P. Scnea. (The Geographical Journal).

Summary of Geological Results.

Preliminary Ruport of the Geological Observations etc. 
of Lithostrotion and Fenestella, Streptorhynchus crenistria, species of Rhynchonella (Pugnax), Spirifer cf. ovalis, cuspidatus, mosquensis: Productus cf. semireticulatus, costatus. punctatus, cora etc."

Über die oben genannten Funde vom Heibergs Land finden wir bei Dr. Screr keinen Hinweis; ebensowenig konnten in den Tagebüchern des Herm Dr. Schel, die Herr Prof. Kiser auf meine Bitte freundlichst daraufhin durchgesehen hat, Angaben darüber nachgewiesen werden. Auf diese Weise bleiben die Briefe des Herrn Dr. Scher und die Etiketten: Sorte Väg Heibergs Land - das einzige Naterial, das uns zur Verfügung steht. Die Fundstelle ist auf einer schematischen Karte, die den Bericht ${ }^{1}$ von Dr. Scheı begleitet, zu ermitteln. Auf dieser Karte ist längs der NO. Küste des Heibergs Landes die Verbreitung der Carhonablagerungen angegeben, so wie auch an dem SW. Teile des Fridtjof Nansen Landes und nach S. von der Nordspitze, die auf der Karte, welche dem zweiten Bande des Report of the Second Norwegian Arctic Expedition in the „Fram" beigelegt ist, als Sorte Väg bezeichnet wird. Aus der folgenden Beschreibung der Fauna, die am Store Björnekap und auf Heibergs Land gesammelt wurde, ist zu ersehen, dass trotz des geringen petrographischen Unterschiedes, die Kalksteine der beiden Fundstellen im wesentlichen identische Fauna führen und zu einem und demselben stratigraphischen Horizont gehören, den man am besten dem Schwagerineu Horizont des Ural und des 'Timan gleichstellt. Die ganze Fauna des Heibergs Landes ist aus drei kleinen Kalksteinen herauspräpariert worden, dagegen stammt die Fauna vom Store Björnekap aus zahlreichen grossen Kalksteinplatten, die von Herrn Dr. Scher an dieser Stelle gesammelt wurden, wodurch die Mannigfaltigkeit der Fauna erklärt sei.

1 Summary of Geological Results. 


\title{
Spongiae.
}

\author{
Familie Hindiadae Raufr.
}

Scheiia n. gen.

Seit dem Erscheinen der Monographie von Hixde ${ }^{1}$ und Rauff $=$, "o die Literatur üher die fossilen, wie auch über die oberpaläozoischen Kieselschwimme ausführlich angeführt ist, wurde eine Reihe von Arbeiteu verölfentlicht, in denen diese Gruppe der oberpalïozoischen Spongien aus dem europäischen, sowie auch aus dem nordamerikanischen Carbon beschriehen ist. In Jahre 1896 heschrieb $\mathrm{H}_{\mathrm{s}^{\prime} \mathrm{EE}}{ }^{3}$ ein prachtvoll erhaltenes Exemplar von einem litistiden Schwamm, der von ihm zur Gatlung Pemmatites (Pemm. constipatus n. sp.) rechnel und in den Yoredal Series in norlwestlichen Teil von Yorkshire gefunden wurde. Die Gattung Pemmatites wurde von Duxikowsky nach Exemplaren, die Prof. Natuorst und Freiherr De Geer auf Spilzbergen gesammelt hatten, festgestellt, aber irtümlich den monaktineliden Schwämmen zugewiesen. IV ie hekannt, wurde die Natur dieser Schwänme durch Hinde aufgeklïrt, der auf den Fehler von Dunıowsky aufmerksam machte, welcher falsclı dentete. was an den Spitzbergener Exemplaren für Kanäle angesehen werden soll und welcher 'Teil an ihnen das Skelett vorstellt. Der Ban des letzleren weist deutlich auf die Zugehörigkeit der Gattung Pemmatiles zu den litisliden Schwämmen hin.

Bald nach Hinnes Beschreibung der Pemmatiles constipatus ver. öffentliclute ich eine Notiz über meine Uulersuchungen der Artinsk- und Carlonsclwiimme des Ural und des Timan ", wobei ich zeigte, dass die Vertreter der Gathng Pemmatites reichlich im Osten des europäischen Russlauds vorhanden sind, wo sie mit den Vertretern der Gathung Hoplistion Yougu \& Young zusimmen vorkommen, und von Hinde

I G. II. Haxos A Monograph of the British Fossil Sponges. Palaconlographical Sncicly. Vol. XI, p, 1-93, yl. I-VIII; Vol. XILI, p. 93, pl. IX. 18Sti-18SS. Billhugrapliy, 1, 3-43.

2 H. Rarr. Palaeospongologie. P'alaeonlographica. BAl. XI,XL, S. 1-271, pl.

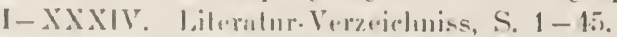

${ }^{3}$ G. II. Haxe. New Fossils rom Hoe carboniferous limestone. Quarlerly Journal.

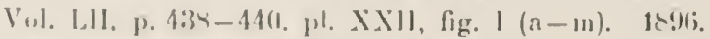

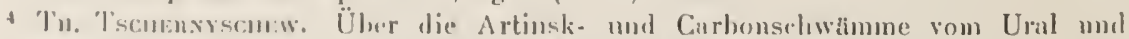
rom Timan. Verlı d. Russ. Kais. Mineralogischen Gesellschaft. 2. Ser. Bil. XXXVI, S. 1-i,t, Taf. I-V. 
irrtümlich nicht zu den lilistiden Schwämmen, sondern zu den monaktineliden gestellt wurden. Zugleich mit diesen Gattungen kamen am Ural und am Timan zwei Arten der Gattung Kazania ans der Familie Rhizomarina und zwei Arten der Gattung Stuckenbergia der Unterordnung (suborder) Tetracladina (Fam. Orthocladinae Rauff) vor. Wahrschein. lich blieben diese Arbeiten Dr. GrRTy ganz unbekannt, da el sie in seiner Monograplie über die Guadalupian Fauna ${ }^{1}$ gar nicht erwähnt. In dieser umfangreichen Monographie sind die Seiten 70-78 der Be. schreibung der Kieselschwämme gewidmet. von denen GIRTy drei neue Gattungen, Anthracosycon, Virgula und Pseudovirgula als Vertreter der Tetracladina beschreibt und die neu bestimmle Gattung Stromatidium zu den Hexactinelliden (Unterordnung Dictyonina) stellt. Leider ist der Erhaltungszustand dieser Schwämme, nach den Angaben Gırtys, derart, dass es ihm meist nicht gelang, den Charakter der Skelettelemente eingehend zu untersuchen. Das hat sich nebenbei in der Illustration der beschriebenen Arten abgespiegelt, da die Zeichnungen dieser Schwämme nur in allgemeinen Zügen gehalten sind, und die Abbildung der sie zusammenstellenden Spiculae, wie auch die Art ihrer Verbindung in Skelettfibern gänzlich fehlt. Infolgedessen wird der Vergleich der guadalupischen Schwämme mit den bekanuten Vertretern aus den Carbonund Artinskablagerungen erschwert; ich kann nur bemerken, dass einige Zeichmungen und Beschreibungen der Vertreter der Gattung Anthracosycon (Anthr. ficus GIRTy) ${ }^{2}$ stark z. B. an Stuckenbergia artiensis mihi ${ }^{3}$ erinnern, und Stromatidium typicale GIRTy ${ }^{4}$, das wieder an die Vertreter der Gattung Haplistion Young \& Young (Hapl. orientale mihi "s und besonders Hapl. Armstrongi i Young \& Young ${ }^{6}$ erinnert, scheint mir nicht den Hexactineliden, wie Gratr anıimmt, sondern den Litistiden anzugehören.

Aus diesen Überblick ersieht man, wie weit unsere Kenntnisse der oberpaläozoischen Fauna der Kieselschwänme ${ }^{\top}$ in den letzten zwanzig

1 G. H. Girty. The Guadalupian Famu, L.S. Geol. Surv. Professional Paper 58 1908.

2 GirTy, l. c. p. 72, pl. XXIV, fig. 1-2.

1. c. p. 41, pl. V, fig. 4-6, fig. 17-15 im 'l'ext.

4 Girty, 1. c. p. 77-78, pl. XXVil, fig. 7-10.

5 I. c., p. 31 , pl. II, fig. 23 ; pl. III, fig. 2 ; pl. $1 \mathrm{~V}$, fig. $6-7$.

Hinde, British fossil Sponges, p. 147-148, pl. V, fig. I, I a, Il.

- So weit es mir bekannt ist, sind bisher weder im Ostell, noch im Norden Russlands, überhaupt nicht im Oberpaläozoicum der Polarländer, Vertreter der Calci. spongiae, die in den entsprechenden Ablagerungen von Himmalaya, Indien, Buchara, Kaukasus, Spanien, Kansas, New-Mexika und Texas weit verbreitet sind, gefunden worden. 
Jahren fortgeschritten sind. Desto interessanter ist das Auffinden der Vertreter der Schwämme in der Sammlung, die Dr. Scheı auf König Osears Land an Store Björnekap mit der unten beschriebenen reichen und verschiedenartigen Fauna zusammengebracht hat. Die beiden aufgefundenen Exemplare sind prachtvoll erhalten und erinnern auf den ersten Blick dermassen an die silurische Hindia, dass ich das Auffinden derselluen inmitten der typischen obercarbonischen Fauna am Store Björnekap anzuzweifeln geneigt war. Freilich wurde Hindia pummila aus den Carlonkalken von Ben Bulben bei Sligo in Irland von HuNDE ${ }^{1}$ heschriehen, aher es waren bloss einzelne Spiculae, die anfangs zur Gattung Doryderma gestellt wurden. Alle meine Zweifel verschwanden jedoch, als Freilherr G. vox Frederuss mir awei Exemplare von Schwämmen überreichte, die жweifelsohne mit denen vom Store Björnekap idenlisch sind und in Schwagerinenkalk der Ungebung von Krasnoufimsk am Ural gefunden wurden. Das nühere Studiun des Skeletts der beiden Schwämme reigte, dass trotz der allgemeinen grossen Ähnlichkeit mit Hindia, ther Charakter ihrer Skelefte sich wesentlich von der ubersilurischen Hindia unterscheidet, was uns gestattet, die obercarbonischen Vertreter in eine selbständige Gattung, die ich zu Ehren des verschiedenen Dr. Scher, Scheiia lenenne, einzureihen. Laut der Klassifikation von Rauff wird der beschriebene Schwamm zur Gruppe Lithistinu gesteltt, die er in Tribus Lutaxicladinidae einschliesst und zur Familie Hindiadae stellt.

Scheiia tuberosa 11. gen. n. sp.

Taf. I, Fig. 1-7, Taf. II, Fig. 1-4.

Kugelförmiger Sclıwanm, olne Anhaftungsstellen. Am Bruch sieht man eine radialstrahlige Verteilnng der Skelettfibern, wie bei Monticuliporilen (Taf. I, Fig. 1-4), wobei sich an der Peripherie die Zahl der Fibern durch the Bifurkation und Einschaltung neuer feinerer Fibern \%ischen den ursprïnglichen (T'af. II, Fig. $1-3)$ vernehrt. Die Dicke der Filsern schwankt awischen $0,14 \mathrm{~mm}$. und $0,53 \mathrm{~mm}$. und die Breite der zwischen iluen gelegenen Kanäle von 0,25-0,57 mm. An der mit Sïure gebcizten Oberfliche des Sclwammes sind hei geringer Vergrösserung zusannmengesetzle l'uberkehn von unregelmaissig elliptischer oder polygonaler Form zı selıen, die durch Querweige vereinigt sind und den linden der einzelnen Fibern und der sie verbindenden Querfibern ent-

1 Hawn. British fossil Spronges, p. 1:7, ,1. V, tig. S. 


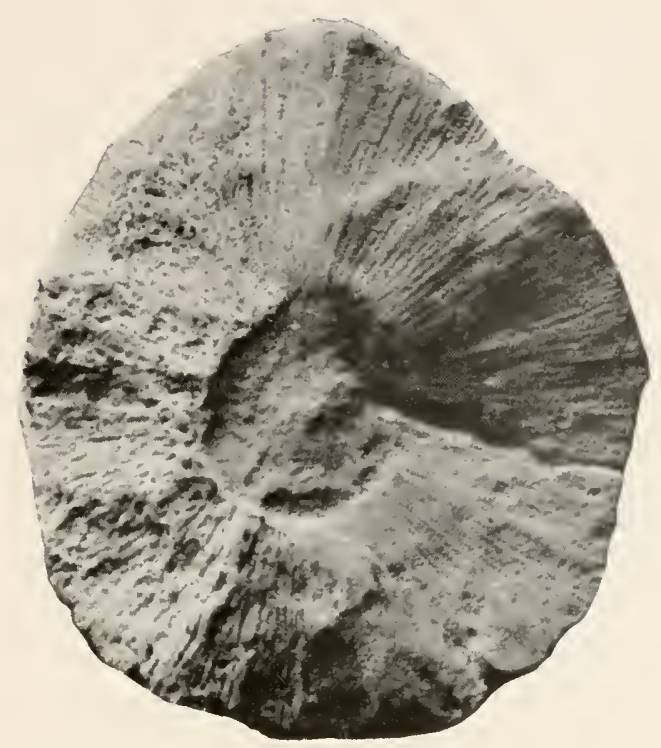

Fig. 1. Scheiia tuberosa. Uralform, aus der Umgegend von Krasnonfimsk (Kiamenny Log). Schwagerinen Kalksteine. 2.š mal vergrössert. (Geol. Museum d. K. Aka. demie d. Wissensch. Peterslurg. $\frac{1402}{2}$ Syst. N. 4946.)

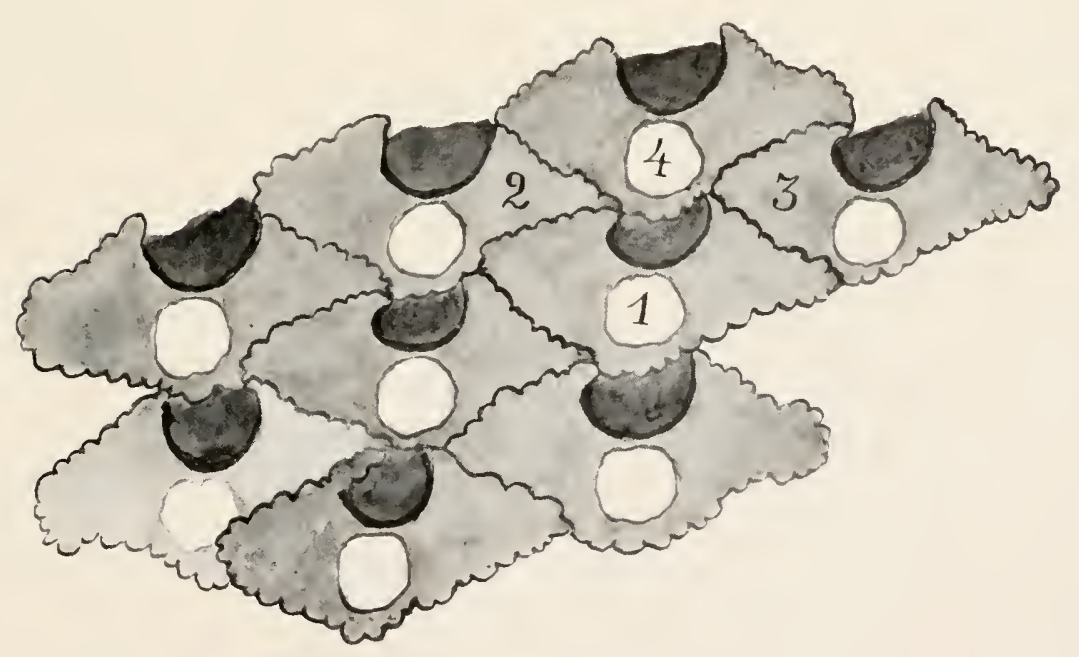

Fig. 9. Scheiia tuberosa. Schema der Verbindung der Spiculae in den Skelett. stïbchen. 135 mal vergrïssert. 



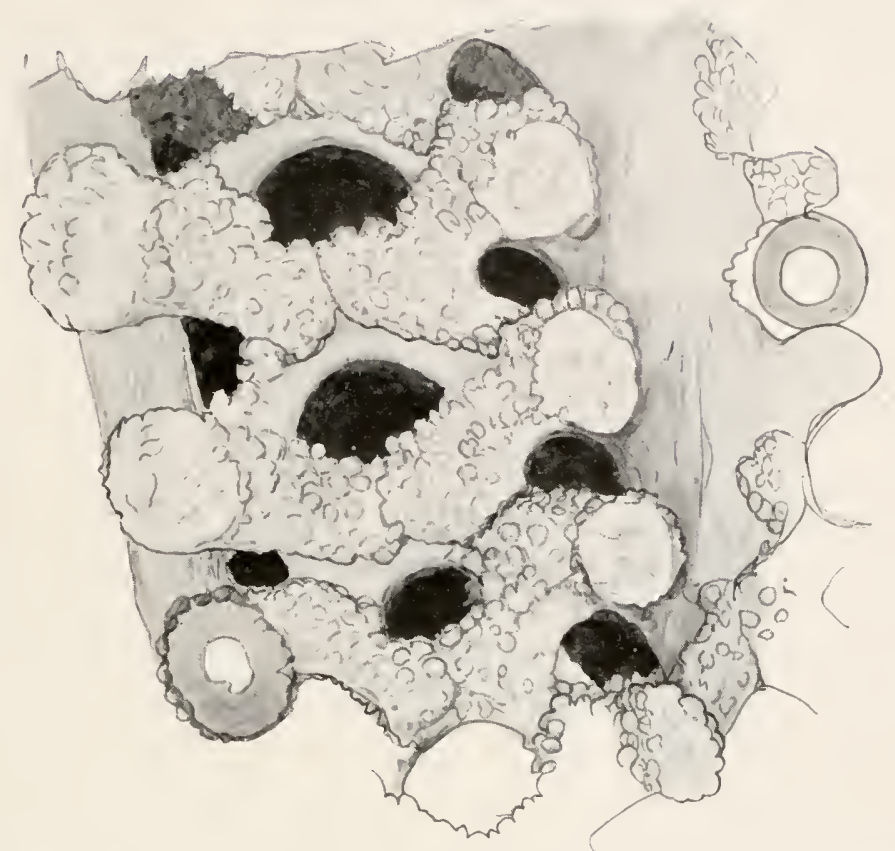

Fig. 3. Scheiia tuberosa. Längsdurchschnitt, der dir Verbindung der Spiculae miteinander im Skelettstrahl darstellt. 135 mal vergrössert.

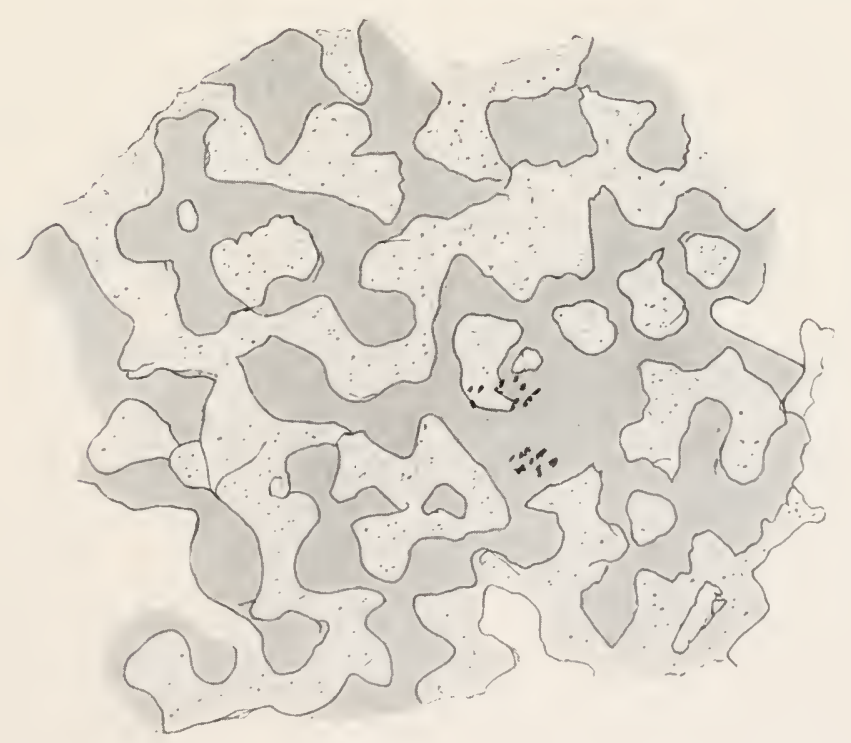

Fig. 4. Scheiia tuberosa. Tangentialdurchschnitt. 135 mal vergrössert. 

sprechen (Taf. I, Fig. 7). Paragaster fehlt, doch wie aus den Zeichnungen zu ersehen ist (Taf. I, Fig. 1-4), wird der Mittelteil des Skeletts von einem sphürischen Kern eingenommen, der sich scharf bei den auf Tafel I, Fig. 1-2 und auf Fig. I im Text (Uralsk.) abgebildeten Exemplaren abhebt. Der Durchmesser des Kerns des auf Taf. I Fig. 1-2 dargestellten Exemplars erreicht $10 \mathrm{~mm}$, bei der Uralform, die auf Fig. 1 der hier in Text eingehefteten Tafeln abgebildet ist, 9,4 mn. und bei dem grösseren Exemplar auf Taf. I, Fig. 3-4, 8,5 mm. Das nähere Studium dieses Kernes, der aus einer Kieselmasse besteht, zeigt, dass er aus denselben Skelettelementen zusammengesetzt ist, wie die Fibern des Schwammes, und dass im Kern bloss in grösserem oder geringerem Grade ihre Normalrichtung gestört ist (Taf. I, Fig. 6), ähnlich dem, wie es Rauff ${ }^{1}$ bei Hindia sphaeroidalis Duncan angilut.

Die Spiculen, aus denen die Fibern zusammengesetzt sind, stellen trider nach RaufF's Nomenklatur vor und bestehen aus drei Strahlen (Clone), glatt an derkonkaven, dem Mittelpunkt des Schwammes zugekehrten Seite und mit Tuberkeln versehen an der konvexen Seite, die der Peripherie des Schwammes zugekehrt ist (Taf. II, Fig. 2-4, Taf. I, Fig. 5-6).

Die Enden der Strahten, oder der Clone, erweitern sich wie die Balken (Cygon) quer zum Strahl und sind mit Tuberkeln und Narben versehen. Bei unserer Spicula ist zum Unterschied von der Spicula bei Hindia der Brachiom oder vierte vertikale Strahl, von dem bei Hindia die genannten Querstrahlen (Clonen) abgehen, unmerkbar. Infolgedessen ist auch die Verbindung der Spiculae im Skelett etwas ander's, als diejenige bei Hindia, die von Rauff und Hinde beschrieben wurde. Auf den angeführten Zeichnungen wie auch den Figuren 2, 3 und 4 der hier in Text eingehefteten Tafeln ist deutlich zu bemerken, dass die Querverbreitung der Clone oder Cygomen der Spiculae (1) auf Fig. 2 durch ihre knollige Oberfläche mit der ebenfalls mit Tuberkeln versehenen konvexen Oberfläche der Clone mit den anliegenden Spiculen (2) und (3) verbunden werden und zum Teil mit dem etwas verdickten mittleren 'Teil der Spiculae (4); an der' letzteren fehlt, wie oben gesagt, der vierte vertikale Strahl oder der zylindrische Auswuchs mit flacher Einschnürung, der an Eucke mit einem tuberosen Ring versehen ist. Der mittlere mit Tuberkeln versehene 'Teil der Spiculae verschwimmt im Gegenteil, unbemerkbar mit der vom Cygom umringten benachbarten Spiculae. Ausser den Tuberkeln, die an den Cygomen und an konvexen Rande der Clonen liegen, ist die ganze Oberfläche der

1. с. S. $334-335$. 
letzteren, mit Ausnahme des schmalen Streifens längs des konkaven Rande- der Clonen und ebenso der mittlere verdickte Teil der Spiculen mit nahestehenden mastartigen Tuberkeh versehen, die den Spiculen ein eigentümliches Gepräige verteihen und sie dadurch von den Spiculen her Hindia stark unterscheiden, die mit Tuberkelı nur an den Gygomen und an konvexen Ronde der Clone versehen sind.

Die Abnessungen der Spiculen sind an allen Exemplaren ziemlich bestiundig. Ihre Dicke erreicht etwa $0,0 S$ mm.. und die Entfermung жwischen den Enden der gegenüherliegenden Clonen ungefähr 0,35 mm.

Unlel den Carbonschwimmen Englands beschrieb Hovos ${ }^{1}$ unter dem Nanen Hindia pumila Hrsve einzelne Spiculen, wobei er the Aufmerksankeit daranf lenkte, dass ihre Abnessungen bedeutend die der Spiculen der silurischen Hindia fibrosa F. Rosm. (IIndia sphaeroidalis Duncan) ïbertreffen, wie auch darauf, dass bei ihnen der vierte verdickte Strahl, der sich bei den silurischen Vertretern von der Mitte der mittleren Verdickung hinzieht. fehılt. Ich möchte noch hinzufügen, dass nach einigen Zeichnungen von Hı⿻上 die Oberflïche der Spiculae von Hindia pumila mit ehensolchen 'Tuberkehn versehen ist. wie bei den von mir beschriebenen. Hinde bemerkt, dass er es nicht für möglich hïlı, auf Grund der angegebenen Verschiedenheiten eine neue Gattung füı die englischen Carhonschwämme aufzustellen, doch dünkl mich, dass, infolge der Wiederhohung der angefülnten Eigentümlichkeiten der Spiculen im Oberpalïozoicum Englands. Oscarslands und des Ural, es zweckmässig wäre, die oberpaläozoischen V'ertreter voı den silurischen zu unterscheiden, indem man ilınen eine neue Gathung:bezeichnung - Scheiia - beilegt; zu diesel Gattung muss. ansser der von mir heschriehenen Scheiia tuberosa, ebenso Scheiia mumila Honne gestellt werden.

Wie oben gesagt, wurde Scheiia tuberosa ansiser anf König Oscars Land in zwei Exemplaren in den Obercarbonkalken des Kammenny Loy hei Kiasnoufimsk gefunden. Die Exenplare von König Oscars Land konmen in prahlvoller brhattung vor und gestatten, die feinsten Eigen. tümlichkeiten ler Kieselfibern und der sie zusammenstellenden Spiculen zu studieren. Dagegen ist an den Krasuonthusk Vertreteru die Kiesel. substan\% in hedentendem Giale durch Kilzil ersetzl, infolgerlessen das Itzen mur Hohlriume liefert, die den Fibern entsprechen und dir Skulptur her Spirula mit geringer Funhoit hervortrelen lassen.

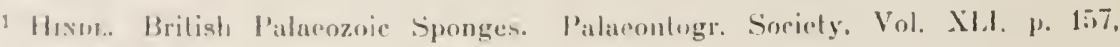
pl. V. lig. St. 


\section{Anthozoa.}

Fanilie Zaphrentidae M. Ew. c.H.

Genus Zaphrentis Rafinesque.

In der Sammlung befinden sich drei Exemplare, die zu Zaphrentis gehören. Zwei von ihnen - N 10, N 11 (P.S. 43) - sind schlecht erhatten, so dass es nicht möglich war, ihren inneren Bau zu erkemnen. Das dritte Exemplar (N S) stellt eine fast vollständig erhaltene Form dar; seine Beschreibung folgt. [N $8,10,11$ (P.S. 43) $]^{1}$.

\section{Zaphrentis sp.}

Taf. III, Fig. 1, a--b.

Die einzelne Koralle besitzt eine schwach kegelige Form, die etwas der Achse nach gebogen ist. Die Basis der Koralle ist abgebrochen. Die Lïnge der gewölbten Seite erreicht $47 \mathrm{~mm}$. und im Durchmesser an der Spitze etwa $20 \mathrm{~mm}$. Der Kelch ist tief, von der gewölbten Seile höher als von der entgegengesetzten. An der äusseren Oberfläche sind schwach ausgeprägte Längsrippen und unbedeutende Querverdickun. gen. Septen I. Ordnung - 35 an der Zahl - reichen nicht bis zum Mittelpunkt. Die Hauptsepten sind kurz. Septen II. Ordnung - 35 an der Zahl - erreichen $1 / 6$ der Länge des Durchmessers.

Die Boden befinden sich in der Entfernung von 1 oder $1.5 \mathrm{~mm}$. voneinander und sind nach der Korallenspitze hin gewölbt. Es gelang nicht. den Kelch zu präparieren.

Fundort: Store Björnekap. König Oscars Land. 1 Exemplar [N \&, 9. (Dünnschliff)].

Familie Cyathophyllidae M. LDw.d.H.

$$
\text { Genus Clisiophyllum (?) Daxa. }
$$

Clisiophyllum (?) sp.

Taf. III, Fig. 2.

Bruchstück einer schwach kegeligen Einzelkoralle, deren Kelch ab. gebrochen ist. Der Durchmesser erreicht an der Spitze des Bruchstückes $12 \mathrm{~mm}$. bei $17 \mathrm{~mm}$. Länge. Septen sind in zwei Ordnungen gruppiert.

1 Die Nummer in der Klammer entspricht der Nummer des Exemplars der Sammlung. Die Bezeichnung (P.S. 43) u. s.w. wurde von Dr. Scuer angewandt (s. Einleitung). Die Nummern der abgebildeten Exemplare sind mit Kursivzahlen. bezeichnet. 
Septen erster Ordnung - 37 an der Zahl; das Hauptseptum ist kurz und befindet sich in der Furche: die ïbrigen erreichen 11+ der Länge des Durchmessers. Septen zweiter Orhnung sind schwach entwickelt. Der Mittelteil der Koralle wird durch eine Fiber eingenommen. die durch lertikalplatten gebildet ist, welche der Zahl nach nicht den Septen erster Ordnumg entsprechen und nur zuweilen sich mit diesen vereinigen. Den Vertikalschnitt der Koralle zu studieren, war unnöglich, deshall, fäll es schwer, den Gattungsnanen genau festzustellen.

Fundort: Store Bjürnekap. King Oscars Land. 1 Exemplar. [N 12.13. (Düunschliff)].

\section{Genus Lithostrotion FlemiNg}

\section{Lithostrotion borealis STCCKENBERg.}

Taf. III, Fig. 3, a-b.

1595. Lithostrotion borealis Stuchenberg. Korallen und Bryozoen der Steinkohlen. ablagerungen des Ural und des Timan. Mèm. du Com. Geol. d. S.P'b.. Vol. X, X. 3, p. 74, Tab. XIV, fig. 2.

Ein zusammengesetzler Polypenstock, der aus sechs- und fünfeckigen prisnatischen Zellen besteht. Die Länge des grössten Durchmessers schwankt von 12-5 mm. Die Höhe einger Exemplare erreicht $11 \mathrm{~cm}$, lie Breite bis $15 \mathrm{~cm}$. Nach den Exemplaren. die mir zur Verfügung standen, konnte ich den Charakter des Kelches nicht erkennen

Aus dem Querschnitt ersieht man, dass die Zellen durch schwach gewölbte Wände voneinander getrennt sind. Septen gruppieren sich in zwei Ordnungen; die einen wie auch die anderen beginnen unmittelbar an den Wïnden. In verschiedenen Zellen ein und desselben Exemplars schwankt die Zahl der Septen erster Ordnung ron 12 bis 17; sie biegen sich zickzackarlig und erreichen nicht den Mittelpunkl. ausser dem Hauptseptum und den ihn enlgegengesetzten, die sich mit der Fiber verknüpfen. Die Septen zweiter Ordnung sind etwas kïr\%er als die Septen erster Ordnung, mond ïbersteigen nicht die Grenzen der endotekalen Zone. Die gewöhuliclue Zahl der Seplen ist 24-34. Die Zahl der endotekalen Blischen ist 5-7. Die Psendowand ist nicht entwichelt. Die Fiber urschuint in eingen \%ellen als ahgesonderte lïngsgezogene Platte. del sich nи zwei Seplen anschliessen: in anderen Zellen besitzt sie eine muregeluässige, etwas ansgezogene sternartige Forn.

Dic Beschreibung des Längsschnittes. Die Septen biegen sich zickzackartig in der Richtung der Zellenachse. Die Peripherie ist durch keine Blïschen eingenomnen, der mittlere Teil durch Boden, die in der 
Richtung des Kelches angeordnet sind und einen spitzen Winkel nuit der sie durchschneidenden Fiber bilden.

Die beschriebene Form steht der von Stuckenberg sehr nahe. Die Zahl der Septen, der Charakter der Fiber, ihr Verhältnis zu den Septen und den Boden - sind bei beiden Formen vollständig gleich. Das einzige Unterscheidungsmerkmal ist ein etwas anders ausgebildeter Charakter der Wände bei den Timanexemplaren. In den Dünnsclıliffen zeigen die Wände nicht solche deutliche Konturen, wie es bei den Polarformen beobachtet wird.

Nach dem äusseren Aussehen zu urteilen, besteht zwischend er beschriebenen Form und Stylastrea inconferta von der Grinnell Insel (Depôt Point), die von Salter ${ }^{1}$ beschrieben wurde, eine gewisse Ähnlichkeit. Nur dass bei Salters Art nicht alle Septen, deren gewöhnliche Anzahl 3S-40 erreicht, deutlich entwickelt sind: „only half are conspicuous, the intermediate once being exceedingly short and obscure...."

SAlter spricht von einer vollständigen Ähnlichkeit zivischen seiner Form und den Uralexemplaren, die von Lonsdale beschrieben vurden. Auf Lonsdales Zeichnungen sieht man deutlich den inneren Bau der Koralle, die augensclieinlich zu einer anderen Gattung (Petalaxis), als unsere Form, gehört.

Unter Iithostrotion basaltiforme von Bathurst Island (G. Lady Franklin) wurde von HaUGHToN $^{3}$ ein Bruchstück eines zusammengesetzten Polypenstocks, der aus prismatisch Unteilbaren besteht, beschrieben. I. basaltiforme wurde zusammen mit Spirifer arcticus, und auf Melville Island (Hillock. Pl.) S. arcticus zusammen mit Productus sulcatus angetroffen. 'Th. Tschernyschew * stellt bei del kritischen Untersuchung der Brachiopoden, die von HaUghton beschrieben wurden, eine grosse Ähnlichkeit zwischen ihnen und den obercarbonischen des Ural und des 'Timan fest. Er bezweifelt auch, dass die Korallen von C. Lady Franklin L. basaltiforme darstellen und einer untercarbonischen Art angehören. Leider gibt Haughton keine Beschreibung der inneren

1 The Last of the arctic Voyages being a Narrative of the Expedition under the command of Captain Sir Edw. Bercuer. Vol. II, 1855. Salter p. 381, PI. XXXVI, fig. 4 .

2 Murchison's Geology of Russ. Vol. 1, p. 621, pl. A, fig. 2.

3 Reminescences of Arctic Ice Travel in Search of Sir I. Franklin and his Companions. By Captain F. L. M'Cuntock. IVith Geol. Notes by S. Haughton. The Journal of the R. Dublin. S, Vol. I, 1856-57, p. 349, PJ. XI, fig. 6.

4 Th. Tschernyschew. Die obercarb. Brachiopoden des Ural und des Timan. S. 381 . 
Struktur der Koralle. I. borealis kommt in den untercarbonischen Ahlagerungen des 'Timan vor.

Fundorl: Store Björnekap. König Oscars Land. 6 Exemplare [14-25 (P.S. 29): 15--1S Dünnschliff].

\section{Familie Monticuliporidae Nıchoьsox. \\ Genus Geinitzella WaAties and Wentzel. \\ Geinitzella columnaris Schuothers. \\ 'Faf. III, Fig. 4. 5.}

1813. Caralliolites columnaris Scmoormis. Leonhard's Mineral. Taschenbuch p. 59.

1812. Ceriopora milleporacea liutonga. Verhandl. d. M. G. zu S.-P., p. 2S, pl. IV fig. $\therefore$.

1845. Stenopora spinigera Loxsdale. Mtırch. Geol. of Russ., p. 632, pl. A, fig. 11.

18i0. Alveolithes Buchiana Kiss. Permian fossils, p. 30, pl. IIl, fig. 10-12.

1850. Stenopora columnaris (Scmotnfim) Kixg. Il. p. 2S, pl. III, fig. 7, 9.

1851. Stenopora spinigera (Lovsdale) Kersentuva. Schrenks Reise. Bd. II, S. 92. Taf. 1I, Fig. 1, 2.

1560. - - (Lonsdale) Eicima.d. Lethaea Rossica. An. p., Vol. I, p. 415.

1860 Stenopora Mackrothi (Gesitz). Il. p. 416.

1861. Stenopora columnaris Geisitz. Dyas. Bd. I, p. 113, pl. XXI (exel. fig. Q(1).

1875. Stenopora tuberosa Toula. Permo-Carbon Foss. von Spitzbergen. N. Jahrb. f. 11 . et cet., p. $947, \mathrm{pl}$. X, fig. 4 .

1877. Stenopora columnaris Drвowskr. Verhandl, d. Ml. G. zu S.P., 2 Sër. Bd. XII, S. 65, Taf. III.

1887. Geinitzella colummaris WAAGEN \& WEXTzEL, Salt-Rang. Foss., p. 852, pl. CVI, fig. 5, 6, pl. CXIl, fig. 1-5, pl. CXIII, fig. $1-4$, pl. CIV, fig. 1.

1594. - - Netscildew. Trav. d. I. Soc. nat. d. l'Univers. hisan. Vol. XXVII, Sër. 4, p. 109, pl. 1. fig. 21, 22. 99-32, 37, 39.

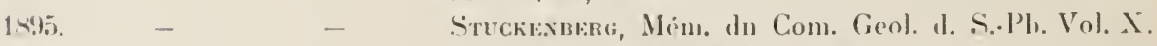
N. 3, p. 122, pl. XXIV, fig. 9.

Die Verlieter der Art Geinitzella columnaris, welche sich in del Samnlumg befinden, müssen zu var. ramosa Gesnıt\%. sparsigemmata WAAlifx d WeNTzEL gestellt werden.

Geinitzella columnaris Sucucotuem. var. ramosa sparsigemmata Geinitz W. \& WeNt.

Kileine Polypenstöcke zylindrischer oder verzweigter Form mil hallh-phatrinchen Spitzen; in den Verzweigungsstellen nimmt der Querschnilt des Polypenstoches eine aligeplattele Form an. Der Durchschnitt der Konlunie schwankt von 2 - $;$ mm. Die Oberfliche les Polypenstockes ist mil klemen Kelchen ron ovaler oder linglich ovaler Form bedeckt. Die 
Zahl der Kelche erreicht auf $5 \mathrm{~mm}$. 12-15; längs der Achse der Kolonie lefinden sich nicht mehr als 12. Die gegenseitige Lage der Kelche ist unregetmässig, bloss an einigen Exemplaren ist es möglich, eine gewisse Regelmässigkeit in der Lage der Kelche zu beobachten. Die Oberfläche des Polypenstockes zerfällt deutlich in einige Teile, die der Form nach an sphärische, schachartig angeordnete Dreiecke erinnern (Taf. III, Fig. 4 a, b). In diesen Teilen verändert sich die vertikale Lage der Zellen in eine schachartige. Es kommen auch solche Exemplare vor, an denen die Lage der Kelche nur zum Teil an der Oberfläche regelmässig ist, während sie an den übrigen Teilen der Oberfläche unregelmässig wird. An der halbsphärischen - spitzigen - Oberfläche des Polypenstocks sind die Kelche streng schachartig angeordnet.

Zwischen älteren Kelchen (Autoporen) liegen Tuberkeln (Acanthoporen) und kleine jüngere Kelche (Mesoporen).

Die Kolonie ist aus auseinandergehenden Bündeln prismatischer Röhren, die am Mittelpunkt parallel der Achse gelagert sind und sich allmählich zur Oberfläche hinbiegen, zusammengesetzt. Alle Polypenstöcke stellen eine ursprüngliche Kolonie dar. Das Wachsen verläuft nur längs der Achse durch periodisches Anwachsen der jungen Röhren. Dieses Merkmal ist für die beschriebene Form bezeichnend.

In zentralen Teilen der Kolonie sind die Röhren dünnwandig und an der Oberfläclıe verdickt. Die Verdickungen ohne Verengungen erreichen 0,50-0,75 mm. Höhe. Die Boden sind selten und nicht einmal an allen Exemplaren zu verfolgen.

Die Struktur der Röhrenwände erscheint in mikroskopischen Präparaten (Ocular N 1, Objektiv N 4) folgendermassen. In den Tangentialschnitten, die an der Oberfläche des Polypenstocks gezogen sind, besitzen die Zellen einen ellipsoidalen Schnitt (Taf. III, Fig. 5 a, b [1]). Die Zellen sind von eimer konzentrischen Schicht durchsichtigen Kalkes (2) umrandet. Die Zwischenräume der Zellen sind durch weniger durchsichtigen Stoff (Sklerenchyma) körniger Substanz ausgefüllt (3). Der Charakter der Tangentialschnitte ist den Abbildungen derselben von Dyвowsey (1. c. Tab. III, Fig. 9) vollständig gleich.

Aus den Radialschnitten ermittelt man, dass der durchsichtige Stoff, der die Zellenhöhle ausfüllt, den Wandstoff der tieferen Teile der Kolonie darstellt (Tab. III, Fig. 5 c). Das Verhältnis zwischen dem Wandstoff der Sklerenchym ist deutlich aus der Zeichnung zu ersehen (Taf. III, Fig. 5 c).

An einer Reihe von Exemplaren ein und desselhen Stückes Kalkstein (Store Björnekap, König Oscars Land) beobachtet man einige äusserst interessante Bildungen. In Radial- und Tangentialschnitten sind 
fir-cantige Adem (f) aus duchsichtigem Gewehe zu verfolgen. welche cimzelne Zellen miteinander verhinden und den Sklerenchymstoff durch- hueilen. Die Adern besitzen einen runden Querschnitt (Taf. III, Fig. 5) und durchziehen die Verdickungen in verschiedenen Richtungen. In den Adern ist ein dunklerer Achsenkern zu unterscheiden. der manchmal den die Zellemhähle inkmstierenden Stoff sich unmittelbar verknüpft. In жеe Fillen (Taf. MII, Fig. 5a) waren die Achsenkerne so breit. dass die Kalkspathkristalle. die die entgegengesetzten Seiten bedecken. sich nicht in eine allgemeine dunkle Faser verschmolzen: in diesen Fällen verursaclute die Inkrustationssubstauz Konturen, die an 'Turnhantelı erimnern. lis dïnkt mich, dass die beschriebenen Bildungen hohle Rühren aus durchsichtigen Gewehe vorstellen, durclı deren Hilfe einzelne Zellenhöhlen sich miteinander verknïpfen.

Es kann die Frage entstehen, ob diese Poren nichl äteren Ursprungs sind, der infolge ïusserer Umstïnde hervortritt. In diesem Falle müssten die Öffunngen die heiden Schichten durchbohren und aus ilınen un̈ssten die Wände der Kanäle entstehen. Freilich bot sich in keinem einzigen Falle Gelegenheit zu beolnachten, dass die Kanäle ummittellıar den Sklerenchynstoff durclızogen und kein Häutchen aus durchsichligem Stoff hesassen.

Auf diese Weise erscheinen die Kanäle als Strukturhildungen, die den Poren entsprechen; ähnliche Bildungen wurden schon in der paläon. tologischen Literatur beschrieben. So haben WaAgen und Picul.' Vertreter der Gattung Pachypora curvata IV. und P. heschrieben und abgelsildet, bei denen die verdickten Teile der Wände von gebogenen Verhindungskanälen durchzogen sind. Diese Kanäle. wie anch die von uns beschriebenen, stellen Strukturbildungen dar. deren Entstehen nicht von heiläufigen Grïnden abhängt, wie \%. B. von hohrenden Parasiten, wie Lindström² voraussetzte. Wenn diese Gänge tatsïchlich von unbefugten Organismen durchbohrt wïren. so wäre es schwer zu erklären. weshall, die Substanz, welche die Wände der Kaıble bildet. sternarlig geordnet ist, was man deutlich in einer ganzen Reilie von (nerilurchschnitten beobachten kann (siehe Taf. XCVII, Fig. 3 l), 3 a).

Die Frage nach dem Vorlıandensein der Poren wurde bei der Gattung Stenopora. die der Geinitzella verwandt ist, berülıt. Die allgemeine

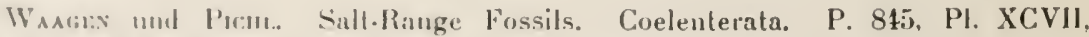
fig. 1 c: : $: 3$ a, b, a.

2. G. Lixustulis. Beschureihung einiger obersilurischen Korallen von der lnsel Gotlund. Bitung. till k. S. V. A. H., Bd. 21. Ab. IV. N 7, S. 27. 28, Tuf. V Fig. $61 \mathrm{~h}$
} 
Übersicht über diese Frage wurde von Prof. Romanowsky ${ }^{1}$ gegeben. Romanowsky gelang es nicht, Poren hei den Vertretern der Gattung Stenopora nachzuweisen, doch verneinte er nicht die Mögtichkeit ihres Vorhandenseins bei den Formen, die „das Verbiulungsglied zwischen den Gattungen Stemopora und Favosites vorstellen". Stuckenberg ${ }^{2}$ weist bei der Charakteristik der Gattung Stenopora darauf hin, dass "die Poren in den Zellen einiger Arten konstatiert wurden".

Die Exemplare von G. colum. v. ram. s., die am Ural gefunden wurden, überschritten im Durchmesser nicht 2,5 mm. Diejenigen aus Salt-Range sind dem äusseren Charakter nach vollständig den polaren gleich. Es ist interessant zu bemerken, dass bei einem Exemplar Geinitzella columnaris aus den Permablagerungen vom Fluss Kuloi (Guv. Arkangelsk), welches im Geologischen Komitee auflewahrt wird, die Lage der Kelche der beschriebenen Form vollständig analog ist (Taf. III, Fig. 4 b).

G. columnaris v. ramosa sparsigemmata wurde im Obercarbon des Ural, im Permocarbon und in den Permablagerungen des östlichen Teiles des Europäischen Russlands gefunden. In Indien kommt diese Form im middle and upper Product.-limestone vor.

Fundort: Store Björnekap. König Oscars Land. Etwa 30 Exemplare. [N 26-39, 56, 67, 73 (P. S. 39); 40-44; 45, 46, Dünnschliffe 47-48 (P. S. 29), 123, 124].

Heibergs Land [49, 5̄1, 52 (Dünnschliffe) $V_{2}$ ].

\section{Genus Stenopora Lonsdale.}

\section{Stenopora aff. ovata Lonsdale.}

Taf. III, Fig. 6.

1887. Stenopora ovata WaAgen \& Wentzel. Salt-Range Foss. p. 888 pl. CX. Eben da s. Synonymik.

Der Polypenstock befestigt sich mit der breiten Basis an verschiedene Gegenstände (Brachiopodenschalen); bein Beginn des Wachstums ist die Form des Polypenstocks halbsphärisch, dann zylindrisch. Der Durchmesser der Kolonie erreicht 10-13 $\mathrm{mm}$. Der Polypenstock besteht aus aufeinanderfolgenden Kolonien, die einander umliegen. Es gelang nicht, die äussere Oberfläche zu studieren. Die paternosterförmigen Verdickungen

1 Romanowsky. Über die Gattung Stenopora LonsD. und eine Beschreibung der neuen Art Stenopora Lahuseni. Verhandl. der Russisch. Kaiserl. Mineral. Gesell, zu St. Petersb., Vol. XXXVIII, 1891, pp. 169-192.

2 Stuckenberg, 1. c. 1895 , p. 124. 
der Wïnde stehen itırem Charakter nach der Stenopora ovata aus SaltRange (I. c. Taf. CX, Fig. e el selır nahe. Die Boden sind selten. flach, manclunal nicht vollstiundig.

W. d. Wextyk weisen darauf hin, dass die Zahl der Verdickungen anf 1 mun. (2, 2 mm.) 6-10 erreicht. Bei der heschrielsenen Form kom. men in einem T'eile der Kolonie 6 Verdickungen vor, in anderen weniger.

Dieses Linterscheidungsmerkmal, wie auch der nicht untersuchte Charakter der äusseren Oberfliiche, gestatten nicht, eine vollstïndige Ühereinstimmung zwischen den polaren Formen und der Art ron L.ONSDALE $\%$ entilecken.

St. ovcetc wurde im middle and upper Prod.-limestone des SaltKange gefunden.

Fundort: Store Bjornekap. König Oscars Land.

4 Exemplare (P.S. 39: N 53. 54. 55, 56, 128).

\section{Bryozoa.}

Familie Fenestellidae Kinc.

Aus den zur Familie Fenestellidae K. gestellten Gattungen wurden in der Sammlung angelroffen: Fenestella Lonsd. (6 Species), Archimedes Lesueur (1 Species), Polypora M'Coy (5 Species) und Phyllopora King (1 Species). Auf diese Weise sind Fenestella und Polypora am zahlreiclssten vertreten. Im Verhältnis zur Zahl der untersuchten Exemplare üherwiegt Polypora (etwa 57 Exemplare), wobei besonders zahlreich Polypora orbicribata Keys. (30 Exemplare) und P. martis Fisch. (16 Ex.) vertreten sind. Zum übrigen Teil aller Arten der Gattung Fenestella zrehören bloss 17 Exemplare.

Genus Fenestella Loxsdale.

Fenestella elegantissima kichwalb.

Tat. III, Fig. 7 a-l).

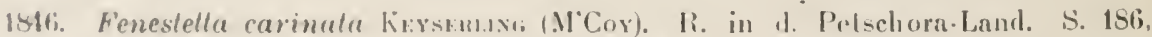
Taf, III, Fig. 12a-b.

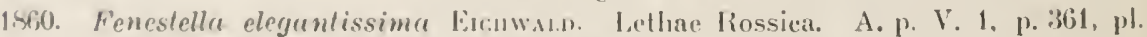
XXIII, fig. 1.

14rif. - - Gavil\%. Carlonformat. und Dyas in Nebraska. S. 67. Tat, V. lig. 7.

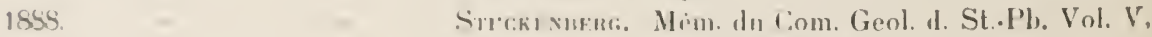

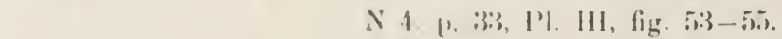

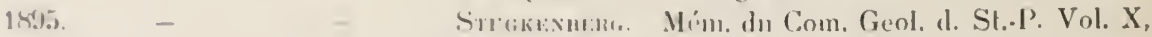
1905. N $3,1.131$.

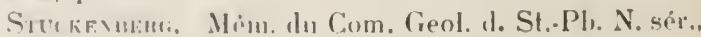
I. 9.3. 1. 29. 
Kleine Netzbruchstücke, die aus 24 Ästen auf $10 \mathrm{~mm}$. zusammengesetzt sind; die Zahl der Quersprossen erreicht 20 auf $10 \mathrm{~mm}$. An jeder Maschenseite liegen drei Zellen. Beim Vergleich der beschriebenen Exenplare mit denjenigen vom Timan und vom Ural, die im Museun des Geologischen Komilees aufbewahrt werden, nimmt man ihre vollständige Übereinstimnung wahr. Zu Erchwalos Art steht die Fenestella perelegans Meєк aus dem Middle Productus Limestone des Salt-Range, die ausführlich von WaAgen und Picul beschrieben wurde ${ }^{1}$, nahe. Auf diese Ähılichkeit wurde schon eimmal hingewiesen?.

F. elegantissima wurde in Russland im Obercarbon $\left(\mathrm{C}_{3}^{2}, \mathrm{C}_{3}^{3}\right)$ des Ural und des 'Timan, in Mittelrussland und am Wolgadurchbiuch bei Samara - Samárskaja Luká - (Zarew Kurgan, Korallenhorizont, Horizont mit Productus Cora d'Orb.) gefunden. Ebenso wurde sie in den Mittel-Permablagerungen $\left(\mathrm{P}_{2}\right)$ des östlichen Teiles des europäischen Russlands ${ }^{3}$ angetroffen. Nord-Amerika: Nebraska. Kohlenkalk Bellevue. Nebraska.City. C. c IV.

Fundort: König Oscars Land. Store Björnekap.

2 Exemplare. [N 57. 58 (P.S. 39)].

\section{Fenestella veneris Fischer. \\ Taf. III, Fig. 8 (a-b).}

1837. Retepora veneris Frschen. Oryctographie du Gouv. de Moscon. p. 165, pl. 39, fig. 1.

1845. Fenestella veneris Lossdale. Im Murchison's "The Geology of Russia" Vol. 1, Ap. A, p. 630.

\begin{tabular}{|c|c|c|c|}
\hline 1860. & - & - & Eichwald. Lethaea Rossica. A. p. Vol. I, p. 365. \\
\hline 1876. & -. & - & $\begin{array}{l}\text { Trautschold. Die Kalk. von Mjatschkowo, p. 91. pl. X, } \\
\text { fig. } 12-13 \text {, pl. XI, fig. } 1 \text {. }\end{array}$ \\
\hline 1888. & - & - & $\begin{array}{l}\text { Stuckenberg. Mém. du Com. Geol. d. St.l'. Vol. II, N. } 4 . \\
\text { p. } 31 \text {, pl. III, fig. } 39,40,41 .\end{array}$ \\
\hline 1895. & - & - & $\begin{array}{l}\text { Stuckenberg. Mém. du Com. Geol. d. St.Pl, Vol. } \\
\text { N 3, p. } 137 .\end{array}$ \\
\hline 1904. & - & - & $\begin{array}{l}\text { Stuckenberg. Mém. du Com. Geol. d. St.Pb. N. S } \\
\text { L. } 14, \text { p. } 63 .\end{array}$ \\
\hline 05. & - & - & Mém. du Com. Geol. d. St.P. N. S \\
\hline
\end{tabular}

Bruchstücke der Kolonien, die aus etwa 20-22 Ästen auf $10 \mathrm{~mm}$. gebildet sind. Die Zahl der Quersprossen in derselben Entfernung erreicht 16. Das Netzwerk ist mit der Vorderseite (nicht Zellenseite)

I WaAgen. Salt-Range Fos. Sér. XIII, Vol. 1, p. 777, pl. LXXXVII, fig. 1-3.

2 Ti. Tschernyschew. Die obercarb. Brachiopoden d. Ural u. d. Timan. Mém. du Conmité Geol. d. St.P. Vol. XVI, N 2, p. 415.

3 A. Netschajew. Die Fauna der Permischen Ablagerungen. Trav. d. la Soc. Nat. d. l'Univers. Kasan. Vol. XXVII, 4, p. 122. 
y.m Beohadhter, gerichtet. Es ist möglich, die Lage der Zellen an einigen Teilen des: Nelzes zu beobacditen : sie liegren zn zweit oder zu dritt an jeder Seile der Maschen. Den Abmessungen und der Lage der Zellen nach -limmt die besprochene Form mit der von Stuckenberg beschriebenen (m) Timan vollständig überein.

F. reneris ist aus dem Obertarthon des Timan $\left(\mathrm{C}_{3}^{3}, \mathrm{C}_{3 \mathrm{~b}}^{\mathrm{I}}\right)$ des Ural $\left(\mathrm{C}_{3}^{3}\right)$. des Wolgadurchloruchs hei Samara - Samårskaja Luki̊ - (Zarew Kurgan, Korallen-Horizont, Kalkstein mit $P$. Cora d'Orb.) bekannt. Guv. Mostiul. In Untercarbon des Guv. Tula.

Fundort: König Oscars Land. Store Björnekap.

3 Exemplare. $[59,60,61,62,73$ (P. S. 39) ].

\section{Fenestella angusta Fischer. \\ Taf. IV, Fig. 1.}

1837. Retepora angusta Fisciner. Orctographie. P. 165, pl. 39, fig. 3.

18ss. Fenestella angusta Steckexneri. Mèm. du Com. Geol. d. St.Pl. Vol. V X 4, p. 34. pl. 111. fig. 50, 51, 52.

1895. - - Stckexberr. Mém. du Com. Genl. d. St.Pb. Vol. X, N 3, p. 139, pl. XXI. lig. 2.

1904. - - Stuchexibeik. Mém. du Com. Geol. d. St.Pl, Xouv. Sér., I. 14, p. 64.

1905. - - Sruckinbeng. Mém. du Com. Geol. d. St.Pb. Nouv. Sér., L. 23, p. 28.

Die Bruchstüche gestatten nichı, die Forn der Kolonie wiederherzu-tellen. Das Netz ist aus 20 Ästen auf $10 \mathrm{~mm}$. zusammengesetzt; die Zahl der Maschen schwankt auf $10 \mathrm{~mm}$, zwischen 12-14. Stuckenberg weist hei der Feslstellung dieser Art darauf hin, dass auf $10 \mathrm{~mm}$. 12 Maschen kommen. Die Vermessung der Exemplare aus der SammInng des Geologischen Konitees, an denen die Etiquette mit der Aufschrift $F$. angusta angegeben ist, erwies, dass man an ein und den-. selhen Exemplar anf $10 \mathrm{~mm} .12$ und 14 Maschen abzälıen kann. Dieses herechtigt uns anch, die Exemplare mit feineren Maschen (14 auf 10 mm.) $\%$ Fiscunss Ant $\%$ stellen. Alle diese Fragmente sind mit der zellenlosen Seite zum Beobachter gerichtet; nur teilweise, da, wo das Nel\% algreriehen isl, bietel sich Gelegenheil, die Lage der Zellen zan rerfolgen: drei an jeder Seile der Masche.

lis ist hier an Plal\%, die Formen zu erwähnen, die zur Galtung Fenestella Loxis), vom Grimnel Laind (Feilden Isthmus) gehören und von Eтumus: ${ }^{1}$ besclurieben wurden.

3 Eimemagi. Pal, of the Consts of the Aret. Lands visited by the late Brit. Expent. under Capp. Sir S. Nan1.s. Quart. I, 1S78, Vol. XXXIV. 
Eine Form (Fenestella sp., p. 619) wird vom Verfasser folgendermassen charakterisiert: "There are two cells in the length of every fenestrule on each side of the keel of the interstices, and one opposite the base of each dissepiment,...." Etheridge erwähnt eine Übereinstimmung der Polarform mit F. cribrosa $\mathrm{HALL}^{1}$ aus dem Niagara limestone (Upper Silurian). Da bei ETheridge keine Abbildungen der beschriebenen Form und keine Massangaben des Netzes angeführt sind, so kann man die Zahl der Äste und Quersprossen, die sich auf einer bestimmten Masslïnge befinden, bloss nach mittelbaren Angaben über die Form von Hall beurteilen. F. cribrosa ist aus 22 Ästen auf $10 \mathrm{~mm}$. gebildet (diese Zahl ist übertrieben, da das von Hall abgebildete Exemplar keine flache, sondern eine konvexe Form besitzt, also muss man auf der Tafel die Projektion zur Fläche messen); die Zahl der Quersprossen beträgt 12. Man muss annehmen, dass die Abmessungen des Netzes der von Etheridge beschriebenen Form den eben erwähnten nahestehen. Es scheint, dass die Älnnlichkeit der Polarform mit der silurischen doch nicht die Möglichkeit der Ähnlichkeit mit den Formen aus jüngeren Ablagerungen. wie z. B. den obercarbonischen, aufhebt. Und tatsächlich stimmen die Abmessungen des Netzes der Fenestella sp. vollständig mit den Massangaben der F. angusta Fischer überein. Die Lage der Zellen, das Vorhandensein des Kiels, alles das steht auch nicht im Widerspruch zu FISCHER's Art.

Die zweite Form (Fenestella sp. p. 620), die der F. bicellulata Eтн. gleichgestellt wird, zeichnet sich durch die Lage der Zellen in den Ecken, die von Ästen und Quersprossen gebildet sind, aus. Folghich befinden sich auf jeder Seite der Masche zwei Zellen. Eine analoge Lage der Zellen wird in einigen Maschen der F. veneris Fischer beobachtet. Allerdings haben die ausgesprochenen Erwägungen bloss einen allgemeinen Wert und erst nach dem Studium der Originale rom Grinnell Land wird man zu einem bestimmten Schluss kommen können.

F. angusta wurde in Russland im Obercarbon von Timan, Ural, Wolgadurchbruch bei Samara (Samårskaja Lukå), Guv. Moscau (Mjatschkowo) gefunden. Diese Art ist auch aus dem Untercarbon bekannt.

Fundort: Store Björnekap. König Oscars Land

5 Exemplare. [63-67 (P. S. 39)].

1 Hall. Pal. N. J. P. VI, Vol. 2, p. 166, pl. 40 D, fig. :3 a-b. 


\section{Fenestella orientalis licuWALD.}

Taf. IV. Fig. $2(\mathrm{a}-\mathrm{b})$.

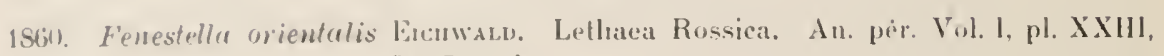
fig $\bar{a} a-b$.

184\%. - - Srrikmbenti, Mem, du Com. Geol. d. St.-Pl, Vol. X. N 3, p. 14t, pl. XXil, fig. 9.

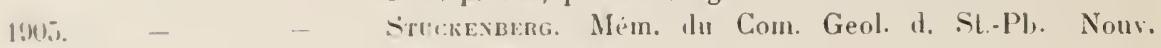
Sír. L. 23. p. 2?.

Las Netz ist fïcherförnigg und erreicht eine berleutende Grösse: ein lixemplar creicht eine Höhe von $80 \mathrm{~mm}$. und eine Breite von $45 \mathrm{~mm}$. Die \%all der $\mathrm{A}$-le betrïgl auf 10 mm. 15 und die Zahl der Quersprossen von J0 his 11. In verschiedenen Teilen der Kolonie verändern sich die Verhültnisse. An ıler Basis sind die Äste dick und die Maschen hesilzen fast eine runde Form, während die Äste an der Spilze der Kolonie dünner werden und auf $10 \mathrm{~mm}$. 16 an Zahl erreichen: die Maschen nehmen eine gestreckte Form an. Die Äste gehen oft aus. einander: es wird auch eine entgegengeselzte Erscheinung beobachtet: nïmlich das Verschmetzen der Äste. Auf der mit Zellen besetzten Seite des '/weiges ist ein schwacher Kiel mit spärlichen Tuberkeln zu beohachten. Zu beiden Seiten des Kiels liegen grosse Zellen, je drei an jerler Seite ler Masche. Bei der Bifurkation an erweiterten Teile des Astes sind die Zellen vorläufig in Mrei Reihen geordnet. Diese Eigentümlichkeit wird auch an dem Exemplar aus Sterlitamak beobachtet. das von Eranwald beschrieberi und ahgebildet wurde. Die zellenlose Seite ist glatt.

$F$. orientais wurde in Russland im Obercarbon des Ural $\left(\mathrm{C}_{4}^{3}\right)$, des Wolgadurchbruchs bei Samara - Samarskaja Luki (Zarew Kurgan, Rorallen-Horizont) angetroffen.

Fundort: Store Börnekap. König Oscars Land.

(i Exemplare. [68--75 (P. S. 39)].

\section{Fenestella plebeja M'Cor.}

Taf. IV, Fig. 3, a-b.

1911 Fenestella plebeja MPCor. A Synopsis of the Carbon. Limestone Fossils of Ireland, p. 20:3, pl. XXIX, fig. 3.

Istil-18li:s -.

$181 ; \%$.

1855 .

$18 \% \%$.
L,viwg. Meyer's Palaeontograplica, p. 224, pl. XXXVH, fig. 2 :1.

Grsxit\%, Carlonformation und Dyas von Nehraska, p. 68, pl. V, fig. 8.

Strokr:xben, Mim. du Com. Geol. d. St.-Pb. Vol. V, N 4. 1. 33i, pl. 111, fig. 45, 49.

Sruckr.menr. Min. du Com. Geol, d. St.Pb. Vol. X, N 3, 1. $1: 24$. 
1904. Fenestella plebeja Stuckexberg. Mém. du Com. Geol. d. St.-P. Noux. Sér, L. 14 , p. 64.

1905 Stuckenberg, Mém. du Com. Geol. d. St.Pb. Nouv. Sér., L. 23, p. 27.

Die Fragmente des Netzes gestatten nicht, die Form der Kolonie wiederherzustellen. Die \%ahl der Äste beträgt auf $10 \mathrm{~mm}$. 15; die Zahl der Maschen auf $10 \mathrm{~mm}$. 8-10. Die Zellen sind, vier an Zahl, an jeder Seite der Masche geordnet. Die besprochenen Formen stimmen vollständig mit den von Stuckenberg beschriebenen überein. Etheridge ${ }^{1}$ gibt eine Beschreibung der Form (Fenestella sp. p. 620) von Grimnel Land (Feilden Isthmus), die der F. plebeja M'Coy nahesteht. Bei der polaren For'n erreicht die Zahl der Zellen in einigen Maschen bis 6 auf jeder Seite, was, wie schon von ETHEridge hemerkt wurde, veranlasst, anzunehmen, dass diese Form nicht zu M'Coy Species gehört.

F. plebeia wurde in Russland am Timan und Ural im Ohercarbon $\left(\mathrm{C}_{3}^{3}\right)$ und in Untercarbon des Wolgadurchbruchs bei Samara - Samarskaja Lukå - gefunden (Korallen-Horizont und Horizont nit Productus Cora d’Orb.) Zentral-Russland Ober- und Untercarbon. England. Irland: Yellow Landstone Group. Carb. Sl.; Limestone Group. Low. L. N. Amerika: Bellevue und Plattesmouth, Nebraska.

Fundort: Store Björnekap. König Oscars Land.

2 Exemplare. $[58,76,77$ (P.S. 39) ].

\section{Fenestella varicosa M'Coy.}

Taf. IV, Fig. 4.

1844. Fenestella varicosa M'Coy. Synopsis of the Carb. Foss. of Ireland, p. 204, pl. XXVlli, fig. 8.

1860. - - (M'Coy) Eichwald. Lethaea Rossica. Am. pér. Vol. I, p. 339.

1895. - - Stuckenbert. Mém. du Com. Geol. d. St.-Pb. Vol. X, N 3, p. 141, pl. XXl, fig. 1.

Ein Netzbruchstück, das aus ungleich dicken Ästen besteht. Die Breite der dicken Äste erreicht $1 \mathrm{~mm}$., der dünnen 0,5 mm. Die Quersprossen liegen ungleichmässig, wodurch die Länge der Maschen von 1 bis 2 mm. schwankt. Die Zahl der Zellen auf jeder Seite der Masche ist 3-4. An der zellenlosen Oberfläche sind die Äste mit schwachen Längsrippen und deutlichen, kleinen Tuberkeln, die in einer Entfernung von $1,5 \mathrm{~mm}$. voneinander entfernt stehen, bedeckt. Der Grösse des Netzes und dem Charakter der Zellen nach deckt sich die beschriebene Form mit denen vom Ural, die bei Stuckenberg abgebildet sind. Bloss sind bei der Uralform die oben erwähnten Tuberkeln nicht zu bemerken.

\footnotetext{
1 Etheridge, l, c. p. 620.
} 
F. varicosa wurde in Russland im Ubercarbon des Ural angetrufferl. In England Ireland: Yellow Landstone Group. Carl. SI.; Jimestone (iroup. Upper L.

Fundorl: Store Bjürnekap. Künig Oscars Land.

1 Exemplar.

\section{Genus Archimedes Lesueur.}

\section{Archimedes sp. Taf."IV, Fig. ‘.}

Die Achst des Bruchstückes erreicht inn Durchmesser 2 mm. bei 10 nmm. Lïnge. Die Entfernung zwisehen den schraubenförmig gedrehten Windungen schwankt vou $3-3,5 \mathrm{~mm}$. Die besprochene Form unterscheidet sich von den Exemplaren, die von Stuckenbenci aus dem Obercarbon des Timan beschrieben wurden, durch geringeren Durchmesser und geringere Höhe der Windungen. Das Bruchstück kommt zusammen mit Fenestella plebeja M'Coy vor.

Fundort: Store Björmekap. Künig Oscars Land.

1 Exemplar. [77 (P.S. 39)].

\section{Genus Polypora M'Cor. \\ l'olypora martis Fischer.}

Taf. IV, Fig. 6.

1837. Retepora martis liscien. Oryclographie, p. 165, pl. XXXIX, fig. ‥

1s60. Polypara inaequalis Escinwall. Lethata Rossica. An. pér., Vol. I, p. 372. pl. 23, fig. 1 a-b.

1876. Polypora martis Thastscumb., Die Kalkbrüche vou Vjatschkowo. Vol. I, 1. 91, pl. XI, fig. 2.

1576. Polypara irregnalis 'Thacrsamoto, I. c., p. 92. pl. XI, fig. 3.

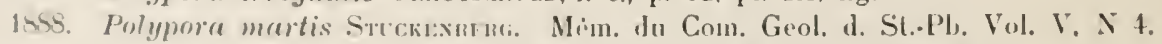
p. 34, pl. III, fig. 56, 57,58, pl. IV, fig. 30 .

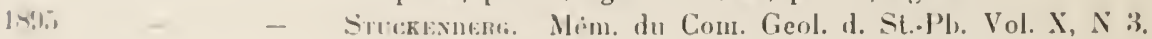
1. 16 il.

Das Bruch-lürlinalerial geslattet nicht, die Form der Kolonie wienlerherzustullen. Die \%alıl der İste auf 10 mun. erreicht 10-11: ron Quersmanen kommen S, selten 7 -9 ror. Die \%ellen liegen zu je 4-5 charlubellarlig msanmen. Die Maschen besitzen eine ovale Form.

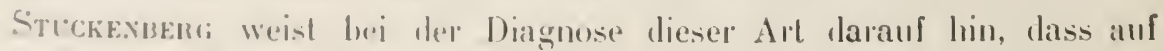
10 mun. 12 Ä.le und T-S ()uerbälkichen kommen. Freilich schwankt die Zahl Ile İste nuf 10 mm. von 9-11 an den Exemplaren dieser Art

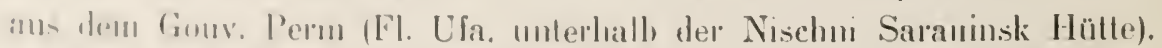
die sich iun Museum des Gentugischen Komitees hefinden. Nach 'I'raut. 
schoud heträgt die Zahl der Äste in derselben Entfernung ebenfalls 11. Dieses berechtigt uns, auch das Exemplar mit 10-11 Ästen auf $10 \mathrm{~mm}$. zu Fischer's Art zu stellen. Bei diesen Abmessungen stimmt das Netzwerk von $P$. martis F. und $P$. biarmica K. fast vollständig überein, obwolıl die beiden Arten leiclıt zu unterscheiden sind. Bei P. biarmica sind die Maschen mehr in die Lünge gezogen, als bei $P$. martis, und die Äste erweitern sich vor der Bifurkation stark keilförmig, was bei P. martis nicht zu beobachten ist, bei der die Breite der Äste keiner Veränderung unterliegt.

$P$. martis wurde in Russland an Ural im Obercarbon und im Gouv. Moscou (Mjatschkowo) gefunden.

Fundort: Store Björnekap. König Oscars Land.

16 Exemplare. [79-90; 140; 57 (P. S. 39) ].

Heibergs Land „Sorte Væg“. [N $\left.49\left(\mathrm{~V}_{2}\right)\right]$.

\section{Polypora biarmica Keyserling. Taf. IV, Fig. 7.}

1846. Polypora biarmica Keyserlins. Reise in d. Petschora-Land. S. 191, Taf. III, Fig. 10.

1861 Geivitz. Dyas ..., p. 117

1866. - - Geinitz. Carbonformat. und Dyas in Nebraska. S. 68, Taf. V, Fig. 13 a-b.

1875. - _ Toula. Eine Kohlenkalk.Fauna von den Barents.Inseln. Sitzb. d. K. Akad. d. Wissensch., LXXI Bd., S. 36, Taf. III, Fig. 15 a-b.

1875. - _ Stuckenberg. Reise in das Petschora-Land. S. 96.

1887. - _ - Wangen. Salt-Range Fossils etc., p. 791, pl. XC, fig. 5, 6, 7.

1894. - - Netschajew. Die Fauna der Permischen Ablagerungen. Trav. d. l. Soc. Nat. d. l'Univers. Kasan. Vol. XXVII, L. 4, p. 128, pl. II, fig. 2 a-b.

1895. - - Stuckenberg. Mém. du Com. Geol. d. St.Pb. Vol. V, N 3, p. 158, pl. XXIII, fig. 1.

Das Netz ist becherförmig. Die Zahl der Äste beträgt auf $10 \mathrm{~mm}$. 10-11; von Quersprossen kommen 8 vor. Die Bifurkation ist dicht. Die Zellen liegen nach der Bifurkation unmittelbar in drei Reihen; dem Wachstum der Äste nach steigt die Zahl der Zellenreihen bis auf 5. Bezeichnend für diese Art ist die längliche ovale Form der Maschen und eine starke keilenförmige Erweiterung der Äste vor der Bifurkation; auf diese Weise wechselt die Breite der Äste beständig. Der Vergleich der beschriebenen Form mit denen vom Timan und Ural bestätigt ihre vollständige Übereinstimmung.

Geinitz beschrieb eine Form aus Nebraska City (l. c.) als P. biarmica. Stuchenberg ${ }^{1}$ stellte diese Form zur Synonymik der $P$. martis. Aler

1 Stuckenberg. Mén. dı Com. Geol. d. St.Pb. Vol V, N 4, p. 34. 
hei dem Exemplar, das von Geıxıтz abgebildet wurde, sind die bezeichnenden Merkmale der P. biarmica, hauptsitchlich die keilförmige Er. weiterung der Äste, so stark ansgeprïgt, dass, wie es uns scheint, kein Grund vortiegl, sie zu Fiscuras Art 7.1 stellen. Die eben erörterte Bemerkung bezieht sicls auclı auf P. biarmica Touls ${ }^{1}$ von der Höferlnsel, die von Stuckinberg zu P. martis gestellt wurde. Étheridge" gilht eine Beschreilung der Exemplare ron Grimnel Land (Feilden Isthmus), die el zu P. biarmica slellt. In der Synonymik weist Etheridge auf die Formen von Toula und Geisitz hin, die zweifellos zu P. biarmica zehören. In ter ausführlichen Beschreihung ist darauf hingewiesen, dass: "the normal number in eatch row is three, sometimes four, and immediately before bifurcation of the stem takes place the enlarged dissepiment may cary six", was wieder für $P$. biarmica bezeichnend ist; doch die Abbildung (Fig. 4) erweckt einigen Zweifel. Auf der Zeich. mung ist die Zahl der Äste $10 \mathrm{~mm}$. - 9, der Maschen S-7 und stellenweise 4. Die Netze von dieser Grösse ïhersteigen bedeutend die Abmessungen der Formen rom Timan und Ural, die als P. biarmica beschrieben wurden. Lis isl hedauerlich, dass Etueringe keine Massangaben des Netzwerkes angeführt hat und dass auch Angaben darï̀l,er fehten. ol) Fig. 4 in natürlicher Grösse gezeichnet ist.

$P$. biarmica wurde in Russland im Obercarbon des Timan und des Ural $\left(\mathrm{C}_{3}^{3}\right)$ gefunden. Netscnasew weist darau hin, dass $P$. biarmica im Obercarbon und in den Mittelperm-Ablagerungen im Osten des Eurofüischen Russland's $\left(\mathrm{P}_{2}\right)$ vorkommt. Dann wurle diese Art auf den Barents-Inselı (die brïunlichen, schiefrigen, an Bivaiven reichen Sandsteine) angetroffen. N. Amerika: Nelraska-City (C. $\left.c^{11}\right)$. Morton (B. b ${ }^{\mathrm{Vl}}$ ). Asien: Salt-Range. Upper Productus limestone.

Fumlort: Store Björnekap. König Oscars Land.

6) Exemplare. [91-95 (P. S. 29), 96-9S (P. S. 39)].

\section{Polyporir pustulata 'Touta. \\ 'Taf. IV, Fig. $S$ a - - b.}

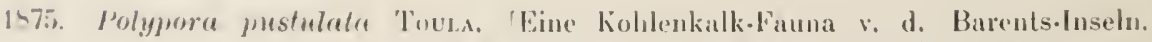
Sitzl. "l, k. Akatl. Il. Wissenseh., Bंd. LXXI, S. 41. Tit. IV, rig. $2 \mathrm{a}-\mathrm{b}$.

Nith den vorhandenen bxemplaren fallt es schwer, die form der Kolonie wiederher\%nstellen; angenselyeinlich besass sie ein schmales. kelchförmiges Aussehen. Das Numwerk bestehl anıs Ästen, die sich oft

1 Tot i.A I r. J. Bi.

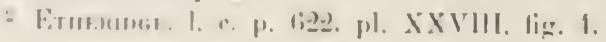


gabeln und auf $10 \mathrm{~mm}$. in einer Anzahl von S-9 vorkommen. Die Breite der Äste erreicht $1 \mathrm{~mm}$. Die Maschen, 6 an Zahl auf 10 mm., haben eine länglich ovale Form und gleichen der Breite nach den Ästen. Die Quersprossen sind etwas schmäler als die Äste. Die Zellen liegen in regelmässigen schachbrettartigen Reihen, die von der Bifurkation abhängen, und leren Zahl zwischen 4 bis 6 schwankt. Aut der mit Zellen beselzten Seite des Zweiges sind deutlich 2 oder 3 mit Tuberkeln bedeckte Reihen sichtbar. Die entgegengesetzte Seite ist nicht deutlich zu sehen. Die Abmessungen des Netzwerkes, der Charakter der Maschen und der allgemeine Habitus der mit Zellen besetzten Seite, die Tuberkeln trägt, stimmen mit der von 'Toula gegebenen Diagnose vollständig überein.

P. pustulata kommt auf den Barents-Inselı (Höfer-Insel, SchedirInsel) vor.

Fundort: Store Björnekap. König Oscars Land.

2 Exemplare. [99, 101].

\section{Polypora orbicribata Keyserling.}

Taf. IV, Fig. 9.

1847. Polypora orbicribata Keyserliva. Reise in das Pelschora.Land. S. 189. Taf. III, Fig. 7.

1875. - $\quad$ - $\quad$ Stuck fnberg. Reise in das Petschora-Land. S. 96.

1887. Polypora ornata WaAger \& Pichl. Salt-Range Foss., Sér. VIll, Vol. I, p. 788, pl. LXXXIX, fig. 4, 5, 6, pl. XC, fig. 2, 3, 4.

1888. Polypora ef. orbicribata Stuckenberg. Mem. du Com. Geol. d. St.Ph. Vol. V, N 4, p. 34, pl. IV, fig. 6.

1895. Polypora orbicribata Stuckenberg. Mém. du Com. Geol. d. St..Pb. Vol. X, N 3, p. 157, pl. XXII, fig. $5 \mathrm{a}-\mathrm{b}$.

Die For'm der Kolonie ist augenscheinlich becherartig. Die Breite ler Äste und der Quersprossen, der Charakter der Maschen und die Lage der Zellen sind vollständig mit denen vom Ural und vom Timan gleich. Ich führe die Hauptabmessungen der Polarexemplare an: die Zahl der Äste auf $10 \mathrm{~mm}$. beträgt 5-8, der Maschen 4-6, die Zahl der Zellenreihen 4-7, bei den Quersprossen bis 7. Dank der seltenen Erhaltung eines Exemplars war es möglich, die Oberfläche der Äste ohne Zellen eingehend kennen zu lernen. Längsirippen, die die Oberfläche der Äste bedecken, sind mit feinen Tuberkeln versehen; ebensolche Tuberkeln bedecken auch die Quersprossen.

Wie bekannt, wurde von der Belcher Expedition ein paläontologisches Material von der Insel Grinnel (Depôt Point) gesammelt, das Salter $^{1}$ bearbeitete. Bei der Beschreibung der Fauna führt Salter

1 Salter. Belcher's Last of the Aretic Voyages. Vol. II, 1855, 1. 377-389. 
sine Furm an, die er als Fenestella arctica (1. c. S. 355, Taf. XXXVI. Fig. S) hezeichnet. Der Verfasser ist geneigh, eine Ähnlichkeit der hesprochenen Form mit den carbonischen Arten $P$. orbicribata Keyser und $P$. martis Fiscuen ${ }^{1}$ \%u sehen. Was die Übereinstimmung mit l'. martis anbetrifft, so sind die Almessungen des Netwerkes der F. arclica (auf $10 \mathrm{~mm}$. kommen 5 Äste und $3-4$ Maschen) zu gross für Frants: Art; Netze diesel Grösse stelen Kesserbings Art näher, bei der manchmal (Stroknnerg l. c.) eine rickzackartige Drehung der Äste zu heobachten ist. Salten hatte keine Möglichkeit, die Lage der \%ellen \%u studieren, deshall, kann man auch nicht behaupten, dass, lie ron ihm heschriebene Form zur Gathung Fenestella gehört. Ferner wurde eine analoge Form von Etheridge ${ }^{2}$ vom Grinmel Land (Feildenlsthmus) als Fenestella: arctica beschrieben. EtuenIDge hatte Gelegenheit, die Lage der Zellen näher kennen \%u lernen. und dieses Studimm veranlasste ihn zu der Vermutung, dass diese Form nicht ler Gattung Goniocladia Etuendie angehören kömute. Auf diese Weise verwickelte sich die Frage über die Stellung der Form von Salten; allein den Literaturangahen nach isl es unmöglıch, eine bestimmte Entscheidung zu treffen.

Eine andere nahestehende Art ist P. ornata W. dP. P. Die Beschreibrr dieser Art weisen auf die uahe Verwandtschaft ihrer Form zu Keyseruncis Art hin und halten die geringe Zahl der Zellenreilıen bei P. orbicribatu (nach Kerserusg 4-5 Reihen) für das Hauptunterscheidungsmerkmal. STuckexber,i wies naclı, weshalb Keyserung die oben angeführte Zahl der \%ellenreihen annahm und weshalt er fül P. orbicribala "j-S Reihen und an den verdickten Teilen der Äste bei der Vereinigung mit deu (Jureprosien bis 10 Reilen" aufstellte. Auf diese Weise fällt aucl diese" linter-chied \%wischen Kesserungs und den W. d. P. Arten weg. Der ummittelthure Vergleich ler Originale aus Salt-Range, vom Timan, Ural und Aler Polarformen vonn König Oscars Land gestattet eine vollständige Girinhleit festzustellen. Fs unterscheidet sich nur ein wenig die Skulptur lwr zellenlosen Oberflitche der Ïste. Bei den Timan und Polarexenplaren sind die İste nit geraden, lïnglichen, feinen Längsrippen bedeckt,

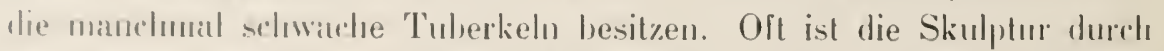
מim. dïnne, glatte oder kïmige Kalkschicht verdeckt. Die Lïngsrippen der Salt-Range Exemplare unterscheiden sich nicht durch sotch rine gerade Anordums. wio die 'limanformen; \%uweilen bilden einige Liing...

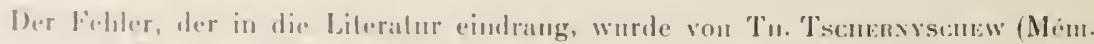

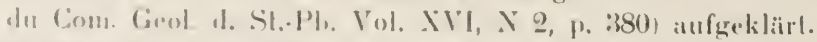

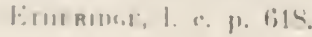


rippen un die Maschen geschlossene Konturen, wie es bei WaAgen in der Abbildung (P. $\mathrm{XC}$, fig. $3 \mathrm{~b}$ ) wiedergegeben wird. Es scheint uns, dass das letztere nicht als Artunterschied gelten kann und $P$. ornata mit $P$. orbicribata K. gleichgestellt werden muss.

P. orbicribata wurde in Russland im Obercarbon des Timan $\left(\mathrm{C}_{3}^{2}, \mathrm{C}_{3}^{3}\right)$ und des Ural $\left(\mathrm{C}_{3}^{3}\right)$ angetroffen. $P$. ornata ist aus der Salt-Range, middle and upper Prod. limestone bekannt.

Fundort: Store Björnekap. König Oscar's Land.

Etwa 30 Exemplare. [102-125; 126 (P. S. 8); 127 (P. S. 29); 57, 128 (P. S. 39) ; 68, 69, 85. 89].

Heibergs Land $\left[\mathrm{N} 49\left(\mathrm{~V}_{2}\right)\right]$.

\section{Polypora micropora Stuckenberg.}

Taf. IV, Fig. $10 \mathrm{a}-\mathrm{b}$.

1895. Polypora micropora Stuckexberti. Mém. du Com. Geol. d. St.Pb. Vol. X. N 3, p. 161, pl. XXIII, fig. 8 .

1905. - - - Stuckenberg, Mém. du Com. Geol. d. St..Pl,. N. Sér L. 23, p. 30.

Die Stöcke besitzen eine fast fächerförmige Gestalt. Die Hölıe eines Exemplar's erreicht $50 \mathrm{~mm}$., die Breite $40 \mathrm{~mm}$. Die Zahl der Äste auf $10 \mathrm{~mm}$. ist 11; ihre Breite vor der Bifurkation erreicht $1 \mathrm{~mm}$., später nimmt sie etwas ab. Die mit Zellen besetzte Seite ist fast flach, die entgegengesetzte ist gewölbt. Die Zahl der Quersprossen auf $10 \mathrm{~mm}$. erreicht 10. Thre Breite auf der Zellenseite schwankt von 3,5 bis $1 \mathrm{~mm}$.; den Abdrücken nach ist die Breite der entgegengesetzten Seite geringer. In Bezug auf die erwähnte Ungleichheit verändert sich auch der Charakter der Maschen. An der Zellenseite besitzen die Maschen eine unregel. mässige schmale Spaltenform $0,25 \mathrm{~mm}$. breit; von der entgegengesetzten Seite erscheinen sie als unregelmässige Kreise. Die Zellen sind schachbrettartig in 4-5 Reihen angeordnet. Die Ausbildung der entgegengesetzten Seite konnte man nicht beobachten, da alle Exemplare mit der Zellenseite dem Beobachter zu gerichtet sind. Die besprochene Form steht Stucrenbergs Art nahe, deren Originale im Museum des Geologischen Komitees aufbewahrt werden.

P. micropora wurde in Russland im Obercarbon des Ural (Gouv. Perm. Fl. Silva), Wolgadurchlıruch bei Samara - Samàrskaja Luki (Zarew Kergan, Horizont mit Prod. Cora d'Orb.) angetroffen.

Fundort: Store Björnekap. König Oscars Land.

3 Exemplare. [125, 129-133 (P. S. 39)]. 
Gems Phyllopora Kixg.

Phyllopora ef. horealis S̈TLCKexBers.

Tal. IV. Fig. 11 a-b.

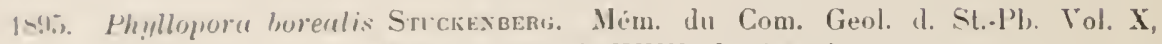
N :3, p. 166i, pl. Xxill, fig. 9 a-b.

Die Almessungen ler Bruchstïcke dieser Kolonie erreichen 40 mm. In einer Richtung und 4.i mm. in der senkrechten. Die allgemeine Form Wer Kolonic ist undentlich. Das Netzwerk besteht aus gebogenen Ästen, die sich mmmittelbar milemander verbinden und sich oft gabeln. Die lireite der Ïste -chwankt von 0,5 his 0,75 mm.; an den Knoten erreicht sie bis zu 1 mm. Mie Öffnungen der Maschen hesitzen eine vollständige Kreis- oder Ovalform. Falls die Maschen mit Gestein ausgefüllt sind, su kann man an einigen Stellen die sechseckige Form des ausfüllenden fiesteins beobachlen, was auf die sechseckige Form des Maschenrandes hinweist. In Folge des schlechten Erhaltungszustandes komnte man die scchseckige Form des Randes nicht heobachten. Der Durchmesser der Maschen errejchl etwa I mm. Stellenweise kann man in der Lage der Maschen zwei Richtungen ausscheiden, die sich in einem Winkel kreuzen; in diesem Falle wird jede Masche von einem ziemlich regelmässigen Sechseck anderer Maschen begrenz. An ein und demselben Exemplar Irifft man Netze mit vollständig unregelmiissiger Lage der Maschen, wobei die umregelmissige Lage rorwiegt. Die Zahl der Maschen beträgt auf 10 mm. an den diagonalen Reihen und an der Achse der Kolonie (j-7, und in der senkrechten Richtung zur Achse S-9. Die Zellen lagern in 3-4 Reilıen, an den Knoten triff man his 6 Reihen an. Die \%ellen sind verschieden gross. Die Seite ohne Zellen ist glatt.

Die hesprochene Form steht ler Phyllopora borealis STuckenbirg am nädisten. Die \%ahl und die Lage der Maschen bei Ph. borealis stimmt mil der von mus unlersuchten vollkommen überein, wie man es der F̈igur Y h (zweimal vergrösserl) entuelmen kann. In der Diagnose weist Strokesueng darauf hiu, dass ndie Lage der Maschen zwischen 1 und 1,5 mm. schwankt; ihre Breite ist nichl grösser als 0,5 mm." Infolgelessen whilıs die Breite ler Aste und die Zahl der Zellen, die in 4--fi Reilren liegen. Die in lie Lüinge gezogene Form der Äste und die grössere Zalıl der Zellemeihen sind die einzigen Unterscheidungsmerk. male der Furm von Stuckisbrizg und der polaren Species. Wenn wir IIIs wienler der otien angeführten Zeichunng zukehren, so müssen wir annelunem, diss diese Unter-cheidungsmerkmale kam so widersprechend

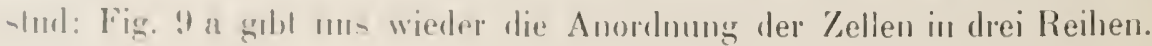


Es fällı schwer, eine vollständige Ähnlichkeit der beiden Formen festzustellen, ohne sie verglichen zu haben, deshalb betrachten wir die Polarform als konform der von Stuckeneerg beschriebenen.

Als eime andere verwandte Art muss man Phyllopora hexagona Netscha.jeW ${ }^{1}$ aus den Mittelpermablagerungen $\left(P_{2}\right)$ des östlichen Russlands ansehen. Diese Form nïhert sich der polaren Species durch die Abmessungen der Maschen, ihre Zahl, die Breite der Äste und endlich durch die Zahl der Zellenreihen; Audeutungen von einer sechseckigen Forı der Maschentiinder - ein bezeichnendes Merkmal der Ph. hexagona finden wir auch bei der Polarform. Diese Formen kann man jedoch nicht als identische auffassen. Bei Ph. hexagona ist die „Breite der Ansatzstellen der Äste gleich der Breite der Äste". was scharf die beiden Arten voneinander trennt.

Aus dem Polargebiet hat Toula" Phyllopora Laubei aus dem Permo. carbon von Spitzbergen beschrieben. Die von Toula beschriebene Art zeichnet sich durch grosse Maschen aus, deren Zahl 4,5 auf $10 \mathrm{~mm}$. beträgt.

Phyllopora sp., die von Ethernge ${ }^{3}$ vom Grinnel Land beschrieben wurde. wird vom Verfasser mit Polypora gracilis Prout ${ }^{4}$ und Ph. Laubei Toula (l. c.) verglichen, mit zwei Arten, die ihrem äusseren Aussehen nach so verschieden sind, dass es nach dem Hinweis allein unmöglich ist, sich irgendeinen Begriff vou der beschriebenen Art zu macheı. Es fehlen bei Étheridge die Massangaben wie auch Abbildungen.

$P h$. borealis wurde in Obercarbon des Timan angetroffen.

Fundort: Store Björnekap. König Oscars Land.

5 Exemplare [137, 138-141 (P. S. 39); 69, 142 (P. S. 8)].

Heibergs Land $\left[49\left(\mathrm{~V}_{2}\right)\right]$.

1 Netschajew, I. c., p. 134, pl. II, fig. 9 a, b, c.

2 Touls. Neues Jahrb. f. M., 1875, S. 230, Taf. IX, Fig. 1.

3 Etheridge, l. c., p. 627.

4 Prout. Illinois Geol. Report II t. 21, fig. 1. 


\title{
Brachiopoda.
}

\section{Familie Productidile Gray.}

\author{
Productus SoweBr:
}

Produrtus holiviensis d'Orbigns.

142. Produrtus boliciensis "l Goudryi l'Orbusis. Voyage dans l'Amérique Méri. dionale. P. 52-53, pl. IV. fig. 5-9.

1:k2. Productus boliciensis Tschfrivscuew. Die obercarb. Brachiopoden des Ural und des Timan. S. 950), Taf. XXXIl. Fig. 5. Taf. XXXV. Fig. :

(Syıonymik s. il,idem.)

'/u dieser Arl muss man einen grossen Productus stellen, bei dem der Visceralrand der Ventralklappe sich nicht erhalten hat. jedoch deutlich ler konkave Charakler der Dorsalklappe zu selien ist. breite, deutlich abgeteille und abstehende Olıen. feine Rippchen, die die Dorsalklappe und den erhaltenen Vorderteil der V'entralklappe bedecken, und ebenso eine Neigung zur Bildung von breiten Falten am Stirnrande. Alles das entspricht vollständig den Originalen von d'OrBugxy aus Yarbichambi. und ebenso den übereinstimmenden Vertretern von Productus boliviensis rom Ural, die von Gruenewald und mir beschrieben wurden.

Fundorl: Store Björnekap. [N 143 (P.S. 29) ].

\section{Productus inflatus Mc Cuessey. Taf. V.}

1567. Productus influtus Mc Cnesser. Trans, of the Chicago Acad, of Sciences Vol. 1, Part. 1, P. 27, Pl. VI, Fig. 1.

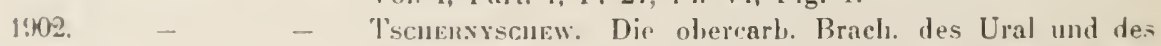
Timan. Mém. dn Com. Gèol. Vol. XVI, N 2, p. 261, pl. XXYlll, fig. 1-6.

1912. Jakowma. Die Fauna der oberen Ableilung der palios. zois.l. Alıagerungen in Donetz.Bassin. Mim. du Com. Giool. N. S. Livr. 79, p. 5. pl. II. fig. 4, 5, pl. III, fig. 8 .

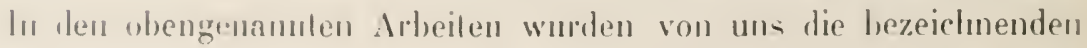
Eigentünlidskeilen dieser Alt, die slark im Otherearlon des Ost. und les Nondeuropä̈sclien Russlands und in den Artinskablarlerungen des Vormrak verbreilet sind, cimgeltend lesproclen. Diese Art ist in der Samm-

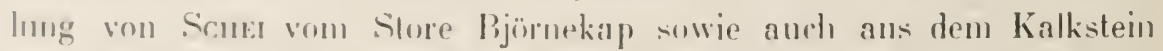
rom Hriberge Land in zahbeiclen Exemplaren, die von den Ural- und 'limanformen nichl zu lremuen sind. vertrelen.

Bishl nach der Veröffentliedreil meiner Monographie über die oberantonischen Burthopodan des L'ral und des T'inan erschien die Arbeit 
von Girty ${ }^{1}$, in der er unter Pr. inflatus eine Form beschreibt, die sich wesentlich von der von Mc Chesney aus Indiana beschriebenen unterscheidet; wovon wir uns durch einen Vergleich der uns von Girty ülerwiesenen Exemplare aus dem Landville District mit den in der Samm. lung des Geol. Museum d. Akadenie d. Wissenschaften vorhandenen Vertreter'n aus Kansas, die sich nicht von den von Mc Chesney heschriebenen und abgebildeten Exemplaren unterscheiden, überzeugten. Die ersteren Formen sind, im Vergleich zu den letzleren, in der Querrichtung bedeutend ausgezogen, in der Längsrichtung geringer zusammengerollt und, was besonders wichtig ist, sie besitzen eine regehnässig konkave Dorsalklappe im Gegensatz zu der vollständig flachen Dorsalklappe der Kansas-Exemplare; der Sinus der Colorado-Formen ist bedeulend schwächer ausgeprägt als bei den typischen Vertretern des Productus inflatus. Man muss hervorheben, das selbst GrRTy an der Übereinstimmung der von ihm beschriebenen Vertreter aus Colorado und des typischen Prod. inflatus aus Nebraska und Kansas zweifelte ", doch nehme ich auf Grund des oben angeführten Baues der Dorsalklappe an, dass Prod. inflatus GirTy aus Colorado und die typischen Prod. inflatus Mc: Chesney zu zwei verschiedenen Gruppen gestellt werden müssen ${ }^{3}$ : die erste zu Prod. boliviensis, die zweile zur Gruppe Prod. semireticulatus. Wenı es sich erweisen würde, dass unsere Ural- und Timanvertreter und die mit ihnen übereinstimmenden Formen aus Ellesmere Island von den typischen Prod. inflatus Mc Chesney getrennt werden müssen, so würde man gezwungen sein, die von mir vorgeschlagene Arthestimmung aufzunehmen.

In der letzten Zeit hat C. Diener ${ }^{4}$ under Prod. inflatus Mc Chesney Formen aus dem Bellerophonkalk der Oberkrain beschrieben, die von ihn mit den oben genannten Vertretern aus Colorado übereinstimmend gefunden wurden. In der Tafelerklärung XIV weist Diener darauf hin, dass Fig. 3 nicht eine typische, sondern eine Zwischenform zwischen Prod. semireticulatus und Prod. inflatus darstellt. Doch aus dem oben Gesagten über die Colorado.Exemplare folgt, dass man sie nicht zu den typischen Prod. inflatus Mc Chesney stellen kann und deshalb auch kaum die mit ihnen übereinstimmenden Ventralklappen (laut Diener, Taf. XIV, F̈ig. 4-5) mit

1 G. Girty. The carboniferons formations and Faunas of Colorado. 1903. P. 359. Pl. III, Fig. I, I l, 2, 2 a, 3.

2 G. Girty I. c. p. 360.

3 S. Th. Tschernyschew. Die obercarb. Brach.; p. 605-606.

4 Rossmat \& Diener. Die Bellerophonkalke von Oberkrain und ihre Brachiopodenfauna. Jahrb. d. k. k. Geol. Reichsanstalt. Bd. LX. 1910. S. 293. Taf. XIV, Fig. 3, 4, 5. 
Bestummtheit \%u der Art, die zuerst ron Mc Cuesser aus Indiana hesolnielien wurde. zurechuen kann. Leider gelang es Duesen uicht, l)orsilklappen im Bellerophonkalk zn finden, wodnrch die Artbestimnung noch meh" erschwert wirl. Ehenso kann man sich kaum mit Gröner? rinverstanden erklïren, der einige Exemplare aus dem mittleren TjanSichjan als Prod. inflatus beschrieben hat. Die starke Aufrollung der Ventrallilappe und die flache Dorsalklappe erimern an Prod. inflatus Mc. Cunsier: Joch die starli entwickelten Ohren und der, infolgerlessen ansgerogene Schlossmond. der die Breite der Schale zweinal (nach (inößzек) ïbertriff, so wie anch (ler allgemeine Charakter der Berippung ter Oherfliache der Schale. schliessen die Mäglichkeit der Identifizierung der 'Tjan-Schamertreter mit Productus inflatus ans. Es ist zu erwiilnen, lass die von N. JAkowsew a aus den Unterperm-Dolomitschichten Iten Donetz-Beckens beschriehenen Prod. inflatus nicht von den Ural. und 'limanformen zu unterscheiden sind. Aus den angeführten Angaben ist zu ersehen, dass die bis zor Zeit nachgewiesenen Prod. inflatus, die nicht von den von Mc: Cuessey aus Indiana beschriehenen Formen zu unterscheiten sind, un' aus den Obercalyon- und Artinskablagerungen des Vorural, ans den homotaxen Ablagernngen Spitzbergens und der Bären-Insel, so wie anch ans den unterpermischen und obercabonischen Ahlagermagen des Donet\%-Beckens bekannt sind.

Fundort: Store Björnekap $[144,145-239$ (P. S. 39); 240-245 (I'. S. 29); 246-24S (P. S. S)].

Heibergs Land [249-251].

\section{Productus Stuckenbergi Krơ.} Taf. VIII, Fig. 1.

1855. Productus Stuckenbergi Knowow. Artinskische Etage. Travanx de la Soc. Nalur. Kazan. 'T, XIll, Livr. 5, p. 267, pl. IT, fig. $4,5,6$.

1 sto - Stickisument. Aligem. Geol. Kurte vou Russiand.

$1 ! \kappa+2$. Blatt 127, S. 262, Tal. IV, Fig. 47, 48, 49.

Tscnenxysconsw. Die oleercarb. Brachiopoden des Ural u. d. Timan. S. 265. Taf. XXIV, Fig. 9.

\%u lieser Art ist olune Zweifel die Dorsalklapye \%n stellen, die bis in die grongsten Einzelheiten mit den oherearbonischen und artinskischen

1 '. Güm:u. Curbon mud Carbonfossilien des nördl. mul zentralen Tjan-Schan. Ahhandl. Bayer. Akud. d. Wiss, II Klasse. XXIV [Bd. Il Abh. S. 378, Taf. II, Fig. 7 a-r, 'Tuf. III, Fig. is n-c.

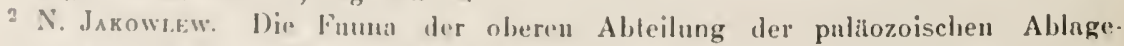
rungen in Donel\%. Bassin. Mŕm. 1. Com. Géol. N. S. I. 79, S. 5, Tuf. Il, Fig. 4-5, Taf. III, Fig. 8 . 
Vertretern des Ural übereinstimmt. Schmale tiefe Einbuchtung, die der scharf ausgeprägten Erhöhurg der Dorsalklappe entspricht und am Stirırande unterbrochen wird, die Lage der Rippchen an den Seiten der Vertiefung und ebenso an den Seiten der Schale, scharf runzelige Falten, die den Visceralteil der Schale und die Ohren bekleiden, und die charak. teristische Verknickung der Ohren, die sich steil unter geradem Winkel aus der horizontalen in die vertikale Richtung umbiegen und in die Seiten der Schale übergehen, alle diese Unterscheidungsmerkmale können an dem beschriebenen Exemplare beobachtet werden. Productus Stuckenbergi tritt selten in Schwagerinenhorizont auf und kommt häufig in den Artinskablagerungen vor.

Fundort: Store Björnekap. [252].

\section{Productus tartaricus T'schers. Taf. VIII, Fig. 2.}

1902. Productus tartaricus Tschensyschew. Die obercarb. Brachiop. des Ural und des Timan. S. 264, 614. Taf, LVII, Fig. 7-9, Taf. LX, Fig. 11-13.

In der beschriebenen Sammlung vom Store Björnekap befindet sich eine einzige Ventralklappe, die vollstïndig dem Productus tartaricus aus den Obercarbon- und Artinskablagerunpen des Ural gleich ist. Alle Eigenheiten des. Wirbels, der scharf von den Seiten der Schale abgetrennt ist, die Dichotomierung der Rippen von verschiedener Dicke und die Entfernung vom Wirbel, ebenso wie die Weite der verhältnismässig dicken Stacheln, die senkrecht zur Oberfläche der Schale stehen, sind gut am vorhandenen Exemplare wahrzunehmen.

Fundort: Store Björnekap. [253].

\section{Productus pseudoaculeatus Krotow. Taf. VI. Fig. 1.}

1888. Productus psendoaculeatus Krotow. Mém. d. Com. Géol. Vol. VI, p. 411. pl. I, fig. 18.

1902.

T'schernyschew. Die obercarb. Brach. d. Ural u. d. Timan. S. 266, Taf. XXX, Fig. 7, Taf. LIII, Fig. $10-12$.

Diese Art ist weit in den Cora- und Schwagerinenkalksteinen (besonder's im letzten) des Ural verbreitet und in der Sammlung von Store Björnekap zahlreich vertreten. Prod. pseudoaculeatus ist uns aus dem Polararchipel von Spitzbergen (Bellsund - Axel Inseln) bekannt. 
Hervorulieben int, dass Dr. Bintr aus den Guadalupienbergen muter Prod. Ilalcoltiamus ${ }^{1}$ zweifellos zwei verschiedene Formen be. - Hrichen hat, son denen er die auf Fig. 27, Taf. XXI abgebildete zı den Iypisclien Vertretern des Prod. Halcottiamus rechnet, während er die andere. die anf Fig. us derselben 'Tafel wiedergegeben ist, mit einem gewisen Zweifel zn derselben Art stellt. Die Kennlnis von Gintrs Orisinalun heweisl, dass las erstere slark an die Ural und die Timan Prod. peredoaculeatus rimnerl, wobei der einzige bemerkbare Unterschied Jarin bestehl, dass an Vrorderleile der Ventralklappe des Prod. Wal. colticums stinker ausgeprïgte, längliche Falten zu beobachten sind. IVas ılie auf 'Tah. XXI Fig. $2 S$ al,gebildelen Exemplare anbetrift, so weisen

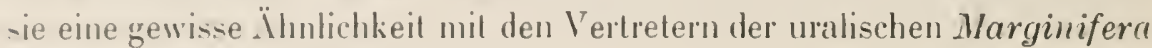
(Marg. uralica 'Tschers.) auf.

Fundort: Store Björnekip). [25千, 255-261 (P. S. 29)].

\section{Prorluctus tastubensis 'T'schemsischew.}

1!02. Productus tastubensis Tscurnisinuw, Die obercarb. Brachiopoden elc.. S. ㅁ6, 615, T'it. LIII, Fig. 7-9.

Zusanmen mit Prod. psendonculeatus kommen in ein und den. selhen Kalksteinstück ron Store Björnekap Venlmalklappen vor, die von Prod. tastubensis aus dem Schwagerinenkalk des Ural nicht zu untershleiden sinul. Bis zur Zeit wurden Vertreter dieser Art an diesem Bergzug un in sehr hegrenzter Zahl aufgefunden; desto interessanter ist es, dass in der Sammlung von Schel Prod. tastubensis verhältnismissig zahlreich vertreten ist. Alle die Skulptureigenheiten der untersuchten Art, ebenso wie die steil fallenden Seiten der Ventralklappe mod lie breiten Furchen am Stimrande sind an den Exemplaren von Store Björnekap dentlich ausgeprägt.

Finutort: Store Björnekaj). [261-266 (P. S. 29)].

\section{Prodnctus Frami n. sp.}

Tal. V'll, Fig. 4; Tal. Xll. Fig. 4.

Das rinzige lixemplar. das wir hesil\%en, ist so eigentrimlich, dasses als eine solbstiondige Form betrachlet werten muss. Es liegen uns mor Ventratklappen ror, die dem labitns nach, dem Productus curvi.

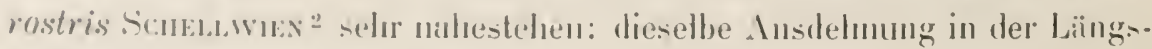

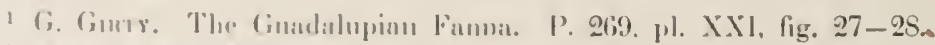

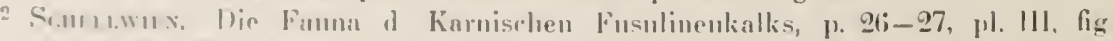

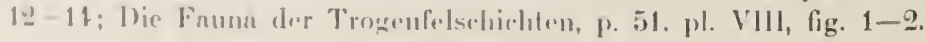


richtung, dieselbe Zusammenpressung an den Seiten und dieselbe starke Krümmung am Wirhelteil. Es ist schon mit blossem Auge, noch besser unter der Lupe, deutlich zu sehen, dass die Oberfläche der Schale mit feinen, fadenartigen, länglichen, selten dichotomierenden und teilweise hesonder's am Stirnrande etwas gehrochenen Rippen versehen ist. Ausserdem werden an der Oberfläche Spuren der Ansatzstellen der Stacheln wahrgenommen, deren Zahl zum Stirnrande hin zunimmt, wo sie Querreihen zu bilden geneigt sind. Die meisten Stachehn nehmen zwei Rippen ein, wobei diese oft durch die Stachelbasis unterbrochen werden, von der zwei, drei und manchmal (bei dem Stirnrande) auch vier neue Rippen beginnen. Die Berippung und die Stachelanlage sind wie bei Productus Konincki ausgebildet, jedoch die Zahl der Rippen und die starke Zusammenpressung an den Seiten unterscheiden unsere Ventralklappe von den gewölnlichen Obercarbonformen, die in der Sammlung von Store Björnekap in zahlreichen typischen Exemplaren vertreten sind. Ähnlich wie bei Prod. Konincki sind die Querrunzeln bei unserer Form nur an den Seiten des Wirbelteils zu beobachten.

Fundort: Store Björnekap. [267].

\section{Productus irginae Stuckenberg.}

Taf. VI, Fig. 2, 3, 4.

1898. Productus irginae Stuckevberg. Allgemeine Geolog. Karte von Russland. Blatt 127, S. 20, Taf. II, Fig. 16.

1902. - - Tscherrysciew. Die obercarb. Brachiopoden des Ural und des Timan. S. 273, 618, Taf. XXX, Fig. 3-4, T'af. LII, Fig. 1-4. S. Synonymik ibidem.

Diese Art ist weit verbreitet im Obercarbon von Nord- und Ostrussland und in zahlreichen Exemplaren im Kalkstein von Store Björnekap vertreten. Die äussere Verzierung der beiden Klappen, so wie auch ihr innerer Bau entspricht vollständig der Beschreibung und der Zeichnung, die einer von uns in der angeführten Arheit gegeben hat. Am Stirnrande der Ventralklappe, wie auch an ihrer kleinen Klappe beobachtet man an einigen Exemplaren gezackte Ḱnickungen, an einigen anderen das Erscheinen grober, länglicher Falten, die ziemlich regelmässig gelagert sind (s. Taf. VI, Fig. 3, 4 a) und durch verschiedene Zwischenräume getrennt werden.

Zur Ergänzung der Synonymik, die in der oben angeführten Arbeit von Th. Tschernysanew gegeben ist, muss hinzugefügt werden, dass man zu Prod. irginae noch die Form, die Fr. Toula ${ }^{1}$ als Prod. cf. Hum-

1 Franz Toula. Permo-Carbon-Fossilien von der Westküste von Spitzbergen. Neues Jahrb. 1875, Taf. V, Fig. 3. 
bohlli wn ter Axcl Insel au- Bellinud auf Spitzbergen beschrichen hat. strllent mills.

Dit Lulersheidungsmerkmale dieser Art von den ihn am nächsten -tolemden Prod. Mumboldti d'Orb. sind bei der Beschreibung der let\%. teren angegeben.

P'roduchs irgincre ersdieint schon im Omphatotrodus.Horizont. kummt ibcr lä̈ufig in den Cora- und Schwagerinenschichten vor, inden 口. anch in die höheren Arlinskahlagerungen übergeht. wo er als eine ter gewöhulichsten Formen auftritt. In der Sammung des Kensington Mnseuns, die ron eler Nares Expedition auf Grinnell Land und Feilden Islhmus gesammelt wude. hefindet sich ein Exemplar des Prod. iryinae, din irrtümlich als Prod. semireticulatus bestimmt wurde.

Prod. irgincte ist uns von verschiedenen Stellen der Insel Spitzhergen bekannt, so kommt diese Form auf der Axel Insel im Bellsund, ferner an Cap Wijk in Nordfjord und auf Havensberg und Tempes.s. lierg (in den Kalksteinen mit Cyathophyllum) vor. Dieselbe Art befindet sich in den Sammlungen des Stockholmer Museums mit der Etikette Beeren Eiland versehen.

Fundort: Store Björnekap. [25s, 269, 270, 271-302, 369 (P. S. 39): 30:)-306, 326, 358 (P.S. 29); 307, 30S, 365 (P. S. S) ].

Heibergs Land [309, $\left.310\left(\mathrm{~V}_{3}\right)\right]$.

\section{Productus Humboldti d'Oraigny.}

Taf. VI, Fig. j.

1412. Productus Humboldti d'Orbigxy. Voyage dans l'Amérique Meridionale. Vol. III Paleontologie, p. 54, pl. V, fig. 4-7.

190. - - Tscuenxisciew. Die obercarb. Brachiopoden des Ural, und des Timan. S. 275, 620, Taf. LI1l, Fig. 1-3.

Einer von uns wies sclıon auf die Unklarheit der Literatur in Bezus auf Prod. Humbolrlti hin, die infolge der mangelhaften Zeichnungen von

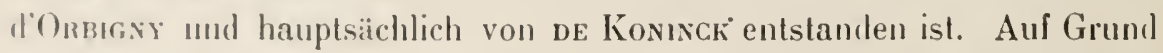
ter Lntersuchung der Originale von d'Onısy komnten wil feststellen, dass Amcu und WaAgex Prod. Mumboldti Formen gegenüberstelleu. die von den typischen Vertretern dieser Art verschieden sind. Ebenso wurde, augenscheintich, Stuckenbens durd, 10: Konıcks Zeichnungen irregefühnt und beschrieb Productus silveanus als eine von Prod. Humboldti d'Onn. verschiedene Form. Wïnrend tatsächlich Productus silve. amus mit Prod. Humboldti d'Onв. (non de Kon.) übereinstimmt.

bibenso wurle durh den einen von uns darauf hingewiesen, dass zu Prod. Humboldt, wie wir ihn verstehen, Prod. irginae Stuck. am nächsten stedst: aher dieser unterscheidet sich leicht von Prod. Humboldti 
durch eine grössere Wälhung der Ventralklappe und infolgedessen durch grössere Mächtigkeit des Visceralraumes; ansserden sind bei Prod. Humboldti die 'Tuherkeln am mittleren Teile der Schale gröher und mehr in die Lünge gezogen, am vorderen 'Teile nnit Stachehn besetzt, wohei sich in allgemeinen die Tuberkeln in länglichen Reihen anordnen und erst am Stimrande feiner werden, während bei Prod. irginae die feinen Tuberkelı auf der ganzen Oberfläche schachbrettartig geordnet sind.

Productus Humboldti ist eine bezeichnende Form für die Schwagerimenschichten des Ural und des T'iman, kommt ebenso in den Artinskablagernngen vor und ist angenscheinlich eine seltene Form in den Kalkschichten des Store Björnekap. In dem umfangreichen Material, das von Scher gesammelt wurde, befindet sich nur ein Exemplar der Ventralklappe in so guter Erhaltung, dass nan an ihrer Gleichheit mit Prod. Humboldti nicht zweifeln kann. Prod. Humboldti, den Franz Toula ${ }^{1}$ vom Südkap von Spilzbergen beschrieben hat, muss zu den typischen Vertretern dieser Form gestellt werden.

Fundort: Store Björnekap. [311, 312, 313].

\section{Productus Aagaardi Toula. Taf. VIII, Fig. 3.}

1875. Prorluctis Aagaardi Toun. Permo-Carbon-Fossilien von der West.Küste ron 1902. Spitzbergen. N. J., S. II, Taf. VII, Fig. 2.

902. - - Tschernyschew. Die obercarb. Brachiopoden. S. 285, Taf. LVI, Fig. 1-2.

Diese Art wurde zuerst von TouLA von Spitzbergen beschrieben und ferner am Ural angetroffen. Bei der Beschreibung der Spitzbergenwie auch der Uratvertreter wird in den angeführten Monographien er. wähnt, dass an den Steinkernen der Ventralklappen, ungefähr in der Mitte ihrer Länge, eine deutliche Verengung wahrzunehmen ist. Die letztere ist ebenso deutlich an den von ScHeı vom König Oscars Land mitgehrachten Exemplaren zu sehen, wobei an einigen von ihnen, ausser einer tieferen, noch zwei schwächer ausgeprägte Verengungen, in Form einer schmalen, näher zu dem Wirbel gerückten Furche, beobachtet werdeı. An den grösseren Exemplaren geht die längliche, plattgedrückte Stelle der Ventralkappe iı einen ziemlich flachen Sinus über. In allem übrigen sind die Exemplare von der Insel Ellesmere nicht von den Spitzliergen- und Uralvertretern des Prod. Aagaardi zu trennen.

1 Frayz Touls. Kohlenkalk-Fossilien von der Südspitze von Spitzbergen. Sitzungsber. d. Akad. d. Wissenschaften. Bd. LXYIII, I Abh. No.-Heft, Jahrg. 1873, S. 16-17, Taf. II, Fig. 3. 
Es ist kamm zu bezweifeln, dass Prod. Wraggeni Gmay ${ }^{1}$ aus den Cillatalupien Bergen von 'Texas mit Prod. Aagaardi völlig übereinstinmt: las eimzige lonterschendungsmerkmal ist. dass Prod. Aagaardi auf $5 \mathrm{~mm}$. 11 lïngstiplen anfweisl. wiblurend Gurs bei Prod. Waageni anf der-eflon Fliache 14 anfühnt; dies ist ein mowesentlicher Unstand, da man an einigen Spitzbergener und malischen Prod. Aagaardi ebenso viel feine Rippen wie hei Prod. Mrageni nachweisen kann.

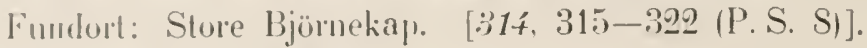

Heriberg- Land [323. 324]

Productus simensis 'T'schen.

Taf. VIII. Fig. 4.

1:k12. Iroductus simensis Tschersysimew. Dir obercarbon. Brachiopoden d. Ural und d. Timan, S. 2S6. 626. Taf. XXXV. Fig. 7, Taf. LV, Fin. Q-5.

Die Eigenheiten dieser Art, die zm Gruppe Productus temistriatus Versectl gehört, werden durch den schwach ausgepräglen Wirbelteil ler Ventralklappe ansgezeichnet, wobei der IVirbel selbst sich schwach vor lem ïbrigen Teil der Schale abhebt und kaum über den Schlossrand herunterhängt. Von dem Schlossand hebt sich steil die Ventralklappe empor und macht dann eine scharfe Biegung fast muter geraden Winkel. Wobei sie beinahe gerade in Längsschnitte und steil abfallend \%u den Seiten im Querprofil erscheint. Die Oberfläche der Ventralklappe ist nut feinen, scharf ausgeprägten Rippchen versehen. die sich durch die Ënschaltung rener Rippchen an Zahl vergrösserı. Stellenweise wirl eine Unregelmässigkeit in der Richtung ler Rippchen in Form von Biegnngen mul Knickungen heohachtet. Die Ohren der Ventrałkiapre sind mit scharf ausgepriiglen Falten versehen.

Die einzige in der Sammlung vom Store Björnekap vorhandente V'rntratklappe entspricht vollstïndig der angeführten Bestimmmog und ist von drol Iypinchen Virhetern des Schwagerinenhorizontes des Ural nicht \%u mutrescheiden.

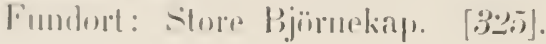

\section{Productus Konincki V'ERELL.}

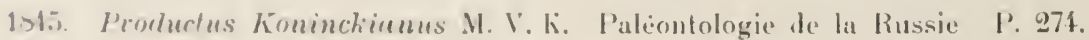

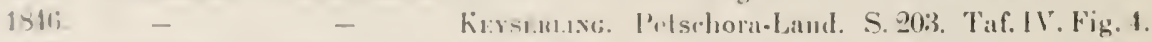

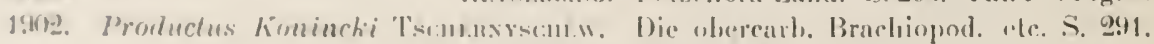
Taf. XXXIV, Fig. 2-3.

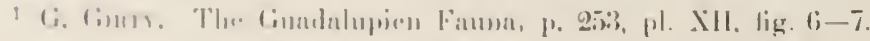


Diese Art ist für die Obercarbonkalke (hauptsächlich des Corahorizontes) des Ural und des Timan gemeinsam und scheint in den Kalksteinen des Björnekap nicht selten vorzukommen, wo ScHer ïber 10 Exemplare gesamnelt hat. An einigen der letzteren werden scharf ausgeprägte tuberkelartige Erhöhungen heobachtet, die in Stacheln und elwas gröbere Rippen, als bei den typischen Prod. Konincki vom Ural und rom Timan, übergehen; doch mit ihnen zusammen konmen typische Vertreter, die his in die geringsten Einzelheiten mit den Timan- und Uralexemplaren übereinstimmen, vor.

Infolgedessen liegt kein Grund vor. die genannten abweichenden Formen als eine neue Varietät auszuscheiden. Prod. Konincki ist überhaupt in den obercarbonischen Ablagerungen des arktischen Archipels nicht selten; es ist von Interesse auf die weite Verbreitung dieser Art auf Spitzbergen hinzuweisen, wo sie in Gyps Bay, Tempel Bay, Green Harbour und Nordfjord (Cap Wijk), in Eisfjord, ebenso wie auch in den Kalksteinen der Axel Insel im Bellsund vorkommt.

Fundort: Store Björnekap. [326-335 (P. S. 29), 358].

Heibergs Land. [339].

\section{Productus cancriniformis 'Tschernyschew.}

1889. Productus cancriniformis Tscinervyschew. Mém du Comité Géolog. Vol. III, N. 4, p. 573, pl. VII, fig. 32-33.

1902. - - $\quad$ - Tschersyschew. Die obercarb. Brachiopoden des Ural und des Timan. S. 292. Taf. LII, Fig. 5-6.

In den Sammlungen von Schei befinden sich nur drei Exemplare, deren vollkommene Übereinstimmung mit den Uralformen aus den Artinsk- und Obercarbonablagerungen nicht an der Genaugkeit der Bestimmung zweifeln lässt.

Beide Exemplare wurden im Kalkstein am Store Björnekap gefunden. $[340,341,342]$.

\section{Productus Weyprechti Toula. Taf. VII, Fig. 5. 6.}

1573. Productus Weyprechti Toula. Kohlenkalk.Fossilien von der Südspitze von Spitzbergen. Sitzungsb. d. K. Akad. d. Wiss. Wien. Bd. LXVIII, S. 13, Taf. V, Fig. 1-3.

1874. - - $\quad$ - Toust. Kohlenkalk- und Zechstein-Fossilien aus dem Hornsund an der SIV-Küiste von Spitzbergen. Silzungsber. d. K. Akad. d. Wiss. Wien. 1. Abth., Bd. LXX, S. 6, Taf. I, Fig. 4 a-e.

1875. - - - Touls. Perno.Carbon-Fossilien ron der Westküste von Spitzbergen. N. J. S. 10, Taf. VI, Fig. 2.

1901. - - Frecr. Lethaea geognostica. I. Teil. Bd. 2, Lief. 3. S. 477-498, Textfig. 3 . 
Die zahlreichen Exemplare, die von Schғ am Store Björnekap gesammelt wurlen, weisen eine vollständige Übereinstimmung mit der von Fr. 'Toura gegebenen Beschreibung und Abbildung auf. Zu dieser Beschreibung bleil,t noclı linzu\%ufügen, dass die Dorsalklappe der Biegung der Ventralklappe folgt, wobei der Visceralraum eine Höhe von nicht melı als $2-3$ mm. erreicht. Was die Stacheln anbetrifft: so wurle ausser den dünnen, die dem Schlossrande entlang an den Seiten des Wirbels des V'entralklappe gelegen sind, noch ein dicker Staclsel an heiden Seilen des Sinus am gewölbten Teile der Ventralklappe, etwas ror ihrer steilen Biegung, beobarhtet.

Die \%unïchst stehenden Formen, die man mit Productus Weyprechti rergleidnen kann, sind Productus artiensis Tschern. ${ }^{1}$ aus ilen Artinst-Ablagermugen des Cral und Produchus mammatus Kers. ${ }^{2}$ aus Jen olsercarlionischen Kalksteinen des Petschora-Gebietes. Der Berip. jung nach nimml Productus Weyprechti eine Zwischenstellung ein, in ofern als er feincre Rippen als Productus artiensis und gröbere als Prod. mammatus besitut. Von den letzteren unterscheidet sich Prod Weyprechti durch einen kowexen Visceralteil der Ventralklappe und durch die konkave Dorsalklappe, die bei Prod. mammatus im Visceralteile fast flach ist. Prod. artiensis unterscheidel sich von Prod. Heyprechti durch das Vorhandensein einer deutlich ausgeprïgten Flïche, die sich läings des Sclılossrandes der Dorsalklappe limzielıt.

In der Monographie äber die Guadalupienfauma slellt Gukty ${ }^{3}$ Prod. guadalupiensis GIRTY + Prod. Weyprechti gegenüber; bei der Beschreibung dieser amerikanischen Art vergleicht er sie jedoch mit Prod. multi. striatus Mrek. Wenn dieser Vergleich auf allgemeiner äusserer Ähnlichkeit lıeruht, so unterscheidet die grössere Querausdehnung und ebenso lie grössere Einrollung in der Längsrichtung Prod. Weyprechti von I'rod. guadulupiensis und Prod. multistriatus.

Ausser dem Oberpaläozoicum von Spitzbergen und ansser den Oberrarbonkalksteinen der Insel Ellesmere, kann die Anwesenheit ron Prod. IVeyprechti in den homotaxen Kalksteinen der Insel Grinnel (Depot

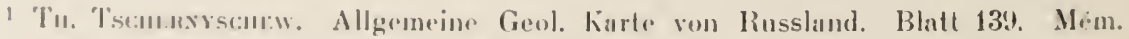
du (a)t. Giol. Vol, III, X 4, S. 370, "laf. VIl, Fig. 29-31.

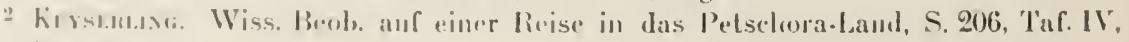
Fis. :

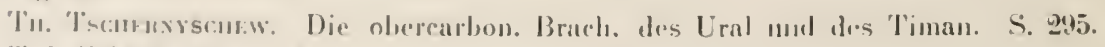
Tne. XXXV, Fig. 4-6.

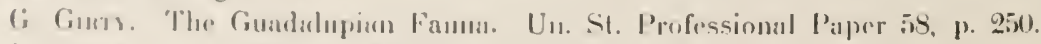

4. fintr, I. 1. p. 2(il, pl. XXIl, fig. 1-3 a. 
Point) und an der Halbinsel Feilten des nordöstlichen 'Teiles des GrinnelLandes angegeben werden. Davon konnte ich mich bei der Durchsicht der Sammlungen im Kensington-Museum, die von Etheridge und Salter bearbeitet wurden, überzeugen. In Russland ist Prod. Weyprechti bis zur Zeit nicht gefunden worden.

Fundort: Store Björnekap. [343, 344, 345-355; 356 (P. S. 8); $357-358$ (P. S. 29)].

\section{Productus porrectus Kutorga. Taf. V, Taf. VIII, Fig. 5.}

1814. Productus porrectus Koronga. Zweiter Beitrag zur Paläontologie Russlands. Verh. d. Russ. Kais. Mineralogisch. Gesellschaft. I. Serie, 1814, S. 96, Tuf. X, Fig. 3.

1902. - - Tschernysciew. Die obercarbonischen Brachiopoden d. Ural und d. Timan, S. 301, 634, Taf. XXXII, Fig. 4, Taf. LV, Fig. 1, Taf. LVI, Fig. 4, Taf. LXII, Fig. 2, Taf, LVI, Fig. 4.

Im Material, das am Store Björnekap gesammelt wurde, befinden sich 6 Exemplare, die ihren Abmessungen nach den grössten Formen von Prod. porrectus vom Ural nahestehen, die ihrerseits wieder besonders für den Schwagerinenhorizont bezeichnend sind.

Fundort: Store Björnekap. [359, 360 (P. S. 8) ; 14́, 361-363 (P. S. 29); 364, 365 (P.S. 39)].

\section{Productus timanicus Sтuck. Taf. VI, Fig. 6.}

1875. Productus timanicus Stcckenberg. Materialien zur Geologie Russlands. Bd. VI, S. 86, Taf. I, Fig. $1-7$.

1902.

Tschernyschew. Die obercarb. Brachiopoden d. Ural u. d. Timan. S. 306, 638, Taf. XXX. Fig. 5, Taf. LVII, Fig. 1-6.

Diese Art ist in der Sammlung von Scher in zahlreichen Exemplaren (über 10 Stück) in verschiedenem Erhaltungszustande und ausschliesslich als Ventralklappen vertreten. Diese Exemplare erreichen nicht die Grösse der Timan- und Uralformen, jedoch alle Speciesunterschiede, die den Timan- und Uralvertretern eigen sind, werden auch an den besprochenen Ventralklappen wiedergefunden.

Zu dem, was in den angeführten Arbeiten gesagt wurde, kann man noch hinzufügen, dass Prod. timanicus, der am Ural und am Timan im Omphalotrochus-Horizont auftritt und sich bis zu den Artinskablagerungen hinstreckt, oft in den Carbonablagerungen von Spitzbergen und 
des nordamerikanischen arktischen Archipels angetroffen wird. In den Spitzbergen-Sammlungen des Museums der Akademie der Wissenschaften z.n Stockholn befinden sich zahlreiche und typische Exemplare von Prod. timanicus vom Bellsund - Axel-Inseln. Cap Wijk im Nordfjord, Hinknen, Lovénsberg. Eisfjord - Green Harbour. Ein Teil der Exemplare winde als Prod. horridus bestimnt. Ebenso befinden sich im Wiener Hofmuseum Sammlungen aus dem Eisfjord, Skans Bai, die von 'Toula als Prod. Payeri hestimmt worden und zweifellos mit Prod. timanicus ähereinstimmen. Im Britischen Museum (Kensington) wird die Sammlung von BeLcher, die an der Insel Grimnel (Depôt Point) und (ler Insel Exmouth gesammelt und von Satrin beschrieben wurde, aufbewahrt. In dieser Sammlung hefindet sich ein typischer Prod. timanicus vom Depôt Point.

Fundort: Store Björnekap. [365, 366-368 (P. S. S); 369-372 (1.. S. 29) ].

\section{Sulgenus Marginifera WAagen. \\ Marginifera involuta Tschersyschew.} Taf. Yll, Fig. 2. 3.

1902. Marginifera involuta Tsumenxscuew. Die obercarbon. Brachiop. des Urial und des Timan. S. 321, 615, Taf. XXXVI, Fig. 7, 9, 13. Taf. LVIII, Fig. 4-6.

Iın Kalkstein. der von Scueı auf Heibergs Land gesammelt wurde. gelang es, vier Exemplare. die eine vollständige Ähnlichkeit mit den Timan- und Uralvertretern der Marginifera involuta besitzen, herauszupriiparieren. Starke Einrollung. schwach ausgeprägte Berippung, und seltener Stachehn, so wie auch das Fehlen der reihenartigen Anordnung der letzteren an den Seiten der Ventralklappe, machen es leicht, Marg. imvoluta von der ihr nahestehenden Marg. typica WAafi. und Marg. uralica 'T'scmens. zu unterscheiden.

An Ural und ann 'Timan kommt Marg. involute im Corahorizont vor unul richt sich bis zu den Schwagerinenschichten hinauf. Die typische Mary involuta befindet sich in dem Material, das von Fendon. dem Teihnehmer der Expedition von Nares, von der Halbinsel Feilden am lap, Henry rom Grinnell Land mitgebracht wurde.

Fundort: Heilergs Land. [373, 37千, 375-377. 
Marginifera typica WAAg. var. septentrionalis 'T'schensyschew. Taf. VII, Fig. 1.

1902. Marginifera typica WaAsien var. septentrionalis Tschennsschew. Dir oborcarb. Brachiop., S. 322, 646, Taf, XXXVI, Fig. 10-12, Taf. LVIII, Fig 13-16.

(Die Synonymik s, ibidem.)

In der von mir beschriebenen Sammlung ist diese Abart in zahlreichen Exemplaren vertreten, die bis in die geringsten Einzelheiten mit den Ural- und 'Timanformen übereinstimmen. Wie schon in der oben angeführten Monographie gezeigt wurde, besteht der Unterschied zwischen dieser Abart und der typischen Marg. typica WAAG. in der Lage und der Zahl der Stacheln an der Ventralklappe und in einer etwas anderer Richtung der Brachialplättchen der Dorsalklappe.

Am Ural und am Timan sind diese beschriebenen Formen dem Cora- und Schwagerinenhorizont eigen. In der Sammlung des Stockholmer Riksmuseum finden sich Exemplare von der Axel-Insel im Bellsund Isfjorden lâs Lovèn und in Green Harbour. Im Kensington Museum gibt es in den Sammlungen von Grinell Land (Feilden Isthmus) ein Exemplar mil der Bestimmung Productus, das von Marg. typica var. septentrionalis nicht zu unterscheiden ist.

Fundort: Store Björnekap. [:378, 379-418].

\section{Marginifera Clarkei 'T'schennyschew.}

Taf. VII, Fig. 7.

1902. Marginifera Clarkei Tschernyscuew. Die oberearb. Brachiopoden des Ural und des Timan. S. 328, 651, Taf, XLVII. Fig. 6-7, Taf. LVIII, Fig. $1-3$.

In der zur Bearbeitung vorliegenden Sammlung kommt nur ein Exemplar der Ventralklappe vor, aus dem unweifelhaft hervorgeht, dass wir in Kalksteine von Store Björnekap den Vertreter von Marg. Clarkiei besitzen - dieser bezeichnenden Form des Schwagerinenhorizontes des Ural. Ähnlich den Uralformen ist der Sinus verhältnismässig schmal, nicht tief und schliesst sich zum Stirnrande; die Rippen, die die Oberfläche der Schale bedecken, dichotomieren und zerfallen in eine Reihe feiner Rippchen. Am beschriebenen Exemplar, wie auclı an den Uralformen kommt in der Mitte der Länge eine zahnige Wulst zum Vorschein, genau von demselhen Charakter', wie es auf 'Taf. LVIII, Fig. 1-3 der angeführten Monographie angegeben ist.

Fundort: Store Björnekap. [419]. 
Familie Strophomenidac Kisg.

Derbyia WAAGEN.

Derbyia grandis WAAg.

T'af. ^. Fig. 1.

18S1. Derbyia grandis Wingex. Salt-Range Fossils. Productus limestone. Brarhiopola. P. 597, pl. LI, LII, fig. 1, 3, pl. LIII, fig. 3, 5.

1!K2. - - Tscnemsiscnew. Die obercarbon. Brachiop. des Ural und d.s Timan. S. 207, 250, Taf. XXIV. Fig. 1-2, Taf. XXVl, Fig. 5.

In der Sammlung vom Store Björnekap ist nur eine Ventralklappe vorhanden, wetche die Abmessungen der indischen und uralischen Vertreter erreicht, die auf den angeführten Zeichnungen angegeben sind. Alles, was üler die Eigenheiten der Umrisse, Skulptur und den inneren Bau der Ural. und T'imanvertreter der Derbyia grandis gesagt wurde, kehrt an Exemplar von der Insel Ellesmere wieder.

Derbya grandis ist ausschliesslich dem Schwagerinen-Horizont des lial und des Timan eigen. In Salt-Range tritt sie im Middle und Upper Productus Limestone auf.

Fundort: Store Björnekap. [420 (P. S. 29)].

\section{Familie Spiriferidae Kıs.}

\section{Reticularia N'Cor.}

\section{Reticularial lineata MarTIN.}

1surg. Conchybiolithus Anomites lineatus Manтr. Petrif. Darbiens. PI. XXXVI, fig. 3.

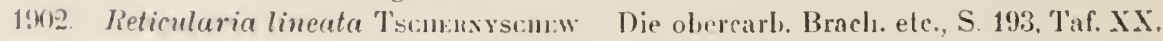
Fig $9-13$.

(Synonymik s. ibilem)

In Kalkstein der Sammlung rom Store Björnekap kommen zahlreiche gesonderte Ventral- und Dorsalklappen vor, die zu den typischen Vertretern der heticularia lineata grehören, wie es in der angeführten Monographie üher die Brachiopoden des Ural und des T'iman verstanden wird. Anf Spitzbergen ist das Auftreten dieser Art, die sirh im allgemeinen durch eine vertikale Verbreitung auszeichnet, nur von der Axel Insel im Bellsumel lockannt.

liumdort: Store Bjömeknp. [421 436 (P'. S. 29)].

Heibergin Lind [437-442]. 
Reticularia guadalupensis SuUmarn.

Taf. IX, Fig. S.

1859. Spirifer guadahpensis Shumarn. Trans. Acad. Srien. St. Louis. Vol. 1, p. 391.

1908. Stuamularia guadalupensis Gurr. The gnadalupian Fanna. P. 367, pl, XIV. fig. 4-11.

Mit den zahlreichen typischen Vertretern der Reticularia lineata kommt in der Sammlung von Store Björnekap ein Exemplar vor, das sich scharf durch die Aufwölbung der beiden Klappen, bei jeglichem Felılen von Merkmalen des Sinus der Ventralklappe und der entsprechen. den Erhöhung des Stirnrandes zur Seite der Dorsalklappe, auszeichnet. Stellenweise ist die Skulptur genügend erhalten und stimmt im allgemeinen mit der von Davidson, WAaGes und anderen Verfassern beschriebenen Reticularia lineata MarT. überein. GIRTy (I. c.) ist geneigt, die beschriebene Art zur Gattung Squamularia Gemmellaro zu stellen, aus dem Grunde, weil man die Gattung Reticularia im Sinne von M'Coy auffassen soll, der bei Reticularia das Vorhandensein von Zahnplatten angab; da bei den obercarbonischen Formen, die gewöhnlich zu Reticularia gestellt werden, die Zahnplatten fehlen, wäre es angebracht, sie bei Squamularia unterzubringen. Man kann sich nach der Auseinandersetzung des inneren Baues der Reticularia kaum damit einverstanden erklären, wie mit ausführlicher Vollständigkeit W AAGEN ${ }^{1}$ angeführt hat, dass die Angaben M'Coy über das Vorkomnen von Zahnplatten bei Reticularia lineata auf einem Irrtum beruhen.

Fundort: Store Björnekap. [ff: ]].

\section{Spirifer Sowerby.}

Spirifer Scheii n. sp.

Taf. IX, Fig. 5, 6, 7.

In den Kalksteinen vom Store Björnekap kommen drei Ventralklappen von elliptischem Umriss vor, die stark in der Querrichtung ausgezogen sind und einen scharf ausgeprägten Sinus tragen, der in Form einer schmalen Furche an Wirbel beginnt, sich bald stark ausbreitet und eine bedeutende Vertiefung in der zweiten Hälfte der Schalenlänge bildet, ähnlich dem, der bei einigen Athyris (A. roussiana) Vertretern zu beobachten ist. Der Wirbel ist am Ende spitz und

1 Wangen. Salt-Range Fossils. Productus limestone, Brachiopoda. P. 538-540. 
- homalielartig ungebogen. Unter ihun ist die areat nicht scharf von den Siten der Schale algetrennt und in der Mitte durch eine Deltidialspalte urteilt. An einen der Exemplare ist am Wirbet ein Teil des Psendodertidium, erhalten geblieben (Tiaf. IX, Fig. jo c). Vom Wirbel ziehen sieh deuttich entwickette Zahnplatten hin, die an den Seiten der Deltidialspalte fortlaufen und an den Steinkernen bis über einem Drittel der Schalenlänge zu bemerken siml. Die Zahnplalten umringen ein breites birnenfürmiges Muskelfelt. Die Oberfliche der Schale ist mit deutlichen konzentrischen Anwachsstreifen versehen in Form von konzentrischen Bogen, wie bei Reticularia, an deren Oberfläche lïsst sich jedoch bloss eine unregelmilswige tuberositas beobachten (Taf. IX, Fig. 7), die sich wesentlich von den in Form einer doppellïufigen Flinte charakteristisch angeordneten-Stacheln, die die Oberfläche der Schale der Reticularia in konzentrischen Reilien bedecken, unterscheidet. Nach dem erhaltenen Teil der Schale 2,1 urteilen, ist ihr Bau faserig, doch nicht punktierartig, wie bei der Gattung oder Untergattung Martiniopsis WAag., zu der man die l,eschriebenen Schalenreste stellen könnte.

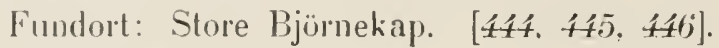

\section{Spirifer condor d'Orbigiv.}

Taf. X, Fig. 3.

1552. Spirifer condor d'Orвıмy. Voyage dans l'Amérique Méridionale. T. III, p. 41). pl. 5, fig. 11-14.

1902. - - T'sineryscnew. Dir obẻrcarbon. Brachiopoden des Ural und des Timan. S. 141, 521, Taf. XII, Fig. 1-2, Taf. XXXVIII. Fig. 1-2.

Nach meiner Angabe in der oben angeführten Monographie sind fast alle amerikanischen Beschreiber geneigl. Spirifer condor als eine mit Spirifer cameratus MarT. übereinstimnende Form an\%usehen. Die Übereinstimmung dieser Arten ist latsïchlich gross, und als ein Unterscheidungs. merkmal kam man auf die grobere Berippung, auf die selwach ausgeIrägten, oder fast fehlenden, bündelartig angeordneten Rippen und auf die schwach ausgeprighten. Inmetenartig angeordneten Anwachsstreifen despirifer condor linweisen. Dieser Unstand in Verbindung mit dem Sturlium der Originale von d'Orbigsy führte dazı, dass einige von den in den Cora- nud Siduwagerinen-Kilksteinen des Timan gefundenen Ventral. mul Dorsalklapyen als Spirifer condor beschriehen wurden. Die eimzige Ventralklappe, die es mir ans den Kalksteinen vom Store

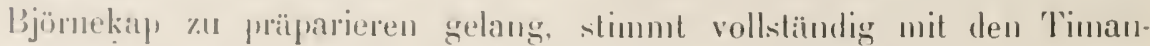
formen ïherein. (O)geglech die Schale sehlecht erhalten ist, sind an Steinkern des stirmandes Querreilien der Vertiefungen, die den groben 
Anwachsstreifen entsprechen, deutlich zu sehen. Die area ist hoch; es gelang, ihren kielartig gebogenen Wirbel mit einer breiten Öfnung in Form eines gleichseitigen Dreiecks aus dem Gestein herauszupräparieren. Die Oberfläche der Schale ist mit nalıestehenden vertikalen Streifen versehen, die durch nicht so scharf ausgeprägte horizontale durchquert werden.

Fundort: Store Björnekap. [\{́千子].

\section{Spirifer fasciger Keyserling. Taf. IX, Fig. 3.}

1846. Spirifer fasciger Keyserlivg, Reise nach Petschora.Land. S. 231, Taf. VIII, Fig. 3.

1889. - - Tschernyscuew. Mém. d. Comité Géologique. Vol. III, N 4, p. 269,366, pl. V, fig. 4 .

1902. - - Tscherxyschew. Die obercarb. Brach. d. Ural und d. Timan. S. 141, Taf. XXXVIII, Fig. 3-4, Taf. XLIX, Fig. 1.

Im Material, das von Dr. Scher gesammelt wurde, sind einige Ventralklappen vorhanden, die bis in die geringsten Einzelheiten mit denjenigen aus den Artinsk- und Obercarbonablagerungen des Ural und des Timan übereinstimmen. Neben der scharf ausgeprägten bündelartigen Anordnung der Falten ist die tometenartige Skulptur an einigen Exemplaren schön erhalten, die für die uralischen Spirifer fasciger, wie auch für die als Spirifer musakheylensis beschriebenen Salt-Range Vertreter so bezeichnend ist. In diesem Material kommt ein Steinkern der Ventralklappe vor, der stark ausgeprägte Zahnplatten und tiefe Muskeleindrücke desselben Typus, wie bei Spirifer striatus MART., aufweist.

Fundort: Store Björnekap. [448, 449, 450 (P. S. 29) ].

\section{Spirifer Marconi WaAgen. Taf. IX, Fig. 4.}

1883. Spirifer Marcoui WaAdex. Salt-Range Fossils. Productus Limestone. Brachiopoda, P. 510, pl. XLVIl.

1902. - - Tschernyschew. Die obercarb. Brachiopoden etc., S. 145 , 533, Taf. VI, Fig. 9, Taf. XII, Fig. 3.

Zu dieser Art stellen wir eine Ventralklappe, die in den Kalksteinen vom Store Björnekap gefunden wurde und mit den in den angeführten Monographien abgebildeten Vertretern vom Ural und Salt-Range übereinstimmt. Der Vorderteil der Schale, der einen tiefen Sinus trägt, ist abgebrochen und verschoben, doch gelang es uns, ihn deutlich genug vom Gestein blosszulegen. Die feine Berippung und die verhältnismässig 
niedrige areal unterscheiden Spirifer Marconi von der nahestehenden spirifer Liovana DIExer ${ }^{1}$. Am Ural wurde Spirifer Marconi aus. schliesslich im Omphalotrochus-Horizont angetroffen, jedoch am Timan steigt er his zum Cora-Horizont.

Fundort: Store Bjürnekial. |fis 1|.

\section{Spirifer tastubensis Tscuenrschew.}

1:k2. Spirifer tastubensis Tscmenxyscnew. Die oberearbon. Brachiopoden d. Urat und d Timan. S. 146, 53t, Taf. IX, Fig. 1-3.

In der beschriebenen Sammlung befindet sich ein fragmentarisches Material: ein Teil der Ventralklappe und drei Dorsalklappen in verschiedenem Erhaltungszustande. Indessen zeigt der unnittelbare Vergleich mit den Originalen aus den Schwagerinenschichten des Ural, dass die lentratklappe, die eine hohe, fast gerade area besitzl, durch eine schmale dreieckige Öffnung geteilt wird und einen miltelständigen, breiten Sinus und flache abgerundete Rippen an den Seiten, bis 14 an Zahl, an Stirn. und Seitenrande besitzt. Die Dorsalklappen, die vollstïndig nit den auf Fig. 1 a, 2 a und 3 der oben angeführten Monographie abgebildeten übereinstimmen, weisen alle Eigenheiten von Spirifer tastubensis auf.

Fundort: Store Björnekap. [452—454 (P. S. 29); 456-457 (P. S. 39) ].

\section{Spirifer Lyra Kưtoria.}

1814. Spirifer Lyra Kutonga. Beitrag zur Palaeontologie Russlands. Verh. d. Rus. siscl. Kais. Mineral. Gesellschaft. S. 92, Taf. IX, Fig. 7.

1902 - - Tschersisciew. Die obercarb. Brachic poden etc. S. 150, 538, Taf. VI, Fig. 6-7, Taf. VII, Fig. 7. Taf. VIII, Fig. 4-5.

(Synonymik s. ilidem.)

In der Sammlung vom Store Björnekap befindet sich nur eine Ventralklappe dieser Art, die für den Schwagerinenhorizont des Ural bezeichnend ist.

Fundort: Store Björnekap. [457].

\section{Spirifer Nikitini 'T'schern.}

'Taf. X, Fig. 2.

1902 Spirifer Nikitini T'scnersyscuew. Die obercurb. Brachiopoden d. Ural ete. S. 512, T'af. X, Fig. 1-2, Tuf. XIII, Fig. 2.

In der Sammlung vom Store Björnekap kommt mur eine Ventralklappe hedentender Grösse vor, die bis in die geringsten Einzelheiten nicht von den typischen Vertretern des Schwagerinen-Horizontes des

1 Dexan Himalayun Fonsils. Vol. 1. Part 4, p. 34. pl. HI, fig. 1-2. 
Ural zu unterscheiden ist. Die Abmessungen der Klappe entsprechen fast vollständig denjenigen, die in der angefülıten Monographie Taf. X, Fig. 1 c angegeben sind.

Fundort: Store Björnekap. [f́̃y].

\section{Subgenus Spiriferella T'schernyschew.}

Diese Benennung wurde einer Gruppe von Formen beigelegt ${ }^{1}$, deren typischer Vertreter Spiriferella Saranae VERN. ist und die eine weite Verbreitung in den Obercarbon- und Artinskablagerungen Russlands besitzt. Bei der Beschreibung des inneren Baus dieser Gruppe gelang es, den Bau der Zahnplatten und der Muskelfelder der Ventralklappen zu verfolgen, wie auch den Bau der Mittelscheidewand, die sich aul die untere (innere) Oberfläche des Pseudodeltidiums stützt, kennen zu lernen. Unter den bekannten Arten kann man zwei Gruppen unterscheiden, die Gruppen Sp. Saranae und Sp. artiensis. Die letztere Art (Sp. artiensis) ist nur durch eine Form vertreten und wurde am Store Björnekap gefunden. Was die erste Gruppe anbetrifft, so gehören zu ihr ausser Sp. Sarance, die im arktischen Obercarbon verbreitet ist, noch folgende Formen: Sp. Parryana Toula ( Sp. Lovéni Diener ${ }^{2}$ ), Sp. Keithavii Buch., Sp. Draschei Toula ( Sp. Salteri Tschenn. $\left.{ }^{3}\right)$, Sp. Wilczeki Toula (- Sp. Keihavii Buch) und ebenso Sp. Rajah Salter, die vom Himalaya beschrieben worden ist.

In der beschriebenen Sammlung kommen die Vertreter des Sp. Sa. ranae, Sp. Lovéni, Sp. Keilhavii, Sp. Draschei und Sp. Salteri vor. Finige Beschreiber sind geneigt, diese Formen für Vertreter einer Art oder einer Abart der Sp. Keilhavii anzusehen. Tatsächlich ist die Arttrennung an den jungen Formen, die verhältnismässig geringe Grösse besitzen, etwas erschwert, doch ist an den ausgewachsenen und grösseren Exemplaren der Unterschied ziemlich deutlich ausgeprägt. Einige davon sind in der Querrichtung ausgezogen und zeichnen sich durch geringe Aufwölbung der Ventralklappe und niedrige area aus (Sp. Lovéni

1 Th. Tscuernyschew. Die obercarbon. Brachiopoden etc., S. 121-130, 522-530.

2 Diener hat vorgeschlagen, die Artbezeichnung $S p$. Parryana, die schon früher (1858) von Hall als eine devonische Form aus dem State Jowa augesprochen wurde, in Sp. Lovéni umzuänderu (Himalaya Fossils, Vol. I, Part 2, p. 68). Da Sp. Parryana Halc (Report on Geol. Survey of Jowa. Vol. I, Part 2, Paläontology, p. 509, pl. IV, fig. 8) zu den typischen Spiriferen aus der Gruppe ostolatis gehört. muss die Benennung von Fr. Toula, die sich auf Spiri. ferella bezieht, beibehalten werden.

3 Unten wird noch nachgewiesen werden, dass diese Benennung zur Synonymik gehört. 
umd Sp. Léllaçii). die anderen sind in der Längsrichtung ausgezogen und hahen eine stark gewölbte Ventralklappe (Sp. Saranae, Sp. Draschei, sj). Saltrit. In len Grenzen dieser Gruppen haben einige Verlreter verhälunismäissig abgerundete und wenig zu unterscheidende Falten. die den Sinus umranden, wie auch die Seiten der Schale (Sp. Saranae. sp. Lovémi): andere besitzen schärfer ausgepräigte Falten. die in drei Zweige zerfallen und sich bündelartig ordnen (Sp. Keilhavii und Sip. Iraschei). Die Skulptur der äusseren Epidernis aler Schale ist hei allen Vertretern der Spiriferella der vom Grafen Keyserurng, Grünewalo' uml Tscuernyscuew beschriebenen Gruppe Sp. Saranae gleich und deutlich unter der Lupe sichthar. Diese Skulptur besteht aus einander mahestehenden feinen 'Tuherkeln, die sich in länglichen wie auch gewölbten Querreihen anordnen. Beim Abrallen der oberen Schicht sind an der Schale feine, den Tuberkeln entsprechende Vertiefungen zu sehen.

Spiriferella saranae Verneuli.

Taf. IX, Fig. 1; Taf. XI. Fig. 1.

18ti) Spirifer Saranae Verseul. Paléontologie de la Russie, p. 169, pl. V, fig. 15 1546. - - Kersentixio Petschora-Land, S. 232. Taf. Vill, Fig. 4, 5. Taf. X, Fig. 3.

1860. - - - Grünewaldo Beiträge zur Kenntnis der sediment. Gebirgs. form. des Ural. S. 98, Taf. IV, Fig. 3.

1902 Spirifer (Spiviferella) Saranae T'scufnxrschew. Die olercarlon. Brachiopod rte. S. 121, 522, Taf. XII, Fig. 4, Taf. XL. Fig. 7. (Synonymik s. ilidem.)

Die äusseren Merkmale von Sp. Saranae, wie auch der Clarakter ler Zahmplatten und der Muskelfelder der Ventralklappe und der mittleren Scheidewand wurden schon in der oben angeführten Monographie eingelıend beschrieben. Jedoch was die Armgerüste der Dorsalklappe inbetrifft, so gelang es in letzter Zeit dem Freiherrn G. v. Ferdericis ${ }^{1}$, diesethen zu erklïren; es glückte ihm, in der Ungehung von Krasnoufinsk жwer vollstindige Exemplare der Sp. Saranae \%u finden und an einem die Spiralgerïste in Form ron zwei aus je 19 Kreisen bestelınden Kegeln nachzuwersen, die dem Typus ryrtina ähnlich angelegr mot mit der Spitze zum Schlossrande gerichtet simd, wobei die Achsen der Spiralen unit der Längsachse der Schale einen geringen Winkel bilden ınd mit der Öfumng zum Wirbel der Schale gerichtet sind. Ingum ist in Furm eines kuryen Bandes vorhanden, dessen genane Form

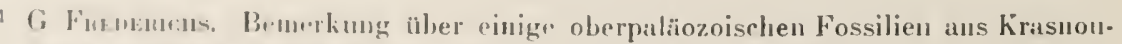
fimsk. Yustily zu den Protokollend der Sitzungen der Naturforsch. Gesellschaft

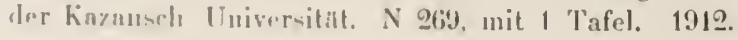


durch angewachsene Kalzitkristalle verbogen ist. Dieser seltene Fund ist auf der Zeichnung wiedergegeben. ('Taf. IX, Fig. 1).

Im ganzen Material, das von Scrieı am Store Björnekap gesammelt wurde, ist nur eine Ventralkappe vorhanden, die durch ihre Aufwölbung, hohe area und eine relative Ausdehnung in der Länge und nach dem Charakter der Faltung den typischen Ural- und Timanvertretern von Sp. Saranae am nächsten steht. Das einzige Unterscheidungsmerkmal ist das Vorkommen einer Längsfalte tief im Sinus und in seiner Mitte, was an den typischen Vertretern des Sp. Saranae nicht beobachtet ivird. Übrigens ist zu hemerken, dass GrünEwaldt an einigen Exemplaren statt einer Furche, die den Sinus teilt, eine zierliche Leiste beobachtet hat. In dieser Hinsicht tritt das beschriebene Exemplar Sp. Parryana Tousa näher, bei dem ebenfalls, wenn auch nicht immer deutlich genug, die miltlere Falte im Sinus beobachtet wird. Überhaupt erinnert $S p$. Parryanae nach dem Charakter der Faltung an Sp. Saranae; jedoch nach dem vorhandenen Material zu urteilen und ebenso nach den Exem. plaren, die in den Museen zu Stockholm und Wien aufbewahrt werden, erreicht Sp. Parryana nicht die Aufwölbung der Ventralklappe und die Höhe der area, die an verluältnismässig wenig Exemplaren von Sp. Saranae beobachtet wird. Man muss bemerken, dass die von Fr. Toura wiedergegebene Abbildung fast die doppelle Verkleinerung des Originals darstellt; dennoch ist die Aufwölbung der angeführten Ventralklappe, wie auch die Faltung an dieser Klappe, geringer ausgeprägt als bei Sp. Saranae. Möglicherweise könnte man den allmählichen Übergang zwischen Sp. Saranae und Sp. Parryana verfolgen, indessen sind die Abweichungen so verschieden, dass wir es für zweckmässig halten die zweite Form als eine selbständige Art, die auf Spitzbergen und der Insel Ellesnere weit verbreitet ist, weiter zu beizubehalten.

Auf Taf. XI, Fig. 4 ist ein Exemplar mit beiden Klappen abge. bildet. Die etwas verdrückte Ventralklappe entspricht vollständig derjenigen der Sp. Parryana, die in zahlreichen Exemplaren an Store Björnekap und in Stücken von Kalkstein am Heibergs Land angetroffen wurde. und auch auf den Zeichnungen von FR. Toula wiedergegeben ist. Was die Dorsalklappe anbetrifft, so ist sie naclı ihrer starken Aufwölbung, an deren Spitze sich eine Längsfurche hinzieht, wie auch nach dem Typus der Seitenfalten an dieser Klappe, so verschieden von Fig. 8 d von Fr. Toula, dass man bezweifeln kann, ob Fig. $S a-c$ und Fig. $S d$ ein und derselben Art angehören. Dieser Zweifel ist um so begrünleter, als bei allen Vertretern von Spiriferella, die Sp. Saranae verwandt sind. der mittlere Teil der Dorsalklappe mehr oder weniger auf- 
gewöht ist mut in keiner Weise der Fig. S I von Fr. Touba entspricht. In dreser Hinsicht erimert unser Exemplar an meisten an Sp. Rajah

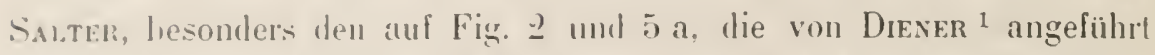
sind. Üherhaupl geniugt der Hinweis, dass Sp. Rajah unserem Exemplar sehr mahesteht. da an der Ventralklapje des beschriebenen Exemplars iun Sinus auch eine mittlere Falte leolachtel wirl, die Diener für $S p$. Rajah bezeichnend hält.

Wie schon in der Monographie ïber die obercarbonischen Brachio poden des Ural und des Timan hingewiesen wurde, tritt Sp. Saranae im Cora-Horizont auf, ebenfalls sehr zahlreich in den Schwagerinen. Srhichten und häufig in den Artinsk-Ablagerungen von Ost-Russland. Es unterliegt auch keinem Zweifel, dass ein Teil der Exemplare, die von der Belcher-Expedition am Depôt Point gesammelt und von SaLten learleitel wurden, zu den typischen Sp. Sarancie gehört. Man musebenso darauf himweisen. dass das Material, das auf Spitzbergen gesammelt wurde, einer gründlichen Untersuchung bedarf, da man darunter typische Sp. Sarance findel, die als Sp. Keilhavii bestimmt wurden.

Fundort: Store Bjürnekap. [459].

\section{Spiriferella Keilhavii v. Buch. \\ Taf. XI, Fig. 2, ?.}

1516. Syirifer Keithavii `. Bucı. Üher Spirifer Keilhavii, über dessen Fundort und Verhältnis zu ähnlichen Formeu. Abhandl. d. Königl. Akat. d. Wiss. Berlin. S. $74-75$, Fig. ?.

18\%. - - SALTEr. The last of the arctic voyages, A Narrative of the Expedition under the command of Sir E. Biscuer. Vol. II, account of the Carhoniferous Fossils by Salter. p. 386, pl. XXXv1, fig. 9, 10.

1902. Spiriferina (Spiriferella) Keilhavii Tscuenxyscifw. Über die obercarbon. Brachiopoden etc. S. 126, 527, Taf. XL, Fig. 1-4.

Diese Art ist in zahlreichen Exemplaren in der Sammlung von Store Björnwap vertrelen. Wie oben angegehen, rechnen wir zu dieser Art Solalen, die verhältnismässig in die Länge gezogen, aber im Vergleich mit Sp. Saranae mit schärferen Falten hedeckt sind, die zugleich in dentliche Bïndel zerfallen. wohei sie nicht nur in den Falten, dir den Sinus hegrenzan, sondern auch von heiden Seiten an den zwei folgomdrn Falten hoohachtet werten. Die Teilumg der Anwachsfalten geht folgendermassen vor sich: Imweit vom Wirbel, an der Seite der zum Sinus gerichteten Faite, tritl eine Furche anf, die die nene und

I Dewern. Himnlaya linssils. Vol. I, part II, p. (iv-71, pl. IV, fig. 1-7, pl. V. fig. 1 . 
schmälere Falte abtrennt, und dann tritt ungefähr in der Mitte der Länge der Schale eine ebensolche Lüngsfurche auf, die die feine Falte an der Seite der erslen Falte, die zur Seite der Schale gerichtet ist, noch stärker abtrennt. Die area ist verhältnismässig niedrig und nimmt die ganze Länge des Schlossrandes ein. In dieser Hinsicht stehen die beschriebenen Exemplare Sp. Parryana seìr nahe, insofern als sie sich durch scharfe Teilung der Falten unterscheiden. die bei Sp. Parryana in Form von Bifurkation bloss an zwei Falten, die den Sinus begrenzen, beob. achtet werden. Über unsere Exemplare der Sp. Keilhavii ist dasselbe zu sagen, wie über $S p$. Saranae: bei den meisten von ihnen beobachtet man in der Tiefe des Sinus eine mittlere oder fast längliche Rippe; es gibt jedoch Exemplare, an denen man diese Rippe nicht wahrnimmt; die Seiten des Sinus sind mit zwei Fältchen bedeckt, die sich infolge der Spaltung einer solchen Falte bilden, die fast am Wirbel beginnt und sich im ersten Drittel del Ringe in zwei Zweige teilt. Auf diese Weise kann man die Anwesenheit der nittleren Rippe im Sinus kaum als wesentlichen Unterschied, den C. Diener ${ }^{1}$ beim Vergleich von Sp. Rajah mit Sp. Keilhavii angibt, anerkennen, umsoweniger als an der Ventralklappe von Sp. Rajah, die Diener auf Taf. IV, Fig.4 seiner Monographie abgebildet hat, die mittlere Rippe am Sinus deutlich zur Geltung kommt. Das unnittelbare Studium der Originale von Salter in Kingston-Museum zeigt, dass dies Exemplare sind, die vollständig seinen Figuren 9 und 10 entsprechen und zu Sp. Keilhavii, nicht zu Sp. Salteri, gestellt werden müssen, wie in meiner Monographie "Über die obercarbonischen Brachiopoden des Ural und des Timan" vorgeschlagen wurde. Man muss noch darauf hinweisen, dass der von $F_{R}$. Toula ${ }^{2}$ vom Südkap auf Spitzbergen beschriebene Sp. Wilczeki wohl zu Sp. Keilhavii gestellt werden muss.

Am Ural wurde Sp. Keilhavii bis zur Zeit ausschliesslich in Schwagerinenkalk gefunden. Auf Spitzbergen kommt diese Art im SpiriferKalkstein und Productus-Kieselschiefer vor. Die Expedition Belcher fand Sp. Keilhavii an Depôt Point auf der Insel Exmouth.

Fundort: Store Björnekap. [460, 461, 462-475].

1 C. Diener. Himalaya Fossils. Vol. 1, Part 2, Anthracolithic Fossils of Kashmir and Spiti, p. $70-71$.

2 Fr. Toula. Kohlenkalk-Fossilien von der Südspitze von Spitzbergen. Sitzungsb. d. K. Akad. d. Wiss. Wien. Jahrg. 1878. I. Abt. Nov.-Heft, S. 5, Taf. 1, Fig. 3. 


\section{Spiriferella artiensis Stuckenberg.}

1595. Spirifer artiensis Stuchexberg. Allgem. Geolog. Karte von Russland. Blatt 197, S. 266, 'Taf. V, Fig. 6.

1902. - - Tscmerxyscinew. Die obercarbon. Brachiop. d. Ural und d. T'iman. S. 129, 529, Taf. XXXVII, Fig. 5-7.

In der beschriehenen Sammlung kommen nur zwei grosse Ventral. klappen vor. die vollständig der Keichnung 5 auf 'Taf. XXXVII der zitierten Monographie von 'T'schernyschew entsprechen. An beiden bxemplaren ist deutlich die bezeichnende tometenartige Skulptur wahrzunehmen, und an der fast geraden area scharfe senkrechte Rippen, die durch schmale, am Schlossıande mit Zacken endende Furchen geteilt sind.

Diese Art wurde bis zur Zeit nur in den Schwagerinen- und Artinskablagerungen des Ural gefunden.

Fundort: Store Björnekap. [476-479].

Spiriferella Parryana 'Tousd.

Taf. XI, Fig. 4; Taf. XII, Fig. 1, 2, 3.

1875. Spririfer Parryana Toula. Permo-Carbon-Fossilien von der Westküste von Spitzbergen. N. J. S. 256, Taf. VIl, Fig. 8 a-c.

Oben wies ich darauf hin, weshalb man Sp. Parryance nicht durch die von DıExen gegebene Bezeichnung Sp. Lovéni ersetzen kann. Ebenso führte ich die Erwägungen an, die gestatten. $S p$. Parryanae von $S p$. Sarancie zu unterscheiden. Auf unseren Zeichnungen trelen diese Unterscheidungsmerkmale deutlich hervor.

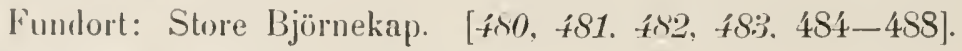

Heilhergs I and [489-493].

\section{Spiriferella Draschei 'Tous.s.}

'Tal. IX, Fig. 2.

187i. Syirifer Draschei Tous. Permo.Carlon-Fossilien von der IVistküste von Spilzbergen. N. J. S. 15, Taf. VII, Fig. 4. (Sep-Abdr.) 1902. Spiriferina (Spriviferella) Salteri Tscimarscinw. Dic oberearb. Brachiopod. $4 k$ S. 126, 528, Taf. VI, Fig. 5, Tat. Xll, Fig. $5,6$.

Nach drom Charakter der hohen area und der relativen Ansdehmung in der Lainge steht diese Art der Sp. Saranae an närhsten, der Faltung anch kommt sic Sp. Keilharii malse; trotzdem mnterscheidet sich $S p$. Draschei von den beiden erwïhnten Arten durch einen ungewöhnlich lreilen simus, der $60 \%$ "der lämge ler Ventralklappe eimnimmt, während die Brreile les Simus lori Spr. Keilhavii nicht 45-50\% der entsprechenden

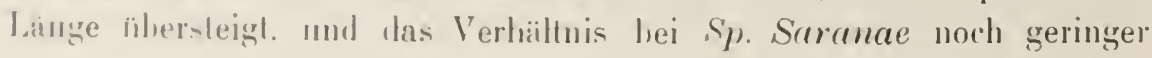


ist. In meiner Monographie über die obercarbonischen Brachiopoden des Ural und des Timan habe ichı unter dem Nannen Sp. Salteri eine neue Art beschrieben, zu der Sp. Keilharii gestellt wurde, die vor Salter auf Fig. 9 und 10, Taf. XXXVI in seiner Arbeit über die Carbon-Fossilien der Insel Exmouth abgebildet worden ist. Das unmittelbare Studium der Originale zeigte, dass sie tatsächlich zu Sp. Keilhavii gerechnet werden müssen. Was jedoch die Ural- und Timanvertreter des Sp. Salteri anbetrifft, so zeigt der Vergleich mit den Originalen von Fr. Toula eine vollständige Übereinstimmung, und deshalb ist $S p$. Salteri als Synonym von Sp. Draschei aufzufassen.

In den Kalksteineı von Store Björnekap, in denen Scнer hauptsächlich das paläontologische Material gesammelt hat, wurde kein Exemplar von $S p$. Draschei ermittelt, jedoch aus einzelnen Stücken des dunkeln Kalksteins, der von ScHer auf Heibergs Land angetroffen wurde, gelang es ein zientich grosses Exemplar einer Ventralklappe herauszupräparieren. Die Ventralklappe trägt eine Faltung, die in Bündel zerfällt, ähnlich wie bei Sp. Keilhavii; bei dem beschriebenen Exemplar sieht man an jeder Seite des Sinus noch eine weitere Teilung der beiden Falten, die sie am Stirnrande im Sinus, mit der Zentralfalte zusammen, etwa 9 an Zahl vorkommen lassen. Die Zentralfalte ist in Sinus, wie auf der Zeichnung von Fr. Toula zu bemerken ist. schärfer ausgeprägt als diejenigen, die an der Seite des Sinus liegen.

Sp. Draschei - Sp. Salteri wurde in den Schwagerinenschichten des Timan und in den Artinskablagerungen des Ural gefunden. Von Spitzbergen ist Sp. Draschei aus den Productus-Kieselgesteinen der Axel Inseln beschrieben.

Fundort: Heibergs Land. [494́].

\section{Spiriferella sp.}

Im Material vom Store Björnekap befindet sich ein Exemplar einer nicht vollständig erhaltenen Ventralklappe, die erwähnenswert ist. Der Wölbung, der area und auch der Skulptur nach erinnert diese Form an Sp. Saranae, unterscheidet sich von ihr jedoch leicht durch flachere und zahlreichere Anfangsfalten, die sich vom Wirbel hinziehen; bei Sp. Saranae erreicht ihre Zahl gewöhnlich 5 und übersteigt nicht 6 auf beiden Seiten des Sinus, an unserem Exemplar beträgt die Zalıl der flachen Falten auf jeder Seite des Sinus 8. Ausserdem ist der Sinus bei unserem Exemplar weniger tief und verhältnismässig schmäler als bei Sp. Saranae. In dieser Hinsicht erinnert unser Exemplar an eine Ventralklappe der 
Spiriferella, die an Flusse Belaja an T'man gefunden wurde, jedoch ist auch dieses Exemplar nicht genügend erhalten, um eine besondere Art z. charakterisieren

Funturt: Store Bjürnekap. [495].

Spiriferina d'OrmigNy.

Spiriferina cristata Schlotu.

1s16. Terebratulites cristatus Scm.otn. Denkschr. Akad. d. Wiss. zn München. S. 2S, Tit: I, Fig. 3.

19102. Spriferina cristatu Tscmensschew. Die ohercarbon. Brachiop. etc. S. 115 Taf. XXXVII, Fig. 1- ?.

(Synonymik s. ibide'm.)

In den Kalksteinen rom Store Bjürnekap kommen жwei Exemplare lieser Art vor. Der allgemeine Umriss, der Charakter des Wirbels und die area der Ventralklappe, lie scharfen Falten der beiden Klappen, die lurch einen Zwischenraum geteill sind, lessen Breite der Breite der Falten entspricht, die Breite les Sinus, die die Breite der Falte nicht ïbersteigt und sie von der henachbarten Falte trennt. und ebenso die punktartige Struktur, alles das entspricht vollständig den Uralvertretern der sip. cristata, und auch den typischen Formen, die von Davidson und Kixr beschrieben wurden. Unter der Spitzbergensammlung ist uns Sp. cristata nur von der Axel Insel vom Bellsund hekannt.

Fundort: Store Björnekaj. [497-499].

Familie Rhymchonellidae Cray.

Camarophoria Kısri.

Camarophoria Kutorgae T'suenischew.

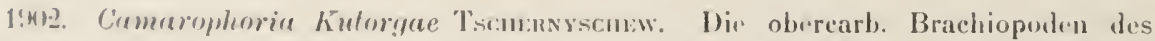
Ural und des Timan. S. 500. Taf. Xxil. Fig. 16-17.

In der heschrielenen Sammlang kommt nur eine Ventralklappe vou hedentender Almessung vor, die in Simms 5 Falten trïgt und 6 an jeder Seile. Diese form ist den lypischen Vertretern des obercarbonischen kalkstrins des Ural und des Timan gleich.

Fundort: Store Bjüruekap. [501 (1'. S. 29)]]. 


\section{Camarophoria mutabilis Tschernyschew.}

1902. Camarophoria mutabilis Tschersvsthew. Die obercarbonischen Brachiopod. des Ural und des Timan. S. 491, Taf. XXII, Fig. 18, Taf. XXIII, Fig. 10, Taf. XLV. Fig. 1-15, Taf. XLVI, Fig. 14.

Diese Art, die für die Schwagerinenschichten des Ural und des 'Timan bezeichnend ist, ist in der Sammlung vom Store Björnekap' nur' mil einem Exemplar vertreten. [502].

\section{Rhynchopora Kivg.}

\section{Rhynchopora Nikitini Tschernyschew.}

1885. Rhynchopora Nikitini Tschernyscrew. Der permische Kalkstein im Gouvern. Kostroma. Verh. d. Kais. Mineralog. Gesell. Bd. XX. S. 295, Taf. XVIII, Fig. 34-36.

1889. - - $\quad-\quad$ Tschernyschew. Mém. du Com. Géol. I, III, N 4, p. 275. pl. VI, fig. 20.

1902. - - $\quad-\quad$ Tschernyschew. Die obercarb. Brachiop. d. Ural und d. Timan. S. 73 .

In den angeführten Arbeiten erörterte ich mit genügender Ausführlichkeit, dass viele Beschreiber diese Art mit Phynchonella Pleurodon PhuLL. v'erwechseln, mit der sie aber nur eine äusserliche Ähnlichkeit besitzt, da die punktartige Struktur der Schale die Vertreter der Rhynchopora wesentlich von den Vertretern der Rhynchonella unterscheidet, bei denen die Schale eine faserartige Struktur aufweist.

Am Ural und am Timan kommt Rhynchopora Nikitini schon im Omphalotrochushorizont vor und zieht sich über das ganze Gebiet der obercarbonischen Ablagerungen bis zu den Artinskschichten hin. Sie ist auch aus den Permablagerungen Russlands bekannt, wo sie mit lihynch. Geinitzi VERn. verwechselt wird.

Die Untersuchung der Sammlungen, die in verschiedenen Museen aufbewahrt werden, beweist, dass Rhynchopora Nikitini sehr häufig im arktischen Paläozoikum verbreitet ist. Ohne Zweifel gehört zu dieser Art die Folm, welche Fr. 'Toula ${ }^{1}$ von der Axel Insel im Bellsund unter dem Namen Rhyuchonella cf. pleurodon beschrieben und abgebildet lıat. In den Sammlungen des Stockholmer Riksmuseum werden typische und von Rhynchopora Nikitini nicht zu unterscheidende Exemplare vom Cap Wijk, Nordfjorden, Green Harbour, Angelingsberg, Lovénsberg,

1 Fr. Toula. Permo-Carbon-Fossilien von der Westküste von Spitzbergen. N. J. 1875, S. 13, Taf. VIII, Fig. 3 (Sep.Abdr.). Wahrscheinlich gehören die Exemplare, die $\mathrm{F}_{\mathrm{r}}$. Toula von den Barents-Insoln beschrieben hat, zu dieser Art und nicht zu Rhynchonella pleurodon. 
lsfjorden, Som Saftenelfaen und der Axel Insel im Bellsund aufbewahrt. Am letzteren Orte wird Rhynchonella Nikitini. wie an Ural. von Rhynchopora variabilis Stuck. begleitet. In den Kalksteinen vom Store Björnekap ist Rhynchopora Nikitini keine seltene Form, da man in der Sammlung von Scum ungefähr 15 Exemplare zählen kann. In den Kalksteinen vom Heibergs Land gelang es einige, unvollstïndig erhaltene Exemplare herauszupräparieren.

F'undort: Store Björnekap [503-518].

Heibergs Land [519-521].

Familie Terebratulidae.

Notothyris Waagen. Rostranteris Gemmellaro.

Notothyris polaris n. sp.

Taf. XII, Fig. 5, 6.

Eine kleine, verhältnismässig ovale Schale, im altgemeinen von fünfeckigem Umriss. Von der Mitte der Länge, zum Stirnrande gerichtel. zieht sich eine verhältnismässig breite, flache Furche hin, die von beiden Seiten durch eine deutlich ausgeprägte Falte begrenzt wird. Auf der Dorsalklappe entspricht der Einbuchtung der Ventralklappe eine flache Erhöhung, die an der Vorderseite der Schale gut bemerkbar und von jerler Seite durch eine Längsvertiefung begrenzt ist. Wenn man die Schale von der Seite des Stirnrandes betrachtet, erscheint die Kommissur in Form einer gebrochenen Linie. Die Oberfliche der Schale weist regehmässige Anwachsstreifen auf, die an Stirnrande näher zueinander stehen. Der Aufbau der Schate ist punktiert, was deutlich unter der Lupe zu selien ist.

Naclı der Abmessung. dem allgemeinen Umriss und der Aufwölbung erimnert die beschriebene Art an die uralische Notothyris (N. mucleolus Kut.), die sizilische (N. ovale Gғмм.) und die indische ( $N$. simplex WAaG.), unterscheidet sich jedoch durch die flache Einbuchtung der Ventralklappe. die einer flachen Erhöhung an der Dorsalklappe entspricht, indessen nieht in Form einer scharfen Falte, wie \%. B. hei $N$. mucleolus, N. ovale und anderen Formen.

Der innere Bau konnte wegen des schlechten Erlaltungszustandenicht heramspräpantert werden.

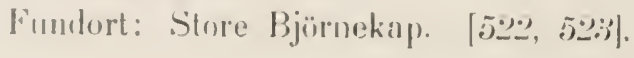


Dielasma King.

Dielasma Moelleti Tschernyschew.

1902. Dielasma Moellevi Tschernyschew. Die obercarb. Brachiop. d. Ural und d. Timan. S. 29, 453, Taf, 1II, Fig. 6-7.

In der Sammlung vom Store Björnekap befindet sich nur ein Exenplar dieser Art, das für die obercarbonischen Kalke des Ural und des Timan bezeichnend ist, obwohl auch dieses Exemplar nicht vollständig erhalten ist, da ein Teil der Dorsalklappe und der Wirbel der Ventralklappe abgebrochen ist. Trotzdem gestattet der Charakter des linealen Sinus der Ventralklappe in Form einer tief in die Dorsalklappe einschneidenden Furche, wie auch der Umriss und die Art der Aufwölbung der beiden Klappen und der breite Wirbel der Ventralklappe mit deutlich ausgeprägten Stirn- und Zahnplatten, keinen Zweifel an der Richtigkeit der Bestimmung auszusprechen, wovon man sich durch den unmittelbaren Vergleich mit den Uraloriginalen überzeugen konnte. Unter der Lupe ist auf beiden Platten die Punktierstruktur deutlich wahrnehmbar.

Dielasma Moelleri ist auf Spitzbergen nicht selten; jedenfalls kommt diese Art zweifellos in Spiriferenkalk des Bellsunds und an Cap Wijk im Nordfjord vor. Es ist von Interesse, dass die Vertreter von D. Moelleri in der guadalupischen Fauna vorhanden sind, die GiRTr als D. prolongatum GrRTy (The Guadalupian Fauna, p. 331, pl. XVI. fig. 5) bestimmt hat, worauf GIRTY auch selbst hinwies.

Fundort: Store Björnekap. [525].

\section{Lamellibranchiata.}

Familie Aviculopectiniclae Etheridge Junr. 1892.

Aviculopecten MaG Coy 1851.

Aviculopecten (Deltopecten?) Bouei Keyserling non Verneull ${ }^{1}$ Text-Figuren 5 und 6.

1846. Pecten Bouei Keyseruivg. Wissenschaftliche Beobachtungen auf einer Reise in das Petschora-Land. S. 244, Taf. X, Fig. 6.

1873. Pecten (aviculopecten) Bouei Toula. Kohlenkalk-Fossilien von der Südspitze von Spitzbergen. Sitzungsb. d. K. Akademie d. Wissensch. Wien. B. LXVIII, Abt. I, S. 19, Taf. X, Fig. 8.

1 Die in der Arbeit angeführte Beschreibung der Lamellibranchiaten aus der Sammlung des Dr. Schei wurde von Herrn Licianew ausgeführt, dem sie nach dem Tode des Herm Akademikers Тн. Tsсnernyschew zur Bearbeitung übergeben wurden. 
157\%. Pecten Bonei Stcchinenc. Geologische Reise nach Petschora.Land und Timan. Mater. zur Geologie Russlands. Bd. VI. S. St.

1595. Aviculopecten Touleanus Sitckinerg. Allgemein. Geologische Karte von Russland, Blatt 127 Mém. du Com. Géolog. Vol. Xit. N 1. S. 202, 335, Tal. I. Fig. 19.

Vicht 1S15. Pecten Borei Vraxelu. Paléentologie de la Russie, S. 320, Taf. XXI, rig 6 .

185i. Aviculopecten Bonei Kovisck Faune du Calcaire Carlonifere de la Belgique. Lannelliliranclies. Amnal. du Mnsée d'Hist. Nat. de Biolg. B. XI, p. V, S. 220, Taf. XXXV, Fig. S, 9.

1912. Aviculopecten Bonei Cuanen. Unterwarbonfanna von Gaablau in Nirderschlesien. Jahrl, d. K. Preuss, Geol. Lauds. B. XXXIII, 'T. I. Heft I, S. 5i, Tiaf. 3, Fig. 9() .

Diese Form hefondet sich in der Sammlung in 5 lixemplaren, die augenscheinlich ausschliesshich zı den linkeı Klappen gehören. Unter ihnen ist nur ein Exemplar einigermassen gut erhalten.

Die Klappe ist schwach konvex, der allgemeine Umriss dreiechig. Die seraten Ränder, die den nittleren Teil der Schale ungrenzen, stossen unter einem Winkel von $\mathrm{S} 0^{\circ}$ zusammen, wobei sie einen nicht eingebogenen, etwas über den Schlossrand hervorragenden Wirbel bilden. Der Ventralrand ist hallorund. Das Vorderohr ist etwas gewölbt und vom mittleren 'Teil der Schale durch einen scharfen, geradwinkligen Vorsprung getrenul; das hintere Olı ist flach und die Abstufung mehr gerundet. Die iiussere Form der Ohren hat sich nicht erhalten. Die Preite und Länge eines Exemplars erreicht $35 \mathrm{~mm}$.

Die Oberfläche der Schale ist durch Radialrippen verziert, die gewöhnlich ziemlich zart sind, jedoch ein Exemplar (Fig. 5), trägt gröbere Rippen. Unter ihnen sind 6-S Hauptrippen, die sich rom Wirluel hinriehen. Die ïbrigen schalten sich allnühlich zwischen denselben ein. so dass man am Ventralrande zwischen den 2 Hauptrissen 15 Sekundiirripuen zithlen kann. wo zwei oder drei Nachbarrippen oft die gleiche Stärke erreichen und teilweise gleichmässig wechseln. Auf der Oberfläche der Sihale benterkt man manchmal ebenfalls einige geringere Erhölumgen, die den Hauptrippen ein knotenartiges Aussehen verleihen. Die Skmlphur an den Ohren hat sich nicht erhalten.

Un\%weifollaft ist Pecten Bonei, die Kersemuxg aus den Obor"arhonablagerungen des Ural und des T'iman heschrieben hat. von denjenigen Formen, die V'erneun aus der unteren Abteilung des Carbonsystens anfühnt: es genügt, die Abhihhngen dieser Formen der beid'n Anturen \%n virgleichen, nn den Unterschied \%wischen Aviculopeclen Bouei Kiss. und Av. Bonei Virn. wahrzunehmen. Nach der Veröffentlichung

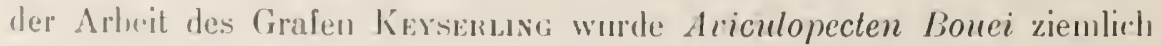
uft in der paliumblogri-chen literatur angeführt, jedoch unter diesem 


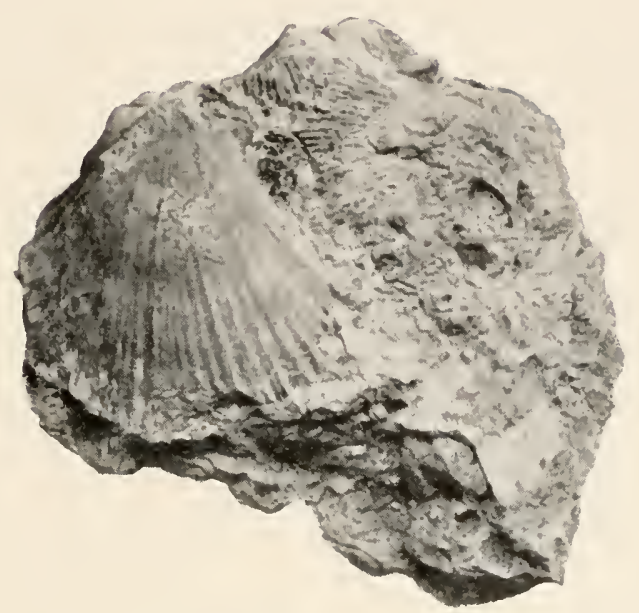

Fig. 5. Aviculopecten Bonei Kersert. Store Björnekap (P. S. 99). Natürliche Grösse.

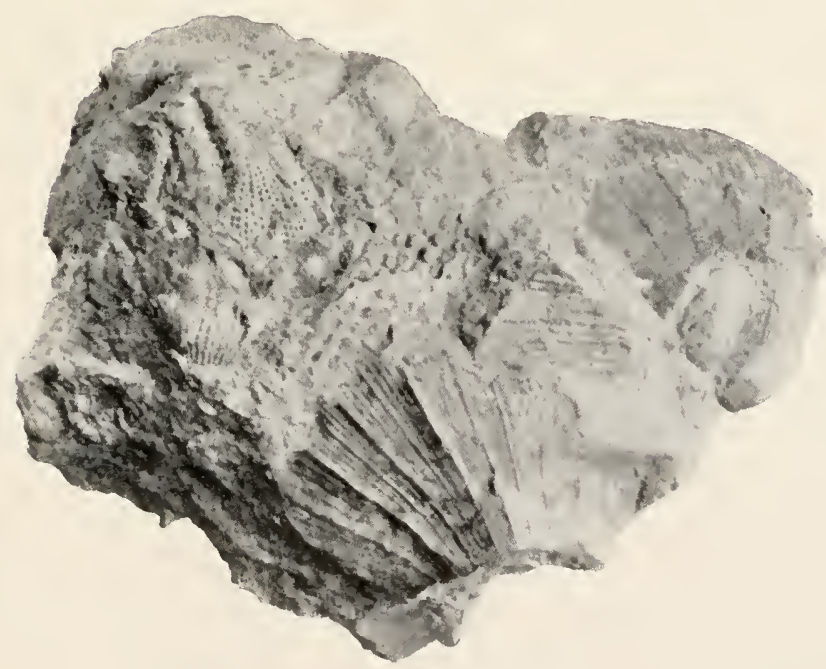

Fig. 6. Aviculopecten Bonei Keyseru. Store Bürnekity (P.S.8). Natürliche Grösse. 

Namen werden diese Formen von verschiedenen Beschureibern in Sinne Verneuils und eimmal im Sinne Keyserungs gebraucht. So gehı̈rt die Art, die von Toula unter denı Namen Av. Bouei von Spitzbergen beschrieben wurde, zweifellos zu Av. Bonei Keys. und nicht zu $A v$. Bouei Vern. ${ }^{1}$ Im Jahre 1898 beschrieb Prof. Stuckenberg unter den Namen Av. Touleanus Stuck. eine neue Art, die sich voll Av. Bonei KEYS. bloss durch einen geraden (nicht eingebogenen) vorderen und hinteren Rand unterscheidet; es liegt mir eine grössere Anzahl der Vertreter der Av. Touleanus Stuck. und Av. Bonei Keys. vor, die eine enge Verwandtschaft zueinander besitzen, und es liegt kaum die Möglichkeit vor, Av. Touleanus als besondere Varietät auszuscheiden. Augenscheinlich verstand Akademiker Th. Tschernyschew in dem gleichen Umfange auch die Formen aus den Obercarbonablagerungen des Ural und des Timan, wo "Aviculopecten Toulai Stuck. (Av. Bouei Keys. non VERN.)" angeführt werden ?

Die grösste Ähnlichkeit mit Av. Bouei Keys. besitzt Av. Kokscharowi (non Vers.); der Unterschied wurde schon von KeyserLing ${ }^{3}$ betont und dann von neuem von Herrn Akademiker Th. Tschernyschew ${ }^{4}$ nachgewiesen. Die von beiden Verfassern angeführten Unterscheidungsmerkmale von $A v$. Bouei Keys. sind tatsächlich für die permischen Vertreter der Av. Kokscharowi KEys. bezeichnend; doch mildern sich dieselben bei den Permocarbon- und Obercarbonvertretern der letzteren Art, für die fast das einzige und wesentlichste Unterscheidungsmerkmal der gerade (jedoch nicht sichelartig gebogene) Vorderrand des vorderen Ohres und die grössere Regelmässigkeit der Skulptur darstellt.

Da ich Av. Kokischarowi Kexs. zur Untergattung Deltopecten ЕтнеRidge Junr. ${ }^{5}$ rechne, so ist es möglich, dass Av. Bouei KeYs. zu derselben Untergattung gehört.

1 Akademiker Th. Tschennyschew stellt dieses Exemplar zu Av. Kokscharowi auf Grund der Begrenzung der Ohren, doch bin ich nicht geneigt, diesem Merkmale eine entscheidende Bedeutung beizulegen. Siehe Tschensyschew. Der permische Kalkstein im Gouvernement Kostrona. Verh. d. R. Miner. Gesellsch. St. Petersb. 2. Serie. Bd. XX, S. 274.

2 Tschernyschew. Die obercarbonischen Brachiopoden des Ural und des 'Timan. Mém. du Com. Géolog. Vol. XVI, N 2, p. 442. Die Benennung Av. Toulai kann nicht für diese Form gerechtfertigt werden, da sie schon vor Stuckenberg von LundrRen angenommen wurde. Anmärkningen om permfossil from Spetzbergen. Bihang till K. Srenska Vetensk. Akad. Handl. B. XIII, Afd. IV, 1888.

3 Keyserling. Petschora-Land. S. 246.

4 Tschernrschew. Der permisithe Kalkstein u. s. w. S. 281.

5 Licharew. Die Fauna der Permischen Ablagerungen aus der Umgebung der Stadt Kirillow. Mém. du Com. Géolog. Nouv. Serie. L. 85. S. 23. 
Wenn แan nun zu den oben heschriebenen Exemplaren zurückkehrt. kann man trotz ihrer schlechten Erhaltung eine vollstandige Übereinstimmung mit den Ural- und Timanformen feststellen. Was indessen die Exemplare mit gröheren Rippen anbetriff, so muss bemerkt werden, dass diese Eigenschaft nicht selten hei den Vertretern der anderen nahe. stehenden Gruppe, wie Av. Kokscharoni Kers., Av. subclathratus lírser., heobachtel wird.

Av. Bonei KeYs. kommt in Cora- und in Schwagerimenhorizont des Liral und des Timan vor und ist, augenscheinlich. in den Permo. 'arbonablagerungen des Voruralgebiets zu finden. Toura beschreibt diese Art aus dem Spiriferenkalkstein von Spitzbergen.

Fundort: Store Björnekaj). (No. P. S. S; P.S. 29).

\section{Statt eines besonderen Schlussworts.}

Wie schon in Vorwort erwïhnt, wurde in den Papieren des verewigten Akademikers Tн. Tschernyschew nicht genügender Stoff für ein Schlusskapitel gefunden. Um dasselbe einigermassen auszuführen, wird nachstehend eine Tabelle aufgestellt, die eine Vergleichung der Fauna von König Oscars und Heibergs Land mit dem Oberpaläozoikum des Europäischen Russlands und einiger anderen Länder gestattet. Dic stratigraphische Einteilung wurde der bekannten Monographie des Akademikers Tr. Tschernyschew über die obercarbonischen Brachiopoden entnommen. Es wurde mur noch der Vergleich mit der GuadaIupien Famna des Staates Texas aus Nordamerika hinzugefügt.

Ehenso wie in der Monographie von 'TH. 'Tscuensyschew wurde das \%eichen + für die Formen angewandt, die sich von den beschriebenen unterscheiden, und das Zeichen $X$ für solche Formen, die den be. schriebenen mahestelıen. Was die stratigraphische Stellung der Bryozoen amlangt, so komnte man sie nicht immer mit der gleichen Genanigkeit feststallen und musste sie mit einem Zeichen + mod einer horizontalen K'lanmer, die melıre Ëinteilungen der 'Tabelle zusammenfasst, versehen. 
Verzeichnis der Obercarbonfauna von König Oscar und Heibergs Land

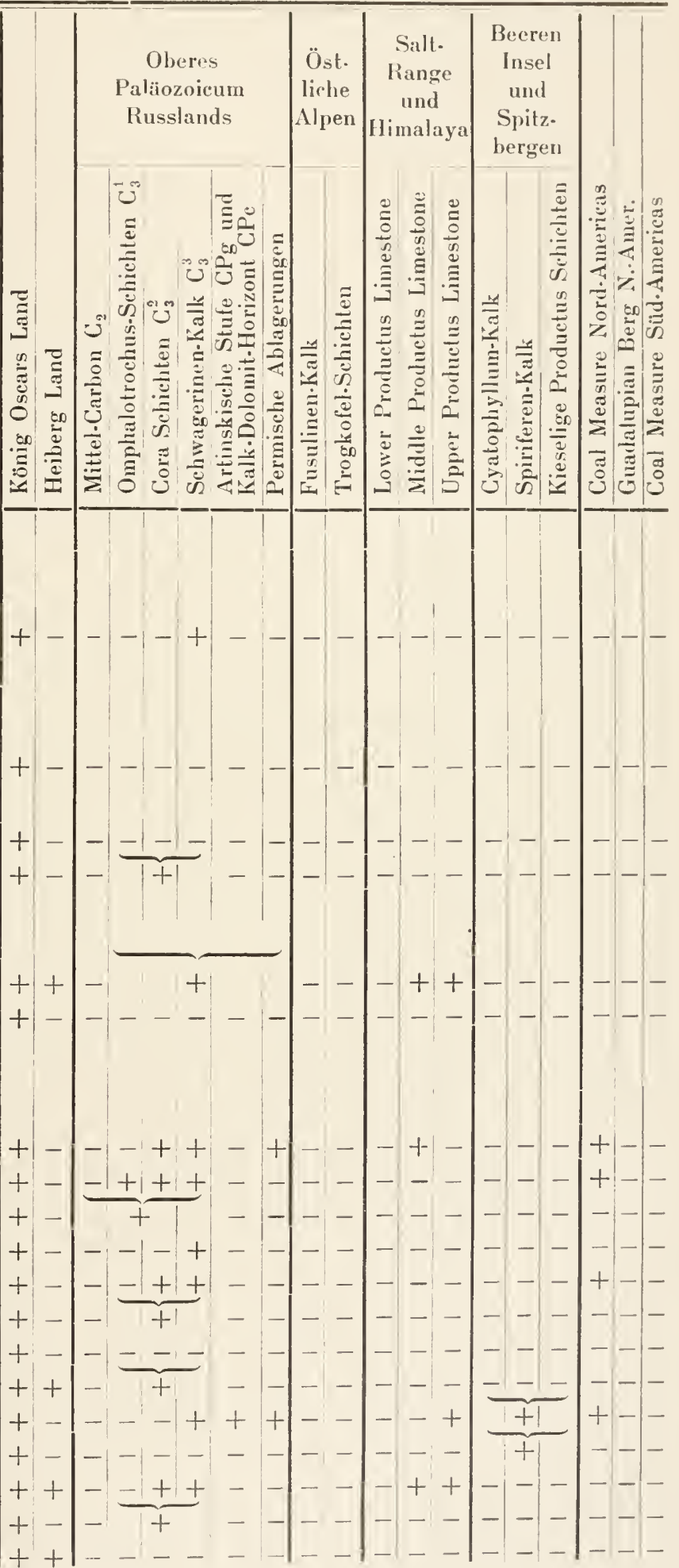

Anthozoa.

Fam. Zaphrentidae.

2. Zaphrentis sp. .

Fam. Cyatophyllidae.

4. Lithostrotion borealis SтUскемв. Fam. Monticuliporidae.

5. Geinitz. column. Scinl. v. ram. spars. G. W. . . . . . . . . .

6. Stenopora aff. ovata Lonsp. ...

\section{Bryozoa.}

Fam. Fenestellidae.

7. Fenestella elegantissima Еіснш.

1 15 16.

17

18

19. Phyllopora cf. borealis Sтиск.. . ++ veneris FISCHER.... +-augusta Fischer orientalis EıcHw. plebeja M'Coy

Archimedes sp. varicosa $\mathrm{M}^{\prime} \mathrm{CoY}$. 
Ver\%eichnis der Ohercarhonfauna von König Oscar und Heibergs Land

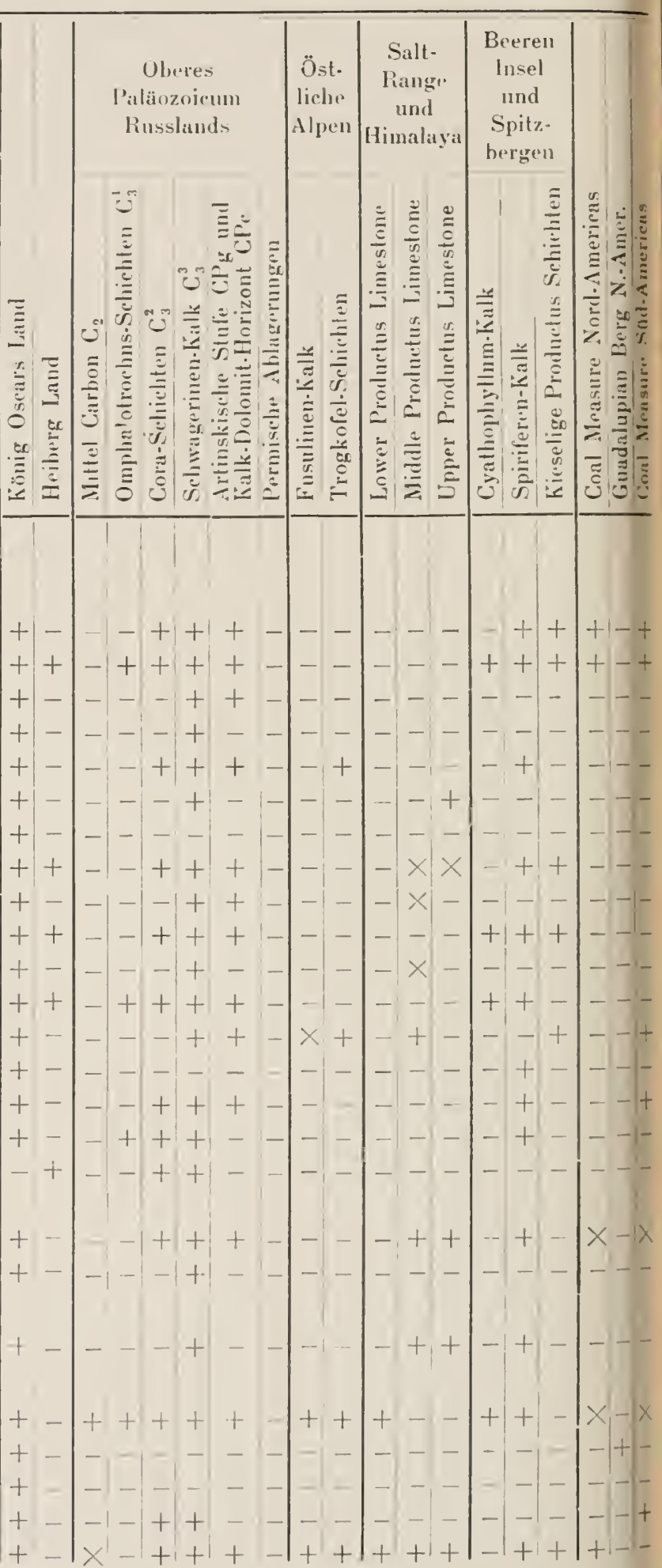


Verzeichnis der Obercarbonfauna von König Oscar und Heibergs Land

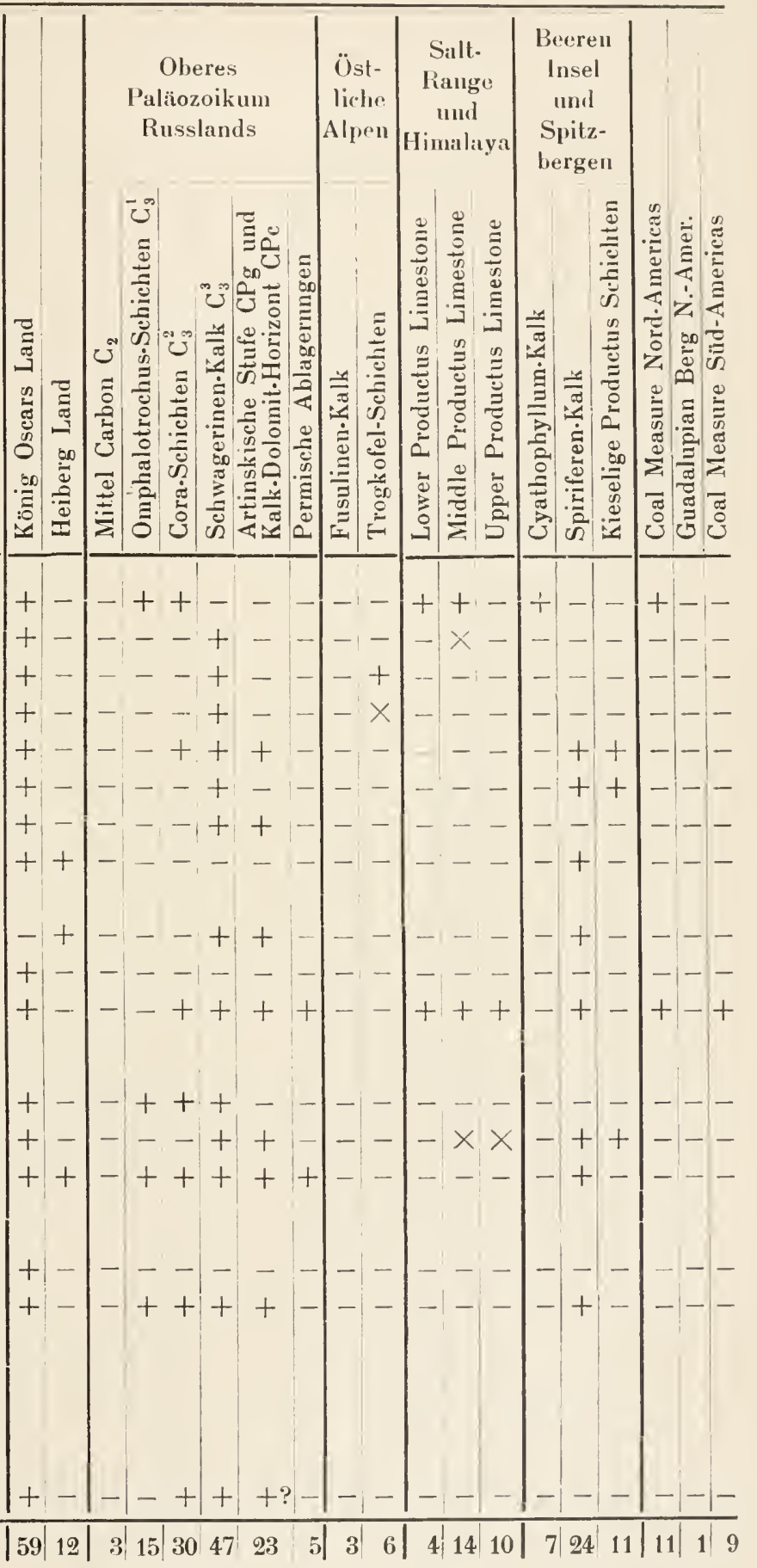

45. Spirifer Marcoui WaAg. . . . 46.

49. Spiriferella Saranae Vers. ...

50. - Keilhavi v. Buch ..

51. $\quad-\quad$ artiensis Stuck. ...

52.

53.

Parryana Toula .

ว3. - $\quad$ Draschei Toula $=$

S. Salteri Tschern.

5 t.

วँ. Spiriferina cristata SснL.

Fam. Rihynchonellidae.

56. Camarophoria Kutorgae Тsсн.

57

58. Rhynchopora Nikitini Tsch. . .

Fam. Terebratulidae.

59. Notothyris polaris $\mathrm{n}$. $\mathrm{sp}$.

60. Dielasma Moelleri Tsch

Lamellibranchiata.

Fam. Aviculopectinidae.

61. Aviculopecten (Deltopecten ?) Bonei

Keyseri. non Vern.

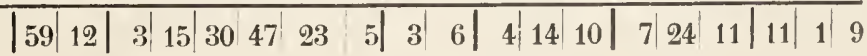


Verzeichnis der beschriebenen Formen.

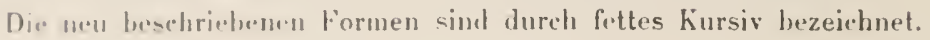

frehimedes -y.. S. 2.2. Thaf. IV. Fig. 5.

Ariculopecten (l)eltopeclen?) Bonei Kt.Y's. non Vers. S. 59. Fig. 5, 6.

C'amarophoria kulorga Tscuer. S. 56.

mutulilis Tschirs. S. 57.

Clisiophyllum? :-1.. S. 9. T'af. III, Fig. ‥

Inielasma Moclleri 'T'sciller.s. S. 59.

Derbyia grandis WaAg., S. 44, Taf. X. Fig. 1.

(icinilzella columnaris ScHL. rar. ramosa sparsigemmata G. WAAG., $\therefore$ 12. Tilf. III. Fig. 4, 5 .

lithostrotion borealis scincik.. S. 10, Taf. III, Fig. 3.

Frmestella angusla Fisch. S. IS, 'Thaf. IV. Fig. 1.

- cleguntissima Ercuw. S. 16, Taf. III, Fig. 7.

- arienlalis Eicrmw. S. 20, 'Taf. IV, Fig. 2.

- plebeja M'Cor, S. 20. Taf. IV. Fig. 3.

- varicosa MCur. S. 21, Taf. IV, Fig. 4.

- reneris Fiscr., S. 17. Tal. III, Fig. S.

Marginifure Clarliei Tscanens.. S. 43.

imeolula Tschern. S. 42.

typica W ANG. var. septentrionalis TSCHERn.. S. 42.

Notothyris polaris 11. sp. S. 58, Taf. XII. Fig. 5, 6.

Phyllopmen if borealis s'ruck. S. 28, Taf. IV, Fig. 11.

I'slypora biarmica Kers., S. 23, Taf. IV. Fig. 7.

marlis Fistu., S. 22.2 T'af. IV, Fig. 6.

- micropora stru:k. S. 27 , Taf. IV, Fig. 10.

- obicribrule Kist. s. 5.5. Taf. IV, Fig. 9.

- mestulula Tour.a. S. 94. Taf. IV, Fig. S.

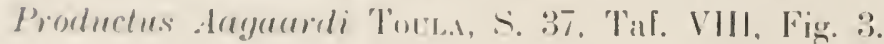

- bolivirusis d"Orno, s. :0)

crencriniformis 'T-anemx. S. 39

- inflatus Mc Cines., s. 30.

- Frami 11. … 33.

llumboldli d'() ris. 36.

- irgimue stuck., S. 35

fominclii Vias. s. : 
Productus porrectus KuT., S. 41.

- psendoaculeatus KuT.. S. 33.

- simensis Tsculern., S. 38.

- Stucliembergi Krotow. S. 32.

- tartaricus Tschern., S. 33.

- tastubensis 'T'schern., S. 34.

- timanicus STuck., S. 41.

- Weyprechti Toula, S. 39.

Reticularia guadalupensis SHum., S. 45.

lineata MART., S. 44.

Rhynchopora Nikitiui 'T'schern., S. 57.

Scheiia tuberosa n. sp. S. 6, Taf. I, Fig. 1-6, 'T'af. II. Fig. 1-4.

Spirifer condor d'ORB, S. 4 i.

- fasciger KEYs., S. 47.

- lyra Kut., S. 48.

- Marconi IVAaG., S. 47.

- Nilitini Tschern., S. 48.

- Scheii n. sp., S. 45.

- tastubensis Tschers., S. 48.

Spiriferella artiensis Stuck., S. 54.

-- Draschei Toula. S. 54.

- Keilhavi v. Buch., S. 52.

- Parryana Vern., S. 54.

- Saranae Vern., S. 50.

- sp.. S. 55.

Spiriferina cristata Scul., S. 56.

Stenopora aff. ovata LonsD., S. 15, Taf. III, Fig. 6.

Zaphrentis sp., S. 9, Taf. III, Fig. 1. 
Geelrukt 14. Marz 1916. 
TAFEL I 


\section{Tafel I.}

Fig. 1-6. Scheiia tuberosa n. gell. 11. sp.

Fig. 1. Bruchflache eines Schwammes mit dentlichem inneren Kern. Natürliche Grösse. (Exemplar $\mathrm{N}$ 1.)

- ‥ Dasselbe. 2.5 mal vergrössert.

* 3. Durehschnitt eines Schwammes dnrclı das Zentrum. Q -s mal vergrössert. (Exemplar $\mathrm{N}$ @.)

7. Dieselbe in natürliclıer Grösse.

". 5. Spiculae des Schwammes. 1 - Clon, 2-Zygom. 3-Brachiomstelle. Ver. grössert 1:35 mal. Spicnla ist angetroffen im Kern des Exemplars $\mathbf{N} 2$. (Sielıw Fig. 6.)

r. Durchschnitt des immeren Kernes des Exemplars N 2: der Kirn besteht aus den zersetzlen Spiculae. 29 mal vergrössert.

. T. ت̈usser Uberfläche des Schwammes, 2.5 mal vergrössert. (Exemplar X 2.) 

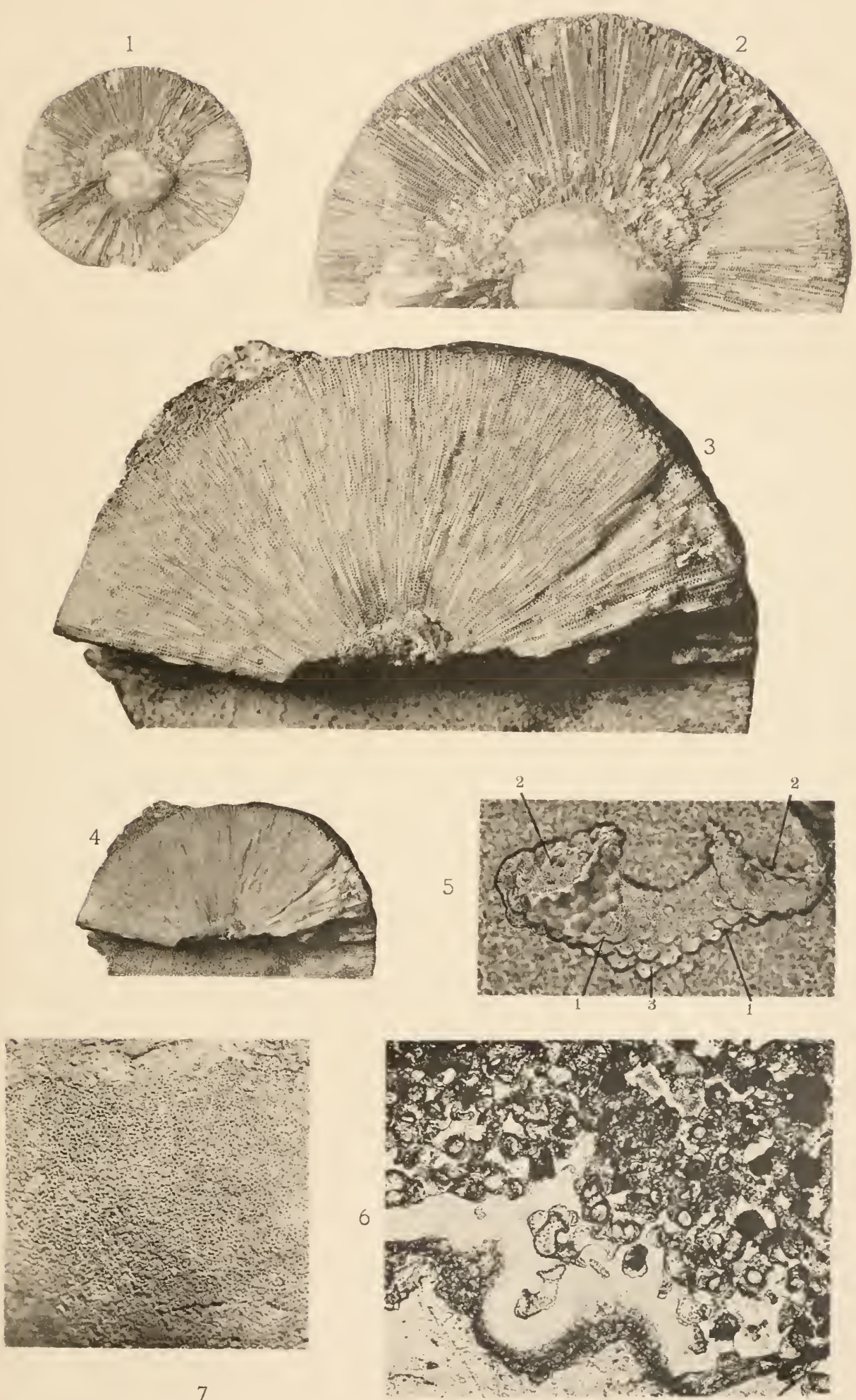

TAFEL II 


\section{Tafel II.}

Fig. 1-4. Scheiia tuberosa 11. gen. n. sp.

Fing 1. Einzelur Skelettril, des Schwammes, 29 mal vergrössert.

‥ Radialhurchschnitt des Schwammes, 17 mal vergrössert. (Exenıplar N 2.)

.3. Äusser Ausicht ter radialen Bruchfläche des Schwammes. 17 mal rergrössert. (Exemplar N 1).

"4. Banl der Skelellstähe des Schwammes. Vergrössert 90 mal. 

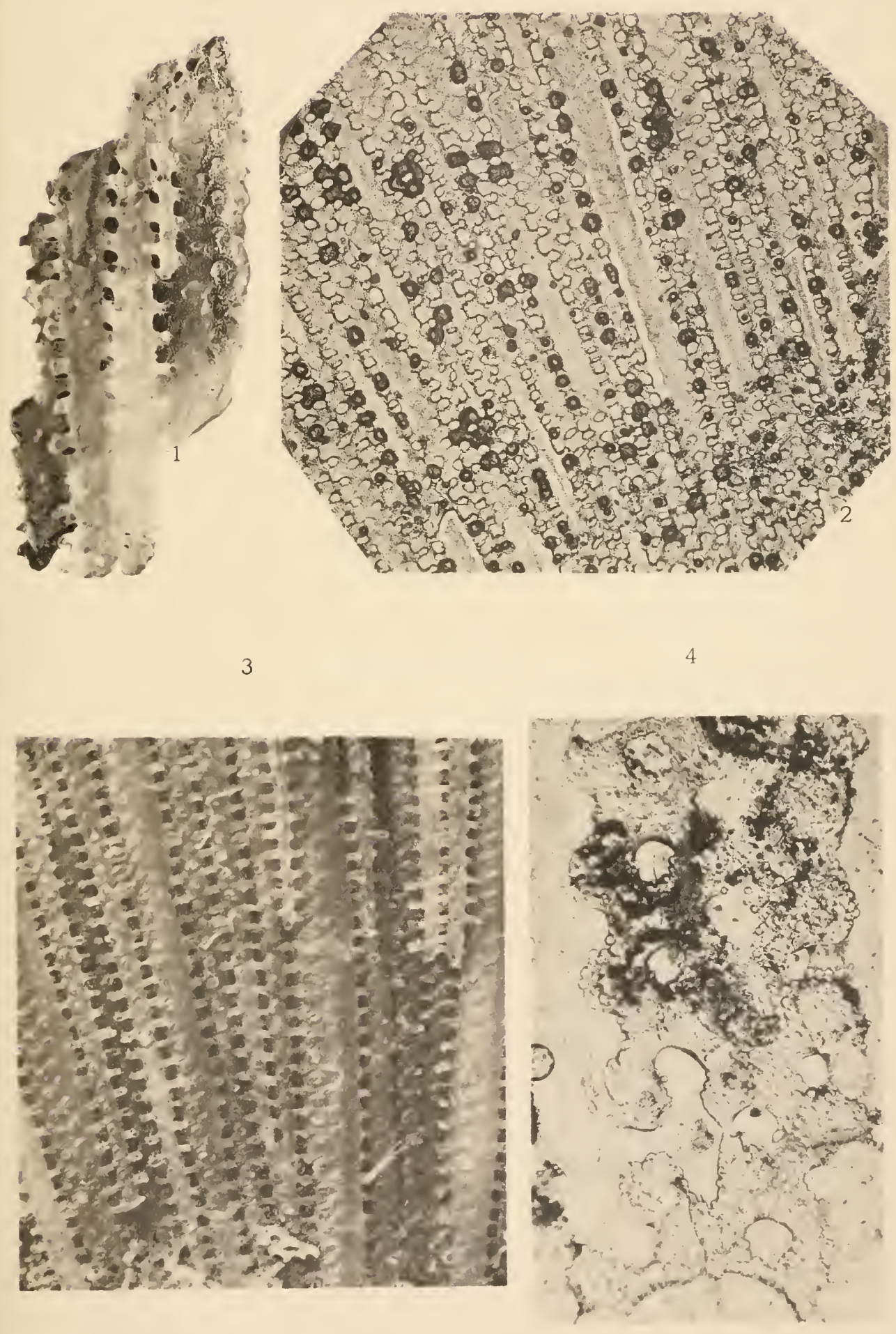

TAFEL III 


\section{Tafel III.}

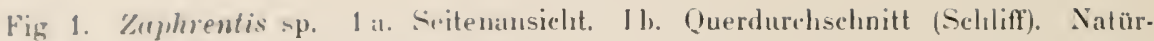
licher Grösse. (Exemplar N s.)

2. Clisiophyllum (?) sp. (Querdurchschnitt. Natürliche Grösse. (Exemplar N 12.)

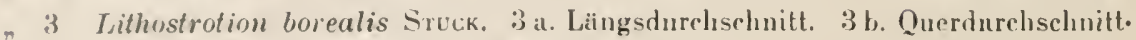
Natiorlıhe Grösse. (Exemplar N 14.)

"4, i. Geinitzella columnaris Scmotn. vat. ramosa sparsigemmata GesstzWaAi, Wrarz. 4 a. Aussenansicht der Kolonie; natürl. Grösse. 4h. OherHiacha desselhen Exemplars 3 mal vergtössert (Exempl. N 26). ja a. b Tangentialdurchschnitte von zwei verschiedenen Exemplaren. $5 \mathrm{c}$. Längsschnitt (45) mal vergrössert). Auf allen Durchschnitten ist: 1. Zellengrnhe: 9. durel. sichtiges Gewebe; 3. Sklerenhim; 4. Adern les durchisichtigen Gewebes (Exrmplare N 47-4S.)

"6. Stenopora aff. ovata Lossdat.e. Vertikaler Durchschuitt der Kolonie. 5 mal vergrössert. (Exemplar N 53.)

"7. Fenestella elegantissima Eucıw. 7 a. Aussenansicht der holonie: natürlichte (irösse. 7 l. Einteilung der Zellen. 10 inal vergrössert. (Exemplar N 57.).

8. F'enestella veneris Fiscuer. Sa. Rückansicht ron der zellenlosen Seite; natîrliche Grösse. 8 b. Einteilung der Zellen. 10 ual vergrössert. (Exemplar.$N$ is..1 


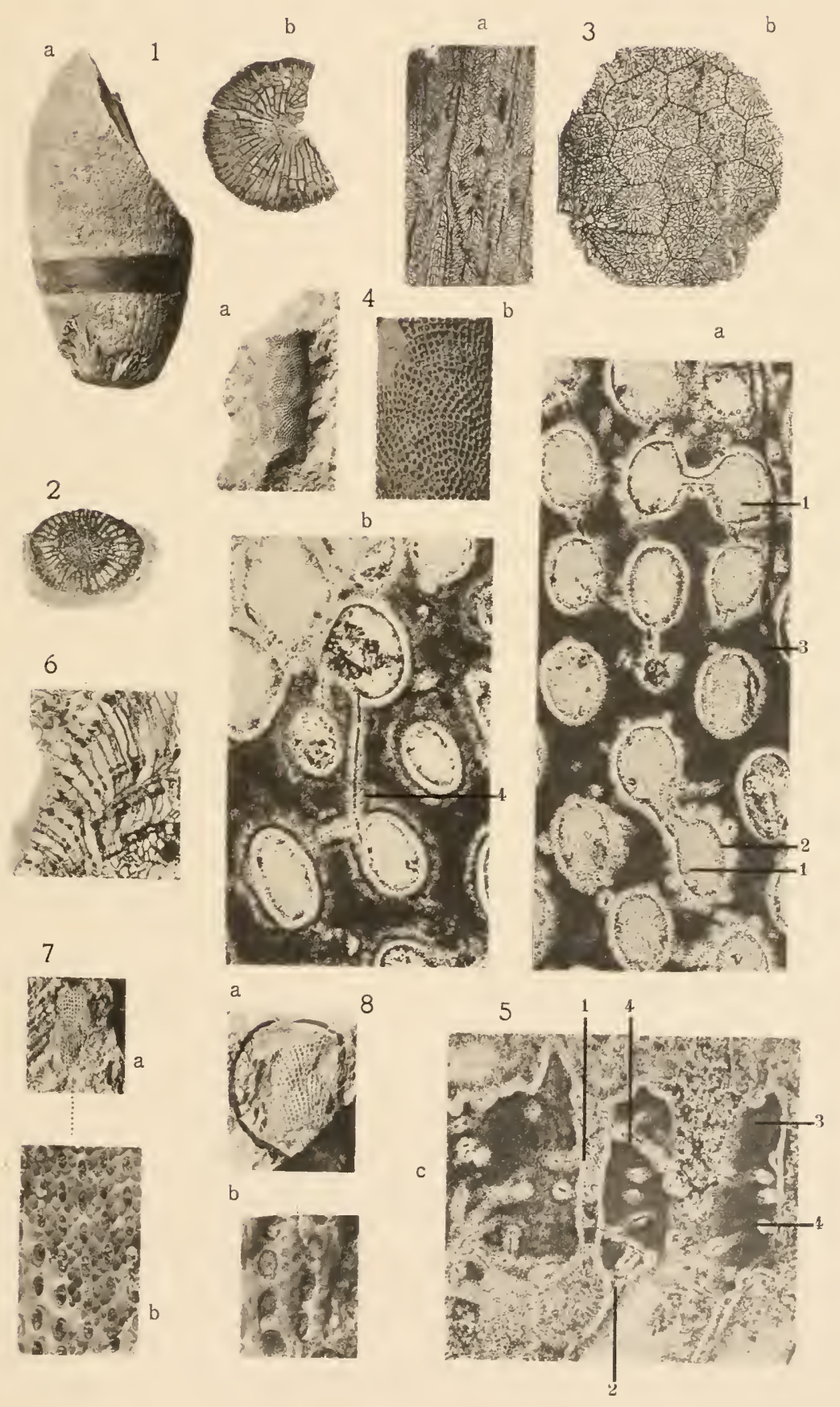



TAFEL IV 


\section{Tafel IV.}

Fig. 1. Fenestella anguste Fiocuen. Aussenansicht der Kolonie. Natñliche Grösse. (biximplar N 6.3 )

-2. Fenestella orientulis Encuw. 2a. Ansielit des Netzes von der zellenlosen Seite. Natürliche Grösse. 2b. Einteihung der Zellen. 5 mal vergrössert. (Fixemplar $\mathrm{Y}$ 6isl.

- 3. Fenestella plebeja M'Cos. 3 a. Alduck des Nelzes von der zellenlosen Srite. Nalürliche Grösse. 3 b. Charakter der Zelleneinteilung. 5 mal vergrössert. (Exemplar $N$ 58.)

- 4. Fenestella varicosa M'Cor. Aussenansicht der Kolonie, rechts ein Brucl. stinck von $F$. angusta Fısı. Nitürliche Grösse. (Exemplar N 67.)

- ¿ Archimedes sp. Bruchsliuck des Sticls. Natürliche Grösse. (Exemplar N 77.)

7. Polypora martis Fiscurr. Aussenansicht des Nelzes von der zellenlosen Seite. Natïrliche Grösse. (Exemplar N 79.)

" 7. Polypora biarmica Kersent. Aussenansicht des Netzes von der zellenlusen Si.ile. Natïrliche Grösse. (Exemplar N 9i.)

- \. Polypora pustulatı Toti.. Sit. Aussenansicht des Netzes von der Zellen. srite. Vuliurliche Grösse. 81. Eintrilung der 7.ellew. 5 mal vergrössert. (Eximplar N 9:.)

- Polypora orbicribrata Kirsen.. Sa. Skulptur der zellenlosen Seite. 9 b. Eintrihung dar \%ellen. 5 mal vergrïssert. (Exemplar $\mathrm{N}$ 102.)

- 10. Polypora micropora Stuck. 10 a. Ansicht der Zellenseite. Natürl. Grösse. 11) h. \%olleneinteilung. :) mal vergriossert. (Exemplar $N$ 129.)

"11. Phyllopora of. borealis Sruck. 11 a, Aussenansicht des Netzes von der zellenlosen Si.ite. Naturliche Grösse. 11 b. Einteilung der Zellen. 5 mal vergrissert. (Exrmplare N 1:37-1:38.) 

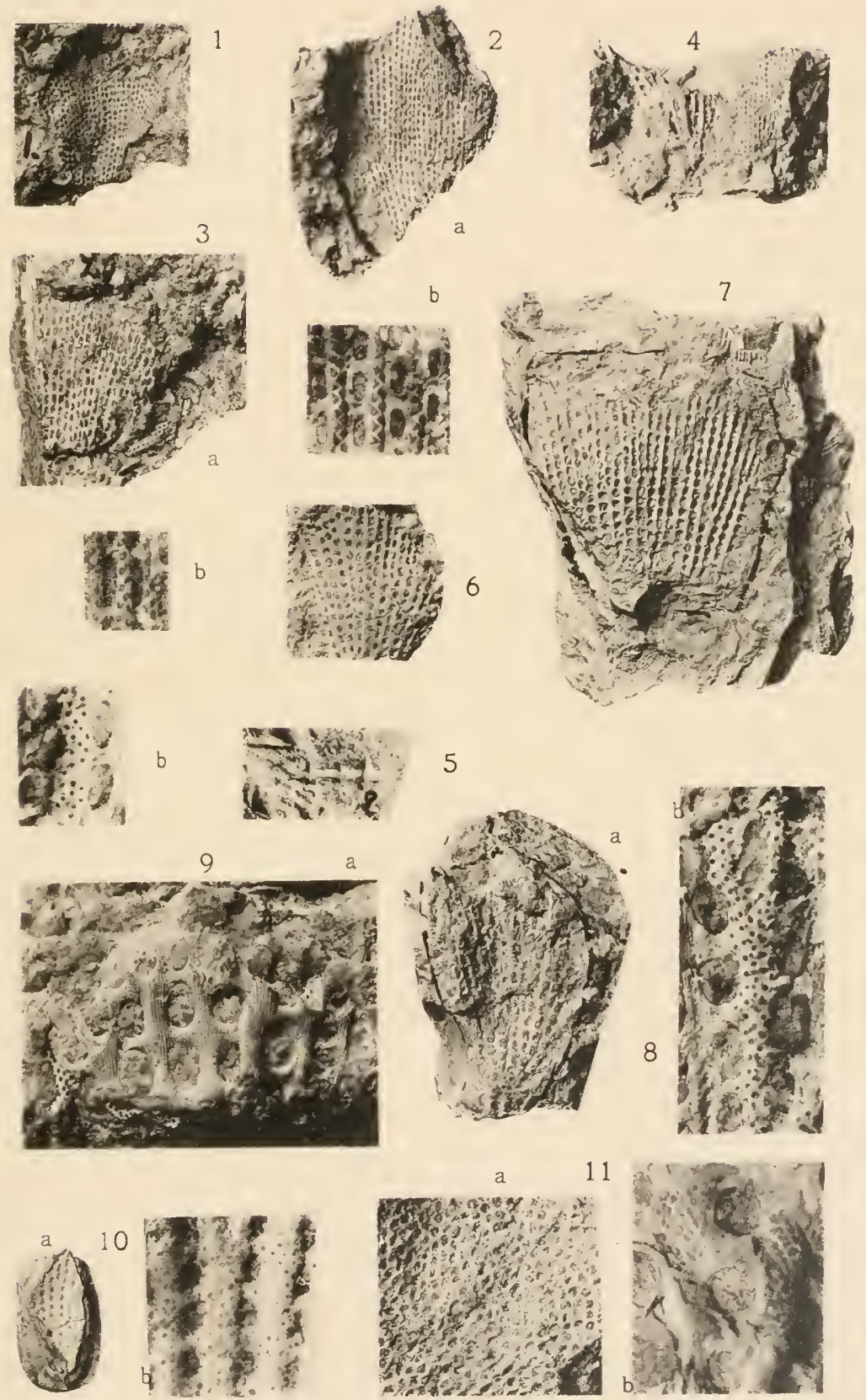

TAFEL V 


\section{Tafel V.}

Kalksteinplatte, versehen mit Ventral. unl Dorsalklappen des Productus inflatus Mc. Cness. Unten rechts Ventralklappe des Productus porrectus Kut. mit deutlich ansgebildeter Kranse. Natïrliche Grösse. (Exemplar N 144.) 


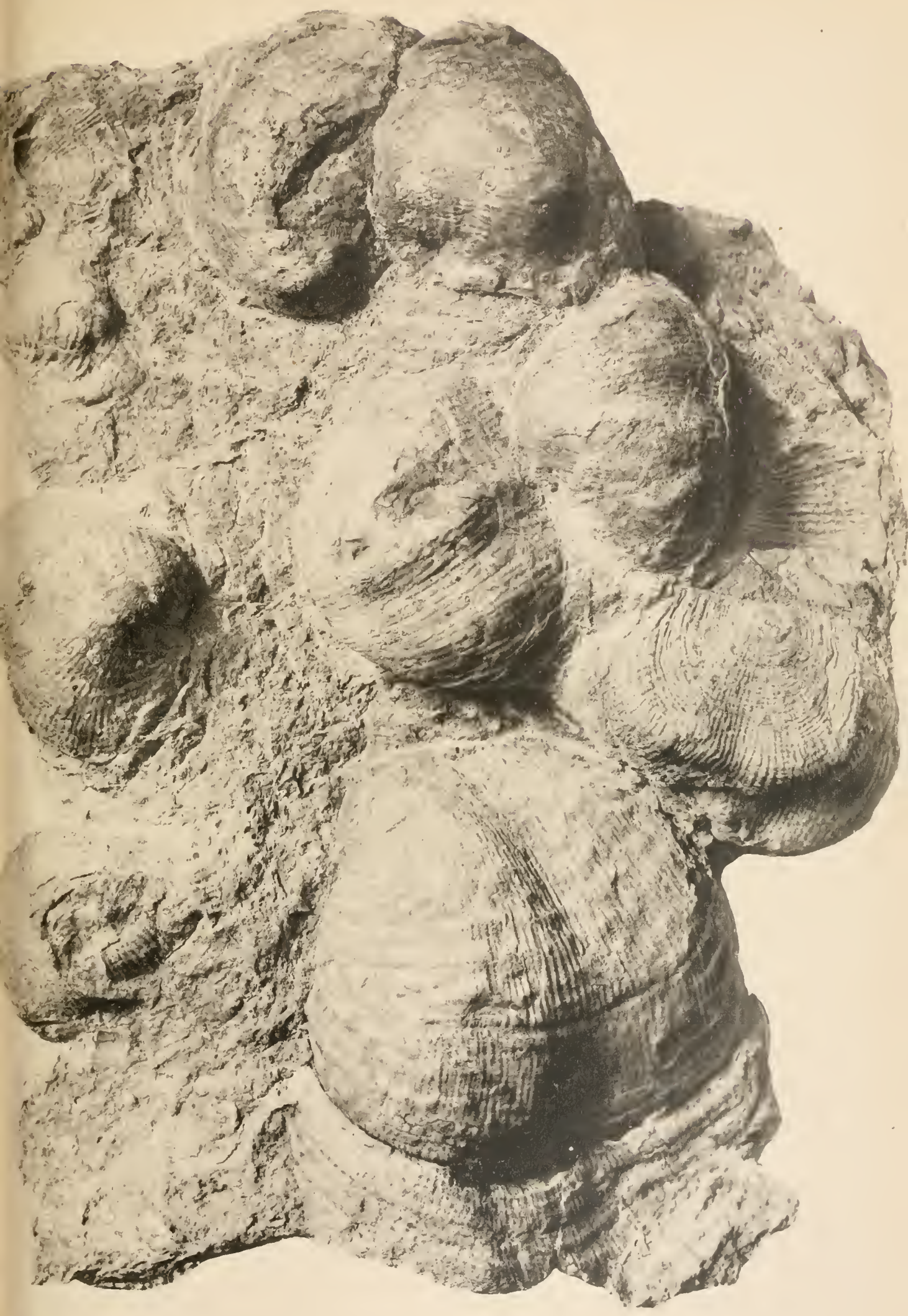



TAFEL VI 


\section{Tafel VI.}

Fig. 1. Prouluctus pseudoaculeatus KRotow. Exemplar N 254. Natürliche Grösse. " 2-4. Productus irginae Sтискғхв. Fig. 2 a, b. Ventralklappe. Exemplar N 269. Fig. 4 a. Dorsalklappe von der Imenseite. 4 b. Seitenansicht desselben Exemplars. Exemplar N 270. Natürliche Grösse.

5. Productus Humboldti d'Orumixy. Ventralklappe. Exemplar N 311. Natürliche Grüsse.

"6. Productus timanicus Stc ckixвевg. Ventralklappe. Exemplar N 365 . Natürliche Grösse.

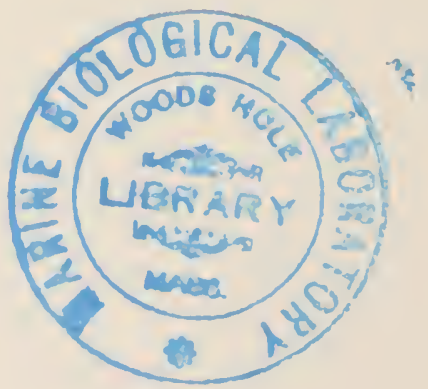



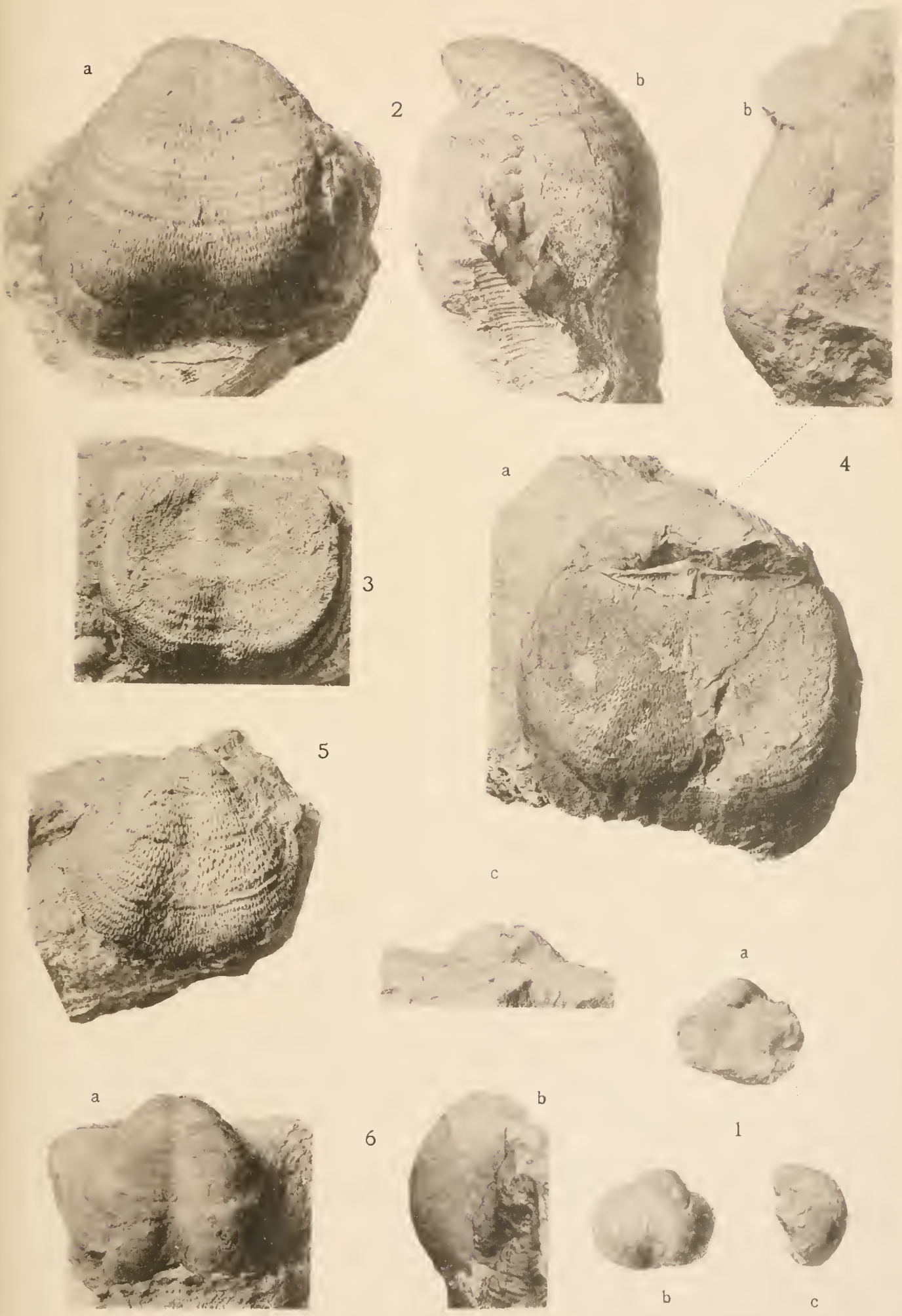

5

6

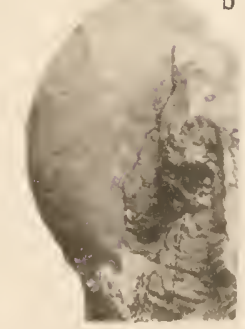

1
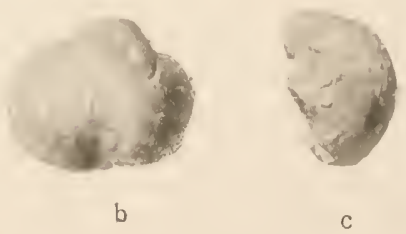

TAFEL VII 


\section{Tafel VII.}

Fig. 1. Maryinifera typica WaAti. var. septentrionalis Tзснвкx. Ventralklappe. Natürliche Grösse. Exemplar N 378.

.2. Maryinifera incoluta Tscnerx. Ventralklappe; natïrliche Grösse; Exenplar $\ 373$, Heilergs Land.

"3. Marginifera involuta Tscmens. Exemplar N 374, das nach dem Typus des halksteins zu urteilen, vom Store Björnekap herstammt. Natürliche Grösse.

" 4. Productus Frami Il. sp. Fig. 4 a, b. Ventralklappe in natürlicher Grősse; Fxrmplar N 267 . Fig. 4 c, d. dasselle Exemplar zweimal vergrössert.

" Ђ. Productus Weyprechti Toura. Exemplar N 344. Natürliche Grösse.

7 6. Productus Weyprechti Toula. Exemplar N 343. Netürliche Grösse.

"7. Marginifera Clarkei Tscuens. Ventralklappe. Fig. 7 a. Ansicht von der IIribelseite. 7 l. Ansicht von der Seite des Stimrandes. 7 c. Seitenansicht. lixemplar N 419. Natürliche Grōsse. 

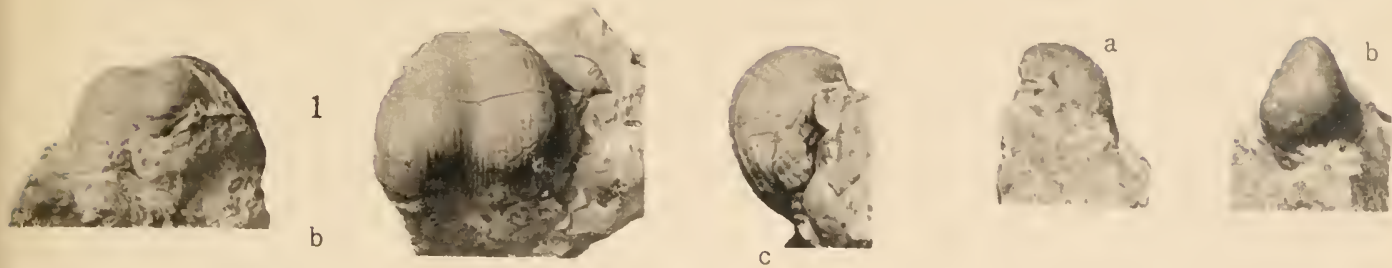

a
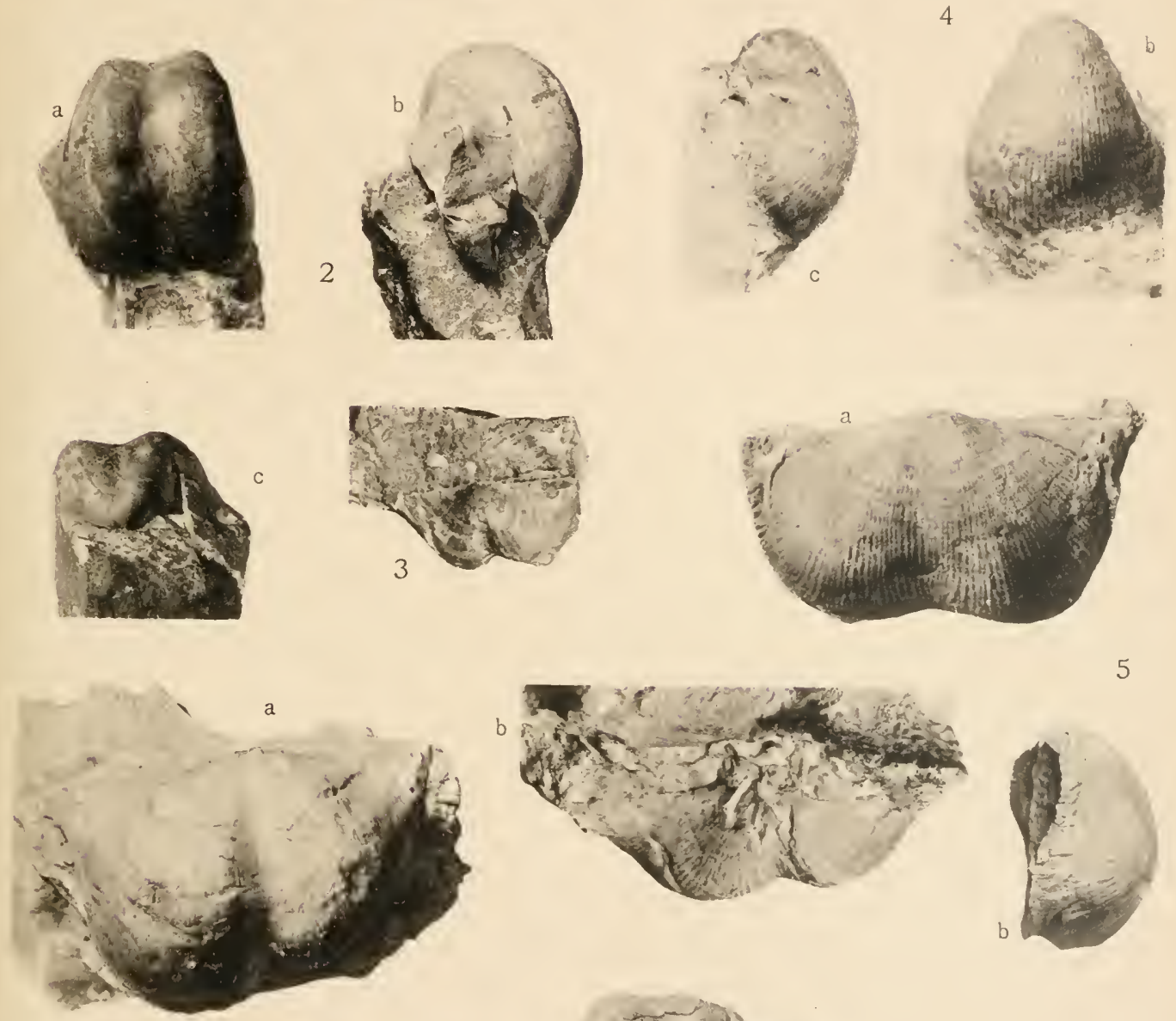

6
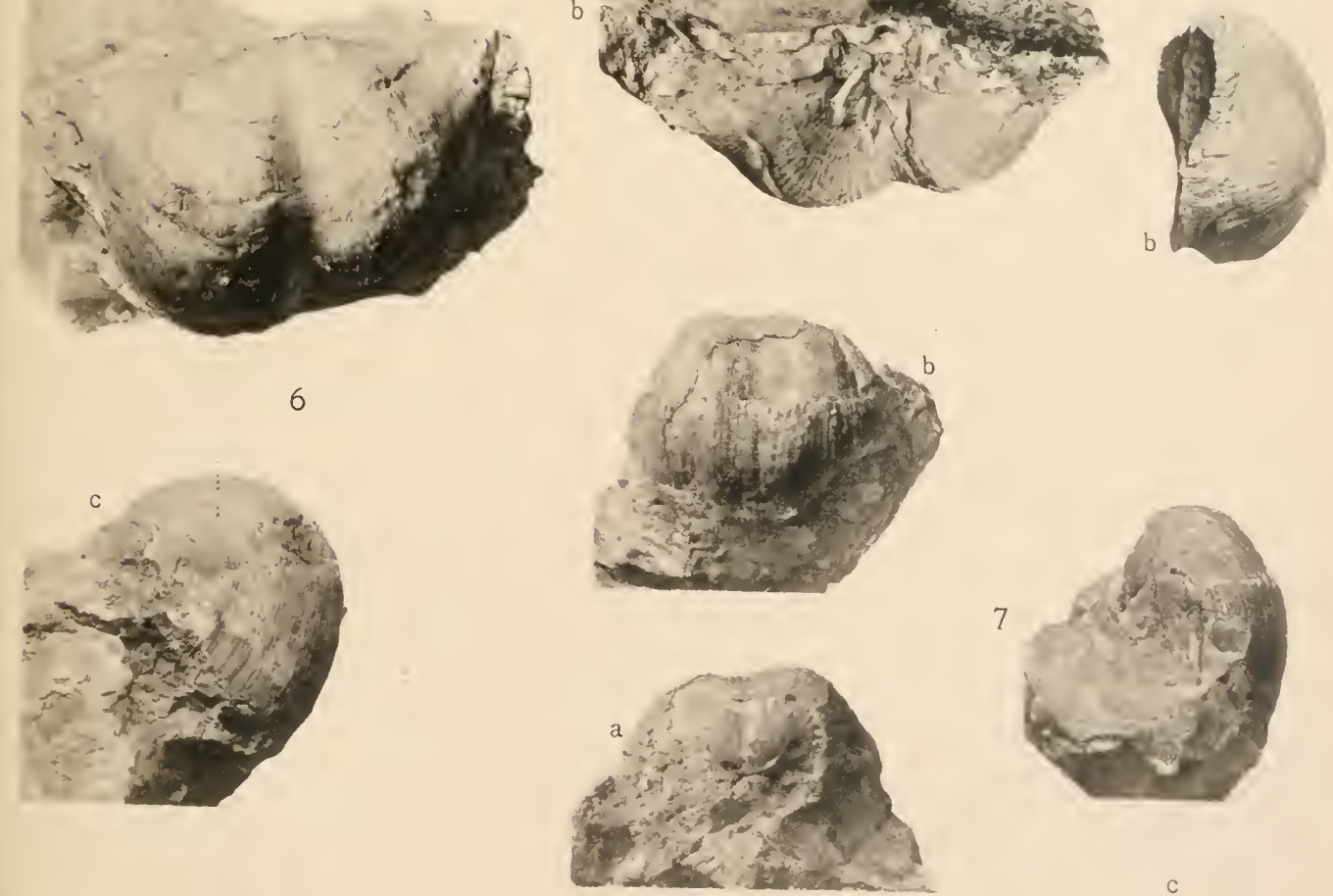

TAFEL VIII 


\section{Tafel VIII.}

Fig. 1. Productus Stuchenbergi hinorow. Exemplar N 259. Natürliche Grösse.

. ‥ Procluctus tarturicus Tscums. Ventralklappe. Exemplar N 253. Natürliche Girisse.

3. I'roductus Aagaurti Toun. Ventralklappe. Exemplar N 314. Natiorliche Grïsse.

" 1. Protuctus simensis Tsentruscinew. Ventralklappe. Exemplar N 325. Natior. liche Grïsse.

- 5. Productus porrectus hut. 5 a. Ansielit ron der Ventralklippe. 5 b. Seitenansirlat. jo. Ansicht ron der Seite der Dorsalklappe. Exemplar N 339. Nistiurlichu Grösse. 

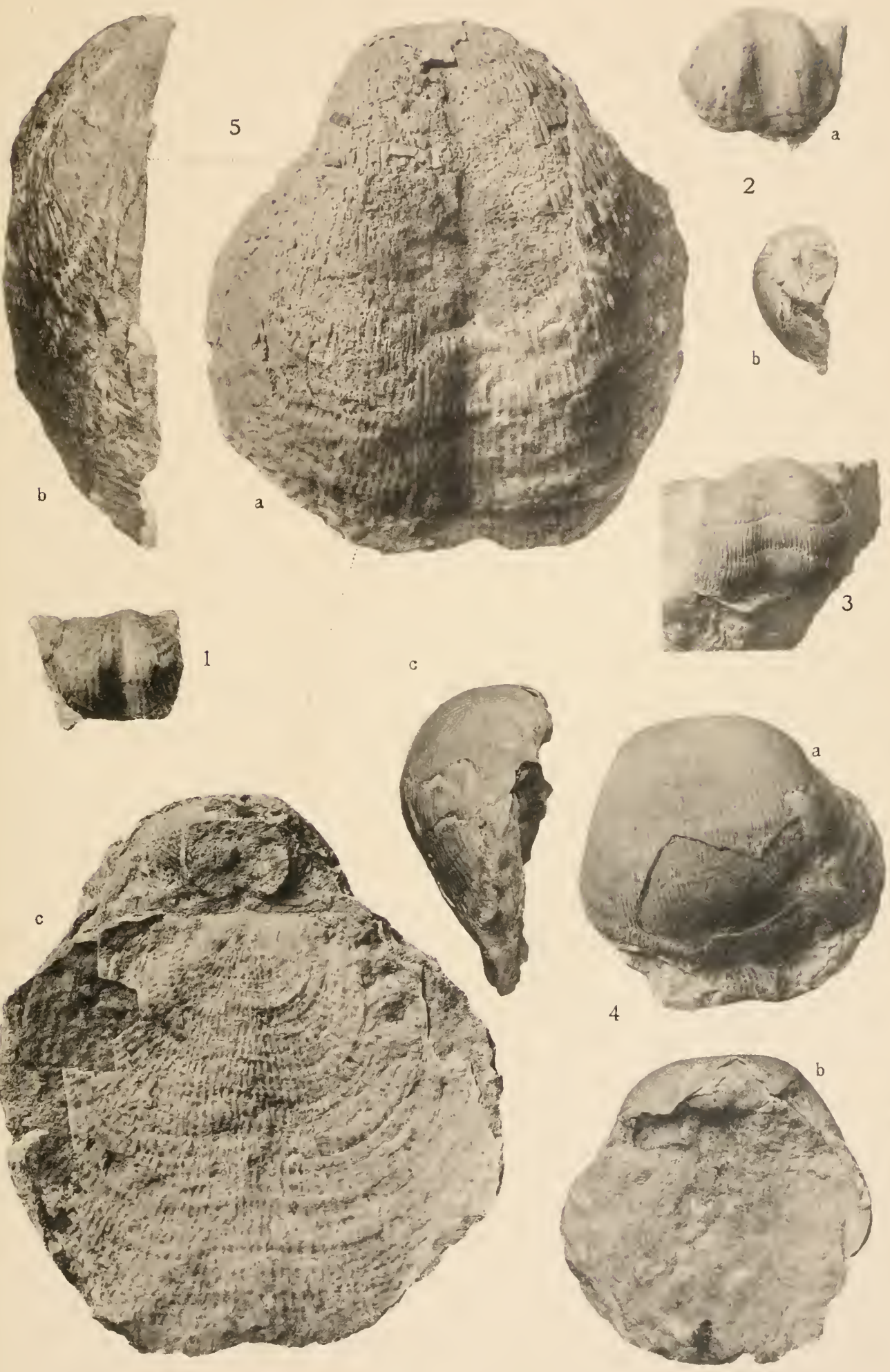

TAFEL IX 


\section{Tafel IX}

Fig. 1. Spiriferella saranae Venx. Exemplar aus der Ungebung der Stadt Kras. unufimsk. Auf der zerdrückten Muschel zeichnen sich Spiralcrura ab. Natürliche Grösse. Sammlung der Kasaner Universität. Siehe Seite $50 \mathrm{f}$.

.2. Spiriferella Draschei Touna. Ventralklappe. Heibergs Land. Exemplar N 494. Natürliche Grösse.

3. Spirifer fasciger Keysend. Ventralklappe. Store Björnekap. Exemplar N 415. Natürliclie Grösse.

- 4. Spirifer Marconi WAati. Ventralklappe. Store Björnekap. Exemplar N 451. Natürliche Grösse.

- 5, 6, 7. Spirifer Scheii 11. sp. 5 a, b, c. Ventralklappe. Exemplar N 444. Fig. 6 Keru mit Spuren von Zahnplatten. Exemplar 445. Fig. 7. Skulptur der Muschel. Exemplar N 446. Fig. 5 und 6 in natirlicher Grösse. Fig. 7 a mal vergrössert.

"8. Reticularia guadalupensis Suumand. Exemplar N 443. Store Björnekap. Natirliche Grösse. 

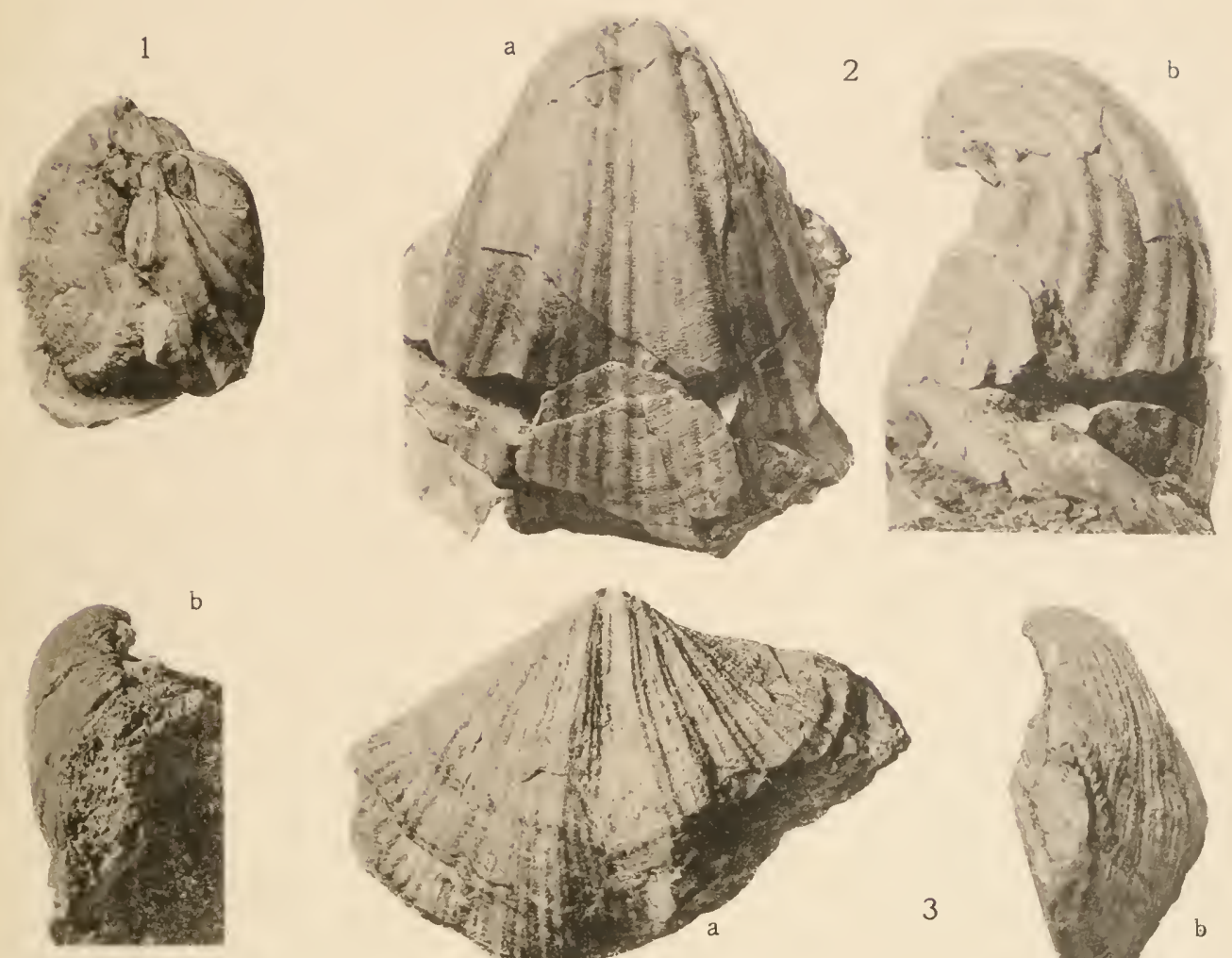

4
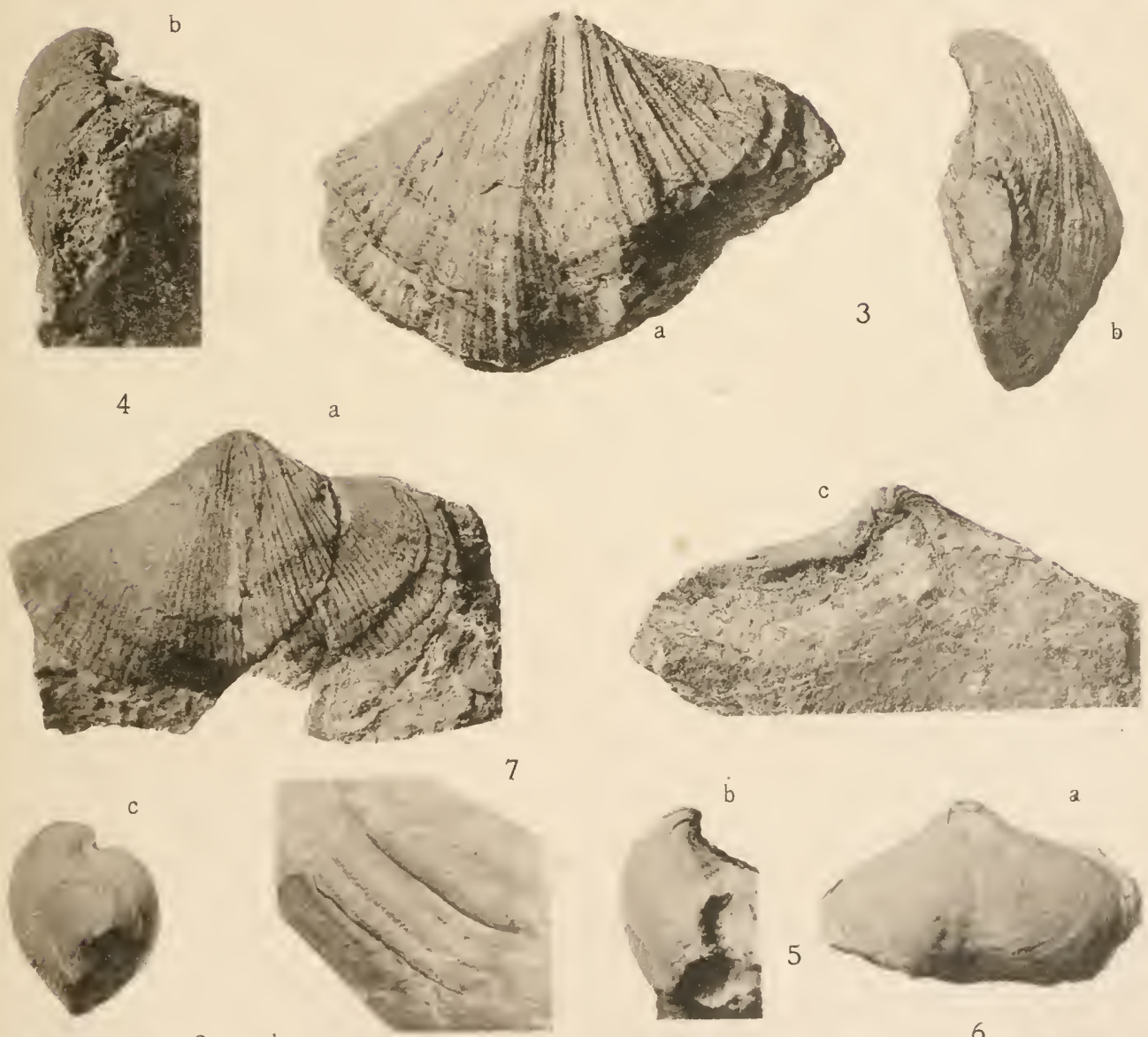

8 b
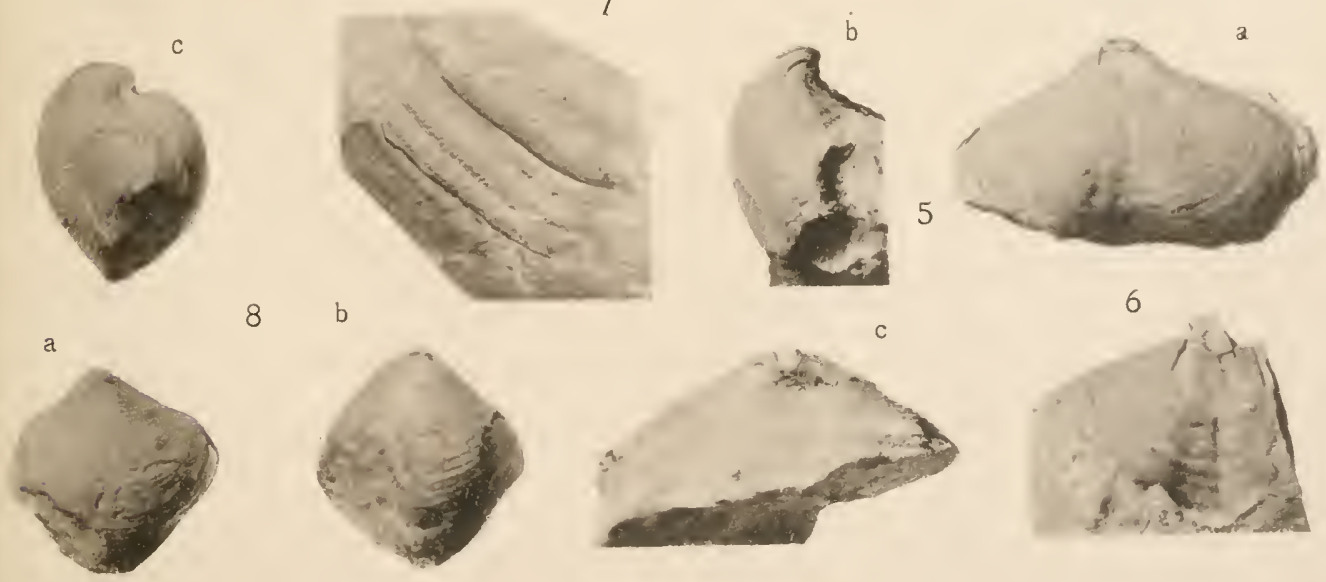

TAFEL $X$ 


\section{Tafel X.}

Fig. 1. Derbyin grandis WAAg. Ventralklappe. Exemplar N 420. Store Bjömekap. Natiorliche Grōsse.

.. 2. Spirifer Nikitini Tscmenxyscuew. Ventralklappe. Store Björnekap. Exemplar N 458. Natürliche Grösse.

3. Spivifer condor d'OrB. Ventralklappe. Store Björnekap. Exemplar N 447. Natnrliche Grösse. 

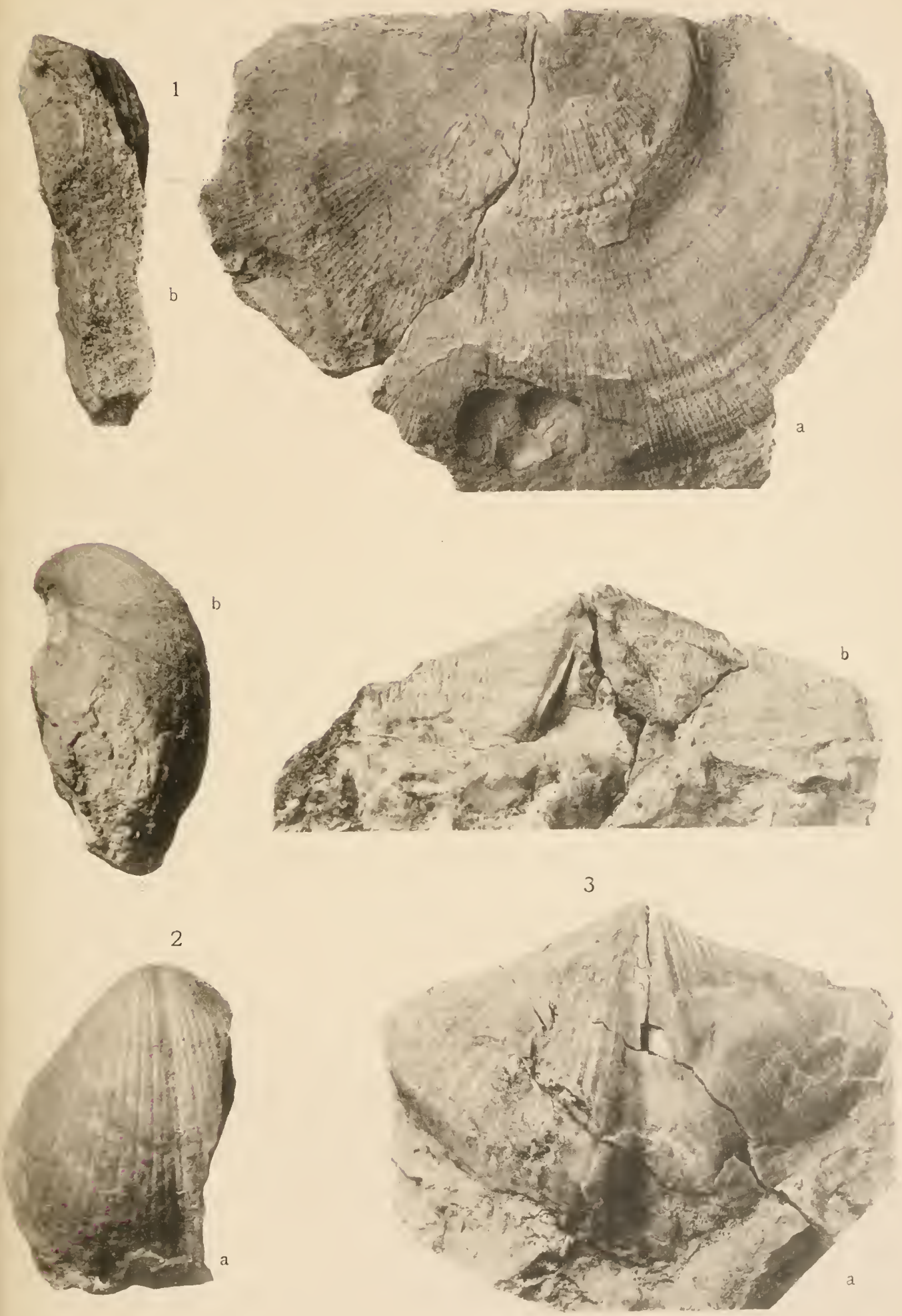

TAFEL XI 


\section{Tafel XI.}

F̈̈. 1. Suriferellu suranae Venx. Ventralklappe. Store Björnekap. Exemplar X 45.9. Nalïrliclıe Grösse.

.. Spriviferella Keilhaci Bucn. Ventralklappe. Store Björnekap. Exemplar N 461 Natiirliche Grïsse.

..: Spririferella Keilhavi Brun. Store Björnekap. Exemplar N 460. Natürliche Grösse.

. 1. Sproiferella Parmana Tot t.A. Sture Björnekal). Exemplar N 480. Natür• licher. ririsue 

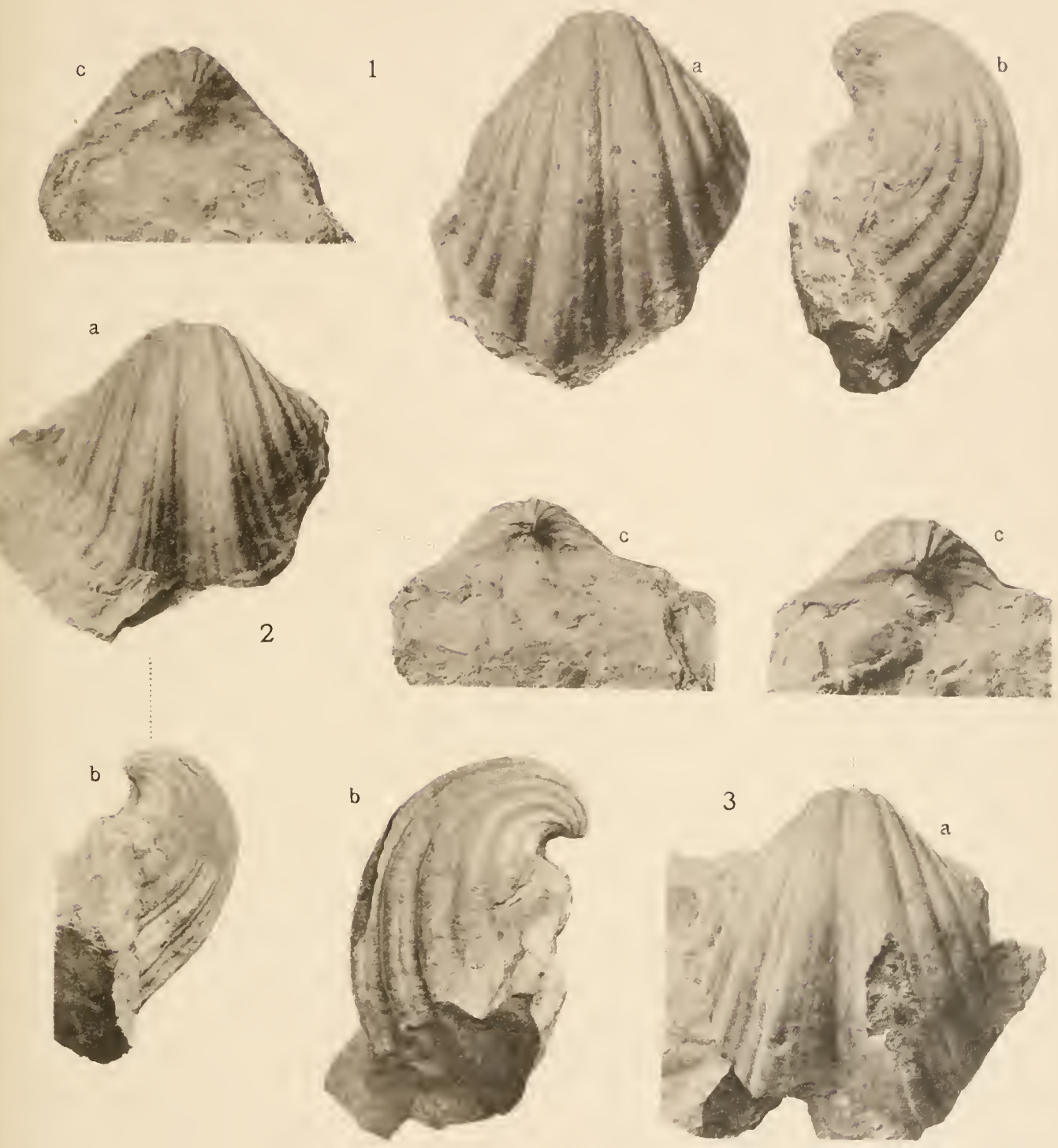

a

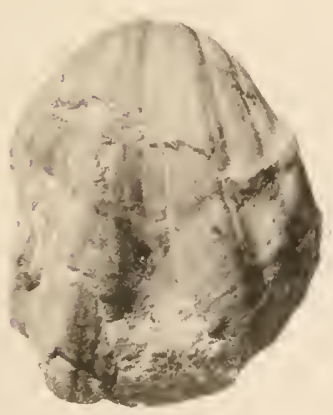

b

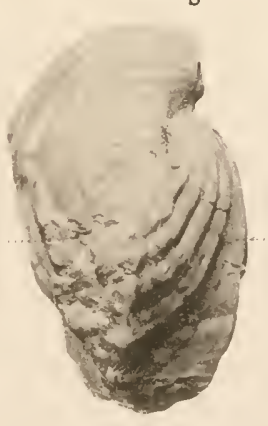

C

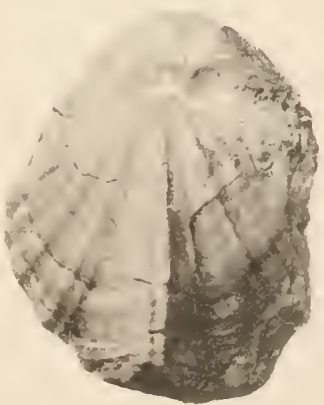



TAFEL XII 


\section{Tafel XII}

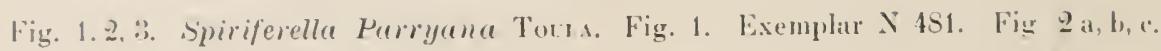
lixemplar $N$ 453. Fig. 3 a, b. e. Exmmplar N 48?. Store Björnekap. Natürliclıe Grïsse.

- 1. Produches Frami n. sp. Ansieht der Muschel von der Wirbelseite. Exemplar $\mathbb{N} 267$. 2.5 mal sergrïssert.

. 5, 6. Notothyris polaris n. sp. Fig. 5. Exmplar $\mathbf{N} 5292$. Fig. 6, Exemplar N ie3. 2.- mal vergrïissert.

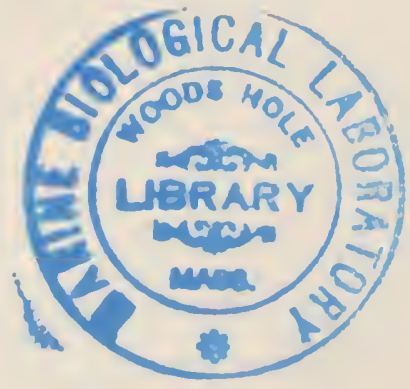



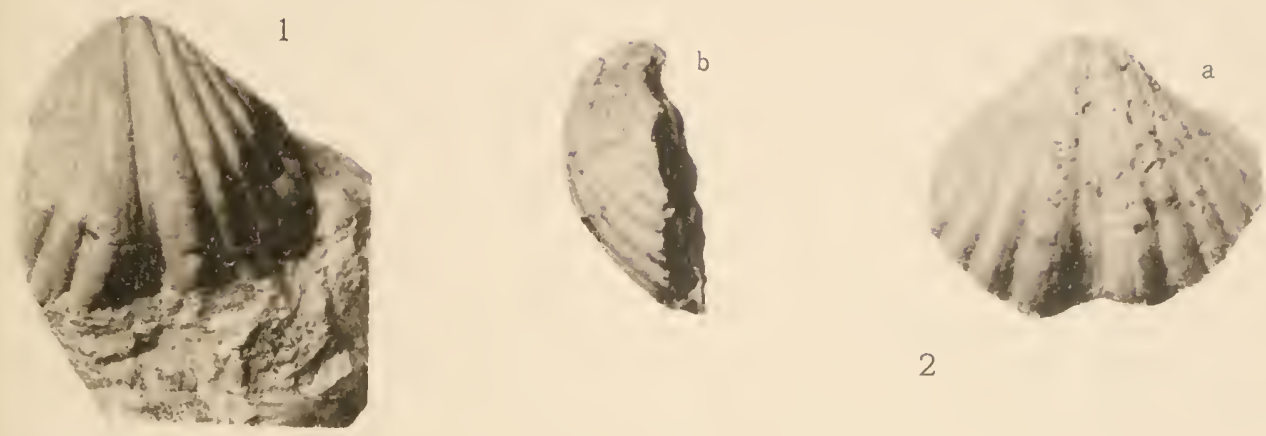

2
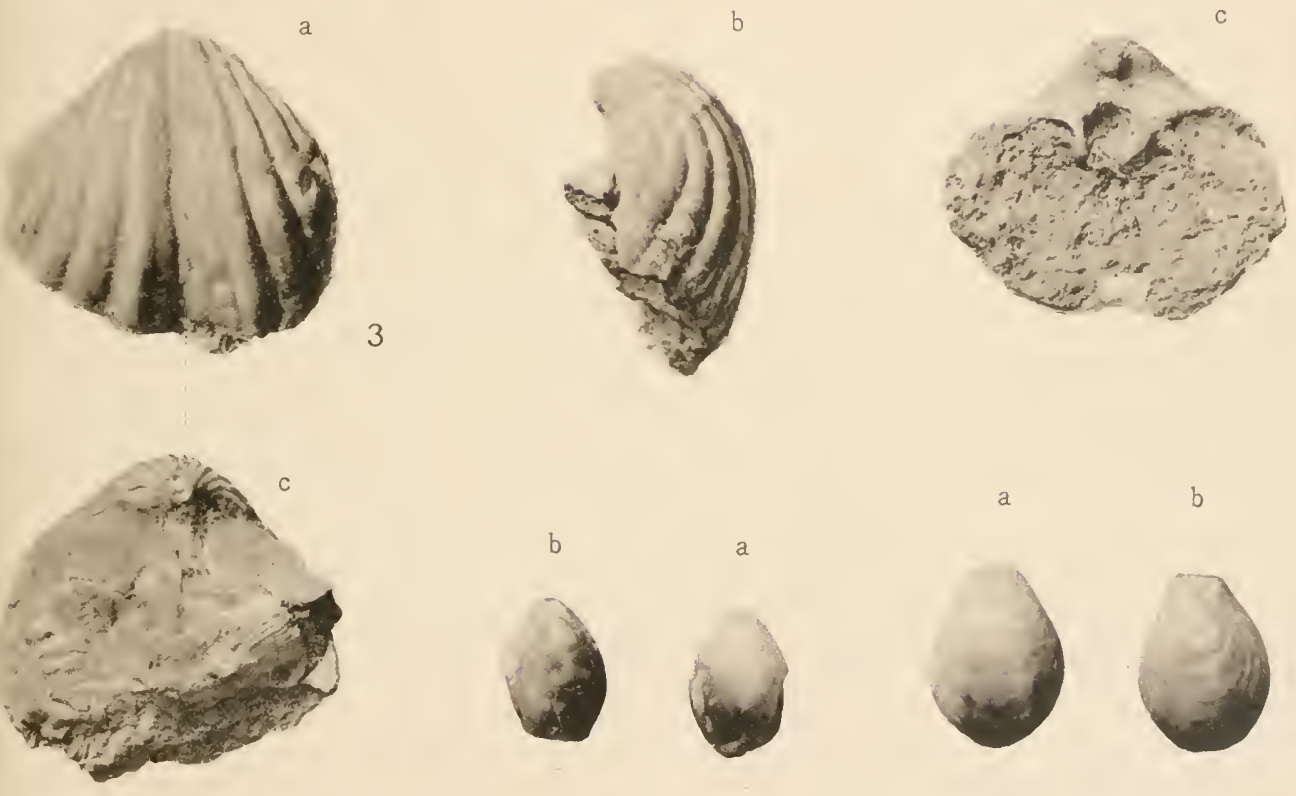

6

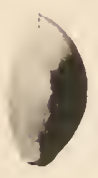

C

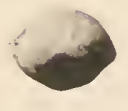

d

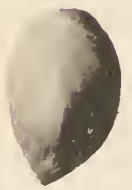

c

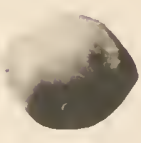

d 



\title{
REPORT OF THE SECOND NORWEGIAN ARCTIC EXPEDITION
} IN THE "FRAM" 1898-1902. No. 35.

\section{A. G. NATHORS T:}

\section{TERTIÄRE PFLANZENRESTE} AUS ELLESMERE-LAND

\author{
MIT உ TAFELN UND 2 FIGUREN IM TEXTE
}

AT THE EXPENSE OF THE FRIDTJOF NANAEX FUND

FOR THE ADVANCEMENT OF SCIENCE

PUBLISHED BY

VIDENSKA BS-SELSKABET I KRISTIANIA

(THE SOCIETY OF ARTS AND SCIENCES OF IRISIIAXIA) 



\section{Entdeckung und Vorkommen der Pflanzenfossilien.}

W ährend einer Schlittenresse im Frühling 1901 hatte der damalige Premierleutnant V. Baumans einige Kohlenflöze in einem Zweiglein des Baumann-Fjordes entdeckt, das demzufolge der Steinkohlenfjord („Stenkulfjorden") genannt wurde. Er spricht (Sverdrup 1903, S. 33S) von „mächtigen Kohlenflüzen, z. 'T. von versteinerten Baumstämmen bedeckt, deren Durchschnitt mehr als einen Meter betrug".

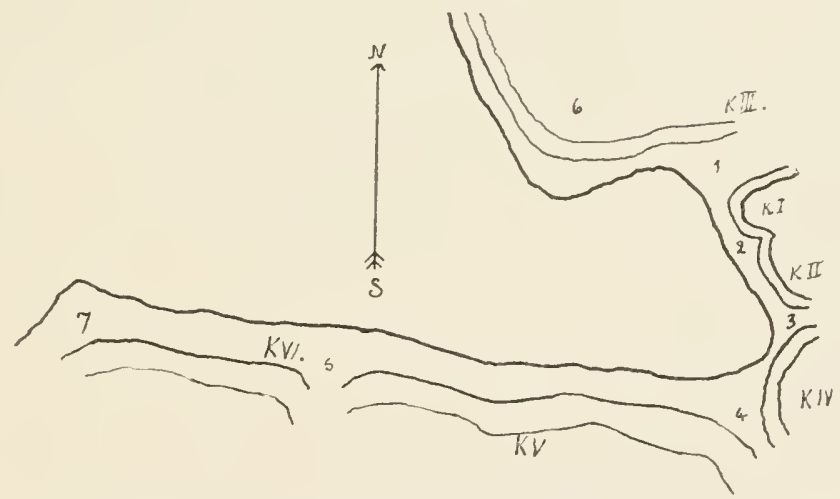

Fig. 1. Der Steinkohlenfjord.

Die kohlenführenden Ablagerungen wurden im folgenden Jahre von Dr. H. G. Sumons und Leutnant (jetzt Rittmeister) Gun. Isachsen untersucht (Sverdrup 1. c., S. 494), wobei auch einige Pflanzenfossilien entdeckt und mitgebracht wurden. Dr. Smuoss hat den nachstehend in Übersetzung wiedergegebenen Bericht, der mir seiner'zeit von dem leider jetzt dahingeschiedenen tüchtigen Geologen der Expedition, Dr. H. Scher, mitgeteilt wurde, über seine Beobachtungen am Steinkohlenfjord zusammengestellt.

"Die von mir mitgebrachte Sammlung stammt von K I (vergl. die Kartenskizze, Fig. 1), in dessen Nïhe wir unseren Zeltplatz hatten, und die von mir geschriebenen Notizen beziehen sich hauptsächlich auf diese Stelle. 
Über die schichtemreihe habe ich folgendes niedergeschriehen:

1. Lose Quarlïrablagerungen (Morämen?) mit rechl häufigen Geschiehen lles Grumlgelniges, sehr zahheichen z. 'T' grossen Geschiehen von rolen, (puarzitartigem, fossilienleerem Sandstein mud vereinzelten Ge. shiehen anderer Gesteine (ein lossilfïlnrentes Stück milgebracht) $30.0 \mathrm{~m}$.

2. Sanul, oder in silu verwitterter Samblein, dessen Oberfliche mit zahlreichen von 1 nimlergefallenen Blöcken bedeckl. ist 45,0 \#

3. Dir obersten (3--4) Kohlenflize. Mächtigkeit nit dem zwischenliegenden Sand zusammen, ca. . . . . . . . . . 3,0 »

4. Sand, са. . . . . . . . . . . . . . . 4, 4 》

5. Unbedentender Kohlenflöz.

6. Feingeschichteter heller Sand, ca. . . . . . . . . . 15.0 »

7. Sambdichl mit vereinzelten kleinen Kohlenpartien, isolierten verkohlten und rerkieselten Stïmmen und auf der Oberflache mit Knollen ron Toneisenstein bestrent, ca. . . . . . . 37.0

S. Kohlenflüze (4-5) mit dümmen Sandschichten, са. . . . 1,5 »

9. Sand mit zahlreichen SplürosideritKnollen, ca. . . . . 1,5 »

10. Kohlenflüze nit wenigen Zwischenlagem, ca. . . . . . 3,0 »

11. Sandschichten mit kleinem Kohlenlager, ca. . . . . . 4,5 »

12. Kohlenflëzе, са. . . . . . . . . . . . . . . 1,5 »

19. Sand und Kolılenflöze (4) alternierend, ca. . . . . . . 6,0 »

14. Saldschichten, ca. . . . . . . . . . . . . 15,0 »

15. Kohlenflïze mit Sand alternierenıl, ca. . . . . . . . 3.0 »

16. Kolılenflüz, сі. . . . . . . . . . . . . . . 1,5 》

17. Simd, ra. . . . . . . . . . . . 9,0 >

18. Vorland von losen Erdlagrern mit Geschieben, Kohlenstücken, Fragmenten ron rerkieselten IJ̈̈lern u. s. w.

Das Vorland, das sich rom Fjord schwacl landeinwärts erheht, wirl von sand nud Ton gebildet, hie und da mit dürfliger V'egetation. Die Simblschichtm häher oben enthehren dagegen, wenigstens am Zeltplat\%, jenter Vegetation, wahrsheinlich weil sie keinen hinreichent stabilen Cimmd lanbieten. Die Büschmmg des Gelirges sellost ist grö̈sstentrils zienliel, schwad, die Kuhlenflöze sind die entschieden am meisten willerstandsfähigen l'arlien und bilden dentliche steile Alssïtze (Fig. 2), zwischen weldhen Santschirhlen mit shwarher Böschung zu finden sind. Nur an rin pan Strellen hat der sand eine solche Festigkeit, dass die

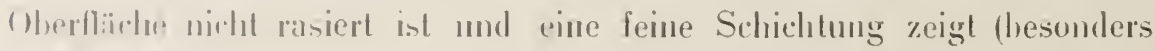
in 6 minl 17). 
Ich habe durch Graben in diesen ungestörten Sandschichten zu konstatieren versucht, ob dieselben durch Verwitterung entstanden sind habe aber kein festes Gestein gefunden. Ebensowenig habe ich Geschiebe von einem andren Sandstein als von dem roten, der in der Moräne vorkommt, beobachtet.

Die grossen verkieselten Strünke und Stammstücke waren insbesondere an der Oberfläche der Schichten 7,11 und 14-15 häufig. Unmittelbar über der Schicht $S$ lag ein Stamm, dessen Länge etwa 3,6 und Durchmesser etwa 0,3 Meter betrug, und der durch die zahlreichen Zweignarben und seine helle Verwitterungskruste den Eindruck eines rezenten Treibholzstammes hervorrief. Mehrere von den grössten Strün-

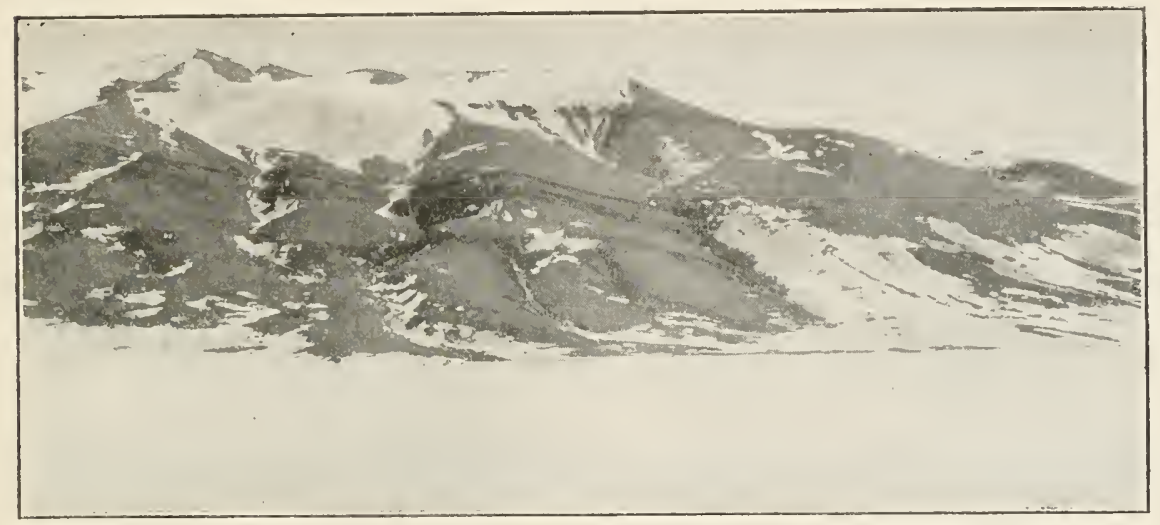

Fig. 2. Die tertiären kohłenführenden Ablagerungen am Steinkohlenfjord.

ken (bis etwa 1 Meter im Durchschnitt) befanden sich unmittelbar oberhalb des untersten Kohlenflözes, wohin sie jedoch wahrscheinlich von den Sandschichten höher oben herabgerutscht waren.

Die eingesammelten Kohlenproben entstammen hauptsächlich den Schichten 12 und 16, deren Kohlen an gut erhaltenen Pflanzenresten am reichsten waren. In der Nähe der Schlucht ( 2 in der Kartenskizze) fand ich an einer Stelle eine mehr schieferartige Partie mit zahlreichen Pflanzenresten. Es handelte sich wahrscheinlich um ein losgetrenntes Stück; dasselbe war sehr stark verwittert.

Die Schichten innerhalb der ganzen Partie K I sind ganz ungestört und können das Gebirge entlang verfolgt werden, soweit sie nicht auskeilen und durch andere Schichten in einem etwas verschiedenen Niveau ersetzt sind.

Das Ausgehen der Schichten in der mit dem Ufer parallelen Richtung ist horizontal, wenigstens habe ich hier kein Fallen konstatieren können. 
Die Südseite des grossen Tales 1 hat eine so schwache Büschung und i-t so vollstindig von losen Erdmassen bedeckt, dass ich keme nemenswerten Kublenflöze hier beobachtet habe. In der Nähe des Talhodens fand sich eine kleine Partie anstehenden stark verwitterten Sandsleins, der wahrscheinlich demselben fossilienleeren Sandstein angehört, von welchem das Gehirge 6 erbaut ist. Es ist ein recht harter und dichter Sandstein von dunkler, rötlicher Farbe. Weiter nach Innen an der Nordseite des 'Tales und hoch oben, gegen den Gipfel des Berges (wenigstens 180 Meter ï. d. M.) traten mehrere Kohlenflüze zulage, die ich jedoch nur aus der Ferne beobachtet luabe. Fis waren dies die höehst helegenen Kohlenflöze, die ich am betreffenden Fjord beohachtete.

Soweit ich es entscheiden konnte, schienen sich die Schichten des Gehirges K I auch im Gebirge K II, das ich jelloch nicht besuchte, fort zusetzen. Nach den Angaben Baumaxss, der 1901 gerade dort seinen Zeltplatz hatte, soll hier ein Kohlenflöz in einem tieferen Niveau fast am Ufer selbst vorkommen.

Die Kohlenflüze setzen sich ferner mit, wie es mir vorkam, schwachem Fallen lïngs der südwestlichen Seite des Fjordes fort. Sie waren sehr deutlich als parallele schwarze Bänder, die Seiten der Gebirge K IV und K $V$ entlang, aus der Ferne zu erkennen. In äusseren Teil des letztgenannten Gehirges scheinen sie sich etwas gesenkt zu haben. Dann kan eine Partie mit ein paar kleinen Schluchten, wo das Gebirge weniger steil und mehr von losen Erdmassen bedeckt war (5 in der Kartenskizze).

Ein kleines Stück weiter answïrts kommt an Ufer eine kleine Gebirgspartie ( $\mathrm{K} \mathrm{V}^{\prime}$ ) vor, die auch Kohlenflüze zeigte. Es ist möglich, dass diese Partie durch eine Verwerfung isoliert ist, doch wage icl keine hestimmte Meinung darüher auszusprechen, da ich die Verhültnisse an Platze sellost nicht untersucht habe. Gegen die Landspitze 7 wird das Gebirge wieder von Sandstein erbant, der, nach den auf der Landspitze vorkommenden Geschieben zu schliessen, mehr feingeschichtel als derjenige an 6 ist. Dersethe scheint auch in Gebirge oberhalb K VI rorzukommen, olme diss man (nach den vorliegenden Beobachtungen) sagen kimn, ol, er seinen Platz hinter oder oberhalb der kohlenführenden Parlie lıat."

\%u dieser Mitteilung von Dr. Srmmoxs über die Verhältnisse am Stembohlenfjord hat Dr. Scum auch üher anderweitige Vorkommuisse von 'Ferliärablagerungen folgende, lier in Übersetzung mitgeteilte Bemerkungen getmacht. 
rAn mehreren Stellen habe ich Ablagerungen beobachtet, die wahrscheinlich am nächsten hierher gehören.

In einem breiten 'Tal östlich vom Kap Blaamanden im Eureka-Sund wurde eine Ablagerung mit schwebender Schichtenlage von mindestens 100 Meter Mächtigkeit beobachtet, die hauptsächlich von z. T. grobem, hellem, wohlgeschichtetem Quarzsand mit vereinzelten Lagen von bituminöser, leicht zerfallender Schiefermasse und 0,3-1,0 Meter mächtigen Lagen von Braunkohlen aufgebaut ist.

Ähnliche Sandmassen sah ich auch westlich vom Blaafjeld auf Grants Land. Die wohlgeschichteten Massen von reinem, hellem Quarzsand in einigen Abhängen unterhalb hoher Gebirgsabfälle von stark dislocierten Triasschiefern mit Diabasintrusiven waren im Vorbeifahren auffallend. Dunkle Schichten wurden aber in dieser Sandablagerung nicht beobachtet.

In der Mitte des Skaarefjordes, und zwar an dessen IVestseite, stützt sich gegen die hinter derselben befindliche Wand von dislocierten Sandsteinen und Diabasen eine Ablagerung mit schwebender Schichtenlage, die von dunklem, sandigem Schiefer und Schieferton mit reihenweise angeordneten Kalkknollen aufgebaut ist. Die Knollen fliessen zuweilen in einander und bilden daun horizontale 0,1-0,2 Meter mächtige, graue, unreine Kalklagen.

Endlich findet sich auf der Richards-Insel in der obersten Partie eines breiten Tales, und zwar auf etwa 100 Meter Meereshöhe die Talseiten entlang, ein feingeschichteter, leicht zerfallender, grauschwarzer Schieferton in fast schwebender Lage. Derselbe ruht diskordant auf dem darunterliegenden, schwach dislocierten Sandstein devonischen (?) oder mesozoischen (?) Alters.

Nur an der ersten der oben erwähnten Lokalitäten wurden Fossilien gefunden. Unter den übrigen wurden solche eigentlich nur an der letzten nachgesucht, jedoch ohne Erfolg."

Die mir zur Untersuchung gesandten Proben stammen wahrscheinlich sämtlich vom Steinkohlenfjord, also von etwa $77^{\circ} 20^{\prime} \mathrm{n}$. Br. Die nördlichste von Schei erwähnte Lokalität, westlich vom Blaafjeld, von welcher aber keine Versteinerungen mitgebracht wurden, befindet sich unter etwa $80^{\circ} 40^{\prime} \mathrm{n}$. Br., also etwa einen Breitengrad südlicher als die seinerzeit von der englischen Polarexpedition under Nares (1S75-76) an der Discovery Bay eingesammelten Tertiärpflanzen.

Die Hauptmasse der Sammlung vom Steinkohlenfjord besteht aus einem leicht zerfallenden bituminösen Schieferton, der reich an Pflanzenresten ist und der unten näher besprochen wird. Ein Stück Toneisen- 
-tein enthïlt unbestimmbare Blattetzen von Dikotyledonen. Ferner litgen teils gragatisierte, teils verkieselte Holzstücke vor, die unten besonder's besprochen werden.

Der Schieferton zeigte sich ron beblätterten Zweigresten von Nadelhïlzern sänzlich erfüllt. Es gelang mir, eine Menge derselben durch Schlïmmung zu isolieren. Die auf solche Weise erhaltenen Exemplare wurden teils wie gewöhnliche Herbarpflanzen auf Papier aufgeklebt, teils in Fläsisigkeit (schwache Alkohollösumg) aufbewahrt. Eine Sammlung der ersteren wurde photographiert und findet sich schon in Srennrurs Reisewerk abgehildet (1. c., S. 424). Die von mir mitgeteilte Unterschrift lautet (in C̈bersetzung): "Blatttragende Zweigpartien von Seguoia und Gilyptostrobus, Nadelhölzer der 'Tertiäızeit".

Auch Blattfetzen von Laubhölzern finden sich mit den erwähnten Narlelholzresten zusammen, sind aber derartig zerbrochen, dass von einer Bestimmung derselben nicht die Rede sein kann. Auch die Anwesenheit von Pollenkürnern hahe ich konstatieren können, ohne daśs jedoch ein Versuch gemacht wurde, dieselben einer näheren Untersuchung zu unterziehen. Es wäre doch zu wünschen, dass ein Spezialist anf diesem Gehiete eine solche, allerdings sehr zeitraubende Arbeit ausführte.

Die tertiären Pflanzenreste des Steinkohlenfjords wurden auch in meinen Vortrag beim internationalen Geologenkongres in Stockholm 1910 (Natnonst 1912,1) wegen ihrer Erhaltung kurz erwïhnt. Die Hoffnung, gute Kutikula-Priparate dersethen zu erhatten, um die Bestimmung kon. trollieren zu können, scheiterte aber vollständig, und zwar wahrscheinlich weil lie Kutikulen von Bakterien grösstenteils zerstört waren. Als Ersatz wurden selır interessante Reste von Parasitpilzen gefunden, üher welche ich seinerzeit (NAtnorst 1912, 2) heilinufig eine kurze Mitteihng gemaclit habe.

Die beiden unten aufgefülnten Arten - Sequoia Langsdorfii und Glyntostrobus Ungeri - finden sich nicht unter den von HEFr (1S7S) beschriehenen Pflanzen von der Discovery Bay, während sie von den 'Tertiärablagerungen West-Grönlands (Diseo-Insel, Halbinsel Nugsuak) schon längst hekannt sind; Sequoia Langsdorfii gehört sogar dort zu den hänfigsten Arten. Durch den Fund an Steinkohlenfjord hat sich also die Nordgronze terselben in diesem Gebiet wesentlich (bis $77^{0} 200^{\prime}$ ) nord. wïrts verschoben. Anf Spitzhergen sind aber beide Arten von Lokalilïten hekannt, die etwa um einen Breitengrad nördlicher situiert sind. 


\title{
Beschreibung der Fossilien.
}

\author{
Sequoia Langsilorfii (Brongniart) Heer.
}

Taf. 1, Fig. 1-15.

Taxites Langsdorfii Brongxunt 189S, S. 108.

Sequoia Langsdorfii Heen 1855, S. 54, Taf. 20, Fig. 2; Taf. 21, Fig. 4.

Heer 1883, S. 61, mit Hinweis auf andere Bände der Flora fossilis arctica, wo die Art beschrieben ist.

Staud 1887, S. 249. Ausführliche Literaturhinweise.

Die begrenzten Zweige dieser Art kommen in grosser Zahl in dem oben genamnten schiefrigen Gestein vor. Sämtliche abgebildete Exemplare sind aus demsetben herausgeschlämmt und also ganz frei. Die Abbildungen Fig. 1-4 und 12 rühren von in Canadabalsam eingeschlossenen Präparaten her, während Fig. 5-11 auf Papier aufgeklebte Zweigreste zeigen. Man beachte die Exemplare Fig. 5 links und Fig. 6, die den basalen Endteil des Zweiges zeigen.

Bei der grossen Ïhnlichkeit, die zwischen den \%weigen von Sequoia Langsdorfii und Taxodium distichum miocenum obwaltet, habe ich natürlich eine besondere Aufmerksamkeit auf die Frage gerichtet, ob nicht die letztere Art ebenfalls unter den Resten vertreten ist. Aber soweit ich ermitteln komnte, ist dies nicht der Fall. Neben den Zweigen mit relativ kurzen und breiten Blättern kommen allerdings auch andere mit relativ schmalen Blättern vor, die demzufolge eine gewisse Taxodiumähnliche Tracht darbieten. Bei näherer Untersuchung hat es sich aber gezeigt, dass auch diese Blätter in der für Sequoia Langsdorfii charakteristischen Weise angeheftet sind, und ich glaube daher nicht, dass Taxodium unter den vorliegenden Resten vertreten ist.

Als die Isolierung derselben aus dem Gestein gelungen war, hoffte ich, dass die gedachte Frage durch die Herstellung von Kutikulapräparaten ihre endgültige Lösung finden würde. Wie aber bereits oben berichtet, hat sich diese Hoffnung leider nicht erfüllt, und zwar, wie ich vermute, weil die Kutikula durch Bakterien z. T. zerstört ist. Ich habe also keine Präparate mit Spaltöffnungen oder mit deutlichem Umriss der Epidermiszellen bekommen können. Dagegen kann man die oben schon erwähnten Parasitpilze sehen, und dazu brachte die Untersuchung ein Merkmal zum Vorschein, das ich jetzt besprechen werde. 
Li zeighte sich nïnlich, dass der Blattrand sehr kleine Ziihne trïgt. Diustben kommen sowoht in der Nïhe der Bass (Tal. 1, Fig. 12 a, 13) wie der Spitze (Fig. 12 1, 14) vor. An der Spitze selbst fehlen sie niemals, wenngleich sie hier dichter zusammengedrangt und dem Blattrand mehr angehliuckt simel und an der änssersten Spitze selhst mehr wie eine Sammlung von lianglichen Papillen (oder Härchen?) aussehen (Taf. 1, Fig. 15). Die Länge der Zähne ist sehr unbedeutend, dieselbe beträgt, von ler inneren Bucht gemessen, umr 0,04千-0.054 mu. Ich habe zum Vergleich die entsprechenden Züilne an den Blältern von Tsuga canadensis gemessen und fand die Lïnge derselhen zumeist zwischen $0,072-0,0 S 2 \mathrm{~mm}$. Wechselnd, doch kamen zmweilen sowoht kürzere $(0,(15)$ f) wie lingere $(0,090$, einmal sogar 0,126$)$ vor. Die Zïhne der fossilen Blätler sind also beträchtlich kleiner ats bei der erwiihnten TsugaArt. (Dass es sich nicht un eine fossile Tsuga handeh kann, geht, beilïufig bemerkt, erstens daraus hervor, dass die Blïtter dieser Gattung wohl nur ausmahmsweise in fossilem Zustand den Zweigen noch anhaften würden. Dazu konnte so viel vom mikroskopischen Bau der fossilen Blitter ermittelt werden, dass man sicher behaupten kann, dass die betreffende Gattung nicht in Betracht kommen kann.)

An recenten Blïtern von Sequoia sempervirens habe ich wenig stens einmal ähnliche - allerdings nur ein paar vereinzelte - Ziihne am Seitenrande des Blattes beobachtet, sie waren sehr klein, die Linge betrug mur 0,022 mm. Wenngleich die Blattspitze dieser Art keine eigentlichen Zälnne trïgl, zeichnet sich dieselbe durch eine gedrïngle Sammlung lïnglicher Papillen oder vielleicht kurzer Härchen aus, die recht sehr an die gezïhnte Spilze der Blïtter von Sequoia Tanysclorfii erinnern.

Unter Prïpraten, die von abgefallenen Taxodium-Blättem aus Schonen angefertigt wurden, fand ich ein Blatt mit einigen Zähnen von etwa 0,036-0,054 mm. Länge, die also hinsichtlich der Dimensionen recht gut mit denjenigen von Serpoia Langsdorfii übereinstimmten, was übrigens, wie aus der Abbildung 'Taf. 1, Fig. 16 erhellt, auch von der form silt.

lis wïre interessint, zu erfahren, ob ähnliche Zähne auch an Exemplaren von Sequoia Langsdorfii von anderen Lokalititen zu finten sind, was aber leider vorläufig nicht konstatiert werden kann. da cine athrliche Erhaltumg wie diejenige der Reste des EllesmereLanules, soviel ich weiss, nicht von anderen Fundstitten bekinnt ist. 


\section{Cf. Glyptostrobus Ungeri Heer.}

Taf. 2, Fig. 1-12.

Glyptostrobus Ungeri Heer 1855, S. 52, Taf. 18: Taf. 21. Fig. 1.

- Heer 1883, S. 61, Taf. 66, Fig. 5 c, 9; Taf. 70, Fig. 9,10;

Taf. 85. Fig. 6-8. Hier findel sich ein Hinweis auf andere

Bände der Flora fossilis aretica, wo die Art beschrieben wurde.

"Unterscheidet sich von Glyptostrobus europaens durch die am Rücken gekielten Blätter und dass die äussersten Zweige abstehende Blätter haben, wie beim lebenden Gl. heterophyllus", sagt HEer (1S76). Die vorliegenden Exemplare scheinen vollständig mit den von HeEr beschriehenen Resten, insonderheit mit denjenigen von Spitzhergen (1876, Taf. 11, Fïg. 2-S; Taf. 12, Fig. 1) übereinzustimmen, und auch vom Steinkohlenfjord liegen zwei Formen vor, die eine mit schuppenähnlichen, an den Zweig angedrückten, die andere (Fig. S) mit abstehenden, linienförmigen Blättern; auch Übergänge beider Formen sind vorhanden.

Wenngleich es also aussieht, als ob die Übereinstimmung mit Gl. Ungeri vollständig wïre, muss doch zugestanden werden, dass auch eine andere Deutung nicht ausgeschlossen ist. Man könnte nämlich auch an kurzblättrige Zweige von Sequoia Langsdorfii denken. Wie Miss A. Eastwood (1895) gezeigt hat, sind die Blätter der oberen Zweige an den grossen Bäumen von Sequoia sempervirens ganz anders gebaut als diejenigen der unteren Zweige. "There are two quite different kinds of leaves on the same tree, the lower heing the ordinary redwood foliage with broad disticlıous leaves, while the upper more nearly resembles that of Sequoia gigantea". Die letzteren ähneln nun, wie sowohl aus der Abbildung, die Miss Eastwood gegeben hat (1. c. Taf. 16, Fig. 1), als auch aus den im hiesigen Museum befindlichen, von ihr geschenkten Exemplaren hervorgeht, recht sehr den als Glyptostrobus Ungeri beschriehenen Resten. Angesichts der grossen Übereinstimmung, die zwischen Sequoia Langsdorfii und S. sempervirens besteht, muss als wahrscheinlich angenommen werden, dass auch die grossen Bäume der ersteren Art Zweige nit angedrückten, schuppenähnlichen Blättern gehabt haben. Die Möglichkeit, dass die als Glyptostrobus Ungeri bezeichneten Reste vielleicht zu Sequoia gehören, kann also nicht in Abrede gestellt werden, wenngleich die vorliegenden Materialien nicht ausreichen, um die Frage zu entscheiden. Auch hier muss man bedauern, dass die Herstellung guter Kutikulapräparate nicht gelingen wollte, demn solche hätten vielleicht zur Lösung der Frage beitragen können. Augenblicklich 
mus diese also unbeantwortet bleiben, und ich wage darmm keine eigene Meinung anszusprechen. sondern hahe die alte Bezeichnung für die betreffenden Reste beibehalten.

\section{Dikotylenblätter.}

Selı kleine Fragmente von Laubblittern wurden auch bei ler Schlïmmung erhalten, sind jedoch meistens für jede Bestimmung unlrauchbar. Nur zwei Blattbasen mit Resten des Plattstiels und fünf Hauptnerven künnen mit grosser Wahrscheinlichkeit als zu Populus garlirent hestimmt werden. Es handelt sich wohl um Populus arc. tica Hr. oder P. Richardsoni Hn, die in den meisten pflanzenführenden Tertikiralilagerungen der Arktis vertreten sind.

\section{Hölzer.}

Die in der Sammlung befindlichen fossilen Hölzer liegen in zwei vershhedenen Erhaltungszustanden vor. Einige sind gagatartig, in dümne Platten zerspalten, die ïusserlich eine sehr dentliche Holzstrulitur zeigen, sehen also kurz wie schwarzes Holz aus. Andere sind dagegen \%. 'T. verkieselt, mit einer ïusseren weissen V'erwitterungskruste, während das Innere dersellsen fast sclwarz ist. Einige Dünnschliffe, die ich in Slockholı hatte infertigen lassen, zeigten aber, dass sïmlliche Stücke schon vor der Terkieselung mehr oder minder stark vermodert waren. $\mathrm{N}^{\circ}$ hei einem einzigen derselhen war die Erhaltung etwas besser; so lass ich an die Möglichkeit einer Bestimmung denken konnte, wenn es von einem Spezialisten untersucht wurde. Ich sandte daher dasselbe nebst 2 Proben von den gagatïhnlichen Holzstücken an Dr. IT. Gotuax in Berlin, der so freundlich war, die Untersuchung vormunehmen und mil äher lie Resultate derselhen folgende Mitteilung sandte:

"C̈her lie von der Sverdrup-Fxpedition gesimmelten fossilen Hälzer lïsint sich leider niclıt viel sagen.

lis sind droi Stück, von welchen zwei homogen vorkolılt sind (.gagat" artig). Fin inderes ist dagegen, zun grössten Teil wenigstens, verkieselt. An wangsten \%eigen die zwei flach zusammengesunkenen, verkohllen Häl\%x, wie dies ja in solehen Fïllen gewöhnlich der Fall ist. Man erkenut hei Betrachtung unter auffallenden licht - am besten noch unter den \%eiss'schen binokularen Mikroskop - zwar noch gut den \%ellenverlauf und die Gesamtstruktur, wonach sich das Hol\% oder die Hölzer (wen sic von werschiedenen Stämmen herrülıren sollten) leicht als 
Koniferenhölzer entschleiern. Man erkennt auch noch, dass es sich nicht um harzgängeführenle Hölzer von Pinus-, Picea- und ähnlicher Struktur handelt, aber Einzelheiten sind nicht wahrzunehmen, insbesondere ob Harzparenchym vorhanden war und wie die Markstrahltüpfelung beschaffen war. Hoftüpfel sieht man noch angedeutet, wenn auch nur schwach. Die Hoffnung, mit Kollodiumabrlı̈ucken etwas mehr zu erreichen, erwies sich als trügerisch; so kann man leider nichts Genaueres über die Hölzer aussagen. Es dürfte sich wohl um Holz im ganzen von Cupressinoxylon-Charakter handeln.

Von dem verkieselten Stück, das oberflächlich angewittert, innen einen schwarzen Kern zeigt, wurden mehrere Dünnschliffe gemacht, die so viel erkennen lassen, dass auch hier aller Wahrscheinlichkeit nach Cupressinoxylon-Struktur vorliegt. Die Gesamtstruktur deckt sich mit diesem Typus, nur Holzzellen konnten nicht sicher beobachtet werden. Leider lassen sich auch hier keine genügenden Einzelheiten feststellen, vielmehr muss das Holz schon vor der Verkieselung stark zersetzt gewesen sein; im Spätholz findet man sogar an vielen Stellen homogen verkohlte Flecke und Partien, die also beim Verkieseln mit eingeschlossen wurden. Hoftüpfel sind noch sichtbar, Jahresringe deutlich periodisch entwickelt, dagegen z. B. die Markstrahlenstruktur unkenntlich geworden.

Man kann daran denken, dass zu den Hölzern die ebenfalls dort gefundenen Zweige von Sequoia in Beziehung stehen, da die Taxodiengruppe ja Cupressinoxylon-Struktur (im älteren weiteren Sinne) besitzt. Indes erübrigt sich bei dem schlechten Erhaltungszustand eine weitere Diskussion hierüber von selbst."

Dass diese von Dr. Gothas ausgesprochene Vermutung der Wirklichkeit entspricht, ist ja sehr wahrscheinlich, wenngleich man es allerdings nicht beweisen kann.

\section{Blattpilze.}

Taf 2. Fig. 13-15.

Bei den leider ziemlich erfolglosen Versuchen, gute Kutikulapräparate der Sequoia-Blätter anzufertigen, fand ich in den mehr oder minder zersetzten Kutikulahäutchen vortrefflich erhaltene, kitinisierte, fadenförmige Hyphen und knollenförmige Haustorien von Blattpilzen. Diese kommen nicht nur in den Blättern, sondern auch in den dieselben tragenden Zweigen vor, wo sie ebenfalls ein wirkliches Netzwverk bilden. Ihre gute Erhaltung rührt natürlich daher, dass sie kitinisiert sind. Ich habe dieses Vor 
kommen schon an anderer Stelle beilïufig kurz e!wähnt und eine Mikro. fhotographie einer Partie eines dieshezüglichen Präparates mitgegehen (Nathorst 1912, 2, S. 321, Taf. 1. Fig. 7). Professor G. Lagerneim. dem ich da- Priiparal gezeigt hahe, sprach die Meimung aus, dass es sich Wahr-cheinlich un einen zur Gattung Asterina gehörigen Parasitpitz lanilete.

Meine Hoffunng, dass Professor Lagerneim die hetreffenden Pilze hestimmen und beschreiben würde, konnte leider vorlüufig wegen anderer dringenden Arbeiten nicht erfültt werten, vielleicht wird er aber spitter Gelegenheit dazu finden. Nachdem er sämtliche Präparate gesehen halle. teitte er mir mit, dass drei Pitze in denselhen rorhanden sind. und zwar:

1. eine Art mit kriechenden Fäden (Asterina?);

2. eime andere, pseudoparenchymatisch;

3. eine dritte, von einem loseliegenden Conferca-ïhnlichen Faden repritsentient.

Das Ausisehen der ersten Art geht aus den Abbildungen in verschiedenen Vergrösserungen Taf. 2. Fig. 13-15 hervor, die dritte Art kann man an uberen Rande der Fig. 13 (110 1) sehen, wïhrent Fig. 15 dasselhe Fxemplar in noch stärkerer Vergrösserung (2S0 1) zeigh.

Hoffentlich wird eine detaillierte Untersuchung dieser ungewöhnlich gut erhaltenen Blattpitze interessante Resultate gewiihren. 


\section{Literaturliste.}

In dieser Liste sind nur solche Arbeiten erwähnt, die im Texte zitiert sind.

Broxginart, A. 1828. Prodrome d'une histoire des végetaux fossiles. Paris.

Eastwoon, A. 1895. On heteromorphic organs of Sequoia sempervirens ExdL. Proceedings California Academy of Sciences. 2nd Ser. Vol. 5. San Francisco.

Heer, O. 1855. Flora tertiaria helvetiae. Bd. 1. Winterthur.

1876. Beiträge zur fossilen Flora Spitzbergens. K. Sv. Vetensk. Akad. Handlingar. Bil. 14, No. 5. Stockholm. (Auch in Flora fossilis arctica. Bit. 4).

- 1878. Die miocene Flora des Grinnell-Landes. Flora fossilis aretica. Bd. 5. Zürich.

- 1883. Flora fossilis Grönlandica. Teil 2. Flora fossilis arctica. Bd. 7. Zürich.

Nathonst, A. G. 1912, 1. Sur la valeur des flores fossiles des régions arcliques comme preuve des climats géologiques. Comptes rend. du 1le Congres géol. internat. Stockholm.

- 1912, 2. Märkliga bevaringstillstiml af fossila växter. K. Sv. Vetensk. Akad. Airsbok 1912. Uppsala.

State, M. 1887. Die aquitanische Flora des Zsiltales im Comitate Humyad. Mitteil. a. d. Jahrb. d. Kgl. Ungar. Geolog. Anstalt. Bd. 7, H. 6. Budapest.

Srendrup, O. 1903. Nyt Land, fire Aar i arktiske Egne. Del 2. Christiania. 


\section{Tafelerklärungen.}

Tafel 1.

\section{Sequoia Langstorfii (Broxgr.) Heer.}

Fig. 1- 4. In Canadabalsam anflewalırte Priparafe von macerierten hattragenden \%weigresten. Nint. Gir.

".-11. Anf Papier autgeklebt, Mattlratgende Zweigreste. Nat. Gr.

7. 1․ In Canalabalsam eingeschlossenes Macerationsprïparat, das sowohl an der Basis (a) wie an der Spitze (b) der Blïtter kleine Zïlne an Rande derallien zeigt. 141.

13. P'artie ron Fig. 12 a, stärker vergriissert. 501.

"14. Partie von Figr. 1느, stärker vergrössert. 501 .

" 15. Spitze eines Blattes, vergrössert. un die Zälnne nnd Unebenheiten (Papillen, Haare?) 7 zeigen. 50) 1.

\section{Taxodium distichum (L.) Ricir.}

16. Ein \%aln am Blattrand. 501.

T a fel 2.

\section{Cf. Gilyptostrobus Tingeri HeEr.}

Fig. 1-12. Zweigreste mit angedrürkten und auch (Fig. S) abstehenden Blitteru sowie C̈bergainge zwischen beiden Formen.

\section{Blattpilze.}

Fig. 13. Pripharat mit Hyphen und Hanstorien eines Asterina-iilnlichen Pilzes und (bei $\mathrm{x}$ ) rinem Conferca-iilunlichen Pilzfaden. 1101.

14. Partic mit den Hyphen und Haustorien des Asterina-illnlichen Pilzes in stïrkerer Vergrösserung. Q 601.

15. Partio mit den Conferea-ähnlichen Pilzfaden (x) in noch stärkerer Vergrösserung. 2801. 

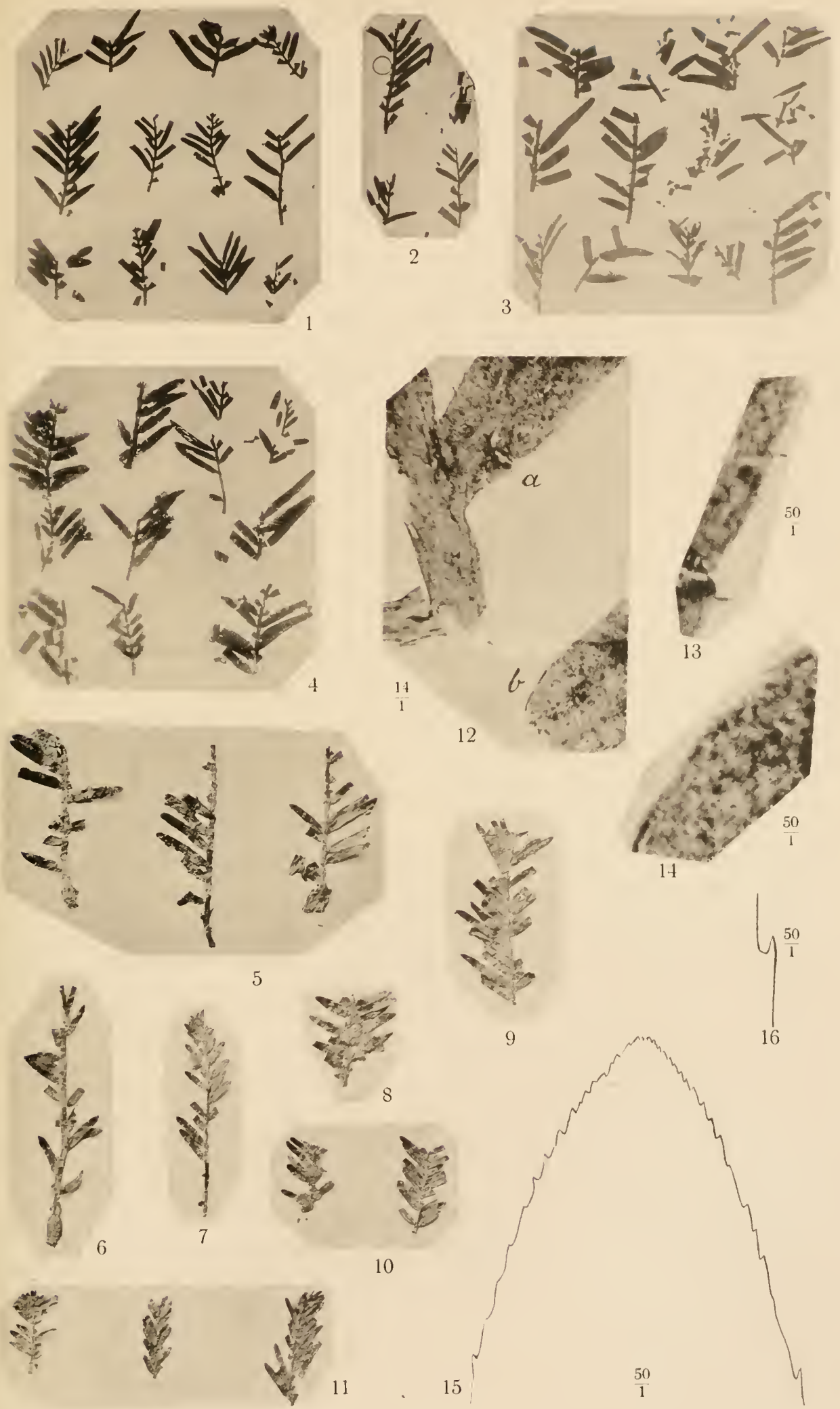



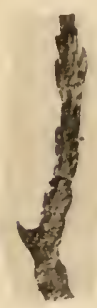

1

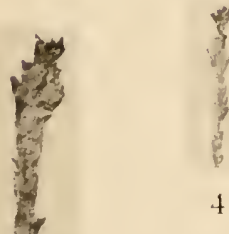

4

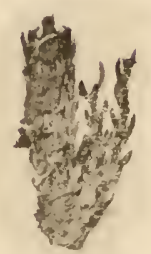

3

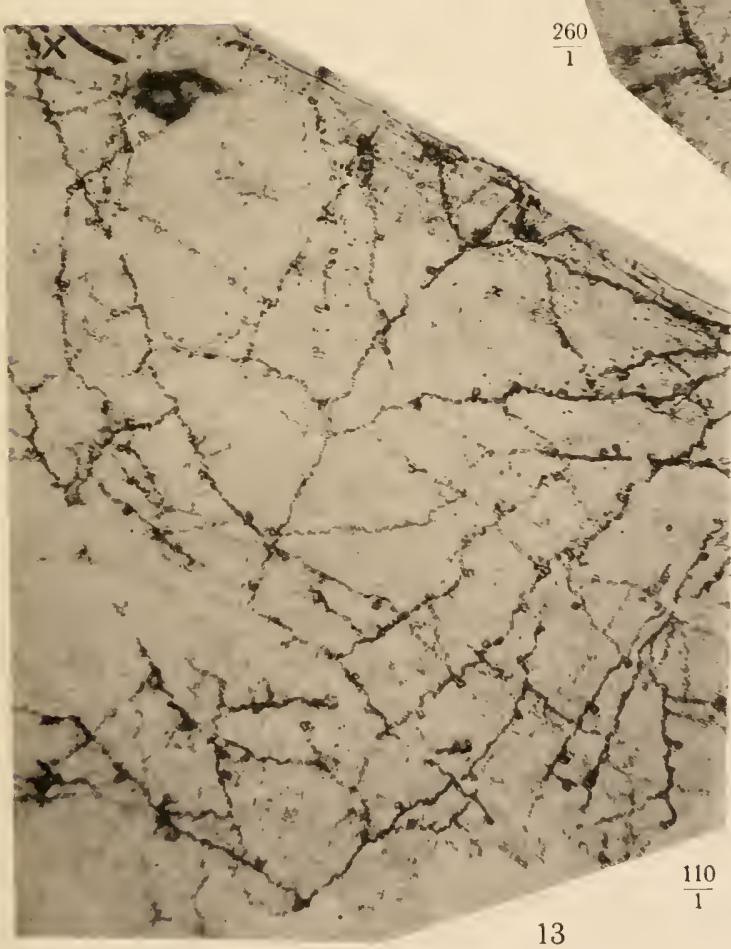

13

Gen. Lith. Anst. $(1-12)$ et Th. Ekblom (13-15) phot.

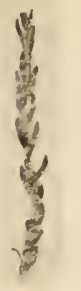

12
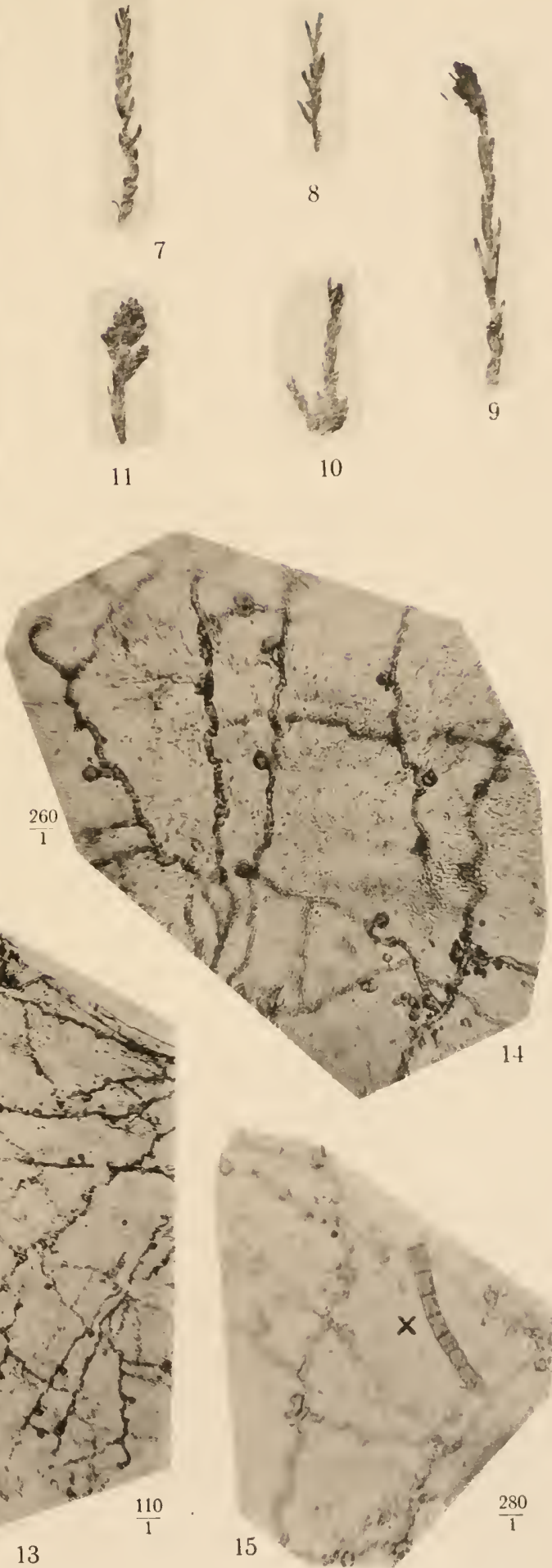

Cederquists Graf, A. B., Sthlm. 




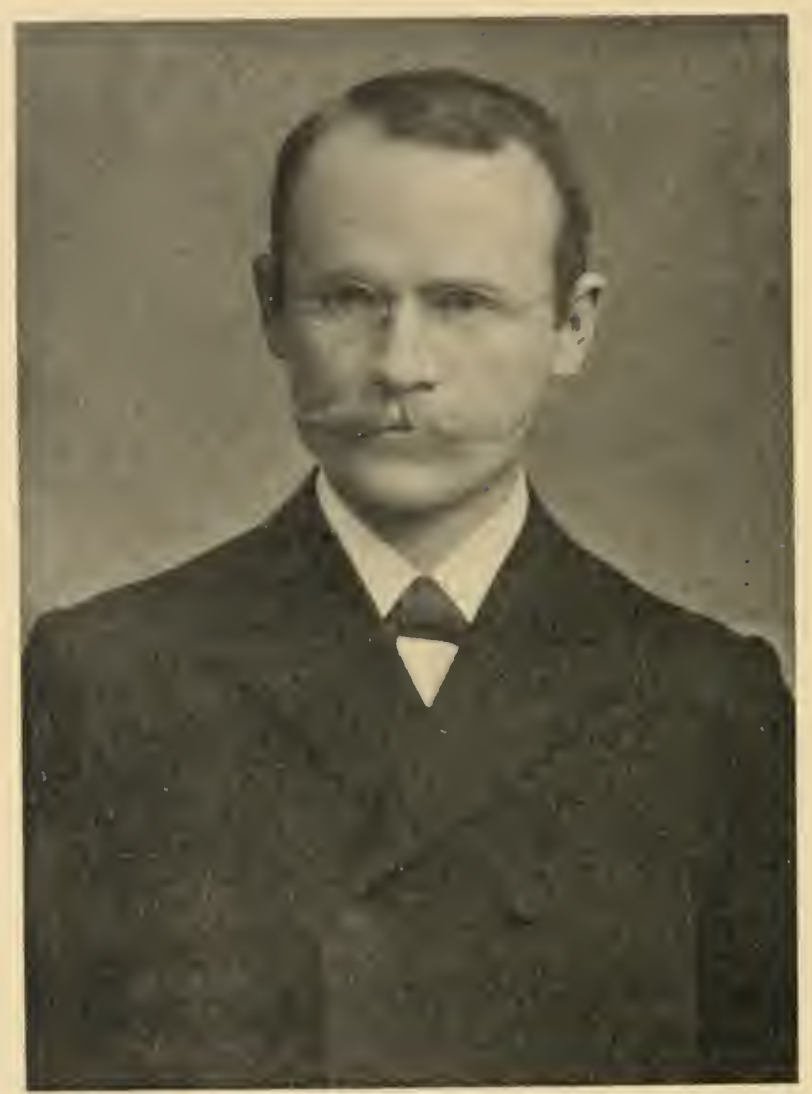

\section{PER SCHEI.}

February 16, 1875-November 4, 1905. 


\title{
REPORT OF THE SECOND NORWEGIAN ARCTIC EXPEDITION
} IN THE "FRAM" 1898-1902. No. 36.

\author{
O LAF H OLTEDA H L:
}

\section{SUMMARY OF GEOLOGICAL RESULTS}

WITH GEOLOGICAL M.AP, 6 PLATES AND 4 FIGURES IN THE TEXT

\footnotetext{
AT THE FXPENSE OF THE FRIDTJOF NAXSEN FUND FOR THE ADVANCEMENT OF SCIENCE
}

PUBLISHED BY VIDENSKABS-SELSKABET I KRISTIANIA (THE SOCIETY OF ARTS AND SCIENCES OF KRISTIANIA)

K R I S T I A N I A PRINTED BY A. W. BRØGGER 1917 



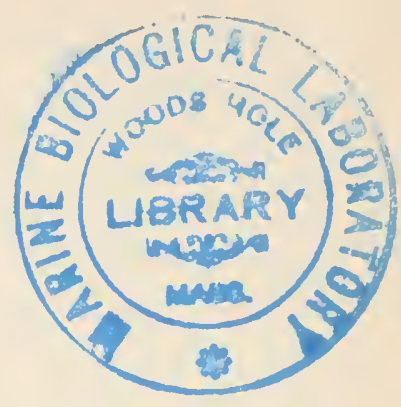

Wore than fifteen years have elapsed since the „Fram" reached home after her second voyage to the Arctic regions. The large and numerous collections of geological, especially paleontological material, brotight logether by the skilful and energetic geologist of the expedition, Per Scher, have during this time been studied by a number of specialists, among whom the material was distributed, and the result is a series of papers published in the "Report of the Second Norwegian Arctic Expedition in the Fram 189S-1902."

PER ScHer before his much regretted early death in 1905 published the most essential results of his studies in some preliminary papers ${ }^{1}$ which, although containing only a few pages, form some of the most important contributions ever made to Arctic geology. Any fuller and more detailed treatment, however, of the many important geological problems with which he had met he was not to give, and cerlainly with his death a great many facts concerning the geological history of Ellesmere Land and adjacent regions were lost.

As it may be convenient to have in one place the more important results of the geological contributions to this "Report", a summary of them is given in this paper.

In the topics where no newer publication has appeared, Scher's statements in his preliminary report will be given, and added to these, such other statements as could be found in his diaries. Finally, P. A. DYen of the University of Kristiania has been so kind as to identify the fossils found during the expedition in quaternary deposits above the present sea-level. A number of photographs illustrating typical landforms, and the glacial geology of Ellesmere Land, are also reproduced.

1 Summary of Geological Results, Geographical Journal XXII, 1903; Preliminary Report on the Geol. Obs. marle during the Sec. Norw. Polar Exp. of the "Fram", Rnyal Geogr. Society: Preliminary Account of the Geol Investigation made during the Second Norwegian Polar Expedition in the "Fram". Appentix I to Sverdrup: "New Land" 1901. 


\section{Pre-Cambrian.}

Pre-Cambrian rocks were studied ly Schei in the following regions: I Foulke Fjorl region in Prudhoe Land, Greenland; II In the opposite district in Ellesmere Land viz. on the coast of Buchanan Bay and adjacent regions (near the winter quarters of the "Fram" 1S9S-99). III At the eastern frat of Jones Sound, especially at and near Havnefjord. the winter quarter's of $1899-1900$.

The rock specimens brought home by Schei have been microscopically investigated by C. Bugge, a paper on which, „Petrographische Resultate der 2ten Fram-Expedition", published 1910, is No. 22 of this report. BugGe lıas besides sturlying the specimens from Scues's diaries obtained all the information available on the subject.

I. From the Foulke Fjord district (Reindeer Point) Bugge has described a lıypersthene-(puarty-diorite; also a rock that comes nearer to a hanatite; and as the youngest rock in this place, pink-coloured aplitic reins. Finally from Elah a gablro. Schei has in his diaries also mentioned gneiss and mica schists from the Foulke Fijorl region, schists that seem to be older than the igneous rocks mentioned. II. South of Buchanan Bay, also, are found hypersthene-(puartz-diorite, iogether with somewhat younger veins of granite. 'The difference in age, however, is slight. 'The granite was probably intruded before the diorite was entirely cooled off. Also a vein of kersantite is seen, at Kjollangen in Pim Island. From other places near the "Fram's" winter quarter's are described broncitequart\%-diorile, quart\%-diorite, norite. In the 'Twin glacier valley rlistrict the igmeous rocks have certainly found their way through older gneissic material, as they are found to contain large pieces of gneiss. At Cape Camperdown, at the SE corner of Bache Peninsula, occurs a hypersthene. fuart\%-potash-syenite. A typical feature in the igneous rocks of the Foulke Fjord and the Buclunan Bay region, is their nearly unpressed condition. III. At Havnefjord and on the coast to the east, similar rocks are found, BugGe mentions granitic as well as more hasic rocks, bronciteadamellite. The first-mentioned rocks are probably the younger. Of diorites scarcely any material was brought from here. 'The rocks from this southem district are distinctly more pressed, sometimes of a somewhat gneiss-like structure. 


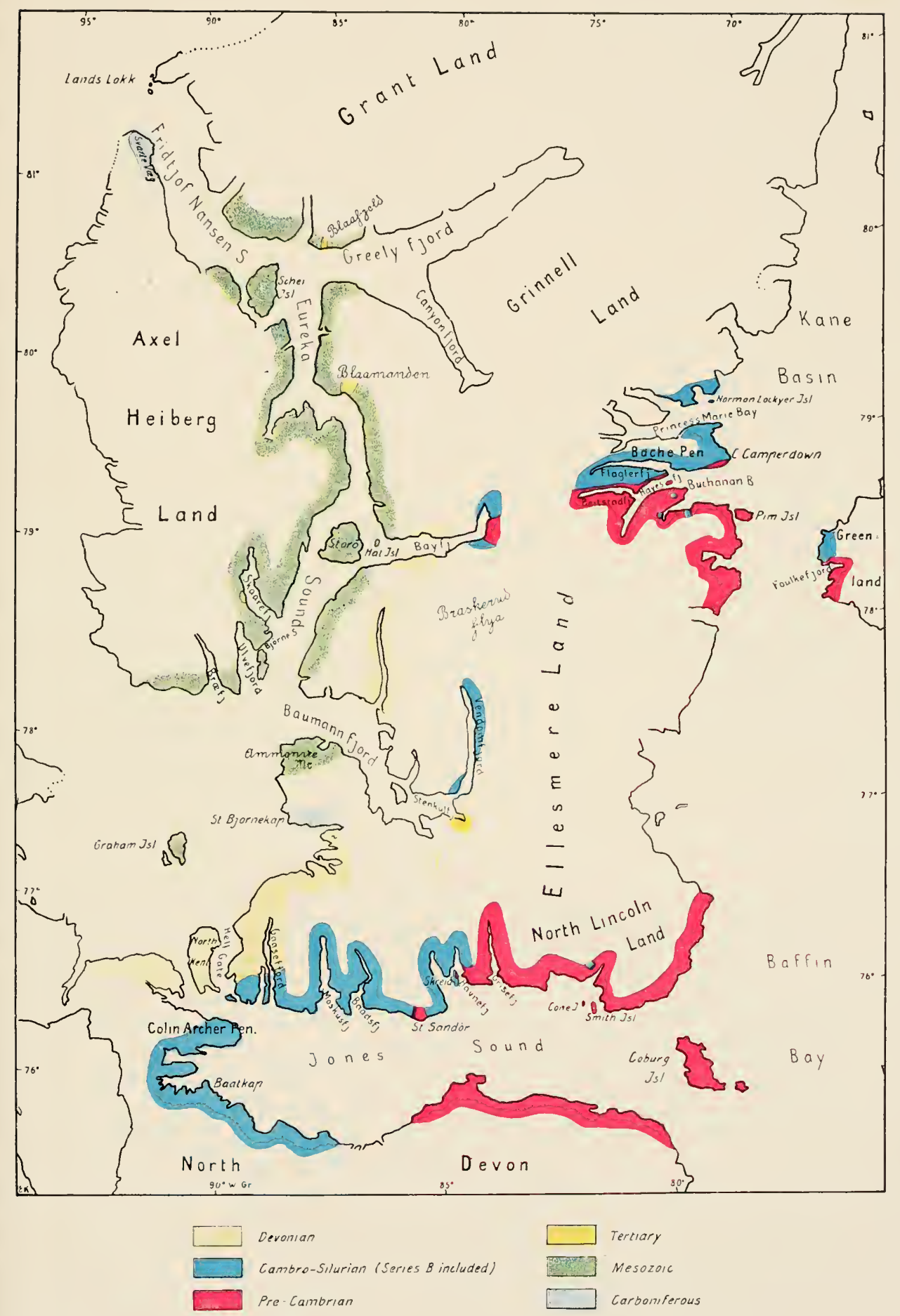

Geological map of the coast districts of Ellesmere Land and neighbouring regions according to Per Schei. 

As a general statement it may be said that the Pre-Cambrian igneous rocks of Eastern Ellesmere Land and the Foulke Fjord region of Greenland contain basic, intermediate and more acid representatives of a series very characteristic by its content of orthorhombic pyroxene (broncite or hypersthene). We have the basic type: norile, the intermediate: broncite- (hyperslhene-) quartz-diorite, also banatite and hypersthene-quartz-potash-syenite, and finally the more acid: broncite- (hypersthene-) arlamellite.

In the Pre-Cambrian in the Havnefjord district, veins of diorite-porphyrite occur, which Bugge has found to be rather similar to rocks that Scuer has brought from mesozoic series in Eureka Sound and other districts of the far North-West, and which he accordingly thinks may also be of relatively young age. Furthermore, this diorite-porphyrite seems to be related to the plutonic rocks just mentioned, and BugGe asks the question whether also these nua not be younger than Pre-Cambrian. As far as the present author can see from ScHer's notes and photographs, such a thing is out of the question. The upper surface of the igneous rocks mentioned is, wherever it appears, a surface of erosion, a peneplain upon which the younger sediments were deposited (see pl II, fig. 1), and not an upper surface of an intrusive body. The younger igneous masses are all hypabyssal or volcanic rocks, and occur in the above mentioned districts in relatively very small quantities. In the Havnefjord district they are not mentioned at all by ScHer.

\section{Paleozoic.}

The paleozoic sedimentary rocks resting directly on the Pre-Cambrian base-levelled surface, are nicely seen in different districts of Ellesmereland and vicinity, both in the Smith Sound- and Jones Sound regions.

At Reindeer Point, on the north side of Foulke Fjord (see fig. I page 1S) the boundary hetween the Pre-Cambrian plutonic rocks and the overlying sandstone, of which the lower part is red, the upper whitish, is seen about $100 \mathrm{~m}$. above sea-level. On the sandstone, which has a visible thickness of $120-150 \mathrm{~m}$. rests diabase.

The paleozoic deposits in the region of the Bache Peninsula have been treated in a paper by the present author, no. $2 S$ of this report. ${ }^{1}$ At Cape Camperdown Scher found, resting on the Pre-Cambrian, beds of coarse sandstone with intrusive diabase, and higher up shates and

1 The Cambro-Ordovician beds of Bache Peninsula and neighbouring regions of Ellesmereland. Kristiania, 1913. 
limestone-conglomerates, and above these beds of limestone. In loose pieces of this latter rock were found fragments of a Ptychoparia, probably a new species, yet too incomplete to he specifically determinerl. The form indicates Middle or Upper Ciambrian.

Alove the limestone again come linestone-conglomerates and a yellowisli-white limestone, $100 \mathrm{~m}$. thick. Here were found fragments of trilobites, Ptychoparia sp., lllcmurus sp., hesides numerous but very laally preserved Orthoceras-specimens. Still higher were found bels of quarlz sandstone alternating with limestone, and finally a $30 \mathrm{~m}$. bed of limestone, where also traces of fossils were found, badly preserved gastropools, among others an incomplete specimen of a Maclurea, and a fragmentary pygidium, belonging to a Bathyuriscus or Ptychoparia form.

The stratigraphic position of the two fossiliferous limestones just mentioned is, in all probability to be found near the Cambro-Ordovician houndary, in the highest Cambrian or hasal Ordovician, - the Ozarkian of Ulricn. The total thickness of the above-mentioned sediments, which may be easily studied on the east coast of Bache Peninsula, is not less than $7-800 \mathrm{~m}$.

Limestone beds with a distinctly younger fauna, are found in Norman Lockyer Island, $18 \mathrm{~km}$. to the north of Victoria Head. Here the following species in well-preserved specimens were found.

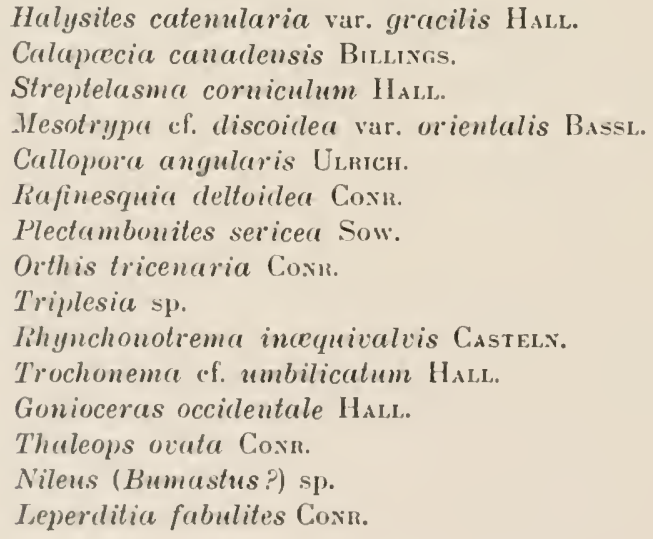

'T'his fauna it undoubterlly of the same age as the bulk of the forms describel by Schucuent from Silliman's Fossil Mount, Frobisher Bay, ${ }^{1}$ belonging to early Trenton.?

${ }^{1}$ On the lower Silurian (Tienton) Fanna of Baffin Land. Proc. U. S. Nat. Musum XXII, 1900, and further: Notes on Aretic Paleozoic Fossils. Am. Journal of Secence XXXVIII. 1914, p. 479.

3 In WhiLis: Strutigraphy of Norll America, p. 217, Uurucr in a note considers the horizon of Sillimans Fossil Mount to belong to upper Black River. 
Also on the north side of Princess Marie Bay, Scher found the linestone of Norman Lockyer Island. It is overlaid by sandstones and a limestone-conglomerate. Farther to the north on the coast of Kane Basin Scher has not been, but from there we have the important observations made by Feilden and De Rance. ${ }^{1}$

The other district in which Scher observed the oldest paleozoic sedimentary rocks was in the eastern part of the north side of Jones Sound. On the western side of Fram Fjord (north of Smith Isl.), he found above the Pre-Cambrian: I light-coloured sandstone with diabase and higher II yellowish magnesian limestone with sandstone layers.

In the Havnefjord (Harbour-Fjord) district we find a basal sandstone overlaid by $4-500 \mathrm{~m}$. of limestone-conglomerates, limestones and shales, and still higher 6-700 m. mostly brownish limestones. In the lower part of these brownish limestones, at the South Cape on the west side of the mouth of Havnefjord, were found Halysites catemularia Lis, Strophomena sp., Machurea sp., the two last mentioned too fragmentary for exact determination.2 This fauna indicutes a Trenton age, though nothing can be said with certainty. As no fossils were brought from the series below the brown limestone we have no direct proof as to the age of the basal beds, a: no material for conclusion as to when the paleozoic sea invaded this district. However, if we consider the vast quantity of sediment lying below the limestones, and the predominance of limestone-conglomerates which belonged to the most characteristic rocks of the basal series of Bache Peninsula, it seems quite safe to assume that also in the present Jones Sound district the sea had invaded the land at earliest Ordovician time. Of some importance is also the occurrence of diabase in sandstone above the Pre-Cambrian at Fram Fjord, as this gives us conditions very similar to those at Cape Camperdown. However, as the diabase is intrusive and not effusive, it cannot be fully relied upon as a guiding zone.

A fact that points strongly towards the conclusion mentioned is the occurrence of an interesting structure found in a piece of limestone brought by Scher from the east side of Havnefjord, taken from a locality near the winter quarter's of the "Fram" 1899-1900, and certainly from a horizon far below the brown limestone and not far above the Pre-Cambrian. (From the same locality were brought pieces of limestone-conglomerate). The structure is illustrated in pl. I and is identical with what, together with

1 Quarterly Journal Geol. Soc. 34, 1878.

2 See Olaf Holtedahl: On the fossil faunas from Per Schei's Series B. This report No. 39, 1914 p. 4. 
other similar structures have been called Cryptozoon hy American geo. logrists. and which are extrenely conmon in the dolomites and limestones of the [Tper Cambrian and Lower Beekmantown in the Appalachian Valley, as well as in New York. I will mol here go into the question of the niture of this structure. as the matter will, in the near future, he treated ly the present antlor in a paper dealing with the geology of Fimmatien in Northem Norway. where similar structures in dolonites are very ronmon. 'The struclures called Cryptozoon in America are of rather different lypes, as some show lamine Horoughoul the rock, as in the specimen from Havmeford. while others show more isolated, single "ㄱecimens" with stuchreless rock in intervals between the concentrically Inilt convex elevilious. The Cryptozoon prolifermm Has from the knox dolomite, illustrated by STose in his paper on "The Sexlimentary rockis of South Mountain, Pennsylvania"1 p. 217, fig. 3, is remarkahly similar to the specimen from Eltesmereland. An interesting fealure in the latter is the existence of oolitic structure in some places, helween the lamine, a feature also known from healities in Pennsylvania.

In this connection also the presence of very considerable quantitien of limestone-conglomerates, certaindy intraformational. in the hasal portion of the Ellesmereland sedimentary series, is of considerable interest. since similar conglomerates are predominant rocks in the Lpper Cambrian series of the Appalachian Valley (Conocochearue) as well as in the Becemantowı.

The petrographical likeness between the basal paleozoic sedimentary series of Ellesmereland and the Ozarkian deposits of the Appalachian Valley strongly indicates an open oceanic comnection between the fwo regions at the time in question. The stratigraphic conditions in the lan mortl also seem to he very similar to what is known from the Saraloga district in New York, where, resting on the Pre-Cambrian we find a not thick sandstone bell on which lie Cryptozoon-bearing linestones and dolomites of Uprer Cambrian age. ${ }^{2}$

The fact that $200 \mathrm{~km}$. to the soutls of Ellesmereland, on llie soutls side of North Drvon, Silurian (Niagiran) limestone is found only sone tens of moters ahove the Pre-Cambrian, probably means that dry land existral Hhere in Cambor-Ordovician time, althongh it camot he considered impossible that sediments corresponding to a part of that time have been Inposited hut later on removed by erosion.

1 . Tournal of Geology, 11, 1906;

"See lismixg and Robrasx: "Geology of Sitratoga springs and Vicinity" in Bullıtin 1(;:), New York State Museum, 1911 
From the higher portion of the hrown limestone series mentioned from the Havnefjord district, fossils, mostly fragmentary, have been found at Baatkap in the north-western part of North Devon'1:

Strophonella if. euglypha $H_{\mathrm{IS}}$.

*Conchidlium arcticum Holtedaht. ${ }^{2}$

Ceraurus sp.

They probably indicate $\mathrm{N}$ iagaran, but are too few and fragmentary to allow of any exact conclusion.

The brown limestones (series A of Scuer) are found along the whole western part of the south coast of Ellesmereland, except in one place Store Sandor) where tectonic disturbances have brought to the surface the underlying conglomerate series, and even the Pre-Cambrian.

The finest paleozoic sections were found in the Gaasefjord (Goosefjord) district. Above the brown limestones come here, without visible unconformity, dark shales with limestone beds, Schei's Series B, with a thickness of $300 \mathrm{~m}$. Fossils were found here, in different localities and from different horizons; lut they do not seem, to judge from the faunas, to be of any very different age. The fossils identified, are, according to the abovementioned paper by the present anthor (report no. 32) the following:

Solenopora sp.

Favosites cf. helderbergiae Hat..

Favosities forbesi E.c. H. var. eifelensis NıcH.

Favosites sp.

"* Parallelopora favositiformis HoLTEDAHL. ${ }^{3}$

Cladopora rectilineata Simps.

Thecia swinderenana GoLdF.

Syringopora sp.

Stromatopora sp.

Monograptus sp.

Fistulipora sp.

Fenestella sp.

Lingula sp

Orbiculoidea sp.

"Stropheodonta patersoni Hall var antiqua Holtedanl.

strophonella ef. euglypha His.

* Schuchertella interstriata HALL var. simuata HoLtedaht.

Gypidula coeymanensis var. prognostica ScHuchert.

"Stenochisma deckerensis WeLLen var. arctica Holtedani.

* Camarotoechia litchfieldensis Schuchert var. angustata Holtedahl.

* Uncinulus septentrionalis Holtedahl.

Atrypa reticularis Lins.

*Tissatrypa scheii Holtedahl.

*Spirifer modestus HaL, var. striatissimus HoltedahL.

Spirifer vamuxemi Hall var. prognostica Schuchert.

1 See Holtedaht: Series B. p. 5.

2 The asterisc means that the species have been for the first time described in the papers of this report.

3 One asterise means a new species or variety, two usterises new genus and species. 


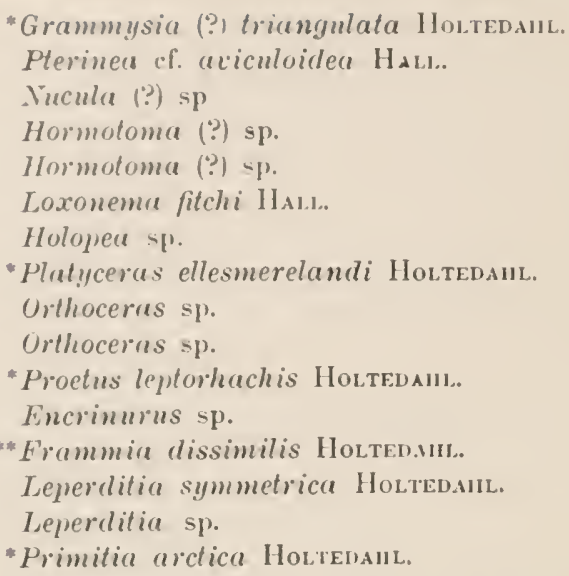

Although of these forms only a few are of importance for conclusions as to age, it may be said with certainty that the fauna must be considered as contemporary with those described from the Keyser member of He Helderluerg group of Maryland, from the Decker Ferry Rondout. Manlius of New Jersey, and the Cobbleskill-Rondout-Manlius of eastern New York. 'The stratigraphical position of series B is thus to be sought in the very transition zones between Silurian and Devonian. As a whole the fauna cited above may be said to have more of a Silurian than of a Devonian aspect.

Above Series B comes Series C, a sequence of marly shales passing upwarls inl" arenacenus deposits. The thickness, as measured in Gaasefjord, is about $300 \mathrm{~m}$. No fossils have been found here.

Still higher comes the richly fossiliferous series D, consisting of 500 n. of shales and limestones, near the top of sandstones. Series D was hy Scmer divided into subdivisions Da-Di. Of the fossils collected hy him the two most dominant groups, the brachioporls and the corals have been studied in detail, the former by Oscar Erich Merer, who las published the results of his work in a paper "Die devonischen Brachioporlen von Ellesmereland" (this report No. 29, 1913), the corats by Strmux Lonwe, who has written a paper entilled "Die devonischen Korallen von lillesmereland" (this report No. 30, 1913).

In the following are cited the list of fossils given in the two papers.

\section{Da.}

No fossils are with certainty found here.

\section{1) $b$}

- Cyathophyllum Suerdrupi Loswe.

Jhillipsastraea gigas H11,1.wis.

Fucosites Helaterbergiae IАI..

* Ireosites frumensis nut. praecursor Low:w. 
"Cyathophyllum quadrigeminum mut. arctica Lowwe.

Syringopora nobilis Billings.

Dalmanella multistriata $\mathrm{H}_{\mathrm{ALL}}(=$ D. striatula SсHцотн).

Dalmanella assimilis HaLL.

Stropheodonta varistriata Coniad ( $=$ S. interstrialis PhIll(?))

*Stropheodonta demissa Cunnad mut. praecursor Meyer.

Stropheodonta Leavenworthana HALL (?).

Stropheodonta spec.

* Stropheodonta aretica MeYer.

Leptaena spec.

Orthothetes woolworthanus HaLL.

* Orthotetes Kiaeri Meyer.

Atrypa reticularis Linvé.

Atrypa aspera ScLlotu.

Spirifer concinmus HaLL.

"Spirifer Scheii MeYer.

Pentamerus pseudogaleatus HaLL

Rhynchonella formosa $\mathrm{H}_{\mathrm{ALL}}$.

Rynchonella transversa HaLL.

Eatonia medialis VANUSEM var.

\section{$D c$}

*Stropheodonta arctica MeYer.

Atrypa reticularis Linsé.

Spivifer concinnus HaLL.

* Spirifer Scheii MeYer.

Spirifer curvatus Sснцотн.

Spirifer Maureri Holz.

* Pentamerus pseudogaleatus Hall mut. recurrens Meyer.

"Rhynchonella Sverdrupi Meyer.

\section{$D f$}

Orthothetes umbraculum Sснцотн.

\section{$D g$}

Cyathophyllum ef. bathycalyx $\mathrm{F}_{\text {RECII. }}$

Dalmanella multistriata HALL.

Stropheodonta varistriata ConRaD.

Stropheodonta inaequiradiata HaLL.

*Stropheodonta callosa HalL var. latior Meyer.

Chonetes lineatus Conrad.

Productella aff. lacrimosa Conrad

Productella arctirostrata HaLL.

Atrypa reticularis LiNve.

Spirifer elegans Stein var.

Spirifer gregarius Clapp.

Rhynchonella Horsfordi Hadt.

Rhynchonella princeps BARR.

\section{$D h$}

Cyathophyllum nepos HaLL.

Mesophyllum (Actinocystis) robustum Hall.

Cyathophyllum caespitosum GoLDFuss. 
Ihiltusastraen Scheii nor. nom.

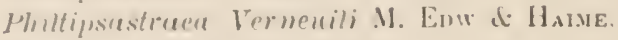

"Fuersites framensis lonfur.

Alcentites suborbicularis LaM.

Sinringupora mobilis Ban Lisis.

* sigrimgopora Veyeri Lorinf.

- Inotmaneltre multistriata Has.L.

S*roplearlonta earistriata Cosrad.

Protuctetla all. lacrimosa Cirsiad.

Proluctetla aretirostrata Has.L.

Proluctettu subuculenta Merin. var. latior Gïmon.

Atrymare reticularis Lavi:

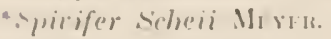

Siprifer etegums sirm var.

spririfer gregurins Cilapr.

Sprivifer inflatus Sconur.

libyuchometla princeps Ban.

Spirifer bisculatus Sow?

$D i$

Spirifer (Martinia) Urii.

splirifer (Ilartinia) inflatus Scuxcr.

As to the age and relations of these fannas, the following statements an marle hy the lwo paleontologists:

D) bolongs to Lower Heldelberg, probably to the middle of that division.

De must he of a distinctly younger age than Dh, though no distinct horizon can be fixed.

Dd, De, Df point towards Uppermost Lower Devonian, and lower Mildle Devonian.

Dy is of Millle Devonian age.

Dh is, according to Loswe, to he placed about the bommlary of the Mihlle.Upper Devonian. According ho Meren Dh as well as Di is of Epper Devonian age amd point toward Chemung.

P’rf. J. Ke.er in his paper: "Upper Devonian Fish remains from Elles. mere lamb" (this report no. 39 . 1915) has from Dh described a cranial shield of a fislo Macropetalichthys Scheii Kr.en, and conchules as to the age of the said \%one that if slomld most probably he assigned to the transition strata between the Middle and Upper Devonian. It does not suem likely that so young a hori\%on as Chemmog is represented in series 1) at all.

With transitional zones anying sandstone heds the marine Series D) passes intu Suries $\mathrm{l}$, consisting of at least 6 -700 $\mathrm{m}$. of sandstone, whose essutial fosisils are scanly fish and plant remains. The former have hern dearribed ly Kixk in the paper just mentioned. From the middle part of the series are identified the following fossils: 
* Psammosteus arcticus Ki.ER.

- Psammosteus complicutus Kisu.

Great Coccosteomorph.

Bothriolepis ef. hydrophilu Ac.

Bothriolepis (.) sp. Large form

* Holoptychius Scheii Ki.ER.

Holoptychins cf. tuberculatus NEWB.

Glyptolepis ef. paucillens Ar.

Teeth with dendrodont structure, presumably belonging to the preceding

Holoptychiidue.

Osteolepis sp.

Phtonia ef. cylindrica HaLL.

Badly preserved remains of plants.

Higher in the series:

Bothriolepis (?) sp. large form.

'Tooth with rhizodont structure.

Still higher:

Bothriolepis of. hydrophila Ag.

Glyptolepis ef. paucidens AG.

Remains of plants.

To judge from the stratigraphical occurrence of these fossils no distinct faunal zones can be distinguished, the lists showing only an impoverishment of the fauna upwards. The lower fish-bearing horizon of Series $\mathrm{E}$ is, according to Kıar, of older Upper Devonian age, and as it is situated in the middle portion of the Series "we must assume that this series with its continental facies commenced in the lowest part of Upper Devonian". The fish fauna of Series E is of a European rather than American character, ${ }^{1}$ in contrast to the marine faunas in the lower horizons of the Cambro-Devonian Series of Ellesmereland, which show a very close American relation, with, however, the exception of the Middle Devonian faunas which have a more European aspect ${ }^{2}$.

The fossil plants of Series E have been studied by A. G. Nathorst, and the result published in "Die oherdevonische Flora des Eflesmerelandes" (this report no. 1, 1904). The following plants have been identified:

Haifuinodendron Sverdrupi NatHorst.

Archaeopteris Archetypus Schmalhausen.

Archueopteris fissilis Schmalhusen.

Cfr. Sphenopteridium Keilhaui Nathorst.

Fragments of stems of uncertain systematic character.

These plant remains indicate an Upper Devonian age.

1 Kiær: 1. c., p. 54.

2 Schuchert: Notes on Aretic Paleozoic Fossils, Am. Journal of Sience, XXXVIII, 1914, p. 467. 
Linfortunately Sciner was not able to stuly the beds next younger than his Series E, so we do not know what is tying hetween these high Devonian heds and the Upper. Carbou if erous limestones sludied at Store Bjornekily (Bear Cape). Probably the lower Carboniferous here, as in ofluer districts of the Arelic Arehipelagn, is developed ats a continental deposition of plant-bearung samblones and shales.

The bulk of the carboniferous fossils collected hy Scuer were found at Store Bjormekap, a locality about $75 \mathrm{~km}$. north of the immer end of Gaanefjom. The rock at Bjmmekap is, areording to Scurs, in the lower part on unfunsiliferous, brownish greg, hart linestone, higher up a white limestone. rich in elsert, and in this upper horizon the fossils were foumil.

Carboniferous limestone was also found far to the north in Axel Heihergs Lind, in Svarte Vieg (Black Wall), hut from this lucality only a few fossils. embedded in dark gray. not cherty limestone were brought.

The carhoniferous fossils were, after the return of the expedition sent to Prof. Tschensischew, who did not, however, live to see the result of his stulies on the fossits printed. In fact the work, in which he was assistorl hy P. STEPAxow, who had taken the sludy of the corals and bryozon, was not quite finished at the dealh of T'schersyscmis about New Year 1914. The closing chapter of the manuscript was still unwritten. Besides Dr. Stepanow also Dr. P. v. Wrttenizurg of Petrograd, has done a very considerable and important work in looking though Tschensychew's manuscript and preparing it for pulplication. This paper by Tschensycuew and Stepaxow ${ }^{\prime}$ "Ohercarhonfanna von Kïnig Oscars und Heibergs Land". printed 1916, is no. 34 of this report.

A list of the fossils described in this paper follows below. When marked with a B the species was found at Bjornekap); when marked wilh S. V. it was found at Svarte l'ag.

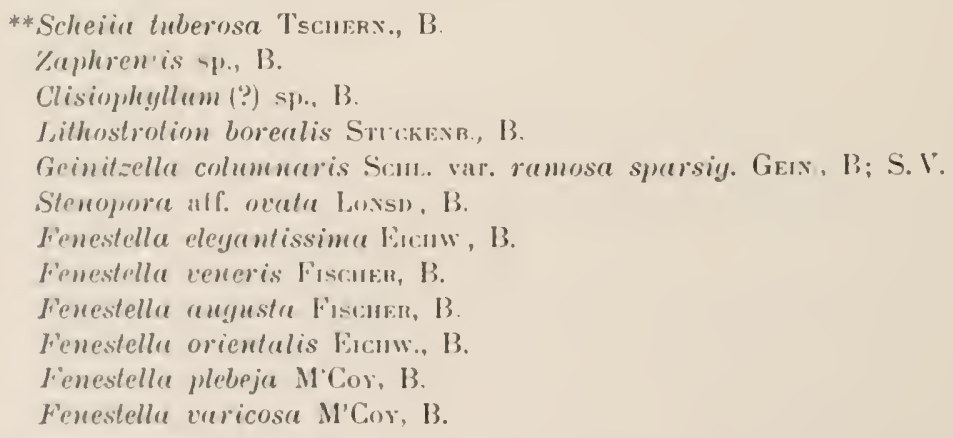


Archimedes sp., B.

Polypora martis Fischer, B; S.V.

Polypora biarmica Kers, B.

Polypora pustulata Toula, B.

Polypora orbicributa Kers., B; S. V.

Polypora micropora Stuck, B.

Plyyllopora cf. borealis Stuck., B; S.V.

Productus boliviensis D'Orв., B.

Productus inflatus McChess., B; S.V.

Prorluctus Stuckenbergi Kroтоw, B.

Productus tartaricus Tscuens., B.

Productus pseudoaculeutus Kirot., B.

Prorluclus tustubensis Tscuenv., B.

* Productus Frami Tschern., B.

Productus irginae Sтucк., B; S. V.

Productus Humboldti d'Orв, B.

Productus Aagaardi Toula, B; S.V.

Productus simensis Tschern., B.

Prorluctus Konincki Vern., B; S.V.

Productus cancriniformis Tschern., B.

Productus Weyprechti Toula, B.

Proluctus porrectus Kưr., B.

Productus timanicus Stuck., B.

Marginifera involuta Tschens., S. V.

Marginifera typica WAag. var. septentrionalis Tscherx., B.

Marginifera Clarkei 'Tscuen., B.

Derbyia grandis WAAg., B.

Reticularia lineatc MART., B.

Reticularia guadalupensis Sнuм, B.

* Spirifer Scheii T'schenN., B.

Spirifer condor d'Ori., B.

Spirifer fasciger KeysenL., B.

Spirifer Marconi IVAAG., B.

Spirifer trustubensis Tschexr., B

Spirifer lyra Kur., B.

Spirifer Nikitini Tschern., B.

Spiviferella Saranae VERN., B.

Spiriferella Keilhavi v. Bucu., B.

Spiriferella artiensis STUCK., B.

Spiriferella Parryana Touma, B; S. V.

Spiriferella Draschei Toula, S.V.

Spiriferella sp., B.

Spiriferina cristata Sснц., B.

Camaraphoria Kutorgae Tsciens., B.

Camaraphoria mutabilis Tschens., B.

Rhynchopora Nikitini Tschers., B; S. V.

* Notothyris polaris 'Tschern., B.

Dielasma Moelleri Tschern., B.

Aviculopecten (Deltopecten ?) Bouei Kerserl. non Vers., B.

Of 55 forms, which are specifically determined, no less than 42 are also known from the Schwagerina-horizon of the Ural and the Timan, thus very nicely giving the age of the limestone as high Upper Carboniferous according to the Russian stratigraphic system; and 
alon giving a new poof of how extrandinarily alike is the fammal

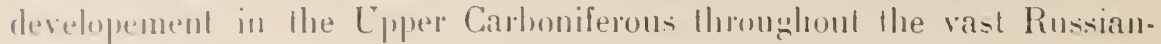
Arrlic realin.

Of comsiderable inlerest is the discorery of effusive rocks above the fo-siliferous chertbearing limestone al Suate Vaeg. and as they are (o) vererl ly serlimentary rocks of the same kind, Here can be no doubt that alon in lins far month voleanic activily is marked in Upper Carboniferous lime. Besides tuffs, lavas are fouml, described by Bugge in .Petrographische Resultale, elc.", !). 36.

\section{Mesozoic.}

Of great importance is the discovery of wide-spread Mesozoic heds that were previously known only in a few localities in the istands lying to the soutli-west of Ringnes and Heiberg Island (Prince Patrick Island and ollsers).

From the shores of Eureka Somnd and adjacent district farther north, fossils were collected in several localities. The fossil fannas were studied hy Prof. E. Kittru, who has published a paper „Die Triasfossilien vom Heureka sund". (This report no. 7, 1907).

Arranged according to locality the fossils described hy Kitru are the following:

1. From calcareous shale and limestone at Blaafjeld (Blue Mountain) In the nortli of Eureka Sound:

Halobia Zalleli Lindstr.

* Daonella Frami hitts.

2. From hlackish calcareous shate at Ammonite Mountain, Bjornekaplandet:

Discime of. Burrentsi Bons.

Malobia Zitteti Inxwstr.

- Avicula potaris kirri..

Gryllurea Shiuld Rogns.

- Protrachyceras Scerdrupi Kitt..

Protrachyceras of. Scerdrupi hitrt.

Protrachyceras aff. Richthofemi Moss.

3. From calcareous arenaceous shale at the depot, Storo, Eureka Sonnel:

Halobia Zitteli Imnstn.

- Avicula polaris hirrt.

J'seurlomonotis (?) sp. 
*Pecten Oscari Kittu.

Pecten Öbergi Luxdgr.

*Palaeopharus Scheii KitTL.

4. From grey limestone in Hat Island, Eureka Sound:

Brachiopod indet.

Halobia juv. indet.

Gervilleia ef. Loewenighi Bонм.

Hoernesia (?) sp.

*Lima hatensis Kittu.

* Lima Hakioni Kittl.

${ }^{*}$ Lima boreas Kitru.

Pecten ef. Öbergi Lundgr.

*Pecten Oscari Kutru.

Gryphaea cf. Keilhaui Bonм.

*Ledla (Phaenodesmia) regia Kittr.

Palaeoneilo (?) ef. lunaris Вону.

Nucula (?) sp. indet.

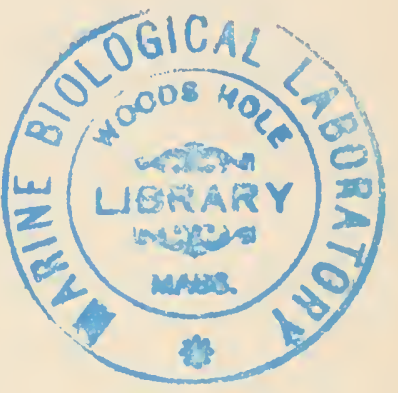

*Cardinia (?) ovula Kitrt.

Paleopharus (?) sp.

Anoplophora (?) ephippium Вøим.

Homomya (?) sp.

Trachyceras sp.

These faunules are all of Triassic age, according to KitTL probably corresponding to the Ladinian or Carinthian horizons of the Alpine Triassic. There does not seem to exist any considerable difference in age, yet there may be some, and the probable succession is as shown above, beds at localily 1 being the oldest, at 4 the youngest. According to Kittl the Triassic; fauna of the Eureka Sound are closely related to those of Spitzbergen and Bear Island. Of the 30 species found 11-12 are known to exist in very similar forms from the Triassic of the last mentioned islands.

At one locality in Eureka Sound, at Bjørneodden, brownish to black arenaceous shales were collected, in which carbonized fragmentary remnants of plants were found. While nothing definite can he said, it looks, according to KITTL, very probable that also this shale is of Triassic age. Similar plant-bearing beds are known, both from the Ladinian of the Alpine Triassic, and from the Keuper of the German. From the same locality, Bjørneodden, loose pieces of sandstone were brought, containing a little fauna, which is thought to be of the same age as that from the depot, Storøen.

Younger than these 'Triassic deposits, but older than the Tertiary beds mentioned below, are, at any rate a great part, possibly all of the intrusive rocks found in the paleozoic and mesozoic series of Ellesmere. land and neighbouring regions. Thus the exceedingly common intrusive 
diabases found in the mesozoic strata of Eureka Sound (see Bugge l. c., 1. 3:3). Here are found two types, one containing quartz and micropegmatite, the other not. Probably also the relatively coarsely crystalline diabases fomnd in the basal part of the paleozoic deposits at Cape Cam. perdown in Bache Peninsula, Reindeer Point in Foulke Fjord and at Fran Fjord in Jones Sound, are of the same age. Scner distinctly emphasizes the fact that the intrusions have especially appeared along two lines, Smith and Eureka Sounds. While the thickness of the diabase
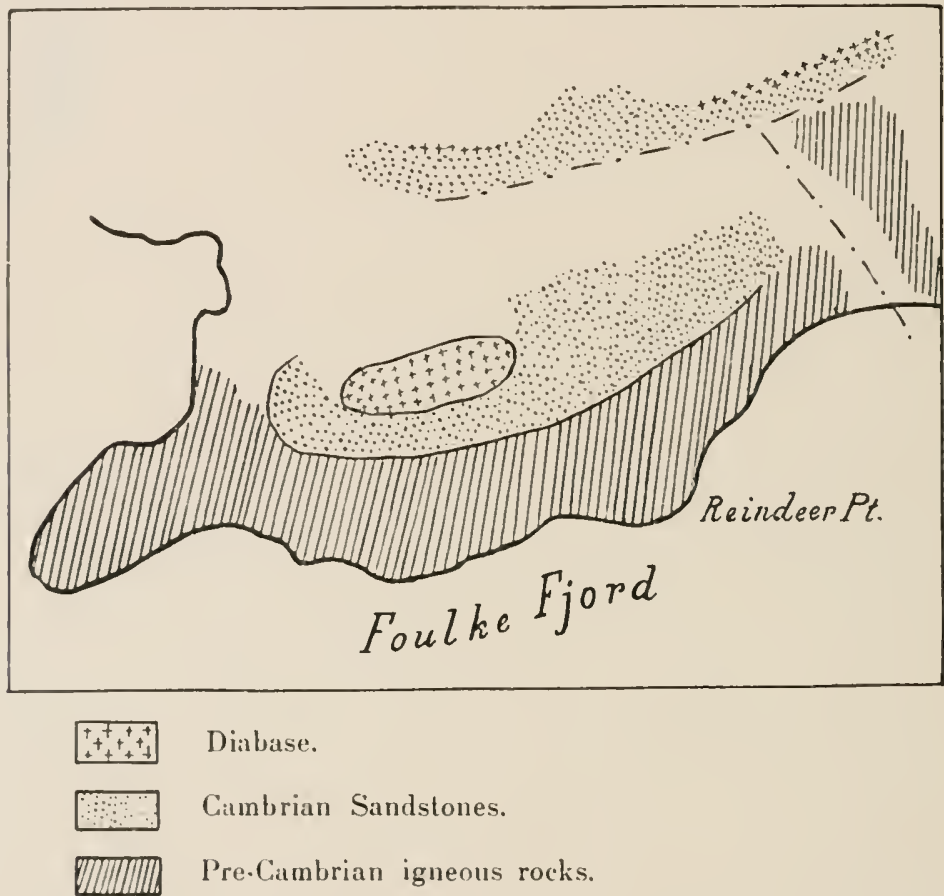

Fig 1. Fitulted district on the north side of Foulkefjord in Greenland. Skelch taken from Scuei's diary.

at Cape Camperdown is $100 \mathrm{~m}$, it decreases farther to the west, and at the immer end of Flagler Fjord the diabases are not at all developed. At Lands Lokk at the extreme west of Grant Land were fonnd lavas, (see Burar, p. 35) and these lava beds were crossed ly veins of dioriteporphyrite, a variety of rock that was also found farther to the southeast in Nansen Sound, as well as to the south-west in Ringnes Island.

Contemporaneons with the great igneous activity in the Post-Triassic but Pre-Miocene time, occurred the majority of crust movenents that lave taken place in Ellesmereland since Pre-Cambrian time. Of these Scula in his prelininary report (p.6) has given a short sketch which follows below: 
"After the various formations spoken of were laid down in horizontal strata, those regions were subjected to disturbances of a radical character. The horizontal strata were folded by lateral pressure, which gave rise to a system of vertical fissures, whereby the Earth's surface became divided into a number of small platear-like areas, some of which, relatively to their surroundings, have subsided, while others have been uplifterl. Hence, it has come about that, while the sea has again overflowed some of them, others are in part elevated above it, as in Ellesmere Land, Heiberg Land, Ringnes Land, etc. Thus the small plateaus nearest the sea in, for example, Turn-again Fjord and the interior of Bay's Fjord, in the vicinity of the great Archæan tableland (horst) of Ellesmere Land, have

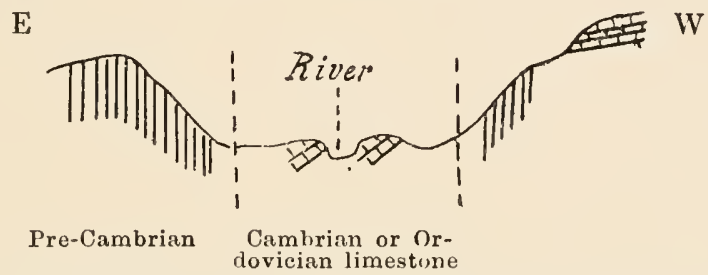

Fig. 2. Sketch showing a sunk bit of land in the Twin Glacier Valley, on the south side of Buchanan Bay. From Schei's diary.

again become suspended. The tektonic movements would seem to have concentrated their energy in the immediate vicinity of Eureka Sound. In both places the plateaus are relatively small, and the effects of the disturbance correspondingly more evident. The dip of the strata is often $50^{\circ}$ to $60^{\circ}$. The circumstance, already alluded to, that there is a great developement of intrusive rocks along the line of Eureka Sound, is no doubt connected with the fact that that same line was the scene of the greatest disturbances. The subsidence has spread outwards from the neighbourhood of the great Archæan tableland; consequently, the dip in Hayes Sound and the western part of Jones Sound is towards the north. north-west. In Bear Cape Land and beside Eureka Sound, it is just as pronounced towards the south-south-east, but without actual folding. The nearest folding is met with on the north side of Greely Fjord. Other foldings were observed, with a north-east and south-west axis, in the Triassic limestones, shales, and sandstones which mark the westward continuation of the coast of Grinnell Land. But the plication is nowhere strongly marked, and disappears towards Lands Look. Although we know that it is met with in Robeson Channel ${ }^{1}$, it does not appear to extend across to Heiberg Land. It is possible that Black Cape, Cape

1 See H. V. Feilden and de Rance, "Geology of the Coast of the Arclic Lands", in Quarterly Journal, etc., vol. XXXIV. p. 556 (London, 1878). 
Rawson, and Cape Cresswell represent the axes of plication of the north side of Greely lijord? What are presumably Mesozoic deposits, as well as Tertiary deposits (e.g. at Cape Murchison), are known to exist in the radius of Fieleten's "Cape Rawson beds," e.g. at Cape Baird and Antoinetle Bay. Is it not possible that these are indentical with the Mesozoic shales and sandstones which were recognizerl at Eureka Sound?

Hence, from what has been already sail, both the Siluro-Devonian series of sedimentary formations which exist in the south-west of Elles-
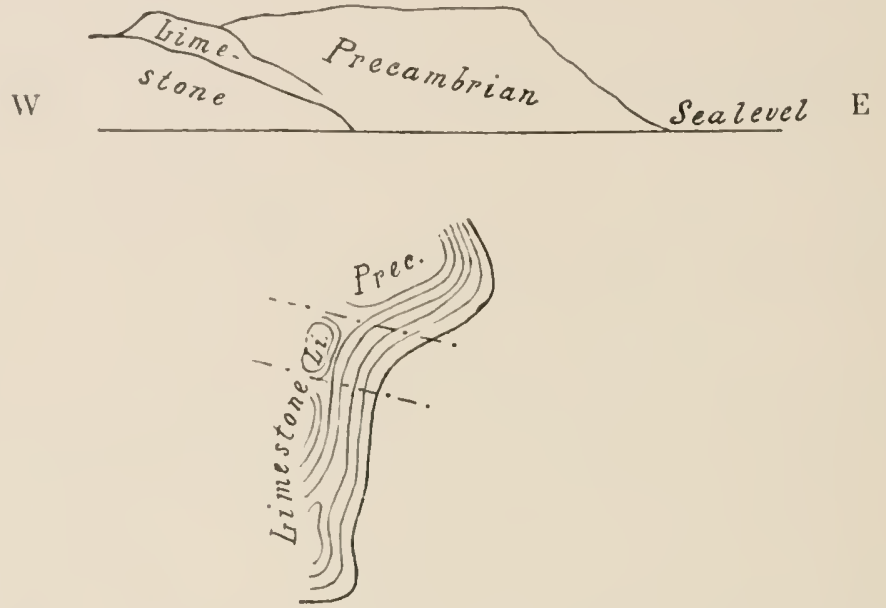

Fig. 3 Sketch showing faults in the south.eastern part of Skreia Island at the entrance of Havmefjord. The island consists of Pre-Cambrian igneous rorks and

(Cambro-?) Ordovician limestone etc. (see p. 7). From Scmb's diary.

mere Land and the T'riassic deposits further north have alike participated in the distucations. Some of these (should there eventually turn out to be more than one system) must thus he later than the Triassic epoch. On the other hand, the Mincene sand and lignite, which occur east of Carpe Blue Man, were laid down in an isoclinal transverse trough, where they still lie horizontally, and are bortered by what are presumably Menowic sandstones. Indeed, everywhere where Tertiary deposits were noticed in similar positions, they all occupied a horizontal position. Hence we are apparently justified in ronchuding that the most conspicuous instances of dislocation are later than 'Triassic, but antecedent to Miocene."

\section{Cenozoic.}

Tertiary deposits were found in several places on the west side of Ellesmere Land, as well as on the east coast of Heiberg Land (Skaarefjord.) They consist of very thick, light-coloured sandstones, shales and 
layers of lignite. Only in two places were fossils found, viz. in the valley east of Cape Blaamanden on the east side of Eureka Sound, and in Stenkul (Coal) Fjord, an inner, sile branch to Baumann Fjord. The fossil plants collected at the latter locality have been studied by Prof. Nathorst, whose results are published in "T'ertiäre Pflanzenreste aus Ellesmere. Land" (this report no. 35, 1915). In this paper are also found statements by Scner concerning the Tertiary deposits in various places, and by Dr. Simmoxs, the botanist of the expedition, on the Tertiary beds at Stenkul Fjord. A detailed stratigraphic section shows a great number of lignite layers, one of which has a thickness of $1,5 \mathrm{~m}$. The plant remnants identified by Nathorst belong to Sequoia Langsdorfii (Brongniart) Heer and Glyptostrobus Ungeri Heer (?). Besides are mentioned leaves that probably belong to a Populus, furthermore fossil wood, and some extraordinarily well-preserved fungi found in the leaves of the Sequoia.

Between the time when these Tertiary beds were deposited and the gravel and sand deposits of late quaternary time were laid down, we have nothing left of geological accumulations. In this space of time considerable denudation certainly took place in this part of the world, and the sculpturing of the chief features of the present land surface was done, the detrital rock being carried out into the surrounding sea. Un. doubtedly, as is evident from the photographs taken during the expedition, a great part of the erosion was done by glaciers, which, contrary to what ScHeI thinks to have been the case ${ }^{1}$, certainly had a much greater distribution than at present. This is evident from the ice-eroded forms of the mountains, as seen in e.g. pl.6, fig. 2, fron the claracter of the valleys, like those seen to the right in ol. 6, fig. 1. A photograph showing nice glacial polishing is given in pl. IV, fig. 2. Furthermore it may be mentioned that ScHeI in his diary telling about his visit to Norman Lockyer Island, lying rather isolated, in Princess Marie Bay, mentiones the occurrence of erratics at the top of the island (250 m. high); among other things he found a piece of granitic rock. In the cairn at the top he found pieces of the limestone of the underlying rock, (which was generally snowcovered at the time of Schei's visit) and these showed distinct glacial polishing with striæ. The typical fjord-landscapes of Ellesmere Land, also, can be explained only by a heavy ice-covering of the whole country.

1 See especially The Geograph. Journal, XXII, p. 61-65. 
A very characteristic landform is the plateau-like surface (see fig. 4) ahout which Scuer writes (prel. report p. 7):

"The Archean plateau in the south-east of Ellesmere Land, which was once covered with sedimentary rocks of the younger formations, has been planed down to the same horizontal level as ihe deeply faulted plateaus on the north and west, so that it now forms a level tableland, witl an average elevation of 3000 feet, and no isolated peaks rising to any considerable height above the general level, while short valleys dip from the crown of the plateau all round to its almost vertical outer edge. On the west of Jones Somnd, this Archean platean (horst) is contimued in the strata of Cambrian, Silurian, and Devonian age, which, inclining gently towards the north-north-west, in part pass under the sea in Norwegian Bay, and in part atre supplanted, e.g. at Bird island Fjord (Fuglöfjord) and Istlumus Fjord (Eidefjord), hy their dislocited equivalents and hy younger deposits. The Cambrian and Silurian deposits are continued northwards in the elevated ground of Barhe Peninsula and abont Flagler Fjord. The more violent dislocations which have taken place in the vicinity of Enreka Sound, conjoined with the smallness of the faulted areas and the steepness of the dip, have produced there a more extensive arliculation of the surface. The plateaus are cut up and divided liy unmerous permanent longiludinal and transverse valleys, while their highest parts have been easily monlded into crests and isolated peaks. Viewed from certain positions, the landscape there presents some of the rich modelling and variely of Alpine forms; whereas from other points of observation it has faithfully preserved the character of the tableland it really is. This same platean type of formation, which is characteristic of Fllesmere Land, appears again west of Eureka Sound, the south, west, and north sides of Heiberg Land, as well as north-west of the folding strilie in Grinnell Land."

The remarkal,ly even rock surface found in Braskerudflya (see pl. II. fig. 2), south of Bay Fjord is, according to Scuer, siluated not more than about $200 \mathrm{~m}$. above sea level - that is unt much above the highest marine late quaternary terances mentioned betow - yet must certainly be of quite another and grealer age. The character of this landscape seems to be that of a wave cut plain; the form of the surface indicates, however, ice erosion following the modelling of the plain, and a period of greater ice extent thus conning hetween the culting of this plain and the building up of the relatively very young marine terraces.

As to the marine terraces Sche in his preliminary report writes (p. 7): nMarine terraces are quite common. They occur everywhere throughout the llayes Sound "field," also at Fort Juliane up to an elevalion of 571 feet. 

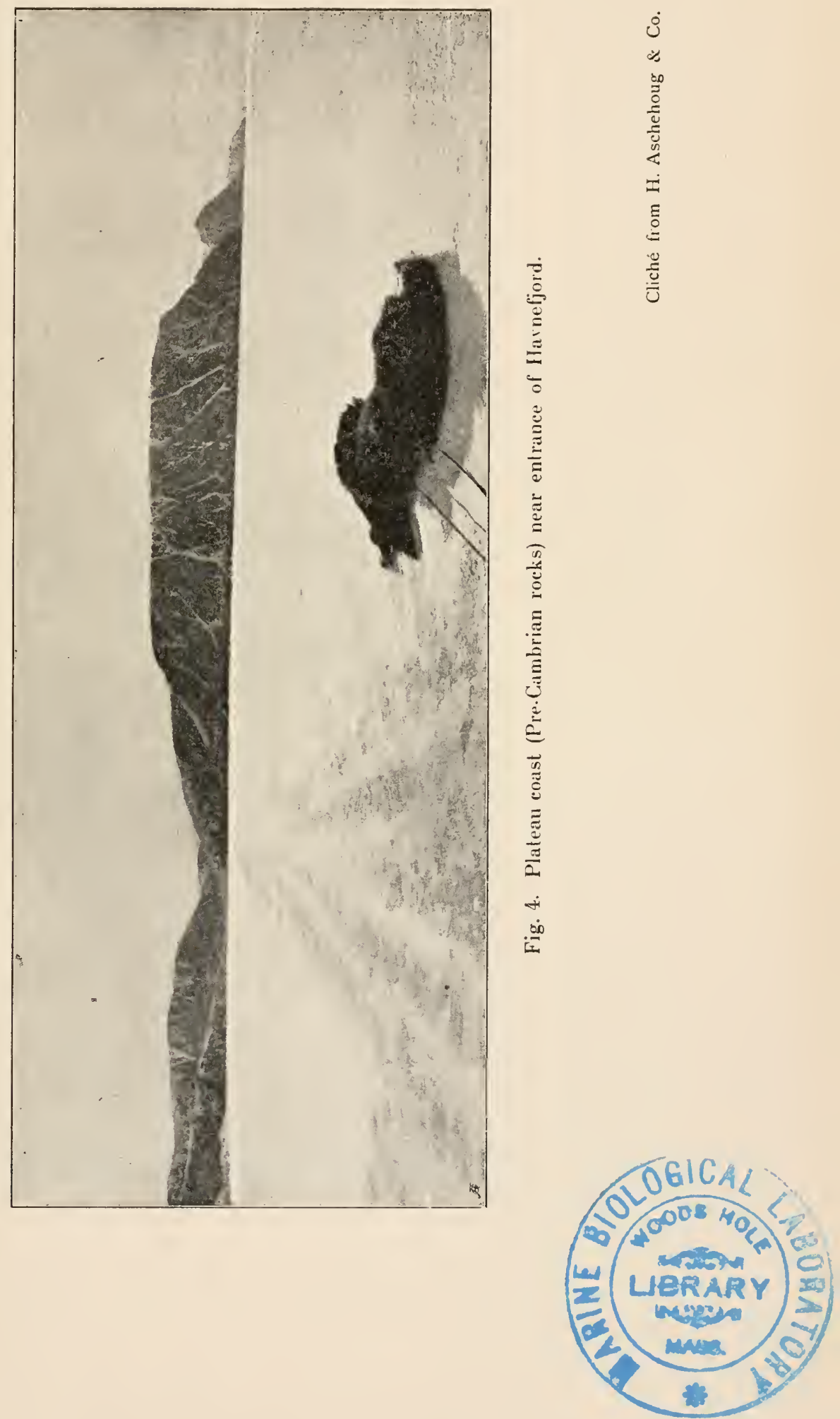
On Rutherford land we measured the highest at $594^{1}$ feet, and on Bedford Pim island at $3 ! 14^{1 / 2}$ feet. At Jones Sound the highest marine terrace was noted at the lread of Goose Fjord, at an altitude of 466 feet; and on the (op) of the pass lealing from the head of 'Trold Fjord over to Bay's Fjord, which proliably lies at the same altitude or a little higher, we ohserved errant blocks of foreign formation. Similat terraces were also noted further north in Eurekia Sound, though no measurement was taken of their elevation."

A few more slatements concerning these raised beaches have been found in Schess diaries.

From the inner part of the Foulke Fjord he mentions several terraces, the lower at ahoul $24 \mathrm{~m}$. ahove sea level, the higher, not measured, but estimated at 100 to $125 \mathrm{~m}$. In Hayes Sound were ob. servel. besides the one mentioned in He report, at $571 \mathrm{f}$. (174 m.), two lower ones, one at 133.6 and the other $95.1 \mathrm{~m}$. (measured by aneroid).

Near the winter-quarter's of the "Fram" 1S9S-99, in Rice St., Scuen has determined the level of several terraces. Near Cape Rutherford were seen six listinct ones. As to their elevation definite figures can he given for $110 s .3$ and 6 , the former lying $22,5 \mathrm{~m}$. the latter $117,0 \mathrm{~m}$. above sea level.

On the north side of Bedford Pim Island Scuer collected in clay, at (3)-40 m., the following shells, which Cirator P. A. OYEx his been so kind as to identify:

\section{Nicania bankisi \\ Macoma calcaria \\ Mya truncata \\ Saxicara pholadis \\ Lepretu coecu \\ Balanus sp.}

In this island a terrace was fomd at $50 \mathrm{~m}$. and another at $105 \mathrm{~m}$., probahly corresponding to terace no. 5 near Cape Rutherford.

Also in the Havnefjort districl marine terraces were seen in many places (see pl. IV, fig. 1), but no definite figures as to their elevation are fombl. In many places shells were collected from the quarternary deprosits, and a comple of lists from occurrences where the height of the focality is known, are riled below. From Odedalen in Havnefjord, alhout 5) n, above sea level, were brouglit:

1 Must le wrong; in the Norwegian text is written $117 \mathrm{~m}$. which is also found in Scun:ss diary. 


\section{Cardium islandicum}

Macoma calcaria

Mya truncata

Saxicava pholadis

Lepeta caca

Balanus sp.

On the east side of Moskusfjord, to the west of Havnefjord, the following species were found in clay about $65 \mathrm{~m}$. above sea level:

\section{Macoma calcaria \\ Pecten islandicus \\ Cardium islandicum \\ Mya truncata var. uddevallensis \\ Saxicava pholadis \\ Balanus sp.}

Terraces of about the same maximum height as found by ScHer in Ellesmere Land are known to occur in other districts of the Arctic Archipelago. In the report of A. P. Low on the cruise of the "Neptune", p. 235, is stated that along the eastern shores of Baffin Island, terraces were constantly seen, which were estimated to rise from 500 to 700 feet above the sea. The same height is given for terraces on the western side of Hudson Bay, while at Cape Wolstenholme, on the south side of Hudson Strait, the terraces rise to 800 feet. The lighest terrace seen (by Dr. BeLL) on the north side of Hudson Strait had an elevation of 528 feet above the sea. Concerning the remarks in the paper cited as to the theory of the greatest post-glacial land-uplift being found where the accumulation of ice was greatest, the quaternary geology of Arctic America does not, in the opinion of the present author, contradict it, since the glaciation in Ellesmere Land seems, indeed, to have been at one time much more intense than at present.

As Scher in his "Summary of geological results" strongly emphasizes the size of the glaciers has not been greater than at present, since the high terraces were formed; that is, we have had no melting off during this rise of the land from about $180 \mathrm{~m}$. to the present level - in other words in fairly recent time. The high marine terraces are found so near present glaciers that we must, on the contrary, assume that the latter must have advanced in this youngest time. This is shown atso by the fact that in the morainic material formed at the margin of Leffert glacier at Rice Street, were found molluscan shells (Mya truncata and Astarte arctica), evidently moved from an original deposit farther inland, now covered by ice.

As to the present glaciation of Ellesmere Land, what Scher in his report, p. 8 , writes on that subject, is cited below:

1 Otlawa 1906. 
"Although glacier tongues were observed in pretly nearly every part of Ellenmere Land, and although the greater part of its surface is covered with ice and snow, yet we nowhere saw inland ice properly so called. The glarialion is nowhere sufficiently developed to hide the configuration of the surface under a mantle of inland ice, but is distributed in local fiekls, the houmdaries of which are determined by the topographical features. Fillesmere Land proper consists of a tolerably level high plain of Archæan formation, and here we find the largest single area of glaciation, and of conrse the nearest approach to inland ice. As a rule, its extremities reach down to the sea in the shape of productive glacier tongues. Their dimensions and rolume are too small to justify us in calling them ice-streams, and for as far as the eye is able to penetrate inland from the sea, individual peaks and eminences are seen to lreak through the accumulations of ice. These features are most pronounced from off Smith fsland in Jones Sound, and to Cadogin and Baird inlet further north; so that in place of the contimuous covering of ice-for, in spite of these numerous protrusions, il does in a way preserve its continuty-we have a number of independent néés. 'The largest névés at Hayes Sound are the Leffert-A!exandra glacier tongues and the glacier tongnes of Hayes Sonnd itself; they fill all the permanent depressions, and on the east side, at any rate, thrust their principal arms down into the sea. On the west they terminate in valley glaciers or are stopped on the walls of the plateau. 'The glaciers of Hayes sound projer, for instance, cover the heights which on the sonth separate Flagler Fjord from Baty's Fiord with an ice-cilp which reaches down into the valley at only one point, but there fills it entirely from side to side, and il the sime time dans hack a lake, On the north of the pass similar glacual conditions prevail, a few arms reaching down to the sea in Princess Marie Bay and in Ciñon Fjord.

'The large expanse of ice on Ellesmere Land approaches the sea on the soull at only one locality, namely, near Cone Island, in a large productue glacier; west of that, along the same coast, the ice-covering retreats inland. It is only at the heads of the fjords, e.g. of South Cape Fjord and linat Ford (Baadsfjord), that a few glacial arms descend as low as the sea-level. ${ }^{1}$ As a rule, you have to arlvance some distance up the villeys which form the continuation of the fjord-trenches before you meet witl them, as is the rase, for instance, in Fran Fjord, in Swine Fjord (Grisefjord), and in Harhour Fjord. In the western part of Jones Sound glaciation on the actual coast is confined to local glacier tongues of the

1 See pl. V, fig. 2. 
snow-avalanche (snefond) type, while the plateaus up above between the several fjords, as well as the deep valleys, are covered by not very thick ice-caps, or stationary névés, which are not yet sufficiently developed to feed glacier-tongues. West of a line drawn from the head of Buffalo Fjord (Böffelfjord), past the head of Coal Fjord (Kulfjord), east of Turn-again Fjord, and so up to the summit of the pass that connects Flagler fjord with Bay's Fjord, all the lower-lying lands are free from snow in the summer. The only exceptions are a few glaciated snow avalanches at Hell Gate.

But although glaciation in the proper sense of the term may be said to cease on the west coast of Ellesmere Land, it appears again on Heiberg Land, in the vicinity of Glaciers Fjord, Wolf Fjord, and Skaare Fjord. This is accounted for, as indeed all glaciation is, by the climatological relations considered in connection with the configuration of the country. The narrow and crowded folds between the lofty plateau ridges (fjelde) form so many sheltered collecting-basins for the precipitation brought by the south winds, as well as for the drift winds that blow from the north. These last play a great part in the distribution of the snow, both locally and generally." 


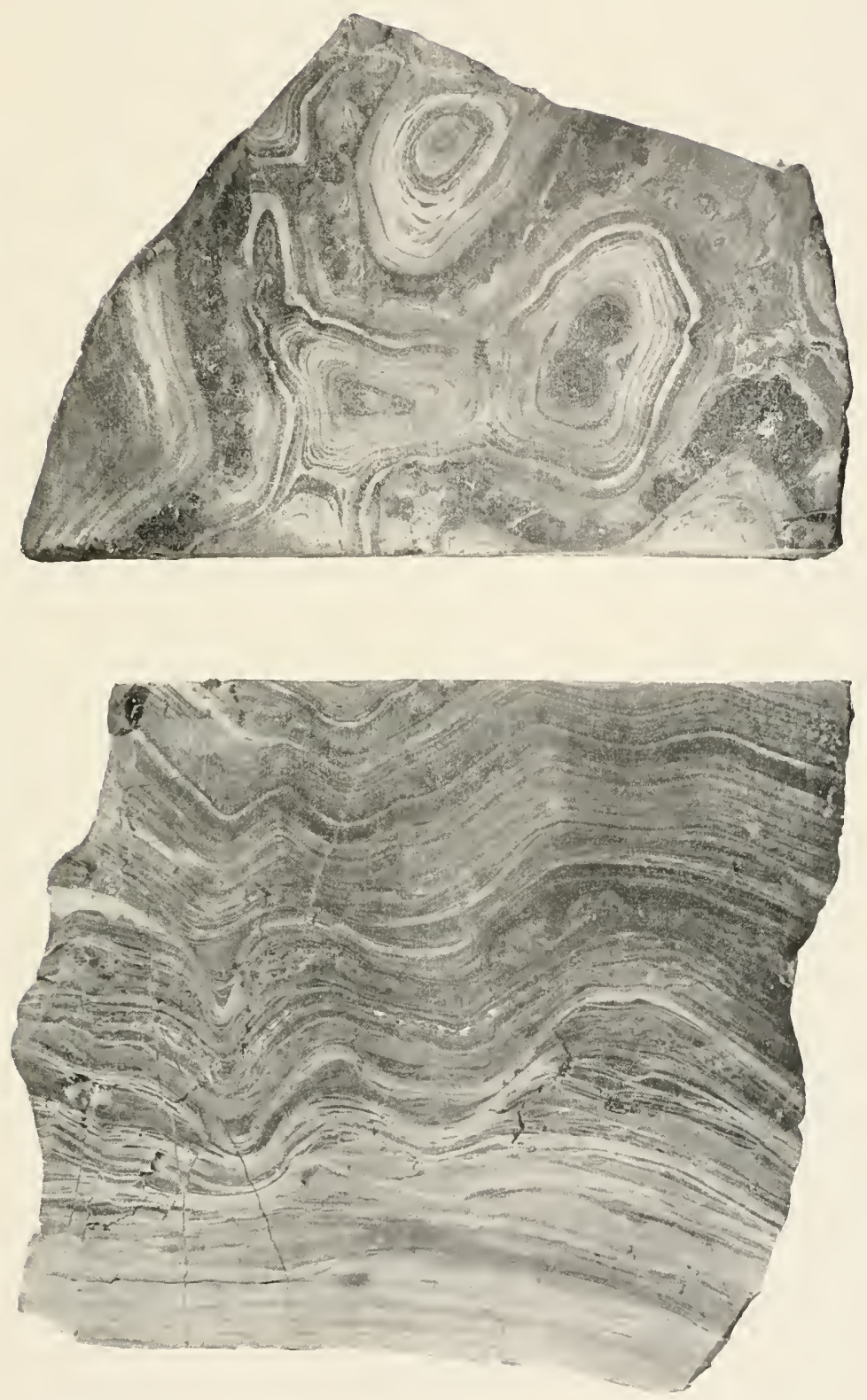

Cryptozoon-like structure, with oolites, in a piece of limestone of the basal sedimentary series on the east side of Havnefjord. Nat. size. 


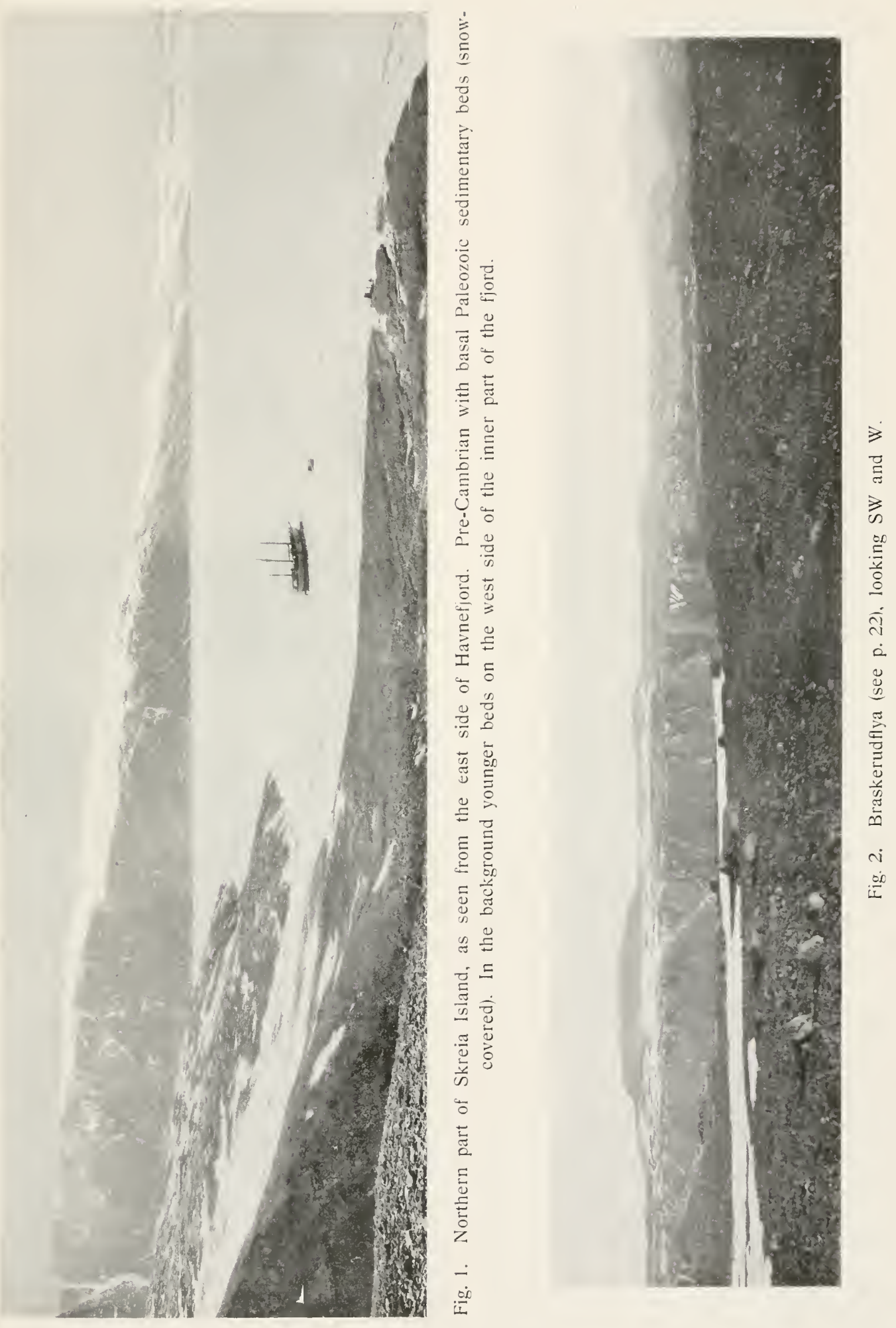



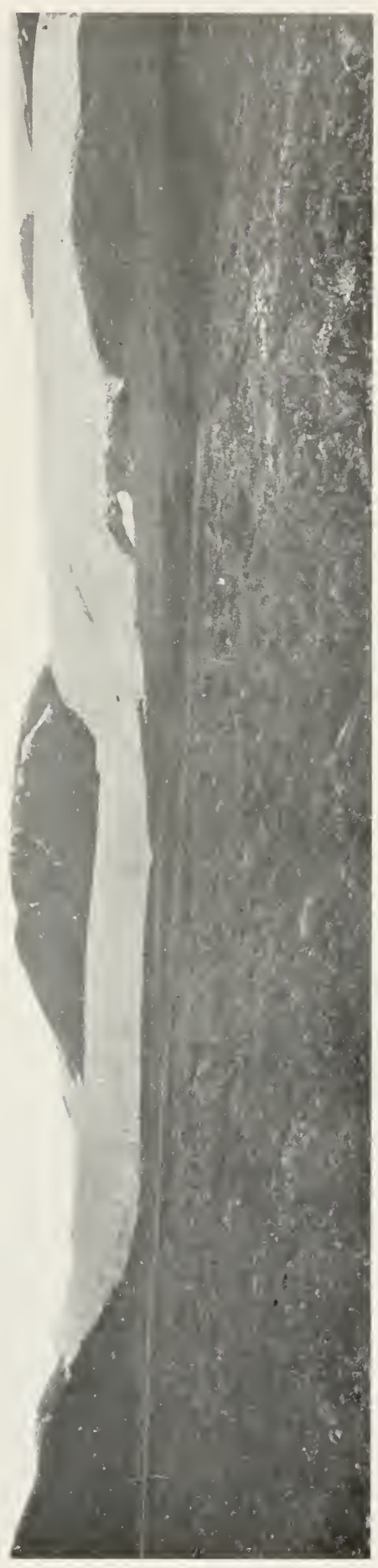

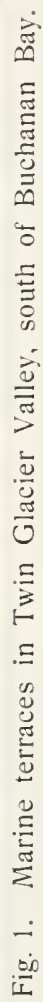

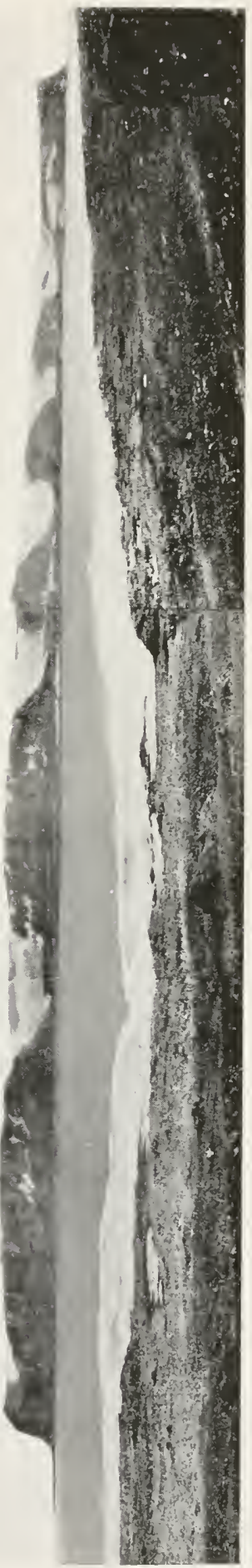

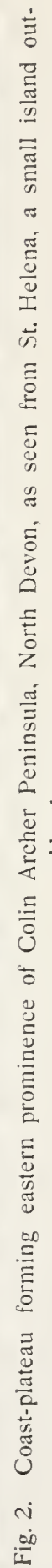





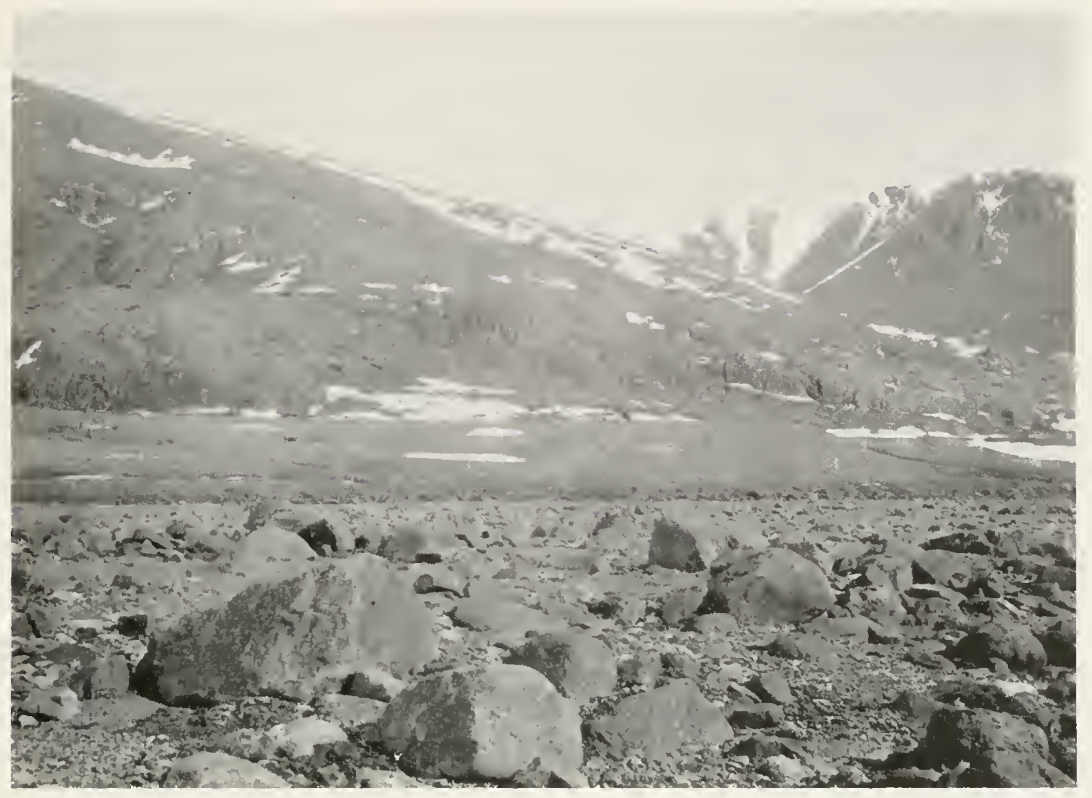

Fig. 1. Marine terraces in Stordalen, east side of Havnefjord.

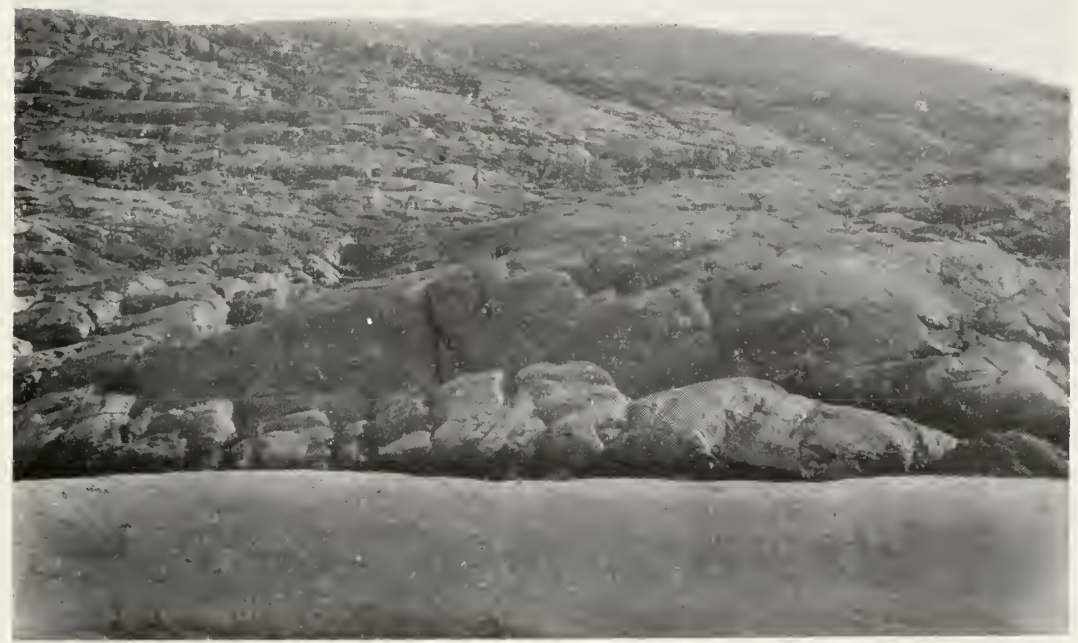

Fig. 2. Rocks at Spadenes, east side of Havnefjord, with distinctly glaciated surface. 



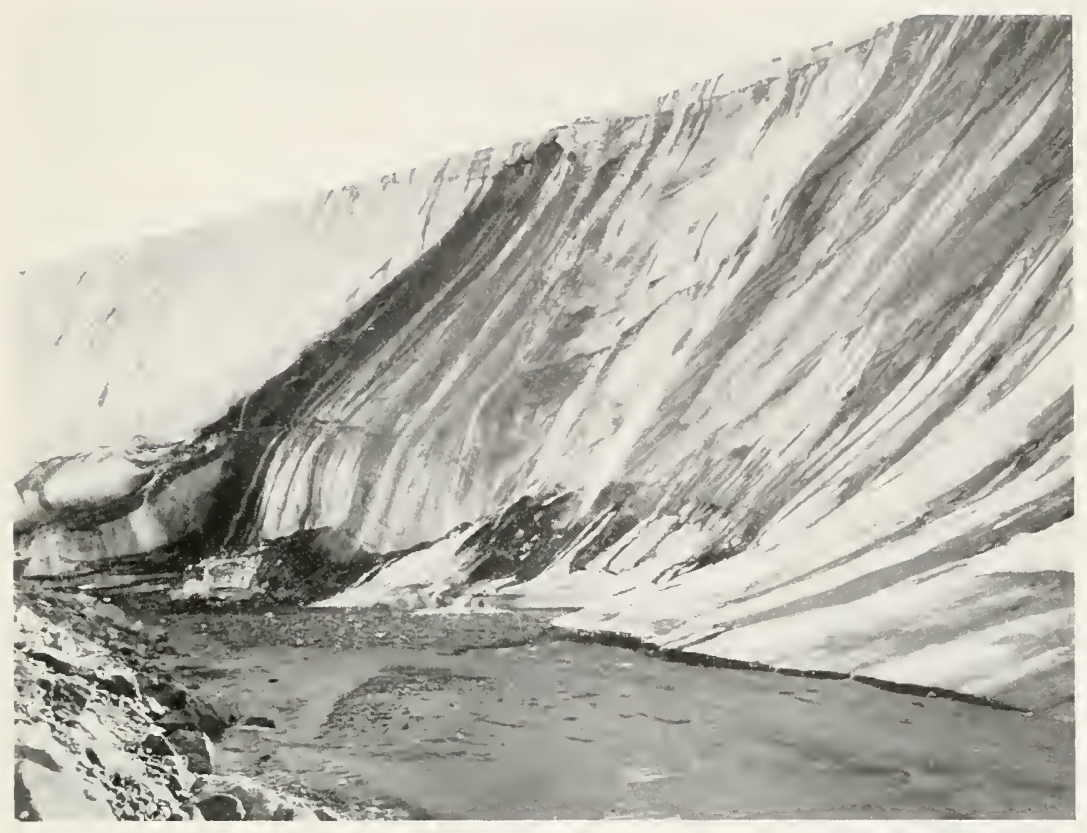

Fig. 1. Wall of Fram Glacier near the coast inside Pim lsland (winter quarters $1898-1899)$.

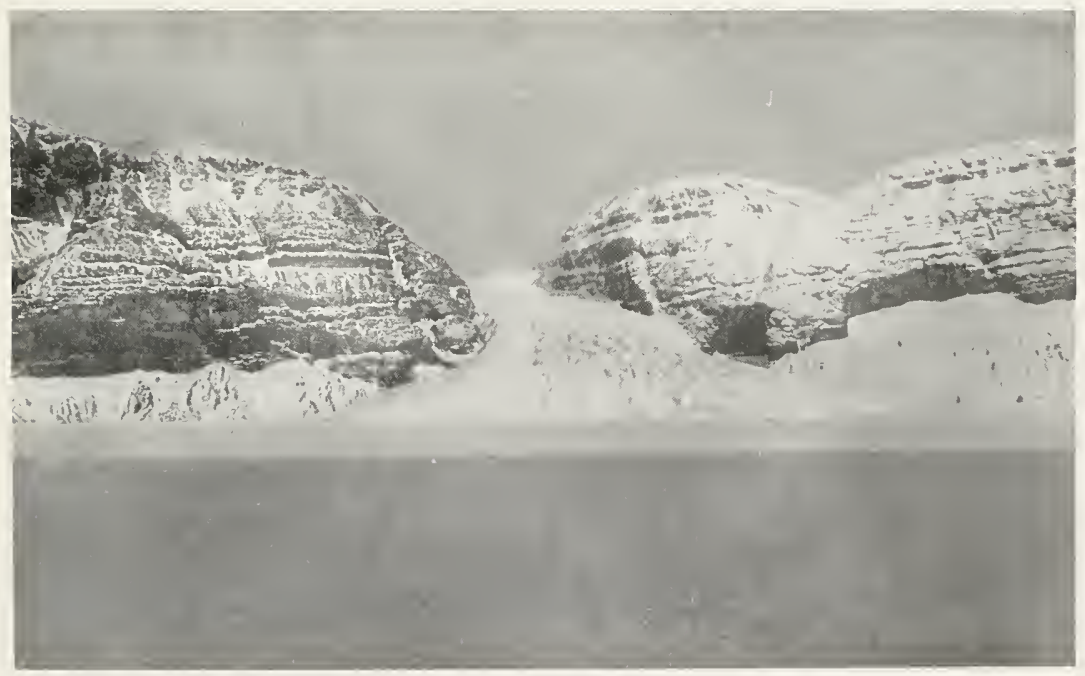

Fig. 2. Glacier in Baadsfjord, Jones Sound. 



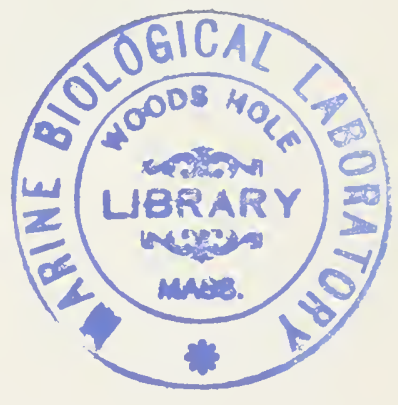


SEC. ARCT. E.YP. FRA.II 1S49-1902. No. 3t).

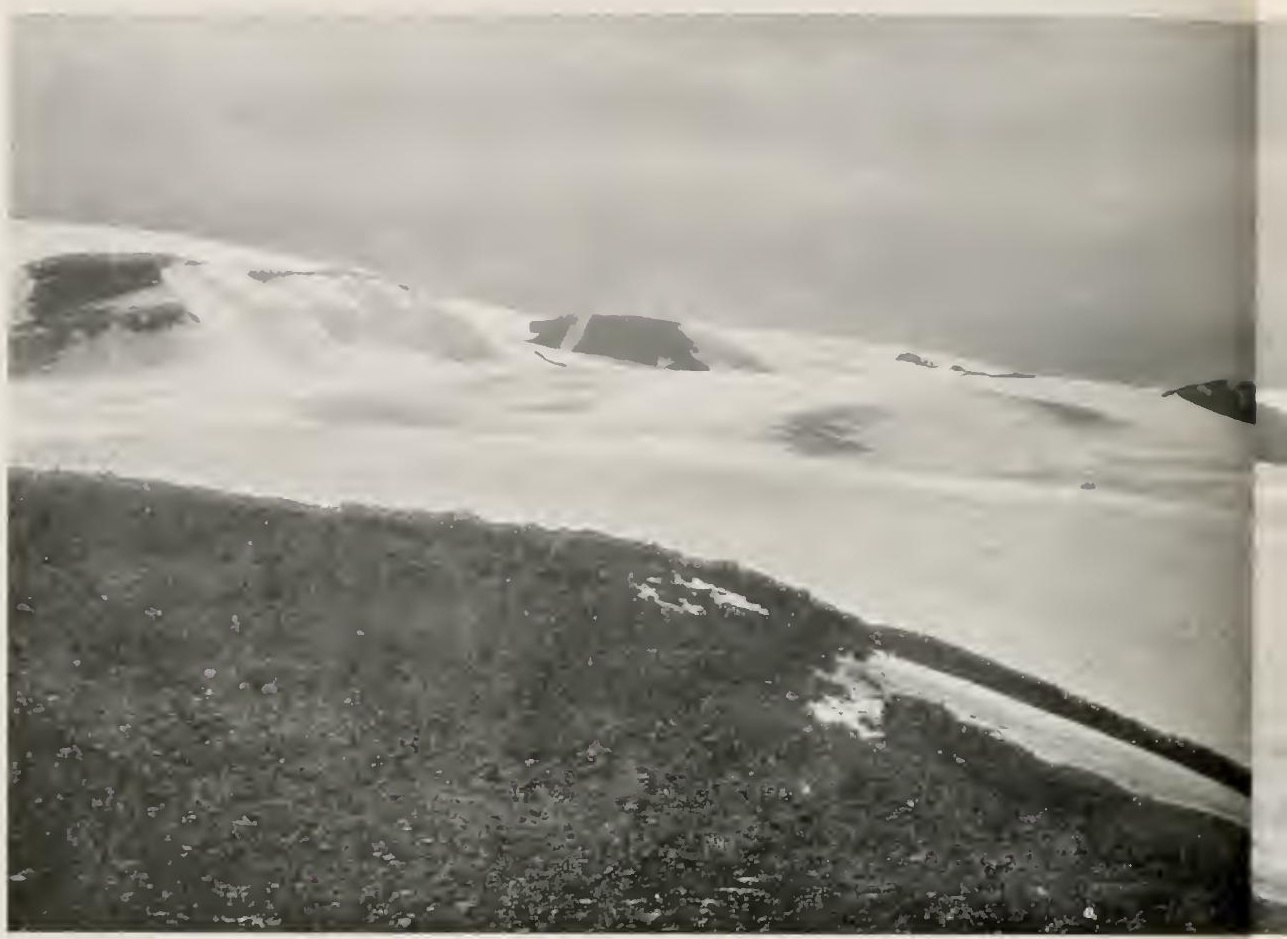

Fig. 1. Northern part of Fram Glacier near the coast inside Pim Island, as seeral

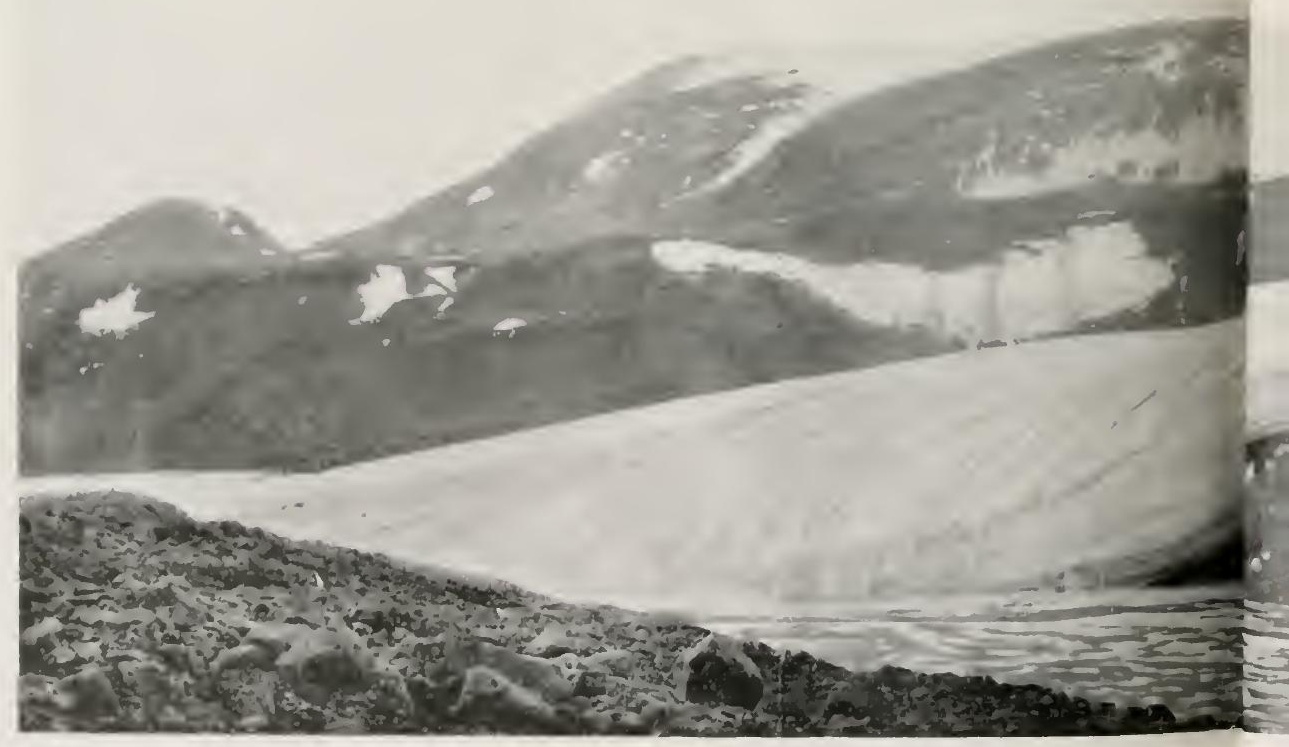

Fig. 2. Southern palicer. 


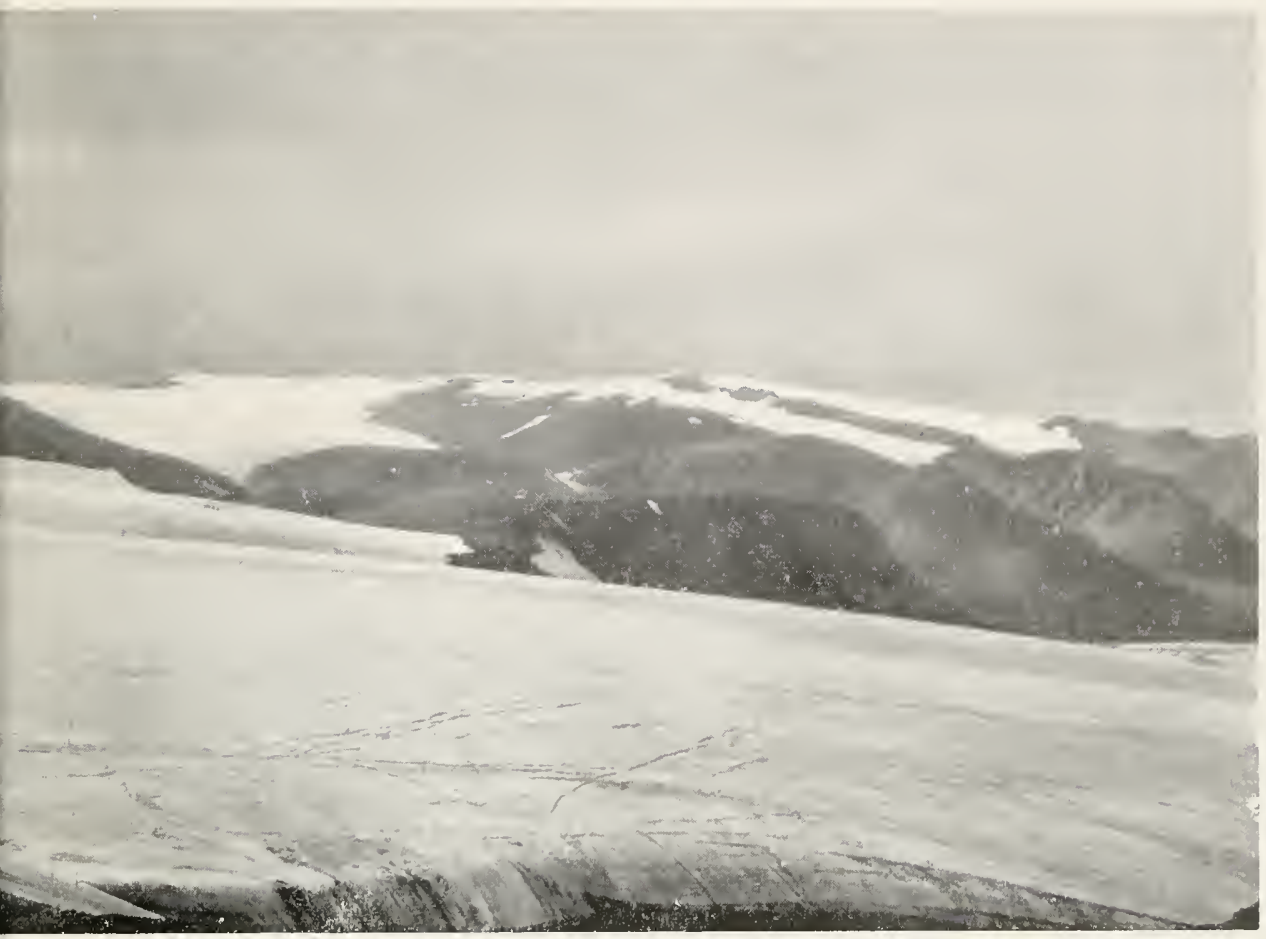

jaa (winter quarters $1898-1899$ ). To the right, valleys west of Rutherford Bay.

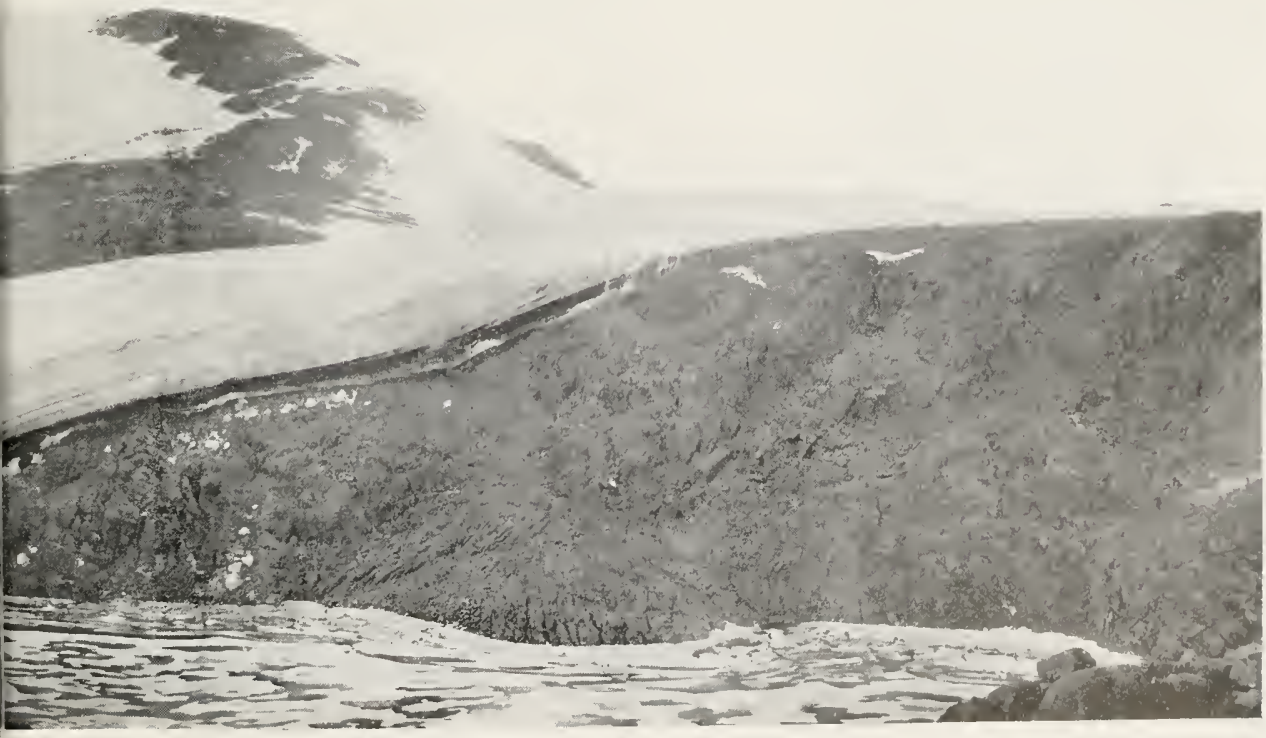

sier, looking south. 








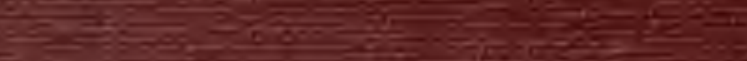

E

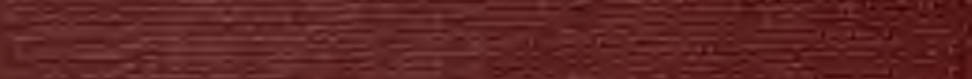

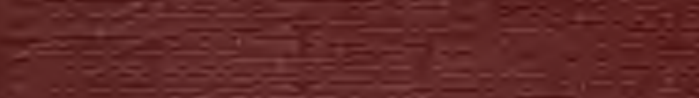

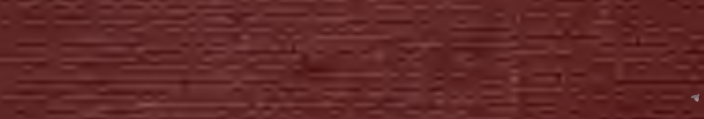

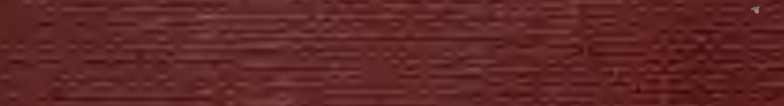

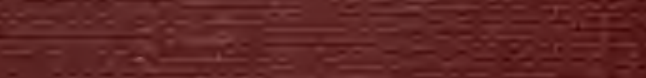

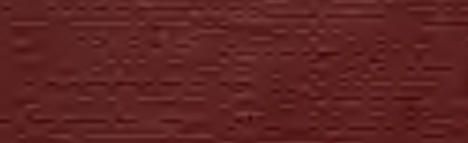

$=0$

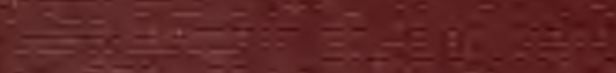

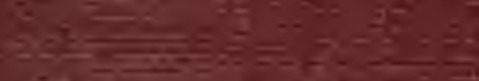

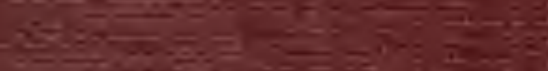

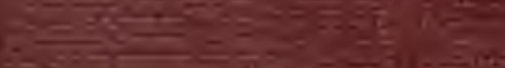

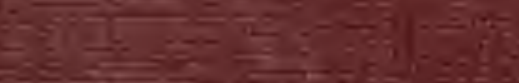

21
4

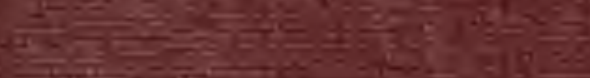

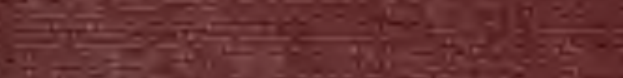

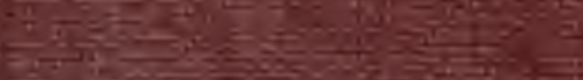

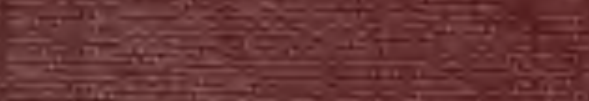

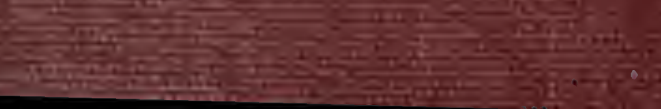

